Geothermometry Mapping of Deep Hydrothermal Reservoirs in Southeastern Idaho: Final Report

Earl D. Mattson ${ }^{1}$, Mark E. Conrad², Ghanashayam Neupane ${ }^{1}$, Travis L. McLing ${ }^{1}$, Thomas R. Wood ${ }^{3}$, Cody J. Cannon $^{3}$

\section{August 2016}

${ }^{1}$ Idaho National Laboratory

2 Lawrence Berkeley National Laboratory

3 University of Idaho

The INL is a U.S. Department of Energy National Laboratory operated by Battelle Energy Alliance 


\section{DISCLAIMER}

This information was prepared as an account of work sponsored by an agency of the U.S. Government. Neither the U.S. Government nor any

agency thereof, nor any of their employees, makes any warranty, expressed or implied, or assumes any legal liability or responsibility for the accuracy, completeness, or usefulness, of any information, apparatus, product, or process disclosed, or represents that its use would not infringe privately owned rights. References herein to any specific commercial product, process, or service by trade name, trade mark, manufacturer, or otherwise, does not necessarily constitute or imply its endorsement, recommendation, or favoring by the U.S. Government or any agency thereof. The views and opinions of authors expressed herein do not necessarily state or reflect those of the U.S. Government or any agency thereof. 
INL/EXT-16-39154

Revision 0

\section{Geothermometry Mapping of Deep Hydrothermal Reservoirs in Southeastern Idaho: Final Report}

Idaho National Laboratory Idaho Falls, Idaho 83415

http://www.inl.gov

Prepared for the

Battelle Memorial Institute, Inc.

Under DOE Idaho Operations Office

Contract DE-AC07-05ID14517 


\section{EXECUTIVE SUMMARY}

The Eastern Snake River Plain (ESRP) in southern Idaho is a region of high heat flow. Sustained volcanic activity in the wake of the passage of the Yellowstone Hotspot through the area created a region with great potential for geothermal resources. Numerous hot springs with temperatures up to $75^{\circ} \mathrm{C}$ are scattered along the margins of the plain. Similarly, several hot water producing wells and a few hot springs are also present within the ERSP. The geothermal reservoirs in the area are likely to be hosted at depth in felsic volcanic rocks and/or Paleozoic rocks underneath the thick sequences of basalts within the ERSP. The heat source for these geothermal resources is thought to be a mid-crustal sill complex that sustains high heat flow in the ESRP. Several anomalous thermal areas are believed to be associated with local thermal perturbations caused by favorable structural settings. However, it is hypothesized that the thermal signatures of these deep-seated geothermal resources are masked by highly productive, coldwater aquifers in the basalts. The dilution of deeper thermal water and re-equilibration at lower temperatures represent significant challenges for the evaluation of potential resource areas in the ESRP.

To address this issue, this project used advanced geothermometry tools including temperature-dependent mineral and isotopic equilibria with mixing models that account for processes such as boiling and dilution with shallow groundwater that could affect calculated temperatures of underlying deep thermal waters. Over the past two years, we collected samples from approximately 100 springs/wells in and around the ESRP for chemical analysis. Similarly, the water chemistry data of several thermal features in the area that were not accessible for sampling during the current sampling campaign were assembled from previously published sources. To all thermal water compositions, we applied several geothermometric and geochemical modeling tools to estimate reservoir temperatures of the several geothermal prospects in the ESRP. Geothermometric calculations based on the principle of multicomponent equilibrium geothermometry with inverse geochemical modeling capability (e.g., Reservoir Temperature Estimator, RTEst) have been useful for evaluation of reservoir temperatures. Similarly, sulfate-water oxygen isotope geothermometry was also applied to several samples in tandem with RTEst. In addition, applications of other isotopic signatures of high-temperature water-rock interaction (e.g., shifts in $\delta^{18} \mathrm{O}$ of water, isotopic signatures of magmatic $\mathrm{CH}_{4}$ ) are also presented.

In summary, geothermometric calculations of ESRP thermal water samples indicated numerous potential geothermal areas with elevated reservoir temperatures. These areas are could be considered to be potentially economic geothermal resources. Specifically, areas around the southern and southwestern sides of the Mount Bennet Hills and within the Camas Prairie in the southwestern portion of the ESRP indicate reservoir temperatures of $140-190^{\circ} \mathrm{C}$. In the northern portion of the ESRP, Lidy Hot Springs, Ashton, Newdale, and areas east of Idaho Falls have expected reservoir temperature $\geq 140{ }^{\circ} \mathrm{C}$. In the southern ERSP, areas near Buhl and Twin Falls with calculated reservoir temperatures as high as $160{ }^{\circ} \mathrm{C}$. In most cases, the isotopic determined reservoir temperature generally agreed with the multicomponent equilibrium geothermometry derived temperatures giving greater confidence in the estimated reservoir temperatures. In a few cases, the sulfate-water isotope temperatures are significantly higher than the RTEst temperatures. Although RTEst and isotopic analyses suggest that many areas of the ESRP that have high reservoir temperatures, further detailed study at each site is necessary to evaluate their suitability for economic use 


\section{CONTENTS}

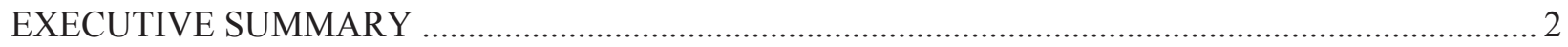

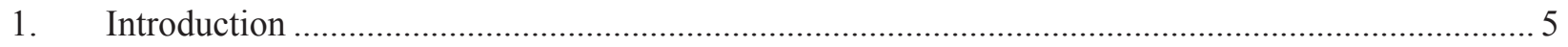

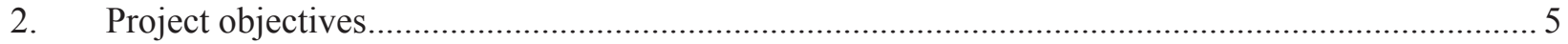

3. Geologic and geothermal setting of eastern Snake River Plain .................................................. 7

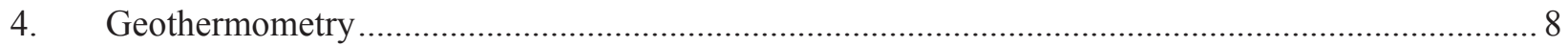

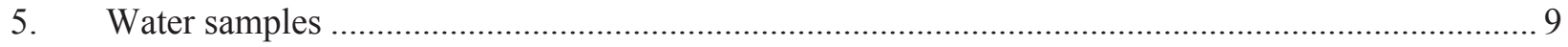

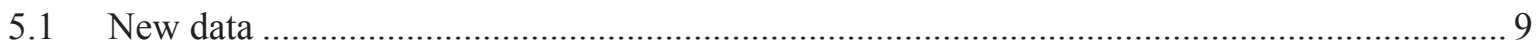

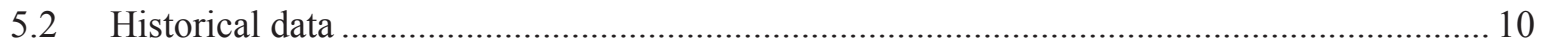

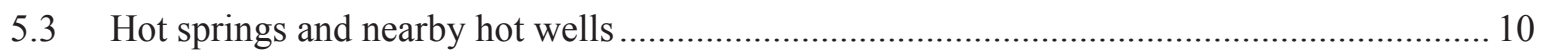

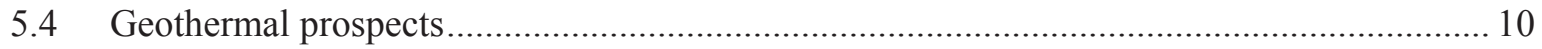

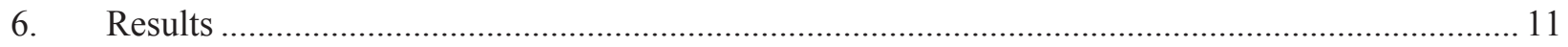

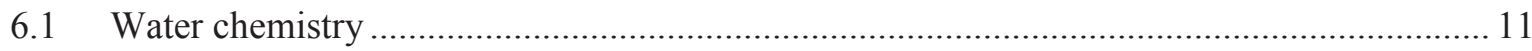

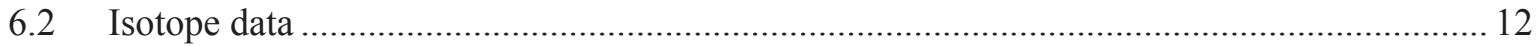

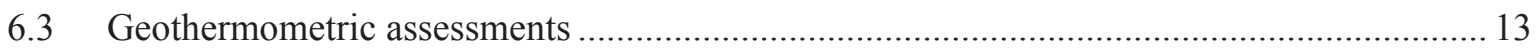

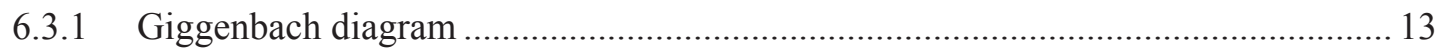

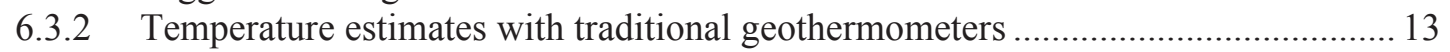

6.3.3 Temperature estimates with RTEst ...................................................................... 15

6.3.4 Temperature estimates from sulfate-water oxygen isotope geothermometry ........... 16

6.4 Some geothermal prospects and their reservoir temperatures....................................... 17

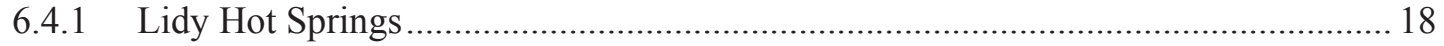

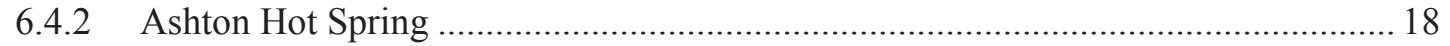

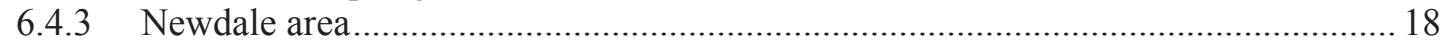

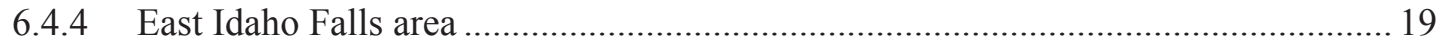

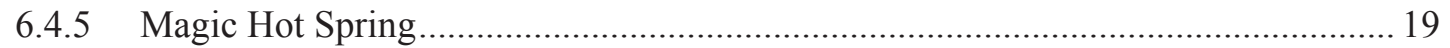

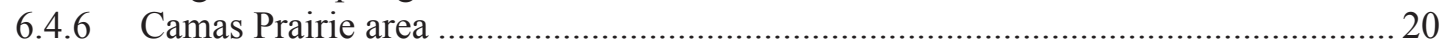

6.4.7 South Mount Bennett Hills .................................................................................... 21

6.4.8 Banbury Hot Springs-Twin Falls area........................................................................ 22

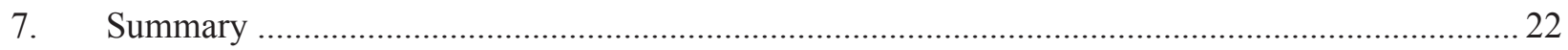

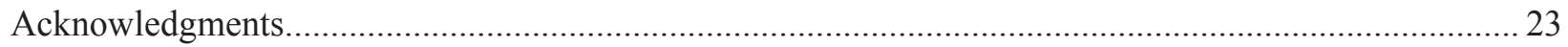

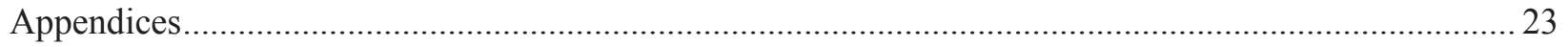

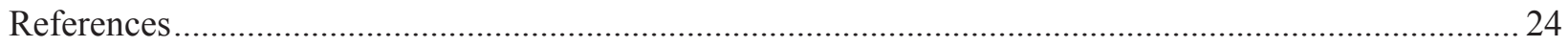




\section{FIGURES}

Figure 1. Map of potential geothermal prospects (stars and polygons) in the southern Idaho. The map was prepared by draping a heat flow map (Williams and DeAngelo, 2011) over digital elevation model (DEM) of the area. The thick red line demarcates the margins of the ESRP from the surrounding Basin and Range province. The codenames of the geothermal prospects are given in Table 1 . The numeric value(s) numbers associated with each geothermal prospect is the RTEst estimated reservoir temperature $\left({ }^{\circ} \mathrm{C}\right)$.

Figure 2. Schematic cross-section across the ESRP (modified from Hughes et al., 1999; Neupane et al., 2014) showing underlying rhyolitic ash-flow tuffs and overlying basalt flows with few sedimentary layers. The underlying rhyolite ash-flow tuffs are assumed to host the ESRP geothermal resources. ................................................................................

Figure 3. Chemistry of the ESRP thermal water samples shown on a Piper diagram

Figure 4. Hydrogen and oxygen isotopic compositions from ESRP water samples with the global meteoric water line for comparison. Most waters fall very close to the meteoric water line, but there are several samples that are significantly shifted to the right of the meteoric water line, which is an indication of oxygen isotope exchange during hightemperature water-rock interaction in hydrothermal systems. Abbreviations are- BW: Barron Well, CHS: Condie Hot Spring, ELHS2: Elk Creek Hot Spring 2, MRLW: Magic Reservoir Landing Well, and MRLWR: Magic Reservoir Landing Well runoff.

Figure 5. Giggenbach ternary diagram for the ESRP thermal water samples

Figure 6. Graphical representation of RTEst analysis of Miracle Hot Spring well located in the Banbury Hot Springs prospect (see Figure 1). a) $\log \mathrm{Q} / \mathrm{K}_{\mathrm{T}}$ plot for assemblage minerals using observed fluid composition, $b$ ) $\log \mathrm{Q} / \mathrm{K}_{\mathrm{T}}$ plot for assemblage minerals using RTEst optimized fluid composition. Mineral assemblage includes: bei: beidellite-Mg, cal: calcite, cha: chalcedony, mor: mordenite-Na, and par: paragonite.

Figure 7. RTEst temperature estimates versus sulfate-water oxygen isotope temperature estimates for the ESRP thermal water samples. The solid line represents a 1:1 comparison and the dashed lines indicate the range of temperatures within $\pm 30^{\circ} \mathrm{C}$ of each other. The abbreviations in the figure are- HHS: Heise Hot Spring, GCHS: Green Canyon Hot Spring, MRLWR: Magic Reservoir Landing well runoff, MRLW: Magic Reservoir Landing well. The Barron well is not shown in this figure because of the sulfate-water oxygen temperature estimate is far above $\left(419^{\circ} \mathrm{C}\right)$ the maximum axis temperature.

\section{TABLES}

Table 1. Estimated temperatures $\left({ }^{\circ} \mathrm{C}\right)$ for potential geothermal prospects in the ESRP 


\title{
Geothermometry Mapping of Deep Hydrothermal Reservoirs in Southeastern Idaho: Final Report
}

\author{
Earl D. Mattson, Mark E. Conrad, Ghanashyam Neupane, Travis L. McLing, Thomas R. Wood, \\ and Cody J. Cannon
}

\section{Introduction}

The eastern Snake River Plain (ESRP) in southeastern Idaho is a region of high heat flow with great potential for significant geothermal resources (Figure 1). A limited number of deep wells (such as INEL1) and several hot springs and wells along the margin of ESRP also provide direct evidence of a hightemperature regime at depth in the area. However, most of the shallow wells within the ESRP generally exhibit low field-measured temperatures, likely due to the Eastern Snake River Plain Aquifer (ESRPA) obscuring the deep geothermal signature. The ESRPA is a prolific aquifer hosted in a thick sequence of thin-layered, highly transmissive basalt flows. The aquifer rapidly transports cold recharge from the Yellowstone Plateau and surrounding mountain basins to springs along the Snake River Canyon west of Twin Falls, Idaho. The flush of cold water through the overlying ESRPA masks the geothermal signature of the heat existing at depth (e.g., Smith, 2004). Importantly, the geothermal gradient below the ESRP aquifer system increases rapidly (Blackwell, 1989; McLing et al., 2002; Nielson et al., 2012) providing additional evidence of the presence of deep geothermal resources in the area.

\section{Project objectives}

This project uses advanced geochemical simulation tools that couple temperature-dependent mineral and isotopic equilibria with mixing models to estimate reservoir temperatures of potential geothermal resources in the ESRP. These tools help account for processes such as boiling and dilution with shallow groundwater that could affect calculated temperatures of deep geothermal reservoirs. Traditional as well as multicomponent geothermometry tools were applied to both existing data (e.g., Idaho Department of Water Resources, literature searches from the Web of Science, dissertations at the University of Idaho, and data located at the Idaho Geologic Survey) and new data collected as part of this study.

Specific objectives of this project were to obtain samples from thermal expressions (Appendix A), analyze samples for chemical and isotope compositions (Appendices B and C), use INL's geothermometry tool (RTEst), traditional geothermometers, and dissolved sulfate $\left(\delta^{34} \mathrm{~S}\right.$ and $\left.\delta^{18} \mathrm{O}\right)$ calculations (Appendix D), and identify potential geothermal areas (prospects) in the ESRP (Appendix E). Initially, we conducted a geothermometric assessment of the ESRP using previously published data from the region (Neupane et al., 2014; Cannon et al., 2014). That was followed by a series of field campaigns where an extensive set of new water samples from geothermal features in the ESRP and surrounding areas were collected and analyzed for chemical and isotopic compositions. These new data were used to expand our geothermometric assessment of the ERSP and have led to identification of several areas with promising potential for geothermal development. Specifically, we present calculated temperatures for geothermal areas distributed around southern/southwestern sides of the Mount Bennett Hills, Camas Prairie area, Lidy Hot Springs, Ashton area, Newdale area, and areas east of Idaho Falls. Similarly, we also present geothermometric results of geothermal areas around Buhl and Twin Falls area in the southern ESRP. The reservoir temperatures of these geothermal sites were estimated with traditional (e.g., Fournier et al., 1977) as well as multicomponent geothermometry tool [e.g., Reservoir Temperature Estimator (RTEst) (Palmer et al., 2014; Mattson et al., 2015)] based on the chemical composition of thermal water samples. 


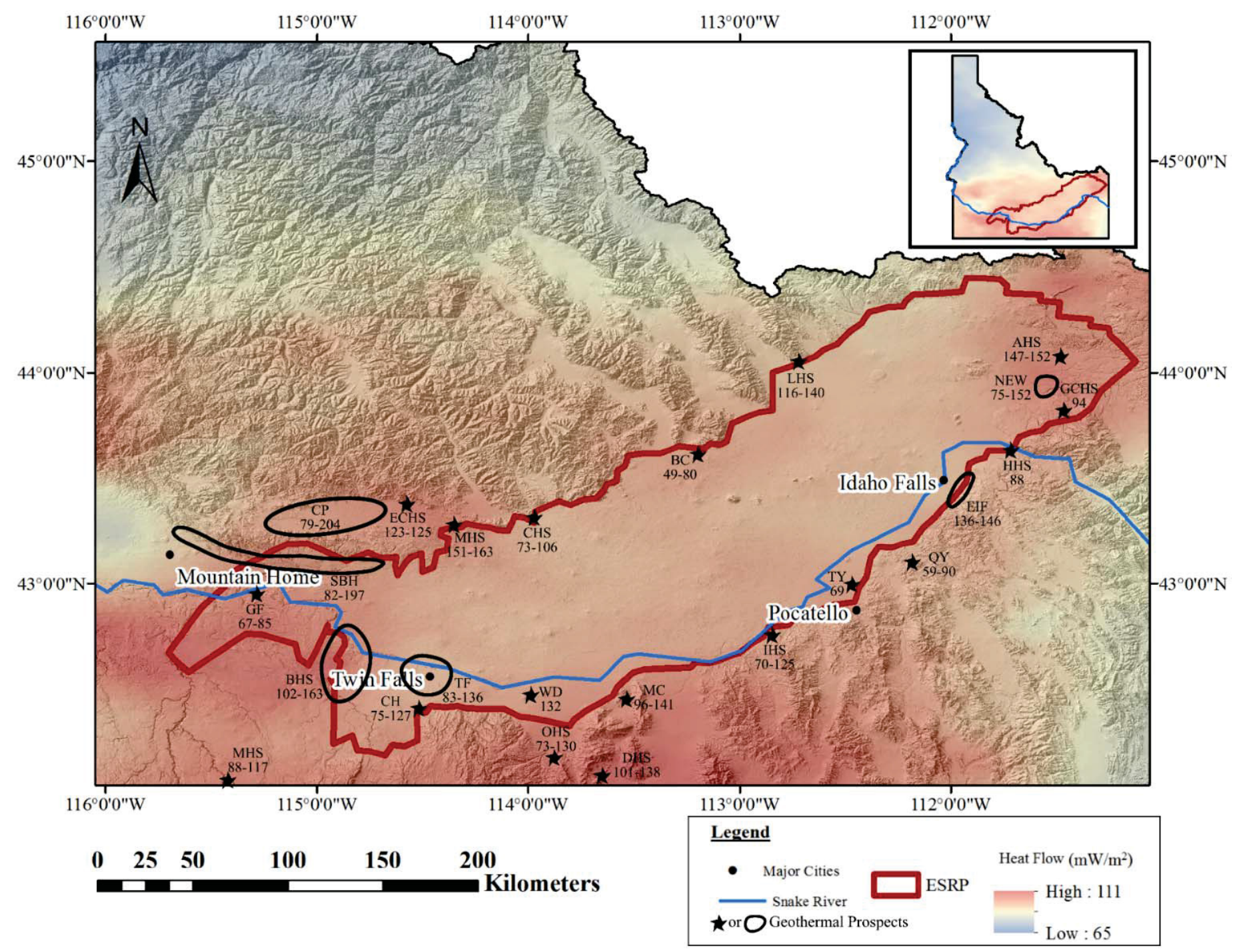

Figure 1. Map of potential geothermal prospects (stars and polygons) in the southern Idaho. The map was prepared by draping a heat flow map (Williams and DeAngelo, 2011) over digital elevation model (DEM) of the area. The thick red line demarcates the margins of the ESRP from the surrounding Basin and Range province. The codenames of the geothermal prospects are given in Table 1. The numeric value(s) numbers associated with each geothermal prospect is the RTEst estimated reservoir temperature $\left({ }^{\circ} \mathrm{C}\right)$. 
Isotopic compositions for a subset of the water samples collected were also measured. Specifically, the $\delta \mathrm{D}$ and $\delta^{18} \mathrm{O}$ were measured. In addition, where concentrations were above the analytical requirements for isotopic analyses of dissolved sulfate $\left(\delta^{34} \mathrm{~S}\right.$ and $\left.\delta^{18} \mathrm{O}\right)$, total dissolved inorganic carbon $\left(\delta^{13} \mathrm{C}\right)$, and methane $\left(\delta \mathrm{D}\right.$ and $\left.\delta^{13} \mathrm{C}\right)$ analyses were done. Reservoir temperatures were calculated from the offset of the $\delta^{18} \mathrm{O}$ values of the water and sulfate using the relationship published by Fowler et al. (2013) and compared with the results from the MEG values determined in this study.

\section{Geologic and geothermal setting of eastern Snake River Plain}

The Snake River Plain (SRP) is a topographic depression along the Snake River (Figure 1) in southern Idaho. The SRP is divided into two parts, the western Snake River Plain (WSRP) and the ESRP. The WSRP is a basalt- and sediment-filled tectonic feature defined by a normal fault-bounded graben whereas the ESRP is formed by crustal down-warping, faulting, and successive caldera formation that is linked to the middle Miocene to ongoing volcanic activities associated with the relative movement of the Yellowstone Hot Spot (Pierce and Morgan, 1992; Hughes et al., 1999; Rodgers et al., 2002). The $100 \mathrm{~km}$ wide ESRP extends over $600 \mathrm{~km}$ (Hughes et al., 1999). Four events in the late Tertiary are important for creating and shaping the ESRP (Hughes et al., 1999): (1) successive Miocene-Pliocene rhyolitic volcanic eruptive centers from the southwest near the common border of Idaho, Oregon, and Nevada trending northeast to Yellowstone National Park in northwest Wyoming, (2) Miocene to Holocene crustal extension which produced the Basin and Range province, (3) Quaternary basaltic flows, and (4) Quaternary glaciation and associated aeolian, fluvial, and lacustrine sedimentation and catastrophic flooding.

The ESRP consists of thick rhyolitic ash-flow tuffs, which are overlain by $>1 \mathrm{~km}$ of Quaternary basaltic flows (Figure 2). The felsic volcanic rocks at depth are the product of super volcanic eruptions associated with the Yellowstone Hotspot. These rocks progressively become younger to the northeast towards the Yellowstone Plateau (Pierce and Morgan, 1992; Hughes et al., 1999). The younger basalt layers are the result of several low-volume, monogenetic shield-forming eruptions of short-duration that emanated from northwest trending volcanic rifts in the wake of the Yellowstone Hot Spot (Hughes et al., 1999). The thick sequences of coalescing basalt flows with interlayered fluvial and aeolian sediments in the ESRP constitute a very productive cold water aquifer system above the volcanic ash-flow tuffs (Whitehead, 1992).

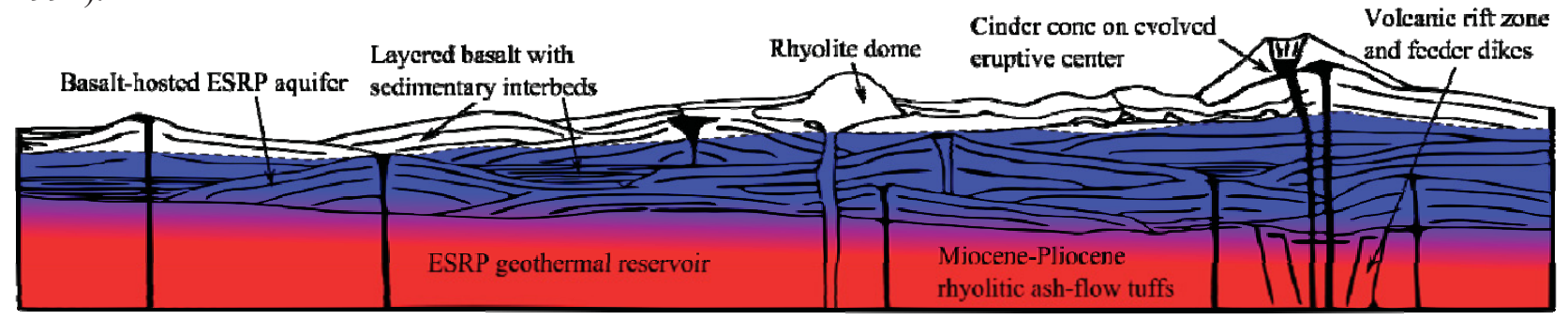

Figure 2. Schematic cross-section across the ESRP (modified from Hughes et al., 1999; Neupane et al., 2014) showing underlying rhyolitic ash-flow tuffs and overlying basalt flows with few sedimentary layers. The underlying rhyolite ash-flow tuffs are assumed to host the ESRP geothermal resources.

Recent volcanic activity, a high heat flux $\left[\sim 110 \mathrm{~mW} / \mathrm{m}^{2}\right.$ (Blackwell, 1989; Smith, 2004)], and the occurrence of numerous peripheral hot springs suggest the presence of potential geothermal resources in the ESRP. In particular, we consider the lower welded rhyolite ash-flow tuff zone (Figure 2) to have exploitable heat sources that can be tapped by conventional or engineered geothermal development.

The ESRP system as a whole (including the deep geothermal reservoir and the overlying cold-water aquifer system) is an open and dynamic hydrogeologic system. Most water from shallow wells and 
springs that exhibit a thermal expression in the ESRP are mixed waters of multiple sources, dominated by meteoric water with some deep-sourced thermal water (McLing et al., 2002; Smith, 2004; Welhan, 2015). The upwelling thermal waters interact with the basalt at the base of the regionally extensive cold water aquifer (Morse and McCurry, 2002), with the altered basalt forming a permeability barrier: this helps mask the expression of the deep thermal resource (Figure 2).

\section{Geothermometry}

One tool used to prospect for a geothermal resource is geothermometry, in which the chemical composition of water from springs and wells is used to estimate reservoir temperature. As an exploration tool, geothermometry offers a cost effective method to decrease exploration risk by evaluating a potential geothermal reservoir's temperature. To conduct geothermometry, the measured chemical compositions of water from wells and springs that exhibit some level of elevated temperatures are needed. The application of geothermometry requires several assumptions. The most important assumptions are that the reservoir minerals and fluid attain chemical equilibrium at reservoir temperatures and that as the water moves from the reservoir to the sample location, it retains its chemical composition (Fournier et al., 1974). The first assumption is generally valid for long residence times, but the second assumption is more likely to be violated because of composition altering processes, such as, re-equilibration at lower temperature, dilution (mixing), and loss of fluids (boiling) and gas degassing (e.g., $\mathrm{CO}_{2}$ ) with the decrease in pressure.

Traditional geothermometers are mostly empirical (semi-empirical) relationships between temperatures and concentrations (or concentration ratios) of one or more components (e.g., such as the Na-K-Ca geothermometer) or based on temperature-dependent solubility of single-phase mineral (e.g., silica geothermometers). To apply a traditional geothermometer, a user needs to collect thermal water sample, conduct a chemical analysis to obtain the concentration of the desired component(s), and enter the measured concentration of certain component(s) into the geothermometer equation to estimate a reservoir temperature. The reliability, sensitivity, and responsiveness of traditional geothermometers to processes that effect the fluid compositions vary. For example, geothermometers based on cation concentration ratios (e.g., $\mathrm{Na} / \mathrm{K}$ geothermometer) are minimally sensitive to boiling or mixing with dilute water, whereas geothermometers based on the concentration of a component(s) (e.g., quartz geothermometer) are highly sensitive to these processes (D'Amore and Arnórsson, 2000)). A drawback of many existing geothermometry approaches is that they do not adequately account for physical processes (e.g., mixing, boiling) and geochemical processes (e.g., mineral dissolution, precipitation, degassing, differences in actual mineral assemblages in the reservoir) that may alter the composition of specific chemical components. If these changes are not taken into account, predictions of in-situ reservoir conditions (e.g., temperature, $\mathrm{fCO}_{2}$ ) based on the chemical composition of water samples taken from shallower depths or at the surface may be erroneous or too imprecise to be useful.

In addition, it is difficult to quantify uncertainties associated with temperatures estimated with these geothermometers. As a result, it is not uncommon to find diverse temperature estimates for the same water using multiple traditional geothermometers. Nevertheless, because these geothermometers are easy to use and sometimes provide good results, they are considered to be an essential part of the geothermal exploration toolkit (D’Amore and Arnórsson, 2000).

A more advanced geothermometric approach is multicomponent equilibrium geothermometry (MEG). The MEG approach of geothermometry utilizes multiple chemical constituents measured in water samples for inverse geochemical modeling considering a suite of selected minerals (selected based on some knowledge of the system) so as to provide more robust temperature estimates with quantifiable uncertainties. Geothermal temperature predictions using MEG provide apparent improvement in reliability and predictability of temperature over traditional geothermometers. The basic concept of this method was developed in 1980s (e.g., Michard and Roekens, 1983; Reed and Spycher, 1984). Some previous investigators (e.g., D’Amore et al., 1987; Hull et al., 1987; Tole et al., 1993) have used this 
technique for predicting reservoir temperatures in various geothermal sites. Other researchers have used the basic principles of this method for reconstructing the composition of geothermal fluids and formation brines (Pang and Reed, 1998; Palandri and Reed, 2001). More recent efforts by some researchers (e.g., Bethke, 2008; Spycher et al., 2011; Smith et al., 2012; Cooper et al., 2013; Neupane et al., 2013, 2014; Cannon et al., 2014; Spycher et al., 2014; Peiffer et al., 2014; Palmer et al., 2014; Neupane et al., 2015a,b,c; Mattson et al., 2015; Neupane et al., 2016a,b) have been focused on improving temperature predictability of the MEG.

For this study, both traditional [e.g., quartz (no steam loss) (Fournier, 1977), chalcedony (Fournier, 1977), and Na-K-Ca (Truesdell and Fournier, 1973; Fournier and Potter, 1979)] and RTEst (Palmer et al., 2014; Mattson et al., 2015) geothermometric approaches were applied to estimate reservoir temperatures. For the silica geothermometers, a $\mathrm{pH}$ correction on silica concentrations was not applied. While applying RTEst to each water sample, a mineral assemblage consisting of 5-7 representative minerals (Mg bearing minerals - clinochlore, illite, saponite, beidellite, talc; Na bearing minerals - paragonite, saponite; K-

bearing minerals $-\mathrm{K}$-feldspar, clinoptilolite-K, illite; Ca bearing minerals - calcite; fluorite, and chalcedony) was used for the development of the reservoir temperature estimate for each sample. For each site, the same mineral assemblage was used for all samples using the same thermodynamic database (e.g., LNNL database based thermo.dat database of Geochemist's Workbench). In general, the mineral assemblage is selected based on available information such as water chemistry (e.g., pH), likely reservoir rock types and temperature range, etc. For more detailed information on selection of the mineral assemblage, see Palmer et al. (2014).

Another independent geothermometric approach is comparing the isotopic compositions of different components of the fluids to calculate the temperature at which the two components would have been in isotopic equilibrium (e.g., the oxygen isotopic composition of dissolved sulfate and the water or the carbon isotopic composition of dissolved inorganic carbon and methane). This approach can be very precise, but can also be affected by other processes including mixing with non-reservoir fluids or microbial metabolic processes that shift the isotopic compositions of the components of interest. Additionally, in some cases, the isotopic signatures of some fluid phases can also be used to identify interaction of fluids with rocks in high-temperature systems. For instance, the hydrogen and oxygen isotopic compositions of meteoric water are generally related to each other in a systematic way (Craig, 1961), but interaction with rocks at high temperatures will shift the oxygen isotopic composition of the water towards equilibrium with the rocks with little effect on the hydrogen isotopic composition of the water (Taylor, 1974) creating a distinctive water isotopic composition that can be used to infer high temperature interaction between the water and rocks. Similarly, the carbon and hydrogen isotopic compositions of dissolved methane can be used to distinguish formation in high temperature water-rock systems from methane formed from microbial processes (Welhan, 1988). The temperature estimates with isotope data were compared with temperature estimates with chemical data.

\section{Water samples}

\subsection{New data}

As a major part of this work, we initiated sampling campaigns during the spring and summer of 2014 and 2015 (Cannon et al., 2014; Dobson et al., 2015; Neupane et al., 2015c). The sampling campaigns were aimed at collecting samples from thermal features that have either incomplete available data or were not previously sampled/analyzed. Our goal was to develop an extensive thermal expression chemistry data set to be used for geothermometry calculations using RTEst as well as for analyzing for other trace elements, isotopes and noble gases (working with Pat Dobson of LBNL, Appendix K). Over the course of the project period, we collected and analyzed about 100 samples from thermal features in the ESRP and surrounding area (Appendix A). With the exceptions of some samples from the Preston, Malad, and Sun Valley, Idaho area, new water samples are used for geothermometry reported here. The general chemical 
compositions of water samples are given in Appendix B. The water chemistry data are also uploaded to the Geothermal Data Repository (GDR) web portal. Similarly, isotopic compositions of ESRP water samples are given in Appendix C.

\subsection{Historical data}

Existing southeast Idaho water composition data have been obtained from the Idaho Department of Water Resources, literature searches from the Web of Science, and dissertations the University of Idaho. Existing water composition data were evaluated for their quality (e.g., charge balance, etc.) and completeness (except Al) for MEG. Almost all of the historical data lacked measured concentrations of Al. For these samples, Al concentrations determined by assuming equilibrium with K-feldspar (Pang and Reed, 1998) was used in the geochemical modeling. In some instances, the Al values measured in new samples collected from nearby hot springs or hot wells were used. New and existing chemical data (Appendices B and C) were used for the estimation of reservoir temperatures with traditional geothermometers as well as with RTEst (Appendix D). In the past, historical data were used for preliminary evaluation of geothermal resources along the margins of the ESRP (e.g., Neupane et al., 2014). Some of the geothermal features with available good quality and complete geochemical data were also sampled as a part of this project. For most of these features, the existing data were found to be similar to the new chemical data. However, despite having good quality and complete existing data, Appendix B only contains data for features sampled for this project.

\subsection{Hot springs and nearby hot wells}

Compositions of water samples collected from hot springs and shallow wells exhibiting a thermal expression were used for the temperature estimation of several geothermal prospects in the ESRP (Appendix E). It is generally assumed that geothermal systems manifest some kind of surface signals such as hot springs or fumaroles, however, there have been some hidden or blind geothermal systems. For example, the Raft River geothermal system was identified when shallow (120-150 m deep) wells that were drilled for domestic and stock use encountered boiling water (Williams et al., 1976). Similarly, in the ESRP, the Newdale prospect (NEW in Figure 1) was first identified by the presence of numerous hot shallow wells in the area. However, how useful hot shallow waters can be for geothermometric calculations in the southern Idaho was an issue for us when we started this work.

To address the viability of using hot shallow wells as sampling locations to collect water samples for MEG analysis, we compared the MEG temperature estimates from hot springs and nearby wells in southern Idaho (Neupane et al., 2015c, see Appendix F). This study indicated that that the reservoir temperatures estimated using water compositions measured from surface thermal features and wells produce similar results. However, there are a few systems where the estimated reservoir temperatures based on water compositions measured from hot springs and hot wells are different. Neupane et al. (2015c) emphasized that when such differences exist, it is imperative to consider the consistency of the water types and distance between the sources when estimating reservoir temperatures. With the exception of the Durfee Hot Spring prospect [the same system was also noted by Neupane et al. (2015c) as one of two systems examined in southern Idaho that have divergent temperature estimates with hot spring and hot well compositions] (DHS in Figure 1), all other prospects with measured compositions from samples collected from hot springs and hot wells in the ESRP yielded similar results (see section 6).

\subsection{Geothermal prospects}

Based on the distribution of sampling features (Appendix A) and range of temperature estimates, 24 geothermal prospects with moderate to high reservoir temperatures have been identified (Figure 1 and Table 1). The number of samples from each prospect (Table 1) varies such that some prospects have multiple samples (e.g., Banbury Hot Springs prospect has 37 samples) from different sources whereas some prospects are based on the results for only a few samples (e.g., Wybenga Diary prospect has only 
one sample). Neupane et al. (2016a) (Appendix G) and Section 6.4 describes these geothermal prospects in the ESRP. More detailed descriptions of these prospects are provided in Appendix E.

\section{Results}

\subsection{Water chemistry}

The concentrations of major anions and cations in the water samples from hot/warm springs and wells in southeastern Idaho (Appendix B) are presented in Figure 3. All springs/wells (with a few exceptions such as the Spackman well in the Newdale prospect) that we sampled represent the expression of geothermal activities (field $\mathrm{T}>20^{\circ} \mathrm{C}$ ) in the ESRP. The highest field temperature within and along the margins of ESRP was recorded at the Magic Hot Spring Landing well $\left(75^{\circ} \mathrm{C}\right)$ in the Magic Hot Spring prospect (MHS in Figure 1). The $\mathrm{pH}$ of ESRP thermal waters ranges from 6.3 to 9.6. These thermal waters show a large range in total dissolved solids (TDS) from about $106 \mathrm{mg} / \mathrm{L}$ (Sturm well in Ashton prospect, AHS in Figure 1) to more than 7,000 mg/L (Heise Hot Spring, HHS in Figure 1).

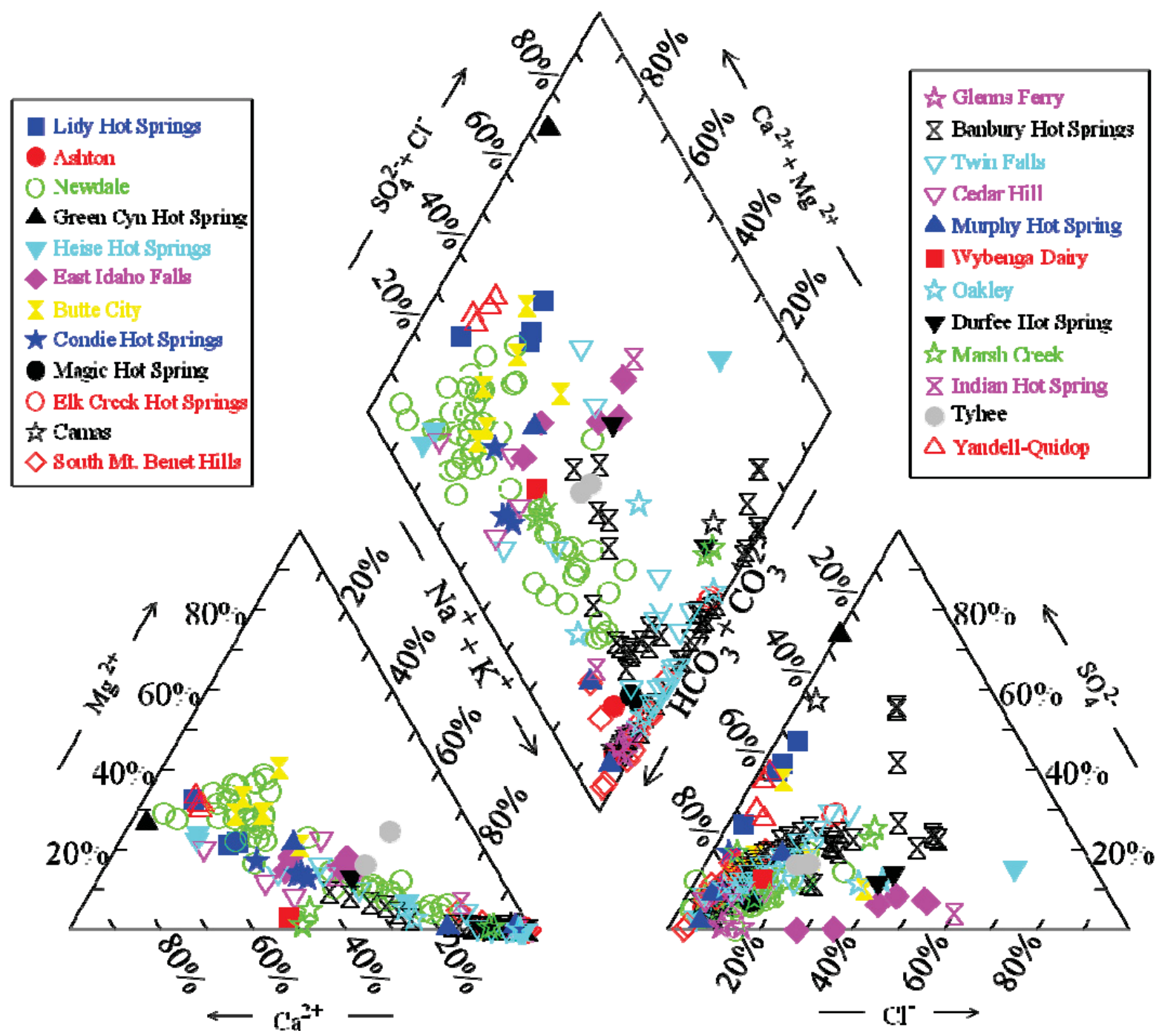

Figure 3. Chemistry of the ESRP thermal water samples shown on a Piper diagram

Based on the dominant ions (Figure 3) in water, ESRP waters can be grouped into 10 water types. These are $\mathrm{Ca}-\mathrm{HCO}_{3}, \mathrm{Mg}-\mathrm{HCO}_{3}, \mathrm{Ca}-\mathrm{Mg}-\mathrm{HCO}_{3}, \mathrm{Na}-\mathrm{HCO}_{3}, \mathrm{Ca}-\mathrm{SO}_{4}, \mathrm{Na}-\mathrm{SO}_{4}, \mathrm{Na}-\mathrm{Cl}, \mathrm{Na}-\mathrm{K}-\mathrm{HCO}_{3}, \mathrm{Na}-\mathrm{K}-\mathrm{Cl}-\mathrm{SO}_{4}$, 
and $\mathrm{Ca}-\mathrm{Na}-\mathrm{HCO}_{3}$ type waters. In general, ESRP waters have either $\mathrm{Ca}-\mathrm{Mg}$ or $\mathrm{Na}$ as the dominant cations and $\mathrm{HCO}_{3}$ as the dominant anion. The ESRP waters with dominant $\mathrm{HCO}_{3}$ may have been the product of carbonated water-rock interaction at low to high temperatures. Specifically, $\mathrm{Na}-\mathrm{HCO}_{3}$ waters are considered deeper ESRP water whereas $\mathrm{Ca}-\mathrm{Mg}-\mathrm{HCO}_{3}$ waters are shallower ESRPA water. The few water samples (e.g., Heise Hot Spring, Green Canyon Hot Spring, etc.) with $\mathrm{Cl}$ and/or $\mathrm{SO}_{4}$ as dominant anions may have originated with water-rock interaction involving Paleozoic evaporite beds.

\subsection{Isotope data}

The isotopic compositions of samples collected for isotope analyses are included in Appendix C.

Analyses were done of the $\delta \mathrm{D}$ and $\delta^{18} \mathrm{O}$ of all samples and plotted in Figure 4. Most of the samples plot close to the meteoric water line (precipitation in this region tends to be slightly offset to the right of the global meteoric water line), but there are several samples that have oxygen isotope composition shifted 1$3 \%$ to the right of the meteoric water line (e.g, Barron Well, Condie Hot Spring, Elk Creek Hot Spring 2, Magic Reservoir Landing Well). In addition, where concentrations were above the analytical requirements for isotopic analyses of dissolved sulfate $\left(\delta^{34} \mathrm{~S}\right.$ and $\left.\delta^{18} \mathrm{O}\right)$, total dissolved inorganic carbon $\left(\delta^{13} \mathrm{C}\right)$, and methane $\left(\delta \mathrm{D}\right.$ and $\left.\delta^{13} \mathrm{C}\right)$ analyses were done. Reservoir temperatures were calculated from the offset of the $\delta^{18} \mathrm{O}$ values of the water and sulfate using the relationship published by Fowler et al. (2013) and compared with the results from the other chemical geothermometers used for this study. Calculated temperatures for other isotopic geothermometers (e.g., carbon isotopes of dissolved inorganic carbon and methane and the hydrogen isotope compositions of water and methane) did not yield consistent results likely due to mixing with other sources of those compounds and are not presented here. The results of some of these data can be, however, useful indicators of potential deep, high-temperature systems.

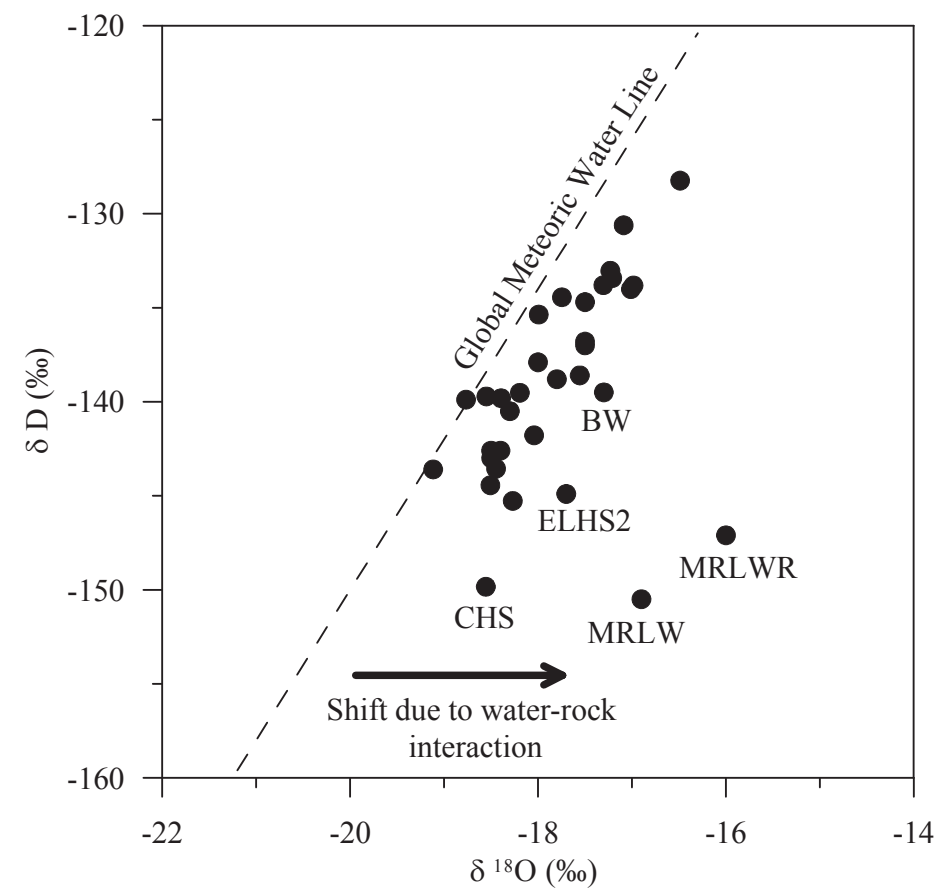

Figure 4. Hydrogen and oxygen isotopic compositions from ESRP water samples with the global meteoric water line for comparison. Most waters fall very close to the meteoric water line, but there are several samples that are significantly shifted to the right of the meteoric water line, which is an indication of oxygen isotope exchange during high-temperature water-rock interaction in hydrothermal systems. Abbreviations are- BW: Barron Well, CHS: Condie Hot Spring, ELHS2: Elk Creek Hot Spring 2, MRLW: Magic Reservoir Landing Well, and MRLWR: Magic Reservoir Landing Well runoff. 


\subsection{Geothermometric assessments}

\subsubsection{Giggenbach diagram}

The sample compositions are plotted on a Giggenbach ternary diagram (Giggenbach, 1988) to determine evidence of equilibration and/or mixing (Figure 5) as well as to illustrate the likely water-rock interaction temperatures in the reservoirs. This plot is useful classifying waters as either fully equilibrated waters, partially equilibrated, or immature waters. The diagram uses the full range of equilibrium relationships between $\mathrm{Na}, \mathrm{K}$, and $\mathrm{Mg}$ to determine the degree of equilibration between the water and the rock at depth. The plot suggests that the waters from several ESRP wells and springs are partially equilibrated that may have interacted with the reservoir rocks at temperatures ranging from $100{ }^{\circ} \mathrm{C}$ to $180{ }^{\circ} \mathrm{C}$. However, majority of the ESRP waters are immature waters, as indicated by elevated Mg contents (Appendix B, Figure 3). The immature waters may indicate significant mixing with cool meteoric waters, and traditional geothermometers may not be suitable tools for temperature estimation for these waters.

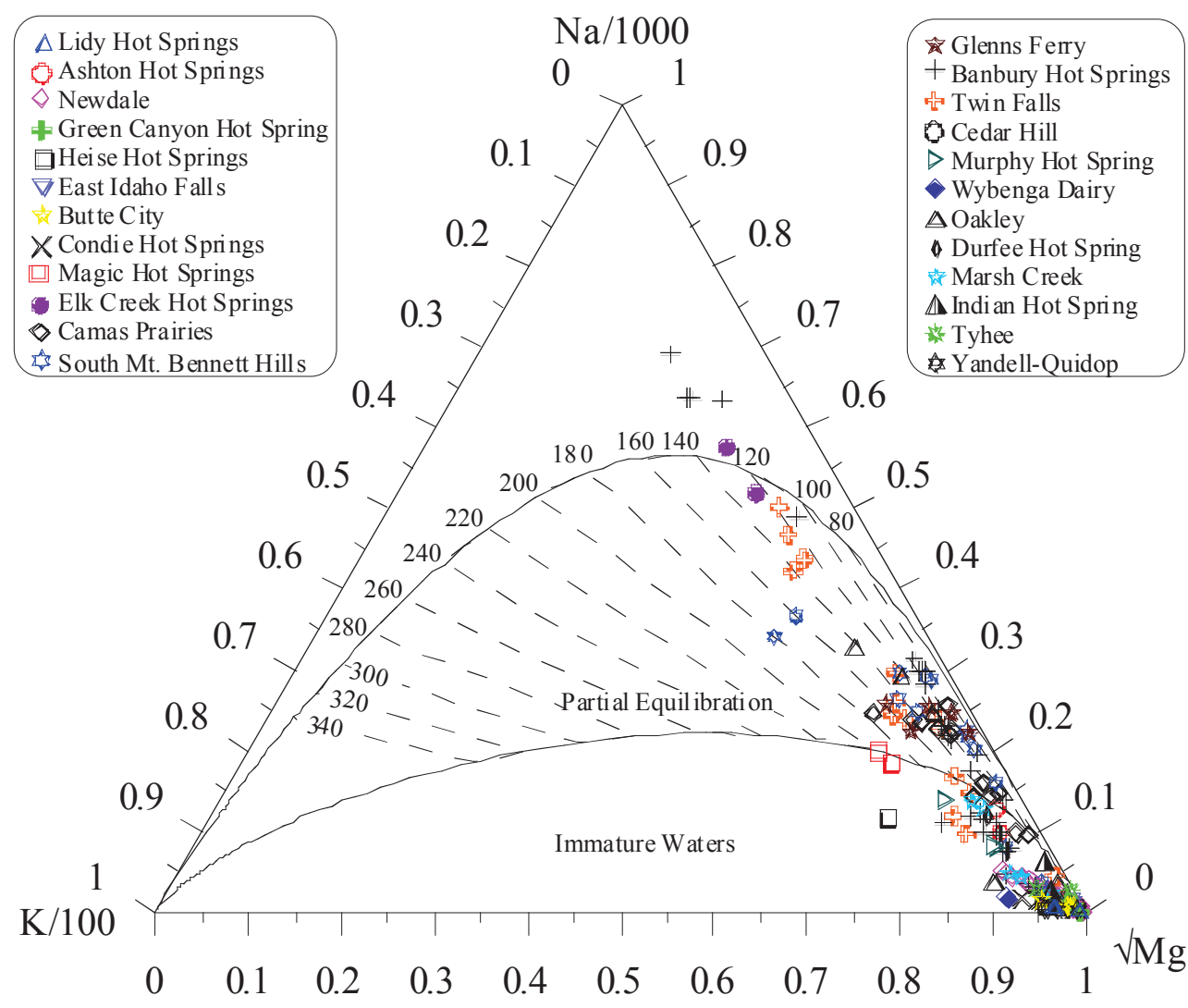

Figure 5. Giggenbach ternary diagram for the ESRP thermal water samples

\subsubsection{Temperature estimates with traditional geothermometers}

Traditional geothermometers were applied to measured water compositions for general assessment of the geothermal temperature at each sampling site. For the ESRP, the traditional geothermometer-based temperatures (Appendix D) can be difficult to use to assess the geothermal potential of prospects. For example, estimated temperature values for the Heise Hot Spring, range from $53{ }^{\circ} \mathrm{C}$ using chalcedony to $243{ }^{\circ} \mathrm{C}$ using $\mathrm{Na} / \mathrm{K}$ ratios. Nevertheless, for some samples from other prospects, such as a well at the College of Southern Idaho (CSI Well2) representing the Twin Falls geothermal prospect, the estimated 
Table 1. Estimated temperatures $\left({ }^{\circ} \mathrm{C}\right)$ for potential geothermal prospects in the ESRP

\begin{tabular}{|c|c|c|c|c|c|c|c|c|}
\hline Prospects & $\begin{array}{c}\text { Map } \\
\text { Code }^{a}\end{array}$ & Measured $^{\mathrm{b}}$ & $\mathrm{RTEst}^{\mathrm{c}}$ & $\begin{array}{c}\mathrm{SO}_{4}-\mathrm{H}_{2} \mathrm{O} \\
\delta^{18} \mathrm{O}^{\mathrm{d}}\end{array}$ & $\begin{array}{l}\text { Quartz } \\
(n s l)^{\mathrm{e}}\end{array}$ & Chalcedony $^{\mathrm{f}}$ & $\mathrm{Na}-\mathrm{K}-\mathrm{Ca}^{\mathrm{g}}$ & $\begin{array}{c}\text { Silica- } \\
\text { enthalpy }\end{array}$ \\
\hline $\begin{array}{l}\text { Lidy Hot } \\
\text { Springs }\end{array}$ & LHS & 56 & $116-140$ & 127 & $57-89$ & $25-58$ & $44-65$ & $60(130)$ \\
\hline $\begin{array}{l}\text { Ashton Hot } \\
\text { Spring }\end{array}$ & AHS & 66 & $147-152$ & & $113-143$ & $84-116$ & $109-117$ & \\
\hline Newdale & NEW & 87 & $75-152$ & 87 & 66-134 & $26-112$ & $29-111$ & $174(224)$ \\
\hline $\begin{array}{l}\text { Green Cyn } \\
\text { Hot Spring }\end{array}$ & GCHS & 44 & 94 & 29 & 75 & 44 & 65 & \\
\hline $\begin{array}{l}\text { Heise Hot } \\
\text { Spring }\end{array}$ & HHS & 48 & 88 & 65 & 84 & 53 & 89 & \\
\hline $\begin{array}{l}\text { East Idaho } \\
\text { Falls }\end{array}$ & EIF & 28 & $136-146$ & & $115-143$ & $86-117$ & $45-74$ & \\
\hline Butte City & $\mathrm{BC}$ & 41 & $49-80$ & $92-95$ & $70-106$ & $38-77$ & $37-43$ & $75(124)$ \\
\hline $\begin{array}{l}\text { Condie Hot } \\
\text { Spring }\end{array}$ & CHS & 51 & $73-106$ & $102-105$ & $71-82$ & $40-51$ & $71-83$ & $52(100)$ \\
\hline $\begin{array}{l}\text { Magic Hot } \\
\text { Spring }\end{array}$ & MHS & 75 & $151-163$ & $233-237$ & $139-142$ & $113-116$ & 143-149 & \\
\hline $\begin{array}{l}\text { Elk Creek Hot } \\
\text { Springs }\end{array}$ & ECHS & 56 & $123-125$ & 136 & 114-115 & 86 & $107-110$ & \\
\hline Camas Prairie & $\mathrm{CP}$ & 73 & 79-204 & $133->300$ & $103-128$ & $74-100$ & $70-124$ & $133(173)$ \\
\hline $\begin{array}{l}\text { South Mt. } \\
\text { Bennett Hills }\end{array}$ & SBH & 68 & $82-197$ & 154 & $110-143$ & $80-117$ & $72-160$ & $150(182)$ \\
\hline Glenn's Ferry & $\mathrm{GF}$ & 39 & $67-85$ & & 80-109 & $48-79$ & $74-138$ & $108(150)$ \\
\hline $\begin{array}{l}\text { Banbury Hot } \\
\text { Springs }\end{array}$ & BHS & 72 & $102-163$ & $99-159$ & 98-139 & $67-127$ & $69-165$ & $135(171)$ \\
\hline Twin Falls & $\mathrm{TF}$ & 43 & 83-136 & 133 & $77-119$ & $45-91$ & $70-132$ & $121(157)$ \\
\hline Cedar Hill & $\mathrm{CH}$ & 38 & $75-127$ & & $62-116$ & $29-87$ & $50-129$ & \\
\hline $\begin{array}{l}\text { Murphy Hot } \\
\text { Spring }\end{array}$ & MHS & 55 & $88-117$ & & $119-148$ & $90-122$ & $57-144$ & \\
\hline $\begin{array}{l}\text { Oakley Hot } \\
\text { Spring }\end{array}$ & OHS & 47 & $73-130$ & $92-157$ & $77-125$ & $45-97$ & $45-155$ & \\
\hline $\begin{array}{l}\text { Durfee Hot } \\
\text { Spring }\end{array}$ & DHS & 45 & $101-138$ & 104 & $96-117$ & $66-88$ & $46-131$ & \\
\hline Marsh Creek & $\mathrm{MC}$ & 60 & 96-141 & 142 & 96-113 & $66-83$ & $48-89$ & \\
\hline $\begin{array}{l}\text { Wybenga } \\
\text { Dairy }\end{array}$ & WD & 34 & 132 & & 118 & 89 & 189 & \\
\hline $\begin{array}{l}\text { Indian Hot } \\
\text { Spring }\end{array}$ & IHS & 39 & 70 & 174 & 64 & 32 & 75 & \\
\hline Tyhee & TY & 41 & 69 & & $63-93$ & $31-62$ & 52 & \\
\hline $\begin{array}{l}\text { Quidop- } \\
\text { Yandell }\end{array}$ & QY & 38 & $59-90$ & & $55-63$ & $23-31$ & $43-63$ & \\
\hline
\end{tabular}

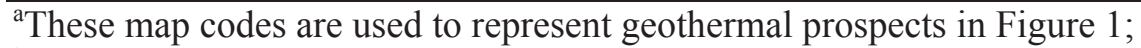

${ }^{\mathrm{b}}$ maximum measured temperature for the prospects;

${ }^{\mathrm{c}} \mathrm{RTEst}$ estimated temperature range;

${ }^{\mathrm{d}}$ sulfate-water ${ }^{18} \mathrm{O}$ isotope geothermometer (Fowler et 1., 2013);

equartz (no steam loss) geothermometer temperature (Fournier,1977);

f chalcedony geothermometer temperature (Fournier,1977);

${ }^{\mathrm{g}} \mathrm{Mg}$-corrected (where applicable) Na-K-Ca geothermometer temperature (Fournier and Truesdell, 1973;

Fournier and Potter II, 1979);

${ }^{\mathrm{h}}$ temperature with silica-enthalpy mixing model (where applicable) using chalcedony solubility

(temperature with quartz solubility given in parenthesis) (Fournier, 1977). 
temperatures range from $85{ }^{\circ} \mathrm{C}$ to $140{ }^{\circ} \mathrm{C}$ suggesting relatively good agreement between the traditional geothermometry temperature estimates. In general, we have found that in the ESRP, the estimated reservoir temperatures using the $\mathrm{Na} / \mathrm{K}$ rations are higher than estimated temperatures obtained $[\mathrm{Na} / \mathrm{K}$ temperatures are not included (except Giggenbach diagram) in this report] with other geothermometers. However, for some systems (e.g., Driscoll Spring and Well, Banbury Hot Spring, etc.), Na/K estimated temperatures are cooler than temperatures with other geothermometers.

\subsubsection{Temperature estimates with RTEst}

All water samples collected during the sampling campaigns of 2014 and 2015 as well as useful water compositions assembled from the literature for this study (Appendix B) were individually used for the temperature estimation with RTEst (Table 1, Appendix D). For each sample, 5-7 minerals (consisting mainly of silica-polymorphs, clays, zeolites, carbonates, sulfates, feldspars, etc.) were selected as a mineral assemblage.

An example of the RTEst results for a water sample collected from Miracle Hot Spring well located in Banbury Hot Springs prospect (BHS in Figure 1) is shown in Figure 6. Figure 6a shows $\log \left(\mathrm{Q} / \mathrm{K}_{\mathrm{T}}\right)$ curves of the reservoir mineral assemblage RMA (calcite, chalcedony, beidellite, mordenite, and paragonite) used for the Miracle Hot Spring water composition. The $\log \left(\mathrm{Q} / \mathrm{K}_{\mathrm{T}}\right)$ curves of these minerals intersect the $\log \left(\mathrm{Q} / \mathrm{K}_{\mathrm{T}}\right)=0$ at a wide range of temperatures, making the $\log \left(\mathrm{Q} / \mathrm{K}_{\mathrm{T}}\right)$ curves derived from the reported water chemistry minimally useful for estimating temperature. The range of equilibration temperature for the assemblage minerals is a reflection of physical and chemical processes that may have modified the Miracle Hot Spring water composition during its ascent to the sampling point.
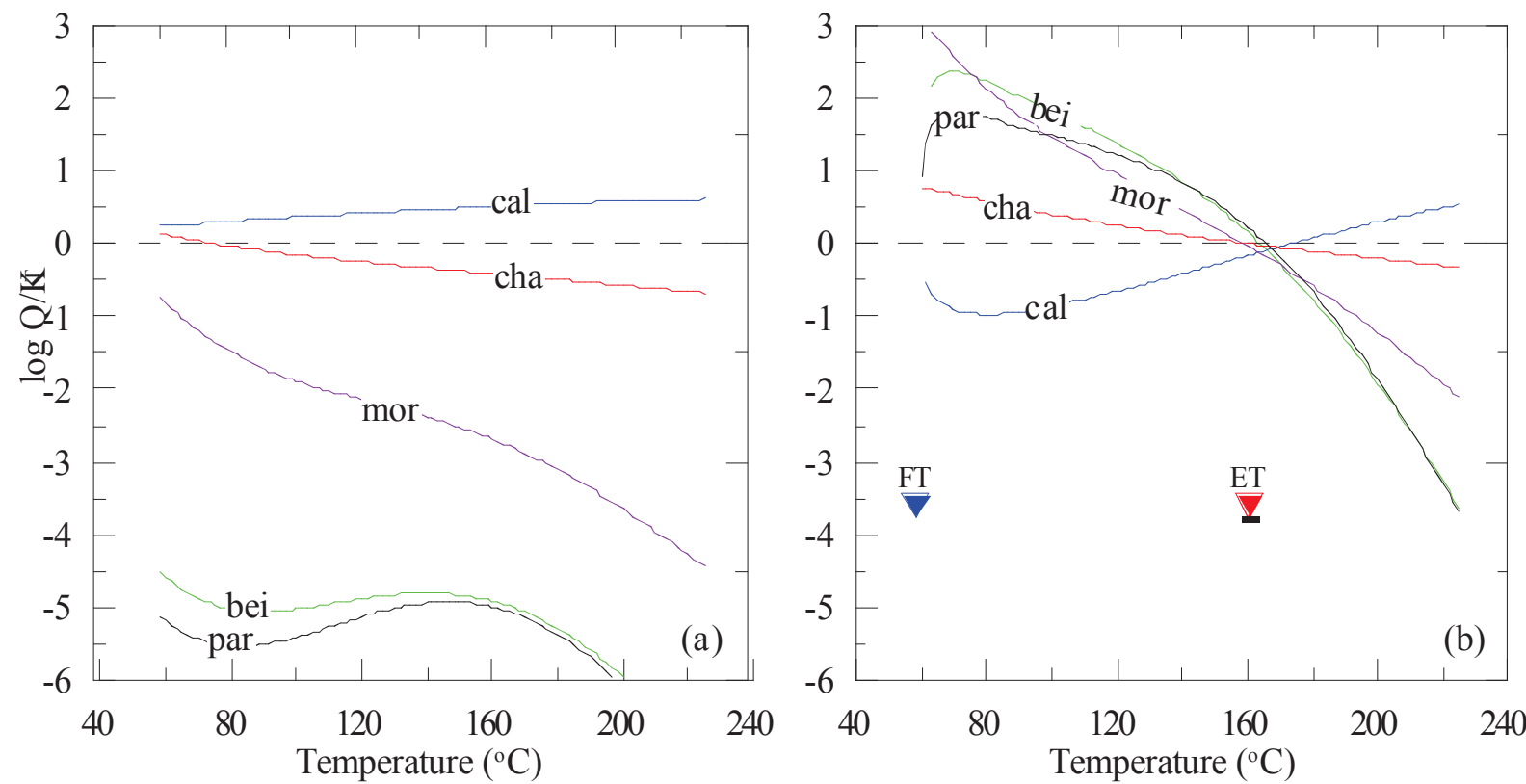

Figure 6. Graphical representation of RTEst analysis of Miracle Hot Spring well located in the

Banbury Hot Springs prospect (see Figure 1). a) $\log Q / K_{T}$ plot for assemblage minerals using observed fluid composition, b) $\log \mathbf{Q} / K_{\mathrm{T}}$ plot for assemblage minerals using RTEst optimized fluid composition. Mineral assemblage includes: bei: beidellite-Mg, cal: calcite, cha: chalcedony, mor: mordenite-Na, and par: paragonite.

To account for possible composition altering processes, RTEst was used to simultaneously estimate a reservoir temperature and optimize the amount of dilute near-surface $\mathrm{H}_{2} \mathrm{O}$ mixed with the thermal water (a physical process) and the fugacity of $\mathrm{CO}_{2}$ change (a chemical process) that may have occurred during 
its ascent to the surface. Using these two additional optimization parameters, the results for the corrected fluid composition of Miracle Hot Spring are shown in Figure 6b. Compared to the $\log \left(\mathrm{Q} / \mathrm{K}_{\mathrm{T}}\right)$ curves calculated using the reported water compositions (Figure 6a), the optimized curves (Figure 6b) converge to $\log \left(\mathrm{Q} / \mathrm{K}_{\mathrm{T}}\right)=0$ within a narrow temperature range (i.e., $161 \pm 3{ }^{\circ} \mathrm{C}$ ).

The optimized temperatures and composition parameters for the other ESRP waters were estimated using RTEst in the same manner. The RTEst estimated temperatures for the ESRP geothermal samples range from about $60{ }^{\circ} \mathrm{C}$ to $204{ }^{\circ} \mathrm{C}$ (Table 1). The hottest reservoir temperature estimate is obtained for Wardrop Hot Spring located in north-central part of Camas Prairie (CP in Figure 1). Similarly, hot springs located on the southern side of the Mount Bennett Hills (e.g., Prince Albert Hot Spring, Latty Hot Spring) (SBH in Figure 1) also have reservoir temperature estimates as high as $200^{\circ} \mathrm{C}$.

\subsubsection{Temperature estimates from sulfate-water oxygen isotope geothermometry}

Also included in Table 1 (and Appendix C) are estimated reservoir temperatures calculated from the relationship between the $\delta^{18} \mathrm{O}$ values of dissolved sulfate and water in samples containing sufficient sulfate for these analyses. In general, the calculated RTEst temperatures and sulfate-water oxygen isotope temperatures are similar (Figure 7). In some cases, most notably for some samples where there are thought to be other sources of subsurface sulfate present (e.g., Heise and Green Canyon samples where evaporite beds are believed to be present in the subsurface), the results are not consistent. In a few other instances, the sulfate-water isotope temperatures are significantly higher than the RTEst temperatures [e.g., the Magic Reservoir Hot Springs well and the Barron's Well). The isotope temperature could be closer to actual temperatures due to significant dilution with shallow groundwater that may have altered the water chemistry without adding sulfate to the water. Conversely, the oxygen isotope composition of the water may have been shifted due to boiling of the fluids in the subsurface leading to erroneously high temperature estimates. It is notable, however, that the samples in question also have other indicators of high temperature fluids in the form of magmatic methane and shifted water isotope compositions. In addition, many of these samples also contained high ${ }^{3} \mathrm{He} /{ }^{4} \mathrm{He}$ values for dissolved helium, another indicator of deep, magmatic systems (Dobson et al., 2015). 


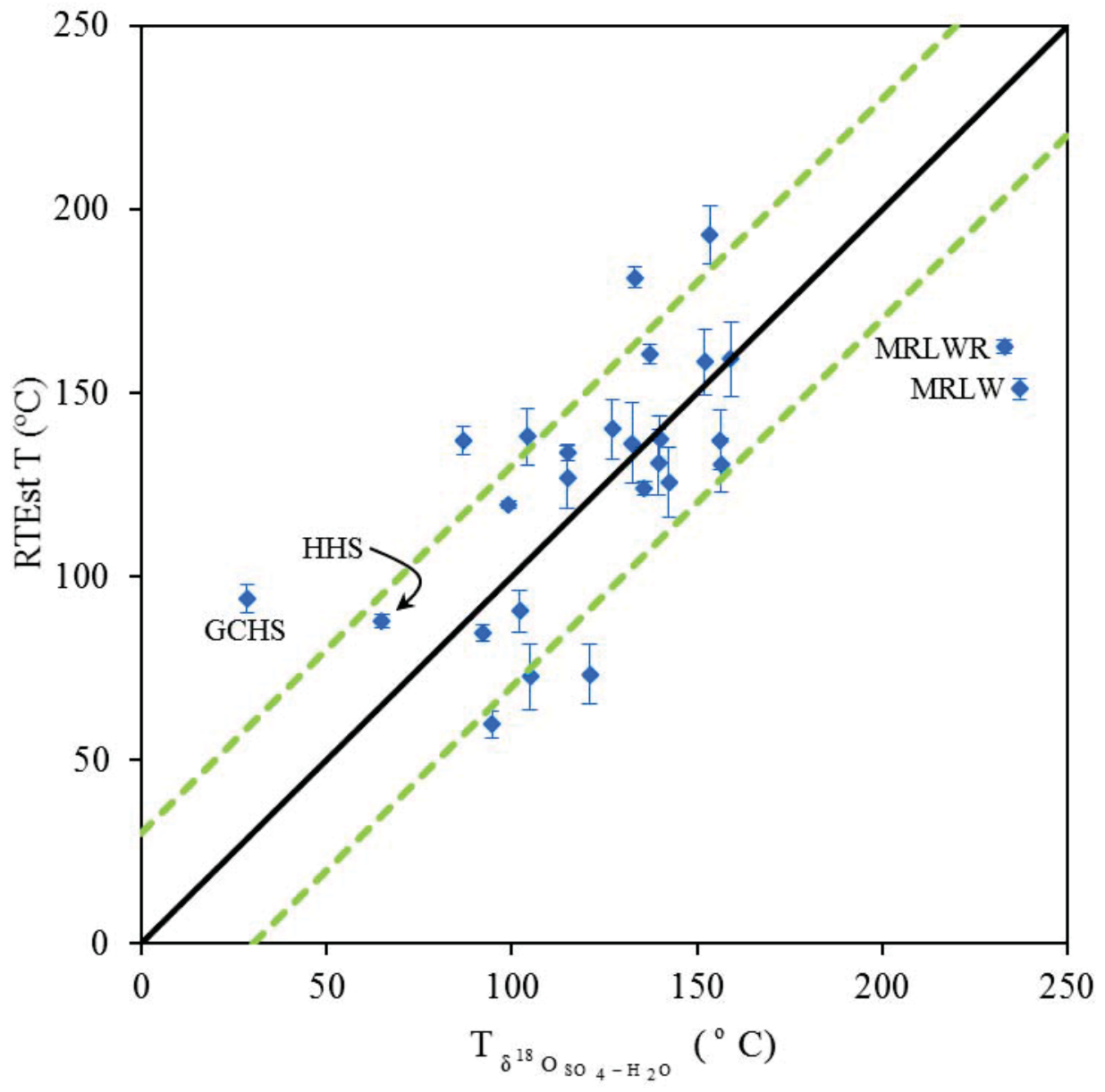

Figure 7. RTEst temperature estimates versus sulfate-water oxygen isotope temperature estimates for the ESRP thermal water samples. The solid line represents a 1:1 comparison and the dashed lines indicate the range of temperatures within $\pm 30^{\circ} \mathrm{C}$ of each other. The abbreviations in the figure are- HHS: Heise Hot Spring, GCHS: Green Canyon Hot Spring, MRLWR: Magic Reservoir Landing well runoff, MRLW: Magic Reservoir Landing well. The Barron well is not shown in this figure because of the sulfate-water oxygen temperature estimate is far above $\left(419^{\circ} \mathrm{C}\right)$ the maximum axis temperature.

\subsection{Some geothermal prospects and their reservoir temperatures}

Table 1 summarizes likely reservoir temperature range for all geothermal prospects within and along the margins of the ESRP identified in this study. The RTEst estimated temperature range for each prospect is also given in Figure 1. Some of the highest temperature prospects in the ESRP region are Lidy Hot Springs (LHS), Magic Hot Spring (MHS), Camas Prairie (CP), south of Mount Bennett Hills (SBH), Banbury Hot Springs (BHS), east Idaho Falls (EIF), Newdale (NEW), and Ashton Hot Spring (AHS) (Figure 1). The geothermal potential of some of these prospects are also identified by the first phase of the SRP Play Fairway analysis (Shervais et al., 2015). Below we provide brief summaries for some of the promising geothermal prospects in the ESRP region. Detailed geologic and geothermal settings along with water chemistry and geothermometric results for all geothermal prospects are given in Appendix E. 


\subsubsection{Lidy Hot Springs}

The Lidy Hot Springs prospect (LHS in Figure 1) is located at the southeastern end of the Beaverhead Mountains in Clark County in Idaho. Beginning in the early 20th century, the area was developed into a commercial recreation site that provided activities such as swimming, soaking, dancing, dining, and lodging to the public. However, with the transfer of ownership in the early 1960s, the site ceased to offer those services and started a travertine mining activity. Two hot springs in the area are still issuing thermal water $\left(52-56^{\circ} \mathrm{C}\right)$. In the vicinity of the Lidy Hot Springs, there are other springs (e.g., Warm Spring 29 ${ }^{\circ} \mathrm{C}$ ) issuing warm to cooler waters.

Rocks underlying the Lidy Hot Springs area consist of young volcanics and older meta-sedimentary rocks (Link, 2002). The younger rocks (Upper Miocene and Pliocene) consist of fluvial and lacustrine deposits, felsic volcanic rocks, rhyolite flows, tuffs, and ignimbrites. Thick sequences of Paleozoic sedimentary rocks $(\mathrm{Pz})$ underlie the Tertiary rock types, and likely constitute the geothermal reservoir in the area (see Appendix E for detailed information).

The RTEst estimated reservoir temperature for the Lidy Hot Springs prospect is about $140{ }^{\circ} \mathrm{C}$ (Table 1). RTEst modeling results show that the Lidy Hot Springs water may contain up to $60 \%$ cooler water and $40 \%$ deeper thermal water. Similarly, no-steam loss silica-enthalpy mixing model with the quartz solubility curve (Fournier, 1977; Fournier and Porter, 1982) yields a reservoir temperature of about $130^{\circ} \mathrm{C}$. The sulfate-water $\delta^{18} \mathrm{O}$ temperature calculated for this sample was in the same range as these temperatures at $127^{\circ} \mathrm{C}$. However, silica-enthalpy mixing model with the chalcedony solubility curve (modified from Fournier, 1977; Fournier and Porter, 1982) yields a cooler temperature (about $60{ }^{\circ} \mathrm{C}$ ).

\subsubsection{Ashton Hot Spring}

The Ashton Hot Spring and associated geothermal area (AHS in Figure 1) is located on the northern side of Ashton in Fremont County in Idaho. The existence of Ashton Hot Spring with a surface water temperature of $41^{\circ} \mathrm{C}$ was previously reported by Mitchell et al. (1980). A $1220 \mathrm{~m}$ deep geothermal exploratory well (Sturm Well-1) was drilled about $2 \mathrm{~km} \mathrm{NE}$ from the Ashton Hot Spring in 1979 (Occidental Geothermal Inc., 1979). Driller's records indicate a bottom-hole temperature of about $63{ }^{\circ} \mathrm{C}$.

Geologic mapping of the area shows thin layers of Quaternary sediments covering underlying volcanic rocks (Link, 2002). Borehole records from the area reveal the presence of thick sequences of flood basalts and felsic volcanics. Specifically, along the Sturm Well-1, the Quaternary sediments near the surface are underlain by layers of flood basalts (up to a depth of $82 \mathrm{~m}$ ), felsic volcanics ( $82-808 \mathrm{~m}$ ), and again flood basalts $(808-1220+\mathrm{m}$ ) with depth (Occidental Geothermal Inc., 1979) (see Appendix E for detailed information).

Quartz and chalcedony geothermometers yielded reservoir temperatures of $143{ }^{\circ} \mathrm{C}$ and $116{ }^{\circ} \mathrm{C}$ for Ashton Hot Spring and $113{ }^{\circ} \mathrm{C}$ and $84{ }^{\circ} \mathrm{C}$ for the Sturm Well, respectively. For these two sampled features, Na-K$\mathrm{Ca}$ geothermometer resulted in $117^{\circ} \mathrm{C}$ and $109^{\circ} \mathrm{C}$, respectively. Similarly, the RTEst produced reservoir temperatures for the Sturm Well and Ashton Hot Spring are $152 \pm 14{ }^{\circ} \mathrm{C}$ and $147 \pm 5^{\circ} \mathrm{C}$, with nearly $70 \%$ and $35 \%$ admixing of cooler water, respectively. All of these temperatures are significantly higher than the bottom hole temperature measured for the Sturm Well $\left(63{ }^{\circ} \mathrm{C}\right)$. Given the measured temperature gradient $\left(48^{\circ} \mathrm{C} / \mathrm{km}\right.$, Blackwell, 1989), such temperature conditions might be found at depths of about 3 $\mathrm{km}$. Samples for isotopic analyses were collected from both locations, but the sulfate concentrations were too low for analysis.

\subsubsection{Newdale area}

The Newdale geothermal prospect (NEW in Figure 1) in Madison and Fremont Counties in Idaho represents a blind geothermal system, as it has no hot springs. The geothermal potential of the Newdale area was identified in late 1970s by several researchers (e.g., Brott et al., 1976), based on the discovery of relatively high heat flow $\left(167 \mathrm{~mW} / \mathrm{m}^{2}\right)$. The area between Newdale town to the NE across the Teton River 
has been considered as a potential area for geothermal energy (Brott et al., 1976, GeothermEx, 2010; Neupane et al., 2016b)). During 1979-1981, Union Oil of California (Unocal) drilled several geothermal test wells in the area ranging in depth from $183 \mathrm{~m}$ (Newdale No. 79-3) to $1204 \mathrm{~m}$ (Madison Geothermal No.1 near Rexburg, ID). The highest recorded temperature in the Unocal wells was $87.2^{\circ} \mathrm{C}$ (Well \# State 2591-07-79-1).

A surficial geologic map of this area shows the presence of Quaternary sediments, Quaternary flood basalts, and Quaternary felsic volcanic rocks (Bond, 1978; Link, 2002; Embree et al., 2011). Early Pleistocene flood basalts are mapped around the town of Newdale whereas felsic volcanic rocks of similar ages (Huckleberry Ridge Tuff) are mapped NE from Newdale. In geologic cross-section, Embree et al. (2011) show Huckleberry Ridge Tuff lying underneath the Early Pleistocene basalt at Newdale. Below the Huckleberry Ridge Tuff lie the Tertiary sediments intercalated with Tertiary basalt. Subsurface lithologic records of numerous wells in the area as compiled by Idaho Geological Survey indicate the presence of thick sequences of rhyolites and tuff at greater depths (see Appendices E and $\mathrm{H}$ for detailed information).

Quartz, chalcedony, and $\mathrm{Na}-\mathrm{K}-\mathrm{Ca}(\mathrm{Mg}$ corrected) geothermometers resulted reservoir temperatures in the range of $66-134{ }^{\circ} \mathrm{C}, 28-112{ }^{\circ} \mathrm{C}, 29-111^{\circ} \mathrm{C}$, respectively. A silica (chalcedony)-enthalpy mixing model using all Newdale area samples results in reservoir temperature of about $174{ }^{\circ} \mathrm{C}$. Similar mixing models using quartz solubility results in even higher temperature estimates $\left(224^{\circ} \mathrm{C}\right)$. The RTEst temperature estimates for the Newdale area samples range $75-152{ }^{\circ} \mathrm{C}$ (Table 1) and a sulfate-water oxygen isotope temperature obtained for a sample from the area was $87^{\circ} \mathrm{C}$. The lower end RTEst temperature estimates and the isotope temperature for this area are similar to the bottom hole temperatures $\left(83-87^{\circ} \mathrm{C}\right)$ measured in two relatively deep $(\sim 1000 \mathrm{~m})$ Unocal wells. Moreover, it is likely that the area hosts even higher temperatures at greater depths that would correspond to a hotter zone at depth reaching to the higher end RTEst temperatures. Assuming an $80^{\circ} \mathrm{C} / \mathrm{km}$ thermal gradient (as indicated by two Unocal wells), the higher end RTEst temperatures would be present at about $2 \mathrm{~km}$ below ground surface.

\subsubsection{East Idaho Falls area}

The foothills (1480-1580 m above sea level) along the margins of the ESRP east of Idaho Falls (EIF in Figure 1) in Bonneville County have been known to have some wells producing warm water. Ralston et al. (1981) initially reported the geothermal potential of the area. Specifically, they noted the existence of two wells in Rim Rock Estate that produce $\geq 20{ }^{\circ} \mathrm{C}$ water. Recently drilled shallow wells (depth up to 244 $\mathrm{m}$ ) in the Comore Loma and Blackhawk communities few kilometers south from Rim Rock Estate also produce warm $\left(21-28^{\circ} \mathrm{C}\right)$ water.

The area lies on the edge of the SRP where pronounced volcanism has taken place throughout the past 6.5 Ma. The foothills to the east of Idaho Falls consist predominantly of tuffs, ignimbrites, and ash flows related to the Miocene-Pliocene Heise volcanic field (Morgan and McIntosh, 2005). Although all shallow wells in the area bottomed out within the volcanic rocks, the volcanic rocks in the area are thought to be about $300 \mathrm{~m}$ in thickness. Mesozoic sedimentary rocks that include the limestones, sandstones, siltstones, conglomerates, and evaporite beds underneath the young volcanic rocks are assumed to be the geothermal reservoir in this area (see Appendix E for detailed information).

Quartz, chalcedony, and Na-K-Ca temperature estimates for east Idaho Falls area range from $115-143{ }^{\circ} \mathrm{C}$, 86-117 ${ }^{\circ} \mathrm{C}$, and $45-74^{\circ} \mathrm{C}$, respectively. The $\mathrm{Mg}$-corrected Na-K-Ca temperature estimates for these samples are lower because of the presence of high concentrations of $\mathrm{Mg}$. The RTEst temperature estimates of east Idaho Falls water samples are very similar with a range from $136-143{ }^{\circ} \mathrm{C}$ (Table 1). No isotope samples were collected from this area.

\subsubsection{Magic Hot Spring}

The Magic Hot Spring prospect (MHS in Figure 1) is located on the northern margin of the ESRP in Camas and Blaine Counties in Idaho. Until a $79 \mathrm{~m}$ deep well (Magic Reservoir landing well) was drilled 
for direct use purposes in 1965 , the hot spring issued $36^{\circ} \mathrm{C}$ water (Ross, 1970). However, with the operation of the well, the hot spring dried out (Mitchell, 1976). At the beginning, the well was producing water at $66^{\circ} \mathrm{C}$, however, the water temperature subsequently increased to $74{ }^{\circ} \mathrm{C}$ by 1975 (Mitchell, 1976; Mitchell et al., 1980). The most recent (2014) temperature record for the surface discharge of the well (our data) is $75^{\circ} \mathrm{C}$.

The Magic Hot Spring area consists predominantly of Miocene-Quaternary silicic volcanic rocks and basalt flows (Struhsacker et al., 1982). The Pliocene-Miocene Poison Creek Tuff is the uppermost unit in the immediate vicinity of Magic Reservoir and is underlain by the Miocene Tuff of the Idavada Group. Other rhyolites and basalt flows are abundant in the surrounding areas but not shown in cross-section. The Cretaceous Idaho Batholith granitic rocks form the basement throughout the region (see Appendix D for detailed information).

Quartz (no steam loss), chalcedony, and Mg-corrected Na-K-Ca geothermometers resulted in 139 and 142 ${ }^{\circ} \mathrm{C}$, and 113 and $116^{\circ} \mathrm{C}$, and 153 and $152^{\circ} \mathrm{C}$ with compositions measured in water samples from the well leak and leak runoff channel, respectively. The chalcedony-enthalpy mixing model resulted in an estimated $145{ }^{\circ} \mathrm{C}$ reservoir temperature with about $50 \%$ dilution. Similarly, the quartz-enthalpy mixing model resulted in $181{ }^{\circ} \mathrm{C}$ reservoir temperature with about $60 \%$ dilution. The RTEst results indicate that the Magic Hot Spring geothermal area has a reservoir temperature about $163{ }^{\circ} \mathrm{C}$ (Table 1).

The sulfate-water $\delta^{18} \mathrm{O}$ temperature for this well is $237^{\circ} \mathrm{C}$, which is higher than the values calculated using the chemical geothermometers. However, the $\delta^{18} \mathrm{O}$ of the waters were highly shifted from meteoric values (Figure 4), indicating extensive high temperature interaction with the reservoir rocks. In addition, the isotopic composition of dissolved $\mathrm{CH}_{4}$ in the sample was typical of $\mathrm{CH}_{4}$ produced in high-temperature magmatic systems (Appendix I). Taken together, these isotopic signals are all indicate a high-temperature system at depth (Conrad et al., 2016).

\subsubsection{Camas Prairie area}

Camas Prairie (CP in Figure 1) is an east-west elongated (about $50 \mathrm{~km}$ by $15 \mathrm{~km}$ ) inter-montane valley in Camas and Elmore Counties in Idaho. The area has several hot springs [besides the Elk Creek Hot Springs (ECHS in Figure 1) in the northeastern part of the prairie]. The Sheep and Wolf Hot Springs are located in the western part of Camas Prairie, about $4 \mathrm{~km}$ north of Hill City in Idaho. These two hot springs, separated approximately $100 \mathrm{~m}$ from each other, issue hot water at about $50{ }^{\circ} \mathrm{C}$. Two additional hot springs in the area are Wardrop Hot Springs $\left(60^{\circ} \mathrm{C}\right)$, located on the northern side of prairie near the base of the Soldier Mountains, and Barron Hot Spring $\left(73^{\circ} \mathrm{C}\right)$, located on the southern side of the prairie near the base of the Mount Bennett Hills. The area also has several hot shallow wells, scattered mostly in the Wardrop Hot Springs and the Barron Hot Spring areas.

Camas Prairie is bounded by the Mount Bennett Hills to the south and the Soldier Mountains to the north (see Appendix D for detailed information). The Mount Bennett Hills are composed predominantly of Miocene rhyolitic ash flows and lava flows of the Idavada Volcanic Group that overlies granodiorite of the Idaho Batholith. Local basalt flows and fluvial/lacustrine sediments are also present. The Soldier Mountains are composed mostly of granodiorite of the Idaho Batholith with minor amounts of younger intrusive rocks. Camas Prairie is host to an unknown thickness of Quaternary alluvial, fluvial, and lacustrine sediments with local lenses of basalt encountered in the shallow subsurface (Cluer and Cluer, 1986). However, the preliminary results of the ongoing Snake River Plain Play Fairway phase II project data indicate that the valley-fill sediments may be in the range of few hundreds of meters at the deepest parts.

All Camas Prairie thermal water samples provide similar reservoir temperatures with the same traditional geothermometer. The quartz, chalcedony, and Na-K-Ca geothermometers result in temperature estimates 
in the range of 103-128, 74-99, and $70-124^{\circ} \mathrm{C}$, respectively. The silica-enthalpy model with chalcedony solubility and quartz solubility curves resulted in temperature estimates of about $133{ }^{\circ} \mathrm{C}$ and $173{ }^{\circ} \mathrm{C}$, respectively.

Unlike the traditional geothermometers, RTEst temperature estimates for the Camas Prairie features have a bimodal distribution of higher temperatures for the samples from northern parts and lower temperatures

for the samples from southern parts. Specifically, the hot springs from the areas along the northern part of Camas Prairie that abuts the prairie with the foothills of the Soldier Mountains (e.g., Wardrop Hot Spring, Wolf/Sheep Hot Spring) results in higher (181-204 $\left.{ }^{\circ} \mathrm{C}\right)$ RTEst reservoir temperatures. On the other hand, RTEst reservoir temperature estimates for hot springs and wells (e.g., Barron Hot Spring) in the southern part of Camas Prairie are $79-108{ }^{\circ} \mathrm{C}$.

Sulfate-water $\delta^{18} \mathrm{O}$ temperatures calculated for the samples from the Camas Prairie range from $133^{\circ} \mathrm{C}$ to $>300^{\circ} \mathrm{C}$. The higher temperature is for the sample collected from the Barron Well which had a relatively low field temperature $\left(37^{\circ} \mathrm{C}\right)$, but used to have a very high temperature (approaching boiling) when it was initially drilled, suggesting that it has been significantly diluted by incursion of cool groundwater after years of production. Similar to the Magic Reservoir sample, all of these samples have $\delta^{18} \mathrm{O}$ values shifted off the meteoric water line (Figure 4) and dissolved methane with isotopic signatures indicating a magmatic origin (Appendix I). This suggests that these samples may be indicating a significant geothermal resource related to a magmatic system at depth (Conrad et al., 2016).

\subsubsection{South Mount Bennett Hills}

Several hot springs located along the southern side of the Mount Bennett Hills in Elmore, Gooding, and Lincoln Counties in Idaho extending over $70 \mathrm{~km}$ represent this prospect (SBH in Figure 1). Some of the known hot springs in the area include the Prince Albert (Coyote) $\left(58^{\circ} \mathrm{C}\right)$, Latty $\left(65^{\circ} \mathrm{C}\right)$, and White Arrow $\left(65^{\circ} \mathrm{C}\right)$. The Bostic 1-A well $(2950 \mathrm{~m})$ drilled to the south from this area indicated the presence of hot (ca. $200^{\circ} \mathrm{C}$ ) rock at depths of about $3 \mathrm{~km}$ (Arney, 1982; Arney and Goff, 1982; Arney et al., 1984). The presence of several hot springs and hot rock at depth suggests that this part the SRP has great potential for geothermal resources.

Rocks in the area consist mainly of mafic and felsic volcanic rocks with thick sequences of sediments and gravels. The Mount Bennett Hills to the north consist of predominantly of Miocene rhyolitic ash flows and lava flows of the Idavada Volcanic Group that overlies Idaho Batholith granodiorite (see Appendix E for detailed information). At the base of the Mount Bennett Hills, the basalt flows are intercalated with quaternary lacustrine sediments deposited in the Pleistocene-Pliocene Lake Idaho and the sandstones and shales of the Tertiary Glenn's Ferry Formation. At depth, an older basalt unit (Banbury basalt) and Idavada volcanics are encountered at Bostic 1-A well (Arney et al., 1984). The basement rock in the area is considered to be the Idaho Batholith granodiorite.

Reservoir temperature estimates for this area calculated from the chemical compositions of several water samples are given in Table 1. Quartz (no steam loss), chalcedony, and Na-K-Ca geothermometers resulted in 110-143, and 80-117, and $72-160{ }^{\circ} \mathrm{C}$, respectively. The Prince Albert and Latty Hot Springs resulted in highest temperatures for the area with these traditional geothermometers. Silica-enthalpy mixing models with chalcedony and quartz solubility curves resulted in 150 and $182{ }^{\circ} \mathrm{C}$ temperature estimates for the area. As with the traditional geothermometers, the RTEst modeling of waters from hot springs yielded higher temperature. The three hot springs in the area, Prince Albert, Latty, and White Arrow Hot Springs resulted in reservoir temperatures at $193 \pm 8,197 \pm 5$, and $177 \pm 6{ }^{\circ} \mathrm{C}$, respectively. A sulfate-water oxygen isotope temperature for a sample from the Prince Albert Hot Spring yielded a high temperature of $154{ }^{\circ} \mathrm{C}$. Similarly, RTEst temperature estimate for a well (Shannon well) in the area is $137 \pm 10^{\circ} \mathrm{C}$. All other wells resulted in lower reservoir temperature estimates $\left(82-122^{\circ} \mathrm{C}\right)$. The reservoir temperature estimates using 
the hot spring waters are similar to the bottom hole temperature $\left(\sim 200^{\circ} \mathrm{C}\right.$, Arney et al., 1984$)$ measured in the Bostic 1-A well. It is likely that deep thermal waters that ascend along the range-forming faults are the source these hot springs.

\subsubsection{Banbury Hot Springs-Twin Falls area}

The southwestern periphery of the ESRP near Twin Falls and Buhl is one of the Known Geothermal Resource Areas in southern Idaho (see Appendix J for detailed information). The area is comprised of two dense clusters of geothermal surface manifestations, Banbury Hot Springs (BHS in Figure 1) and Twin Falls (TF in Figure 1). Discharging thermal waters range in temperature from $25^{\circ} \mathrm{C}$ to $70{ }^{\circ} \mathrm{C}$. At this time thermal waters are being used for space heating, agriculture, and recreation.

The Twin Falls and Banbury hydrothermal areas show characteristics of both the ESRP and Basin and Range regional extension. Tertiary rhyolitic volcanic rocks underlie younger Quaternary and Tertiary basaltic units throughout the study area. Paleozoic meta-sedimentary rocks are thought to underlie the entire area (Lewis and Young, 1989). The thermal aquifer system in the area is located beneath basalt units within the Idavada volcanics and is under artesian conditions with temperatures of the waters increasing to the northwest. Thermal waters are thought to originate from deep circulation paths from the Cassia Mountain recharge zone to the south and through fractures in the overlying basalts of the thermal area. The high regional thermal gradient coupled with the young volcanic sill complexes associated with the ERSP volcanism in the area then heat these waters resulting in the thermal features (McLing et al., 2014, Dobson et al., 2015).

Reservoir temperature estimate ranges obtained with traditional geothermometers and RTEst are given in Table 1 for both the Banbury Hot Springs and Twin Falls prospects. The highest reservoir temperatures (ca. $160^{\circ} \mathrm{C}$ ) for the Banbury Hot Springs prospect are obtained for Banbury Hot Spring, Miracle Hot Spring well, and Salmon Falls Hot Spring with RTEst as well as other geothermometers. Similarly, for the Twin Falls prospect, the highest reservoir temperatures (ca. $135^{\circ} \mathrm{C}$ ) are obtained for samples from two hot shallow wells (used for direct heating - Neely, 1996) within the premises of the College of Southern Idaho. Nearly identical temperatures were obtained using the sulfate-water oxygen isotope geothermometer. Two samples taken from the Banbury hot springs yielded temperatures of 159 and 152 ${ }^{\circ} \mathrm{C}$ and a sample from one of the College of Southern Idaho wells was $133{ }^{\circ} \mathrm{C}$. Samples from 7 additional thermal features in the region ranged from 99 to $156^{\circ} \mathrm{C}$.

\section{Summary}

The specific objectives of this project were to obtain samples from thermal expressions (Appendix A), analyze samples for chemical and isotopic concentrations (Appendix B \& C), use INL's geothermometry tool (RTEst), traditional geothermometers, and dissolved sulfate $\left(\delta^{34} \mathrm{~S}\right.$ and $\left.\delta^{18} \mathrm{O}\right)$ calculations (Appendix D), and identify potential geothermal areas (prospects) in the ESRP (Appendix E). All objects for this project were accomplished and a map of the ESRP (Figure 1) was produced describing the locations and calculated reservoir temperatures of potential geothermal resource areas.

Geothermometric calculations of ESRP thermal water samples indicate numerous potential geothermal areas with elevated reservoir temperatures. Specifically, RTEst results of thermal water samples from areas around the southern/southwestern side of the Mount Bennett Hills and within the Camas Prairie in the southwestern portion of the ESRP suggest temperatures of $140-200^{\circ} \mathrm{C}$. In the northern portion of the ESRP, Lidy Hot Springs, Ashton, Newdale, and areas east of Idaho Falls have expected reservoir temperatures $\geq 140^{\circ} \mathrm{C}$. Resource temperatures in the southwestern ERSP, specifically, areas near Buhl and Twin Falls are estimated to as high as $160^{\circ} \mathrm{C}$. These areas are likely to host potentially economic geothermal resources; however, further detailed study is warranted for each site to evaluate their suitability for economic use. 


\section{Acknowledgments}

This work was supported by funding by the Assistant Secretary for Energy Efficiency and Renewable Energy, Geothermal Technologies Office of the U.S. Department of Energy under the U.S. Department of Energy Contract Numbers DE-AC07-05ID14517 for Idaho National Laboratory and DE-AC0205CH11231 for Lawrence Berkeley National Laboratory. We thank landowners who provided access to sampling locations. We also thank Dr. Ross Spackman (Brigham Young University-Idaho) for his assistance in coordinating with landowners and field work during summer 2014 sampling campaign. Ms. Debbie Lacroix (University of Idaho) at Center for Advanced Energy Studies (CAES) conducted chemical analyses of the samples. Dr. Pat Dobson (LBNL) and Wade Worthing (University of Idaho) helped during collection of thermal water samples. We appreciate the discussion with Drs. Bill Phillips (Idaho Geological Survey), Glenn Embree (BYU-Idaho), and Dan Moore (BYU-Idaho). Mr. Trevor Atkinson (Utah State University) helped construct geologic cross-sections of several prospects.

\section{Appendices}

Appendix A. Map showing distribution of thermal features in and around the ESRP.

Appendix B. Water chemistry data for thermal features in and around the ESRP.

Appendix C. Water isotope data for thermal features in and around the ESRP.

Appendix D. Geothermometric temperature estimates for thermal features in and around the ESRP.

Appendix E. Descriptions of geothermal prospects in and around the ESRP.

Appendix F. Neupane, G., Mattson, E.D., Mines, G.L., McLing, T.L., Dobson, P.F., Conrad, M.E., Wood, T.R., Cannon, C., Worthing, W., 2015c. Geothermometric temperature comparison of hot springs and wells in southern Idaho. GRC Transactions, 39, 495-502.

Appendix G. Neupane, G., Mattson, E.D., Cannon, J.C., Atkinson, T.A., McLing, T.L., Wood, T.R., Worthing, W.C., Dobson, P.F., and Conrad, M.E., 2016b. Potential hydrothermal resource areas and their reservoir temperatures in the Eastern Snake River Plain, Idaho. Proceedings, 41st Workshop on Geothermal Reservoir Engineering, Stanford University, Stanford, CA.

Appendix H. Neupane, G., Mattson, E.D., Cannon, J.C., Atkinson, T.A., McLing, T.L., Wood, T.R., Worthing, W.C., and Conrad, M.E., 2016b. Mixing effects on geothermometric calculations of the Newdale Geothermal area in the Eastern Snake River Plain, Idaho. Proceedings, 41st Workshop on Geothermal Reservoir Engineering, Stanford University, Stanford, CA.

Appendix I. Conrad, M.E., Dobson, P.F., Sonnenthal, E.L., Kennedy, B.M., Cannon, C., Worthing, W., Wood, T., Neupane, G., Mattson E., and McLing, T., 2016. Application of isotopic approaches for identifying hidden geothermal systems in southern Idaho. Proceedings, 41st Workshop on Geothermal Reservoir Engineering, Stanford University, Stanford, CA.

Appendix J. Cannon, C.J., 2015. Evidence for mixing and re-equilibration in the Twin Falls - Banbury hydrothermal system and its effects on reservoir temperature estimation. MS Thesis, University of Idaho, $184 \mathrm{p}$.

Appendix K. Dobson, P.F., Kennedy, B.M., Conrad, M.E., McLing, T., Mattson, E., Wood, T., Cannon, C., Spackman, R., van Soest, M., and Robertson, M., 2015. He isotopic evidence for undiscovered geothermal systems in the Snake River Plain. Proceedings, 40th Workshop on Geothermal Reservoir Engineering, Stanford University, Stanford, CA. 


\section{References}

Arney, B., 1982. Evidence of former higher temperatures from alteration minerals, Bostic 1-A well, Mountain Home, Idaho. GRC Transactions, 6, 3-6.

Arney, B.H., Gardner, J.N., and Belluomini, S.G., 1984. Petrographic analysis and correlation of volcanic rocks in Bostic 1-A well near Mountain Home, Idaho. LA-9966-HDR, Los Alamos National Laboratory.

Arney, B.H. and Goff, F., 1982. Evaluation of the hot-dry-rock geothermal potential of an area near Mountain Home, Idaho. LA-9365-HDR, Los Alamos National Laboratory.

Bethke, C.M., 2008. Geochemical and Biogeochemical Reaction Modeling. Cambridge University Press, $547 \mathrm{p}$.

Blackwell, D.D., 1989. Regional implications of heat flow of the Snake River Plain, northwestern United States. Tectonophysics, 164, 323-343.

Bond, J. G., Kauffman, J. D., Miller, D.A., and Venkatakrishnan, R., 1978. Geologic Map of Idaho: Moscow. Idaho, Idaho Bureau of Mines and Geology Map GM-1.

Brott, C.A., Blackwell, D.D, and Mitchell J.C., 1976. Geothermal investigations in Idaho, Part 8: Heat flow study of the Snake River Plain, Idaho, Idaho Department of Water Resources. Water Information Bulletin, 30, $195 \mathrm{p}$.

Cannon, C., Wood, T., Neupane, G., McLing, T., Mattson, E., Dobson, P., and Conrad, M., 2014. Geochemistry sampling for traditional and multicomponent equilibrium geothermometry in southeast Idaho. GRC Transactions, 38, 524-431.

Cluer, J.K., Cluer, B.L., 1986. The late Cenozoic Camas Prairie Rift south-central Idaho, Contributions to Geology, University of Wyoming, 24(1), 91-101.

Cooper, D.C., Palmer, C.D., Smith, R.W., and McLing, T.L., 2013. Multicomponent equilibrium models for testing geothermometry approaches. Proceedings, 38th Workshop on Geothermal Reservoir Engineering Stanford University, Stanford, CA.

Conrad, M.E., Dobson, P.F., Sonnenthal, E.L., Kennedy, B.M., Cannon, C., Worthing, W., Wood, T., Neupane, G., Mattson E., and McLing, T., 2016. Application of isotopic approaches for identifying hidden geothermal systems in southern Idaho. Proceedings, $41^{\text {st }}$ Workshop on Geothermal Reservoir Engineering, Stanford University, Stanford, CA.

Craig, H., 1961. Isotopic variations in meteoric waters. Science, 133(3465), 1702-1703.

D’Amore, F. and Arnórsson, S., 2000. Geothermometry, in Isotopic and Chemical Techniques in Geothermal Exploration, Development and Use (S. Arnórsson, ed.): IAEA (Editorial), Vienna, 152199.

D'Amore, F., Fancelli, R., and Caboi, R., 1987. Observations on the application of chemical geothermometers to some hydrothermal systems in Sardinia. Geothermics, 16, 271-282.

Dobson, P.F., Kennedy, B.M., Conrad, M.E., McLing, T., Mattson, E., Wood, T., Cannon, C., Spackman, R., van Soest, M., and Robertson, M., 2015. He isotopic evidence for undiscovered geothermal systems in the Snake River Plain. Proceedings, $40^{\text {th }}$ Workshop on Geothermal Reservoir Engineering, Stanford University, Stanford, CA.

Embree, G.F., Phillips, W.M., and Welhan, J.A., 2011. Geologic map of the Newdale quadrangle, Fremont and Madison Counties, Idaho. Idaho Geological Survey, University of Idaho, Moscow, Idaho 83844-3014. 
Fournier, R.O. and Truesdell, A.H., 1973. An empirical Na-K-Ca geothermometer for natural waters. Geochim. Cosmochim. Acta, 37, 1255-1275.

Fournier, R.O., 1977. Chemical geothermometers and mixing models for geothermal systems. Geothermics, 5, 41-50.

Fournier, R.O., 1979. A revised equation for the Na/K geothermometer. GRC Transactions, 3, 221-224.

Fournier, R.O. and Potter II, R.W., 1979. Magnesium correction to the Na-K-Ca chemical geothermometer. Geochim. Cosmochim. Acta, 43, 1543-1550.

Fowler, A.P.G., Hackett, L.B., and Klein, C.W., 2013. Reformulation and Performance Evaluation of the Sulfate-Water Oxygen Isotope Geothermometer. GRC Transactions 9, p. 31.

GeothermEx, Inc., 2010. Independent technical report: Resource evaluation of the Newdale geothermal prospect, Madison and Fremont Counties, Idaho, USA. Geothermix, Inc., Richmond, California, USA, $101 \mathrm{p}$.

Giggenbach, W.F., 1988. Geothermal solute equilibria. Derivation of Na-K-Mg-Ca geoindicators. Geochim. Cosmochim. Acta, 52, 2749-2765.

Hughes, S.S., Smith, R.P., Hackett, W.R., and Anderson, S. R., 1999. Mafic volcanism and environmental geology of the eastern Snake River Plain. Idaho Guidebook to the Geology of Eastern Idaho. Idaho Museum of Natural History, 143-168.

Hull, C.D., Reed, M.H., and Fisher, K., 1987. Chemical geothermometry and numerical unmixing of the diluted geothermal waters of the San Bernardino Valley Region of Southern California. GRC Transactions, 11, 165-184.

Lewis, R.E. and Young, H.W., 1989. The hydrothermal system in central Twin Falls County, Idaho: U.S. Geological Survey Water Resources Investigations Report 88-4152, 44 p.

Link, P.K., 2002. Clark County, Idaho. Digital Atlas of Idaho, Idaho State University, Geosciences Department, p. 3.

Mattson, E.D., Smith, R.W., Neupane, G., Palmer, C.D., Fujita, Y., McLing, T.L., Reed, D.W., Cooper, D.C., and Thompson, V.S., 2015. Improved geothermometry through multivariate reaction-path modeling and evaluation of geomicrobiological influences on geochemical temperature indicators: Final Report No. INL/EXT-14-33959, Idaho National Laboratory (INL), Idaho Falls, Idaho.

McLing, T.L., Smith, R.W., and Johnson, T.M., 2002. Chemical characteristics of thermal water beneath the eastern Snake River Plain. In: Geology, Hydrogeology, and Environmental Remediation: Idaho National Engineering and Environmental Laboratory, Eastern Snake River Plain, Idaho, P.K. Link and L.L. Mink, eds. GSA Special Paper, 353, 205-211.

McLing, T., McCurry, M., Cannon, C., Neupane, G., Wood, T., Podgorney, R., Welhan, J., Mines, G., Mattson, E., Wood, R., Palmer, C. and Smith, R., 2014. David Blackwell's Forty Years in the Idaho Desert, The Foundation for 21st Century Geothermal Research. GRC Transactions, 38, 143-153.

Michard, G. and Roekens, E., 1983. Modelling of the chemical components of alkaline hot waters. Geothermics, 12, 161-169.

Mitchell, J.C., 1976. Geothermal Investigations in Idaho - Part 7: Geochemistry and geologic setting of the thermal waters of the Camas Prairie Area, Blaine and Camas Counties, Idaho. Idaho Department of Water Resources, Water Information Bulletin 30.

Mitchell, J.C., Johnson, L.L, and Anderson, J.E., 1980. Geothermal Investigations in Idaho - Part 9: Potential for direct heat applications of geothermal resources. Idaho Department of Water Resources, Water Information Bulletin 30. 
Morgan, L.A., and McIntosh, W.C., 2005. Timing and development of the Heise volcanic field, Snake River Plain, Idaho, western USA. GSA Bulletin, 117, 288-306.

Morse, L.H. and McCurry, M., 2002. Genesis of alteration of Quaternary basalts within a portion of the eastern Snake River Plain aquifer. Special Papers Geological Society of America, 213-224.

Neely, K.W., 1996. Geothermal heat keeps students warm at the College of Southern Idaho. GRC Transactions, 20, 129-136.

Neupane, G., Smith, R. W., Palmer, C. D., and McLing, T. L., 2013. Multicomponent equilibrium geothermometry applied to the Raft River geothermal area, Idaho: preliminary results. In GSA Abstracts with Programs, 45 (7).

Neupane, G., Mattson, E.D., McLing, T.L., Palmer, C.D., Smith, R.W., and Wood, T.R., 2014. Deep geothermal reservoir temperatures in the Eastern Snake River Plain, Idaho using multicomponent geothermometry. Proceedings, Thirty-Ninth Workshop on Geothermal Reservoir Engineering, Stanford University, Stanford, CA.

Neupane, G., Mattson, E.D., McLing, T.L., Palmer, C.D., Smith, R.W., Wood, T.R., and Podgorney, R.K., 2015a. Geothermal reservoir temperatures in southeastern Idaho using multicomponent geothermometry. Proceedings, World Geothermal Congress 2015, Melbourne, Australia, 19-25 April 2015 .

Neupane, G., Baum, J.S., Mattson, E.D., Mines, G.L., Palmer, C.D., and Smith, R.W., 2015b. Validation of multicomponent equilibrium geothermometry at four geothermal power plants. Proceedings, Fortieth Workshop on Geothermal Reservoir Engineering Stanford University, Stanford, CA.

Neupane, G., Mattson, E.D., Mines, G.L., McLing, T.L., Dobson, P.F., Conrad, M.E., Wood, T.R., Cannon, C., Worthing, W., 2015c. Geothermometric temperature comparison of hot springs and wells in southern Idaho. GRC Transactions, 39, 495-502.

Neupane, G., Mattson, E.D., McLing, T.L., Palmer, C.D., Smith, R.W., Wood, T.R., and Podgorney, R.K., 2016a. Geothermometric evaluation of geothermal resources in southeastern Idaho. Geoth. Energ. Sci, 4(1), 11-22.

Neupane, G., Mattson, E.D., Cannon, J.C., Atkinson, T.A., McLing, T.L., Wood, T.R., Worthing, W.C., and Conrad, M.E., 2016b. Mixing effects on geothermometric calculations of the Newdale Geothermal area in the Eastern Snake River Plain, Idaho. Proceedings, 41st Workshop on Geothermal Reservoir Engineering, Stanford University, Stanford, CA.

Nielson, D.L., Delahunty, C., and Shervais, J.W., 2012. Geothermal systems in the Snake River Plain, Idaho, characterized by the Hotspot project. GRC Transactions, 36, 727-730.

Occidental Geothermal, Inc., 1979. Sturm 1, Computer Processed Log. Department of Water Resources, Idaho, $18 \mathrm{p}$.

Palandri, J.L. and Reed, M.H., 2001. Reconstruction of in situ composition of sedimentary formation waters. Geochim. Cosmochim. Acta, 65, 1741-1767.

Palmer, C.D., Ohly, S.R., Smith, R.W., Neupane, G., McLing, T., Mattson, E.: Mineral selection for multicomponent equilibrium geothermometry. GRC Transactions, 38, (2014), 453-459.

Pang, Z.H. and Reed, M., 1998. Theoretical chemical thermometry on geothermal waters: Problems and methods. Geochim. Cosmochim. Acta, 62, 1083-1091.

Peiffer, L., Wanner, C., Spycher, N., Sonnenthal, E., Kennedy, B.M., Iovenitti, J., 2014. Optimized multicomponent vs. classical geothermometry: insights from modeling studies at the Dixie Valley geothermal area. Geothermics, 51, 154-169. 
Pierce, K. L., and Morgan, L. A., 1992. The track of the Yellowstone hot spot: Volcanism, faulting, and uplift. GSA Memoirs, 179, 1-54.

Ralston, D.R., Arrigo, J.L., Baglio, J.V. Jr., Coleman, L.M., Souder, K., and Mayo, A.L., 1981. Geothermal evaluation of the thrust area zone in southeastern Idaho, Idaho Water and Energy Research Institute, University of Idaho.

Reed, M. and Spycher, N., 1984. Calculation of $\mathrm{pH}$ and mineral equilibria in hydrothermal waters with application to geothermometry and studies of boiling and dilution. Geochim. Cosmochim. Acta, 48, 1479-1492.

Rodgers, D.W., Ore, H.T., Bobo, R.T., McQuarrie, N., and Zentner, N., 2002. Extension and subsidence of the eastern Snake River Plain, Idaho. Tectonic and Magmatic Evolution of the Snake River Plain Volcanic Province. Idaho Geological Survey Bulletin, 30, 121-155.

Ross, S.H., 1970. Geothermal potential of Idaho. Geothermics, 2, 975-1008.

Shervais, J.W., Glen, J.M., Liberty, L.M., Dobson, P., Gasperikova, E., Sonnenthal, E., Visser, C., Garg, S., Evans, J.P., Siler, D., DeAngelo, J., Athens, N., and Burns, E., 2015. Snake River Plain play fairway analysis - Phase 1 Report. GRC Transactions, 39, 761-769.

Smith, R.P., 2004. Geologic setting of the Snake River Plain aquifer and vadose zone. Vadose Zone Journal, 3, 47-58.

Smith, R.W., Palmer, C.D., and Cooper, D., 2012. Approaches for multicomponent equilibrium geothermometry as a tool for geothermal resource exploration. Abstracts, AGU Fall Meeting, San Francisco, CA.

Spycher, N.F., Sonnenthal, E., and Kennedy, B.M., 2011. Integrating multicomponent chemical geothermometry with parameter estimation computations for geothermal exploration. GRC Transactions, 35, 663-666.

Spycher, N., Peiffer, L., Sonnenthal, E. L., Saldi, G., Reed, M. H., and Kennedy, B. M., 2014. Integrated multicomponent solute geothermometry. Geothermics, 51, 113-123.

Struhsacker, D.W., Jewell, P.W., Ziesloft, J., and Evans, S.H. Jr., 1982. The geology and geothermal setting of the Magic reservoir area, Blaine and Camas Counties, Idaho. In: Cenozoic geology of Idaho, B. Bonnichsen and R.M. Breckenridge, eds., Idaho Bureau of Mines and Geology Bulletin 26, 377-393.

Taylor, H.P., 1974. Application of oxygen and hydrogen isotope studies to problems of hydrothermal alteration and ore deposition. Econ. Geol., 69, 843-883.

Tole, M.P., Ármannsson, H., Pang, Z.H., \& Arnórsson, S., 1993. Fluid/mineral equilibrium calculations for geothermal fluids and chemical geothermometry. Geothermics, 22, 17-37.

Welhan, J.A., 2015. Thermal and Trace-Element Anomalies in the Eastern Snake River Plain aquifer: toward a conceptual model of the EGS resource. GRC Transactions, 39, 363-375.

Whitehead, R.L., 1992. Geohydrologic framework of the Snake River Plain regional aquifer system, Idaho and eastern Oregon. Regional aquifer system analysis-Snake River Plain, Idaho. US Geological Survey Professional Paper 1408-B.

Williams, C.F., and DeAngelo, J., 2011. Evaluation of approaches and associated uncertainties in the estimation of temperatures in the upper crust of the western United States, GRC Transactions, 35, $1599-1605$.

Williams, P.L., Mabey, D.R., Zohdy, A.A.R., Ackermann, H., Hoover, D.B., Pierce, K.L., and Oriel, S.S., 1976. Geology and geophysics of the southern Raft River Valley geothermal area, Idaho, USA. 
Proceedings, Second UN Symposium on the Development and Use of Geothermal Resources, San Francisco, Lawrence Berkeley National Laboratory, 1273 
Appendix A. Map showing distribution of thermal features in and around the Eastern Snake River Plain (ESRP) 


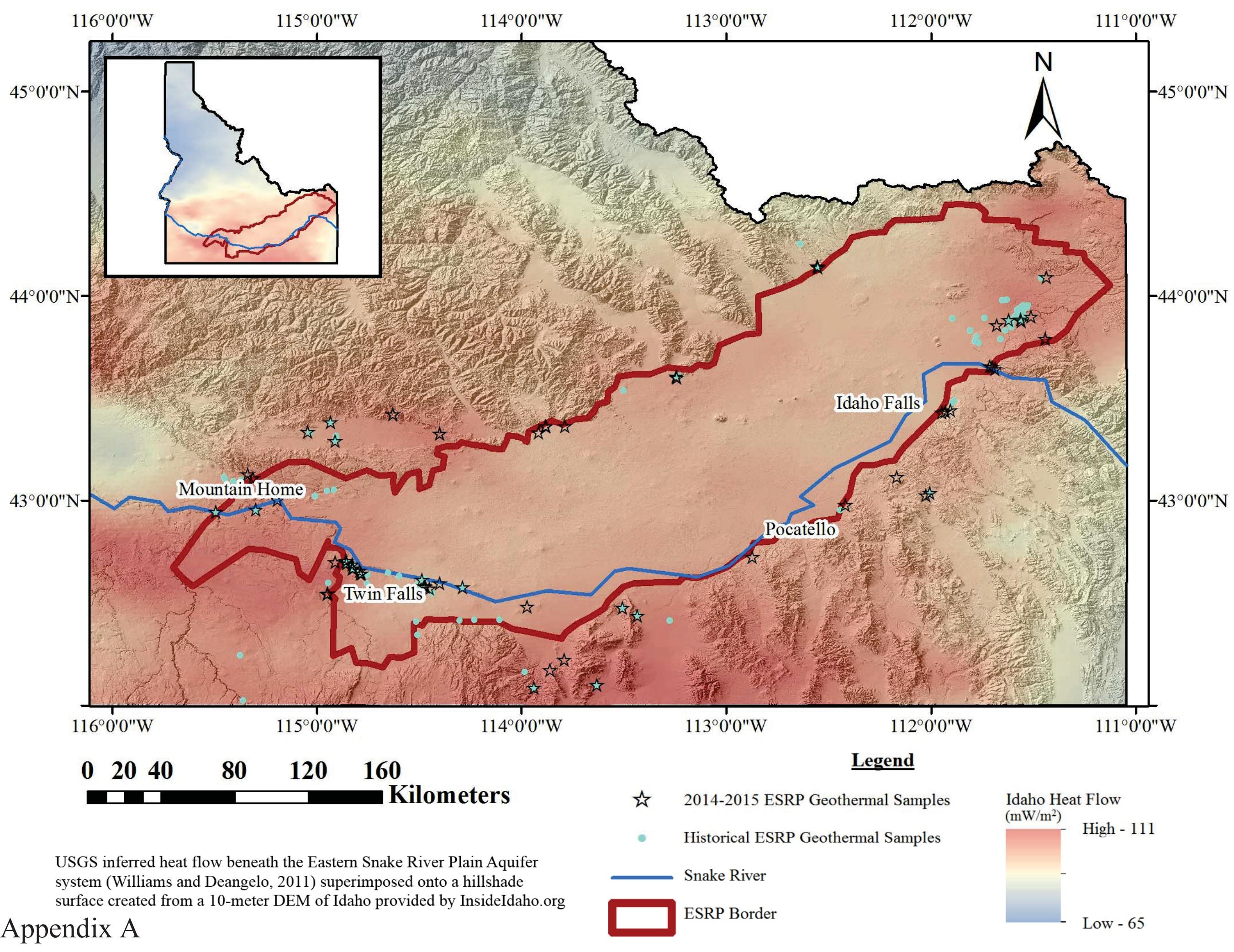


Appendix B. Water chemistry data for thermal features in and around the Eastern Snake River Plain (ESRP) 
Appendix B. Water chemistry data for thermal features in and around the Eastern Snake River Plain (ESRP).

\begin{tabular}{|c|c|c|c|c|c|c|c|c|c|c|c|c|c|c|c|c|c|c|c|}
\hline Sampling Features & Latitude & Longitude & $\begin{array}{c}\mathrm{T} \\
\left({ }^{\circ} \mathrm{C}\right)\end{array}$ & $\mathrm{pH}$ & $\mathrm{Ca}$ & $\mathrm{Mg}$ & $\mathrm{Na}$ & $\mathrm{K}$ & $\mathrm{HCO}_{3}$ & $\mathrm{SO}_{4}$ & $\mathrm{Cl}$ & $\mathrm{F}$ & $\begin{array}{l}\mathrm{SiO}_{2} \\
\text { (aq) }\end{array}$ & $\mathrm{Al}$ & $\mathrm{Sr}$ & $\mathrm{Li}$ & B & $\begin{array}{c}\text { TDS } \\
(\mathrm{g} / \mathrm{L})\end{array}$ & Ref. \\
\hline Lidy HS1 & 44.14558 & -112.55494 & 56.1 & 7.17 & 66 & 16 & 25 & 13 & 132 & 102 & 7.3 & 4.6 & 38 & 0.001 & 0.60 & 0.05 & 0.09 & 0.36 & $\mathrm{TS}$ \\
\hline Lidy HS2 & 44.14166 & -112.55240 & 52.3 & 7.21 & 64 & 16 & 28 & 14 & 163 & 98 & 6.9 & 4.7 & 34 & 0.001 & 0.61 & 0.05 & 0.09 & 0.38 & $\mathrm{TS}$ \\
\hline Lidy HS W & 44.140500 & -112.550167 & 59.0 & 7.60 & 55 & 14 & 24 & 12 & 180 & 100 & 7.1 & 4.4 & 37 & & & 0.04 & 0.09 & 0.34 & M-80 \\
\hline Warm Spring WS & 44.256500 & -112.639167 & 29.0 & 7.00 & 54 & 19 & 10 & 2.9 & 209 & 62 & 5.3 & 1 & 17 & & & & & 0.27 & YM-73 \\
\hline Sturm W & 44.09325 & -111.43534 & 31.4 & 8.73 & 3 & 0.0 & 33 & 0.9 & 66 & 5.8 & 3.3 & 2.1 & 63 & 0.005 & 0.005 & 0.05 & 0.04 & 0.11 & $\mathrm{TS}$ \\
\hline Ashton WS & 44.091333 & -111.4595 & 41.0 & 7.60 & 1 & 0.1 & 36 & 1.6 & 92 & 4.7 & 2.9 & 2.2 & 110 & 0.010 & 0.002 & 0.05 & 0.03 & 0.21 & M-80 \\
\hline Warm River S1 & 44.098133 & -111.368144 & 27.1 & 6.84 & 10.5 & 1.3 & 21.8 & 0.724 & 184.2 & 8.11 & 6.53 & 2.58 & 37.7 & 0.010 & 0.02 & 0.07 & 0.03 & 0.21 & TS \\
\hline Warm River S2 & 44.099381 & -111.382628 & 21 & 6.73 & 27.5 & 2.5 & 36.3 & 1.56 & 82.4 & 7.62 & 5.87 & 2.05 & 51.7 & 0.010 & 0.04 & 0.1 & 0.04 & 0.21 & $\mathrm{TS}$ \\
\hline Newdale City W & 43.88308 & -111.6186 & 30.0 & 7.34 & 28 & 4.7 & 71 & 8.1 & 251 & 29.7 & 24.9 & 5.0 & 70 & 0.002 & 0.09 & 0.12 & 0.22 & 0.30 & $\mathrm{TS}$ \\
\hline Wanda Woods W2 & 43.861167 & -111.608333 & 27.0 & 7.60 & 31 & 7.6 & 70 & 8.5 & 217 & 26 & 25 & 4.5 & 80 & & & & & 0.36 & M-80 \\
\hline Walz Enterprises W & 43.862167 & -111.606833 & 26.0 & 7.70 & 31 & 6.9 & 65 & 9.0 & 232 & 26 & 27 & 3.7 & 65 & & & & & 0.35 & M-80 \\
\hline Wanda Woods W1 & 43.868167 & -111.617167 & 24.0 & 8.00 & 33 & 7.2 & 64 & 8.6 & 240 & & 24 & 3.5 & 66 & & & & & 0.32 & M-80 \\
\hline Wallace Little W & 43.88308 & -111.6186 & 36.0 & 7.90 & 28 & 6.3 & 78 & 8.6 & 240 & 33 & 24 & 5.4 & 75 & & & & & 0.38 & M-80 \\
\hline Henry Harris W & 43.890667 & -111.598 & 33.0 & 7.60 & 25 & 5.9 & 69 & 6.9 & 204 & 26 & 22 & 5.7 & 64 & & & & & 0.33 & M-80 \\
\hline Donald Trupp W & 43.901333 & -111.5735 & 32.0 & 7.80 & 23 & 3.3 & 88 & 12.0 & 181 & 26 & 25 & 6.2 & 76 & & & & & 0.35 & M-80 \\
\hline Wayne Larson W & 43.905667 & -111.586667 & 22.0 & 8.10 & 19 & 2.7 & 93 & 12.0 & 243 & 23 & 28 & 7.1 & 94 & & & & & 0.40 & M- 80 \\
\hline Schwendiman W & 43.87717 & -111.55890 & 28.0 & 7.57 & 27 & 6.9 & 39 & 5.5 & 165 & 25.2 & 13.7 & 2.6 & 62 & 0.002 & 0.08 & 0.05 & 0.09 & 0.30 & $\mathrm{TS}$ \\
\hline Clyde W & 43.88566 & -111.55949 & 32.7 & 7.5 & 25 & 7.3 & 46 & 5.3 & 183 & 23.0 & 15.4 & 3.2 & 65 & 0.002 & 0.08 & 0.06 & 0.12 & 0.30 & $\mathrm{TS}$ \\
\hline Cinder Block W & 43.90127 & -111.50967 & 26.3 & 7.35 & 18 & 3.5 & 52 & 5.0 & 182 & 17.2 & 12.2 & 4.2 & 70 & 0.002 & 0.05 & 0.07 & 0.15 & 0.30 & TS \\
\hline G23 & 43.90150044 & -111.53902 & 43 & 8.22 & 37 & 6.3 & 56 & 4.5 & 166 & 35.4 & 54.5 & & 44 & & & & & 0.40 & G-10 \\
\hline G25 & 43.92297413 & -111.55408 & 51 & 8.03 & 16 & 4.2 & 92 & 9.1 & 241 & 22.3 & 25.1 & & 102 & & & & & 0.51 & G-10 \\
\hline G41 & 43.89159947 & -111.55900 & 25 & 7.44 & 17 & 3.6 & 75 & 9.2 & 180 & 27.4 & 38.6 & & 89 & & & & & 0.44 & G-10 \\
\hline G43 & 43.88352634 & -111.60607 & 32 & 6.60 & 34 & 6.9 & 76 & 8.5 & 230 & 31.0 & 27.0 & 5.3 & 71 & & & & & 0.47 & G-10 \\
\hline G44 & 43.88983677 & -111.57849 & 32 & 8.20 & 22 & 7.5 & 69 & 9.1 & 211 & 30.6 & 33.0 & & 52 & & & & & 0.43 & G-10 \\
\hline G50 & 43.89855088 & -111.57878 & 39 & 7.80 & 22 & 3.1 & 95 & 12.2 & 243 & 22.5 & 28.3 & & 91 & & & & & 0.52 & G-10 \\
\hline G54 & 43.90885357 & -111.57828 & 41 & 7.84 & 18 & 3.8 & 93 & 10.3 & 251 & 19.6 & 25.0 & & 87 & & & & & 0.51 & G-10 \\
\hline
\end{tabular}




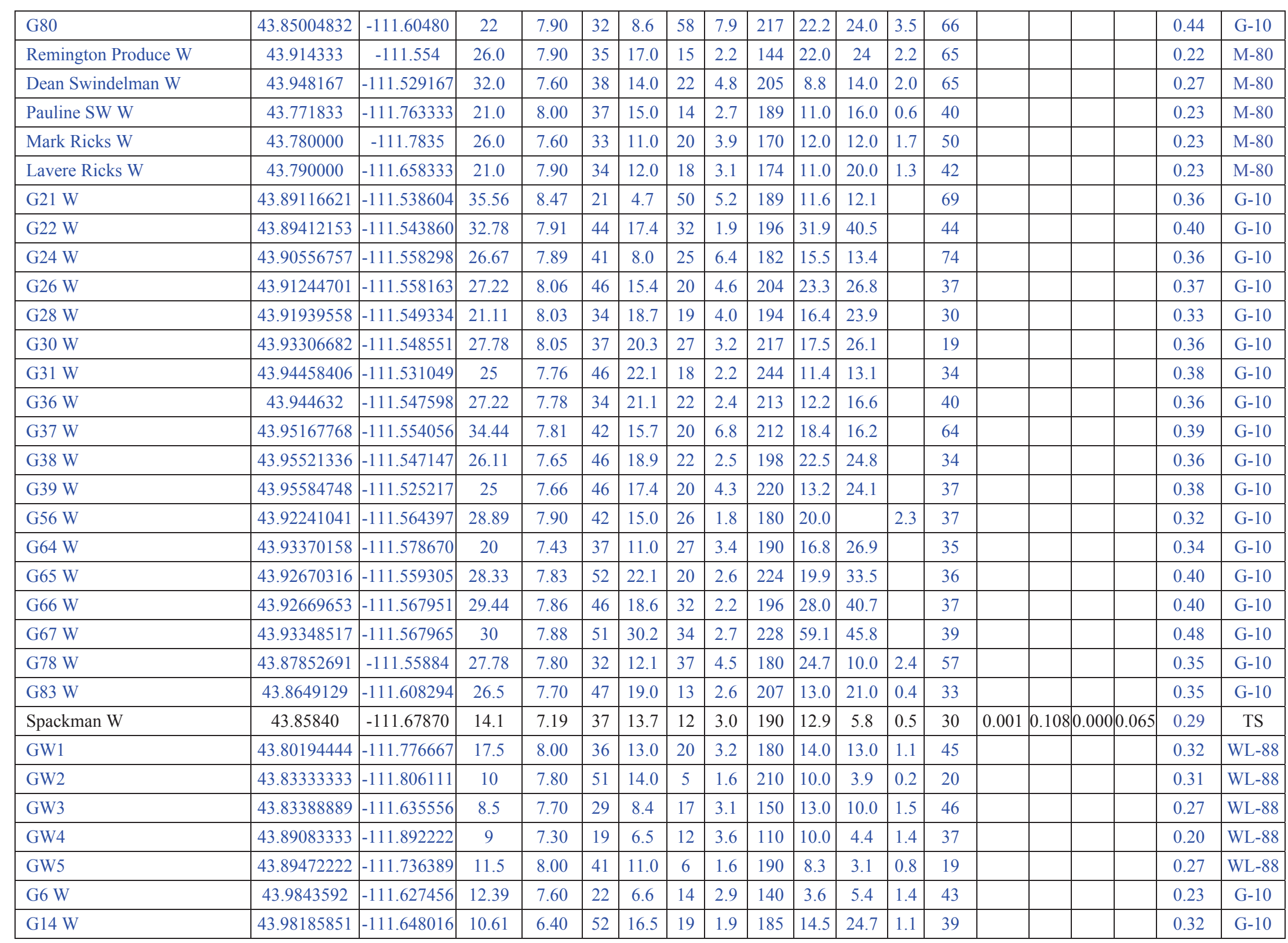




\begin{tabular}{|c|c|c|c|c|c|c|c|c|c|c|c|c|c|c|c|c|c|c|c|}
\hline G16 W & 43.98158212 & -111.649123 & 13.22 & 7.40 & 26 & 6.6 & 12 & 3.3 & 116 & 4.5 & 4.7 & 1.3 & 43 & & & & & 0.21 & G-10 \\
\hline Green Canyon HS & 43.79211 & -111.44009 & 44 & 7.2 & 144 & 33.8 & 5 & 4.5 & 137 & 314 & 0.9 & 1.5 & 27 & 0.0005 & 1.17 & 0.02 & 0.02 & 0.59 & $\mathrm{TS}$ \\
\hline Heise HS & 43.64283 & -111.68768 & 48.2 & 6.32 & 488 & 94 & 1540 & 206.2 & 986 & 712.3 & 2267.5 & 4.0 & 34 & 0.131 & 5.47 & 2.48 & 4.55 & 7.00 & $\mathrm{TS}$ \\
\hline Hawley WS & 43.657882 & -111.712868 & 16.4 & 6.93 & 39 & 9.7 & 10 & 3.2 & 214 & 6.0 & 6.2 & 0.7 & 56 & 0.010 & 0.11 & 0.02 & 0.01 & 0.22 & $\mathrm{TS}$ \\
\hline Elkhorn WS & 43.654338 & -111.701418 & 20.2 & 7.11 & 40 & 9.1 & 11 & 3.3 & 134 & 7.6 & 5.1 & 0.8 & 57 & 0.010 & 0.12 & 0.02 & 0.01 & 0.22 & $\mathrm{TS}$ \\
\hline Comore Loma W6 & 43.44244 & -111.90484 & 20.9 & 6.7 & 51 & 15.2 & 97 & 16.0 & 222 & 32.2 & 126 & 0.4 & 65 & 0.002 & 0.31 & 0.12 & 0.22 & 0.59 & $\mathrm{TS}$ \\
\hline Comore Loma W5 & 43.43774 & -111.93018 & 27.7 & 6.94 & 52 & 18.5 & 90 & 15.8 & 251 & 25.6 & 120 & 0.3 & 85 & 0.002 & 0.23 & 0.09 & 0.22 & 0.59 & $\mathrm{TS}$ \\
\hline Blackhawk W2 & 43.43142 & -111.94501 & 26.8 & 6.64 & 77 & 22.1 & 124 & 17.3 & 271 & 37.0 & 205 & 0.2 & 84 & 0.002 & 0.41 & 0.13 & 0.34 & 0.84 & $\mathrm{TS}$ \\
\hline Blackhawk W1 & 43.43121 & -11.94469 & 25.1 & 6.77 & 75 & 21.0 & 122 & 16.7 & 268 & 39.1 & 197 & 0.3 & 82 & 0.002 & 0.43 & 0.13 & 0.34 & 0.76 & $\mathrm{TS}$ \\
\hline Dyer W & 43.4900 & -111.8833 & 21 & 7.7 & 50 & 13 & 50 & 3 & 188 & 1 & 61 & 0.29 & 68 & & & & & 0.43 & $\mathrm{R}-81$ \\
\hline Anderson W & 43.4790 & -111.8970 & 20 & 7.7 & 50 & 10 & 45 & 7 & 199 & 0.0 & 45.0 & 0.44 & 111 & & & & & 0.47 & $\mathrm{R}-81$ \\
\hline Butte City W & 43.60827 & -113.24432 & 32.5 & 7.4 & 52 & 20.9 & 32 & 7.5 & 386 & 49.4 & 19.8 & 0.6 & 33 & 0.002 & 0.56 & 0.03 & 0.16 & 0.43 & TS \\
\hline Greenhouse W & 43.60234 & -113.24214 & 36.3 & 7.09 & 78 & 27.7 & 34 & 9.4 & 285 & 57.5 & 22.2 & 0.7 & 32 & 0.000 & 0.72 & 0.04 & 0.15 & 0.48 & $\mathrm{TS}$ \\
\hline E Butte City W & 43.60911 & -113.23064 & 22.8 & 7.4 & 65 & 28.7 & 31 & 5.8 & 228 & 35.3 & 95.2 & 0.4 & 24 & & & & & & NWIS \\
\hline W Butte City W & 43.60861 & -113.24417 & 27 & 7.4 & 52 & 21.2 & 33 & 7.2 & 273 & 42.5 & 18.2 & 0.5 & 30 & & & & & & NWIS \\
\hline Birch and 7th St W & 43.60917 & -113.24611 & 28 & 8.1 & 32 & 23.3 & 23 & 6.7 & 174 & 39.4 & \begin{tabular}{|l|}
37.4 \\
\end{tabular} & 0.4 & 38 & & & & & & NWIS \\
\hline Lewis Rothwell W & 43.540500 & -113.502 & 41 & 6.3 & 74 & 24.0 & 72 & 21.0 & 322 & 170.0 & 21.0 & 3.2 & 55 & & & & & & NWIS \\
\hline Condie HS & 43.33278 & -113.91790 & 50.5 & 7.03 & 61 & 11.5 & 62 & 22.5 & 315 & 33.5 & 14.0 & 1.6 & 30 & 0.003 & 0.93 & 0.09 & 0.26 & 0.48 & TS \\
\hline Milford Sweat HS & 43.36414 & -113.78943 & 38.1 & 7.25 & 66 & 13.7 & 43 & 8.5 & 251 & 49.9 & 6.6 & 1.9 & 25 & 0.003 & 0.45 & 0.05 & 0.17 & 0.42 & $\mathrm{TS}$ \\
\hline Rush WS1 & 43.364911 & -113.882168 & 29.5 & 6.65 & 48 & 9.8 & 47 & 14.5 & 278 & 27.4 & 13.4 & 1.5 & 30 & 0.010 & 0.84 & 0.05 & 0.16 & 0.40 & $\mathrm{TS}$ \\
\hline Rush WS2 & 43.36479 & -113.882468 & 23.2 & 7.08 & 45 & 8.7 & 43 & 13.0 & 281 & 24.8 & 13.4 & 1.3 & 32 & 0.010 & 0.75 & 0.05 & 0.15 & 0.36 & $\mathrm{TS}$ \\
\hline $\begin{array}{l}\text { Magic HS Landing W } \\
\text { Runoff }\end{array}$ & 43.32777 & -114.39941 & 39.1 & 8.61 & 13 & 1.3 & 333 & 20.9 & 710 & 52.9 & 79.1 & 10.6 & 109 & 0.007 & 0.65 & 1.17 & 1.24 & 1.14 & $\mathrm{TS}$ \\
\hline Magic HS Landing W & 43.32777 & -114.39941 & 75.0 & 6.79 & 22 & 1.4 & 311 & 19.8 & 703 & 50.3 & 74.1 & 9.9 & 104 & 0.009 & 0.93 & 1.18 & 1.20 & 1.18 & TS \\
\hline Elk Creek HS1 & 43.42341 & -114.62857 & 50.0 & 9.12 & 2 & 0.004 & 90 & 1.7 & 93 & 42.6 & 23.2 & 15.1 & 65 & 0.022 & 0.11 & 0.21 & 0.25 & 0.34 & $\mathrm{TS}$ \\
\hline
\end{tabular}




\begin{tabular}{|c|c|c|c|c|c|c|c|c|c|c|c|c|c|c|c|c|c|c|c|}
\hline Elk Creek HS2 & 43.42322 & -114.62865 & 55.5 & 9.05 & 2 & 0.003 & 91 & 1.6 & 90 & 42.6 & 23.1 & 15.2 & 65 & 0.026 & 0.11 & 0.21 & 0.25 & 0.34 & $\mathrm{TS}$ \\
\hline Wardrop HS & 43.38290 & -114.93224 & 67.5 & 9 & 1.2 & 0.27 & 56 & 0.9 & 193 & 11.5 & 5.1 & 3.4 & 77 & 0.09 & 0.05 & 0.05 & 0.05 & 0.21 & TS \\
\hline Hot Spring Rnach HS1 & 43.382791 & -114.932445 & 60 & 9.2 & 1 & 0.1 & 56 & 0.8 & 82 & 11 & 5.7 & 3.7 & 81 & & & & & & M-76 \\
\hline Hot Spring Rnach HS2 & 43.382791 & -114.932445 & 67 & 9.2 & 1 & 0.1 & 56 & 2.0 & 89 & 12 & 5.7 & 3.3 & 78 & & & & & & M-76 \\
\hline Hot Spring Rnach HS3 & 43.382791 & -114.932445 & 64 & 9.2 & 1.2 & 0.1 & 55 & 1.2 & 87 & 11 & 5.7 & 3.2 & 78 & & & & & & M-76 \\
\hline Sheep HS & 43.333898 & -115.033219 & 45 & 9.9 & 0.8 & & 49 & 0.4 & 57 & 8.2 & 3.2 & 1.9 & 68 & & & & & & M-76 \\
\hline Wolf HS. & 43.33723 & -115.0443 & 50 & 9.48 & 1.4 & 0.019 & 52 & 2.3 & 71 & 6.5 & 3 & 1.9 & 64 & 0.08 & 0.02 & 0.02 & 0.02 & 0.19 & $\mathrm{TS}$ \\
\hline Barrons HS1 & 43.29365 & -114.910036 & 49 & 8.3 & 3.4 & 0.1 & 106 & 2.7 & 211 & 12 & 14 & 13 & 84 & & & & 0.11 & & M-76 \\
\hline Barrons HS2 & 43.29383333 & -114.908667 & 73 & 8.2 & 3.6 & 0.1 & 108 & 3.1 & 227 & 13 & 13 & 13 & 84 & & & & 0.11 & & M-76 \\
\hline Barron W1 & 43.29241 & -114.91002 & 38 & 8.03 & 17 & 0.62 & 156 & 3.0 & 183 & 211 & 9.5 & 7.1 & 52 & 0.01 & 0.36 & 0.36 & 0.17 & 0.62 & $\mathrm{TS}$ \\
\hline Lee Barron W2 & 43.30166667 & -114.909167 & 35 & 8 & 3 & 0.1 & 94 & 1.6 & 210 & 5.8 & 11 & 11 & 83 & & & & 0.11 & & M-76 \\
\hline Lee Barron W3 & 43.30116667 & -114.908333 & 45 & 8.5 & 2.2 & 0.1 & 99 & 2.0 & 215 & 9.1 & 12 & 10 & 64 & & & & & & M-76 \\
\hline Punkin Corner Area W & 43.30216667 & -114.906667 & 35 & 7.4 & 3.2 & 0.1 & 96 & 1.3 & 216 & 6.4 & 12 & 11 & 78 & & & & & & YM-73 \\
\hline Sun Valley Ranch W & 43.317763 & -114.90548 & 26 & 7.8 & 3 & 0.6 & 86 & 2.4 & 193 & 5.3 & 10 & 9.8 & 78 & & & & & & M-76 \\
\hline Prince Albert HS & 43.12966 & -115.33841 & 57.7 & 9.08 & 0.3 & 0.006 & 55 & 2.7 & 105 & 8.4 & 2.6 & 7 & 110 & 0.02 & 0.001 & 0.01 & 0.04 & 0.20 & TS \\
\hline Latty HS & 43.11025 & -115.31258 & 65.0 & 9.25 & 0.2 & 0.005 & 54 & 1.9 & 107 & 11.5 & 2.7 & 6.8 & 103 & 0.02 & 0.001 & 0.02 & 0.04 & 0.17 & $\mathrm{TS}$ \\
\hline White Arrow HS & 43.04867 & -114.95150 & 65 & 7.5 & 1.2 & 0.04 & 91 & 1.6 & 141 & 15.0 & 6.6 & 12 & 99 & & & & & 0.37 & $\mathrm{TS}$ \\
\hline Janns Farm W1 & 43.02467 & -115.00917 & 38 & 7.8 & 3.2 & 0.2 & 160 & 3.7 & 447 & 5.4 & 10 & 3 & 86 & & & & & 0.72 & YM-73 \\
\hline Dave Archer W & 43.02444 & -115.00944 & 43 & 8.6 & 1.6 & 0.1 & 90 & 0.8 & 83 & 19.0 & 8.4 & 19 & 62 & & & & & 0.28 & YM-73 \\
\hline Shannon W & 43.05333 & -114.91600 & 47 & 7 & 9.8 & 1.2 & 100 & 5.9 & 278 & 19.0 & 8.2 & 12 & 92 & & & & & 0.53 & YM-73 \\
\hline Leslie Beam W & 43.114631 & -115.452562 & 68 & 8.5 & 1.5 & 0.04 & 87 & 0.8 & 125 & 14.0 & 4.5 & 17 & 86 & & & & & 0.34 & YM-73 \\
\hline Bill Davis W & 43.09583 & -115.40833 & 62 & 9.2 & 0.9 & 0.1 & 82 & 0.8 & 81 & 14.0 & 3.2 & 16 & 85 & & & & & 0.28 & YM-73 \\
\hline Diamond Laundry W & 42.95543 & -115.29997 & 35.0 & 8.89 & 1.7 & 0.18 & 142 & 1.3 & 315 & 4.3 & 23.3 & 13.1 & 30 & 0.01 & 0.007 & 0.02 & 0.89 & 0.44 & $\mathrm{TS}$ \\
\hline Johnston Well W & 43.00294 & -115.19222 & 39.0 & 9.26 & 2.4 & 0.05 & 77 & 1.3 & 117 & 10.3 & 5.9 & 17 & 41 & 0.01 & 0.002 & 0.02 & 0.33 & 0.26 & $\mathrm{TS}$ \\
\hline Laib W & 42.94632 & -115.49423 & 32.5 & 7.64 & 9.4 & 0.6 & 292 & 9.8 & 886 & 10.4 & 66 & 1.7 & 58 & 0.18 & 0.09 & 0.34 & 2.17 & 0.92 & $\mathrm{TS}$ \\
\hline Charles Boyd W & 42.946500 & -115.493333 & 34.0 & 7.7 & 9.1 & 1 & 320 & 11 & 797 & 6.5 & 59 & 2.2 & 58 & & & & & 0.86 & YM-73 \\
\hline Magic West CO W & 42.947833 & -115.295833 & 37.5 & 7.9 & 2.5 & 0.2 & 130 & 0.9 & 270 & 2.5 & 29 & 13 & 46 & & & & & 0.37 & YM-73 \\
\hline
\end{tabular}




\begin{tabular}{|c|c|c|c|c|c|c|c|c|c|c|c|c|c|c|c|c|c|c|c|}
\hline Eckart Office W & 42.69940 & -114.91040 & 24.7 & 9.47 & 5.7 & 0.74 & 113 & 4.2 & 81 & 90.9 & 46.5 & 12.2 & 52 & 0.007 & 0.02 & 0.01 & 0.19 & 0.40 & $\mathrm{TS}$ \\
\hline Campbell W1 & 42.64497 & -114.78706 & 34.5 & 7.98 & 23 & 3.0 & 58 & 7.7 & 144 & 40.5 & 23.1 & 2.2 & 72 & & 0.16 & 0.06 & 0.11 & 0.25 & $\mathrm{TS}$ \\
\hline Campbell W2 & 42.64432 & -114.78294 & 34.4 & 7.96 & 27 & 3.5 & 56 & 8.0 & 127 & 31.8 & 20.0 & 2.5 & 69 & & 0.18 & 0.06 & 0.11 & 0.29 & TS \\
\hline Miracle HS W & 42.69457 & -114.85592 & 58.4 & 9.53 & 0.8 & 0.001 & 128 & 1.9 & 93 & 33.7 & 31.7 & 22.4 & 100 & 0.022 & 0.001 & 0.05 & 0.33 & 0.42 & $\mathrm{TS}$ \\
\hline Driscoll W & 42.54479 & -114.94855 & 37.5 & 8.59 & 11 & 0.36 & 149 & 1.4 & 95 & 188.0 & 53.3 & 2.4 & 46 & 0.005 & 0.06 & 0.19 & 0.12 & 0.56 & $\mathrm{TS}$ \\
\hline Driscoll S & 42.54348 & -114.94897 & 36.2 & 8.65 & 11 & 0.79 & 147 & 1.9 & 98 & 186.6 & 53.6 & 2.4 & 48 & 0.016 & 0.07 & 0.19 & 0.11 & 0.57 & $\mathrm{TS}$ \\
\hline Sligers W & 42.70399 & -114.85699 & 72.0 & 9.5 & 0.9 & 0.004 & 136 & 1.6 & 212 & 30.1 & 50.4 & 24.2 & 94 & 0.074 & 0.001 & 0.05 & 0.50 & 0.49 & $\mathrm{TS}$ \\
\hline Banbury HS W & 42.68841 & -114.82680 & 58.8 & 9 & 0.9 & 0.001 & 97 & 1.6 & 249 & 23.5 & 16.9 & 11.4 & 103 & 0.014 & 0.001 & 0.035 & 0.22 & 0.33 & $\mathrm{TS}$ \\
\hline Banbury HS & 42.68841 & -114.82680 & 58.5 & 9 & 1 & 0.001 & 95 & 1.6 & 168 & 23.5 & 16.8 & 11.4 & 103 & 0.015 & 0.001 & 0.034 & 0.22 & 0.33 & $\mathrm{TS}$ \\
\hline Leo Ray Hill W & 42.66778 & -114.82673 & 35.0 & 8.69 & 5.9 & 0.19 & 62 & 3.4 & 140 & 31.3 & 14.0 & 3.4 & 54 & 0.002 & 0.010 & 0.060 & 0.13 & 0.23 & TS \\
\hline Leo Ray Road W & 42.66851 & -114.82436 & 35.5 & 8.41 & 7.6 & 0.45 & 56 & 4.1 & 139 & 24.8 & 11.7 & 3.4 & 54 & 0.011 & 0.018 & 0.060 & 0.13 & 0.22 & $\mathrm{TS}$ \\
\hline Kanaka Rapids W & 42.65772 & -114.79054 & 30.1 & 7.98 & 18 & 1.86 & 50 & 6.7 & 120 & 29.4 & 16.2 & 2.7 & 68 & 0.020 & 0.118 & 0.057 & 0.14 & 0.25 & $\mathrm{TS}$ \\
\hline Hensley W & 42.70501 & -114.85701 & 31.8 & 9.55 & 1.9 & 0.01 & 122 & 1.6 & 232 & 33.1 & 51.9 & 24.1 & 83 & 0.011 & 0.007 & 0.043 & 0.58 & 0.43 & $\mathrm{TS}$ \\
\hline Unnamed W near Buhl & 42.596667 & -114.755833 & 29 & 7.9 & 36 & 5.4 & 61 & 10.0 & 170 & 61 & 31 & 1.9 & 66 & & & 0.070 & 0.12 & 0.36 & LY -82 \\
\hline $\begin{array}{l}\text { Unnamed W N of Balanced } \\
\text { Rock }\end{array}$ & 42.598667 & -114.945 & 30 & 8 & 26 & 3.9 & 35 & 7.9 & 120 & 35 & 16 & 1.8 & 86 & & & 0.050 & 0.06 & 0.28 & LY -82 \\
\hline Unnamed W Melon Valley & 42.634333 & -114.7775 & 25 & 8.1 & 17 & 1.1 & 53 & 7.5 & 160 & 22 & 14 & 2.4 & 87 & & & 0.050 & 0.12 & 0.29 & LY -82 \\
\hline Unnamed W Buhl Wendell & 42.637667 & -114.753 & 26 & 8.3 & 7.4 & 0.2 & 62 & 5.6 & 140 & 21 & 9.9 & 4.8 & 82 & & & 0.080 & 0.14 & 0.26 & LY-82 \\
\hline Kanaka Rapids W4 & 42.658667 & -114.81 & 32 & 8.3 & 10 & 0.5 & 62 & 3.5 & 150 & 25 & 11 & 2.9 & 51 & & & 0.050 & 0.11 & 0.24 & LY-82 \\
\hline Kanaka Rapids W 3 & 42.660500 & -114.815 & 31.5 & 8.6 & 7.5 & 0.3 & 63 & 2.8 & 120 & 26 & 11 & 3.2 & 51 & & & 0.050 & 0.12 & 0.23 & LY-82 \\
\hline Kanaka Rapids W1 & 42.661833 & -114.811333 & 33 & 8.4 & 11 & 0.5 & 61 & 3.9 & 150 & 24 & 11 & 3.1 & 53 & & & 0.060 & 0.11 & 0.25 & LY -82 \\
\hline Kanaka Rapids W2 & 42.661833 & -114.8145 & 32 & 8.4 & 8 & 0.2 & 62 & 2.8 & 140 & 26 & 11 & 3.1 & 53 & & & 0.050 & 0.11 & 0.24 & LY-82 \\
\hline Unnamed W3 Briggs Creek & 42.667167 & -114.816667 & 35 & 8.3 & 7.8 & 0.3 & 63 & 4.0 & 140 & 22 & 13 & 3.6 & 54 & & & 0.060 & 0.10 & 0.24 & LY-82 \\
\hline Unnamed W2 Briggs Creek & 42.670000 & -114.825 & 34 & 8.7 & 5.4 & 0.2 & 66 & 2.9 & 110 & 30 & 13 & 3.7 & 56 & & & 0.050 & 0.12 & 0.24 & LY-82 \\
\hline Unnamed W1 Briggs Creek & 42.675167 & -114.825 & 42.5 & 9.2 & 1.3 & 0.1 & 93 & 1.7 & 89 & 27 & 24 & 12 & 76 & & & 0.030 & 0.21 & 0.30 & LY-82 \\
\hline $\begin{array}{l}\text { Near Banbury Natatorium } \\
\text { W5 }\end{array}$ & 42.682667 & -114.8285 & 30 & 9.3 & 0.9 & 0.1 & 97 & 1.6 & 85 & 28 & 20 & 13 & 64 & & & 0.030 & 0.21 & 0.29 & LY -82 \\
\hline $\begin{array}{l}\text { Near Banbury Natatorium } \\
\text { W2 }\end{array}$ & 42.683667 & -114.833833 & 42.5 & 9.3 & 1.3 & 0.1 & 90 & 1.7 & 85 & 28 & 14 & 9.4 & 67 & & & 0.040 & 0.17 & 0.27 & LY-82 \\
\hline $\begin{array}{l}\text { Near Banbury Natatorium } \\
\text { W4 }\end{array}$ & 42.686000 & -114.826333 & 44.5 & 9.4 & 3.3 & 0.1 & 100 & 1.8 & 83 & 27 & 22 & 12 & 88 & & & 0.04 & 0.23 & 0.32 & LY-82 \\
\hline $\begin{array}{l}\text { Near Banbury Natatorium } \\
\text { W3 }\end{array}$ & 42.686333 & -114.825333 & 42 & 9.2 & 3.7 & 0.2 & 100 & 2.1 & 88 & 27 & 23 & 13 & 94 & & & 0.03 & 0.23 & 0.33 & LY-82 \\
\hline $\begin{array}{l}\text { Near Banbury Natatorium } \\
\text { W1 }\end{array}$ & 42.688000 & -114.831167 & 45.5 & 9.1 & 0.9 & 0.1 & 100 & 1.8 & 100 & 29 & 30 & 26 & 86 & & & 0.04 & 0.23 & 0.34 & LY -82 \\
\hline
\end{tabular}




\begin{tabular}{|c|c|c|c|c|c|c|c|c|c|c|c|c|c|c|c|c|c|c|c|}
\hline Banbury Natatorium W & 42.688500 & -114.825833 & 59 & 9.3 & 1.1 & 0.1 & 110 & 1.6 & 78 & 30 & 23 & 15 & 88 & & & 0.04 & 0.26 & 0.34 & LY-82 \\
\hline Harry Huttanus W2 & 42.688500 & -114.825833 & 59 & 9 & 1.1 & 0.1 & 100 & 1.5 & 90 & 27 & 25 & 14 & 100 & & & 0.04 & 0.23 & 0.34 & LY-82 \\
\hline Hot Sulphur Miracle HS & 42.692000 & -114.859333 & 57 & 9.4 & 0.9 & 0.1 & 130 & 1.5 & 59 & 34 & 34 & 21 & 86 & & & 0.04 & 0.34 & 0.38 & LY-82 \\
\hline $\begin{array}{l}\text { Unnamed W3 near Salmon } \\
\text { Falls Creek HS }\end{array}$ & 42.700667 & -114.850333 & 62 & 9.4 & 0.7 & 0.1 & 150 & 1.4 & 56 & 35 & 48 & 15 & 84 & & & 0.05 & 0.49 & 0.40 & LY-82 \\
\hline $\begin{array}{l}\text { Unnamed W2 near Salmon } \\
\text { Falls Creek HS }\end{array}$ & 42.702500 & -114.856667 & 71.5 & 9.5 & 1.5 & 0.1 & 140 & 1.5 & 56 & 33 & 51 & 27 & 82 & & & 0.06 & 0.51 & 0.40 & LY-82 \\
\hline $\begin{array}{l}\text { Unnamed W1 near Salmon } \\
\text { Falls Creek HS }\end{array}$ & 42.703667 & -114.8555 & 72 & 9.3 & 0.9 & 0.1 & 140 & 1.2 & 59 & 35 & 51 & 27 & 86 & & & 0.06 & 0.47 & 0.41 & LY-82 \\
\hline Salmon Falls Creek HS & 42.703667 & -114.8555 & 70.5 & 9.1 & 1.2 & 0.1 & 140 & 1.1 & 70 & 32 & 50 & 27 & 89 & & & 0.06 & 0.44 & 0.40 & LY-82 \\
\hline CSI W2 & 42.58318 & \begin{tabular}{|l|}
-114.47496 \\
\end{tabular} & 38.1 & 8.79 & 4.5 & 0.19 & 95 & 3.3 & 127 & 46.8 & 26.4 & 9.6 & 64 & 0.001 & 0.02 & 0.01 & 0.15 & 0.33 & $\mathrm{TS}$ \\
\hline CSI W1 & 42.58050 & -114.47089 & 37.7 & 8.81 & 4.0 & 0.22 & 86 & 3.0 & 154 & 45.4 & 25.8 & 8.6 & 61 & 0.003 & 0.02 & 0.02 & 0.19 & 0.31 & $\mathrm{TS}$ \\
\hline Larry Anderson W1 & 42.59755 & \begin{tabular}{|l|}
-114.40018 \\
\end{tabular} & 43.0 & 9.16 & 1.2 & 0.013 & 118 & 2.2 & 188 & 36.3 & 21.1 & 15.8 & 69 & 0.005 & 0.002 & 0.03 & 0.29 & 0.40 & $\mathrm{TS}$ \\
\hline Pristine $\mathrm{S}$ & 42.61390 & \begin{tabular}{|l|}
-114.48799 \\
\end{tabular} & 43.0 & 9.18 & 1.3 & 0.014 & 109 & 2.1 & 154 & 30.8 & 26.7 & 16.5 & 72 & 0.004 & 0.004 & 0.01 & 0.32 & 0.38 & $\mathrm{TS}$ \\
\hline Twin Falls High School W & 42.57256 & -114.45175 & 31.0 & 7.77 & 40 & 9 & 55 & 4.9 & 161 & 76 & 37.5 & 2.4 & 59 & 0.002 & 0.19 & 0.03 & 0.11 & 0.39 & $\mathrm{TS}$ \\
\hline Anderson Campground W & 42.57750 & \begin{tabular}{|l|}
-114.28870 \\
\end{tabular} & 37.0 & 9.05 & 1.5 & 0.02 & 126 & 3.1 & 246 & 37.4 & 34.4 & 23.4 & 66 & 0.024 & 0.004 & 0.07 & 0.50 & 0.42 & $\mathrm{TS}$ \\
\hline Unnamed W & 42.410000 & -114.513333 & 37.0 & 7.30 & 37 & 9.9 & 46 & 11 & 250 & 20 & 5.8 & 2.2 & 28 & & & 0.07 & 0.14 & 0.28 & M-80 \\
\hline Cedar Hill W & 42.415333 & -114.3015 & 38.0 & 7.6 & 18 & 2.0 & 16 & 6.0 & 95 & 9.3 & 8 & 0.6 & 67 & & & & & 0.18 & YM-73 \\
\hline Theodore Sturgill W & 42.417500 & -114.106 & 32.0 & 7.5 & 43 & 8.9 & 11 & 7.4 & 186 & 13 & 5 & 0.7 & 28 & & & & & 0.21 & $\mathrm{R}-70$ \\
\hline Sam High \& Sons W & 42.417667 & -114.228833 & 33.0 & 6.6 & 27 & 3.9 & 17 & 8.6 & 118 & 12 & 15 & 0.3 & 63 & & & & & 0.21 & M-1980 \\
\hline Nat-Soo-Pah HS & 42.345833 & -114.508 & 36.0 & 7.6 & 34 & \begin{tabular}{|l|}
14.0 \\
\end{tabular} & 43 & 11.0 & 266 & 18 & 8 & 1.9 & 19 & & & & & 0.28 & YM-73 \\
\hline Murphy HS & 42.025333 & -115.361667 & 54.5 & 8.5 & 6 & 0.1 & 30 & 2.1 & 56 & 4.7 & 2 & 3.6 & 120 & & & 0.03 & 0.03 & 0.20 & YL-82 \\
\hline $\begin{array}{l}\text { Unnamed W NE of } \\
\text { Mosquito Lake Butte }\end{array}$ & 42.245000 & -115.375 & 26.5 & 7.9 & 31 & 10.0 & 30 & 5.4 & 140 & 32 & 19 & 1.0 & 71 & & & 0.02 & 0.07 & 0.28 & YL-82 \\
\hline Wybenga Dairy & 42.48216 & \begin{tabular}{|l|}
-113.97341 \\
\end{tabular} & 33.9 & 7.45 & 25 & 1.1 & 21 & 8.7 & 115 & 16 & 13.1 & 0.7 & 69 & 0.002 & 0.21 & 0.01 & 0.05 & 0.18 & TS \\
\hline $\begin{array}{l}\text { Unnamed W west of Lower } \\
\text { Goose River }\end{array}$ & 42.164833 & -113.983833 & 43.0 & 8.00 & 14 & 1.1 & 44 & 9.6 & 144 & 15 & 7.0 & 1.3 & 47 & & & & & 0.21 & $\mathrm{TS}$ \\
\hline Basin Cemetery W & 42.22333 & -113.79167 & 30.7 & 7.85 & 18 & 2.4 & 58 & 2.0 & 122 & 21 & 47.4 & 3.6 & 40 & 0.001 & 0.17 & 0.008 & 0.06 & 0.28 & TS \\
\hline Oakley HS & 42.17334 & -113.86163 & 46.9 & 9.32 & 2.2 & 0.02 & 86 & 2.2 & 107 & 21 & 52.6 & 7.6 & 79 & 0.02 & 0.05 & 0.04 & 0.05 & 0.32 & $\mathrm{TS}$ \\
\hline
\end{tabular}




\begin{tabular}{|c|c|c|c|c|c|c|c|c|c|c|c|c|c|c|c|c|c|c|c|}
\hline Richard Austin Well 1 & 42.08533 & -113.93984 & 45.7 & 8.95 & 2.1 & 0.06 & 106 & 1.9 & 205 & 23 & 16.2 & 2.4 & 30 & 0.03 & 0.04 & 0.07 & 0.07 & 0.35 & $\mathrm{TS}$ \\
\hline Morris Mitchell W1 & 42.086833 & -113.941333 & 46.0 & 8.70 & 2 & 0.1 & 110 & 1.8 & 230 & 21 & 17 & 2.4 & 28 & & & & & 0.31 & M-80 \\
\hline Harold Ward W & 42.099167 & -113.631167 & 38.0 & 7.40 & 37 & 9.3 & 70 & 3.1 & 169 & 33 & 80 & 2.9 & 44 & & & & & 0.37 & YM-73 \\
\hline Durfee HS & 42.10008 & -113.63354 & 44.9 & 8.78 & 8.2 & 0.35 & 84 & 3.3 & 107 & 28 & 59 & 6.2 & 68 & 0.003 & 0.12 & 0.09 & 0.08 & 0.33 & $\mathrm{TS}$ \\
\hline Marsh Creek W & 42.47663 & -113.50770 & 59.6 & 8.24 & 9.1 & 0.41 & 108 & 4.3 & 124 & 50 & 52 & 13.2 & 63 & 0.007 & 0.09 & 0.07 & 0.06 & 0.43 & $\mathrm{TS}$ \\
\hline SKAGGS Ranch W1 & 42.476833 & -113.506833 & 60.0 & 7.70 & 8.2 & 0.5 & 110 & 3.9 & 125 & 59 & 55 & 14 & 60 & & & & & 0.37 & YM-73 \\
\hline Skaggs Ranch W & 42.43758 & -113.43432 & 33.3 & 7.66 & 28 & 2.0 & 33 & 3.9 & 181 & 14.5 & 20.4 & 1.5 & 44 & & 0.13 & 0.02 & 0.03 & 0.22 & $\mathrm{TS}$ \\
\hline Critchfield Land \& Cattle W & 42.439833 & -113.432167 & 35.0 & 7.60 & 31 & 0.4 & 34 & 4.1 & 141 & 13.0 & 20.0 & 1.4 & 47 & & & & & & M-80 \\
\hline SKAGGS Ranch W2 & 42.445333 & -113.433833 & 32.0 & 7.90 & 31 & 0.5 & 34 & 3.8 & 143 & 29.0 & 5.9 & 1.6 & 46 & & & & & & M-80 \\
\hline Ruby Farms W & 42.415000 & -113.275 & 39.0 & 8.30 & 27 & 9.5 & 212 & 4.6 & 270 & 17.0 & 20.0 & 4.9 & 59 & & & & & 0.68 & $\mathrm{R}-70$ \\
\hline Indian HS & 42.72589 & -112.87381 & 32.7 & 7.23 & 81 & 19.5 & 126 & 11.5 & 223 & 19.8 & 216 & 0.5 & 20 & 0.002 & 2.12 & 0.08 & 0.10 & 0.83 & $\mathrm{TS}$ \\
\hline Robert Brown W2 & 42.954333 & 112.4428333 & 25 & 7.2 & 45 & 37.0 & 160 & 2.7 & 468 & 100 & 100.0 & 2.5 & 41 & & & & & 0.72 & YM-73 \\
\hline Robert Brown W1 & 42.955833 & -112.441166 & 41 & 7.7 & 70 & 25.0 & 150 & 21 & 478 & 95 & 87.0 & 3.2 & 20 & & & & & 0.71 & YM-73 \\
\hline Fort Hall Thermal W & 42.97813 & -112.41654 & 21.1 & 7.92 & 55 & 21.3 & 29 & 7.1 & 223 & & & & 50 & 001 & 0.31 & 0.03 & & 0.39 & $\mathrm{TS}$ \\
\hline & & & & & & & & & & & & & & & & & & & $\mathrm{TS}$ \\
\hline Yandell WS & 43.11448 & -112.16660 & 22.2 & 7.33 & 72 & 26.3 & 14 & 3.9 & 266 & 90 & 16.3 & 0.6 & 17 & & 0.49 & 0.02 & 0.04 & 0.44 & $\mathrm{TS}$ \\
\hline Alkali Flats WS & 43.037667 & -112.0035 & 34.0 & 6.60 & 210 & 68.0 & 34 & 37.0 & 640 & 340 & 17.0 & 0.9 & 19 & & & & & 1.04 & M- 80 \\
\hline Quidop S1 & 43.02583 & -112.02551 & 21.0 & 6.73 & 165 & 55.8 & 28 & 23.0 & 617 & 224 & 23.3 & 0.8 & 16 & 0.005 & 1.82 & 0.13 & 0.09 & 0.92 & $\mathrm{TS}$ \\
\hline Quidop S2 & 43.03717 & -112.00427 & 38.1 & 6.58 & 199 & 69.0 & 34 & 34.1 & 710 & 345 & 15.2 & 0.8 & 20 & 0.42 & 2.60 & 0.21 & 0.13 & 1.10 & $\mathrm{TS}$ \\
\hline Sampling Features & Latitude & Longitude & $\begin{array}{c}\mathrm{T} \\
\left({ }^{\circ} \mathrm{C}\right)\end{array}$ & $\mathrm{pH}$ & $\mathrm{Ca}$ & $\mathrm{Mg}$ & $\mathrm{Na}$ & $\mathrm{K}$ & $\mathrm{HCO}_{3}$ & $\mathrm{SO}_{4}$ & $\mathrm{Cl}$ & $\mathrm{F}$ & $\begin{array}{l}\mathrm{SiO}_{2} \\
\text { (aq) }\end{array}$ & $\mathrm{Al}$ & $\mathrm{Sr}$ & $\mathrm{Li}$ & B & $\begin{array}{c}\text { TDS } \\
(\mathrm{g} / \mathrm{L})\end{array}$ & Ref \\
\hline $\begin{array}{l}\text { HS: Hot spring } \\
\text { S: Spring } \\
\text { WS: Warm Spring } \\
\text { W: Well }\end{array}$ & & \multicolumn{10}{|c|}{$\begin{array}{l}\text { TS: This study. } \\
\text { R-70: Ross (1970). } \\
\text { M-80: Mitchell et al. (1980). } \\
\text { LY-82: Lewis and Young (1982). } \\
\text { NWIS: USGS National Water Information System (2016) }\end{array}$} & \multicolumn{8}{|c|}{$\begin{array}{l}\text { YL-82: Young and Lewis (1982). } \\
\text { YM-73: Young and Mitchell (1973) } \\
\text { WL-88: Wood and Low (1988) } \\
\text { G-10: GeothermEx (2010) } \\
\text { R-81: Ralstone et al. (1981). }\end{array}$} \\
\hline
\end{tabular}




\section{References}

GeothermEx, Inc.: Independent technical report: Resource evaluation of the Newdale geothermal prospect, Madison and Fremont Counties, Idaho, USA. Geothermix, Inc., Richmond, California, USA, February 10, 2010, p. 101, (2010).

Lewis, R.E. and Young, H.W. (1982) Geothermal resources in the Banbury Hot Springs Area, Twin Falls County, Idaho. USGS Water-Supply Paper 2186, p. 31.

Mitchell, J.C., Johnson, L.L, and Anderson, J.E. (1980) Geothermal Investigations in Idaho - Part 9: Potential for direct heat applications of geothermal resources. Idaho Department of Water Resources, Water Information Bulletin 30.

NWIS (2016). USGS National Water Information System, http://waterdata.usgs.gov/nwis.

Ralston, D.R., Arrigo, J.L., Baglio, J.V. Jr., Coleman, L.M., Souder, K., Mayo, A.L. (1981) Geothermal evaluation of the thrust area zone in southeastern Idaho, Idaho Water and Energy Research Institute, University of Idaho.

Ross, S.H.: Geothermal potential of Idaho. Geothermics Special Issue 2, (1970), 975-1008.

Wood, W.W. and Low, W.H. (1988) Solute geochemistry of the Snake River Plain aquifer, Idaho and eastern Oregon. USGS Professional Paper 1408-D, p. 91.

Young, H.W. and Lewis, R.E. (1982) Hydrology and geochemistry of thermal groundwater in southwestern Idaho and north-central Nevada. Geological Survey Professional Paper 1044-J, USGS, p. 26.

Young, H. W., \& Mitchell, J. C. (1973). Geothermal investigations in Idaho. Part 1. Geochemistry and geologic setting of selected thermal waters. Idaho Dept. of Water Admin., Water Inj Bul, 30, 24. 
Appendix C. Water isotope data for thermal features in and around the Eastern Snake River Plain (ESRP) 


\begin{tabular}{|c|c|c|c|c|c|c|c|c|c|c|c|c|}
\hline Sampling Features & $\begin{array}{l}\delta^{18} \mathrm{O} \\
\mathrm{H}_{2} \mathrm{O} \\
\end{array}$ & $\begin{array}{c}\delta \mathrm{D} \\
\mathrm{H}_{2} \mathrm{O} \\
\end{array}$ & $\begin{array}{c}\text { d-excess } \\
(\% 0)\end{array}$ & $\begin{array}{c}\mathrm{d}^{34} \mathrm{~S}_{\mathrm{SO} 4} \\
(\% \mathrm{o})\end{array}$ & $\begin{array}{l}\delta^{18} \mathrm{O} \\
\mathrm{SO}_{4} \\
\end{array}$ & $\begin{array}{c}\begin{array}{c}\mathrm{T} \delta^{18} \mathrm{O}_{\text {sO4-H2O }} \\
\left({ }^{\circ} \mathrm{C}\right)\end{array} \\
\end{array}$ & $\begin{array}{c}\mathrm{DIC} \\
(\mathrm{mM}) \\
\end{array}$ & $\begin{array}{c}\delta^{{ }^{13}} \mathrm{C}_{\text {DIC }} \\
(\% 0)\end{array}$ & $\begin{array}{l}\text { Dissolved } \\
\mathrm{CH}_{4}(\mathrm{uM})\end{array}$ & $\begin{array}{c}\mathrm{Gas}_{\mathrm{CH}}{ }_{4} \\
(\mathrm{ppm})\end{array}$ & $\begin{array}{c}\delta^{13} \mathrm{C}_{\mathrm{CH} 4} \\
(\% \mathrm{o}) \\
\end{array}$ & $\begin{array}{c}\delta \mathrm{D}_{\mathrm{CH} 4} \\
(\% 0)\end{array}$ \\
\hline Lidy HS1 & -18.2 & -140 & 6.0 & 3.8 & -3.4 & 127 & 5.4 & -1.5 & 2.6 & & -19.7 & -29 \\
\hline Sturm W & -18.6 & -140 & 8.7 & & & & 1.6 & -11.6 & & & & \\
\hline Schwendiman W & -19.1 & -144 & 9.3 & & 0.5 & 87 & 2.2 & -6.5 & $\mathrm{BD}$ & & & \\
\hline Green Canyon HS & -18.8 & -140 & 10.2 & 22.6 & 11.6 & 29 & 4.2 & -2.8 & 0.4 & & -16.1 & \\
\hline Heise HS & -17.6 & -139 & 1.9 & 20.3 & 5.4 & 65 & 21.4 & 3.7 & & & & \\
\hline Greenhouse W & -18.4 & -144 & 4.0 & 14.4 & 0.1 & 95 & 9.4 & -3.5 & $\mathrm{BD}$ & & & \\
\hline Condie HS & -18.6 & -150 & -1.4 & 18.2 & -0.9 & 102 & 9.9 & -2.1 & 1.4 & & 3.6 & -9 \\
\hline Condie $\mathrm{HS}^{\mathrm{GD}}$ & & & & & & & & & & 1282 & 3.7 & 27 \\
\hline Milford Sweat HS & -18.3 & -141 & 5.9 & 15.8 & -1.0 & 105 & 3.2 & -1.6 & 1.6 & & -55.5 & \\
\hline Magic HS Landing W Runoff & -16.0 & -147 & -19.1 & 21.6 & -8.7 & 233 & & & & & & \\
\hline Magic HS Landing W & -16.9 & -151 & -15.3 & 21.9 & -9.8 & 237 & 13.1 & -0.9 & & & & \\
\hline Magic HS Landing $\mathrm{W}^{\mathrm{GD}}$ & & & & & & & & & & 3160 & -22.0 & -203 \\
\hline Elk Creek HS2 & -17.7 & -145 & -3.3 & 13.1 & -3.7 & 136 & 1.4 & -4.2 & 6.8 & & -13.8 & -189 \\
\hline Wardrop HS & -18.4 & -143 & 4.6 & 7.0 & -4.2 & 133 & 1.0 & -7.0 & 2.8 & & -12.8 & \\
\hline Wardrop HS ${ }^{\mathrm{GD}}$ & & & & & & & & & & 2016 & -15.8 & -173 \\
\hline Barron W & -17.3 & -140 & -1.1 & -8.3 & -15.9 & 419 & 2.1 & -6.9 & 2.6 & & -48.9 & \\
\hline Wolf HS & -18.4 & -140 & 7.3 & & - & & 0.6 & -9.1 & & & & \\
\hline Wolf HS ${ }^{G D}$ & & & & & & & & & & 491 & -51.0 & \\
\hline Prince Albert HS & -18.5 & -143 & 5.0 & 8.3 & -6.1 & 154 & 0.9 & -8.6 & 0.5 & & -23.7 & \\
\hline Diamond Laundry W & -18.5 & -144 & 3.6 & & & & & & & & -54.9 & -186 \\
\hline Laib W & -16.5 & -128 & 3.7 & & & & & & & & -53.1 & -168 \\
\hline Eckart Office W & -18.3 & -145 & 0.9 & 5.5 & -2.2 & 115 & 1.9 & -3.1 & $\mathrm{BD}$ & & & \\
\hline Campbell W1 & -17.0 & -134 & 2.1 & 6.2 & -3.4 & 140 & 3.7 & -7.5 & $\mathrm{BD}$ & & & \\
\hline Campbell W2 & -17.2 & -133 & 4.3 & 6.3 & -3.6 & 140 & 3.7 & -7.2 & $\mathrm{BD}$ & & & \\
\hline Miracle HS W & -18.0 & -142 & 2.6 & 6.6 & -4.2 & 137 & 1.5 & -4.6 & 2.2 & & -44.0 & -195 \\
\hline Driscoll S & -17.0 & -134 & 2.1 & 5.7 & -4.8 & 156 & 2.9 & -11.2 & $\mathrm{BD}$ & & & \\
\hline
\end{tabular}




\begin{tabular}{|c|c|c|c|c|c|c|c|c|c|c|c|c|}
\hline Banbury HS W & -17.5 & -137 & 3.2 & 6.0 & -5.6 & 159 & 1.9 & -5.9 & 1.7 & & -51.3 & \\
\hline Banbury HS & -17.5 & -137 & 3.0 & 4.7 & -5.0 & 152 & & & & 2140 & -50.5 & -242 \\
\hline Sligers W & -17.8 & -139 & 3.6 & 11.6 & -1.7 & 115 & 1.2 & -4.2 & 2.2 & & -47.6 & \\
\hline Leo Ray Road W & -17.2 & -133 & 4.8 & & 0.8 & 99 & & & $\mathrm{BD}$ & & & \\
\hline CSI W2 & -17.3 & -134 & 4.6 & 6.6 & -3.0 & 133 & 2.6 & -7.2 & $\mathrm{BD}$ & & & \\
\hline Wybenga Dairy W & -18.0 & -135 & 8.6 & & & & 1.5 & -2.5 & $\mathrm{BD}$ & & & \\
\hline Oakley WS & -18.0 & -138 & 6.1 & 13.4 & -5.9 & 157 & & & $\mathrm{BD}$ & & & \\
\hline Richard Austin W1 & -18.5 & -143 & 5.4 & 14.8 & 0.4 & 92 & 1.5 & -2.7 & 12.9 & & -29.8 & -186 \\
\hline Basin Cemetery W & -17.1 & -131 & 6.1 & & -1.6 & 121 & 1.5 & -6.2 & $\mathrm{BD}$ & & & \\
\hline Durfee HS & -17.7 & -134 & 7.5 & 10.9 & -0.4 & 104 & 1.2 & -7.7 & $\mathrm{BD}$ & & & \\
\hline Marsh Creek W & -17.5 & -135 & 5.3 & 10.2 & -4.1 & 142 & 1.7 & -4.4 & 2.4 & & -31.5 & \\
\hline Grush Dairy W & & & & & & & 1.6 & -2.2 & $\mathrm{BD}$ & & & \\
\hline
\end{tabular}

BD: Below detection

GD: gas duplicate sample

HS: Hot spring

S: Spring

WS: Warm Spring

W: Well 
Appendix D. Geothermometric temperature estimates for thermal features in and around the Eastern Snake River Plain (ESRP). 
Appendix D. Geothermometric temperature estimates for thermal features in and around the Eastern Snake River Plain (ESRP.

\begin{tabular}{|c|c|c|c|c|c|c|c|c|c|c|c|c|c|}
\hline \multirow{2}{*}{ Sampling Features } & \multirow{2}{*}{$\begin{array}{l}\text { Field } \\
\mathrm{T}(\mathrm{C})\end{array}$} & \multirow{2}{*}{ RTEst $^{1}$} & \multirow{2}{*}{$\begin{array}{l}\text { Sulfate } \\
\text {-water } \\
{ }^{18} \mathrm{O}^{2} \\
\end{array}$} & \multicolumn{10}{|c|}{ Temperature $\left({ }^{\circ} \mathrm{C}\right)$} \\
\hline & & & & $\begin{array}{c}\text { Quartz (no } \\
\text { steam loss) }\end{array}$ & Chalcedony $^{2}$ & Quartz $^{4}$ & Silica $^{5}$ & Quartz $^{6}$ & $\mathrm{Na}-\mathrm{K}^{7}$ & $\mathrm{Na}-\mathrm{K}^{8}$ & $\mathrm{Na}-\mathrm{K}^{9}$ & $\mathrm{Na}-\mathrm{K}^{5}$ & $\begin{array}{c}\mathrm{Na}-\mathrm{K}-\mathrm{Ca}- \\
(\mathrm{Mg})^{10}\end{array}$ \\
\hline Lidy HS1 & 56.1 & $140 \pm 8$ & 127 & 89 & 58 & 90 & 60 & 75 & 477 & 416 & 410 & 457 & 67 \\
\hline Lidy HS2 & 52.3 & $138 \pm 6$ & & 85 & 54 & 85 & 56 & 71 & 459 & 405 & 401 & 442 & 69 \\
\hline Lidy HS W & 59.0 & $140 \pm 5$ & & 88 & 57 & 89 & 60 & 74 & 466 & 409 & 405 & 448 & 67 \\
\hline Warm Spring WS & 29.0 & $116 \pm 7$ & & 57 & 25 & 57 & 29 & 42 & 343 & 330 & 336 & 338 & 22 \\
\hline Sturm W & 31.4 & $152 \pm 14$ & & 113 & 84 & 113 & 84 & 100 & 79 & 125 & 145 & 91 & 50 \\
\hline Ashton WS & 41.0 & $147 \pm 5$ & & 143 & 116 & 143 & 114 & 131 & 114 & 156 & 175 & 125 & 130 \\
\hline Warm River S1 & 27.1 & $104 \pm 7$ & & 89 & 58 & 90 & 60 & 75 & 93 & 138 & 157 & 104 & 21 \\
\hline Warm River S2 & 21 & $111 \pm 5$ & & 103 & 74 & 104 & 75 & 90 & 112 & 154 & 173 & 122 & 28 \\
\hline Newdale City W & 30.0 & $96 \pm 4$ & & 118 & 90 & 119 & 90 & 105 & 203 & 229 & 243 & 209 & 81 \\
\hline Wanda Woods W2 & 27.0 & $141 \pm 7$ & & 125 & 97 & 125 & 97 & 112 & 210 & 234 & 248 & 216 & 76 \\
\hline Walz Enterprises W & 26.0 & $131 \pm 8$ & & 114 & 86 & 115 & 86 & 101 & 226 & 247 & 260 & 231 & 80 \\
\hline Wanda Woods W1 & 24.0 & $110 \pm 7$ & & 115 & 86 & 115 & 87 & 102 & 222 & 244 & 257 & 227 & 78 \\
\hline Wallace Little W & 36.0 & $106 \pm 4$ & & 122 & 93 & 122 & 93 & 109 & 199 & 225 & 240 & 205 & 79 \\
\hline Henry Harris W & 33.0 & $133 \pm 5$ & & 114 & 85 & 114 & 85 & 100 & 188 & 217 & 232 & 195 & 77 \\
\hline Donald Trupp W & 32.0 & $115 \pm 3$ & & 122 & 94 & 123 & 94 & 109 & 224 & 245 & 258 & 229 & 98 \\
\hline Wayne Larson W & 22.0 & $122 \pm 3$ & & 134 & 107 & 134 & 105 & 122 & 217 & 240 & 254 & 223 & 111 \\
\hline Schwendiman W & 28.0 & $137 \pm 4$ & 87 & 112 & 83 & 112 & 83 & 98 & 227 & 247 & 261 & 232 & 63 \\
\hline Clyde W & 32.7 & $139 \pm 5$ & & 114 & 86 & 115 & 86 & 101 & 205 & 230 & 245 & 211 & 65 \\
\hline Cinder Block W & 26.3 & $119 \pm 3$ & & 119 & 90 & 119 & 90 & 105 & 184 & 214 & 229 & 191 & 71 \\
\hline G23 & 43 & $75 \pm 6$ & & 96 & 65 & 96 & 67 & 82 & 164 & 198 & 215 & 173 & 54 \\
\hline G25 & 51 & $135 \pm 3$ & & 138 & 112 & 138 & 110 & 126 & 187 & 216 & 232 & 194 & 73 \\
\hline G41 & 25 & $138 \pm 3$ & & 131 & 103 & 131 & 102 & 118 & 212 & 236 & 250 & 218 & 83 \\
\hline G43 & 32 & $136 \pm 5$ & & 119 & 90 & 119 & 90 & 106 & 200 & 227 & 241 & 207 & 79 \\
\hline G44 & 32 & $102 \pm 4$ & & 104 & 74 & 104 & 75 & 90 & 220 & 242 & 256 & 226 & 60 \\
\hline
\end{tabular}




\begin{tabular}{|c|c|c|c|c|c|c|c|c|c|c|c|c|c|}
\hline G50 & 39 & $113 \pm 3$ & & 132 & 105 & 132 & 104 & 119 & 217 & 240 & 253 & 222 & 110 \\
\hline G54 & 41 & $118 \pm 2$ & & 130 & 102 & 130 & 101 & 117 & 199 & 226 & 241 & 206 & 83 \\
\hline G80 & 22 & $103 \pm 2$ & & 115 & 86 & 115 & 86 & 102 & 224 & 245 & 258 & 229 & 74 \\
\hline Remington Produce W & 26.0 & $134 \pm 7$ & & 114 & 86 & 115 & 86 & 101 & 233 & 252 & 265 & 238 & 26 \\
\hline Dean Swindelman W & 32.0 & $129 \pm 12$ & & 114 & 86 & 115 & 86 & 101 & 291 & 294 & 303 & 291 & 47 \\
\hline Pauline SW W & 21.0 & $85 \pm 5$ & & 92 & 61 & 92 & 63 & 78 & 271 & 281 & 291 & 273 & 29 \\
\hline Mark Ricks W & 26.0 & $125 \pm 4$ & & 102 & 72 & 102 & 73 & 88 & 273 & 282 & 292 & 275 & 43 \\
\hline Lavere Ricks W & 21.0 & $116 \pm 8$ & & 94 & 63 & 94 & 65 & 80 & 255 & 268 & 280 & 258 & 36 \\
\hline $\mathrm{G} 21$ & 35.56 & $138 \pm 3$ & & 118 & 89 & 118 & 89 & 104 & 193 & 221 & 236 & 200 & 69 \\
\hline G22 & 32.78 & $104 \pm 10$ & & 96 & 66 & 97 & 68 & 82 & 138 & 176 & 194 & 147 & 24 \\
\hline G24 & 26.67 & $117 \pm 6$ & & 121 & 93 & 121 & 93 & 108 & 317 & 313 & 320 & 315 & 55 \\
\hline G26 & 27.22 & $118 \pm 13$ & & 88 & 57 & 89 & 60 & 74 & 298 & 300 & 308 & 298 & 42 \\
\hline G28 & 21.11 & $122 \pm 2$ & & 79 & 48 & 80 & 50 & 65 & 288 & 292 & 302 & 288 & 43 \\
\hline G30 & 27.78 & $101 \pm 10$ & & 61 & 28 & 61 & 32 & 46 & 205 & 231 & 245 & 211 & 38 \\
\hline G31 & 25 & $92 \pm 7$ & & 85 & 54 & 86 & 56 & 71 & 206 & 232 & 246 & 212 & 23 \\
\hline G36 & 27.22 & $110 \pm 8$ & & 92 & 61 & 92 & 63 & 78 & 198 & 225 & 240 & 205 & 31 \\
\hline G37 & 34.44 & $138 \pm 3$ & & 114 & 85 & 114 & 85 & 100 & 369 & 348 & 352 & 362 & 55 \\
\hline G38 & 26.11 & $98 \pm 3$ & & 85 & 54 & 86 & 56 & 71 & 205 & 230 & 245 & 211 & 28 \\
\hline G39 & 25 & $121 \pm 1$ & & 89 & 58 & 89 & 60 & 75 & 288 & 293 & 302 & 289 & 40 \\
\hline G56 & 28.89 & $102 \pm 8$ & & 88 & 57 & 89 & 60 & 74 & 151 & 187 & 205 & 160 & 22 \\
\hline G64 & 20 & $96 \pm 4$ & & 85 & 54 & 86 & 57 & 71 & 213 & 237 & 251 & 219 & 40 \\
\hline G65 & 28.33 & $89 \pm 7$ & & 87 & 56 & 88 & 58 & 73 & 219 & 241 & 255 & 224 & 26 \\
\hline G66 & 29.44 & $102 \pm 7$ & & 88 & 58 & 89 & 60 & 74 & 151 & 187 & 204 & 160 & 28 \\
\hline G67 & 30 & $134 \pm 12$ & & 90 & 59 & 91 & 61 & 76 & 163 & 197 & 214 & 171 & 31 \\
\hline G78 & 27.78 & $152 \pm 5$ & & 108 & 78 & 108 & 79 & 94 & 209 & 233 & 247 & 215 & 53 \\
\hline Green Canyon HS & 44 & $94 \pm 4$ & 29 & 75 & 44 & 76 & 47 & 61 & 671 & 521 & 499 & 622 & 12 \\
\hline Heise HS & 48.2 & $88 \pm 2$ & 65 & 84 & 53 & 85 & 56 & 70 & 222 & 243 & 257 & 227 & 86 \\
\hline Hawley WS & 16.4 & $109 \pm 11$ & & 107 & 78 & 108 & 79 & 94 & 367 & 347 & 350 & 360 & 29 \\
\hline Elkhorn WS & 20.2 & $117 \pm 6$ & & 108 & 79 & 108 & 79 & 94 & 353 & 337 & 342 & 347 & 30 \\
\hline
\end{tabular}




\begin{tabular}{|c|c|c|c|c|c|c|c|c|c|c|c|c|c|}
\hline Comore Loma W6 & 20.9 & $136 \pm 9$ & & 115 & 86 & 115 & 86 & 101 & 249 & 264 & 276 & 252 & 63 \\
\hline Comore Loma W5 & 27.7 & $138 \pm 11$ & & 128 & 101 & 129 & 100 & 116 & 258 & 271 & 282 & 261 & 56 \\
\hline Blackhawk W2 & 26.8 & $140 \pm 10$ & & 127 & 100 & 128 & 99 & 115 & 226 & 247 & 260 & 231 & 65 \\
\hline Blackhawk W1 & 25.1 & $140 \pm 10$ & & 126 & 99 & 127 & 98 & 114 & 224 & 246 & 259 & 229 & 66 \\
\hline Dyer W & 21 & $146 \pm 7$ & & 117 & 88 & 117 & 88 & 104 & 139 & 177 & 195 & 148 & 37 \\
\hline Anderson W & 20 & $143 \pm 7$ & & 143 & 117 & 143 & 115 & 132 & 241 & 258 & 270 & 245 & 59 \\
\hline Butte City W & 32.5 & $61 \pm 4$ & & 84 & 52 & 84 & 55 & 69 & 301 & 302 & 310 & 300 & 58 \\
\hline Greenhouse W & 36.3 & $60 \pm 4$ & 95 & 82 & 50 & 82 & 53 & 67 & 332 & 323 & 329 & 328 & 56 \\
\hline E Butte City W & 22.80 & $49 \pm 4$ & & 70 & 38 & 71 & 42 & 56 & 267 & 277 & 288 & 269 & 45 \\
\hline W Butte City W & 27.00 & $57 \pm 4$ & & 80 & 49 & 80 & 51 & 66 & 288 & 293 & 302 & 289 & 57 \\
\hline Birch and 7th St W & 28.00 & $66 \pm 8$ & & 90 & 59 & 90 & 61 & 76 & 339 & 328 & 333 & 335 & \\
\hline Lewis Rothwell W & 41.00 & $80 \pm 3$ & & 106 & 77 & 107 & 78 & 93 & 342 & 330 & 335 & 337 & 60 \\
\hline Condie HS & 50.5 & $91 \pm 6$ & 102 & 79 & 47 & 79 & 50 & 64 & 385 & 359 & 361 & 376 & 85 \\
\hline Milford Sweat HS & 38.1 & $73 \pm 9$ & 105 & 71 & 40 & 72 & 43 & 57 & 275 & 283 & 293 & 276 & 59 \\
\hline Rush WS1 & 29.5 & $103 \pm 6$ & & 79 & 48 & 80 & 50 & 65 & 351 & 336 & 341 & 345 & 83 \\
\hline Rush WS2 & 23.2 & $97 \pm 2$ & & 83 & 51 & 83 & 54 & 68 & 351 & 336 & 341 & 346 & 80 \\
\hline $\begin{array}{l}\text { Magic HS Landing W } \\
\text { Runoff }\end{array}$ & 39.1 & $163 \pm 2$ & 233 & 142 & 116 & 142 & 114 & 131 & 143 & 180 & 198 & 152 & 143 \\
\hline Magic HS Landing W & 75.0 & $151 \pm 3$ & 237 & 139 & 113 & 139 & 111 & 127 & 144 & 181 & 199 & 153 & 149 \\
\hline Elk Creek HS1 & 50.0 & $126 \pm 2$ & & 114 & 86 & 115 & 86 & 101 & 57 & 105 & 126 & 69 & 86 \\
\hline Elk Creek HS2 & 55.5 & $124 \pm 2$ & 136 & 115 & 86 & 115 & 86 & 101 & 53 & 102 & 122 & 65 & 85 \\
\hline Wardrop HS & 67.5 & $181 \pm 3$ & 133 & 123 & 95 & 123 & 95 & 110 & 48 & 97 & 118 & 60 & 74 \\
\hline Hot Spring Rnach HS1 & 60 & $188 \pm 3$ & & 126 & 98 & 126 & 97 & 113 & 44 & 93 & 113 & 56 & 75 \\
\hline Hot Spring Rnach HS2 & 67 & $194 \pm 2$ & & 124 & 96 & 124 & 95 & 111 & 98 & 142 & 162 & 109 & 130 \\
\hline Hot Spring Rnach HS3 & 64 & $188 \pm 1$ & & 124 & 96 & 124 & 95 & 111 & 67 & 114 & 134 & 78 & 114 \\
\hline
\end{tabular}




\begin{tabular}{|c|c|c|c|c|c|c|c|c|c|c|c|c|c|}
\hline Sheep HS & 45 & $198 \pm 11$ & & 117 & 88 & 117 & 88 & 104 & 17 & 68 & 89 & 30 & 57 \\
\hline Wolf HS. & 50 & $204 \pm 2$ & & 114 & 85 & 114 & 85 & 100 & 112 & 154 & 173 & 123 & 141 \\
\hline Barrons HS1 & 49 & $103 \pm 2$ & & 128 & 100 & 128 & 99 & 115 & 76 & 122 & 143 & 88 & 122 \\
\hline Barrons HS2 & 73 & $104 \pm 6$ & & 128 & 100 & 128 & 99 & 115 & 84 & 129 & 149 & 95 & 127 \\
\hline Barron W1 & 38 & $79 \pm 0$ & 419 & 103 & 74 & 104 & 75 & 90 & 59 & 107 & 127 & 71 & 68 \\
\hline Lee Barron W2 & 35 & $104 \pm 4$ & & 127 & 99 & 127 & 99 & 114 & 53 & 101 & 122 & 65 & 79 \\
\hline Lee Barron W3 & 45 & $103 \pm 5$ & & 114 & 85 & 114 & 85 & 100 & 62 & 110 & 130 & 74 & 115 \\
\hline Punkin Corner Area W & 35 & $105 \pm 6$ & & 122 & 94 & 123 & 94 & 109 & 43 & 92 & 113 & 55 & 71 \\
\hline Sun Valley Ranch W & 26 & $108 \pm 4$ & & 124 & 96 & 124 & 95 & 111 & 82 & 128 & 148 & 93 & 90 \\
\hline Prince Albert HS & 57.7 & $193 \pm 8$ & 154 & 143 & 117 & 143 & 115 & 131 & 121 & 162 & 180 & 131 & 161 \\
\hline Latty HS & 65.0 & $197 \pm 5$ & & 139 & 112 & 139 & 111 & 127 & 97 & 141 & 161 & 108 & 147 \\
\hline White Arrow HS & 65 & $177 \pm 6$ & & 136 & 110 & 137 & 108 & 124 & 55 & 103 & 123 & 66 & 112 \\
\hline Janns Farm W1 & 38 & $88 \pm 5$ & & 129 & 101 & 129 & 101 & 116 & 70 & 117 & 137 & 82 & 124 \\
\hline Dave Archer W & 43 & $101 \pm 2$ & & 112 & 83 & 112 & 84 & 99 & 21 & 71 & 93 & 33 & 70 \\
\hline Shannon W & 47 & $137 \pm 10$ & & 133 & 105 & 133 & 104 & 120 & 137 & 176 & 193 & 147 & 110 \\
\hline Leslie Beam W & 68 & $102 \pm 3$ & & 129 & 101 & 129 & 101 & 116 & 23 & 73 & 94 & 35 & 71 \\
\hline Bill Davis W & 62 & $122 \pm 1$ & & 128 & 101 & 128 & 100 & 116 & 25 & 75 & 96 & 37 & 81 \\
\hline Diamond Laundry W & 35.0 & $70 \pm 2$ & & 80 & 48 & 80 & 51 & 65 & 22 & 72 & 93 & 34 & 90 \\
\hline Johnston Well W & 39.0 & $67 \pm 4$ & & 93 & 62 & 93 & 64 & 79 & 51 & 99 & 120 & 63 & 74 \\
\hline Laib W & 32.5 & $83 \pm 1$ & & 109 & 79 & 109 & 80 & 95 & 94 & 139 & 158 & 105 & 138 \\
\hline Charles Boyd W & 34.0 & $85 \pm 1$ & & 109 & 79 & 109 & 80 & 95 & 96 & 140 & 159 & 107 & 123 \\
\hline Magic West CO W & 37.5 & $74 \pm 3$ & & 98 & 68 & 98 & 69 & 84 & 11 & 61 & 82 & 23 & 68 \\
\hline Eckart Office W & 24.7 & $127 \pm 9$ & 115 & 104 & 74 & 104 & 75 & 90 & 101 & 144 & 163 & 111 & 107 \\
\hline Campbell W1 & 34.5 & $137 \pm 6$ & 140 & 120 & 91 & 120 & 91 & 106 & 221 & 243 & 257 & 227 & 80 \\
\hline Campbell W2 & 34.4 & $131 \pm 9$ & 140 & 118 & 89 & 118 & 89 & 105 & 231 & 250 & 263 & 235 & 79 \\
\hline Miracle HS W & 58.4 & $161 \pm 3$ & 137 & 137 & 110 & 137 & 109 & 125 & 45 & 93 & 114 & 57 & 112 \\
\hline Driscoll W & 37.5 & $134 \pm 8$ & & 98 & 67 & 98 & 69 & 84 & 23 & 73 & 94 & 35 & 53 \\
\hline Driscoll S & 36.2 & $137 \pm 8$ & 156 & 100 & 70 & 101 & 72 & 86 & 39 & 88 & 110 & 51 & 62 \\
\hline
\end{tabular}




\begin{tabular}{|c|c|c|c|c|c|c|c|c|c|c|c|c|c|}
\hline Sligers W & 72.0 & $134 \pm 2$ & 115 & 133 & 106 & 134 & 105 & 121 & 34 & 83 & 104 & 46 & 103 \\
\hline Banbury HS W & 58.8 & $159 \pm 10$ & 159 & 139 & 113 & 139 & 111 & 127 & 53 & 101 & 122 & 65 & 114 \\
\hline Banbury HS & 58.5 & $159 \pm 9$ & 152 & 139 & 112 & 139 & 111 & 127 & 52 & 101 & 121 & 64 & 112 \\
\hline Leo Ray Hill W & 35.0 & $121 \pm 6$ & & 105 & 76 & 106 & 77 & 92 & 132 & 171 & 189 & 141 & 144 \\
\hline Leo Ray Road W & 35.5 & $120 \pm 1$ & 99 & 106 & 76 & 106 & 77 & 92 & 156 & 191 & 208 & 164 & 140 \\
\hline Kanaka Rapids W & 30.1 & $112 \pm 7$ & & 117 & 88 & 117 & 89 & 104 & 222 & 244 & 257 & 227 & 121 \\
\hline Hensley W & 31.8 & $138 \pm 17$ & & 127 & 100 & 127 & 99 & 115 & 40 & 89 & 110 & 52 & 102 \\
\hline Unnamed W near Buhl & 29.0 & $130 \pm 11$ & & 115 & 86 & 115 & 87 & 102 & 248 & 263 & 275 & 251 & 80 \\
\hline $\begin{array}{l}\text { Unnamed W N of } \\
\text { Balanced Rock }\end{array}$ & 30.0 & $163 \pm 6$ & & 129 & 101 & 129 & 101 & 116 & 296 & 298 & 307 & 296 & 102 \\
\hline $\begin{array}{l}\text { Unnamed W Melon } \\
\text { Valley }\end{array}$ & 25.0 & $129 \pm 9$ & & 130 & 102 & 130 & 101 & 117 & 229 & 249 & 262 & 233 & 148 \\
\hline $\begin{array}{l}\text { Unnamed W Buhl } \\
\text { Wendell }\end{array}$ & 26.0 & $127 \pm 3$ & & 126 & 99 & 127 & 98 & 114 & 177 & 208 & 224 & 185 & 165 \\
\hline Kanaka Rapids W4 & 32.5 & $102 \pm 2$ & & 103 & 73 & 103 & 74 & 89 & 133 & 172 & 190 & 143 & 136 \\
\hline Kanaka Rapids W 3 & 31.5 & $106 \pm 1$ & & 103 & 73 & 103 & 74 & 89 & 114 & 156 & 175 & 125 & 133 \\
\hline Kanaka Rapids W1 & 33.0 & $103 \pm 3$ & & 105 & 75 & 105 & 76 & 91 & 144 & 181 & 199 & 153 & 140 \\
\hline Kanaka Rapids W2 & 32.0 & $107 \pm 5$ & & 105 & 75 & 105 & 76 & 91 & 116 & 157 & 176 & 126 & 133 \\
\hline $\begin{array}{l}\text { Unnamed W3 Briggs } \\
\text { Creek }\end{array}$ & 35.0 & $109 \pm 3$ & & 105 & 76 & 106 & 77 & 92 & 144 & 181 & 198 & 153 & 146 \\
\hline $\begin{array}{l}\text { Unnamed W2 Briggs } \\
\text { Creek }\end{array}$ & 34.0 & $116 \pm 4$ & & 107 & 78 & 108 & 79 & 94 & 113 & 155 & 174 & 124 & 136 \\
\hline $\begin{array}{l}\text { Unnamed W1 Briggs } \\
\text { Creek }\end{array}$ & 42.5 & $121 \pm 2$ & & 122 & 94 & 123 & 94 & 109 & 57 & 105 & 125 & 68 & 114 \\
\hline $\begin{array}{l}\text { Near Banbury } \\
\text { Natatorium W5 }\end{array}$ & 30.0 & $145 \pm 6$ & & 114 & 85 & 114 & 85 & 100 & 51 & 100 & 120 & 63 & 113 \\
\hline $\begin{array}{l}\text { Near Banbury } \\
\text { Natatorium W2 }\end{array}$ & 42.5 & $139 \pm 7$ & & 116 & 87 & 116 & 87 & 103 & 59 & 106 & 127 & 70 & 114 \\
\hline $\begin{array}{l}\text { Near Banbury } \\
\text { Natatorium W4 }\end{array}$ & 44.5 & $139 \pm 7$ & & 130 & 103 & 130 & 102 & 118 & 56 & 104 & 125 & 68 & 108 \\
\hline $\begin{array}{l}\text { Near Banbury } \\
\text { Natatorium W3 }\end{array}$ & 42.0 & $142 \pm 8$ & & 134 & 107 & 134 & 105 & 122 & 65 & 112 & 132 & 76 & 113 \\
\hline $\begin{array}{l}\text { Near Banbury } \\
\text { Natatorium W1 }\end{array}$ & 45.5 & $157 \pm 6$ & & 129 & 101 & 129 & 101 & 116 & 56 & 104 & 125 & 68 & 116 \\
\hline Banbury Natatorium W & 59.0 & $148 \pm 6$ & & 130 & 103 & 130 & 102 & 118 & 45 & 93 & 114 & 57 & 108 \\
\hline Harry Huttanus W2 & 59.0 & $155 \pm 8$ & & 137 & 110 & 137 & 109 & 125 & 46 & 95 & 116 & 58 & 108 \\
\hline $\begin{array}{l}\text { Hot Sulphur Miracle } \\
\text { HS }\end{array}$ & 57.0 & $150 \pm 4$ & & 129 & 101 & 129 & 101 & 116 & 33 & 83 & 104 & 45 & 103 \\
\hline
\end{tabular}




\begin{tabular}{|c|c|c|c|c|c|c|c|c|c|c|c|c|c|}
\hline $\begin{array}{l}\text { Unnamed W3 near } \\
\text { Salmon Falls Creek HS }\end{array}$ & 62.0 & $152 \pm 2$ & & 128 & 100 & 128 & 99 & 115 & 23 & 73 & 95 & 35 & 98 \\
\hline $\begin{array}{l}\text { Unnamed W2 near } \\
\text { Salmon Falls Creek HS }\end{array}$ & 71.5 & $135 \pm 5$ & & 126 & 99 & 127 & 98 & 114 & 30 & 79 & 101 & 42 & 98 \\
\hline $\begin{array}{l}\text { Unnamed W1 near } \\
\text { Salmon Falls Creek HS }\end{array}$ & 72.0 & $150 \pm 3$ & & 129 & 101 & 129 & 101 & 116 & 20 & 70 & 91 & 32 & 93 \\
\hline Salmon Falls Creek HS & 70.5 & $148 \pm 5$ & & 131 & 103 & 131 & 102 & 118 & 16 & 66 & 87 & 28 & 92 \\
\hline CSI W2 & 38.1 & $136 \pm 11$ & 133 & 114 & 85 & 114 & 85 & 101 & 96 & 140 & 160 & 107 & 132 \\
\hline CSI W1 & 37.7 & $134 \pm 12$ & & 111 & 82 & 112 & 83 & 98 & 96 & 140 & 160 & 107 & 131 \\
\hline Larry Anderson Wl & 43.0 & $108 \pm 3$ & & 118 & 89 & 118 & 89 & 104 & 58 & 105 & 126 & 69 & 118 \\
\hline Pristine S & 43.0 & $130 \pm 11$ & & 119 & 91 & 120 & 91 & 106 & 60 & 108 & 128 & 72 & 118 \\
\hline $\begin{array}{l}\text { Twin Falls High School } \\
\text { W }\end{array}$ & 31.0 & $115 \pm 4$ & & 110 & 80 & 110 & 81 & 96 & 175 & 207 & 223 & 183 & 56 \\
\hline $\begin{array}{l}\text { Anderson Campground } \\
\mathrm{W}\end{array}$ & 37.0 & $123 \pm 3$ & & 115 & 86 & 116 & 87 & 102 & 74 & 120 & 141 & 85 & 129 \\
\hline Unnamed W & 37.0 & $98 \pm 1$ & & 77 & 45 & 77 & 48 & 62 & 306 & 305 & 313 & 305 & 73 \\
\hline Cedar Hill W & 38.0 & $122 \pm 5$ & & 116 & 87 & 116 & 87 & 103 & 394 & 364 & 366 & 384 & 65 \\
\hline Theodore Sturgill W & 32.0 & $90 \pm 4$ & & 77 & 45 & 77 & 48 & 62 & 559 & 462 & 450 & 528 & 50 \\
\hline Sam High \& Sons W & 33.0 & $127 \pm 5$ & & 113 & 84 & 113 & 84 & 100 & 469 & 411 & 406 & 451 & 68 \\
\hline Nat-Soo-Pah HS & 36.0 & $75 \pm 5$ & & 62 & 29 & 62 & 33 & 47 & 318 & 313 & 320 & 315 & 54 \\
\hline Murphy HS & 54.5 & $117 \pm 4$ & & 148 & 122 & 148 & 120 & 136 & 152 & 188 & 205 & 161 & 62 \\
\hline $\begin{array}{l}\text { Unnamed W NE of } \\
\text { Mosquito Lake Butte }\end{array}$ & 26.5 & $88 \pm 3$ & & 119 & 90 & 119 & 90 & 106 & 261 & 273 & 284 & 264 & 57 \\
\hline Wybenga Dairy W & 33.9 & $132 \pm 3$ & & 118 & 89 & 118 & 89 & 105 & 419 & 380 & 379 & 406 & 72 \\
\hline $\begin{array}{l}\text { Unnamed W west of } \\
\text { Lower Goose River }\end{array}$ & 43.0 & $84 \pm 5$ & & 99 & 69 & 99 & 70 & 85 & 291 & 294 & 303 & 291 & 155 \\
\hline Basin Cemetery W & 30.7 & $73 \pm 8$ & 121 & 92 & 61 & 92 & 63 & 78 & 95 & 140 & 159 & 106 & 45 \\
\hline Oakley HS & 46.9 & $130 \pm 7$ & 157 & 125 & 97 & 125 & 96 & 112 & 76 & 122 & 143 & 88 & 122 \\
\hline Richard Austin Well 1 & 45.7 & $85 \pm 2$ & 92 & 79 & 48 & 80 & 50 & 65 & 55 & 103 & 124 & 67 & 111 \\
\hline Morris Mitchell W1 & 46.0 & $82 \pm 2$ & & 77 & 45 & 77 & 48 & 62 & 51 & 99 & 120 & 63 & 109 \\
\hline
\end{tabular}




\begin{tabular}{|c|c|c|c|c|c|c|c|c|c|c|c|c|c|}
\hline Harold Ward W & 38.0 & $101 \pm 6$ & & 96 & 66 & 96 & 67 & 82 & 114 & 156 & 175 & 124 & 46 \\
\hline Durfee HS & 44.9 & $138 \pm 8$ & 104 & 117 & 88 & 117 & 88 & 103 & 105 & 148 & 167 & 116 & 80 \\
\hline Marsh Creek W & 59.6 & $125 \pm 10$ & 142 & 113 & 83 & 113 & 84 & 99 & 106 & 149 & 168 & 116 & 89 \\
\hline SKAGGS Ranch W1 & 60.0 & $141 \pm 11$ & & 111 & 81 & 111 & 82 & 97 & 98 & 142 & 161 & 109 & 88 \\
\hline Skaggs Ranch W & 33.3 & $96 \pm 11$ & & 96 & 66 & 96 & 67 & 82 & 207 & 232 & 246 & 213 & 51 \\
\hline $\begin{array}{l}\text { Critchfield Land \& } \\
\text { Cattle W }\end{array}$ & 35.0 & & & 99 & 69 & 99 & 70 & 85 & 209 & 234 & 248 & 215 & 51 \\
\hline SKAGGS Ranch W2 & 32.0 & & & 98 & 68 & 98 & 69 & 84 & 200 & 227 & 241 & 207 & 48 \\
\hline Ruby Farms W & 39.0 & $125 \pm 12$ & & 110 & 80 & 110 & 81 & 96 & 66 & 114 & 134 & 78 & 60 \\
\hline Indian HS & 32.7 & $70 \pm 11$ & & 64 & 32 & 64 & 36 & 49 & 178 & 209 & 225 & 186 & 75 \\
\hline Robert Brown W2 & 25 & $69 \pm 2$ & & 93 & 62 & 93 & 64 & 79 & 52 & 101 & 121 & 64 & \\
\hline Robert Brown W1 & 41 & & & 63 & 31 & 64 & 35 & 49 & 227 & 248 & 261 & 232 & 52 \\
\hline Fort Hall Thermal W & 21.1 & & & 102 & 72 & 102 & 73 & 88 & 309 & 308 & 315 & 308 & 54 \\
\hline Yandell WS & 22.2 & $59 \pm 9$ & & 57 & 24 & 56 & 28 & 41 & 342 & 330 & 335 & 337 & 27 \\
\hline Alkali Flats WS & 34.0 & $90 \pm 4$ & & 62 & 29 & 62 & 33 & 47 & 770 & 568 & 538 & 703 & 62 \\
\hline Quidop S1 & 21.0 & $75 \pm 7$ & & 55 & 23 & 55 & 27 & 40 & 629 & 499 & 481 & 586 & 65 \\
\hline Quidop S2 & 38.1 & $81 \pm 5$ & & 63 & 31 & 63 & 34 & 48 & 730 & 550 & 523 & 670 & 60 \\
\hline Sampling Features & & & & & & & & & & & & & \\
\hline $\begin{array}{l}\text { HS: Hot spring } \\
\text { S: Spring } \\
\text { WS: Warm Spring } \\
\text { W: Well }\end{array}$ & & & & \multicolumn{4}{|c|}{$\begin{array}{l}\text { 1: Palmer et al. (2014); Mattson et al. (2015). } \\
\text { 2: Fowler et al. (2013). } \\
\text { 3: Fournier (1977). } \\
\text { 4: Fournier and Potter II (1982). } \\
\text { 5: Arnorsson et al. (1983). }\end{array}$} & \multicolumn{6}{|c|}{$\begin{array}{l}\text { 6: Arnorsson (2000). } \\
\text { 7: Truesdell (1976). } \\
\text { 8: Fournier (1979). } \\
\text { 9: Giggenbach (1988). } \\
\text { 10: Fournier and Truesdell (1973); Fournier and Potter II (1979). }\end{array}$} \\
\hline
\end{tabular}




\section{References}

Arnorsson, S., Gunnlaugsson, E., \& Svavarsson, H. (1983). The chemistry of geothermal waters in Iceland. III. Chemical geothermometry in geothermal investigations. Geochim. Cosmochim. Acta, 47(3), 567-577.

Amorsson, S. (2000). The quartz-and Na/K geothermometers. I. New thermodynamic calibration. In Proceedings of the World Geothermal Congress (pp. 929-934).

Fournier, R.O. and Truesdell, A.H. (1973) An empirical Na-K-Ca geothermometer for natural waters. Geochim. Cosmochim. Acta, 37, $1255-1275$.

Fournier, R.O. (1977) Chemical geothermometers and mixing models for geothermal systems. Geothermics, 5, 41-50.

Fournier, R.O. (1979) A revised equation for the Na/K geothermometer. GRC Transactions, 3, , 221-224.

Fournier, R.O. and Potter II, R.W. (1979). Magnesium correction to the Na-K-Ca chemical geothermometer. Geochim. Cosmochim. Acta, 43, 15431550.

Fournier, R. O., \& Potter II, R. W. (1982). Revised and expanded silica (quartz) geothermometer. GRC Bulletin 11(10), 3-12.

Fowler, A. P. G., Hackett, L. B., \& Klein, C. W. (2013). Reformulation and Performance Evaluation of the Sulfate-Water Oxygen Isotope Geothermometer. In In: GRC Transactions. GRC Annual Meeting (Vol. 9, p. 31).

Giggenbach, W.F.: Geothermal solute equilibria. Derivation of Na-K-Mg-Ca geoindicators. Geochim. Cosmochim. Acta, 52, (1988), $2749-2765$.

Mattson, E.D., Smith, R.W., Neupane, G., Palmer, C.D., Fujita, Y., McLing, T.L., Reed, D.W., Cooper, D.C., and Thompson, V.S.: Improved geothermometry through multivariate reaction-path modeling and evaluation of geomicrobiological influences on geochemical temperature indicators: Final Report No. INL/EXT-14-33959, Idaho National Laboratory (INL), Idaho Falls, Idaho, (2015).

Palmer, C.D., Ohly, S.R., Smith, R.W., Neupane, G., McLing, T., Mattson, E.: Mineral selection for multicomponent equilibrium geothermometry. GRC Transactions, 38, (2014), 453-459.

Truesdell, A. H., 1976, Summary of Section III Geochemical Techniques in Exploration, Proceedings of the Second United Nations Symposium on the Development and Use of Geothermal Resources, San Francisco 1975, v. 1, p. liii - 1xxix . 
Appendix E. Descriptions of geothermal prospects in and around the Eastern Snake River Plain (ESRP) 


\section{Prospects}

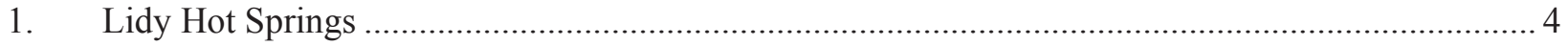

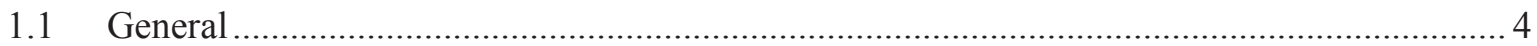

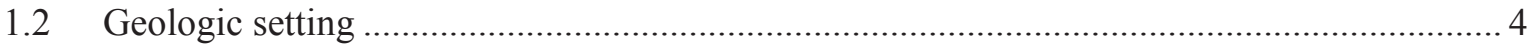

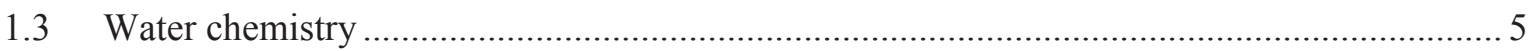

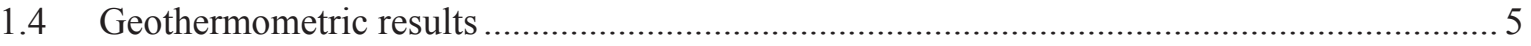

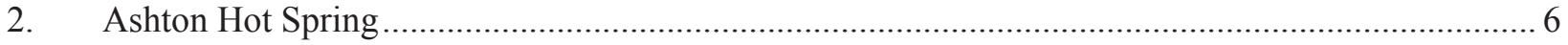

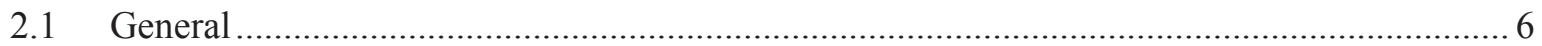

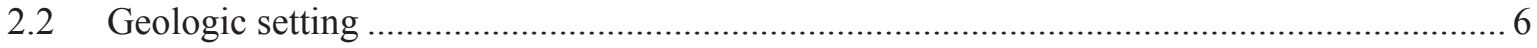

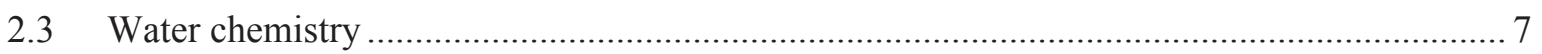

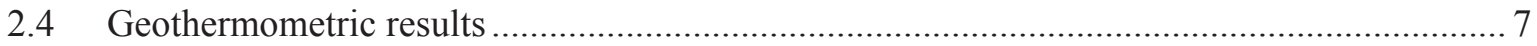

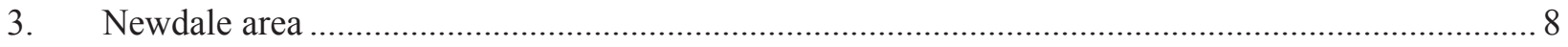

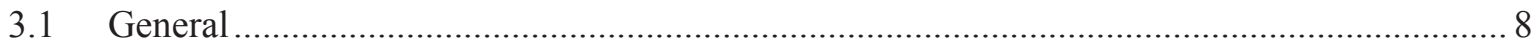

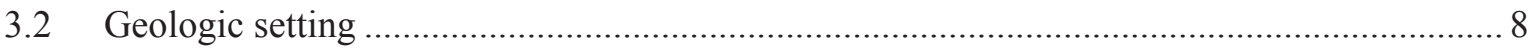

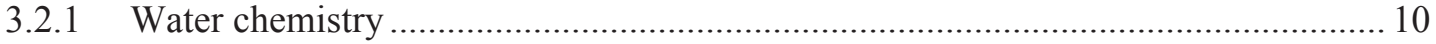

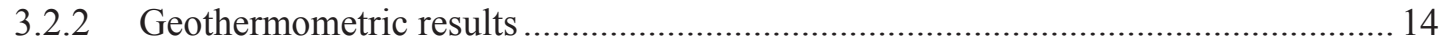

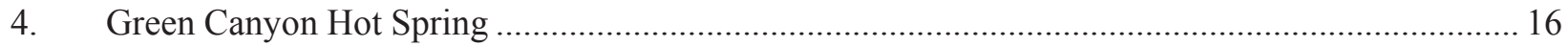

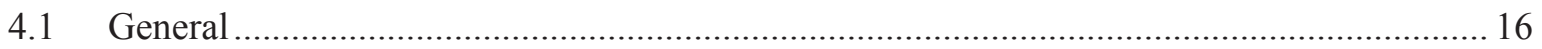

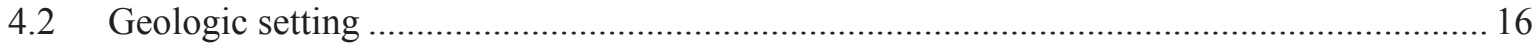

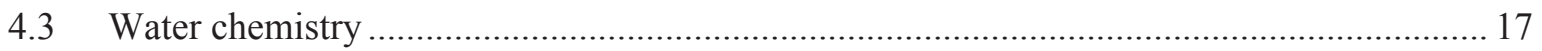

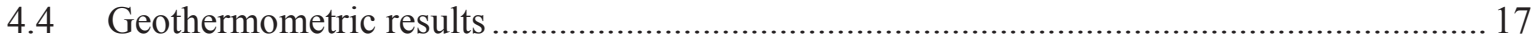

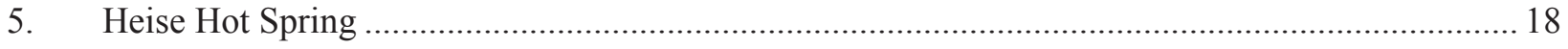

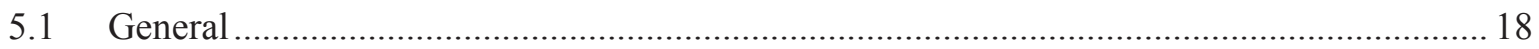

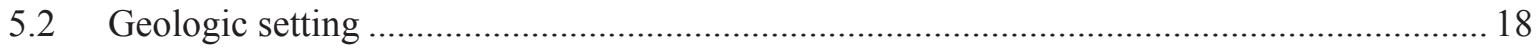

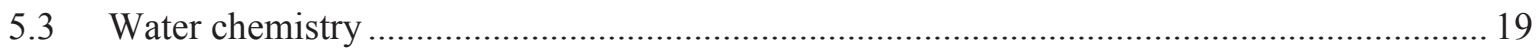

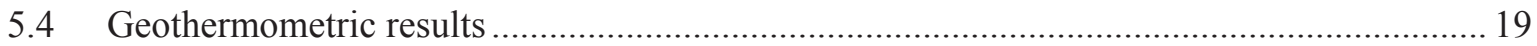

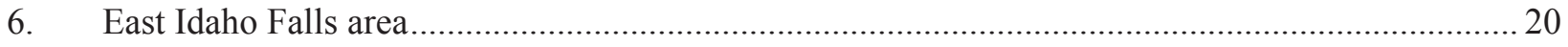

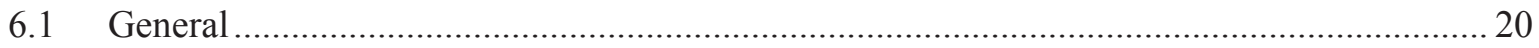

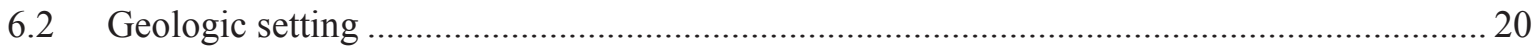

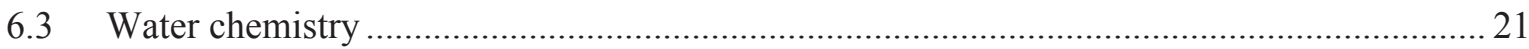

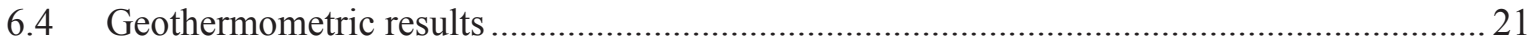

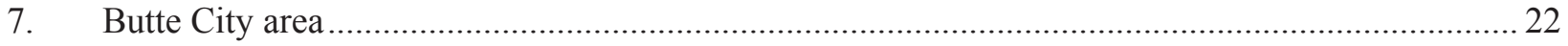

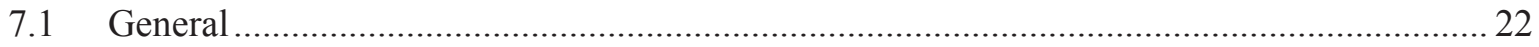

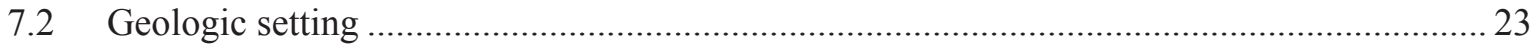

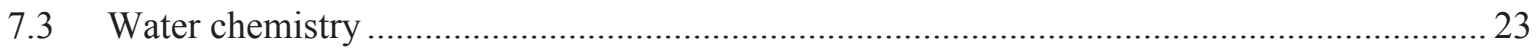

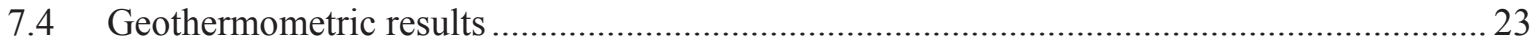




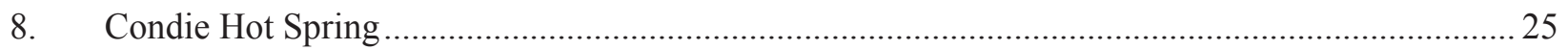

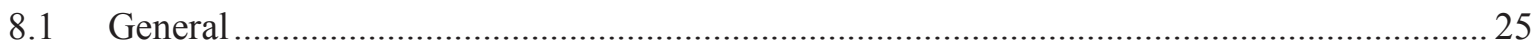

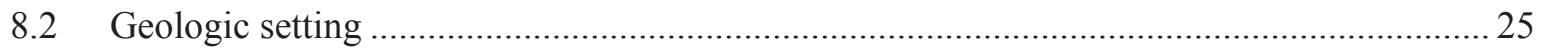

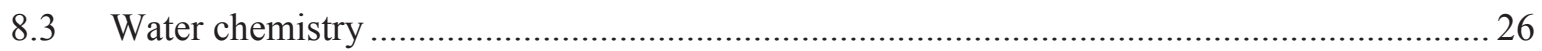

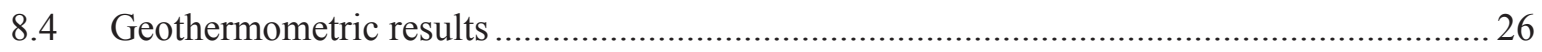

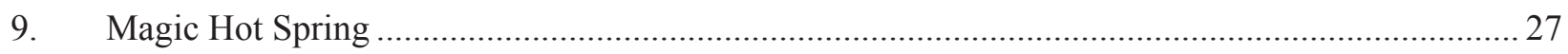

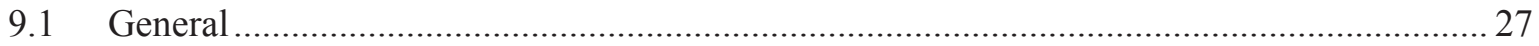

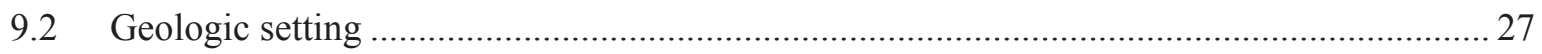

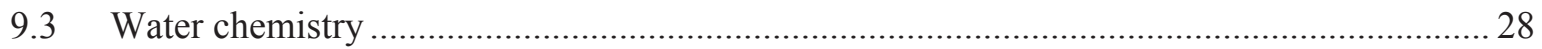

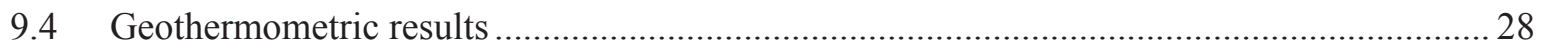

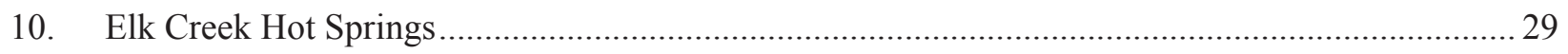

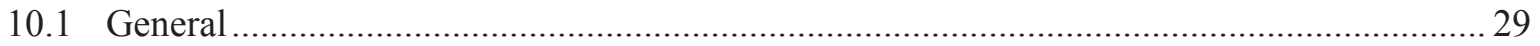

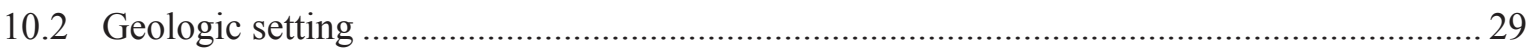

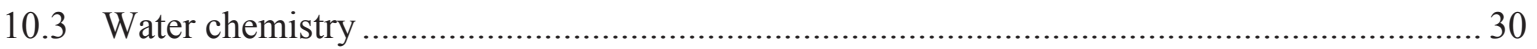

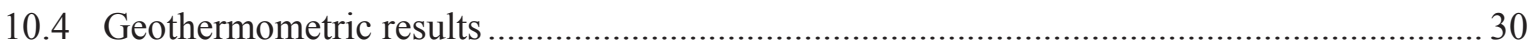

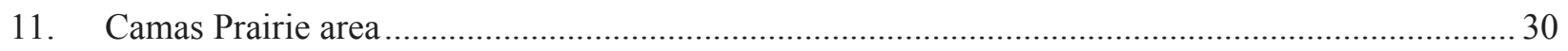

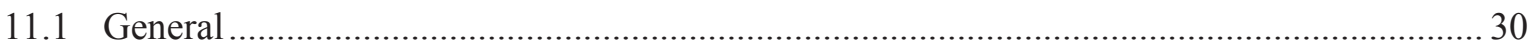

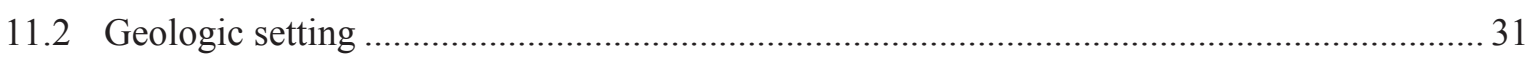

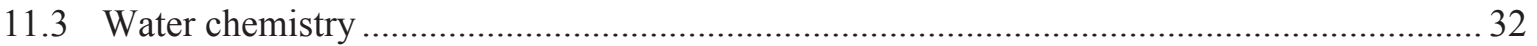

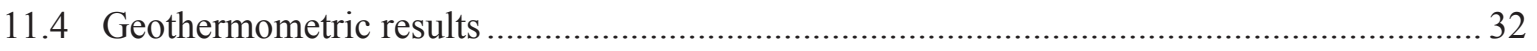

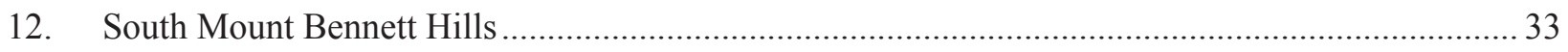

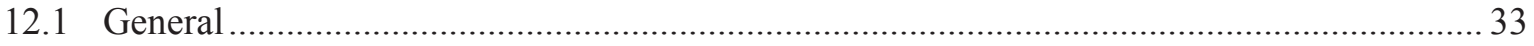

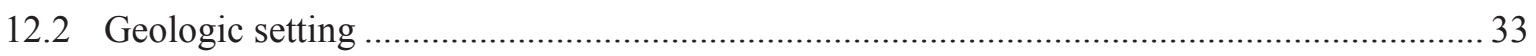

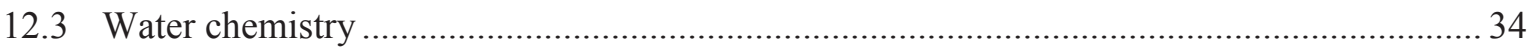

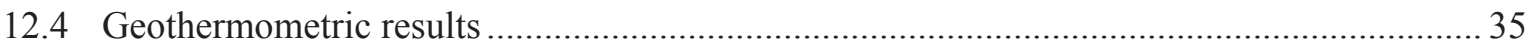

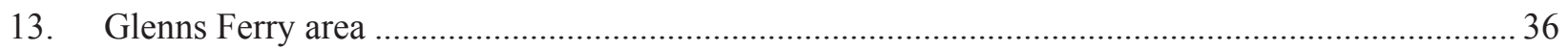

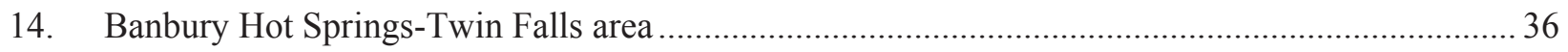

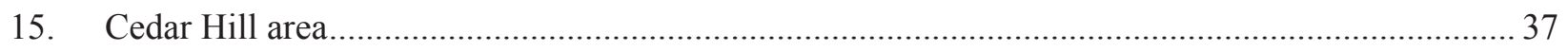

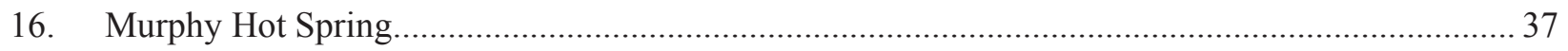

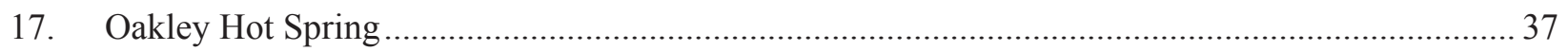

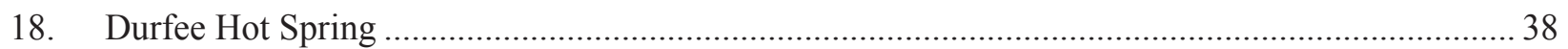

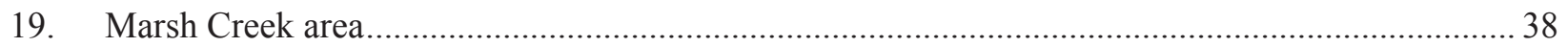

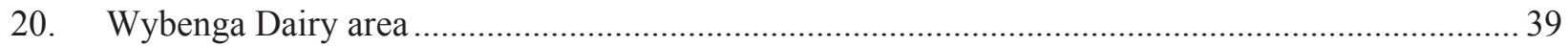

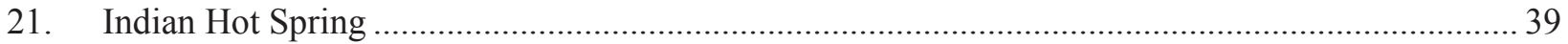




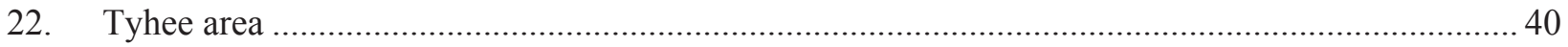

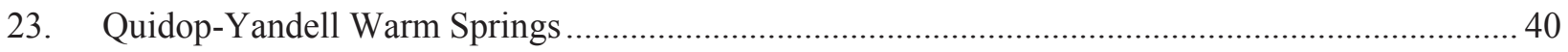

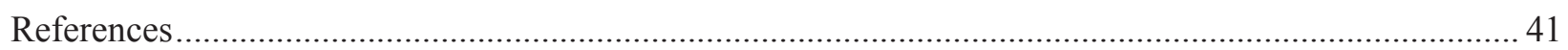




\section{Lidy Hot Springs}

\subsection{General}

The Lidy Hot Springs (LHS) area (Figure 1) is located at the southeastern end of the Beaverhead Mountains on the northwestern margins of the ESRP in Clark County in Idaho. The area is about $27 \mathrm{~km}$ west from Dubois, Idaho along route 22 . From the early $20^{\text {th }}$ century, the area was gradually developed into a commercial recreation site that provided services such as swimming, soaking, dancing, dining, and lodging to public. However, with the transfer of ownership in the early 1960s, the site ceased to offer those recreational services, and started a travertine mining activity.

Two hot springs in the area are issuing thermal water $\left(52-56^{\circ} \mathrm{C}\right)$. Similarly, in the vicinity of the LHS, there are other springs [e.g., Warm Spring $\left(29^{\circ} \mathrm{C}\right)$ ] issuing warmer to cooler waters.

\subsection{Geologic setting}

Rocks underlying the LHS area consist of young volcanics and older meta-sedimentary rocks (Bond et al., 1978; Link, 2002a). The younger rocks (Upper Miocene and Pliocene) consist of fluvial and lacustrine deposits, felsic volcanic rocks, rhyolite flows, tuffs, ignimbrites. Although massive ongoing travertine deposition is lacking, the area may have had greater hydrothermal activities in the past when the travertine currently being mined was deposited. Thick sequences of Paleozoic sedimentary rocks $(\mathrm{Pz})$ underlie the Tertiary rock types, and likely constitute the geothermal reservoir in the area (Figure E1).

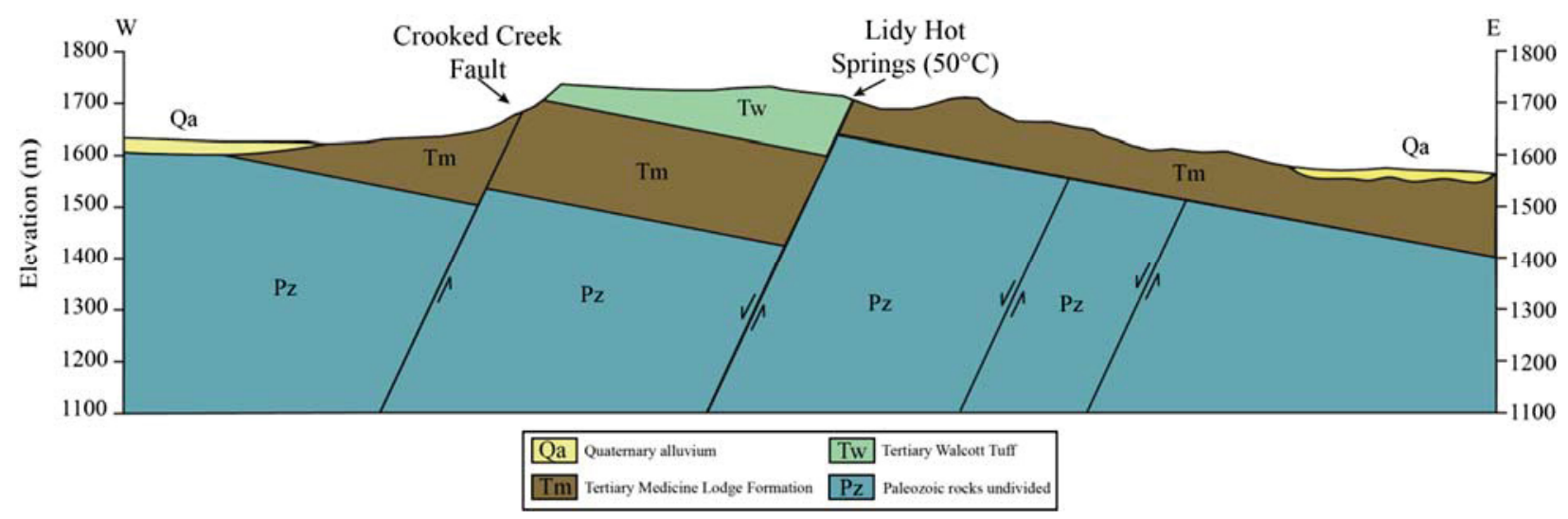

Figure E1. Geologic cross-section through Lidy Hot Springs area.

Regionally, the area represents the northwestward continuation of the Idaho-Wyoming thrust belt associated with Sevier orogeny. However, the physical continuation of this region to the Idaho-Wyoming thrust belt located southeast of the ESRP has been obscured by the middle Miocene to Recent volcanic activities associated with Yellowstone hot spot. Nevertheless, several extensional Tertiary-Quaternary normal faults truncate thrusts and folds of the Sevier orogeny (similar to that traced in Idaho-Wyoming thrust belts in southeastern Idaho and west-central Wyoming) have been mapped in the Beaverhead Mountains and other mountain ranges in the surrounding areas (Skipp, 1985).

Locally, the area has been intersected by numerous westward dipping imbricate faults that are believed to plunge into the Tertiary-Quaternary volcanic rocks of the ESRP to the southeast (Ross, 1970). Overlapping faults are reported to be one of the major geothermal settings in the Basin and Range Province (Faulds et al., 2011). As with the numerous geothermal sites of the Basin and Range Province, the hydrothermal activity in the area is also controlled by the fault-bound circulation of deep water. 


\subsection{Water chemistry}

The two hot springs in the LHS area that were sampled are near-neutral $(\mathrm{pH})$ water containing $\mathrm{Ca}$, bicarbonate, and sulfate as the dominant ions (Appendix B). Water samples from these two features in the LHS area have been sampled multiple times since early 1970s for chemical analysis. The available data indicate that the composition of springs' water have remained constant over the last several decades. The higher content of $\mathrm{Ca}$ in water may have been related to carbonate-rich Paleozoic reservoir rocks in the area. The chemical analyses of water samples also show a significant amount of Mg. The total dissolved solid (TDS) level in these waters range from 360 to $400 \mathrm{mg} / \mathrm{L}$.

A water sample from another spring (Warm Spring) in the area has lower TDS values. Specifically, the concentrations of $\mathrm{SiO}_{2}(\mathrm{aq}), \mathrm{K}, \mathrm{Na}$, in Warm Spring water are less than the concentrations in the samples from LHS. However, the Mg content is higher in Warm Spring water. When plotted on a Giggenbach plot (Giggenbach, 1988), water samples from LHS area plot in the immature zone (Figure E2). The immaturity of thermal water emerging from LHS area is likely to be related with higher concentration of $\mathrm{Mg}$. The higher Mg content is believed to be the result of either mixing of cooler water groundwater or reequilibration of the water at low temperature (or, that the reservoir temperature is low).

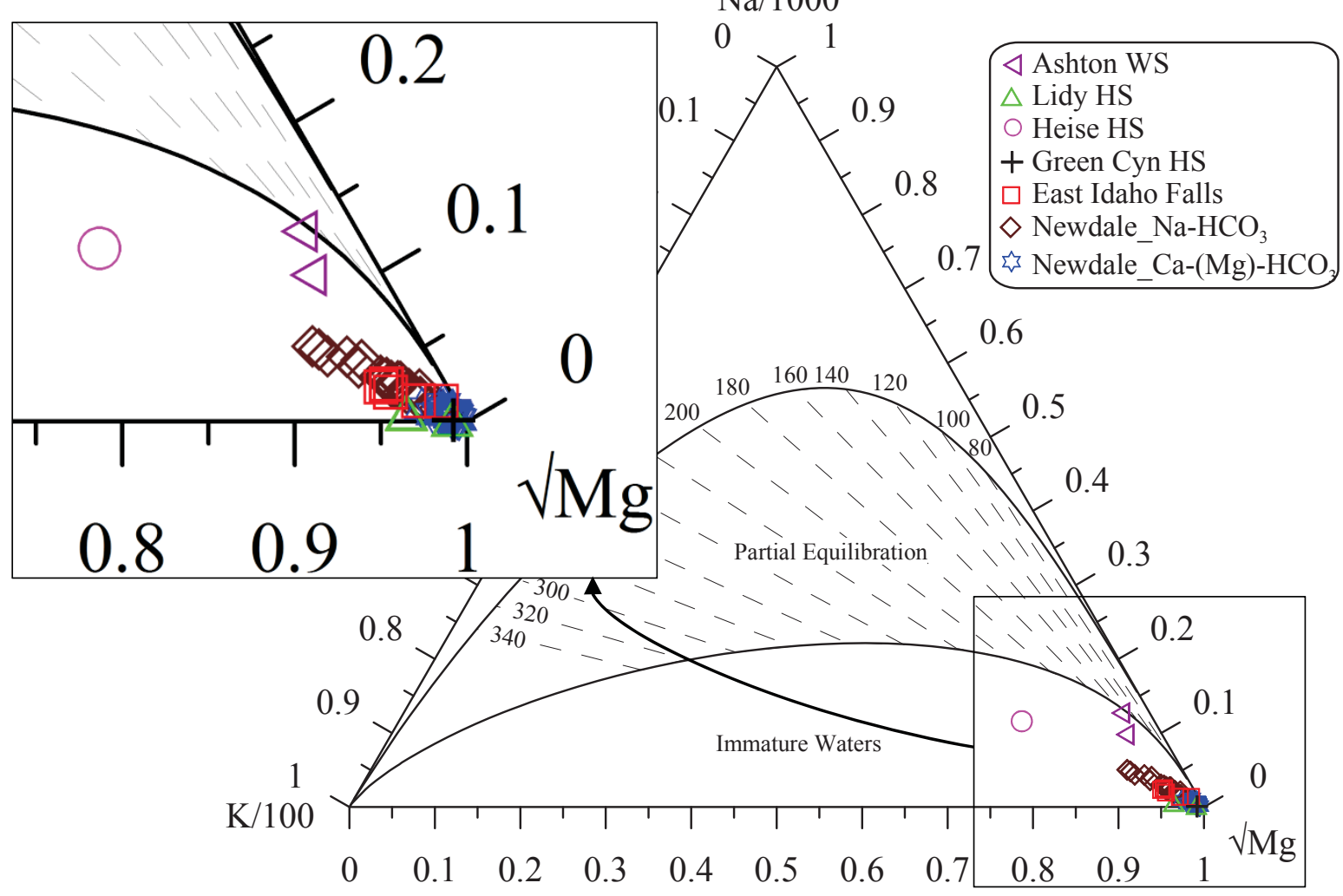

Figure E2. Northeastern ESRP water samples plotted on Giggenbach diagram.

\subsection{Geothermometric results}

Reservoir temperatures calculated for the LHS samples are given in Appendix D. Quartz (no steam loss) and chalcedony (Fournier, 1977) geothermometers resulted in $85-89^{\circ} \mathrm{C}$ and $54-58{ }^{\circ} \mathrm{C}$, respectively. Similarly, Mg-corrected Na-K-Ca reservoir temperatures for the area range from 60 to $67{ }^{\circ} \mathrm{C}$. The reservoir temperature estimated for the Warm Spring sample is cooler than the temperatures calculated for the LHS samples. 
The RTEst (Palmer et al., 2014; Mattson et al., 2015) estimated reservoir temperatures for the LHS reservoir is about $140{ }^{\circ} \mathrm{C}$ (Appendix D). RTEst modeling result shows that the LHS water may contain up to $60 \%$ cooler water and $40 \%$ deeper thermal water. Similarly, no-steam loss silica-enthalpy mixing model with quartz solubility curve yields a reservoir temperature of about $130^{\circ} \mathrm{C}$. However, silicaenthalpy mixing model with chalcedony solubility curve yields a rather cooler temperature (about $60{ }^{\circ} \mathrm{C}$ ). A sulfate-water oxygen isotope temperature of $127^{\circ} \mathrm{C}$ calculated for one of the samples from the LHS are (Appendix D) is also in the same range as the RTEst temperatures.

\section{Ashton Hot Spring \\ 2.1 General}

The Ashton Hot Spring (AHS) and associated geothermal area (Figure 1) is located on the northern side of Ashton in Fremont County in Idaho. The existence of AHS with a water temperature $41{ }^{\circ} \mathrm{C}$ was previously reported by Mitchell et al. (1980). A 1220 m deep geothermal exploratory well (Sturm Well-1) was drilled about $2 \mathrm{~km}$ NE from the AHS in 1979 (Occidental Geothermal Inc., 1979). Driller's records indicate a bottom-hole temperature of about $63^{\circ} \mathrm{C}$. In March 2014, however, we recorded a water temperature of $31^{\circ} \mathrm{C}$. The lower temperature of the produced water may indicate that the well is currently tapping water from the upper section of the well. The Sturm well water is now used for space heating.

\subsection{Geologic setting}

The AHS is the one of the few hot spring that is located within the ESRP proper. A geologic map of the area shows thin layers of Quaternary sediments overlying volcanic rocks (Link, 2002b). Borehole records from the area reveal the presence of thick sequences of flood basalts and felsic volcanics. Specifically, for Sturm Well-1, the Quaternary sediments near the surface are underlain by layers of flood basalts (up to a depth of $82 \mathrm{~m})$, felsic volcanics $(82-808 \mathrm{~m})$, and again flood basalts $(808-1220+\mathrm{m})$ with depth (Occidental Geothermal Inc., 1979) (Figure E3).

It is not clear whether the AHS area is located in the inter-caldera zone or along the caldera ring fracture (Pierce and Morgan, 1992; Anders et al., 2014). This area is located outside, about $9 \mathrm{~km}$ south, of the overlapping Island Park area calderas [2.1 Ma Big Bend caldera and 1.3 Ma Henry's Fork Caldera (Christiansen, 2001)]. The gravimetrically and geologically inferred Rexburg caldera complex (RCC) zone (Heise volcanic field of Anders et al., 2014) has been mapped to the south of Ashton (Prostka and Embree, 1978; Mabey, 1978). However, some researchers (e.g., Malde, 1991; Blackwell et al., 1992; Anders et al., 2014) have mapped the rim of Kilgore caldera (4.61 Ma) passing through Ashton. Collectively, RCC represents the pre-2.1 Ma multiple nested and overlapping calderas to the south and southwest of the Island Park area (Prostka and Embree, 1978; Malde, 1991; Morgan and McIntosh, 2005). If these suggestions are valid, the AHS area may be a durface expression of the highly fractured zone at depth. However, the deeper zone with multiple fractures may have been buried underneath the $1220+\mathrm{m}$ thick layers of sediments and volcanics (both rhyolitic and basaltic rocks) in the Ashton area. Bond (1978) shows a left-lateral fault that extends from southern side of the Island Park/Henry's Fork caldera rim and ends near the AHS area. Either this fault or some other local fractures in rocks beneath the Quaternary sediments may act as a path for the hot water that emerges as the AHS (Figure E3).

Finally, we could also speculate that the pre-caldera Basin and Range type faults that would have been continued from the eastern side of Big Hole Mountain (or the western side of the Teton Range) to Centennial or Beaverhead range through Ashton and Spencer-High Point [this later segment represents an active rift zone in the ESRP, and Kuntz et al. (1992) suggest that the active rifting zone in the SRP may have been controlled by pre-caldera fault systems], and these fault systems may still provide pathways for deep circulation. Bond et al. (1978) shows a series of discontinuous faults striking NW-SE to the SE and NW of Ashton. However, the lack of seismicity in the area (Christiansen, 2001) makes it unlikely that the continuation (if any) of the pre-caldera fault through Ashton could be contributing to the hydrothermal activities in the area at present. 


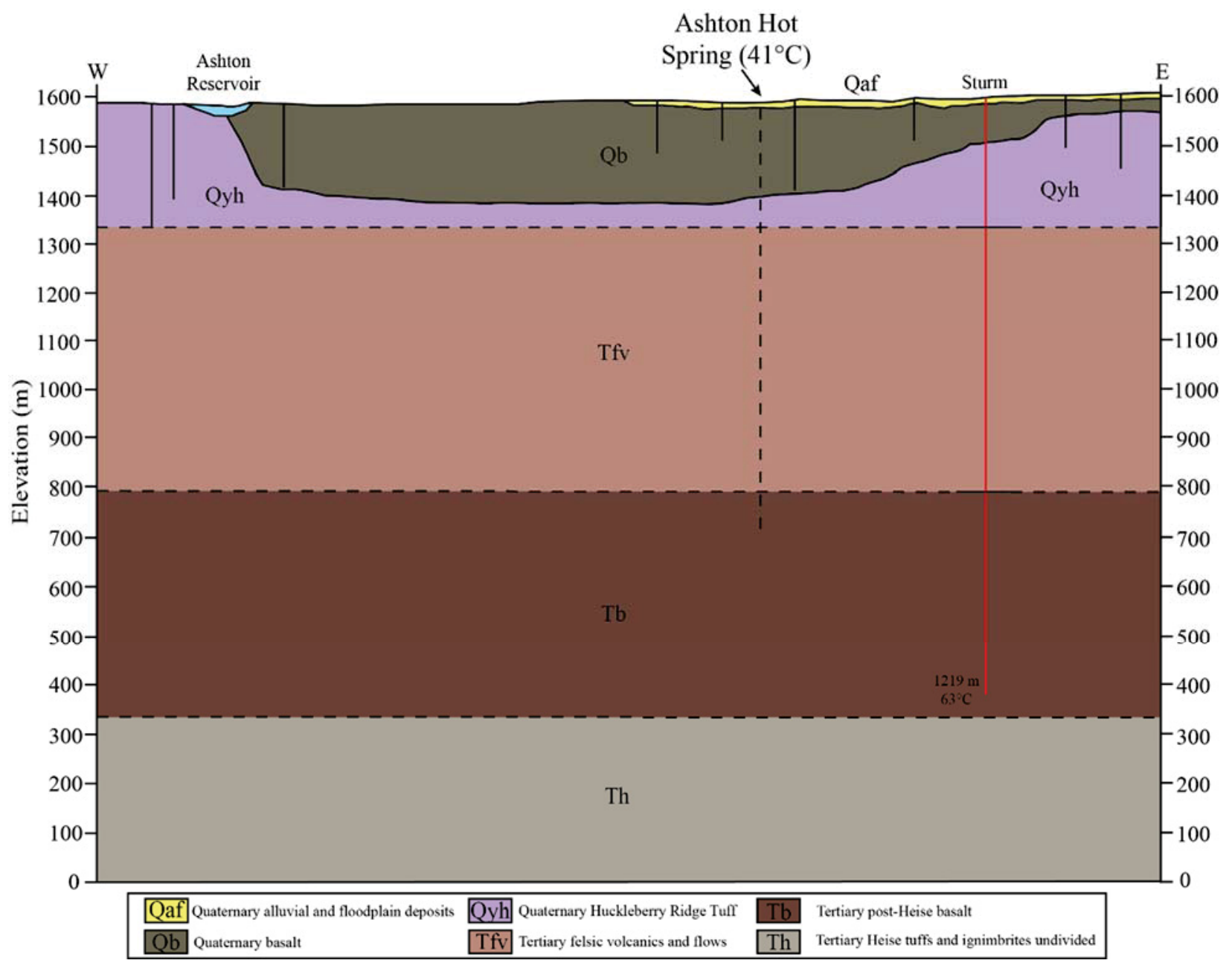

Figure E3. Geologic cross-section through Ashton Hot Spring and Sturm Well near Ashton, Idaho.

\subsection{Water chemistry}

Both AHS and Sturm Well produce slightly alkaline low TDS water. Relatively, the $\mathrm{pH}$ of water from Sturm Well is more alkaline ( $>1$ unit of $\mathrm{pH}$ ) than water from the neighboring Ashton Warm Spring (Appendix B). The AHS water contains higher concentrations of $\mathrm{SiO}_{2}(\mathrm{aq})$ and $\mathrm{HCO}_{3}$. The higher concentration of $\mathrm{SiO}_{2}(\mathrm{aq})$ in hot spring water may indicate an elevated temperature at depth (Mitchell et al., 1980). On the other hand, waters from these two expressions have similar concentrations of $\mathrm{Na}, \mathrm{SO}_{4}$, $\mathrm{Cl}$, and F. On Giggenbach diagram (Figure E2), both the AHS and SW water samples plot in immature water field.

\subsection{Geothermometric results}

Quartz and chalcedony geothermometers gave reservoir temperatures of $143{ }^{\circ} \mathrm{C}$ and $116{ }^{\circ} \mathrm{C}$ for AHS and $113{ }^{\circ} \mathrm{C}$ and $84^{\circ} \mathrm{C}$ for Sturm Well, respectively (Appendix D). For these two features, Na-K-Ca geothermometer resulted in temperatures of $117^{\circ} \mathrm{C}$ and $109^{\circ} \mathrm{C}$, respectively. With the un-optimized (unreconstructed) AHS composition, all these three traditional geothermometers resulted in slightly higher reservoir temperature than with the un-optimized Sturm Well composition. We applied RTEst to both water compositions with the same modeling constraints such as the same mineral assemblage (beidellite, calcite, chalcedony, clinoptilolite, K-felsdapr, and paragonite) and optimization parameters. For both water samples, pure water was used during RTEst modeling to optimize mass of thermal water. Unlike 
the traditional geothermometers, RTEst provided similar reservoir temperatures based on the optimized (reconstructed) compositions of water from these two sources. The RTEst produced reservoir temperatures for the Sturm well and AHS are $152 \pm 14{ }^{\circ} \mathrm{C}$ and $147 \pm 5^{\circ} \mathrm{C}$, with nearly $70 \%$ and $35 \%$ of cooler water, respectively. Although the Sturm well was drilled to over $1200 \mathrm{~m}$ depth, it may be tapping water from the upper cooler section. According to the owner, the well was originally cased only in the upper sections, and the lower portion of the well might have plugged because of caving. The temperature record (bottom hole temperature and temperature of produced water) over time for the Sturm well also indicates that the lower portion of the well might have caved in long ago. The initial recorded bottom-hole temperature of the well is $63{ }^{\circ} \mathrm{C}$ (Occidental Geothermal Inc., 1979). Blackwell et al. (1992) provide a temperature measured during early 1990 s for the produced water at $38{ }^{\circ} \mathrm{C}$. During our sampling campaign in 2014, the water was measured at $31^{\circ} \mathrm{C}$. Therefore, it is likely that the Sturm well is currently producing water from a shallower depth that may have higher fraction of cooler water. The sulfate concentrations of samples collected from both of these thermal features were two low for isotope geothermometry.

\section{Newdale area}

\subsection{General}

The Newdale geothermal area (Figure E4 and Figure 1) in Madison and Fremont Counties in Idaho represents a blind geothermal system. The geothermal potential of the Newdale area was identified in the late 1970s by several researchers, specifically, with the discovery of relatively higher heat flow (167 $\mathrm{mW} / \mathrm{m}^{2}$ ) (Brott et al. 1976). Subsequent studies of the area identified a zone called the Newdale thermal anomaly zone (Mabey, 1978; Prostka and Embree, 1978; Mitchel et al., 1980).

Specifically, the area from Newdale town to the NE across the Teton River has been considered as potential area for geothermal energy (Brott et al., 1976, GeothermEx, 2010). During 1979-1981, Union Oil of California (Unocal) drilled several geothermal test wells in the area ranging in depth from $183 \mathrm{~m}$ (Newdale No. 79-3) to 1204 m (Madison Geothermal No.1 near Rexburg, ID). The highest recorded temperature in Unocal wells was $87.2^{\circ} \mathrm{C}$ (Well \# State 2591-07-79-1). Currently, Standard Steam Trust LLC (SST) holds a set of leases for further exploration and development in an area of about $53.4 \mathrm{~km}^{2}$ around Newdale and defines this area as 'Newdale geothermal energy prospect' (GeothermEx, 2010).

\subsection{Geologic setting}

A surficial geologic map of this area shows the presence of Quaternary sediments, flood basalts, and felsic volcanic rocks (Bond et al., 1978; Embree et al., 2011). Early Pleistocene flood basalts are mapped around the town of Newdale whereas felsic volcanic rocks of similar ages (Huckleberry Ridge Tuff) are mapped NE from Newdale. In a geologic cross-section, Embree et al. (2011) show the Huckleberry Ridge Tuff lying beneath the Early Pleistocene basalt in Newdale town. Below the Huckleberry Ridge Tuff are the Tertiary sediments intercalated with Tertiary basalt flows (Figure E5). Subsurface lithologic records of numerous wells in the area compiled by Idaho Geological Survey indicate the presence of thick sequences of rhyolites and tuff at greater depths.

Based on geologic, geomorphologic (Prostka and Embree, 1978) and gravity anomaly features (Mabey, 1978), a series of overlapping and intersecting calderas that developed 4.45-6.62 Ma (Morgan and McIntosh, 2005) have been inferred as the RCC around Rexburg, Teton, Sugar City, and Newdale areas that possibly extend further north to Ashton (Malde, 1991; Blackwell et al., 1992; Anders et al., 2014). Specifically, the Newdale geothermal area lies along the three inferred caldera margins (Prostka and Embree, 1978). Recently, Anders et al. (2014) mapped the Blacktail Creek Tuff caldera (a caldera unit of RCC) rim that passes through the Newdale geothermal area along the Teton River. 


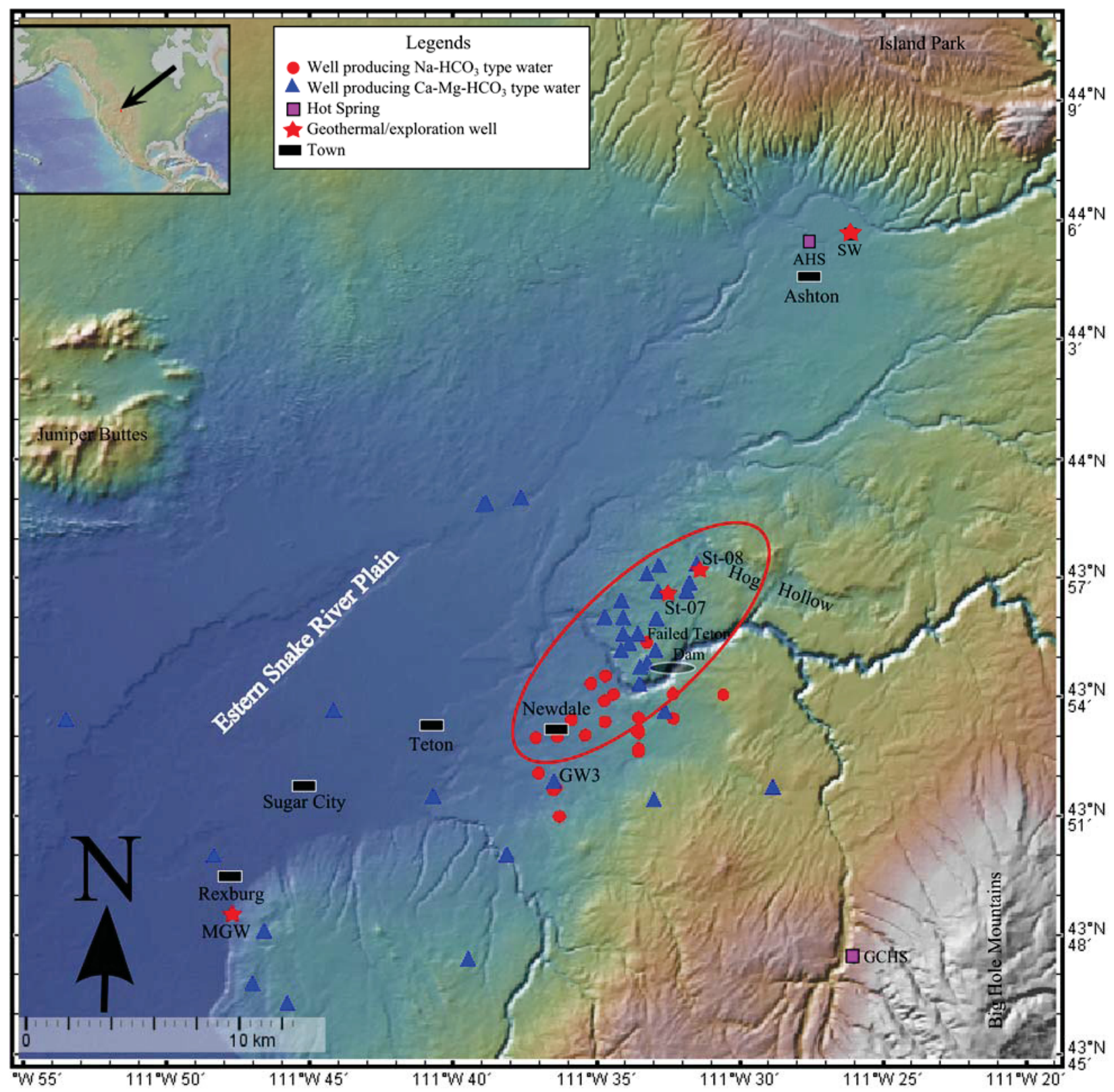

Figure E4. Location of sampling features around Newdale geothermal prospect. Red circles and blue triangles are two groups water with distinct chemistry and mixing trends. Ashton hot spring (AHS), Sturm well (SW), and Green Canyon Hot Spring (GCHS) are not included in the Newdale area samples. Wells St-08 and St-07 are two Unocal thermal wells in the prospect.

It is likely that this area has a highly fractured zone at depth that is buried beneath thick sequences of post-RCC volcanic and sedimentary rocks. Two NE trending parallel faults are also mapped in the area (Embree et al., 2011). Specifically, the Teton Dam Fault has been traced along a stretch of the Teton River near the failed Teton dam, and extended further to the NE and SW (Prostka and Embree, 1978; Embree et al., 2011). The other fault is located NW of the Teton Dam Fault. Both of these faults dip to the SE. Prostka and Embree (1978) also show a NW striking and SW dipping fault (Warm Creek Fault) that extends from the Big Hole Mountains to the SE and intersects the NE terminus of the Teton Dam Fault. However, this fault is not shown on the new geologic map (e.g., Embree et al., 2011). Moreover, Embree and Hoggan (1999) show a series of shallow and short faults that transect the Hog Hollow area located a 
little further NE from the Newdale area. The significance of the Teton Dam Fault and other associated faults for the development of Newdale geothermal area is yet to be fully evaluated. In general, these faults may act structural control for the geothermal setting in the area by providing upward pathways for migration of hotter fluid from depth. However, the Teton Dam fault and the other fault in the area may have a limited role in circulating hotter fluids from depth to the surface such that these faults may be limited by the post-RCC zone and may lack to provide a continuous flow path from ring fracture zones to the surface. Moreover, the lack of surface expressions (e.g., hot springs) in the area may be related to lack of sufficient hydraulic/convective head such that the water table in the area is located several tens of meters below ground surface.

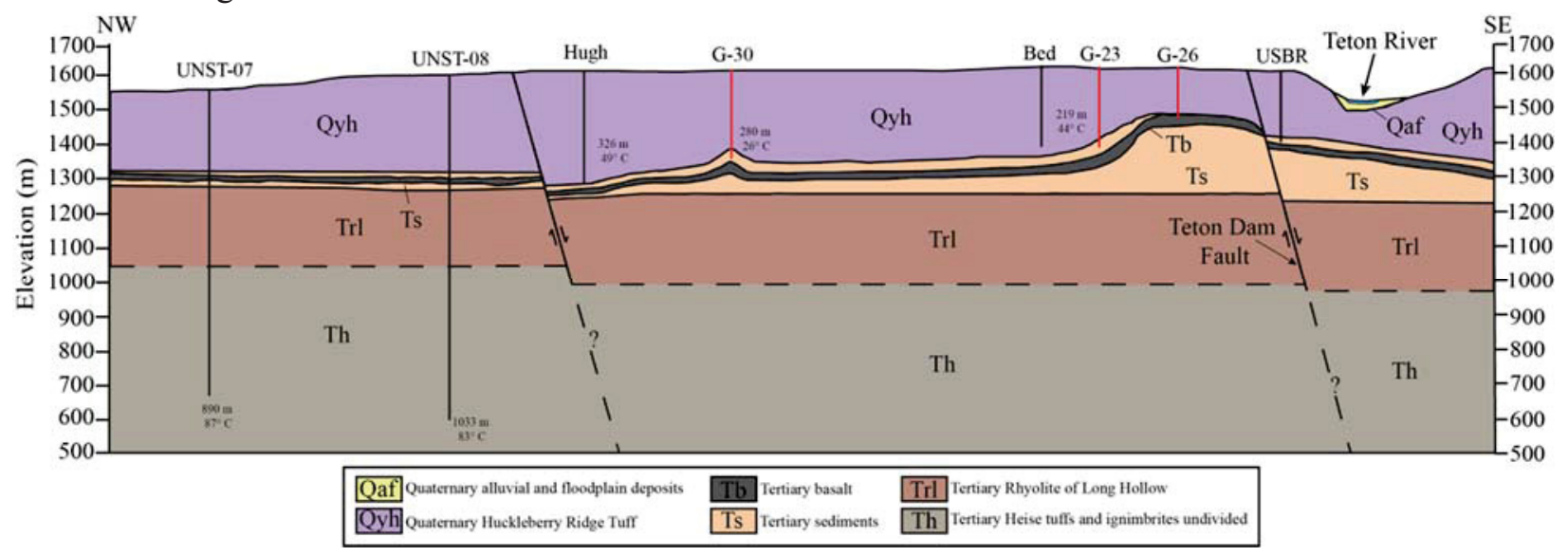

Figure E5. Geologic cross-section through Newdale geothermal area.

\subsubsection{Water chemistry}

The locations of Newdale water samples are shown in Figure E4. The compiled water composition dataset (Appendix B) includes wells producing waters at both elevated temperatures and cooler temperatures. The warmer wells have temperatures ranging from 21 to $51.1^{\circ} \mathrm{C}$ whereas the temperatures of the cooler wells range from 8.5-17.5 ${ }^{\circ} \mathrm{C}$. All Newdale area wells produce dilute (TDS ranging from 200 to $520 \mathrm{mg} / \mathrm{kg}$ with an average value $375 \pm 80 \mathrm{mg} / \mathrm{kg}$ ), immature (Figure E2), and near-neutral ( $\mathrm{pH} 6.4-8.5$ ) water. The major cations in water samples are $\mathrm{Na}, \mathrm{Ca}$, and $\mathrm{Mg}$ whereas major anions are $\mathrm{HCO}_{3}, \mathrm{Cl}, \mathrm{F}$, and $\mathrm{SO}_{4}$.

Water samples are either $\mathrm{Na}-\mathrm{HCO}_{3}$ or $\mathrm{Ca}-(\mathrm{Mg})-\mathrm{HCO}_{3}$ types (Figure E6). In the ESRP, the $\mathrm{Na}-\mathrm{HCO}_{3}$ and $\mathrm{Ca}-(\mathrm{Mg})-\mathrm{HCO}_{3}$ type waters are often related to deeper water that have interacted with rhyolite and shallower groundwater that have interacted with basalt, respectively (McLing et al., 2002). The $\mathrm{Na}-\mathrm{HCO}_{3}$ waters have slightly higher TDS (ranging from 340 to $520 \mathrm{mg} / \mathrm{kg}$ with average value $440 \pm 60 \mathrm{mg} / \mathrm{kg}$ ) than the $\mathrm{Ca}-(\mathrm{Mg})-\mathrm{HCO}_{3}$ waters (ranging from 200 to $480 \mathrm{mg} / \mathrm{kg}$ with average value $330 \pm 60 \mathrm{mg} / \mathrm{kg}$ ).

The cations ternary and the diamond plots in Figure E6 show that these two groups of water aligned along a trend from $\mathrm{Na}+\mathrm{K}$ vertex to $\mathrm{Ca}-\mathrm{Mg}$ baseline; however, such trend is missing in the anions ternary plot. Nevertheless, the anions ternary diagram shows a type-water independent trend from the $\mathrm{HCO}_{3}$ vertex towards middle of the $\mathrm{Cl}-\mathrm{SO}_{4}$ base line. Similar type-water independent trend can be found on a bivariate plot constructed for $\mathrm{HCO}_{3}$ and $\mathrm{Cl}$ (Figure E7a). The type-water independent trend depicted in Figure E7a is likely to reflect the intensity of water-rock interaction (regardless of the rock type) that a water might have interacted. In general, higher the degrees of water-rock interaction, higher the concentrations of $\mathrm{HCO}_{3}$ and $\mathrm{Cl}$ in water are. Other bivariate plots (Figure E7b-f), however, show linear alignment of Na$\mathrm{HCO}_{3}$ and $\mathrm{Ca}-(\mathrm{Mg})-\mathrm{HCO}_{3}$ type water samples. Traditionally, such linear alignment of water samples on bivariate plots is considered to be the result of mixing of two end member water compositions in different proportions. Figure E7f also indicates that the original source water for both $\mathrm{Na}-\mathrm{HCO}_{3}$ and $\mathrm{Ca}-(\mathrm{Mg})-$ $\mathrm{HCO}_{3}$ type waters is meteoric water. 


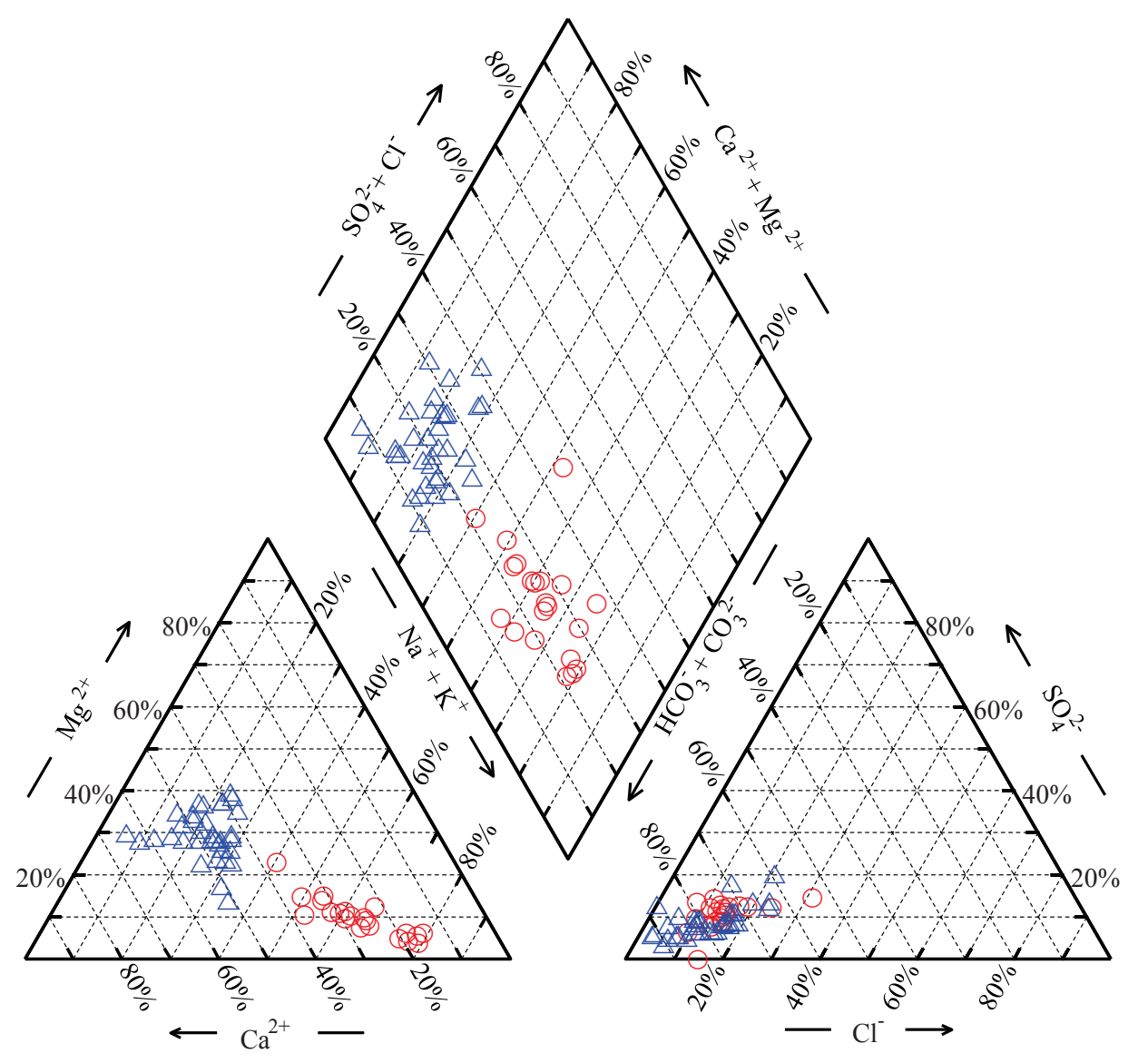

Figure E6. Piper diagram representing chemistry of water samples from Newdale geothermal prospect and surrounding areas

Although the bivariate plots shown in Figure E7b-f depict the apparent linear alignment of $\mathrm{Na}-\mathrm{HCO}_{3}$ and $\mathrm{Ca}-(\mathrm{Mg})-\mathrm{HCO}_{3}$ type waters, some additional bivariate plots with other components and ratios (Figure E8a-f) show two distinct mixing (and/or degree of water rock interaction) trends, one for $\mathrm{Na}-\mathrm{HCO}_{3}$ and the other for $\mathrm{Ca}-(\mathrm{Mg})-\mathrm{HCO}_{3}$ type waters. These diagrams indicate that for $\mathrm{Ca}-(\mathrm{Mg})-\mathrm{HCO}_{3}$ type waters, the dilute end-member can be represented by a pristine water (rain/snow melt). The composition of the higher TDS end member has not been directly measured, but this composition was inferred with RTEst modeling for each sample. Intermediate waters are likely to be formed either by mixing of two endmember waters at various proportions, or by water-rock interactions of various intensities.

Some bivariate plots (e.g., Figure E8b, d, and f) that include $\mathrm{Cl}$ (concentration or as part of ratio) indicate (the low TDS trends of $\mathrm{Na}-\mathrm{HCO}_{3}$ type waters in these plots point towards origin) that the cooler end member water that mixed with the $\mathrm{Na}-\mathrm{HCO}_{3}$ type waters is a very dilute $\mathrm{Ca}-(\mathrm{Mg})-\mathrm{HCO}_{3}$ type water or even a pristine water. However, the other plots that do not include $\mathrm{Cl}$ (e.g., Figure E8a, c, and e) indicate (the low TDS trends of $\mathrm{Na}-\mathrm{HCO}_{3}$ type waters in these plots do not point towards origin) that the dilute end member water that might have mixed with $\mathrm{Na}-\mathrm{HCO}_{3}$ type waters may have a composition similar to some intermediate $\mathrm{Ca}-(\mathrm{Mg})-\mathrm{HCO}_{3}$ type water or such non-linear (trends not pointing towards origin) behavior is noticed because of non-conservative nature of non-Cl components. Since RTEst does not handle precipitation, cation exchange, and so on, we assume that some variant of intermediate $\mathrm{Ca}-(\mathrm{Mg})$ $\mathrm{HCO}_{3}$ type water is the end member water that might have mixed with $\mathrm{Na}-\mathrm{HCO}_{3}$ type waters. As with the cases of $\mathrm{Ca}-(\mathrm{Mg})-\mathrm{HCO}_{3}$ type waters, the higher TDS end member compositions of $\mathrm{Na}-\mathrm{HCO}_{3}$ type waters are also not known, and for each sample, the original thermal water is reconstructed with RTEst modeling. 

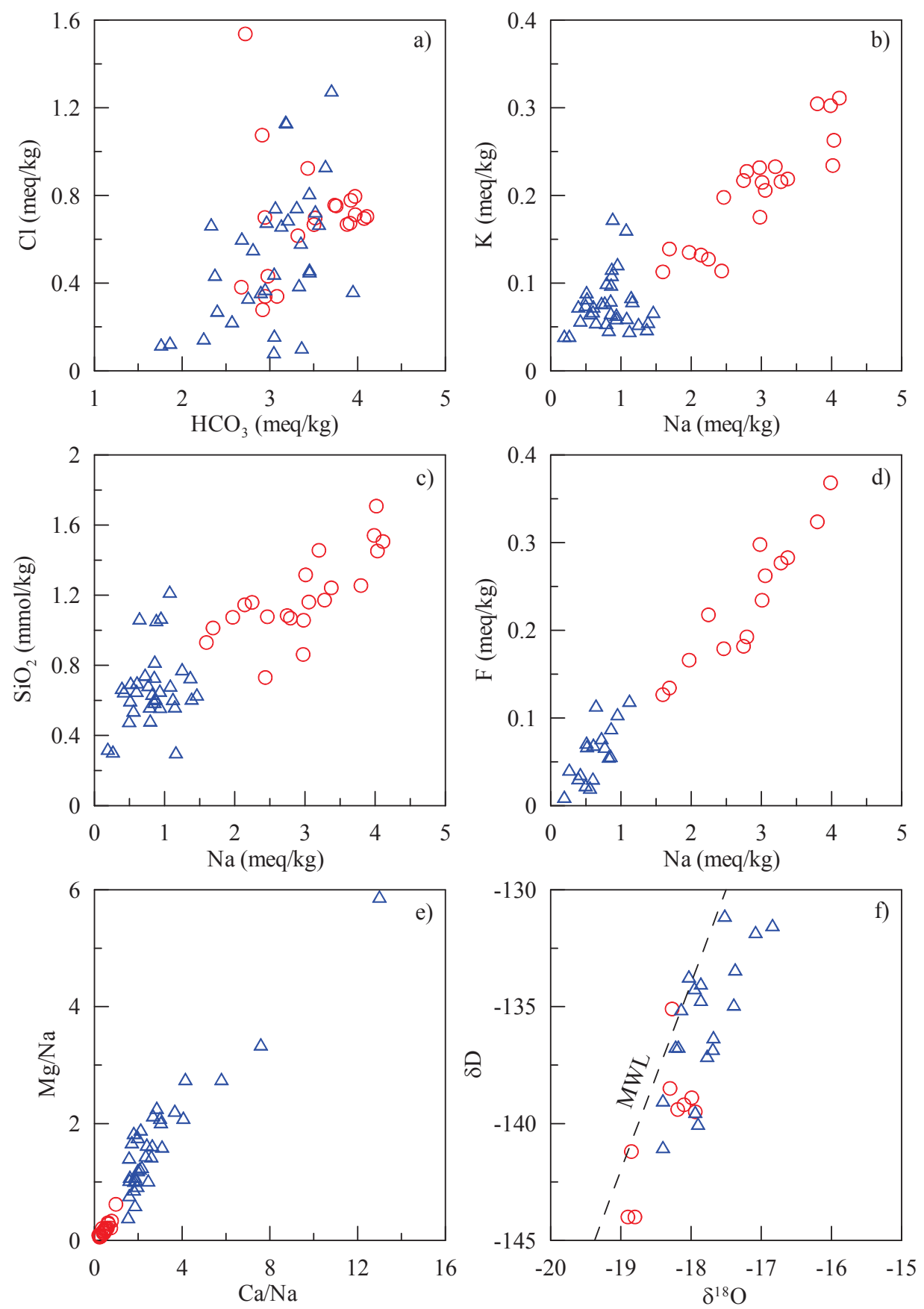

Figure E7. Bivariate diagrams constructed for some components, isotopes, and ratios for Newdale and surrounding area water samples. 

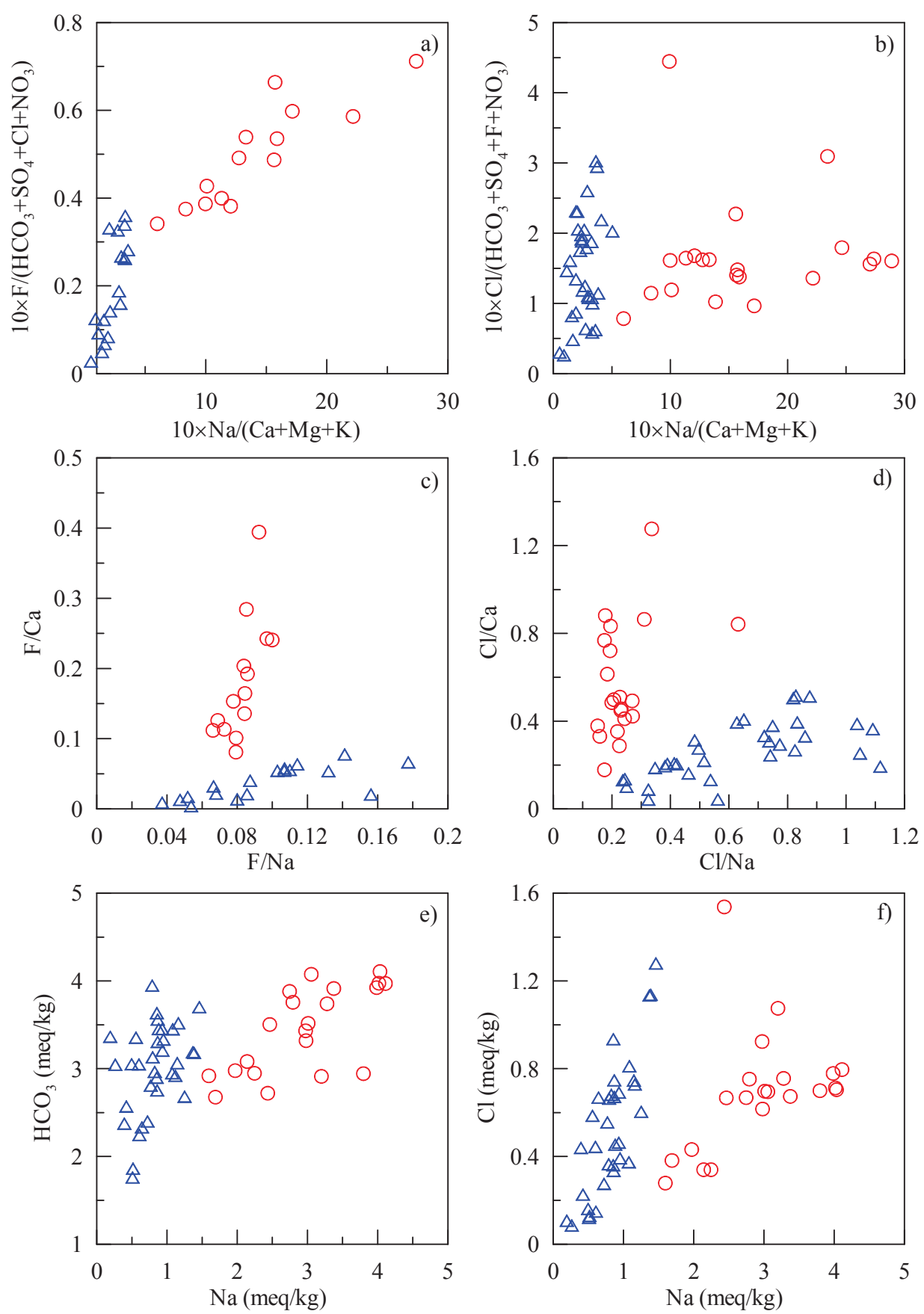

\section{Figure E8. Bivariate diagrams constructed for some components and ratios for Newdale and surrounding area water samples.}

The bivariate plots shown on Figure E9 also support the assumption that some intermediate Ca-(Mg)$\mathrm{HCO}_{3}$ type water is likely to be the dilute end-member water that might have mixed with $\mathrm{Na}-\mathrm{HCO}_{3}$ type waters at different proportions. Figure E9a also indicates that the $\mathrm{Na}-\mathrm{HCO}_{3}$ type water may be divided into two groups resulting in slightly different mixing trends. Figure E9b indicates that the $\mathrm{Ca}-(\mathrm{Mg})-\mathrm{HCO}_{3}$ waters may have two sub-groups with two mixing/water rock interaction trends- one group may have only interacted with basaltic rocks and may have not received any fraction $\mathrm{Na}-\mathrm{HCO}_{3}$ water whereas the other 
group may have either weakly interacted with felsic volcanic rocks or received some fraction of $\mathrm{Na}-\mathrm{HCO}_{3}$ waters. The first group of $\mathrm{Ca}-(\mathrm{Mg})-\mathrm{HCO}_{3}$ type water samples has low $\mathrm{F}$, and these water samples do not show further enrichment in $\mathrm{F}$ with progression of water-rock interaction. On the other hand, the second group of water samples show a tendency of slightly increasing $\mathrm{F}$ with increasing concentration of $\mathrm{Ca}$ (and TDS as well, figure not shown); however, it is may be difficult to discern whether the increasing F concentration merely reflects the fact that these waters may have limited water-rhyolite interaction or they receive increasing amount of $\mathrm{Na}-\mathrm{HCO}_{3}$ type water as they persistently interact with basalt.
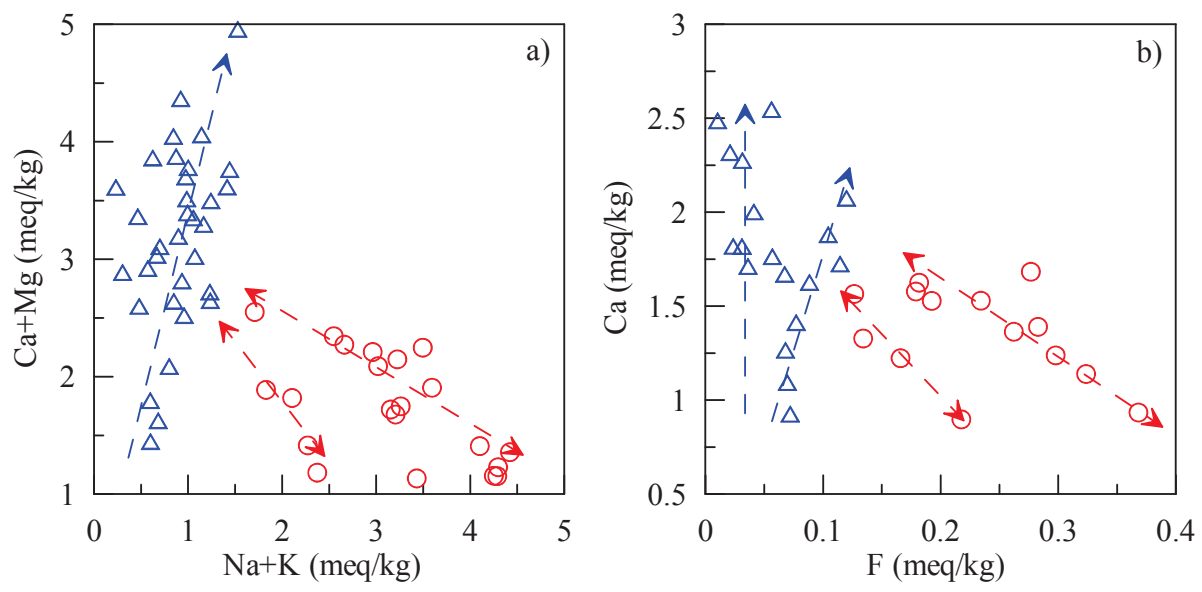

Figure E9. Bivariate diagrams constructed for some components for Newdale and surrounding area water samples.

The concentration of $\mathrm{F}$ in water samples is highly influenced by the degree of past interaction with felsic volcanic rocks. However, the majority of low $\mathrm{F}$ water samples are from the area north of the Teton River where the subsurface lithology is dominated with felsic rocks. At first, it appears odd with the near surface rock types, however, the wells located north of Teton River tap water from a sediment-basalt aquifer sandwiched between pre-Huckleberry Ridge and Huckleberry Ridge felsic volcanic rocks (Figure E5). Similarly, wells distributed on the southern side of the Teton River where near surface rocks are basalts mostly tap $\mathrm{Na}_{-} \mathrm{HCO}_{3}$ type water from felsic volcanic rock units underneath the basalts.

\subsubsection{Geothermometric results}

Temperature estimates for the Newdale area samples are included in Appendix D. Quartz, chalcedony, and $\mathrm{Na}-\mathrm{K}-\mathrm{Ca}$ (Mg corrected) geothermometers resulted in lower reservoir temperatures for Ca-(Mg)$\mathrm{HCO}_{3}$ type waters compared to the temperatures for the $\mathrm{Na}-\mathrm{HCO}_{3}$ type waters. The range of temperatures with quartz, chalcedony, and $\mathrm{Na}-\mathrm{K}-\mathrm{Ca}$ (Mg corrected) geothermometers for $\mathrm{Ca}-(\mathrm{Mg})-\mathrm{HCO}_{3}$ type waters are $66-119{ }^{\circ} \mathrm{C}, 28-93{ }^{\circ} \mathrm{C}, 29-81{ }^{\circ} \mathrm{C}$, respectively. Similarly, the range of estimated temperatures calculated with these geothermometers for $\mathrm{Na}-\mathrm{HCO}_{3}$ type waters are $97-134{ }^{\circ} \mathrm{C}, 65-112{ }^{\circ} \mathrm{C}$, and $50-111$ ${ }^{\circ} \mathrm{C}$, respectively. A silica (chalcedony)-enthalpy mixing model using all Newdale are samples results in reservoir temperatures of around $174^{\circ} \mathrm{C}$ (Figure E10). A similar model using quartz solubility results in even higher temperatures $\left(224^{\circ} \mathrm{C}\right)$.

Since $\mathrm{Na}-\mathrm{HCO}_{3}$ type waters show mixing trends (Figure E9) with a variant of $\mathrm{Ca}-(\mathrm{Mg})-\mathrm{HCO}_{3}$ type water; RTEst modeling of the Newdale samples were performed using option that reconstructs thermal fluid using mixing, fugacity of $\mathrm{CO}_{2}$, and $\mathrm{T}$ as optimization parameters. The $\mathrm{GW} 3$ water composition was selected to define the end member cooler water composition for RTEst modeling of $\mathrm{Na}-\mathrm{HCO}_{3}$ type waters because of its close geographical location to the Newdale geothermal anomaly area. The GW3 is a Ca- 
$(\mathrm{Mg})-\mathrm{HCO}_{3}$ type water that approximately falls along the mixing trends for both types of water on some bivariate plots (Figure E7, Figure E8a,b,e,f). During RTEst modeling, some variant of this water composition is found applicable to all $\mathrm{Na}-\mathrm{HCO}_{3}$ type waters as well as to the majority of $\mathrm{Ca}-(\mathrm{Mg})-\mathrm{HCO}_{3}$ type waters. Specifically, the $\mathrm{SiO}_{2}(\mathrm{aq})$ concentration of $\mathrm{GW} 3$, which has an unusually high concentration of $46 \mathrm{mg} / \mathrm{L}$ at $8.5^{\circ} \mathrm{C}$, was not included in the end member cooler water for RTEst modeling. The same approach was used for most of the $\mathrm{Ca}-(\mathrm{Mg})-\mathrm{HCO}_{3}$ type waters, however, for some $\mathrm{Ca}-(\mathrm{Mg})-\mathrm{HCO}_{3}$ type waters (Remington Produce, Dean Swindelman, Pauline, Mark Rick, and Lavere Rick wells), RTEst modeling was performed using pure water to account for the mixing. For these samples, use of the GW3 based end member water resulted in a similar estimated temperatures (similar temperature estimates obtained with the pure end member) but poor convergence (large standard error). As noted in the previous section, the assumption of some pristine water as end member cooler water for $\mathrm{Ca}-(\mathrm{Mg})-\mathrm{HCO}_{3}$ type waters is geochemically satisfactory to all bivariate plots (Figure E7, Figure E8, and Figure E9).

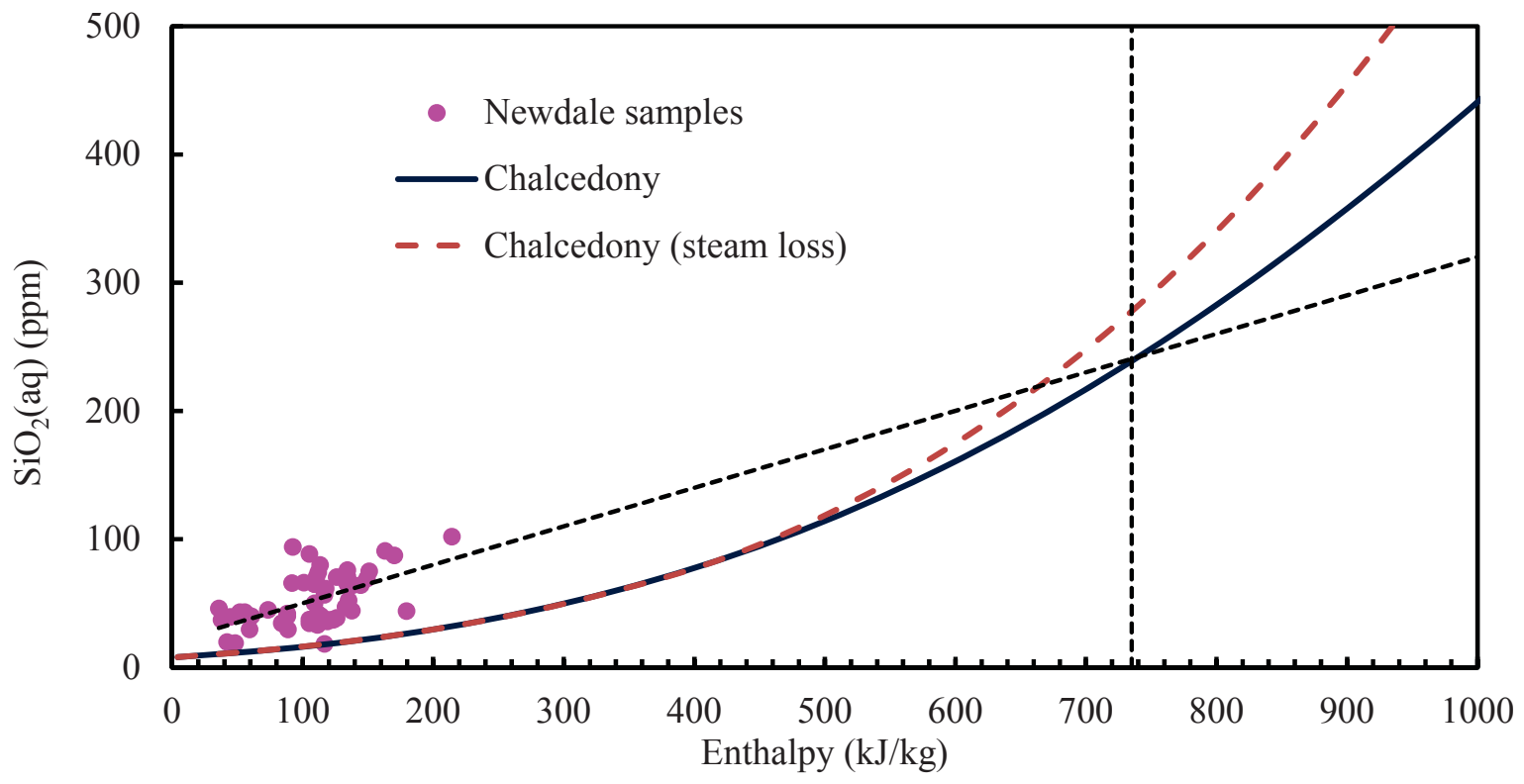

Figure E10. Silica (chalcedony)-enthalpy mixing model applied to all Newdale area samples.

The ranges of RTEst temperature estimates for $\mathrm{Na}-\mathrm{HCO}_{3}$ and $\mathrm{Ca}-(\mathrm{Mg})-\mathrm{HCO}_{3}$ type waters are $85-152{ }^{\circ} \mathrm{C}$ and $75-141^{\circ} \mathrm{C}$, respectively. RTEst results indicate that Newdale area samples contained 10 to $75 \%$ of cooler water fractions. Relatively, $\mathrm{Ca}-(\mathrm{Mg})-\mathrm{HCO}_{3}$ type waters have greater fractions $(30-75 \%)$ of cooler water than $\mathrm{Na}-\mathrm{HCO}_{3}$ type waters $(10-50 \%)$. The relatively cooler temperatures obtained with the traditional geothermometers for the $\mathrm{Ca}-(\mathrm{Mg})-\mathrm{HCO}_{3}$ type waters may have been resulted because of the fact that they are more diluted with cooler waters than the $\mathrm{Na}-\mathrm{HCO}_{3}$ type waters.

The lower end RTEst temperature estimates of this area are similar to the bottom hole temperatures (83$\left.87^{\circ} \mathrm{C}\right)$ measured at two relatively deeper $(\sim 1000 \mathrm{~m})$ Unocal wells. Moreover, it is likely that the area hosts hotter zone at depth reaching to the higher end RTEst temperatures. Assuming an $80^{\circ} \mathrm{C}$ thermal gradient (as indicated by two Unocal wells), the higher end RTEst temperatures could occur at about a 2 $\mathrm{km}$ depth. A sulfate-water oxygen isotope temperature was calculated for a sample from the Schwendiman well in this area gave a relatively low temperature of $87^{\circ} \mathrm{C}$. The water isotope composition of this sample $\left(\delta^{18} \mathrm{O}=-19.1 \%\right.$, $\delta \mathrm{D}=-144 \%$ ) indicates that the sample is dominated by relatively unaltered meteoric water and may not have circulated deeply through the system. 


\section{Green Canyon Hot Spring}

\subsection{General}

The Green Canyon Hot Springs (GCHS) (Figure E4 and Figure 1) is located along the margin of the ESRP on the northwestern edge of Big Hole Mountains in Madison County, Idaho. It sits at approximately $1558 \mathrm{~m}$ above sea level and is approximately $28 \mathrm{~km}$ east of Rexburg and $20 \mathrm{~km}$ southeast from Newdale, Idaho. This area was originally developed as a local limestone mining location because of the large tufa/travertine deposits nearby. However, with the discovery of the hot spring, the area was later developed into a soaking facility in 1910. An upgraded commercial recreational facility is still in operation in the area. The GCHS issues water at $46^{\circ} \mathrm{C}$ from a vent located about $300 \mathrm{~m}$ to the east from the facility.

\subsection{Geologic setting}

The GCHS is located on the eastern margin of the inferred Heise caldera complex that produced many of the silicic eruptions from 6.5-4.4 Ma (Prostka and Embree, 1978; Christiansen, 2001; Morgan and McIntosh, 2005). These eruptions produced voluminous tuffs, ash flows, lava flows, and ignimbrites and are labeled as undivided Tertiary Heise (Th) volcanic rocks in Figure E11. A post-caldera rhyolite lava flow, Rhyolite of Long Hollow (Trl), is documented to only occur west of the GCHS area (Morgan and McIntosh, 2005). Quaternary basalt (Qb) is abundant to the north and documented in well logs in the shallow subsurface around GCHS. The Quaternary Huckleberry Ridge Tuff (Qyh) caps most of the hillsides throughout the area. A $50 \mathrm{~m}$ thick deposit of travertine is reported near the hot spring (Prostka and Embree, 1978).

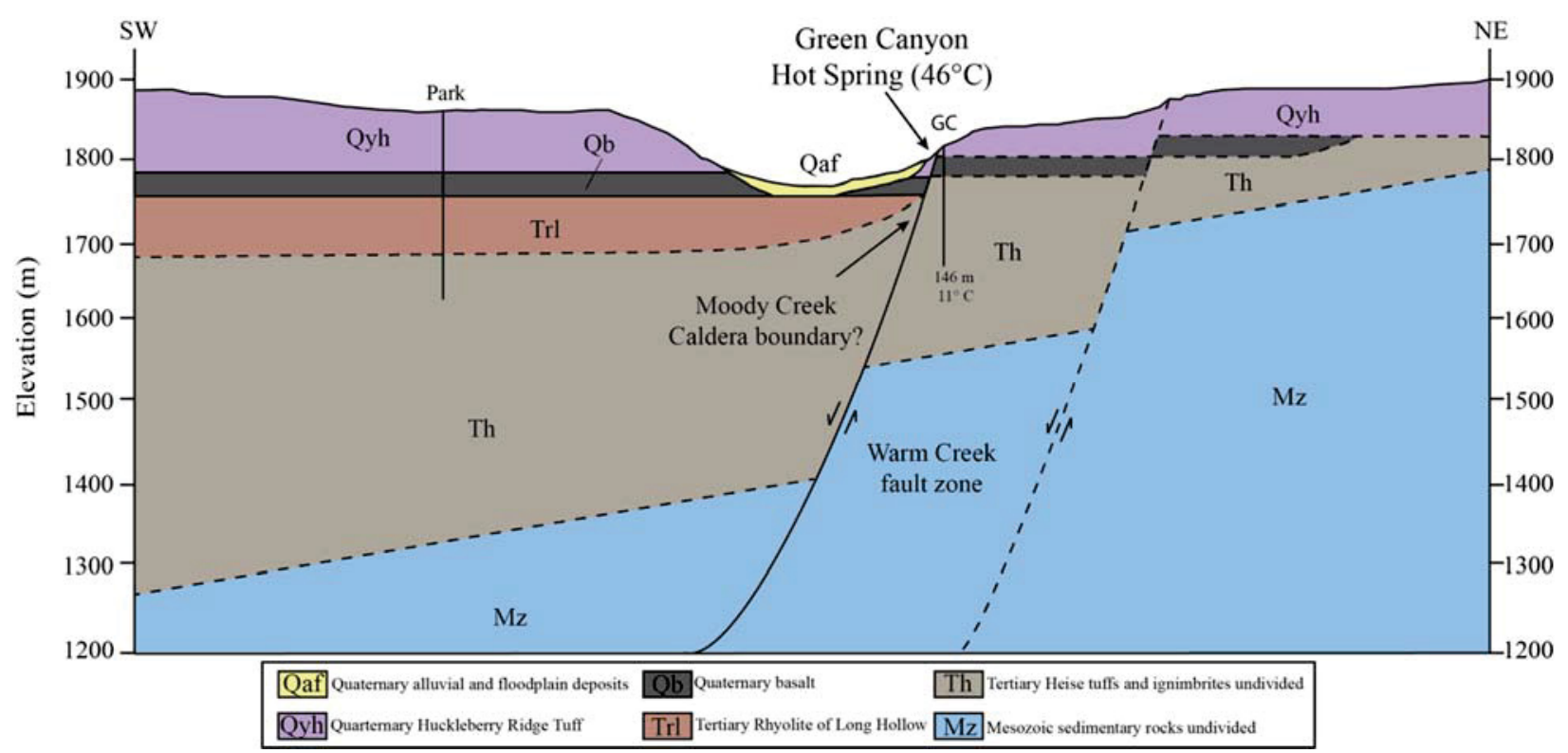

Figure E11. Geologic cross-section of the Green Canyon Hot Springs area; Wells used to constrain lithology are in black.

Mesozoic sedimentary rocks $(\mathrm{Mz})$ are inferred from adjacent maps to extend into this area and form the basal units of the area. These include various limestones, sandstones, siltstones, conglomerates, and evaporite beds which are reported to have undergone extensive folding and faulting associated with the Sevier-Laramide orogeny (Prostka and Embree, 1978; Oriel and Platt, 1980). The northwest trending Warm Creek Fault Zone is the dominant structure controlling geothermal fluids in this area. This normal fault zone extends from the southeastern corner of the area and continues up Warm Creek where it intersects with a north trending normal fault that extends up Green Canyon. These faults have a down to 
the west/southwest sense of displacement with unknown amount of slip. Anders et al. (2014) have recently modified the boundaries of the Blacktail Creek Tuff and Kilgore Tuff calderas which both intersect in the GCHS valley. The combination of intersecting faults with caldera ring fractures suggests that the increased fracture permeability gives rise to higher fluid flux from depth.

\subsection{Water chemistry}

GCHS issues near neutral water containing $\mathrm{Ca}, \mathrm{Mg}, \mathrm{SO}_{4}$, and $\mathrm{HCO}_{3}$ as major ions. The measured TDS in water is $585 \mathrm{mg} / \mathrm{L}$. On a Giggenbach diagram (Figure E2), the GCHS water plots in immature water field. The reported hydrogen $\left(\delta\right.$-D: $-136.2 \%$ ) and oxygen $\left(\delta-{ }^{18} \mathrm{O}:-18.08 \%\right)(G e o t h e r m E x, 2010)$ isotope values indicate that the GCHS issues heated meteoric water. The GCHS issues waters with low concentrations of $\mathrm{Cl}$ and $\mathrm{Na}$ with high concentrations of $\mathrm{Ca}$ and $\mathrm{SO}_{4}$. Similarly, the GCHS water has a lower $\mathrm{F}$ concentration than water that equilibrated with felsic volcanic rocks in the ESRP but higher than typical basalt-hosted ESRP water. Although high $\mathrm{Ca}$ and $\mathrm{Mg}$ waters in the ESRP are regarded as the product of water-basalt interaction, the presence of higher concentration of $\mathrm{SO}_{4}$ in GCHS water indicate that it must have interacted with rocks other than basaltic rocks. The geologic cross-section (Figure E11) through GCHS shows a rather thin ca. $20 \mathrm{~m}$ thick basalt layer (Qb) sandwiched between Tertiary (Th, Trl) and Quaternary (Qyh) felsic volcanic rocks. Underneath the Tertiary felsic rocks are the Mz units comprising passive-margin sedimentary rocks (Mansfield, 1927; Oriel and Platt, 1980). It is apparent that the GCHS water has limited interaction with basaltic rocks, and its composition is largely shaped by the water-rock interaction in the Mz units, which may have been slightly changed by limited interaction with felsic volcanic rocks and mixing with shallow groundwater. Thick deposits of travertine in the area (Prostka and Embree, 1978) also support that the GCHS issues water that interacted with carbonates of the Mz units. The low concentration of $\mathrm{Cl}$ in GCHS water, however, precludes its interaction with Preuss Sandstone of the Jurassic Period that contains both halite and gypsum rich evaporite beds. It is, therefore, likely that the hot water from the reservoir migrates upward along the Warm River Fault zone interacting with felsic volcanic rocks before emanating as hot spring at the surface. However, the deeper water also mixes with dilute cooler shallow subsurface water.

The GCHS water appears to be similar to LHS water such that both features produce waters with low concentrations of $\mathrm{Cl}$ and $\mathrm{Na}$ along with higher concentrations of $\mathrm{Ca}$ and $\mathrm{SO}_{4}$. Similarly, there have been some other hot/warm springs [e.g., the Bear Lake Hot Springs (BLHS) near Idaho-Utah boarder and the Warm Spring near Big Elk Mountain] in the Idaho-Wyoming fold-thrust belt that produce $\mathrm{Ca}-\mathrm{SO}_{4}$ type water (Ralston et al., 1981; Neupane et al., 2015a). Geologically, the GCHS, BLHS, and Warm Spring (near Big Elk Mountain) areas share the same Mz stratigraphic units at depth. However, the Heise Hot Spring (HHS) which issues chemically distinct (high $\mathrm{Na}, \mathrm{Cl}$, and $\mathrm{SO}_{4}$ ) water that is also interacted with $\mathrm{Mz}$ rocks in its reservoir at depth. It is likely that a fraction of the GCHS water (and similar other waters) may have interacted with $\mathrm{Mz}$ units containing $\mathrm{SO}_{4}$ rich (and $\mathrm{Cl}$ poor) beds.

\subsection{Geothermometric results}

Quartz, chalcedony, and Na-K-Ca temperature estimates for GCHS are 75, 44, and $65^{\circ} \mathrm{C}$, respectively (Appendix D). However, these traditional geothermometer temperatures are obtained using un-optimized (un-reconstructed) composition of the GCHS. The fluid composition of this water was reconstructed with RTEst using a mineral assemblage of chalcedony, clinoptilolite, fluorite, anhydrite, and calcite. As alluded in the water chemistry section, the intermediate concentration of F indicate that the GCHS water is likely to have mixed with dilute cooler water. Geochemical speciation calculations indicate that both anhydrite and fluorite are undersaturated at field temperature and composition. RTEst modeling was performed to reconstruct GCHS thermal water composition using pure water as a substitute for dilute cooler water that may have mixed with along the flow path to the surface. RTEst modeling results indicate that the GCHS water may contain up to $60 \%$ of cooler water and $40 \%$ thermal water with reservoir temperature at $94 \pm 4{ }^{\circ} \mathrm{C}$. Both fluorite and anhydrite are found to be at equilibrium in 
reconstructed reservoir water. A sulfate-water oxygen isotope temperature of $29^{\circ} \mathrm{C}$ (Appendix D) was calculated for a sample from GCHS. This is likely indicating that the source of sulfate in the sample is coming from interaction of the fluids with anhydrite and/or gypsum in the subsurface and does not represent formation of the sulfate in a high temperature system. In addition, the $\delta^{34} \mathrm{~S}$ of the sulfate is high at $22.6 \%$, supporting a sedimentary sulfate origin.

\section{Heise Hot Spring}

\subsection{General}

The Heise Hot Springs (HHS) area (Figure 1) lies at the base of a cliff (Heise cliff) along the flanks of the Snake River at $1530 \mathrm{~m}$ above sea level in Jefferson County, Idaho. It is approximately $33 \mathrm{~km}$ northeast of Idaho Falls, along highway 26. Since the early $20^{\text {th }}$ century, the area has been used for camping, swimming, and soaking. The facilities include a large swimming pool, a warm pool, and a hot pool for soaking. The spring that supplies the water to these facilities is issuing thermal waters at $48^{\circ} \mathrm{C}$. Approximately $1.7 \mathrm{~km}$ and $3 \mathrm{~km}$ northwest of HHS, there are two additional warm springs [Hawley Spring $\left(16^{\circ} \mathrm{C}\right)$ and Elkhorn Spring $\left.\left(20^{\circ} \mathrm{C}\right)\right]$ issuing waters from higher elevations.

\subsection{Geologic setting}

Between 10 and $2 \mathrm{Ma}$, the area was blanketed by thick sequences of silicic volcanic rocks, including tuffs, rhyolite flows, and ignimbrites. These units include the Tertiary Arbon Valley Tuff (Tav) originating from the Picabo Caldera (Kellogg et al., 1994), and the Tertiary Heise volcanic field (Th) consisting of the Blacktail Tuff, Rhyolite of Kelly Canyon, Wolverine Creek Tuff, Tuff of Elkhorn Spring, Tuff of Hawley Gulch, and Kilgore Tuff (Morgan and McIntosh, 2005). Other minor units in the area include the Rhyolite of Long Hollow and various Tertiary and Quaternary basalt flows. The Quaternary Huckleberry Ridge Tuff (Qyh), associated with Yellowstone caldera volcanism (Christiansen, 2001), is the uppermost unit located throughout the area. A minor travertine deposit (ca. $10 \mathrm{~m}$ thick) is located near the HHS.

Underlying the volcanic rocks are Mesozoic sedimentary rocks $(\mathrm{Mz})$ including the Jurassic Nuggett Sandstone, Twin Creek Limestone, Stump Formation, and Preuss Sandstone, and the Cretaceous Gannett Group (for simplicity, these units are lumped together in the cross-section shown in Figure E12). These units were extensively folded and faulted during the Sevier-Laramide orogeny.

This region represents the termination of the Idaho-Wyoming thrust belt as is evidenced by truncation of folded and thrust faulted Mesozoic sedimentary rocks as they enter the Snake River Plain volcanic province. The Jurassic units exposed in the area have been documented to have various dip angles and an overturned nature as part of a thrust package (Phillips et al., 2016a,b). The more recent Heise and Snake River faults, NW trending splays of the Grand Valley Fault Zone (Piety et al., 1992), have dropped the SW edge of the Big Hole Mountains down and raised the Rexburg Bench exposing the Heise volcanics and underlying Mesozoic rocks. There is an estimated $350 \mathrm{~m}$ of displacement along this fault system (Piety el al., 1992).

The springs in the area are located at the intersections of the NW trending Heise Fault and unnamed NE trending faults. Along with the faulted nature of the area, the tuffs and rhyolites associated with the Heise volcanic field are highly fractured and hydrothermally altered suggesting possible increased fracture permeability to allow for hydrothermal fluids to travel to the surface. Furthermore, the Kelly Mountain Caldera (Prostka and Embree, 1978) rim fractures may lie underneath the HHS. Similarly, the existence of a dense intrusive body [likely to be the lateral end of the mid-curstal sill complex (Sparlin et al., 1982; Peng and Humphreys 1998; Shervais et al., 2006)] is suggested by Mabey (1978) based on regional Bouguer gravity anomaly. 


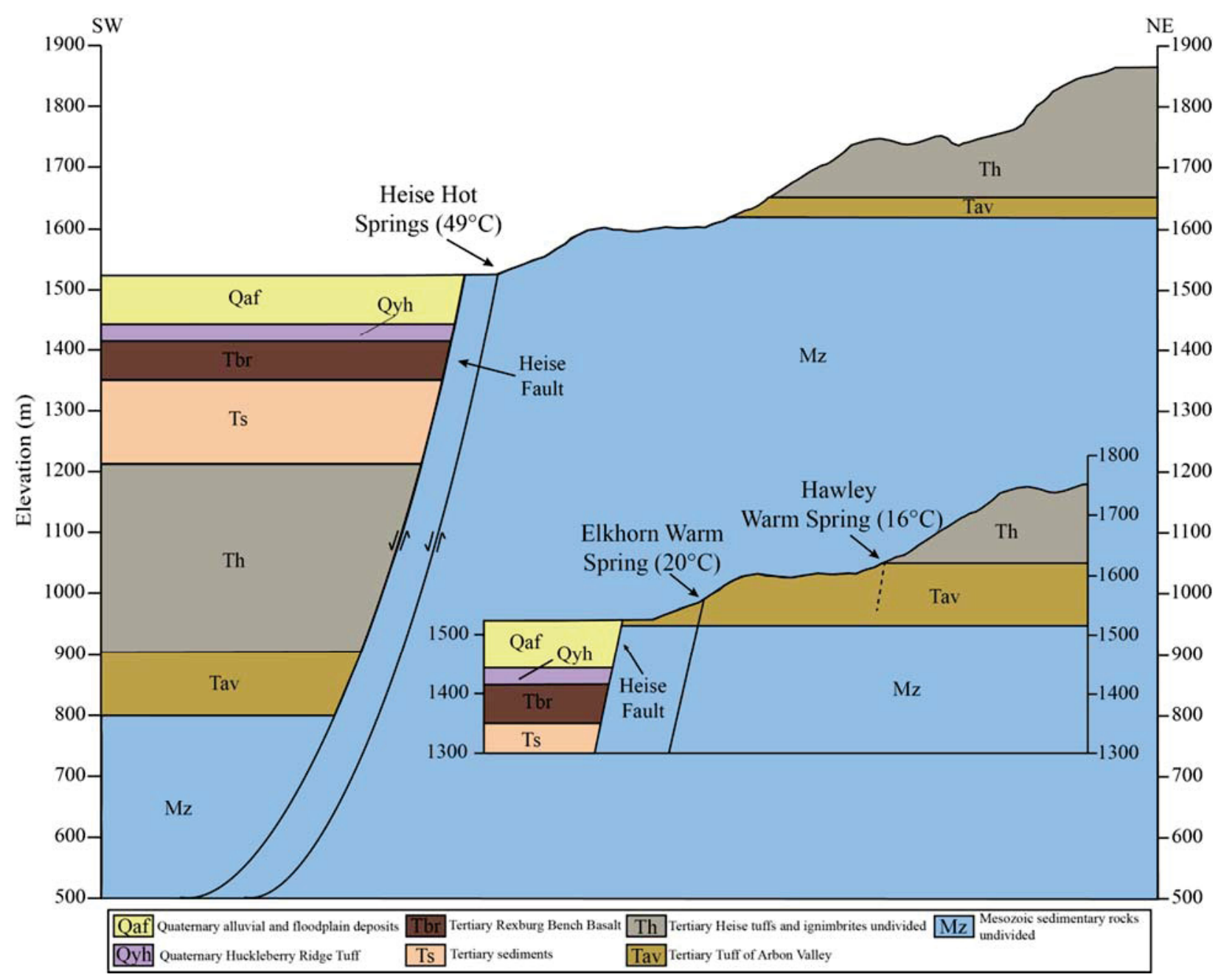

Figure E12. Geologic cross section of the Heise Hot Springs area; In-set cross section is representing the area $\mathrm{NE}$ of Heise showing Elkhorn and Hawley warm springs.

\subsection{Water chemistry}

The chemical property of HHS water makes it unique among the water samples from ESRP/ESRP margins hot springs and wells (Appendix B). This spring produces near neutral ( $\mathrm{pH}$ 6.32) water with very high TDS (>7000 mg/L) and a strong hydrogen sulfide smell. Specifically, the HHS water is enriched in $\mathrm{Cl}, \mathrm{Na}, \mathrm{HCO}_{3}$, and $\mathrm{SO}_{4}$. It also contains significant amounts of $\mathrm{K}, \mathrm{Ca}$, and $\mathrm{Mg}$. On Giggenbach diagram (Figure E2), the HHS water plots in immature water field. The evaporite beds in the Preuss Sandstone of the Mz units (Figure E12; Phillips et al., 2016a,b) are the likely source of elevated $\mathrm{Cl}$ and $\mathrm{SO}_{4}$ in $\mathrm{HHS}$ water.

The two nearby springs (Hawley and Elk Horn Springs) produce chemically different water than the HHS. These two springs issue neutral water containing lower TDS content $(\sim 335 \mathrm{mg} / \mathrm{L})$. The water of these two springs also have very low $\mathrm{Cl}$ and $\mathrm{SO}_{4}$ concentrations, indicating that they do not interact with evaporite beds of the $\mathrm{Mz}$ units at depth.

\subsection{Geothermometric results}

Quartz, chalcedony, and Na-K-Ca temperature estimates for HHS field water composition are 84, 53, and $89^{\circ} \mathrm{C}$, respectively (Appendix D). The reservoir fluid composition for HHS was reconstructed with 
RTEst using a mineral assemblage of anhydrite, beidellite, chalcedony, clinoptilolite, illite, and Kfeldspar. The reconstructed fluid resulted in a reservoir temperature of $88 \pm 2{ }^{\circ} \mathrm{C}$. RTEst results also indicate that the HHS water is diluted by a factor of almost 2. As with GCHS, the calculated sulfate-water oxygen isotope temperature for this site was relatively low at $65^{\circ}$ (Appendix D) compared to the RTEst temperatures. This is probably also an artifact of interaction with anhydrite beds in the subsurface. In addition, as with the GCHS sulfate, the $\delta^{34} \mathrm{~S}$ of the sulfate is high at 20.3\% supporting a sedimentary sulfate origin. However, unlike the GCHS sample, the concentration of dissolved inorganic carbon compounds (DIC) in the HHS sample was very high and had a high $\delta^{13} \mathrm{C}$ suggesting a marine carbonate source.

The other two nearby warm springs provide $64-108^{\circ} \mathrm{C}$ as reservoir temperatures based on field water composition applied to traditional geothermometers. Specifically, for field water compositions, quartz, chalcedony, and Na-K-Ca geothermometers resulted in very similar temperatures for both of these springs about $108^{\circ} \mathrm{C}$ and $79{ }^{\circ} \mathrm{C}$, and $64-68^{\circ} \mathrm{C}$, respectively. Because of the differences in the water compositions of these two springs relative to the HHS water, a slightly different minerals assemblage was used for the RTEst modeling. Specifically, anhydrite that was used in the RTEst modeling of HHS water was not included in the mineral assemblage for the RTEst modeling of waters from these two springs. Specifically, a mineral assemblage consisting of calcite, chalcedony, clinoptilolite, saponite, paragonite, and disordered dolomite was used for these springs. For Hawley and Elkhorn springs, the RTEst reservoir temperature estimates are 109 and $117^{\circ} \mathrm{C}$, respectively.

\section{East Idaho Falls area}

\subsection{General}

The foothills (1480-1580 m above sea level) along the margins of the ESRP east of Idaho Falls in Bonneville County have some wells that have been producing warm water since the early 1980s (Ralston et al. (1981). The geothermally anomalous area (Figure 1) along the foothills covers an area $10 \times 3 \mathrm{~km}^{2}$. Ralston et al. (1981) reported the existence of two wells in Rim Rock Estate that were producing water at $\geq 20{ }^{\circ} \mathrm{C}$. Recently drilled shallow wells (depth up to $244 \mathrm{~m}$ ) in the Comore Loma and Blackhawk communities a few kilometers south from Rim Rock Estate also produce warm water $\left(21-28{ }^{\circ} \mathrm{C}\right)$. As a part of this study, we collected and analyzed several water samples from wells in the area.

\subsection{Geologic setting}

The area lies on the edge of the SRP where pronounced volcanism has taken place throughout the past 6.5 Ma. The foothills to the east of Idaho Falls consist predominantly of tuffs, ignimbrites, and ash flows related to the Miocene-Pliocene Heise volcanic field (Th; Morgan and McIntosh, 2005). To the west of the foothills, the SRP Quaternary basalts $(\mathrm{Qb})$ become the dominant rock type with a thin layer of Quaternary sediments (Qs).

Beneath the Heise volcanic rocks and quaternary basalts are inferred Mesozoic sedimentary rocks (Mz) including limestones, sandstones, siltstones, conglomerates, and evaporite beds. For simplicity, these units are lumped together in the cross-section (Figure E13).

Although, there are no mapped faults in the area, reverse faults associated with the Idaho-Wyoming thrust belt have been mapped in the Mesozoic units to the south. Allmendinger (1982) has mapped multiple late Cenozoic normal faults in the northern Blackfoot Mountains, including the Gateway Fault. These northnorthwest trending faults are associated with the oldest regional range front faults in the area and have been mapped both to the north and south with throws ranging from 775-1000 $\mathrm{m}$. They faults have been projected into the study area showing offset within the Mesozoic units without continuing into the overlying Heise units. There is evidence, however, of late normal faulting having occurred in recent time within the Heise units to the east in the Ririe Reservoir area (Phillips et al., 2016b). These faults, as well as other north-northeast trending normal faults mapped by Allmendinger (1982), could represent the late 
Cenozoic adjustments that occurred as the SRP downwarp developed. The faults along with the highly permeable nature of the Heise volcanics could be facilitating fluid flow for several wells in the area.

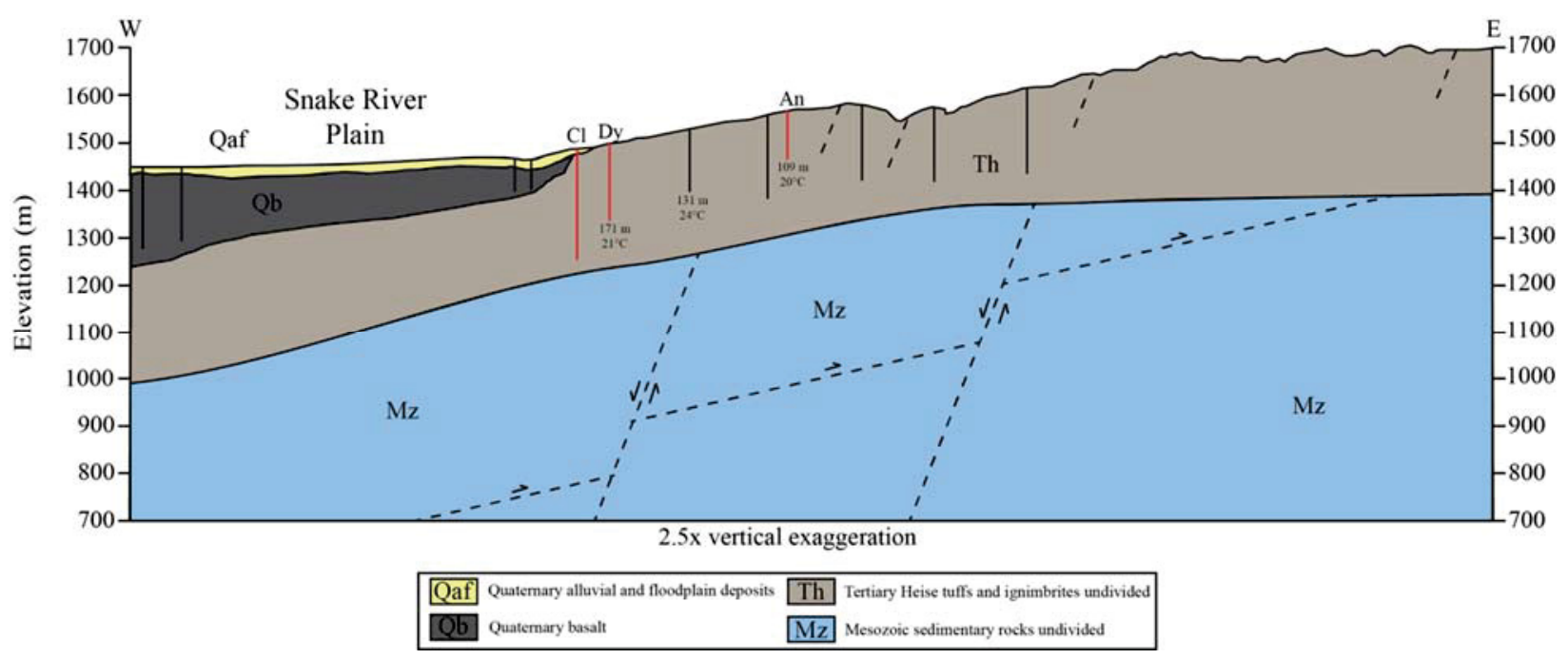

Figure E13. Geologic cross-section of an area east of Idaho Falls, ID; Black vertical lines indicate well logs used to constrain lithology and red lines indicate wells that were used for both lithology and geochemistry. (Cl: Comore Loma, Dy: Dyer, An: Anderson wells).

\subsection{Water chemistry}

All wells in the east Idaho Falls foothills produce neutral (pH from 6.7-7.7) water with TDS levels in the range of 430 to $835 \mathrm{mg} / \mathrm{L}$ (Appendix B). Chemically, water from these wells is Na-HCO 3 type (Figure E14), and contain relatively higher (compared to other ESRP waters except HHS water) concentration of Cl. Similarly, these water samples contain significant amount of Ca (50-77 mg/L). Wells in the northern part of the area (Rim Rock Estate) produce water containing very low concentration of $\mathrm{SO}_{4}$ whereas wells in the southern part of the area (Comore Loma and Blackhawk communities) produce water containing $>25 \mathrm{mg} / \mathrm{L} \mathrm{SO}_{4}$. Similarly, water from the southern part has relatively higher concentrations of $\mathrm{Na}$ and $\mathrm{K}$. However, when plotted on a Giggenbach plot (Giggenbach, 1988), all water samples from this area plot in the immature zone (Figure E2) because of higher $(10-22 \mathrm{mg} / \mathrm{L})$ concentration of Mg. Despite all wells being drilled within the felsic volcanic rocks, they produce water having low $(<0.5 \mathrm{mg} / \mathrm{L})$ concentration of F. Low concentration of $\mathrm{F}$ in these water samples may indicate that the wells in the east Idaho Falls foothills are mostly getting water chemically influenced by the underlying $\mathrm{Mz}$ units containing carbonates. It is likely that the higher $\mathrm{Cl}$ and $\mathrm{SO}_{4}$ concentrations in the waters from these wells are the results of water-rock interaction occurred with the $\mathrm{Mz}$ units. The wells in this area are very productive and can sustain pumping rates of $>1500$ gallon-per-min for several days. The rocks in the area are reported to be highly fractured and it is likely that the wells in the area also tap groundwater from the deeper Mz rock units through the fracture-dominated permeable zones.

\subsection{Geothermometric results}

The quartz, chalcedony, and Na-K-Ca temperature estimates for east Idaho Falls area range from 115 to $143{ }^{\circ} \mathrm{C}, 86$ to $117^{\circ} \mathrm{C}$, and 45 to $74{ }^{\circ} \mathrm{C}$, respectively (Appendix D). For these water samples, RTEst was applied using a mineral assemblage of clay mineral(s), calcite, chalcedony, clinoptilolite, and K-feldspar. The $\mathrm{Mg}$ concentrations in these waters are found to be controlled by mineral equilibria with clay minerals such as chlorite, saponite, illite, and beidellite. The RTEst temperature estimates for these 6 water samples are very similar with a range from $136-143{ }^{\circ} \mathrm{C}$ (Appendix D). East Idaho Falls waters are diluted by 1.5 to 2.5 times with the dilute water. Similarly, RTEst modeling of these samples indicate that these waters are subjected with high fugacity of $\mathrm{CO}_{2}(6-20 \mathrm{bar})$ in the reservoir at depth. The gas rich Comore 
Loma and Blackhawk samples also support the RTEst results that indicate high fugacity of $\mathrm{CO}_{2}$ in the reconstructed fluids.

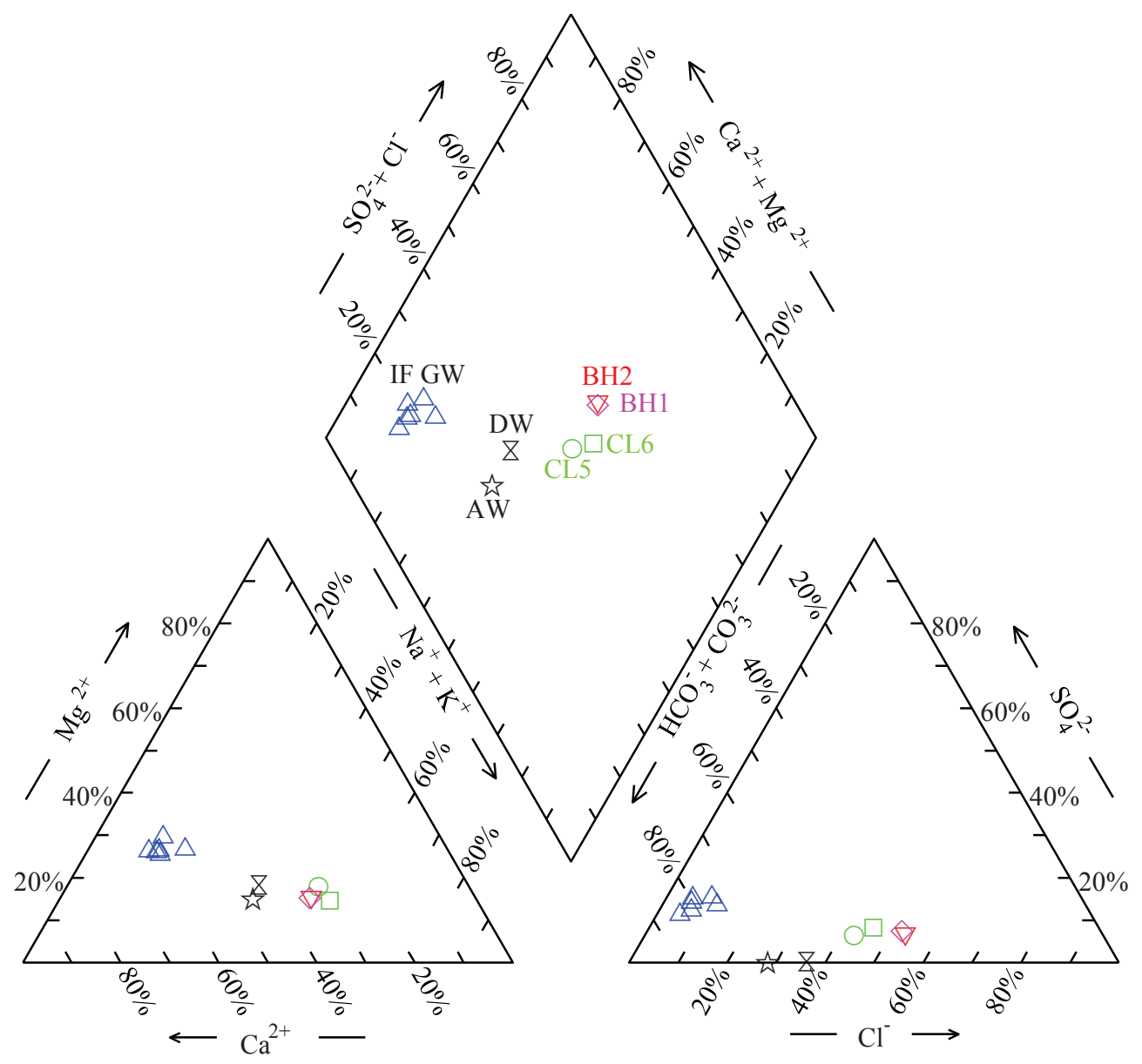

Figure E14. Chemical composition of water samples from Idaho Falls and from foothills on the east of Idaho Falls area plotted on Piper diagram. IF GW: Groundwater from Idaho Falls and Ammon; wells from foothills are - DW: Dryer well, AW: Anderson well, CL5: Comore Loma well \#5, CL6: Comore Loma well \#6, BH1: Blackhawk well \#1, and BH2: Blackhawk well \#2.

\section{Butte City area}

\subsection{General}

The Butte City geothermal area (Figure 1) is located about $16 \mathrm{~km}$ to the west from Idaho National Laboratory desert site along route 26 in Butte County, Idaho. This area is about $100 \mathrm{~km}$ west from Idaho Falls and about $5 \mathrm{~km}$ east from Arco. The thermal anomaly of the area was identified when a well drilled by Butte City intercepted warm water (Ross, 1970). The area has several warm wells that produce water at $23-36{ }^{\circ} \mathrm{C}$. The two hottest wells in the area, Butte City Well and Greenhouse Well, are currently used for municipal water supply and heating greenhouses, respectively. Previously, a hot water producing well $\left(41^{\circ} \mathrm{C}\right.$, the Lewis Rothwell Well) from an area about $22 \mathrm{~km}$ west from Butte City was reported by Young and Mitchell (1973). 


\subsection{Geologic setting}

The Butte City geothermal area lies near the ESRP margins. Surficial Quaternary alluvial deposits are mapped around Butte City, but tholeiitic Quaternary basalts are mapped to the south of this area (Kuntz et al., 1994). Therefore, it is likely that alternating sequences of Quaternary basalts and alluvial deposits constitute the near subsurface materials in the area. The thickness of basalts/sediment layers in this area may range from 200-300 $\mathrm{m}$ (Whitehead, 1992; Blackwell et al., 1992). Paleozoic sedimentary rocks outcrop in the Arco Hills of the Lost River Range located a few kilometers to the north from the area. The geologic contact between ESRP and Lost River Range has been interpreted by different workers as being a fault, a down warp or a shear accommodation zone (Sparlin et al., 1982; Peng and Humphreys, 1998; McQuarrie and Rodgers, 1998; Payne et al., 2013). The type of contact between these two geologic and geographic provinces could make a significant effect on the type of basement rock under the basalt/sediment sequences in the area. If the contact is a fault, a thick sequence of Tertiary rhyolites may underlie the Quaternary rocks. However, if the contact is defined by a down warp, a thin sequence of rhyolite is likely to be present sandwiched between underlying Paleozoic sedimentary rocks and overlying quaternary rocks. Regardless of the type of north-south boundary between the ESRP and Lost River Range, two N-S and SE-NE striking faults that make the Arco Peaks and Arco Hills, respectively, seem to intersect or plunged down the Butte City geothermal area. this area is located within the Arco-Big Southern Butte volcanic rift zone that is characterized by linear trends of eruptive centers, eruptive and non-eruptive fissures, monoclines, and grabens (Kuntz and Kork, 1978; Kuntz et al., 1994).

\subsection{Water chemistry}

Two water samples from two wells (Butte City Well and Greenhouse Well) in the area were collected and analyzed during the sampling campaign of this study. Water samples from these wells have been analyzed several times over the last several decades, and their compositions are found to be consistent over time. Besides these two wells, four other water compositions measured from warm wells $\left(23-41^{\circ} \mathrm{C}\right)$ in the area were also compiled from existing literature (e.g., Young and Mitchell, 1973). The concentrations of major cations and anions in these samples (Appendix B) are shown on a Piper diagram (Figure E15). Waters from this area are near-neutral $\left(\mathrm{pH}\right.$ 6.3-8.1) $\mathrm{Ca}-(\mathrm{Mg})-\mathrm{HCO}_{3}$ type with TDS ranging from $370-720 \mathrm{mg} / \mathrm{kg}$. Silica concentrations in the water samples from Butte City are relatively low (24-38 mg/L). Similarly, F concentrations in Butte City water samples represent typical values of basalt-interacted ESRP waters with a narrow concentration range from $0.4-0.7 \mathrm{mg} / \mathrm{L}$. However, the Lewis Rothwell Well which is located further west from Butte City has been reported to produce water with relatively higher concentrations of $\mathrm{SiO}_{2(\mathrm{aq})}, \mathrm{F}$, and $\mathrm{SO}_{4}$ possibly indicating that this water may have interacted with rhyolites (or even Paleozoic sedimentary rocks as indicated by higher $\mathrm{SO}_{4}$ content) at greater depth (and potentially at higher temperature) and latter re-equilibrated with basalts at shallow depth.

\subsection{Geothermometric results}

Reservoir temperatures for the Butte City geothermal area are given in Appendix D. Quartz (no steam loss) and chalcedony (Fournier, 1977) geothermometers resulted in $70-90{ }^{\circ} \mathrm{C}$ and $38-59{ }^{\circ} \mathrm{C}$, respectively. Similarly, Mg-corrected temperature clustered around $40{ }^{\circ} \mathrm{C}$, and for one sample locally re-equilibrated temperature is indicated. Silica-enthalpy mixing model (no-steam loss) temperatures are 75 and $124{ }^{\circ} \mathrm{C}$ obtained with chalcedony and quartz solubility curves, respectively. The fractions of thermal water in the sampled waters as indicated by silica-enthalpy mixing models are $40 \%$ and $25 \%$, respectively. However, RTEst modeling showed good convergence with no mixing scenarios for the Butte City area samples. RTEst modeling for Buttte City area samples were performed using a mineral assemblage consisting of calcite, chalcedony, clinoptilolite, dolomite, phengite, and saponite. The RTEst modeling resulted in temperatures around $60{ }^{\circ} \mathrm{C}$ for these samples. When compared, RTEst temperature estimates are more aligned with chalcedony and $\mathrm{Na}-\mathrm{K}-\mathrm{Ca}$ temperatures, and slightly warmer than the temperatures of the water that these wells produce. Moreover, Blackwell et al. (1992) recorded a temperature of about $53{ }^{\circ} \mathrm{C}$ for the lower part of the Greenhouse well (reported as the Richardson well). Therefore, the Butte City 
wells are taping water from a reservoir that is located at a shallow depth and is equilibrated at lower temperature. Notwithstanding the cooler geothermometric temperatures from water samples from this area, Dobson et al. (2015) reported an unusually high ${ }^{3} \mathrm{He} /{ }^{4} \mathrm{He}$ ratio for one sample (Greenhouse Well) from this area, indicating that the area may have a deep magmatic heat source. The sulfate-water oxygen isotope temperatures for these two wells were similar, but somewhat higher than the RTEst temperatures at $95{ }^{\circ} \mathrm{C}$ for the Greenhouse well and $92{ }^{\circ} \mathrm{C}$ for the Butte City wells (Appendix D).

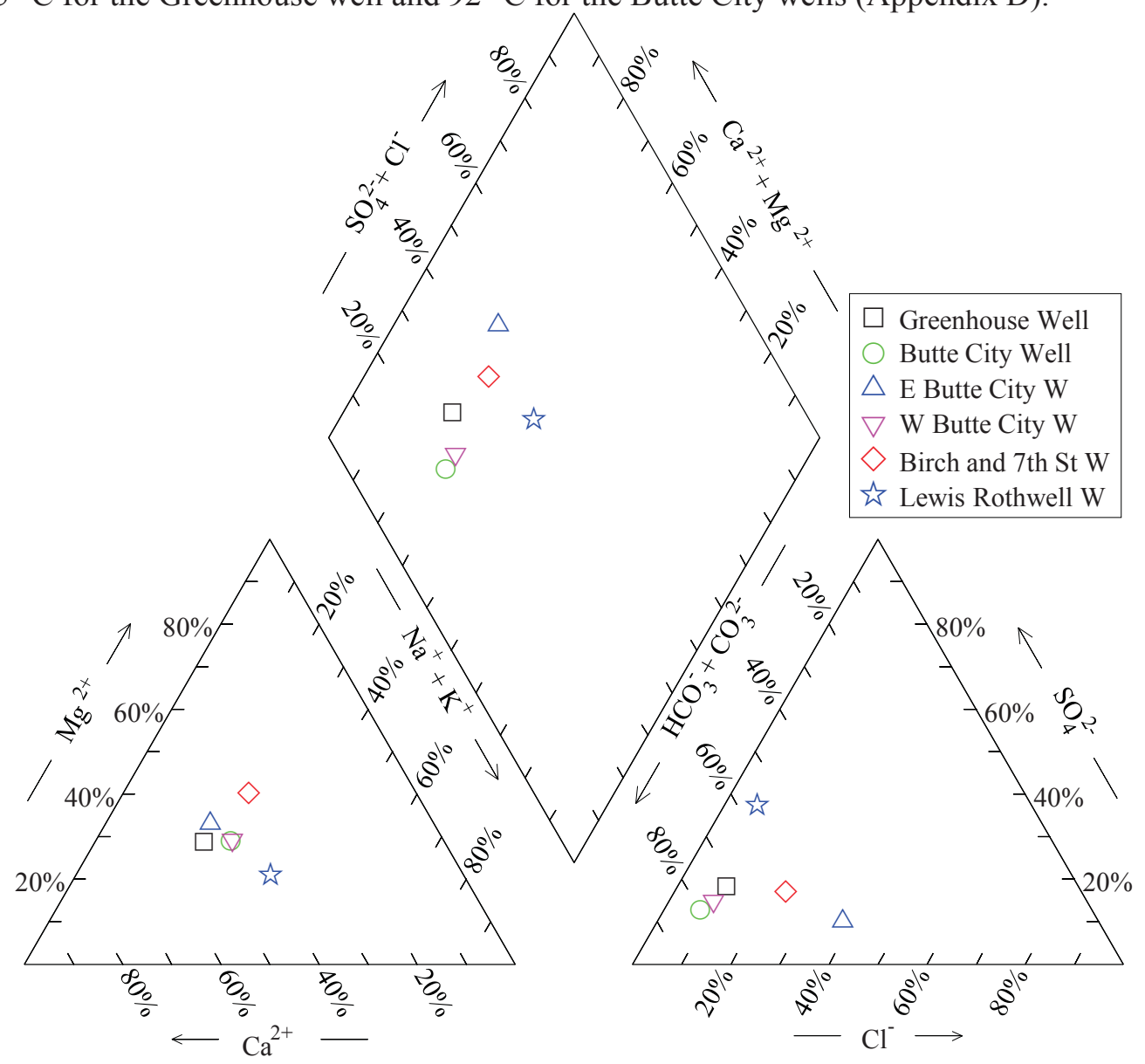

Figure E15. Piper diagram representing chemistry of water samples from Butte City area

The Lewis Rothwell Well yielded lower temperatures. Estimated reservoir temperatures for this well with chalcedony, quartz, Na-K-Ca, and RTEst geothermometers are $77,106,49$, and $80 \pm 3{ }^{\circ} \mathrm{C}$, respectively. Low estimated temperature but higher concentration of $\mathrm{F}$ in water indicate that the Lewis Rothwell Well may be tapping water that has interacted with rhyolites at greater depth and potential higher temperature but latter modified by interactions with basalts at lower temperature.

It is likely that the heat source for the Butte City geothermal area is a mid-crustal mafic sill complex identified with regional seismic studies (Sparlin et al., 1982; Peng and Humphreys, 1998) and petrochemical analysis of sequences of ESRP basalt (Shervais et al., 2006). Another likely possibility for the elevated temperature in the area is its hydrogeological setting. Groundwater modeling of the ESRP aquifer system indicates rather low transmissivity for this area (Whitehead, 1992). Thinner aquifers with lower transmissivity and longer residence times may help produce a local thermal anomaly. 


\section{Condie Hot Spring}

\subsection{General}

The Condie Hot Spring (CHS) geothermal area (Figure 1) is located about $3.5 \mathrm{~km}$ northeast of Carey in Blain County, Idaho. This area sits at about $1450 \mathrm{~m}$ above sea level along the Route 26/93. The area is characterized by three hot springs. The main geothermal feature of the area is the CHS which issues water at $50.5^{\circ} \mathrm{C}$. Two additional spring systems in the area - Milford Sweat Hot Spring (MS) and Rush Warm Springs (RWS) - issue water at 38.1 and $29^{\circ} \mathrm{C}$, respectively. None of the hot springs in the area are currently being used for any economical or recreational activities.

\subsection{Geologic setting}

The CHS geothermal area is located along the north-central margin of the ESRP. A generalized geological section for the area is shown in Figure E16. To the ESRP side of the cross-section, Quaternary alluvial and flood basalt layers are present at shallow depth. However, non-ESRP area (Basin and Range type geographic province) to the north, the Tertiary Challis volcanic rocks outcrop. Underneath the both Tertiary and Quaternary rocks/sediments are the Paleozoic sedimentary units. The contact between the ESRP and Basin and Range in this area is not properly understood, and cross-section is constructed based on geologic interpretation made by McQuarrie and Rodgers (1998) that the Paleozoic rock units warp down into the ESRP rocks. Other competing views either consider fault(s) (Sparlin et al., 1982) or a shear zone (Payne et al., 2013) as the boundary that separates the ESRP from the Basin and Range in this area.

Because of the lack of well log data from the area, the thickness of the Quaternary basalts is not known. Similarly, whether any rhyolite units exist between the basalt layers and Paleozoic rocks is not known. The thickness of basalt layers (or aquifer thickness) as depicted in Figure E16 is based on the information provided by Whitehead (1992). Similarly, no rhyolite sequence is shown underneath the basalt layers because of the lack of geochemical signatures in the water compositions from the CHS area geothermal waters that would indicate the presence of felsic volcanic rock at depth. However, the lack of rhyolite signatures in thermal waters may stem from the fact that the area does have very thick basalt layers and the felsic volcanic rocks are buried at greater depth. This scenario seems equally valid if the contact between ESRP and the area to the north (Basin and Range Province) is a structural fault or caldera ring fracture(s).

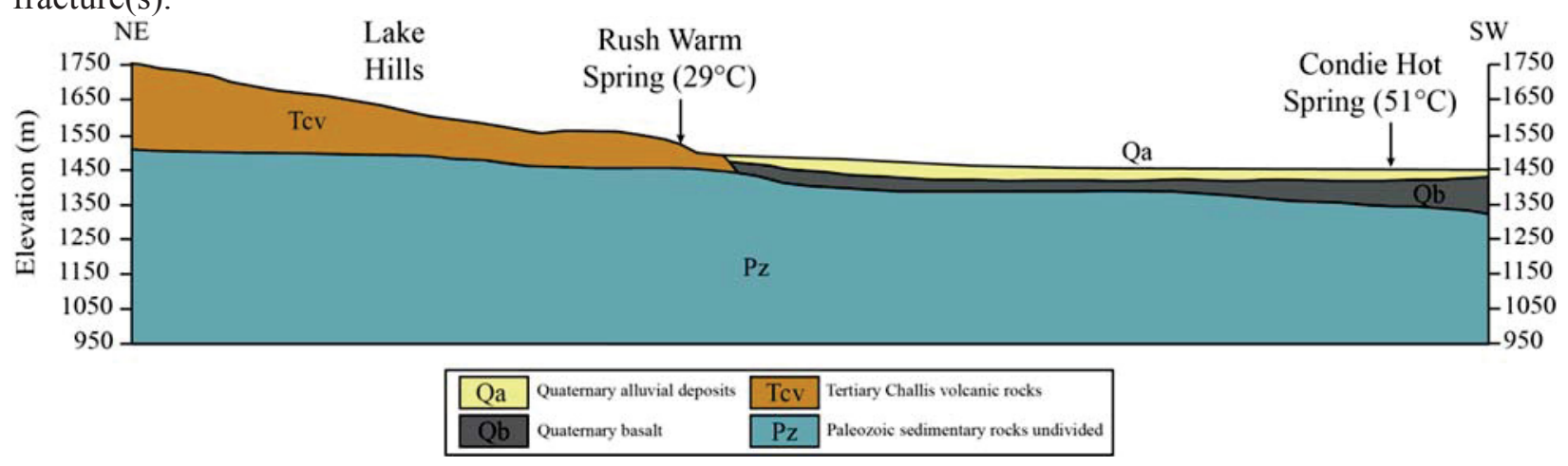

Figure E16. Geologic cross-section of the Condie Hot Spring geothermal area

The geologic map of the area shows a fault extending to the MS, however there were no mapped faults in the vicinity of CHS and RWS (Lewis et al., 2012). The Tertiary Challis volcanic rocks in the vicinity of RWS are highly jointed. The warm water that these springs issue may have been moving from depth along the joint openings or along the gravel/conglomerate layer between Paleozoic units and Challis volcanic rocks. Similarly, the CHS may have flow paths controlled by deep joints in the basalt layers or the area may have unmapped fault(s). 


\subsection{Water chemistry}

We collected four water samples from three hot springs systems representing the CHS geothermal area (Appendix B). Field temperatures of these samples range from $23.2{ }^{\circ} \mathrm{C}$ (RWS2) to $50.5^{\circ} \mathrm{C}$ (CHS). In addition to these samples with elevated temperatures, several water compositions measured from cooler $\left(11-15^{\circ} \mathrm{C}\right)$ wells around the area are also compiled from NWIS database. Chemical compositions of major cation and anions in these samples are depicted in Figure E17. Both warmer and cooler sampling features in this area produce near neutral $\left(\mathrm{pH}\right.$ 6.7-7.7) $\mathrm{Ca}-\mathrm{HCO}_{3}$ type waters with TDS levels ranging from 300 to $500 \mathrm{mg} / \mathrm{L}$. Since CHS geothermal area waters have relatively low F (1.5-1.8 mg/L) concentrations and are near neutral in $\mathrm{pH}$, these waters might have had limited exposure to felsic volcanic rocks. However, the water isotope composition of the CHS sample $\left(\delta \mathrm{D}=-150 \%\right.$, $\delta^{18} \mathrm{O}=-18.6 \%$ ) falls significantly to the right of the Meteoric Water Line and is consistent with high levels of high-temperature interaction with rocks. This was not the case with the MS sample $\left(\delta \mathrm{D}=-141 \%, \delta^{18} \mathrm{O}=-18.3 \%\right.$ ) which lies very close to the Meteoric Water Line, suggesting they followed different pathways in the subsurface.

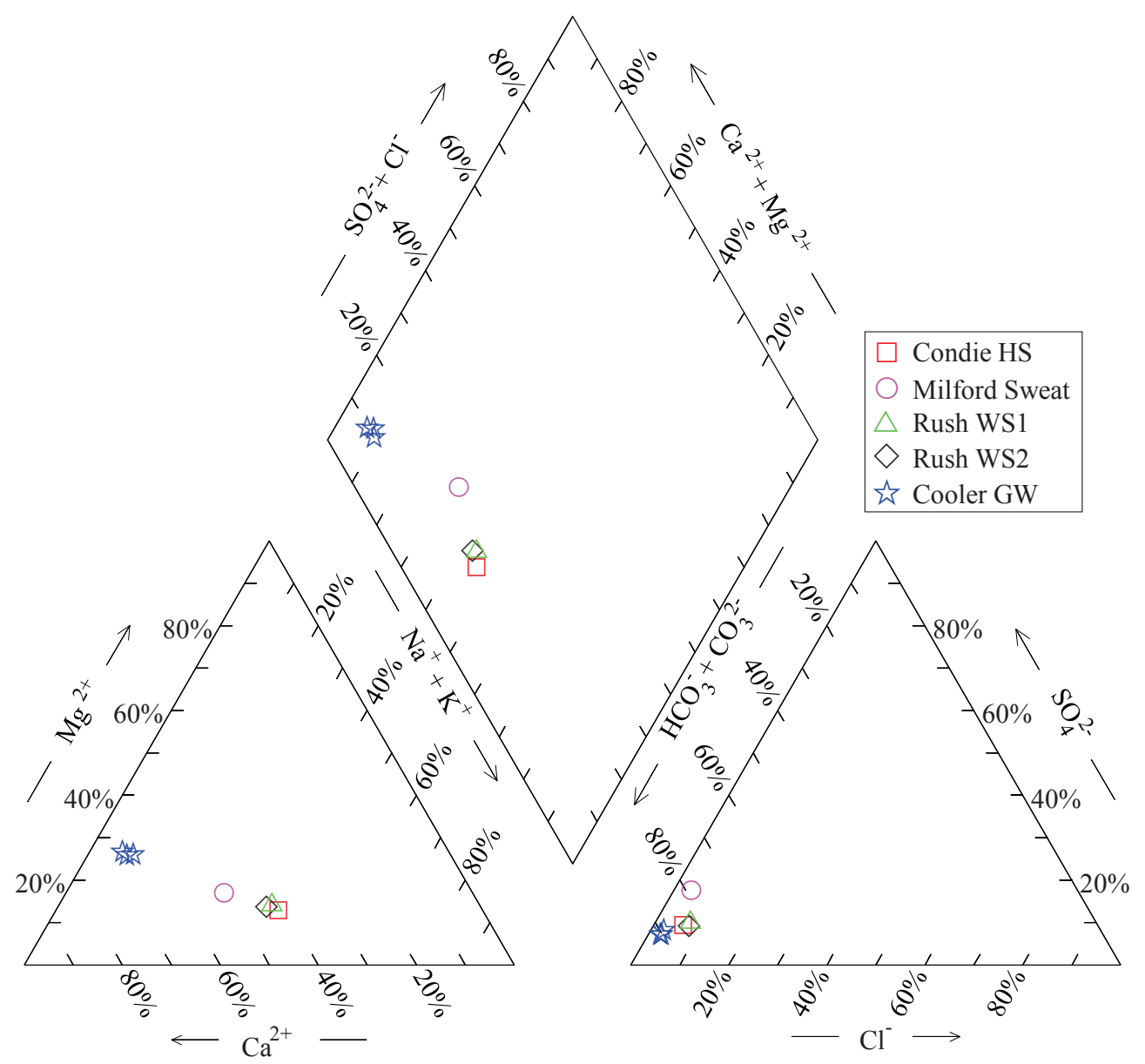

Figure E17. Piper diagram representing chemistry of water samples from Condie Hot Spring area

\subsection{Geothermometric results}

Reservoir temperature estimates of the CHS area are given in Appendix D. All thermal features in the area resulted in very similar temperature with traditional geothermometers. The quartz (no steam loss), chalcedony, and $\mathrm{Na}-\mathrm{K}-\mathrm{Ca}\left(\mathrm{Mg}\right.$ corrected) temperatures ranges are $71-82{ }^{\circ} \mathrm{C}, 40-51$, and $71-83{ }^{\circ} \mathrm{C}$, respectively. Reservoir temperature estimates with chalcedony geothermometer are similar to the hottest 
feature (CHS) in the area. Silica-enthalpy (chalcedony-enthalpy) mixing model using four samples from thermal features and three additional cooler (field temperature $10-15^{\circ} \mathrm{C}$ ) samples from shallow wells from this area also resulted in reservoir temperature $\left(52^{\circ} \mathrm{C}\right)$ similar to $\mathrm{CHS}$ field temperature with essentially no mixing with cooler water. However, quartz-enthalpy mixing model resulted in reservoir temperature of about $100{ }^{\circ} \mathrm{C}$ with $50 \%$ dilution with cooler water.

Multicomponent geothermometric tool RTEst was applied to these water samples using a mineral assemblage consisting of beidellite, calcite, clinoptilolite, chalcedony, illite, and fluorite with three optimization parameters (mass of water, fugacity of $\mathrm{CO}_{2}$ and temperature). For the optimization of mass of thermal water, a composition of water based on a local groundwater $\left(10.4^{\circ} \mathrm{C}\right)$ was used during RTEst modeling. The Milford Sweat hot spring resulted in the lowest $\left(73 \pm 9{ }^{\circ} \mathrm{C}\right)$ and Rush Warm Spring1 resulted in the highest $\left(106 \pm 9{ }^{\circ} \mathrm{C}\right)$ reservoir temperatures for the area. The RTEst results also indicate that the CHS area thermal features are issuing waters that may have diluted 50-65\% with local groundwater. Sulfate-water oxygen isotope geothermometry for the CHS and MS samples yielded temperatures of 102 and $105^{\circ} \mathrm{C}$, respectively. These temperatures are somewhat higher than the RTEst temperatures.

\section{Magic Hot Spring}

\subsection{General}

The Magic Hot Spring (MHS) area (Figure 1) is located on the northern margins of the central ESRP near the Camas-Blaine county line, Idaho. It sits at $1470 \mathrm{~m}$ above sea level on the edge of the Magic Reservoir approximately $40 \mathrm{~km}$ south of Ketchum, Idaho and is located on the eastern end of the Camas Prairie.

Until a 79 m deep well (Magic Reservoir Landing Well, MRLW) was drilled for direct heating purpose in 1965 , the MHS was issuing $36^{\circ} \mathrm{C}$ water (Ross, 1970). However, with the operation of well, MHS dried out (Mitchell, 1976). At the beginning, the MRLW was producing water at $66^{\circ} \mathrm{C}$, however, the water temperature subsequently increased to $74^{\circ} \mathrm{C}$ by 1975 (Mitchell, 1976; Mitchell et al., 1980). The most recent (2014) temperature record for the well is $75^{\circ} \mathrm{C}$.

\subsection{Geologic setting}

The MHS area consists predominantly of Miocene-Quaternary silicic volcanic rocks and basalt flows. The Pliocene-Miocene Poison Creek Tuff (Tpct) is the uppermost unit in the immediate vicinity of Magic Reservoir and is underlain by the Miocene Tuff of City of Rocks (Tcort), a rhyolite tuff from the Idavada Group (Figure E18). Other rhyolites and basalt flows are abundant in the surrounding areas but are not shown in the cross-section. The Cretaceous Idaho Batholith granitic rocks $(\mathrm{Kg})$ form the basement throughout the region.

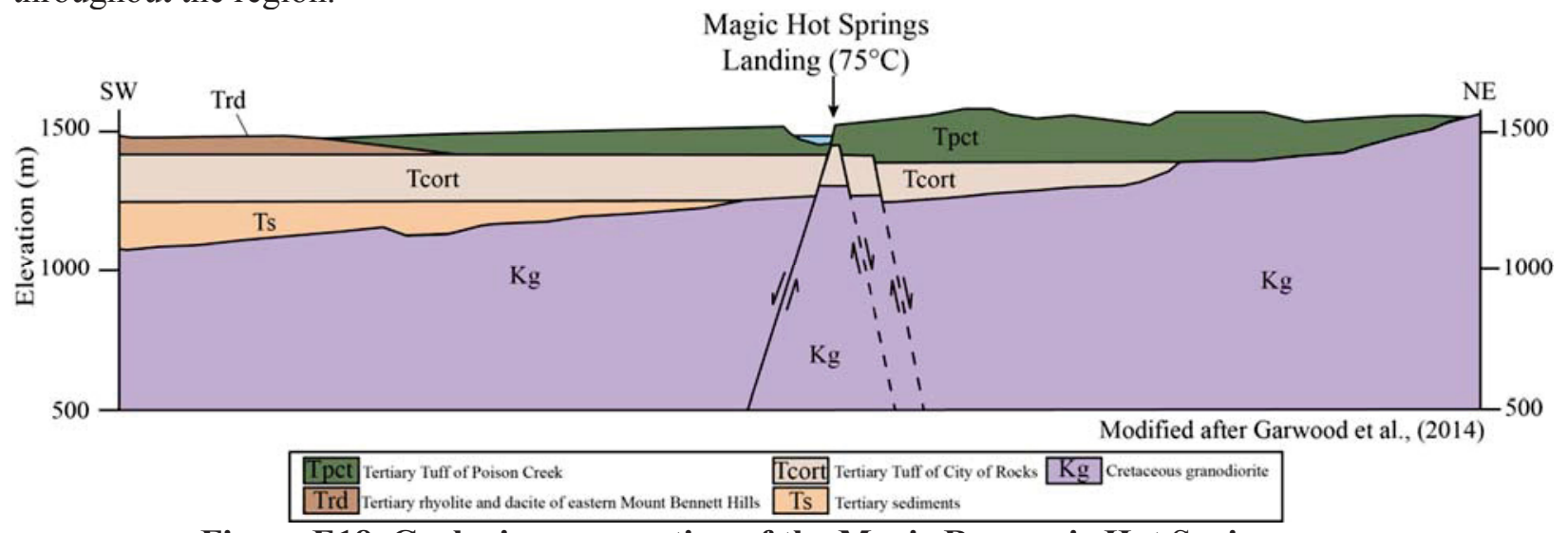

Figure E18. Geologic cross-section of the Magic Reservoir Hot Springs area 
Structurally, this area is interesting because of its location at the inter-section of several regional to local geographic and geologic features including the ESRP, Camas Prairies, eastern part of Mt. Bennett Hills, and Idaho Batholith. The MHS area is in a tensional stress regime and includes many high-angle normal faults that create block-faulted configurations (Struhsacker, 1982). Mitchell (1976) recognized two curvilinear features from Landsat false color infrared satellite imagery and discusses their controlling nature in the immediate area. The Magic Reservoir Fault trends northwest and extends the length of the reservoir and into the northern Soldier Mountains. Another fault extends at a slightly less northwest trend along the Clay Bank Hills and intersects the Magic Reservoir fault near the location of the MHS landing well (Malde et al., 1963). Struhsacker et al. (1982) refer to the resulting structure as the Hot Springs Landing horst. These structures are interpreted to have occurred prior to Quaternary volcanism due to the lack of deformation in the flat lying young basalts and sediments. They may also be related to a buried caldera inferred from stratigraphic thicknesses and basalt vent locations in the surrounding regions (Leeman, 1982).

\subsection{Water chemistry}

Two sets of samples were collected from this well- one sample was directly collected from a shallow leak in the MHS-RLW and another sample collected from a runoff channel (Appendix B). Both of the samples show similar chemical results except for slightly higher $\mathrm{pH}$ and lower recorded temperature for the sample collected from runoff channel indicating a higher degree of degassing of $\mathrm{CO}_{2}$ and cooling. The MHS-RLW produces near neutral ( $\mathrm{pH} 6.79$, degassed sample $\mathrm{pH} 8.61$ ) Na-HCO3 type water (Figure E19) with higher amount of TDS $(1500 \mathrm{mg} / \mathrm{L})$. The well water contains higher concentrations of $\mathrm{SiO}_{2}$ $(103 \mathrm{mg} / \mathrm{L})$ and $\mathrm{Cl}(75 \mathrm{mg} / \mathrm{L})$.

\subsection{Geothermometric results}

Reservoir temperatures of the MHS area are given in Appendix D. Quartz (no steam loss), chalcedony, and $\mathrm{Mg}$-corrected Na-K-Ca geothermometers resulted in 139 and $142{ }^{\circ} \mathrm{C}$, and 113 and $116{ }^{\circ} \mathrm{C}$, and 153 and $152^{\circ} \mathrm{C}$ with compositions measured in water samples from the well leak and leak runoff channel, respectively. Silica-enthalpy mixing models were applied with compositions measured in water samples from well leak and a well producing cooler groundwater. The runoff channel sample was not considered because of the apparent heat loss. The chalcedony-enthalpy mixing model resulted in $145^{\circ} \mathrm{C}$ reservoir temperature with about $50 \%$ dilution. Similarly, the quartz-enthalpy mixing model resulted in $181{ }^{\circ} \mathrm{C}$ reservoir temperature with about $60 \%$ dilution.

The RTEst modeling of MHS samples were performed using a local groundwater composition to optimize the mass of water along with two other optimization parameters - fugacity of $\mathrm{CO}_{2}$ and temperature. A mineral assemblage consisting of beidellite, clinoptilolite, chalcedony, dolomite, and Kfeldspar was used. The RTEst results (Appendix D) indicate that the MHS geothermal area has a reservoir temperature of about $163^{\circ} \mathrm{C}$. However, the RTEst temperature estimate with the runoff water composition is about $10^{\circ} \mathrm{C}$ cooler than the temperature estimate with composition water directly collected from the well leak. Similar to the estimated degree of dilution derived from the chalcedonyenthalpy mixing model, the RTEst modeling indicates that the MHS-RLW water is diluted by almost $50 \%$ with local groundwater.

Sulfate-water isotope temperatures for both the well and runoff samples were quite high at 237 and 233 ${ }^{\circ} \mathrm{C}$, respectively. Although these temperatures are high, there are other isotope indicators that these samples underwent significant high temperature water rock interaction. The water isotope composition of the well water $\left(\left(\delta \mathrm{D}=-151 \%, \delta^{18} \mathrm{O}=-16.9 \%\right)\right.$ is significantly shifted off the meteoric water line (the runoff sample was also shifted, but was also clearly evaporated during cooling). In addition, the isotopic composition of dissolved methane in the water $\left(\delta \mathrm{D}=-203 \%, \delta^{13} \mathrm{C}=-22.0 \%\right.$ ) is typical of methane produced in a magmatic system, suggesting that these fluids interacted with magmatic rocks at depth. 


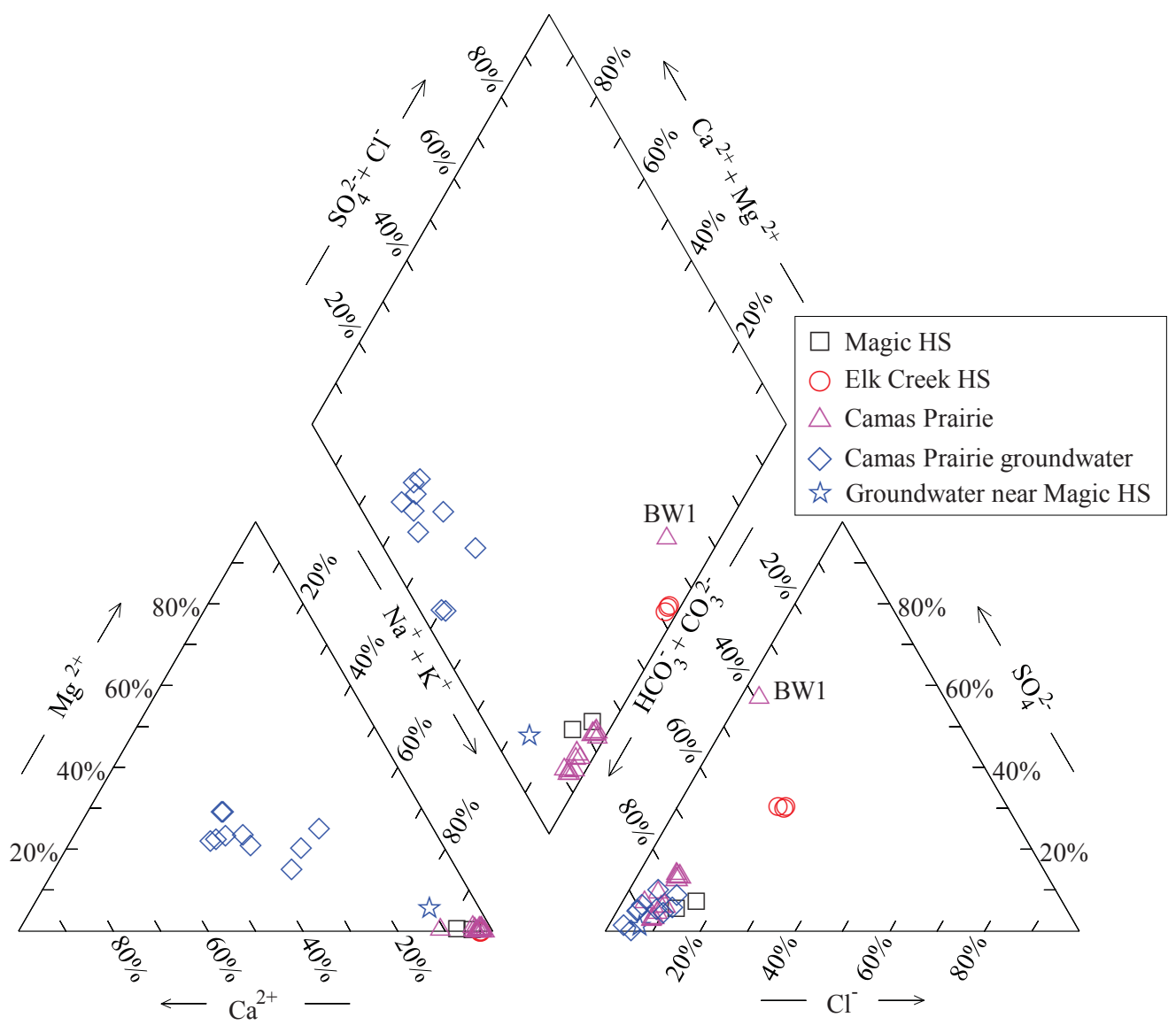

Figure E19. Piper diagram representing chemistry of water samples from Camas Prairies area. Composition of water measured from Barron Well 1 (BW1) has high $\mathrm{SO}_{4}$ concentration compared to the concentration of $\mathrm{SO}_{4}$ in all other Camas Prairie samples.

\section{Elk Creek Hot Springs}

\subsection{General}

The Elk Creek Hot Springs (ECHS) area (Figure 1) is located in the southern Soldier Mountains near the Elk Creek drainage in Camas County, Idaho. It sits at $1730 \mathrm{~m}$ above sea level approximately $15 \mathrm{~km}$ northeast of Fairfield, Idaho. There are a series of springs in the area that issue thermal waters from fractures in granitic rock that range in temperature from $45-55^{\circ} \mathrm{C}$. Currently, the geothermal resource at this site is not utilized for any commercial activities.

\subsection{Geologic setting}

The ECHS area is located on the southeastern margin of the Idaho Batholith region near the eastern part of Camas Prairie. Rocks in the area include - Miocene Tuff of Cannonball Mountain Formation (Tcm) of the Idavada Group, Eocene dacite and rhyodacite of the Challis Volcanic Group (Tcvd), a diorite and gabbro unit (Tdg), and the Cretaceous Idaho Batholith granodiorite (Kg) (Garwood et al., 2014). Various Tertiary dacite and rhyolite dikes (Td) are mapped throughout the area intruding into batholith granodiorites and based on local abundance, are inferred in cross-section. Alluvial fan deposits are localized to slopes and valleys. 


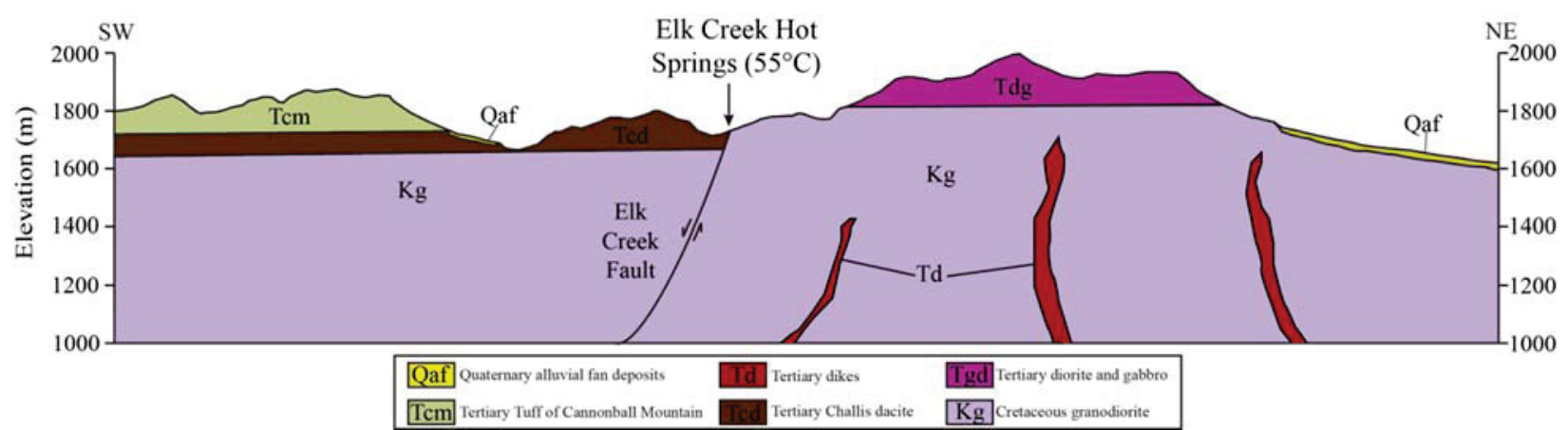

Figure E20. Geologic cross-section through the Elk Creek Hot Springs area

Many NW trending normal faults with orientations similar to Basin and Range extensional structures dominate. Locally, the SW dipping, NW trending Elk Creek Fault extends from the Camas Prairie north into the Soldier Mountains. This fault and associated breccia and gouge facilitate flow from deeply jointed and fractured granodiorite (Figure E20). Also, the presence of numerous dikes in the area represents planes of weakness within the batholith and could be analogous to geothermal flow pathways.

\subsection{Water chemistry}

In our sampling campaigns, we collected samples from two thermal expressions- ECHS1 and ECHS2 (Appendix B). Previously, Mitchell (1976) reported chemical compositions of three ECHS features. Over time, the compositions and field temperature of water from these hot springs remain unchanged. All ECHS expressions issue alkaline ( $\mathrm{pH} \geq 9), \mathrm{Na}-\mathrm{HCO}_{3}$ type water at $50-55^{\circ} \mathrm{C}$ with TDS about $340 \mathrm{mg} / \mathrm{L}$. Concentrations of $\mathrm{Mg}, \mathrm{Ca}$, and $\mathrm{K}$ are low compared to the concentration of $\mathrm{Na}$ (Figure E19). Concentration of $\mathrm{F}$ in these hot springs is very high $(>15 \mathrm{mg} / \mathrm{L})$. Generally, alkaline $\mathrm{pH}$ and very high $\mathrm{F}$ concentration are used as distinct chemical characteristics of waters that interact with Idaho batholith. The F-bearing accessory minerals in the granite/granodiorite of the Idaho batholith (Figure E20) are thought to be the source of unusually high F content in these waters (Mitchell, 1976).

\subsection{Geothermometric results}

When plotted on Giggenbach diagram (figure not shown), the ECHS samples appear as partially equilibrated waters that may have interacted with reservoir rocks at $120-140{ }^{\circ} \mathrm{C}$ (Figure 5). Both ECHS1 and ECHS2 samples result in very similar quartz (no steam loss) $\left(115^{\circ} \mathrm{C}\right)$, chalcedony $\left(86{ }^{\circ} \mathrm{C}\right)$, and Na$\mathrm{K}-\mathrm{Mg}\left(99^{\circ} \mathrm{C}\right)$ reservoir temperatures (Appendix D).

The RTEst was applied to the ECHS water samples using a mineral assemblage consisting of beidellite, calcite, clinoptilolite, chalcedony, K-feldspar, and paragonite with three optimization parameters (mass of water, fugacity of $\mathrm{CO}_{2}$ and temperature). Pure water is used during RTEst modeling because the water samples from ECHS geothermal area contain very low concentrations of $\mathrm{Ca}$ and $\mathrm{Mg}$ (major cations in local ground water) indicating that pristine water is diluting the thermal waters. The RTEst temperature estimates for the ECHS geothermal are about $125^{\circ} \mathrm{C}$ (Appendix D) with almost $50 \%$ dilution. A sulfatewater temperature of $136^{\circ} \mathrm{C}$ was calculated for one the samples.

\section{Camas Prairie area}

\subsection{General}

Camas Prairie (Figure 1) is an east-west elongated (about $50 \mathrm{~km}$ by $15 \mathrm{~km}$ ) intermontane valley in Camas and Elmore Counties, Idaho. Besides the Magic Hot Spring and the Elk Creek Hot Springs that are located in the eastern part of Camas Prairie, the area has several other hot springs and hot wells. The Sheep and Wolf Hot Springs (SWHS) are located in the western part of Camas Prairie, about $4 \mathrm{~km}$ north 
from Hill City in Idaho. These two hot springs, separated by approximately $100 \mathrm{~m}$, sit at $1565 \mathrm{~m}$ above sea level and issue hot water at about $50^{\circ} \mathrm{C}$. The Wardrop Hot Springs (WHS) $\left(60^{\circ} \mathrm{C}\right)$ located near the base of the Soldier Mountains is approximately $10 \mathrm{~km}$ northeast from SWHS whereas the Barron Hot Spring (BHS) $\left(73^{\circ} \mathrm{C}\right)$ located near the base of the Mount Bennett Hills (MBH) is approximately $12 \mathrm{~km}$ to the southwest from SWHS. Numerous hot wells are located in the vicinity of BHS. Currently, these resources are not used for any commercial activities.

\subsection{Geologic setting}

Camas Prairie is bounded by the MBH to the south and the Soldier Mountains to the north. The MBH are composed predominantly of Miocene rhyolitic ash flows and lava flows of the Idavada Volcanic Group (Tfv) that overlies Idaho Batholith granodiorite $(\mathrm{Kg})$. Local basalt flows and fluvial/lacustrine sediments are also present. The Soldier Mountains are composed of mostly of $\mathrm{Kg}$ with minor amounts of younger intrusives. Camas Prairie is host to an unknown thickness of Quaternary alluvial, fluvial, and lacustrine sediments (Qs) with local lenses of basalt $(\mathrm{Qb})$ encountered in the shallow subsurface (Figure E21).

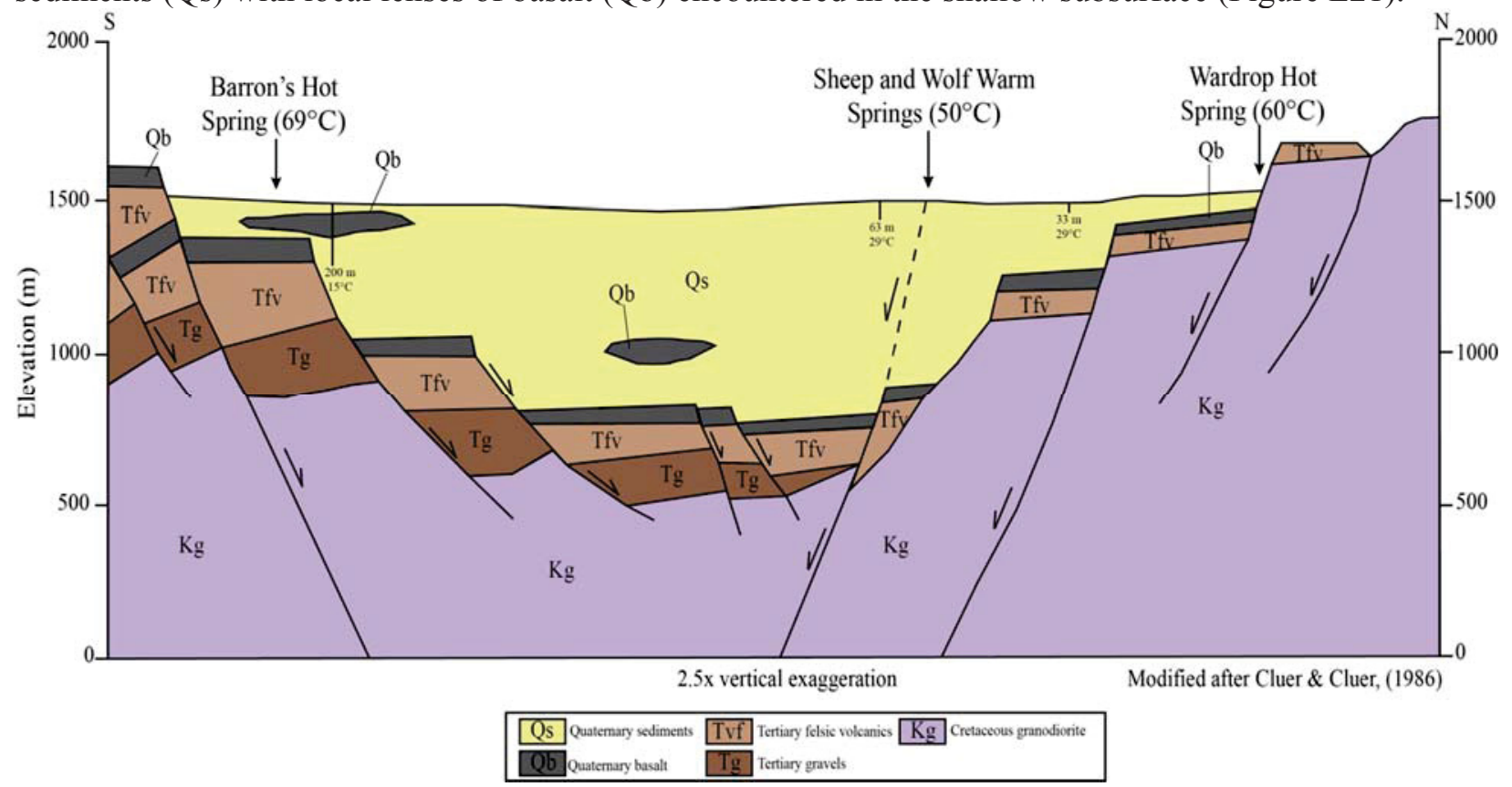

Figure E21. Schematic geologic cross-section of Camas Prairie (after Cluer and Cluer, 1986).

The Camas Prairie experienced north-south extensional tectonics during recent geologic time. Cluer and Cluer (1986) make an argument for a "Camas Prairie Rift" which they believe to have occurred between 2-5 Ma and lasted a relatively short time. The loading and down-warping of the SRP to the south created an extensional regime along the Camas Prairie region that created marginal faulting and development of rift valley separating the SRP from the Idaho Batholith region. Subsequently, basalt and sediment layers filled in the rift valley and shaped the present day Camas Prairie (Figure E21). Although the schematic diagram (Figure E21) shows almost a kilometer of valley-fill sediments at the center of Camas Prairie, preliminary results of the ongoing Snake River Play Fairway Phase II project indicate that the valley-fill sediments may be much thinner (a few hundred meters at the deepest parts). Concerted efforts combining seismic, electromagnetic, and gravity surveys could help define the structural setting of this area. In general, faults that parallel the SRP with opposite senses of displacement are present in the MBH and along the edge of the Soldier Mountains. One of these faults is inferred to be continuous but concealed through the prairie in close proximity to SWHS. The spring waters have likely migrated upward from a deeply buried fracture zone in the granodiorite along this fault. The water could also be under slight artesian pressure because most of the Camas Prairie is below the potentiometric surface (Mitchell, 1976). 


\subsection{Water chemistry}

Besides water samples from MHS-RLW and ECHS, compositions of water measured from several thermal $\left(26-73{ }^{\circ} \mathrm{C}\right)$ and groundwater $\left(10-15.5^{\circ} \mathrm{C}\right)$ sampling features are assembled for Camas Prairie (Appendix B). All thermal waters except Barron Well 1 (BW1) are of $\mathrm{Na}-\mathrm{HCO}_{3}$ type water (Figure E19). The BW1 sample is $\mathrm{Na}_{-} \mathrm{SO}_{4}$ type that contains unusually high concentration $(210 \mathrm{mg} / \mathrm{L})$ of $\mathrm{SO}_{4}$. Thermal water samples in Camas Prairie can be separated into two groups. The first group of samples is collected from the hot springs located in the northern parts of Camas Prairie. These hot springs include Wardrop, Hot Spring Ranch 1-3, Wolf, and Sheep (Figure E21). These hot springs issue waters with high pH (9.09.9), relatively low level of TDS (220-350 $\mathrm{mg} / \mathrm{L}$ ), low concentrations of both $\mathrm{Ca}$ and $\mathrm{Mg}$, and intermediate concentration of $\mathrm{F}(1.9-3.7 \mathrm{mg} / \mathrm{L})$. The second group of samples is collected from the hot springs and wells located in the southern parts of Camas Prairie. The notable sampling features of this group are Barron Hot Springs and wells (Figure E21). These samples are near-neutral to slightly alkaline ( $\mathrm{pH}$ 7.4-8.5) with slightly higher level of TDS (380-640 mg/L), low concentration of $\mathrm{Mg}$, and high concentration of F (7-13 mg/L).

The majority of groundwater samples in Camas Prairie are of $\mathrm{Ca}-\mathrm{HCO}_{3}$ type; however, $\mathrm{Na}-\mathrm{HCO}_{3}$ type groundwater samples are not uncommon in the area (Figure E19). In general, the Camas Prairie groundwater samples have near neutral $\mathrm{pH}$ (6.9-8.4), low level of TDS (125-270 mg/L), higher concentrations of $\mathrm{Ca}$ and $\mathrm{Mg}$, and low concentrations of $\mathrm{F}(<0.8 \mathrm{mg} / \mathrm{L})$.

\subsection{Geothermometric results}

All Camas Prairie thermal water samples provide similar reservoir temperatures with the same traditional geothermometers (Appendix D). The quartz, chalcedony, and Na-K-Ca geothermometers results in temperature estimates in the range of $103-128,74-99$, and $70-124^{\circ} \mathrm{C}$, respectively. Despite the similar temperature estimates with traditional geothermometers, the silica-enthalpy model was applied separately to water samples from the northern and central-southern parts of Camas Prairie. Nevertheless, both groups result in similar temperature estimates with chalcedony-enthalpy $\left(126-133{ }^{\circ} \mathrm{C}\right)$ and quartz-enthalpy $(162-$ $173^{\circ} \mathrm{C}$ ) models.

The RTEst was applied to Camas Prairie thermal water samples using a mineral assemblage consisting of calcite, clinoptilolite, chalcedony, fluorite, and K-feldspar. Analcime was added to the mineral assemblage while running RTEst for northern area samples whereas beidellite was added to the mineral assemblage while running RTEst for southern area samples. All RTEst runs were performed with three optimization parameters (mass of water, fugacity of $\mathrm{CO}_{2}$ and temperature) using pure water as an end member cooler water while optimizing the mass of thermal water. Unlike the traditional geothermometers and mixing models, RTEst temperature estimates of Camas Prairie area samples show bimodal distribution- higher temperatures for the samples from northern parts and lower temperatures for the samples from southern parts (Appendix D). The RTEst reservoir temperature estimates for hot springs in the northern part are $181-204{ }^{\circ} \mathrm{C}$ with dilution up to $75 \%$ whereas RTEst reservoir temperature estimates for hot springs and wells in the southern parts are much cooler at $79-108^{\circ} \mathrm{C}$ with negligible dilution. Sulfate-water oxygen isotope temperatures for a sample from Wardrop Hot Spring of the northern Camas Prairie and the Barron Well of the southeastern Camas Prairie of yielded temperatures of 133 and $419^{\circ} \mathrm{C}$, respectively. The Barron Well temperature exceeds the effective range of the geothermometer, but does indicate a very high temperature source for the sulfate. This is supported by the $\delta^{34} \mathrm{~S}$ of the sulfate, which at $-8.3 \%$ was by far the lowest of any of the measured samples. This is very low value for the sulfate usually indicates that it is formed from oxidation of pyrite, suggesting it might be a reliable indicator of formation in a hydrothermal system. In addition to the high sulfate-water oxygen isotope temperature, the isotopic composition of the water is shifted off the meteoric water line indicating the possibility of high temperature water-rock interaction. The Wardrop Hot Spring temperature is lower than the RTEst 
temperatures, but that sample had a very low concentration of sulfate and could have been compromised (see Appendix C).

The chemical compositions of thermal waters indicate that the northern and central-southern parts of the Camas Prairie have different hydrogeological and geochemical settings at depth. In general, both surface and subsurface waters of the Camas Prairie area flow from west to east to the Big Wood River and ultimately to the Magic Reservoir (Wallace, 1972). Precipitation falling in the Soldier Mountains to the north provides the majority of recharge water to the northern Camas Prairie groundwater/geothermal systems. The thermal water that moves up along the range forming faults near/along the northern boundary of the Prairie is significantly diluted with pristine water that several south flowing creeks from the mountains bring in to the Prairie. On the other hand, the MBH to the south offers only minor recharge to the Camas Prairie. Unlike the northern part of the Prairie, the groundwater/geothermal aquifers in the southern parts the Prairie are likely to have longer residence times. Although a long residence time results in higher field temperatures (the hottest hot spring in the area is Barron Hot Spring II with a reported temperature of $73{ }^{\circ} \mathrm{C}$, Mitchell, 1976), it also helps re-equilibrate the thermal water at lower temperature. Because of the structural and hydrogeological controls, the hot springs in the northern parts of the Prairie are issuing diluted thermal water whereas the sampling features in the southern part are issuing reequilibrated water. The RTEst results also support this argument. Despite the cooler temperature estimates for the southern part, this part of the Camas Prairie is likely to have similar geothermal resources at depth as the northern parts of the Camas Prairie. This is consistent with the high temperature calculated with from the sulfate-water oxygen isotope temperature, which would not be strongly impacted by equilibration with the rock as it moved to the surface.

\section{South Mount Bennett Hills}

\subsection{General}

Several hot springs are located along the southwestern-southern base of the MBH (Figure 1) in Elmore, Gooding, and Lincoln Counties in Idaho. Some of the known hot springs in the area are the Prince Albert (Coyote) (PAHS, $57.7^{\circ} \mathrm{C}$ ), Latty (LHS, $65^{\circ} \mathrm{C}$ ), and White Arrow (WAHS, $65^{\circ} \mathrm{C}$ ). Another hot spring (named Hot Spring) is located further to the west, but is reportedly dried out recently. Similarly, some hot wells [e.g., Northwest Pipeline $\left(38^{\circ} \mathrm{C}\right)$, Dave Archer $\left(43^{\circ} \mathrm{C}\right)$, Shannon $\left(47^{\circ} \mathrm{C}\right)$, etc.] are also reported from this area. The Bostic 1-A well $(2950 \mathrm{~m})$ drilled to the south from this area indicated the presence of hot rock (Arney et al., 1982). Presence of several hot springs and hot rock at depth suggests that the areas along the southern base of the MBH have great potential for geothermal resources. However, except for WAHS and LHS, none of the other resources in the area have been used for any commercial purpose. The WAHS has been used for heating greenhouses and LAHS is currently being used for space heating by local ranchers.

\subsection{Geologic setting}

This geothermal area extends over $70 \mathrm{~km}$ along the northern margins of the SRP (some parts of both WSRP and ESRP) abutting the MBH. A geologic cross-section shown in Figure E22 is constructed for the western part of the area near LHS and PAHS. Rocks underlying the LHS area mainly consist of mafic and felsic volcanic rock with thick sequences of sediments and gravels. The MBH to the north consists of predominantly of Miocene rhyolitic ash flows and lava flows of the Idavada Volcanic Group (Tir) that overlie the Idaho Batholith granodiorite $(\mathrm{Kg})$. At the base of the MBH, the WSRP basalt flows are intercalated with quaternary sediments (Qs) from the Pleistocene-Pliocene Lake Idaho and the Tertiary Glenn's Ferry Formation (Tgf) sandstones and shales. At depth, an older basalt unit (Banbury basalt, $\mathrm{Tbb}$ ) and Idavada volcanics are reported from a $2950 \mathrm{~m}$ deep oil and gas wildcat well (Bostic 1-A, Arney, 1984). Although, not penetrated, $\mathrm{Kg}$ is inferred to make up the basement underlying the WSRP. 

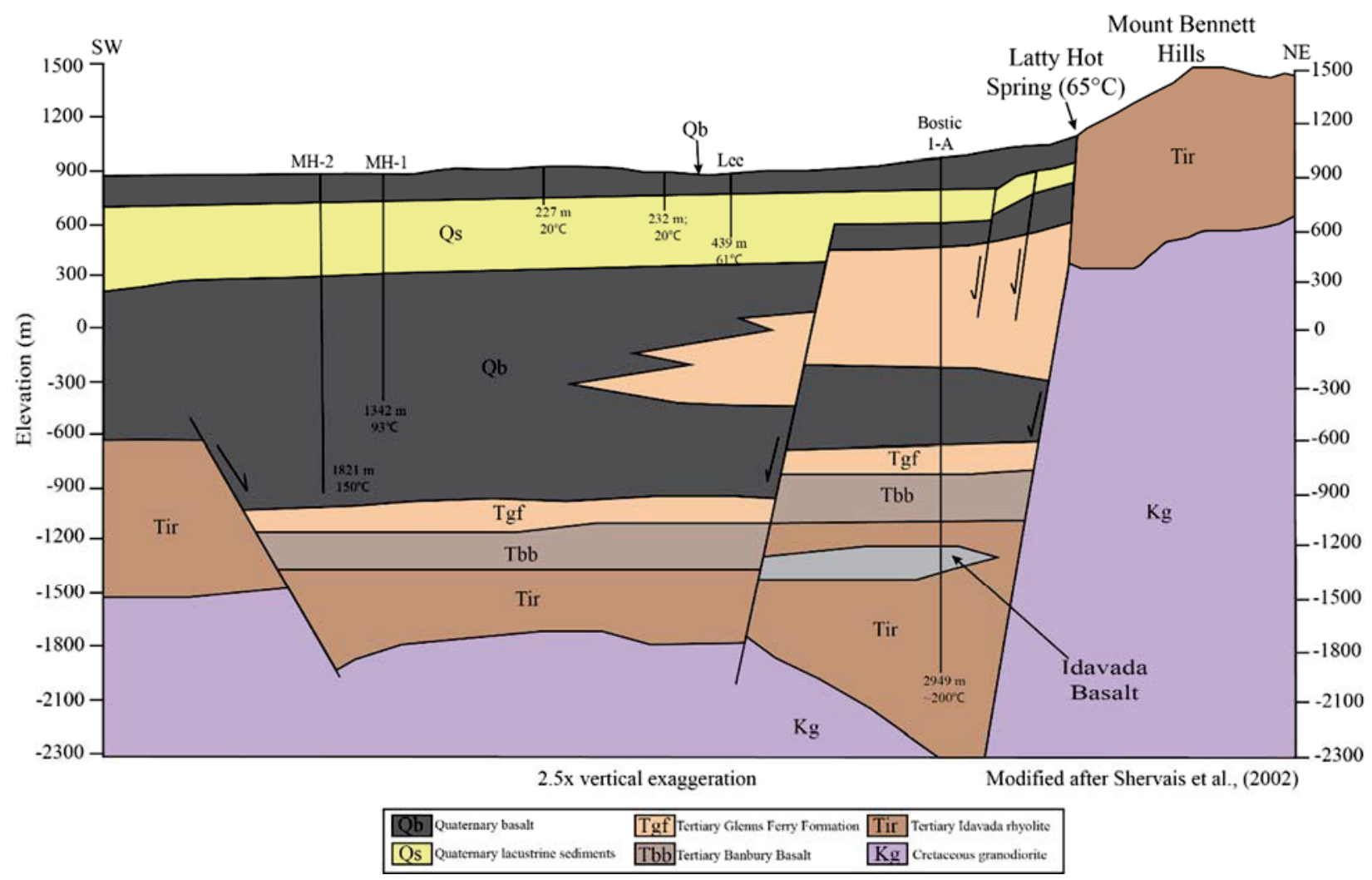

Figure E22. Geologic cross-section through the WSRP and Latty Hot Springs area along with three deep geothermal wells (MH-1, MH-2 and Bostic 1-A) (modified from Shervais et al., 2002).

Regionally, extensional tectonics dominate with many high-angle northwest trending normal faults that parallel the WSRP and dip to the southwest. These are responsible for the uplift of the MBH and have a cumulative throw along the major range-front fault of approximately $2900 \mathrm{~m}$ based on the presence of Idavada volcanics in the Bostic 1-A well (Arney et al., 1984). The hot springs in the area are mostly distributed along the base of the $\mathrm{MBH}$ whereas hot wells are distributed further south from the base of the $\mathrm{MBH}$. The range-front fault(s) and associated fracture zones are most likely facilitating fluid flow from deep circulation in the batholith to the surface as hot springs. The hot water wells further south are likely taping water that flow and is potentially re-equilibrated in the basalt and sediment layers.

\subsection{Water chemistry}

During our sampling campaign, we collected and analyzed three samples from the PAHS, LHS, and WAHS. Similarly, the compositions of thermal waters measured from hot wells from this area are assembled from Young and Mitchell (1973) (Appendix B). The water compositions assembled for this area given in Appendix B. Thermal waters from this area are neutral to slightly alkaline in $\mathrm{pH}$ (7-9.4) with TDS range $270-720 \mathrm{mg} / \mathrm{L}$. All thermal waters are $\mathrm{Na}-\mathrm{HCO}_{3}$ type water with field temperature in the range of 26.5-68 ${ }^{\circ} \mathrm{C}$. In general, these water samples share low concentrations of $\mathrm{Ca}, \mathrm{K}, \mathrm{Mg}$, and $\mathrm{Cl}$, and higher concentrations of $\mathrm{Na}$ and $\mathrm{SiO}_{2}(\mathrm{aq})$. However, they have variable $\mathrm{F}$ concentration. Specifically, the hot spring waters and a few hot well waters are low to moderately high $(1-12 \mathrm{mg} / \mathrm{L})$ in concentration of $\mathrm{F}$ whereas the majority of the hot wells have very high F concatenations (13-20 mg/L). The high F waters are at or near saturation with fluorite at their field temperatures. 


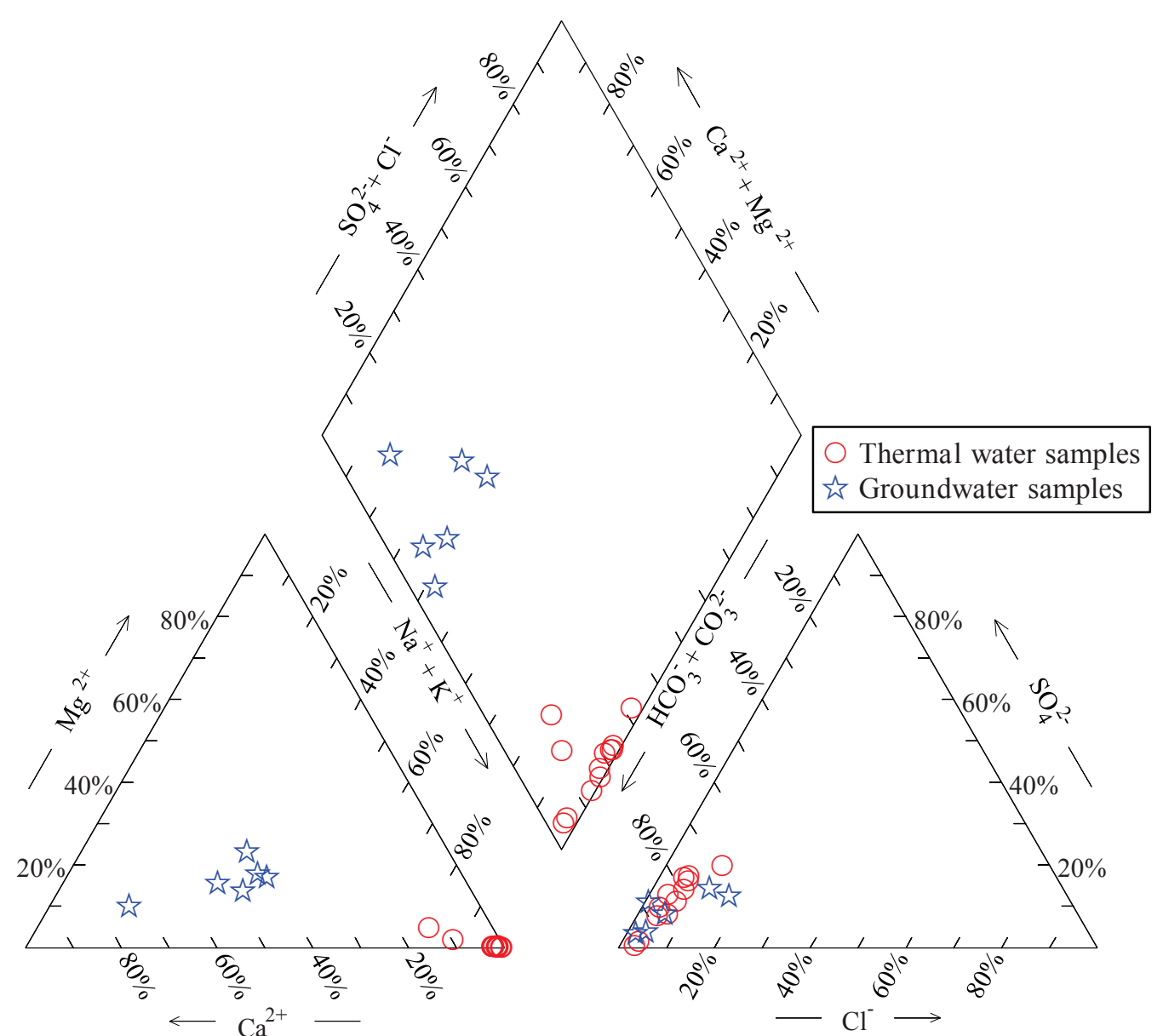

Figure E23. Piper diagram representing chemistry of water samples from Camas Prairies area.

\subsection{Geothermometric results}

Reservoir temperature estimates for this area calculated from several water samples are given in Appendix D. Quartz, chalcedony, and Na-K-Ca geothermometers resulted in 110-143, and 80-117, and $72-160{ }^{\circ} \mathrm{C}$, respectively. The PAHS and LHS resulted in highest temperatures for the area with these traditional geothermometers. Silica-enthalpy mixing models with chalcedony and quartz solubility curves resulted in 150 and $182{ }^{\circ} \mathrm{C}$ temperature estimates for the area.

RTEst temperature estimates for the area are developed using two separate mineral assemblages - one for the hot spring (and Shannon Well) waters and another for hot well waters. For hot springs, a mineral assemblage consisting of calcite, chalcedony, chlorite, clinoptilolite, K-feldspar, and phengite was used, whereas for hot wells, a mineral assemblage consisting of calcite, chalcedony, clinoptilolite, K-feldspar, kaolinite, and beidellite was used. As with the traditional geothermometers, the RTEst modeling of waters from hot springs yielded higher temperatures. The three hot springs in the area, PAHS, LHS, and WAHS resulted in reservoir temperatures at $193 \pm 8,197 \pm 5$, and $177 \pm 6^{\circ} \mathrm{C}$, respectively. A sulfate-water oxygen isotope temperature of $154^{\circ} \mathrm{C}$ was calculated for PAHS which is lower than the RTEst temperature, but still relatively high. Similarly, RTEst temperature estimate for Shannon well is $137 \pm 10^{\circ} \mathrm{C}$. All the other wells resulted in lower reservoir temperatures $\left(82-122^{\circ} \mathrm{C}\right)$. The reservoir temperature estimates using hot spring waters are similar to the bottom hole temperature $\left(\sim 200^{\circ} \mathrm{C}\right.$, Arney et al., 1984) measured in Bostic 1-A Well. It is likely that these hot springs are issuing deep thermal waters that ascent along the range forming faults. Along the flow path, these deep thermal waters get mixed with dilute water. RTEst results indicate that the hot spring waters are issuing diluted (up to $70 \%$ ) thermal waters. On the other hand, the 
hot wells are producing re-equilibrated or low-temperature equilibrated waters with small $(<20 \%)$ or negligible dilution.

\section{Glenns Ferry area}

The Glenns Ferry area is located at the junction between ESRP and WSRP in southern Idaho (Figure 1). The prospect is an elongate area along the Interstate 84 from King Hill to Hammett covering Glenns Ferry town in Elmore County, Idaho. The presence of a few shallow hot wells in the area were noted in earlier previous reports. The hottest feature in the area is the Johnston well which produces water at $39^{\circ} \mathrm{C}$. Besides this feature, we sampled two additional shallow hot wells during our sampling campaign. In addition, chemical data for two additional wells were taken from previous reports (e.g., Young and Mitchell, 1973).

The shallow hot wells $\left(32.5-39^{\circ} \mathrm{C}\right)$ of this area are producing near-neutral to slightly alkaline $(\mathrm{pH} 7.64-$ 9.26) $\mathrm{Na}_{-} \mathrm{HCO}_{3}$ type waters. The Glenns Ferry area water samples contain very minute amounts of $\mathrm{Mg}$, and consequently, these samples plot as partially equilibrated waters on Giggenbach diagram (see Figure 5 of the report). Some samples also contain a large amount of $F$ that indicates that presence of volcanic ash/rhyolite rocks in the reservoir. One of the samples contains a large amount of $\mathrm{NO}_{3}$, which indicates surface water contamination of well water.

Reservoir temperature estimates with traditional as well as RTEst (Appendix D) geothermometric approaches indicate a moderately hot geothermal system in the area. Temperature estimates with quartz, chalcedony, and Na-K-Ca geothermometers are 80-109, 48-79, and 74-138 ${ }^{\circ} \mathrm{C}$, respectively. Silica enthalpy mixing models using chalcedony and quartz solubility curves yield reservoir temperatures of about 108 and $150^{\circ} \mathrm{C}$, respectively. The RTEst reservoir temperatures $\left(67-85^{\circ} \mathrm{C}\right)$ of the Glenns Ferry samples are within the range of temperature estimates of the traditional geothermometers. Two samples were collected for isotope analyses, but the sulfate concentrations were too low for calculating temperatures.

\section{Banbury Hot Springs-Twin Falls area}

The southwestern periphery of the ESRP near Twin Falls and Buhl is one of the Known Geothermal Resource Areas in southern Idaho (more detailed information can be found in Appendix J). The area is comprised of two dense clusters of geothermal surface features, Banbury Hot Springs (BHS in Figure 1) and Twin Falls (TF in Figure 1). Discharging thermal waters range in temperature from $25^{\circ} \mathrm{C}$ to $70{ }^{\circ} \mathrm{C}$. These thermal waters are being used for space heating, agriculture, and recreation.

The Tertiary rhyolitic volcanic rocks underlie the Quaternary and Tertiary basaltic units in these prospect areas. Paleozoic metasedimentary rocks are thought to underlie the entire area (Lewis and Young, 1989). The thermal aquifer system in the area is located beneath basalt units within the Idavada volcanics and is under artesian conditions with the temperatures of the waters increasing to the northwest. Thermal waters (Appendix B) are thought to originate from deep circulation paths from the Cassia Mountain recharge zone to the south through fractures in the overlying basalts of the thermal area (Street and DeTar, 1987).

Reservoir temperature estimates obtained with traditional geothermometers and RTEst are given in Appendix D for both the Banbury Hot Springs and Twin Falls prospects. The highest reservoir temperatures (ca. $160^{\circ} \mathrm{C}$ ) for the Banbury Hot Springs prospect are obtained for Banbury Hot Spring, Miracle Hot Spring well, and Salmon Falls Hot Spring with RTEst as well as other geothermometers. Sulfate-water oxygen isotope temperatures calculated for the Banbury samples range from 115 to $159^{\circ} \mathrm{C}$ and are very similar to the RTEst temperature. For the Twin Falls prospect, the highest reservoir temperatures (ca. $135^{\circ} \mathrm{C}$ ) are obtained for samples from two hot shallow wells (used for direct heating Neely, 1996) within the premises of the College of Southern Idaho. A sulfate-water isotope temperature for one of College of Southern Idaho waters was $133^{\circ} \mathrm{C}$. 


\section{Cedar Hill area}

A series of shallow hot wells and a hot spring (Nat-So-Pah) located on the northern to northwestern base of the Cassia Mountains from Artesian City-Rock Creek (in Cassia County) to Hollister (in Twin Falls County) are grouped in the Cedar Hill geothermal prospect (Figure 1). The Hollister area contains the Nat-Soo-Pah Hot Spring and a few hot $\left(32-38^{\circ} \mathrm{C}\right)$ shallow $(65-180 \mathrm{~m})$ wells. Additional shallow wells near towns of Rock Creek and Artesian City have also encountered hot water. The chemical compositions of thermal waters from this prospect were taken from previous reports/papers (e.g., Ross, 1970; Young and Mitchell, 1973; Mitchell et al. 1980).

Geologically, all sampling features from this prospect are located in areas with or without thin basaltic and rhyolite surface layers. The basement rocks for all these wells are the Paleozoic marine limestone, dolomite, siltstone, quartzite, and chert that are exposed in the Cassia Mountains. The area has several NE dipping faults. The Nat-So-Pah Hot Spring is located along a NE-SW fault east of Hollister. Furthermore, a NW-SE striking (NE dipping) fault may have intersected the NE-SW fault at this hot spring. An unnamed well located northeast of Hollister likely intersects the NW-SW fault at depth. The wells near Rock Creek and Artesian City are located at the NW terminals of NW-SE faults that are mapped in the Cassia Mountains and likely to have plunged down to the Quaternary sediments.

Compositions of all thermal waters of this prospect are given in Appendix B. In general, thermal waters of this prospect are neutral ( $\mathrm{pH}$ 6.6-7.6) $\mathrm{Ca}-\mathrm{HCO}_{3}$ or $\mathrm{Na}-\mathrm{HCO}_{3}$ type. Specifically, the hot spring and a nearby unnamed well produce $\mathrm{Na}-\mathrm{HCO}_{3}$ type water. However, concentrations of silica in these two water samples are relatively low compared to other three $\mathrm{Ca}-\mathrm{HCO}_{3}$ type water samples.

Geothermometric results for these water samples are given in Appendix D. The reservoir temperature estimates range from 75 to $127^{\circ} \mathrm{C}, 62$ to $116^{\circ} \mathrm{C}, 29$ to $87^{\circ} \mathrm{C}$, and 50 to $73{ }^{\circ} \mathrm{C}$ with RTEst, quartz, chalcedony, and $\mathrm{Na}-\mathrm{K}-\mathrm{Ca}-(\mathrm{Mg})$ geothermometers, respectively. No isotope samples were taken from these thermal features.

\section{Murphy Hot Spring}

The Murphy Hot Spring (MHS) geothermal prospect (Figure 1) is located in southeastern part of Owyhee County along the East Fork of the Jarbidge River in southern Idaho near its border with Nevada. The small unincorporated town Murphy Hot Spring is the only nearby establishment in the area. A road (Three Creek Road) links this small town to Rogerson, Idaho and Jarbidge, Nevada. Currently, the hot spring is used as a recreational facility for local people and campers.

Geologically, the MHS area is located within the Bruneau-Jarbidge super volcanic filed associated with the past (11-13 Ma) Yellowstone hotspot activities (Pierce and Morgan, 1992; Beranek et al., 2006). The hot spring sits in rhyolite lava flows and ignimbrites produced from the Bruneau-Jarbidge eruptive center. The Basin and Range type extensional post-volcanic tectonics has been active in the area creating several NW-SE trending normal faults. A N-S fault that passes through the MHS area (Rember and Bennett, 1979) may provide the subsurface plumbing for the hot spring.

For geothermometric calculations, the composition of the MHS water (Appendix B) was obtained from Young and Lewis (1982). The hot spring issues near-neutral ( $\mathrm{pH} 8.5) \mathrm{Na}-\mathrm{HCO}_{3}$ type water at about $55^{\circ} \mathrm{C}$. The reservoir temperature estimates with quartz, chalcedony, and $\mathrm{Na}-\mathrm{K}-\mathrm{Ca}$ geothermometers are 148 , 122 , and $62{ }^{\circ} \mathrm{C}$, respectively. The RTEst results for this hot spring indicate a reservoir temperature estimates about $117^{\circ} \mathrm{C}$ (Appendix D).

\section{Oakley Hot Spring}

The Oakley Hot Spring geothermal prospect (Figure 1) is located near town of Oakley in Cassia County, Idaho. The prospect area extends to the south from the Oakley Fan along the southern margins of the SRP 
in the Goose Creek basin, a down-dropped basin surrounded by the Albian Mountains-Middle Mountains to the east and Cassia Mountains to the west.

Previously, the USGS performed reconnaissance drilling (95-197 m) and conducted a geological investigation for coal and uranium-bearing lignite beds in this area (Hilderbrand, 1983). Using previously available regional information (e.g., Mapel and Hail, 1959; Axelrod, 1964), Hildebrand (1983) suggested a general stratigraphy for the area with the Idavada Volcanics containing shale, tuff, and lacustrine sediments underlain by Tertiary rhyolite and Paleozoic meta-sediments. The geologic map of Cassia County Idaho compiled by Link (2002c) shows several intersecting normal faults in the region of these geothermal features that may have provide flow paths for the hot water to the surface (e.g., Oakley Hot Spring) and shallow wells (e.g., Richard Austin well and others).

Three thermal features (one hot spring and two wells) in this area were sampled for this study. In addition, water compositions from two additional shallow wells in the area were taken from the literature. All water compositions for the thermal features in this prospect are given in Appendix B. The hot spring and wells in this area issuing $\mathrm{Na}-\mathrm{HCO}_{3}$ (or Na-Cl- $\mathrm{HCO}_{3}$ ) type waters with neutral to slightly alkaline $\mathrm{pH}(7.85-$ 9.32) and temperatures ranging from $31-47^{\circ} \mathrm{C}$. Geothermometric results (Appendix D) of these water samples indicate moderately hotter reservoir temperatures. Quartz and chalcedony geothermometers indicate temperatures in the range from $77-125^{\circ}$ and $45-97^{\circ} \mathrm{C}$, respectively. Mg-corrected Na-K-Ca temperatures show a much wider range of temperatures $\left(45-155^{\circ} \mathrm{C}\right)$. Sulfate-water oxygen isotope and RTEst multicomponent geothermometers resulted in reservoir temperature estimates in the range of 92 $157^{\circ} \mathrm{C}$ and $77-130{ }^{\circ} \mathrm{C}$, respectively.

\section{Durfee Hot Spring}

The Durfee Hot Spring (DFS) geothermal prospect is also located at Almo in Cassia County, Idaho (Figure 1). This hot spring has been in use for recreational purposes since the early 1900s. Geologically, the hot spring is located along a fault at the southeastern base of the Albian Mountains (Link, 2002c). The reservoir rock is likely to be the metamorphosed quartz monzonite rocks of the Archean basement underneath the Quaternary valley (basin) fill sediments.

During our sampling campaign, the DFS was sampled and analyzed. Similarly, the composition of water from a nearby well (Harold Ward well) was obtained from Young and Mitchell (1973). Both of these features produce near neutral ( $\mathrm{pH}$ 7.4-8.8) $\mathrm{Na}-\mathrm{Cl}-\mathrm{HCO}_{3}$ type water at $38-45^{\circ} \mathrm{C}$ (Appendix B).

Geothermometric reservoir temperature estimates for the hot spring are $117,88,80,104$, and $138^{\circ} \mathrm{C}$ with quartz, chalcedony, $\mathrm{Na}-\mathrm{K}-\mathrm{Ca}$ (Mg-corrected), sulfate-water oxygen isotope, and RTEst multicomponent geothermometers, respectively. The reservoir temperature estimates from the well water composition are cooler than temperature estimates for the hot spring (Appendix D).

\section{Marsh Creek area}

The Marsh Creek geothermal prospect is located to the east of Burley in Cassia County, Idaho (Figure 1). The area covers both sides of the northern end of the Cotterel Mountains. Two hot springs (Marsh Creek Hot Springs and Marsh Gulley Hot Springs) and some shallow hot wells Ross (1970) are located in the western part of the area. In the report, Ross (1970) refers this area as the Albion Basin (prospect). The eastern part of the area (eastern side of the Cotterel Mountains) is also characterized by the presence of several shallow wells that produce hot water.

Geologically, this area consists of three formations- Quaternary sediments, the Salt Lake Formation (ash, tuff, conglomerate, sand, clay, and marl), and Precambrian basement rocks. The Cotterel Mountains is a faults-bounded horst (Link, 2002c), and the thermal activities in the area may be related to the fluid movement along these faults. 
During our sampling campaign, we collected water samples from two wells- one on each side of the Cotterel Mountains. We were not able to collect water samples from the hot springs reported to be present in this area by Ross (1970), but water chemistry data for four additional shallow hot wells were obtained from literature. All of these composition data are given in Appendix B. Thermal wells in this area produce near neutral $\left(\mathrm{pH}\right.$ 7.6-8.3), $\mathrm{Na}-\mathrm{HCO}_{3}$ type water at temperatures up to $60^{\circ} \mathrm{C}$. The reservoir temperature estimates (Appendix D) with geothermometers quartz, chalcedony, and $\mathrm{Na}-\mathrm{K}-\mathrm{Ca}$ range from $96-113{ }^{\circ} \mathrm{C}$, $66-83{ }^{\circ} \mathrm{C}$, and $48-89^{\circ} \mathrm{C}$, respectively. Similarly, a sulfate-water oxygen isotope temperature for a sample from the Marsh Creek well was calculated to $142{ }^{\circ} \mathrm{C}$. RTEst temperature estimates range from 96 to 141 ${ }^{\circ} \mathrm{C}$. It is likely that the western part of the prospect may have geothermal system with reservoir temperature as high as $140{ }^{\circ} \mathrm{C}$.

\section{Wybenga Dairy area}

The Wybenga Dairy prospect is located west of Burley on the southern side of the Snake River in Cassia County, Idaho (Figure 1). We sampled the Wybenga Dairy well $\left(34^{\circ} \mathrm{C}\right)$ for this study. The Kimberley hotspot well (Shervais et al., 2013, $1958 \mathrm{~m}$ ) was located about $26 \mathrm{~km}$ west from Wybenga Dairy area in a similar geologic setting. Shervais et al. (2013) reported that the areas around Kimberley (including Wybenga Dairy) lie on the southern margin of the Twin Falls eruptive complex. The lithologic logs recorded for the Kimberley well show pre-dominantly rhyolite lava and welded ash flow tuffs beneath the surface basalts and sediments. The temperature measurements made during drilling of this well indicate an isothermal zone with temperatures between $55-60{ }^{\circ} \mathrm{C}$ from $400 \mathrm{~m}$ to bottom of the well (Shervais et al., 2013). No hot springs have been reported in this area, but several hot shallow wells are present to the southwest $(>13 \mathrm{~km})$ of this area near the base of the Cassia Mountains (these features are included in Cedar Hill prospect).

The Wybenga Dairy well produces near neutral (pH 7.45), Ca- $\mathrm{HCO}_{3}$ water (Appendix B). The reservoir temperature estimates with quartz, chalcedony, Na-K-Ca, and RTEst geothermometers are 118, 89, 189, and $132{ }^{\circ} \mathrm{C}$, respectively (Appendix D). An unpublished RTEst temperature for a water sample from the Kimberley well was $137^{\circ} \mathrm{C}$. However, as mentioned above, the highest measured temperature in the Kimberley well was about $60{ }^{\circ} \mathrm{C}$. Therefore, we believe it is likely that there is hotter reservoir in this part of the ESRP at $>2 \mathrm{~km}$ depth.

\section{Indian Hot Spring}

The Indian Hot Springs (IHS) area is located south of American Falls in Power County, Idaho (Figure 1). This area is reported to have two hot springs, each discharging just under $3785 \mathrm{~L} / \mathrm{min}$ (Ross, 1970). Ross (1970) also mentioned the presence of additional warm shallow wells in the area. However, during our sampling campaign, we collected water sample only from the main hot spring of the area that is currently used to fill a recreational pool.

Figure E24 shows the simplified geologic cross-section of the IHS area. Quaternary basalts cover the area, but underneath the basalt lie 400-600 m of the Tertiary Starlight and Salt Lake Formations consisting of sediments and ash deposits. Paleozoic rocks underlie these rocks. Ross (1970) shows two west dipping normal faults in the area. The subsurface plumbing of the IHS system seems to be controlled by the western normal fault (Figure E24).

The IHS issues neutral (pH 7.23), Na-Cl-HCO3 type water at $33{ }^{\circ} \mathrm{C}$ (Appendix B). Several geothermometers are used to estimate reservoir temperatures. All geothermometers but sulfate-water oxygen isotope geothermometer, which resulted in about $174^{\circ} \mathrm{C}$, yielded potential reservoir temperature $<80^{\circ} \mathrm{C}$ (Appendix D). 


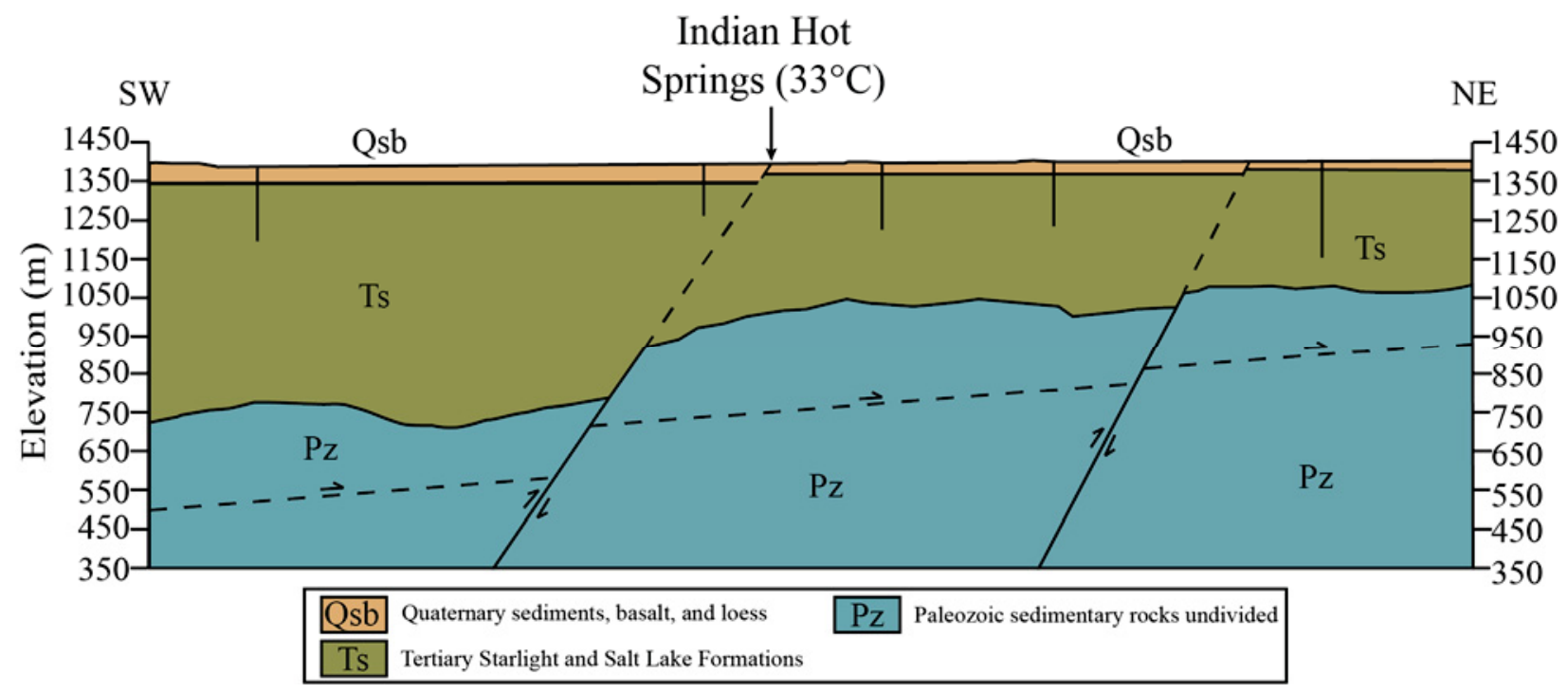

Figure E24. Generalized geologic cross-section through the Indian Hot Springs area, south of American Falls in Idaho

\section{Tyhee area}

This area is located near the small town of Tyhee, north of Pocatello, in Bannock County, Idaho. The prospect area (Figure 1) extends further to the north into the Fort Hall Indian Reservation along Interstate Highway 15. Earlier, Ross (1970) reported the presence of some hot shallow wells in the area, including the Fort Hall well, which produces water at $41{ }^{\circ} \mathrm{C}$. Similarly, within the Tyhee town, two warm (21-25 ${ }^{\circ} \mathrm{C}$ ) wells (Robert Brown well 1 and 2) are reported by Young and Mitchell (1973).

The area around Tyhee and Fort Hall is covered by young ESRP flood basalts (of unknown thickness) that are likely underlain by rhyolite and ash-tuff deposits. Geologically, the hottest well (Fort Hall thermal well) in the area is located at the northwestern base of the Pocatello Range. However, no fault is mapped between the Pocatello Range and the ESRP rocks (Bond et a., 1978; Lewis et al., 2012).

For this project, we collected samples from the hottest well in the area. Chemical data for samples from two other wells were obtained from Young and Mitchell (1973) (Appendix B). Geothermometers applied to these chemical data indicate a moderately hot (up to $93{ }^{\circ} \mathrm{C}$ ) reservoir temperature for this geothermal system (Appendix D).

\section{Quidop-Yandell Warm Springs}

The Quidop-Yandel prospect (Figure 1) is located southeast of Blackfoot in Bingham County, Idaho. The area has several warm/hot springs with temperatures ranging from 21 to $38^{\circ} \mathrm{C}$. The Yandell Warm Spring (YWS) system has been sampled multiple times over the years. However, the thermal resource in the area has never been used.

The area is covered by thin layers of the Quaternary loess deposits (Trimble, 1982). Underlying the loess deposits are Paleozoic sedimentary rocks. An inferred fault shown in the cross-section (Figure E25) likely controls fluid movement to the YWS and other springs in the area. 


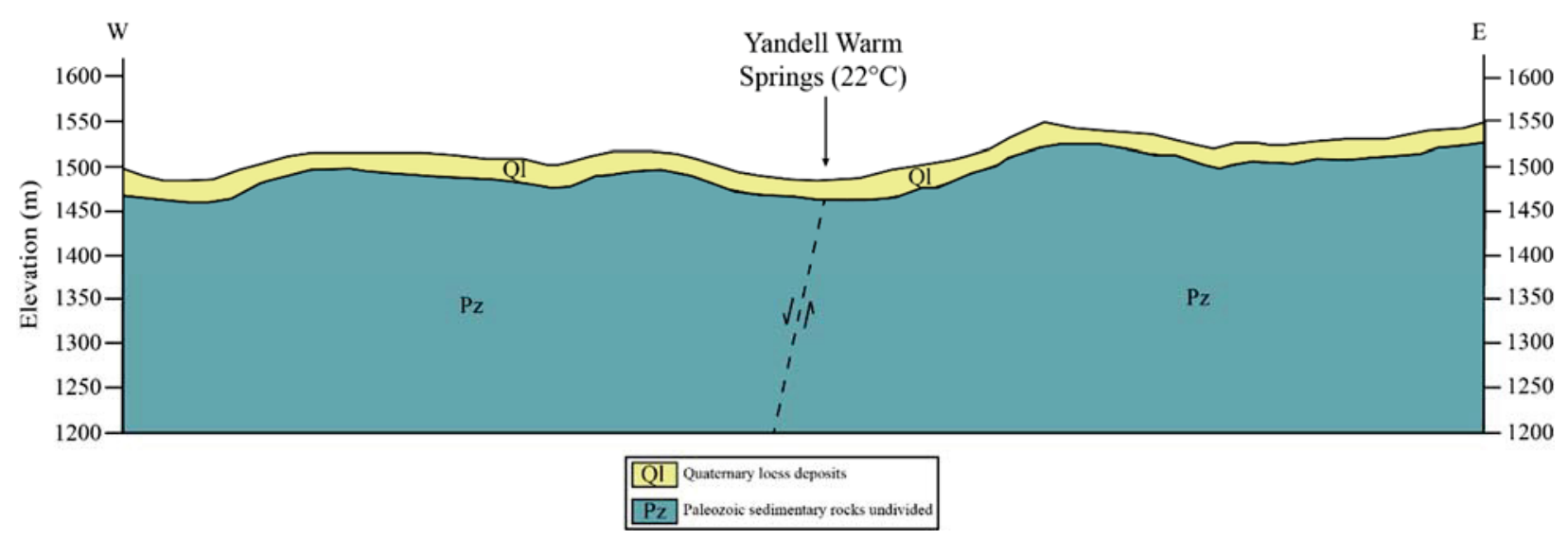

Figure E25. Generalized geologic cross-section through the Yandell Warm Spring area, southwest of Balckfoot, Idaho.

During our sampling campaign, we were able to collect samples from three thermal features (YWS and two Quidop springs) in the area. Similarly, water chemistry data for an additional feature (Alkali Flat Warm Spring) were obtained from Mitchell et al. (1980). All water compositions are given in Appendix B. The RTEst multicomponent chemical geothermometric approach resulted in a moderately hot (59-90 $\left.{ }^{\circ} \mathrm{C}\right)$ reservoir temperature for the area. Other traditional geothermometers applied to this area water samples resulted in low temperature $\left(23-63{ }^{\circ} \mathrm{C}\right)$ estimates (Appendix D).

\section{References}

Allmendinger, R.W., 1982. Sequence of late Cenozoic deformation in the Blackfoot Mountains, Southeastern Idaho. In: Bonnichsen and R.M. Breckenridge, eds., Cenozoic Geology of Idaho. Idaho Bureau of Mines and Geology Bulletin 26, p 505-516.

Anders, M. H., Rodgers, D. W., Hemming, S. R., Saltzman, J., DiVenere, V. J., Hagstrum, J. T., Embree, G. F., and Walter, R. C., 2014. A fixed sublithospheric source for the late Neogene track of the Yellowstone hotspot: Implications of the Heise and Picabo volcanic fields. Journal of Geophysical Research: Solid Earth, 119, 2871-2906.

Arney, B., 1982. Evidence of former higher temperatures from alteration minerals, Bostic 1-A well, Mountain Home, Idaho. GRC Transactions, 6, 3-6.

Arney, B. H. and Goff, F., 1982. Evaluation of the hot-dry-rock geothermal potential of an area near Mountain Home, Idaho. LA-9365-HDR, Los Alamos National Laboratory.

Arney, B.H., Gardner, J.N., Belluomini, S.G., 1984, Petrographic analysis and correlation of volcanic rocks in Bostic 1-A well near Mountain Home, Idaho, LA-9966-HDR, Los Alamos National Laboratory.

Arnórsson, S., 1985. The use of mixing models and chemical geothermometers for estimating underground temperature in geothermal systems. J. Volc. Geotherm. Res., 23, 299-335.

Arnórsson, S., Gunnlaugsson, and Svavarsson, H., 1983. The chemistry of geothermal waters in Iceland. III. Chemical geothermometry in geothermal investigations. Geochim. Cosmochim. Acta, 47, 567577.

Axelrod, D. I., 1964. The Miocene Trapper Creek flora of southern Idaho. University of California, Publications in Geological Sciences, 51, 148 p.

Beranek, L. P., Link, P. K., \& Fanning, C. M., 2006. Miocene to Holocene landscape evolution of the western Snake River Plain region, Idaho: Using the SHRIMP detrital zircon provenance record to track eastward migration of the Yellowstone hotspot. Geological Society of America Bulletin, 118(910), 1027-1050. 
Blackwell, D.D., Kelley, S., and Steele, J.L., 1992. Heat flow modeling of the Snake River Plain, Idaho. US Department of Energy Report for contract DE-AC07-761DO1570, 109.

Bond, J. G., Kauffman, J. D., Miller, D. A., and Venkatakrishnan, R., 1978. Geologic Map of Idaho: Moscow. Idaho, Idaho Bureau of Mines and Geology Map GM-1.

Brott, C.A., Blackwell, D.D. and Mitchell, J.C., 1976. Geothermal Investigations in Idaho, Part 8, Heat Flow in the Snake River Plain Region, Idaho. Idaho Department of Water Resources, Water Information Bulletin No.30.

Cannon, C., Wood, T., Neupane, G., McLing, T., Mattson, E., Dobson, P., and Conrad, M., 2014. Geochemistry Sampling for Traditional and Multicomponent Equilibrium Geothermometry in Southeast Idaho. GRC Transactions 38, 524-431.

Christiansen, R.L., 2001. The Quaternary and Pliocene Yellowstone plateau volcanic field of Wyoming, Idaho, and Montana, United States Geological Survey Professional Paper 729-G.

Cluer, J.K. and Cluer, B.L., 1986. The late Cenozoic Camas Prairie Rift south-central Idaho. Contributions to Geology, University of Wyoming, 24(1), 91-101.

Dobson, P.F., Kennedy, B.M., Conrad, M.E., McLing, T., Mattson, E., Wood, T., Cannon, C., Spackman, R., van Soest, M., and Robertson, M., 2015. He isotopic evidence for undiscovered geothermal systems in the Snake River Plain. Proceedings, 40th Workshop on Geothermal Reservoir Engineering, Stanford University, Stanford, CA.

Embree, G.F., and Hoggan R.D., 1999. Secondary deformation within the Huckleberry Ridge Tuff and subjacent Pliocene units near the Teton Dam: Road log to the regional geology of the eastern margin of the Snake River plain, Idaho. In S.S. Hughes and G.D. Thackray, eds., Guidebook to the Geology of Eastern Idaho, Idaho Museum of Natural History, Pocatello, Idaho, p. 181-202.

Embree, G.F., Phillips, W.M., and Welhan, J.A., 2011. Geologic map of the Newdale quadrangle, Fremont and Madison Counties, Idaho. Idaho Geological Survey, University of Idaho, Moscow, Idaho 83844-3014.

Faulds, J. E., Hinz, N. H., Coolbaugh, M. F., Cashman, P. H., Kratt, C., Dering, G., Edwards, J., Mayhew, B., and McLachlan, H., 2011. Assessment of favorable structural settings of geothermal systems in the Great Basin, western USA. GRC Transactions, 35, 777-783.

Fournier, R. O., and Potter, R.W. II, 1982. Revised and expanded silica (quartz) geothermometer. Geotherm. Resour. Counc. Bullet. 11(10), 3-12.

Fournier, R.O., 1977. Chemical geothermometers and mixing models for geothermal systems. Geothermics 5, 41-50.

Fournier, R.O., 1979. A revised equation for the Na/K geothermometer. GRC Transactions, 3, 221-224.

Fournier, R.O. and Truesdell, A.H., 1973. An empirical Na-K-Ca geothermometer for natural waters. Geochim. Cosmochim. Acta 37, 1255-1275.

Fournier, R.O. and Potter II, R.W., 1979. Magnesium correction to the Na-K-Ca chemical geothermometer. Geochim. Cosmochim. Acta 43, 1543-1550.

Garwood, D.L., Kauffman, J.D., Othberg, K.L., Lewis, R.S., 2014 Geologic map of the Fairfield 30x60 Minute Quadrangle, Idaho, Idaho Geological Survey.

GeothermEx, Inc., 2010. Independent technical report: Resource evaluation of the Newdale geothermal prospect, Madison and Fremont Counties, Idaho, USA. Geothermix, Inc., Richmond, California, USA, $101 \mathrm{p}$.

Giggenbach, W.F., 1988. Geothermal solute equilibria. Derivation of Na-K-Mg-Ca geoindicators. Geochim. Cosmochim. Acta, 52, 2749-2765.

Hildebrand, R. T., 1983. Reconnaissance drilling during 1980 in the Goose Creek coal field, Cassia County, Idaho. US Geological Survey Open-File Report 83-477, 28 p.

Lewis, R.E. and Young, H.W., 1989. The hydrothermal system in central Twin Falls County, Idaho: U.S. Geological Survey Water Resources Investigations Report 88-4152, 44 p. 
Lewis, R.S., Link, P.K., Stanford, L.R., and Long, S.P., 2012. Geologic map of Idaho. Idaho Geological Survey, Geologic Map 9.

Link, P.K., 2002a. Clark County, Idaho. Digital Atlas of Idaho, Idaho State University, Geosciences Department, $3 \mathrm{p}$.

Link, P.K., 2002b. Fremont County, Idaho. Digital Atlas of Idaho, Idaho State University, Geosciences Department, $3 \mathrm{p}$.

Link, P.K., 2002c. Cassia County, Idaho. Digital Atlas of Idaho, Idaho State University, Geosciences Department, $3 \mathrm{p}$.

Kellogg, K.S., Harlan, S.S., Mehnert, H.H., Snee, L.W., Pierce, K.L., Hackett, W.R., and Rodgers, D.W., 1994. Major 10.2-Ma rhyolitic volcanism in the Eastern Snake River Plain Idaho-Isotopic age and stratigraphic setting of the Arbon Valley Tuff Member of the Starlight Formation. US Geological Survey Bulletin 2091, 28 p.

Kuntz, M. A., and Kork, J. O., 1978. Geology of the Arco-Big Southern Butte area, eastern Snake River Plain, and volcanic hazards to the radioactive waste management complex, and other waste storage and reactor facilities at the Idaho National Engineering Laboratory, Idaho (No. 78-691). US Geological Survey.

Kuntz, M. A., Covington, H. R., and Schorr, L. J., 1992. An overview of basaltic volcanism of the eastern Snake River Plain, Idaho. Geological Society of America Memoirs 179, 227-268.

Kuntz, M.A., Skipp, B.A., Lanphere, M.A., Scott, W.E., Pierce, K. L., Dalrymple, G.B., Champion, D.E., Embree, G.F., Page, W.R., Morgan, L.A., Smith, R.P., Hackett, W.R., and Rodgers, D.W., 1994. Geologic map of the Idaho National Engineering Laboratory and adjoining areas, eastern Idaho. US Geological Survey, Miscellaneous Investigations Series, Map I-2330.

Leeman, W.P., 1982. Geology of the Magic Reservoir area, Snake River Plain, Idaho, in Bill Bonnichsen and R.M. Breckenridge, Cenozoic Geology of Idaho, Idaho Bureau of Mines and Geology Bulletin 26, 369-376.

Mabey, D.R., 1978. Gravity and aeromagnetic anomalies in the Rexburg area of eastern Idaho. U.S. Geological Survey Open-File Report 78-382, 19p.

Malde, H. E., 1991. Quaternary geology and structural history of the Snake River Plain, Idaho and Oregon. The Geology of North America, 2, 251-281.

Malde, H. E., Powers, H. A., and Marshall, C. H., 1963. Reconnaissance geologic map of west-central Snake River Plain, Idaho (No. 373).

Mansfield, G. R., 1927. Geography, geology, and mineral resources of part of southeastern Idaho, with description of Carboniferous and Triassic fossils. U.S. Geological Survey Prof. Pap., 928, 92 p.

Mapel, W. J., and Hail, W. J., Jr., 1959. Tertiary geology of the Goose Creek district, Cassia County, Idaho, Box Elder County, Utah, and Elko County, Nevada. US Geological Survey Bulletin 1055-H, 217-254.

Mattson, E.D., Smith, R.W., Neupane, G., Palmer, C.D., Fujita, Y., McLing, T.L., Reed, D.W., Cooper, D.C., and Thompson, V.S., 2015. Improved geothermometry through multivariate reaction-path modeling and evaluation of geomicrobiological influences on geochemical temperature indicators: final report (No. INL/EXT-14-33959). Idaho National Laboratory (INL).

McLing, T.L., Smith, R.W., and Johnson, T.M., 2002. Chemical characteristics of thermal water beneath the eastern Snake River Plain. In: Geology, Hydrogeology, and Environmental Remediation: Idaho National Engineering and Environmental Laboratory, Eastern Snake River Plain, Idaho, P.K. Link and L.L. Mink, eds. Geological Society of America Special Paper 353, 205-211.

McLing, T., McCurry, M., Cannon, C., Neupane, G., Wood, T., Podgorney, R., Welhan, J., Mines, G, Mattson, E., Wood, R., Plamer, C., and Smith, R., 2014. David Blackwell's Forty Years in the Idaho Desert, The Foundation for 21st Century Geothermal Research. GRC Transactions 38, 143-153. 
Mitchell, J.C., 1976. Geothermal investigations in Idaho Part 7: Geochemistry and geologic setting of the thermal waters of the Camas Prairie Area, Blaine and Camas Counties, Idaho, Idaho Department of Water Resources, Water Information Bulletin No. 30

Mitchell, J.C., Johnson, L.L., and Anderson, J.E., 1980. Geothermal investigations in Idaho Part 9: Potential for direct heat application of geothermal resources, Idaho. Idaho Department of Water Resources, Water Information Bulletin No. 30.

Morgan, L.A., and McIntosh, W.C., 2005. Timing and development of the Heise volcanic field, Snake River Plain, Idaho, western USA. Geological Society of America Bulletin 117, 288-306.

Neely, K.W., 1996. Geothermal heat keeps students warm at the College of Southern Idaho. GRC Transactions, 20, 129-136.

Neupane, G., Mattson, E.D., McLing, T.L., Palmer, C.D., Smith, R.W., and Wood, T.R., 2014. Deep Geothermal Reservoir Temperatures in the Eastern Snake River Plain, Idaho using Multicomponent Geothermometry. Proceedings, Thirty-Nineth Workshop on Geothermal Reservoir Engineering, Stanford University, Stanford, California, February 24-26, 2014.

Neupane, G., E.D. Mattson, T.L. McLing, C.D. Palmer, R.W. Smith, T.R. Wood, and R.K. Podgorney, 2015a. Geothermal reservoir temperatures in southeastern Idaho using multicomponent geothermometry. Proceedings, World Geothermal Congress 2015a, Melbourne, Australia, 19-25 April 2015.

Neupane, G., J.S. Baum, E.D. Mattson, G.L. Mines, C.D. Palmer, and R.W. Smith, 2015b. Validation of multicomponent equilibrium geothermometry at four geothermal power plants. Proceedings, Fortieth Workshop on Geothermal Reservoir Engineering Stanford University, Stanford, California, January 26-28, 2015.

Neupane, G., Mattson, E.D., Mines, G.L., McLing, T.L., Dobson, P.F., Conrad, M.E., Wood, T.R., Cannon, C., Worthing, W., 2015c. Geothermometric temperature comparison of hot springs and wells in southern Idaho. GRC Transactions 39, 495-502.

Occidental Geothermal, Inc., 1979. Sturm 1, Computer Processed Log. Department of Water Resources, Idaho, $18 \mathrm{p}$.

Oriel, S.S. and Platt, L.B., 1980. Geologic map of the Preston 1 X 2 quadrangle, southeastern Idaho and western Wyoming. US Geological Survey, Miscellaneous Investigation Series, Map I-1127.

Palmer, C.D., Ohly, S.R., Smith, R.W., Neupane, G., McLing, T., Mattson, E., 2014. Mineral Selection for Multicomponent Equilibrium Geothermometry. GRC Transactions 38, 453-459.

Peng, X., and Humphreys, E.D., 1998. Crustal velocity structure across the eastern Snake River Plain and the Yellowstone swell. Journal of Geophysical Research 103, 7171-7186.

Phillips, W.M., Moore, D.K., and Feeney, D.M., 2016a. Geologic map of the Poplar Quadrangle, Bonneville County, Idaho. Idaho Geological Survey.

Phillips, W.M., Moore, D.K., Feeney, D.M., and Embree, G.F., 2016b. Geologic map of the Heise Quadrangle, Bonneville, Jefferson, and Madison Counties, Idaho. Idaho Geological Survey.

Pierce, K. L., and Morgan, L. A., 1992. The track of the Yellowstone hot spot: Volcanism, faulting, and uplift. Geological Society of America Memoirs 179, 1-54.

Piety, L.A., Sullivan, J.T., and Anders, M.H., 1992. Segmentation and paleoseismicity of the Grand Valley fault, southeastern Idaho and western Wyoming in Regional Geology of Eastern Idaho and Western Wyoming. Geological Society of America Memoirs, 179, 155-182.

Prostka, H.J. and Embree, G.F., 1978. Geology and geothermal resources of the Rexburg area, eastern Idaho. U.S. Geological Survey Open-File Report 78-1009.

Ralston, D.R., Arrigo, J.L., Baglio, J.V. Jr., Coleman, L.M., Souder, K., Mayo, A.L., 1981. Geothermal evaluation of the thrust area zone in southeastern Idaho, Idaho Water and Energy Research Institute, University of Idaho.

Rember, W.C. and Bennett, E.H., 1979. Geologic map of the Twin Falls quadrangle, Idaho. Idaho Bureau of Mines and Geology, Geologic Map Series, Twin Falls 2 Quadrangle, scale 1:250,000, Reference ID-R274. 
Ross, S.H., 1970. Geothermal Potential of Idaho. Geothermics, 2, 975-1008.

Shervais, J.W., Shroff, G., Vetter, S.K., Matthews, S., Hanan, B.B., McGee, J.J., 2002. Origin and Evolution of the Western Snake River Plain: Implications from stratigraphy, faulting, and the geochemistry of basalts near Mountain Home, Idaho, in Bill Bonnichsen, C.M., White, and Michael McCurry eds., Tectonic and magmatic evolution of the Snake River Plain Volcanic Province: Idaho Geological Survey Bulletin 30, p. 343-361.

Shervais, J.W., Vetter, S.K., and Hanan, B.B., 2006. Layered mafic sill complex beneath the eastern Snake River Plain: Evidence from cyclic geochemical variations in basalt, Geology, vol. 34, no. 5, p 365-368.

Shervais, J. W., Schmitt, D.R., Nielson, D., Evans, J.P., Christiansen, E.H., Morgan, L., Shanks, W.C.P, Blackwell, D.D., Glen, J.M., Champion, D., Potter, K.E., and Kessler, J.A., 2013. First results from HOTSPOT: The Snake River Plain scientific drilling project, Idaho, USA. Sci. Drill., 15, 36-45.

Skipp, B., 1985.Contraction and extension faults in the southern Beaverhead Mountains, Idaho and Montana. US Geological Survey, Open-File Report 85-545, 183 p.

Souder, K.C., 1985. The hydrochemistry of thermal waters of southeastern Idaho, western Wyoming, and northeastern Utah. MS Thesis, University of Idaho, Moscow, Idaho, 139 p.

Sparlin, M.A., Braile, L.W., and Smith, R.B., 1982. Crustal structure of the Eastern Snake River Plain determined from ray trace modeling of seismic refraction data, Journal of Geophysical Research, 87, 2619-2633.

Street, L. V., \& DeTar, R. E. (1987). Geothermal investigations in Idaho: Geothermal resource analysis in Twin Falls County, Idaho. Idaho Dept. of Water Resources, Twin Falls (USA); Bureau of Land Management, Boise, ID (USA), 106 p.

Struhsacker, D.W., Jewell, P.W., Zeisloft, J., Evans, S.H., 1982. The geology and geothermal setting of the Magic Reservoir area, Blaine and Camas Counties, Idaho, in Bill Bonnichsen and R.M.

Breckenridge, Cenozoic Geology of Idaho, Idaho Bureau of Mines and Geology, Bulletin 26, 377 393.

Trimble, D.E., 1982. Geologic map of the Yandell Springs quadrangle, Bannock and Bingham Counties, Idaho. US Geological Survey, Geologic Quadrangle Map, Yandell Springs Quadrangle, Idaho GQ1553.

Truesdell, A.H., 1976. Summary of Section III. Geochemical techniques in exploration. Proceedings of the Second United Nations Symposium on the Development and Use of Geothermal Resources, San Francisco 1975, 1, liii - lxxix.

Wallace, R.W., 1972. A finite-element, planar-flow model of Camas Prairie, Idaho. Doctoral dissertation, University of Idaho, Moscow, Idaho, $178 \mathrm{p}$.

Young, H.W. and Lewis, R.E., 1982. Hydrology and geochemistry of thermal groundwater in southwestern Idaho and north-central Nevada. US Geological Survey Professional Paper 1044-J, 26 p.

Young, H. W., and Mitchell, J. C., 1973. Geothermal investigations in Idaho. Part 1. Geochemistry and geologic setting of selected thermal waters. Idaho Dept. of Water Admin., Water Inf Bul, 30, 24 p. 


\section{Appendix F.}

Neupane, G., Mattson, E.D., Mines, G.L., McLing, T.L., Dobson, P.F., Conrad, M.E., Wood, T.R., Cannon, C., Worthing, W., 2015c. Geothermometric temperature comparison of hot springs and wells in southern Idaho. GRC Transactions, 39, 495-502. 


\title{
Geothermometric Temperature Comparison of Hot Springs and Wells in Southern Idaho
}

\author{
Ghanashyam Neupane ${ }^{1,2}$, Earl D. Mattson', Travis L. McLing ${ }^{1,2}$, Patrick F. Dobson ${ }^{3}$, \\ Mark E. Conrad ${ }^{3}$, Thomas R. Wood ${ }^{2,4}$, Cody Cannon ${ }^{2,4}$, and Wade Worthing ${ }^{2,4}$ \\ ${ }^{1}$ Idaho National Laboratory, Idaho Falls ID, USA \\ ${ }^{2}$ Center for Advanced Energy Studies, Idaho Falls ID, USA \\ ${ }^{3}$ Lawrence Berkeley National Laboratory, Berkeley CA, USA \\ ${ }^{4}$ University of Idaho-Idaho Falls, Idaho Falls ID, USA \\ ghanashyam.neupane@inl.gov
}

\section{Keywords}

Geothermal sites, hot springs, wells, reservoir temperature, Snake River Plain, RTEst

\begin{abstract}
Conventional geothermal resource prospecting often begins with geochemical analysis of geothermal fluids sampled from surface expressions (hot springs and fumaroles). Similarly, water samples from hot wells located near the surface expressions are also routinely collected and analyzed as a part of regional exploration efforts. The chemical compositions of these water samples can be used to assess the likely reservoir temperatures of the geothermal sites as well as to understand other reservoir characteristics. In this paper, we present comparative results of geothermometric reservoir temperatures based on water compositions measured from pairs of hot springs and nearby wells of 10 potential geothermal sites in southern Idaho using both traditional and multicomponent equilibrium geothermometric approaches. Our results show that the reservoir temperatures estimated using water compositions measured surface thermal features and wells produce similar results. However, for two of the 10 sites, Durfee Hot Spring and Fairchild Hot Spring, the estimated reservoir temperatures based on water compositions measured from hot springs were significantly higher than the estimated reservoir temperatures using the well water sample. In the case of the Durfee system, the well water may have chemically re-equilibrated within the aquifer resulting in a lower estimated temperature than that calculated using the hot spring. Similarly, in the case of the Fairchild system, the hot spring and well water chemistry are chemically distinct and had the greatest distance between the hot spring and well pairs of the examined geothermal sites. The difference in fluid chemistry suggests that the Fairchild Hot Spring reservoir is compartmentalized and the two expressions are issuing waters migrated from two separate portions of the reservoir. Although the majority of the hot spring/well pairs in southern Idaho provided concordant reservoir temperatures, it is imperative to consider the consistency of the water types and distance between the sources when estimating reservoir temperatures.
\end{abstract}

\section{Introduction}

Sampling of water from surface thermal features (hot springs, fumaroles) as well as hot shallow wells for geochemical analyses may constitute an early prospecting phase of geothermal exploration. Geochemical data of water samples collected from geothermal can provide insights into diverse reservoir characteristics such as age of water, residence time, recharge, and subsurface temperatures. Geothermometric calculations use chemical concentrations of single (e.g., silica), a limited number (e.g., $\mathrm{Na} / \mathrm{K}, \mathrm{Na}-\mathrm{K}-\mathrm{Ca}$, etc.), or multiple species in water and gas samples collected from surface expressions to assess reservoir temperatures.

In many cases, geothermal resources manifest their deeper hydrothermal activities in the form of surface expressions such as hot springs and fumaroles (e.g., Roosevelt Hot Springs). However, in some cases there have been no prior natural surface expressions (i.e., hidden systems), such as in Raft River Geothermal field where shallow wells drilled for domestic/irrigation purposes produced hot water and prompted further study to evaluate the potential geothermal resource. 
Therefore, it is also important to assess the water compositions of warm- or hot-water producing shallow wells to evaluate geothermal potential of an area.

The United States Geological Survey (USGS), state geological surveys and water resource departments, and research groups supported by the US Department of Energy have conducted multiple campaigns to collect and analyze water samples from numerous sources including hot springs and hot shallow wells located throughout the western US. In this paper, we report comparative geothermometric results of water samples from hot springs and nearby hot shallow wells from numerous geothermal sites located near and along the margin of the Snake River Plain (SRP) in southern Idaho (Figure 1). The main objective of this study was to evaluate whether the chemical compositions of hot water measured from hot shallow wells are also equally useful in determining reservoir temperatures as those of compositions of water measured from hot springs.

\section{Water Samples}

Compositions of water samples measured from paired sources which are assumed to represent individual geothermal sites in southern Idaho were assembled for this study (Table 1). Nine of the paired sources were composed of hot springs and hot shallow wells. In the case of one example (Magic Reservoir Hot Spring), both compositions represent water derived from a well with one sample directly collected from a shallow leak in the well whereas the other sample was collected from a runoff channel that has experienced cooling and degassing.

Most of the sites considered in this study represent the geothermal systems located within and along the margins of the eastern and western SRP except two sites (Battle Creek HS and Durfee HS) that are located south-southeast from the SRP in the Basin and Range Province (Figure 1).

\section{Geothermometric Approaches}

The underlying assumption of geothermometry is that waters collected from geothermal expressions maintain a chemical signature that reflects equilibrium with the minerals in the deeper reservoir (Fournier et al., 1974). There are numerous empirical and semi-empirical traditional geothermometers (e.g., silica geothermometers (Fournier, 1977), Na-K-Ca geothermometer (Truesdell and Fournier, 1973), and so on) routinely used within the geothermal prospecting community. Although many of the traditional geothermometers are fitted relationships, there have been some geochemical postulations supporting these relationships. For example, silica geothermometers are based on the assumption of the solubility of solid-phase silica (e.g., quartz, chalcedony, etc.) controlling the aqueous concentration of silica (Fournier, 1977). Similarly, several variations of sodium-potassium geothermometers are based on water-rock interaction involving albite and potassium feldspar. The reliability, sensitivity, and responsiveness of traditional geothermometers to various composition altering processes (such as boiling, mixing, degassing, etc.) vary. For example, geothermometers based on cation concentration ratios (e.g., $\mathrm{Na} / \mathrm{K}$ geothermometer) are minimally sensitive to boiling or mixing with dilute water; while geothermometers based directly on the concentration of component(s) (e.g., quartz geothermometer) are highly sensitive to these processes ((D'Amore and Arnórsson, 2000)). A drawback to many existing geothermometry approaches is that they do not adequately account for physical processes (e.g., mixing, boiling) and geochemical processes (e.g., mineral dissolution, precipitation, degassing) that may occur after the water leaves the reservoir and thereby alter its composition. If these changes are not taken into account, predictions of in-situ reservoir conditions (e.g., temperature, $\mathrm{fCO}_{2}$ ) based on the chemical composition of water samples taken from shallower depths or at the surface may be erroneous, or too imprecise to be useful.

In addition, it is difficult to quantify uncertainties associated with temperatures estimated with these geothermometers. As a result, it is not uncommon to find diverse temperature estimates for the same water using multiple traditional geothermometers. Nevertheless, because these

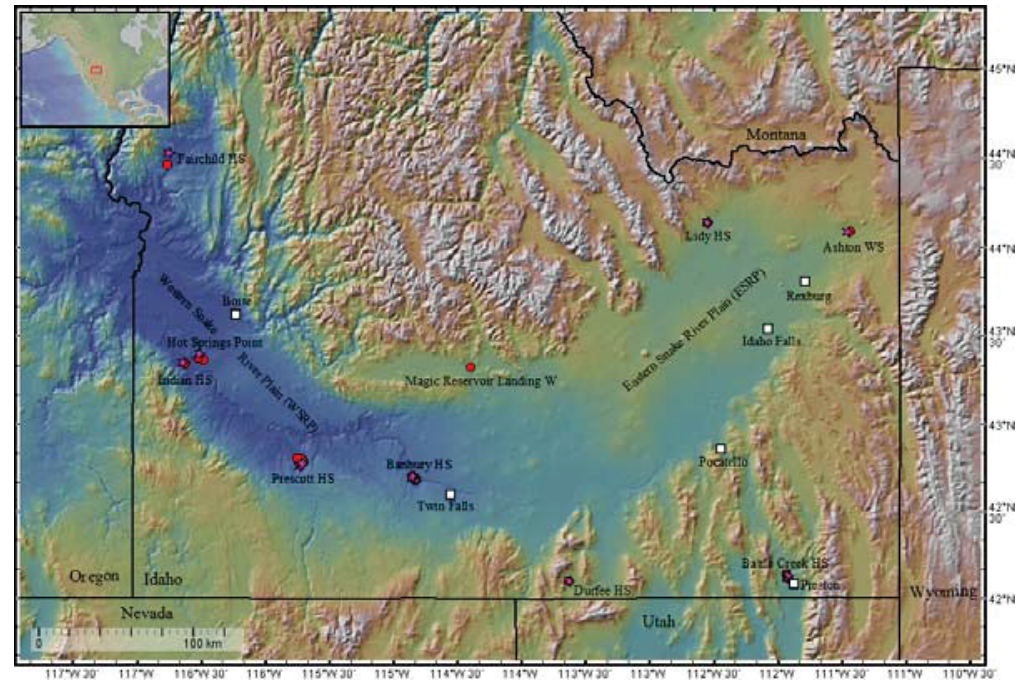

Figure 1. Shaded relief map of southern Idaho with locations of hot springs and nearby wells used in this study. Purple stars represent the hot springs whereas red circles represent the wells. The map was prepared from NASA 10-m DEM data in GeoMapApp. 
Table 1. Composition of water samples $(\mathrm{mg} / \mathrm{L})$. Hot springs are italicized. Bold-faced names represent the geothermal sites.

\begin{tabular}{|c|c|c|c|c|c|c|c|c|c|c|c|c|c|c|c|}
\hline Samples & $\mathrm{T}^{1}$ & $\mathrm{pH}$ & $\mathrm{Al}^{2}$ & $\mathrm{Na}$ & $\mathrm{K}$ & $\mathrm{Ca}$ & $\mathrm{Mg}$ & B & $\mathrm{Li}$ & $\mathrm{SiO}_{2}(\mathrm{aq})$ & $\mathrm{HCO}_{3}$ & $\mathrm{SO}_{4}$ & $\mathrm{Cl}$ & $\mathrm{F}$ & $\operatorname{Ref}^{3}$ \\
\hline Ashton $W^{4}{ }^{4}$ & 41.0 & 7.60 & & 36 & 1.6 & 1.1 & 0.10 & & & 110 & 92 & 4.7 & 2.9 & 2.2 & $a$ \\
\hline Sturm $\mathrm{W}^{5}$ & 31.4 & 8.73 & \begin{tabular}{|l|}
0.005 \\
\end{tabular} & 33 & 0.89 & 3.2 & 0.05 & 0.04 & 0.05 & 63 & 66 & 5.8 & 3.3 & 2.1 & $\mathrm{~b}$ \\
\hline Lidy $\mathbf{H S} 1^{6}$ & 56.1 & 7.17 & 0.001 & 25 & 13 & 66 & 16 & 0.09 & 0.05 & 38 & 132 & 102 & 7.3 & 4.6 & $b$ \\
\hline Lidy HS2 & 52.3 & 7.21 & 0.001 & 28 & 13 & 64 & 16 & 0.09 & 0.05 & 34 & 163 & 98 & 6.9 & 4.7 & $b$ \\
\hline Lidy HS W & 59.0 & 7.60 & & 24 & 12 & 55 & 14 & 0.09 & 0.04 & 37 & 180 & 100 & 7.1 & 4.4 & C \\
\hline Magic Reservoir HS Landing W & 75.0 & 6.79 & 0.009 & 311 & 20 & 22 & 1.4 & 1.2 & 1.2 & 104 & 703 & 50 & 74 & 9.9 & $\mathrm{~b}$ \\
\hline $\begin{array}{l}\text { Magic Reservoir HS Landing } \\
\text { Runoff }\end{array}$ & 39.1 & 8.61 & 0.007 & 333 & 21 & 13 & 1.3 & 1.2 & 1.2 & 109 & 710 & 53 & 79 & 11 & b \\
\hline Banbury $H S$ & 58.5 & 9.15 & 0.01 & 95 & 1.6 & 1.0 & 0.001 & 0.22 & 0.03 & 103 & 168 & 24 & 17 & 11 & $b$ \\
\hline Hot Sulphur Miracle HS & 57.0 & 9.40 & & 130 & 1.5 & 0.9 & 0.1 & 0.34 & 0.04 & 86 & 59 & 34 & 34 & 21 & $d$ \\
\hline Salmon Falls HS & 70.5 & 9.10 & & 140 & 1.1 & 1.2 & 0.1 & 0.44 & 0.06 & 89 & 70 & 32 & 50 & 27 & C \\
\hline Miracle HS W & 58.4 & 9.53 & 0.02 & 128 & 1.9 & 0.8 & 0.001 & 0.33 & 0.05 & 100 & 93 & 34 & 32 & 22 & $\mathrm{~b}$ \\
\hline Banbury HS Well & 58.8 & 9.24 & 0.01 & 97 & 1.6 & 0.9 & 0.001 & 0.22 & 0.03 & 103 & 249 & 23 & 17 & 11 & $\mathrm{~d}$ \\
\hline Near Banbury Natatorium W5 & 30.0 & 9.30 & & 97 & 1.6 & 0.9 & 0.1 & 0.21 & 0.03 & 64 & 85 & 28 & 20 & 13 & d \\
\hline Near Banbury Natatorium W2 & 42.5 & 9.30 & & 90 & 1.7 & 1.3 & 0.1 & 0.17 & 0.04 & 67 & 85 & 28 & 14 & 9 & d \\
\hline Near Banbury Natatorium W4 & 44.5 & 9.40 & & 100 & 1.8 & 3.3 & 0.1 & 0.23 & 0.04 & 88 & 83 & 27 & 22 & 12 & $\mathrm{~d}$ \\
\hline Near Banbury Natatorium W3 & 42.0 & 9.20 & & 100 & 2.1 & 3.7 & 0.2 & 0.23 & 0.03 & 94 & 88 & 27 & 23 & 13 & $d$ \\
\hline Near Banbury Natatorium W1 & 45.5 & 9.10 & & 100 & 1.8 & 0.9 & 0.1 & 0.23 & 0.04 & 86 & 100 & 29 & 30 & 26 & d \\
\hline Banbury Natatorium W & 59.0 & 9.30 & & 110 & 1.6 & 1.1 & 0.1 & 0.26 & 0.04 & 88 & 78 & 30 & 23 & 15 & d \\
\hline Harry Huttanus W2 & 59.0 & 9.00 & & 100 & 1.5 & 1.1 & 0.1 & 0.23 & 0.04 & 100 & 90 & 27 & 25 & 14 & C \\
\hline Sliger W & 72.0 & 9.37 & 0.07 & 136 & 1.6 & 0.9 & 0.004 & 0.50 & 0.05 & 94 & 212 & 30 & 50 & 24 & $\mathrm{~b}$ \\
\hline Unnamed W1 near SFHS ${ }^{7}$ & 72.0 & 9.30 & & 140 & 1.2 & 0.9 & 0.1 & 0.47 & 0.06 & 86 & 59 & 35 & 51 & 27 & d \\
\hline Unnamed_W_SF CREEK & 62.0 & 9.40 & & 150 & 1.4 & 0.7 & 0.1 & 0.49 & 0.05 & 84 & 56 & 35 & 48 & 15 & d \\
\hline Unnamed W2 near SFHS & 71.5 & 9.50 & & 140 & 1.5 & 1.5 & 0.1 & 0.51 & 0.06 & 82 & 56 & 33 & 51 & 27 & d \\
\hline Durfee $H S$ & 44.9 & 8.78 & 0.003 & 84 & 3.3 & 8.2 & 0.35 & 0.08 & 0.09 & 68 & 107 & 28 & 59 & 6.2 & $b$ \\
\hline Harold Ward W & 38.0 & 7.40 & & 70 & 3.1 & 37 & 9.3 & & & 44 & 169 & 33 & 80 & 2.9 & $d$ \\
\hline Battle Creek HS1 & 77.0 & 7.00 & & 3100 & 660 & 160 & 16 & & & 80 & 699 & 50 & 5400 & 12 & e \\
\hline Battle Creek HS2 & 43.0 & 6.50 & & 3071 & 535 & 166 & 15 & 7.3 & & 107 & 697 & 29 & 5048 & 6.0 & e \\
\hline Battle Creek HS3 & 81.0 & 6.50 & & 3053 & 533 & 162 & 19 & 7.2 & & 109 & 757 & 37 & 5034 & 6.0 & $\mathrm{e}$ \\
\hline Battle Creek HS5 & 82.0 & 6.70 & & 3161 & 552 & 174 & 19 & 7.6 & & 109 & 696 & 35 & 5241 & 6.0 & e \\
\hline Battle Creek HS4 & 84.0 & 6.80 & & 4184 & 686 & 215 & 24 & 10 & & 97 & 610 & 33 & 6967 & 6.4 & e \\
\hline Squaw HS1 & 69.0 & 6.50 & & 4184 & 708 & 135 & 23 & 7.3 & & 126 & 816 & 27 & 6877 & 4.3 & e \\
\hline Squaw HS2 & 73.0 & 6.60 & & 3844 & 533 & 241 & 26 & 9.7 & & 126 & 866 & 23 & 6396 & 4.8 & e \\
\hline Bosen W & 90.0 & 6.65 & 0.08 & 4523 & 795 & 207 & 18 & 5.6 & 6.1 & 95 & 583 & 49 & 7129 & 5.2 & $b$ \\
\hline Squaw HS W1 & 82.0 & 7.80 & & 4300 & 880 & 250 & 23 & & & 130 & 733 & 54 & 7700 & 7.0 & $\mathrm{e}$ \\
\hline Squaw HS W2 & 84.0 & 6.50 & & 4368 & 782 & 279 & 24 & 8.1 & & 124 & 791 & 35 & 7398 & 4.3 & $\mathrm{e}$ \\
\hline Squaw HS W3 & 82.0 & 6.90 & & 3996 & 694 & 261 & 21 & & & 139 & 725 & 35 & 7291 & 4.9 & $\mathrm{e}$ \\
\hline Indian HS & 71.5 & 9.40 & & 80 & 0.8 & 1.3 & 0.1 & 0.11 & 0.06 & 71 & 56 & 23 & 9.1 & 16.0 & $d$ \\
\hline Earl Foote $\mathrm{W}$ & 45.0 & 9.20 & & 130 & 1.2 & 1.4 & 0.1 & 0.25 & 0.01 & 61 & 140 & 45 & 22 & 12.0 & d \\
\hline Prescott HS & 41.0 & 9.10 & & 55 & 5.5 & 6.2 & 0.3 & 0.01 & & 83 & 103 & 18 & 8.8 & 8.5 & $d$ \\
\hline Prescott WS & 40.0 & 8.50 & & 43 & 6.7 & 13 & 1.8 & 0.11 & 0.01 & 89 & 126 & 15 & 8.8 & 4.5 & d \\
\hline Indian Bathtub HS & 39.0 & 8.30 & & 53 & 6.7 & 6.5 & 0.6 & 0.08 & 0.01 & 87 & 113 & 15 & 9.1 & 6.0 & $d$ \\
\hline Owens W7 & 38.0 & 8.00 & & 36 & 6.9 & 16 & 2.8 & 0.10 & 0.02 & 82 & 134 & 15 & 8.6 & 3.1 & d \\
\hline Prescott W & 43.0 & 9.20 & & 48 & 6.2 & 12 & 1.1 & 0.08 & 0.01 & 84 & 129 & 17 & 8.6 & 5.4 & $\mathrm{~d}$ \\
\hline Rose W & 44.0 & 8.30 & & 53 & 7.2 & 12 & 1.1 & 0.12 & 0.02 & 100 & 126 & 17 & 8.7 & 8.2 & d \\
\hline HS Ranch W & 43.0 & 8.50 & & 54 & 4.6 & 6 & 0.3 & 0.07 & & 82 & 91 & 18 & 9.0 & 12 & d \\
\hline Unnamed W NE of Bat HS & 45.0 & 8.00 & & 40 & 6.3 & 16 & 1.9 & 0.09 & 0.02 & 86 & 124 & 15 & 8.4 & 3.7 & $\mathrm{~d}$ \\
\hline Owens W2 & 42.5 & 8.50 & & 49 & 5.1 & 7.4 & 0.4 & 0.06 & 0.01 & 81 & 99 & 18 & 9.0 & 8.9 & $d$ \\
\hline HS Point & 60.0 & 6.90 & & 285 & 56 & 46 & 40 & 2.9 & 0.99 & 70 & 949 & 116 & 48 & 7.0 & $d$ \\
\hline Charters W & 25.5 & 8.20 & & 48 & 4.7 & 16 & 6.9 & & & 43 & 133 & 41 & 15 & 0.5 & $d$ \\
\hline Melba City W & 25.0 & 8.20 & & 88 & 3.8 & 9.1 & 2.3 & & & 42 & 200 & 34 & 17 & 1.4 & $d$ \\
\hline Fairchild HS & 50.0 & 8.50 & & 80 & 1.9 & 8.0 & 0.8 & & & 55 & 81 & 110 & 15 & 0.8 & $d$ \\
\hline Fairchild Lumber W & 26.9 & 8.70 & 0.3 & 80 & 9.1 & 3.5 & 0.2 & 0.18 & & 69 & 187 & 14 & 3.8 & 0.7 & d \\
\hline
\end{tabular}

${ }^{1}$ Field temperature in ${ }^{\circ} \mathrm{C} ;{ }^{2}$ Potassium feldspar was used for missing Al during RTEst modeling; ${ }^{3}$ Ref: Reference (a: Young and Mitchell, 1973; b: this study; c: Mitchell et al., 1980; d: Parliman and Young, 1992; e: Mitchell, 1976; ${ }^{4}$ WS: warm spring; ${ }^{5} \mathrm{~W}$ : Well; ${ }^{6} \mathrm{HS}$ : hot spring; ${ }^{7}$ SFHS: Salmon Falls hot spring.

geothermometers are easy to use and sometimes provide good results, they are considered to be an essential part of the geothermal exploration toolkit (D’Amore and Arnórsson, 2000).

A more advanced geothermometric approach is multicomponent equilibrium geothermometry (MEG). The MEG approach of geothermometry utilizes multiple chemical constituents measured in water samples for inverse geochemical modeling considering a suite of selected minerals (selected based on some knowledge of the system) so as to provide more robust temperature estimates with quantifiable uncertainties. Geothermal temperature predictions using MEG provide ap- 
parent improvement in reliability and predictability of temperature over traditional geothermometers. The basic concept of this method was developed in 1980s (e.g., Michard and Roekens, 1983; Reed and Spycher, 1984). Some previous investigators (e.g., D'Amore et al., 1987; Hull et al., 1987; Tole et al., 1993) have used this technique for predicting geothermal temperature in various geothermal sites. Other researchers have used the basic principles of this method for reconstructing the composition of geothermal fluids and formation brines (Pang and Reed, 1998; Palandri and Reed, 2001). More recent efforts by some researchers (e.g., Bethke, 2008; Spycher et al., 2011; Smith et al., 2012; Cooper et al., 2013; Neupane et al., 2013, 2014; Spycher et al., 2014; Peiffer et al., 2014; Palmer et al., 2014; Neupane et al., 2015a,b) have been focused on improving temperature predictability of the MEG.

For this study, both traditional [e.g., quartz (no steam loss) (Fournier, 1977), chalcedony (Fournier, 1977), and Na-K$\mathrm{Ca}$ (Truesdell and Fournier, 1973; Fournier and Potter II, 1979)] and multicomponent (Palmer et al., 2014) geothermometric approaches were applied to the water compositions measured from paired sources (hot springs and nearby wells) to estimate reservoir temperatures. Specifically, the MEG approach implemented in Reservoir Temperature Estimator (RTEst) (Palmer et al., 2014) was used to assess the reservoir temperatures of several geothermal sites in southern Idaho. While applying RTEst to each water sample, a mineral assemblage with 5-7 representative minerals (Mg bearing minerals - clinochlore, illite, saponite, beidellite, talc; Na bearing minerals - paragonite, saponite; K-bearing minerals - K-feldspar, mordenite-K, illite; Ca bearing minerals - calcite; and chalcedony) was used for the development of each reservoir temperature estimate. For each site, the same mineral assemblage was used for all samples. For the selected compositions of southeastern Idaho thermal waters that do not have measured Al concentrations (Table 1), a value determined by assuming equilibrium with K-feldspar (Pang and Reed, 1998) was used in the geochemical modeling.

\section{Results and Discussion}

\subsection{Southern Idaho waters}

Compositions of water samples measured from hot springs and wells in southern Idaho are presented in Table 1. The $\mathrm{pH}$ values of the southern Idaho thermal waters range from 6.5 to 9.5. Similarly, the field temperatures of southern Idaho springs/wells range between 25 to $90{ }^{\circ} \mathrm{C}$. The aqueous chemistry of these southeastern Idaho thermal waters show a large range in total dissolved solids (TDS) from about $100 \mathrm{mg} / \mathrm{L}$ (Sturm Well) to >14,000 mg/L (Bosen Well).

The dominant cations in the southern Idaho thermal waters are $\mathrm{Na}$ and $\mathrm{Ca}$ whereas bicarbonate is the dominant anion for most of the samples except Battle Creek group water samples where $\mathrm{Cl}$ is by far the dominant anion species. A limited number of other water samples (e.g., Fairchild and Indian Hot Springs) have $\mathrm{SO}_{4}$ or $\mathrm{F}$ as the dominant anions.

When specifically comparing water chemistry from hot springs and nearby wells, it is not unusual to find some variations in the concentration of a particular solute in water from different sources representing the same site. For example, the $\mathrm{pH}$ of water from Sturm Well is more alkaline $(>1$ unit of $\mathrm{pH})$ than water from the neighboring Ashton Warm Spring. Similarly, Ashton Warm Spring water contains significantly higher concentrations of $\mathrm{SiO}_{2}(\mathrm{aq})$ and $\mathrm{HCO}_{3}$. On the other hand, waters from these two expressions have similar concentrations of $\mathrm{Na}, \mathrm{SO}_{4}, \mathrm{Cl}$, and $\mathrm{F}$. In some cases (e.g., Durfee Hot Spring), the concentration of Mg in well water is significantly higher than the concentration in the hot spring. At the Hot Spring Point site, the total dissolved solid (TDS) in hot spring water is several times higher than the TDS value in nearby wells. Despite these differences, our data from southern Idaho suggests that most of the water samples from hot springs and nearby well(s) representing the same site are typically the same type waters with the exception of the Fairchild site where different water types from the hot springs and a well $\sim 7 \mathrm{~km}$ from the spring were found.

Due to these variations in solute concentrations in water samples collected from hot springs and nearby wells, nonratio traditional geothermometers (e.g., silica variants, Na-K-Ca) provide diverse temperature estimates from their paired thermal expressions. Based on previous geothermometric studies of south/southeastern Idaho waters (e.g. Neupane et al., 2014; Neupane et al., 2015a), traditional geothermometers based on cation ratios (specifically, the variants of Na/K geothermometers) rarely provide acceptable reservoir temperatures in the region because of the likely violation of underlying geochemical assumptions for these geothermometers. However, it has been reported in our previous studies that MEG as implemented in RTEst consistently provides acceptable temperature estimates for numerous sites in the south/southeastern Idaho and other producing geothermal areas in the western US.

\subsection{Reservoir Temperatures}

\subsubsection{Giggenbach Diagram}

When plotted on a Giggenbach Na-K-Mg diagram (Giggenbach, 1988), water samples representing Battle Creek, Magic, Banbury, and Indian Hot Springs geothermal sites plot in the partially equilibrated zone whereas water samples from rest of the other sites lie in the immature zone (Figure 2). Water-rock interaction associated with the Battle Creek (Preston) reservoir could have occurred at a temperature range of $260-300{ }^{\circ} \mathrm{C}$. Other partially equilibrated water samples may have 
interacted with rock at about $200{ }^{\circ} \mathrm{C}$ (Magic Reservoir Hot Spring well waters) and between $80-140^{\circ} \mathrm{C}$ (Banbury Hot Spring site), and at about $100{ }^{\circ} \mathrm{C}$ (Indian Hot Spring site).

The perceived lack of equilibrium (immaturity) of water samples from other sites could be related to low $\mathrm{Na}$ content, as suggested by Giggenbach (1988), as well as to their relatively higher $\mathrm{Mg}$ content. The waters containing high $\mathrm{Mg}$ content are deemed to be poor for some traditional solute geothermometry (this often indicates mixing with shallow, cooler fluids); although there have been some efforts made to implement an $\mathrm{Mg}$ correction in the estimated temperature (e.g., Fournier and Potter, 1979).

Immature waters from both springs and wells representing each site are either clustered or aligned together along an isotherm (e.g., Prescott Hot Springs system, Figure 2) with two exceptions being the Fairchild and Durfee sites. In the case of the Fairchild site, spring water appears to be relatively more immature; however, the opposite trend is found for the Durfee site. It is likely that the clustered or aligned immature samples representing the same site may have undergone similar geochemical consequences (e.g., mixing) along the flow path.

\subsubsection{Temperature Estimated by Traditional Geothermometers}

Temperature estimates with quartz (no steam loss; Fournier, 1977), chalcedony (Fournier, 1977), and Mgcorrected Na-K-Ca (Fournier and Truesdell, 1973; Fournier and Potter II, 1979) are presented in Table 2. In general, the two variants of silica geothermometers resulted in similar (with respect to each geothermometer and each site) reservoir temperatures with water compositions measured from springs and wells for the majority of the geothermal sites. For some sites (e.g., Ashton, Durfee, and HS Point), however, temperature estimates based on spring

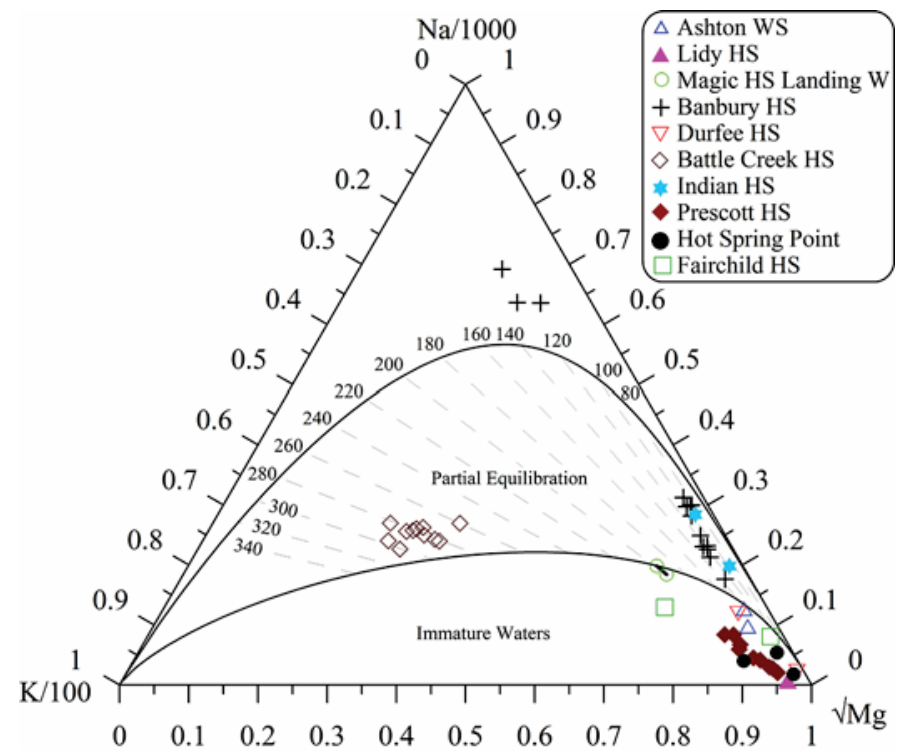

Figure 2. Water samples from south Idaho hot springs and wells plotted on a Giggenbach diagram (Giggenbach, 1988).
Table 2. Estimated reservoir temperatures obtained from compositions of water from hot springs and wells at ten geothermal sites in southern Idaho. Mean estimated temperatures ae also included for geothermal sites with more than one sample from the same type of source.

\begin{tabular}{|c|c|c|c|c|}
\hline Sampling sites & ${ }^{1} \mathrm{~T} \pm \sigma_{\mathrm{T}}$ & ${ }^{2}$ Quartz) & ${ }^{3}$ Chalcedony & ${ }^{4} \mathrm{Na}-\mathrm{K}-\mathrm{Ca}$ \\
\hline Ashton WS & $147 \pm 5$ & 143 & 116 & 130 \\
\hline Sturm W & $152 \pm 14$ & 113 & 84 & 109 \\
\hline Lidy HS1 & $111 \pm 6$ & 89 & 58 & 77 \\
\hline Lidy HS2 & $105 \pm 6$ & 85 & 54 & 71 \\
\hline Lidy HS W & $106 \pm 5$ & 88 & 57 & 71 \\
\hline Mean: Spring & 108 & 87 & 56 & 74 \\
\hline Magic HS Landing Well & $133 \pm 8$ & 139 & 113 & 149 \\
\hline Magic HS Landing Runoff & $132 \pm 4$ & 142 & 116 & 143 \\
\hline Banbury HS & $159 \pm 9$ & 139 & 112 & 112 \\
\hline Hot Sulphur Miracle HS & $150 \pm 4$ & 129 & 101 & 103 \\
\hline Salmon Falls HS & $148 \pm 5$ & 131 & 103 & 92 \\
\hline Miracle HS W & $161 \pm 3$ & 137 & 110 & 112 \\
\hline Banbury HS Well & $159 \pm 10$ & 139 & 113 & 114 \\
\hline Near Banbury Natatorium W5 & $145 \pm 6$ & 114 & 85 & 113 \\
\hline Near Banbury Natatorium W2 & $139 \pm 7$ & 116 & 87 & 114 \\
\hline Near Banbury Natatorium W4 & $139 \pm 7$ & 130 & 103 & 108 \\
\hline Near Banbury Natatorium W3 & $142 \pm 8$ & 134 & 107 & 113 \\
\hline Near Banbury Natatorium W1 & $157 \pm 6$ & 129 & 101 & 116 \\
\hline Banbury Natatorium W & $148 \pm 6$ & 130 & 103 & 108 \\
\hline Harry Huttanus W2 & $155 \pm 8$ & 137 & 110 & 108 \\
\hline Sliger W & $134 \pm 2$ & 133 & 106 & 103 \\
\hline Unnamed W1 near SFHS & $150 \pm 3$ & 129 & 101 & 102 \\
\hline Unnamed_W_SF CREEK & $152 \pm 2$ & 128 & 100 & 115 \\
\hline Unnamed W2 near SFHS & $135 \pm 5$ & 126 & 99 & 98 \\
\hline Mean: Spring & 152 & 133 & 105 & 102 \\
\hline Mean: Well & 147 & 129 & 102 & 110 \\
\hline Durfee $H S$ & $138 \pm 8$ & 117 & 88 & 131 \\
\hline Harold Ward W & $101 \pm 6$ & 96 & 66 & 60 \\
\hline Battle Creek HS1 & $175 \pm 6$ & 125 & 97 & 230 \\
\hline Battle Creek HS2 & $169 \pm 5$ & 141 & 115 & 215 \\
\hline Battle Creek HS3 & $170 \pm 5$ & 142 & 116 & 202 \\
\hline Battle Creek HS5 & $171 \pm 4$ & 142 & 116 & 205 \\
\hline Battle Creek HS4 & $175 \pm 5$ & 136 & 109 & 204 \\
\hline Squaw HS1 & $179 \pm 9$ & 151 & 125 & 204 \\
\hline Squaw HS2 & $157 \pm 6$ & 151 & 125 & 183 \\
\hline Bosen Well & $175 \pm 4$ & 134 & 107 & 227 \\
\hline Squaw HS W1 & $175 \pm 5$ & 152 & 127 & 229 \\
\hline Squaw HS W2 & $174 \pm 6$ & 150 & 124 & 217 \\
\hline Squaw HS W3 & $171 \pm 7$ & 156 & 132 & 216 \\
\hline Mean: Spring & 171 & 141 & 115 & 206 \\
\hline Mean: Well & 174 & 148 & 123 & 222 \\
\hline Indian $H S$ & $98 \pm 1$ & 119 & 90 & 73 \\
\hline Earl Foote W & $103 \pm 4$ & 111 & 82 & 90 \\
\hline Prescott HS & $110 \pm 4$ & 127 & 99 & 158 \\
\hline Prescott WS & $112 \pm 6$ & 131 & 103 & 110 \\
\hline Indian Bathtub HS & $122 \pm 2$ & 130 & 102 & 143 \\
\hline Owens W7 & $112 \pm 11$ & 126 & 99 & 94 \\
\hline Prescott W & $104 \pm 6$ & 128 & 100 & 131 \\
\hline Rose W & $107 \pm 3$ & 137 & 110 & 135 \\
\hline HS Ranch W & $105 \pm 5$ & 126 & 99 & 151 \\
\hline Unnamed W NE of Bat HS & $102 \pm 6$ & 129 & 101 & 115 \\
\hline Owens W2 & $104 \pm 3$ & 126 & 98 & 152 \\
\hline Mean: Spring & 115 & 129 & 101 & 137 \\
\hline Mean: Well & 106 & 129 & 101 & 130 \\
\hline HS Point & $144 \pm 9$ & 118 & 90 & 24 \\
\hline Charters W & $159 \pm 7$ & 95 & 64 & 35 \\
\hline Melba City W & $147 \pm 14$ & 94 & 63 & 66 \\
\hline Mean: Well & 153 & 95 & 64 & 51 \\
\hline Fairchild HS & $196 \pm 2$ & 106 & 77 & 107 \\
\hline Fairchild Lumber W & $144 \pm 8$ & 117 & 89 & 179 \\
\hline
\end{tabular}

${ }^{1}$ RTEst temperature and standard error; ${ }^{2}$ Quartz no steam loss, Fournier (1977); ${ }^{3}$ Fournier (1977); ${ }^{4}$ Fournier and Truesdell (1973), Mg correction applied according to Fournier and Potter II (1979). 
water compositions are warmer than the temperature estimates with well water compositions (Table 2). This variation in estimated temperature is also true with Na-K-Ca geothermometer for the Ashton and Durfee sites (Table 2). On the other hand, one hot spring within the Battle Creek (Preston) site resulted in slightly lower reservoir temperature estimates compared to other hot springs or wells.

For some geothermal sites, the Na-K-Ca temperatures estimates for spring water and well water compositions are more diverse compared to the temperature estimates with silica geothermometers. For example, regardless of the source, silica geothermometer specific temperature estimates for the Prescott site are very similar. However, Na-K-Ca temperatures for this site are not similar for many samples. In general, Na-K-Ca temperatures for this system fall into two- slightly cooler temperature $\left(94-115^{\circ} \mathrm{C}\right)$ and warmer temperature $\left(131-158^{\circ} \mathrm{C}\right)$ groups. However, the cooler and warmer Na-K-Ca temperatures cannot be grouped according to the type of source since both wells and spring(s) resulted in cooler (Prescott WS, Owens W7, and Unnamed W NE of Bat HS) and warmer (all other expressions for this site) temperatures.

\subsubsection{Temperature Estimated by RTEst}

RTEst estimated reservoir temperatures are shown in Figure 3. With the exceptions of Durfee and Fairchild systems, RTEst temperatures for all other sites are similar regardless of the sampling source. Several samples representing the Banbury site resulted in temperature estimates in the range of 134 to $161{ }^{\circ} \mathrm{C}$. Although slightly cooler reservoir temperature estimates for this system are obtained for water compositions measured from a few wells (e.g., Sliger Well), the majority of the wells resulted in similar geothermometry reservoir temperatures to those estimates based on water composition measured for the three hot springs in the area. The difference in mean estimated temperature obtained from hot springs and wells is about $5{ }^{\circ} \mathrm{C}$ for the Banbury site (Table 2). Similarly, the estimated temperatures for the Battle Creek

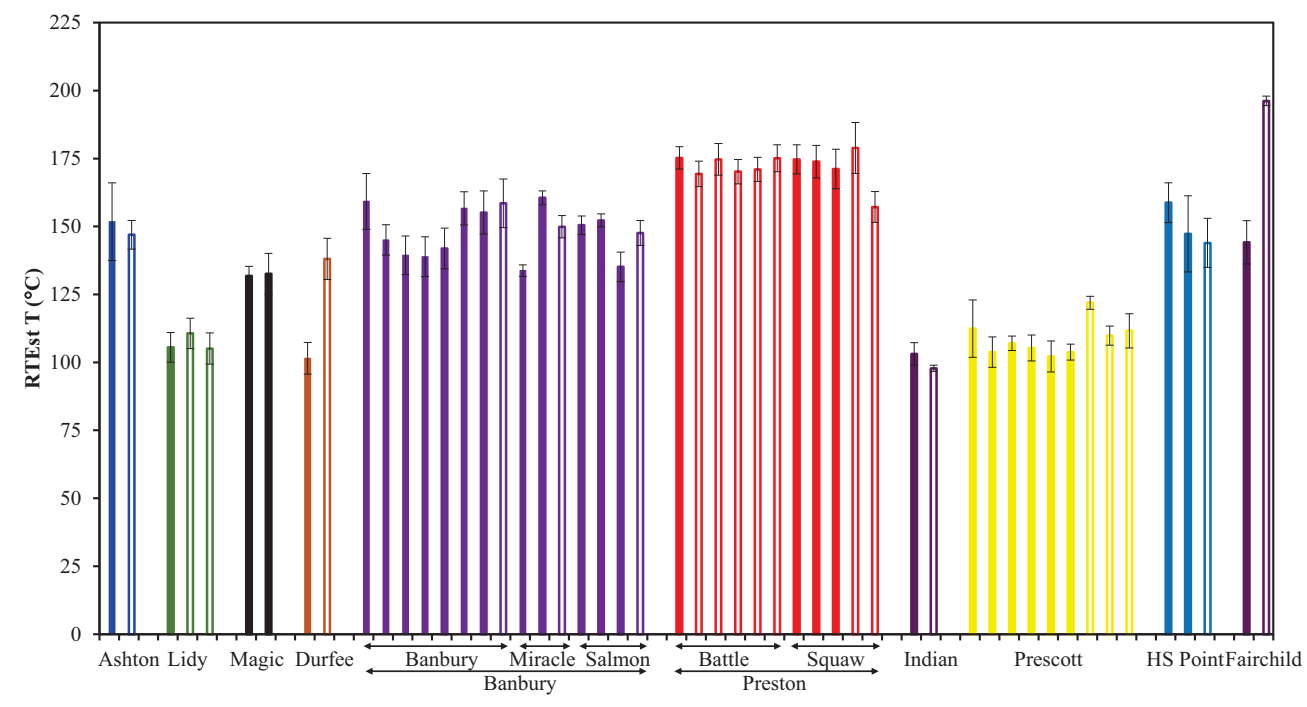

Figure 3. RTEst (Palmer et al., 2014) temperature estimates for several geothermal sites in southern Idaho using composition of water samples collected from hot springs (open bars) and nearby wells (solid bars). For Magic Reservoir Hot Spring geothermal site, both temperature estimates are based on the composition of water samples derived from the same well (one from the shallow leak, and the other from surface runoff). (Preston) site range from 157 to $179^{\circ} \mathrm{C}$. With the exception of the relatively cooler temperature estimate from the composition of Squaw HS2, all other hot springs and wells in the area resulted in reservoir temperature estimates within a tight temperature range from 169 to $179{ }^{\circ} \mathrm{C}$. The Prescott site, which has a large number of samples from various sources, also resulted in similar reservoir temperatures within a range of 102 to $122^{\circ} \mathrm{C}$ (Figure 3). Similarly, reservoir temperature estimates obtained from spring and well water composition pairs for the Lidy, Indian, and HS Point sites are similar (Figure 6). The difference in mean reservoir temperatures estimated from water compositions of hot springs and wells for the Banbury, Battle Creek, Prescott, Lidy, and Indian sites are about 5, 3, 9, 2, 5, and $9^{\circ} \mathrm{C}$, respectively (Table 2).

Although variants of silica geothermometers and the Na-K-Ca geothermometer resulted in discordant reservoir temperature estimates for the Ashton geothermal site when using water compositions from Ashton Warm Spring and Sturm Well, RTEst provided similar reservoir temperatures (Figure 3, Table 2) obtained from the compositions of water from these two sources. Since the traditional geothermometers only use a limited numbers of solute(s) present in the water for the development of reservoir temperature estimates, they tend to have limited capability to address physico-chemical processes that may have affected the composition of water along the flow path, it is likely that we can get discordant temperature estimates with water samples collected from different expressions if they have different flow paths and are subjected to different physico-chemical processes. However, MEG uses multiple components and a suite of minerals in estimating equilibrated reservoir temperatures, and RTEst has the ability to reconstruct reservoir fluid as a function of fugacity of $\mathrm{CO}_{2}$, mass of water, and temperature and uses that reconstructed fluid to estimate reservoir temperature.

An interesting example we considered in this paper is the Magic Reservoir Hot Spring site. For this site, paired water samples do not represent a spring and a well but only a single well. Water samples were directly collected from a shallow 
leak in the well and from the surface runoff (outflow) of the well. Although the field temperature of the runoff water was much cooler than the temperature of well water, the chemistries of both samples are very similar (except higher $\mathrm{pH}$ of the runoff water because of enhanced degassing of $\mathrm{CO}_{2}$ ) indicating no significant water loss due to evaporation upon cooling. The RTEst temperature estimates based on these two waters are identical with a slightly higher uncertainty value in the reservoir temperature estimated using runoff water.

As noted above, RTEst estimated reservoir temperatures obtained using the composition of paired sources of waters for two sites (Durfee and Fairchild) are different. For the Durfee site, the composition of water measured from a hot spring resulted in reservoir temperature that is $37^{\circ} \mathrm{C}$ hotter than the reservoir temperature that the composition of water measured from a nearby hot shallow well produced (Table 2). At this site, the hot spring (Durfee Hot Spring) and a nearby well (Harold Ward Well) are located about $220 \mathrm{~m}$ apart. Both expressions issue $\mathrm{Na}-\mathrm{Cl}-\mathrm{HCO}_{3}$ type water at similar temperatures (Table 1). Based on the concentrations of non-conservative components $\mathrm{Na}$ and $\mathrm{SiO}_{2}(\mathrm{aq})$ in these waters, it appears that the Harold Ward Well water may have been diluted slightly more than the Durfee Hot Spring. However, the concentration of $\mathrm{Cl}$ (a conservative component), which has been detected at higher concentration in well water than its concentration in spring water, does not support this hypothesis. Furthermore, these two waters have distinctively different $\mathrm{Ca}$ and $\mathrm{Mg}$ concentrations (well water having significantly higher concentration of $\mathrm{Mg}$ and $\mathrm{Ca}$ than their concentrations in spring water). Although it is inconclusive to implicate further dilution of reservoir fluid before it issues to the well, it is likely that the well produces reservoir fluid that may have re-equilibrated to lower temperature.

Similar to the Durfee site, estimated reservoir temperature for the Fairchild site obtained from the composition of hot spring water is $52{ }^{\circ} \mathrm{C}$ hotter (Table 2) than that obtained from the composition of water measured from a hot well located at a relatively large distance (over $7 \mathrm{~km}$ ). These two sources issue different types of water, with the spring issuing $\mathrm{Na}-\mathrm{SO}_{4}$ type water and well issuing $\mathrm{Na}-\mathrm{HCO}_{3}$ type water. The diverse reservoir temperature estimates with these two water compositions may be related to that they represent different reservoir systems, as they are located fairly far apart. It is not uncommon to have compartmentalized reservoir systems with distinct chemical composition within a small area. Ayling and Moore (2013) reported such a compartmentalized reservoir system at the Raft River geothermal field in south Idaho. However, unlike the Fairchild site situation, water samples from different Raft River geothermal field wells (deep wells) with high and low TDS result in similar temperature estimates for the reservoir. Nevertheless, the results of the Durfee and Fairchild site indicate that it is important to consider (compare) the chemistry of water from different sources and the distance between these sources while using the compositions of water measured from multiple sources to evaluate the geothermal potential of a prospect.

\section{Conclusions}

Our geothermometric study of multiple geothermal sites in southern Idaho indicates that the water chemical compositions from hot shallow wells can be as useful in determining reservoir temperatures using multicomponent geothermometry as those from hot springs. Seven of the nine geothermal sites that had paired hot springs and nearby wells in southern Idaho calculated similar reservoir temperatures. For these sites, the largest difference in the mean estimated reservoir temperatures (calculated when more than one spring and well are present) was less than $\leq 9^{\circ} \mathrm{C}$.

Two geothermal sites exhibited a large difference in the calculated reservoir temperature between the hot spring and the nearby well. At the Durfee and Fairchild sites, the estimated reservoir temperatures using RTEst from hot springs are higher than nearby hot shallow wells by $37{ }^{\circ} \mathrm{C}$ and $52{ }^{\circ} \mathrm{C}$, respectively. In the case of the Durfee site, water from the well may have re-equilibrated with the minerals in the aquifer at a lower temperature along its flow path. Similarly, for the Fairchild site, the water may have re-equilibrated with different mineral assemblages along its flow path to the well, or that the hot spring and well expressions are issuing waters migrated from two separate geothermal reservoirs. The water composition of the hot spring and the well are chemically distinct types of water and may not be located close enough together ( $>7 \mathrm{~km}$ distance between them) to be considered an appropriate pair for this study.

Although the majority of southern Idaho geothermal sites have water compositions from hot springs and nearby wells that provide concordant reservoir temperatures, it is imperative to consider the water types, variations in water chemistry, and distance between the sources prior to assessing potential geothermal reservoir temperatures. These results suggest that besides the existing hot springs thermal expressions that have used to assess the potential geothermal reservoir temperatures in the past, there exist a large number of wells that can be used to develop a more complete picture of the subsurface geothermal reservoir temperature.

\section{Acknowledgments}

Funding for this research was provided by the U.S. Department of Energy, Office of Energy Efficiency \& Renewable Energy, Geothermal Technologies Office. 


\section{References}

Ayling, B. and J. Moore, 2013. "Fluid geochemistry at the Raft River geothermal field, Idaho, USA: New data and hydrogeological implications." Geothermics, 47, 116-126.

Bethke, C.M., 2008. "Geochemical and Biogeochemical Reaction Modeling." Cambridge University Press, 547 pp.

Cooper, D.C., C.D. Palmer, R.W. Smith, and T.L. McLing, 2013. "Multicomponent equilibrium models for testing geothermometry approaches." Proceedings, 38th Workshop on Geothermal Reservoir Engineering Stanford University, Stanford, February 11-13, 2013 SGP-TR-198.

D’Amore, F. and S. Arnórsson, 2000. “Geothermometry.” In: Isotopic and chemical techniques in geothermal exploration, development and use, Ed. S. Arnórsson. International Atomic Energy Agency, Vienna, Australia.

D'Amore, F., R. Fancelli, and R. Caboi, 1987. "Observations on the application of chemical geothermometers to some hydrothermal systems in Sardinia." Geothermics, 16, 271-282.

Fournier, R.O., D.E. White, and A.H. Truesdell, 1974. "Geochemical indicators of subsurface temperature - 1, Basic assumptions.” U.S. Geol. Survey J. Res., 2, 259-262.

Fournier, R.O., 1977. "Chemical geothermometers and mixing models for geothermal systems." Geothermics, 5, 41-50.

Fournier, R.O., and R.W. Potter II, 1979. "Magnesium correction to the Na-K-Ca chemical geothermometer." Geochimica et Cosmochimica Acta, 43, $1543-1550$

Fournier, R.O. and A.H. Truesdell, 1973. "An empirical Na-K-Ca geothermometer for natural waters.” Geochimica et Cosmochimica Acta, 37, $1255-1275$.

Giggenbach, W.F., 1988. "Geothermal solute equilibria. Derivation of Na-K-Mg-Ca geoindicators." Geochimica et Cosmochimica Acta, 52, $2749-2765$.

Hull, C.D., M.H. Reed, and K. Fisher, 1987. "Chemical geothermometry and numerical unmixing of the diluted geothermal waters of the San Bernardino Valley Region of Southern California.” GRC Transactions, 11, 165-184.

Michard, G. and E. Roekens, 1983. "Modelling of the chemical components of alkaline hot waters." Geothermics, 12, 161-169.

Mitchell, J.C., 1976. "Geothermal Investigations in Idaho: Part 5, Geochemistry and geologic setting of the thermal waters of the northern Cache valley area, Franklin county, Idaho.” Idaho Dep. Water Resources, Water Inf. Bull., No. 30.

Mitchell, J.C., L.L. Johnson, and J.E. Anderson, 1980. "Geothermal Investigations in Idaho, Part 9, Potential for direct heat application of geothermal resources.” Idaho Dep. Water Resources, Water Inf. Bull., No. 30.

Neupane, G., R.W. Smith, C.D. Palmer, and T.L. McLing, 2013. "Multicomponent equilibrium geothermometry applied to the Raft River geothermal area, Idaho: preliminary results." Geological Society of America Abstracts with Programs, 45(7), 859.

Neupane, G., E.D. Mattson, T.L. McLing, C.D. Palmer, R.W. Smith, and T.R. Wood, 2014. "Deep geothermal reservoir temperatures in the Eastern Snake River Plain, Idaho using multicomponent geothermometry." Proceedings, Thirty-Ninth Workshop on Geothermal Reservoir Engineering, Stanford University, Stanford, California, February 24-26, 2014 SGP-TR-202.

Neupane, G., E.D. Mattson, T.L. McLing, C.D. Palmer, R.W. Smith, T.R. Wood, and R.K. Podgorney, 2015a. "Geothermal reservoir temperatures in southeastern Idaho using multicomponent geothermometry.” Proceedings, World Geothermal Congress 2015, Melbourne, Australia, 19-25 April 2015.

Neupane, G., J.S. Baum, E.D. Mattson, G.L. Mines, C.D. Palmer, and R.W. Smith, 2015b. "Validation of multicomponent equilibrium geothermometry at four geothermal power plants." Proceedings, Fortieth Workshop on Geothermal Reservoir Engineering Stanford University, Stanford, California, January 26-28, 2015.

Palmer, C.D., S.R. Ohly, R.W. Smith, G. Neupane, T. McLing, E. Mattson, 2014. "Mineral selection for multicomponent equilibrium geothermometry." GRC Transactions, 38, 453-459.

Palandri, J.L. and M.H. Reed, 2001. "Reconstruction of in situ composition of sedimentary formation waters." Geochimica et Cosmochimica Acta, $65,1741-1767$.

Pang, Z.H. and M. Reed, 1998. "Theoretical chemical thermometry on geothermal waters: Problems and methods." Geochimica et Cosmochimica Acta, 62, 1083-1091

Parliman, D.J. and H.W. Young, 1992. “Compilation of selected data for thermal-water wells and springs, 1921 through 1991.” US Geological Survey, Open-File Report 92-175.

Peiffer, L., C. Wanner, N. Spycher, E. Sonnenthal, B.M. Kennedy, J. Iovenitti, 2014. “Optimized multicomponent vs. classical geothermometry: insights from modeling studies at the Dixie Valley geothermal area." Geothermics, 51, 154-169.

Reed, M. and Spycher, N. (1984): Calculation of $\mathrm{pH}$ and mineral equilibria in hydrothermal waters with application to geothermometry and studies of boiling and dilution. Geochimica et Cosmochimica Acta, 48, 1479-1492.

Smith, R.W., C.D. Palmer, and D. Cooper, 2012. "Approaches for multicomponent equilibrium geothermometry as a tool for geothermal resource exploration.” AGU Fall Meeting, San Francisco, 3-7 December 2012.

Spycher, N.F., E. Sonnenthal, and B.M. Kennedy, 2011. "Integrating multicomponent chemical geothermometry with parameter estimation computations for geothermal exploration.” GRC Transactions, 35, 663-666.

Spycher, N., L. Peiffer, E.L. Sonnenthal, G. Saldi, M.H. Reed, and B.M. Kennedy, 2014. "Integrated multicomponent solute geothermometry." Geothermics, 51, 113-123.

Tole, M.P., H. Ármannsson, Z.H. Pang, and S. Arnórsson, 1993.” Fluid/mineral equilibrium calculations for geothermal fluids and chemical geothermometry." Geothermics 22, 17-37.

Young, H.W. and J.C. Mitchell, 1973. "Geothermal investigations in Idaho. Part 1. Geochemistry and geologic setting of selected thermal waters." U.S. Geological Survey and Idaho Dept. of Water Administration. 


\section{Appendix G.}

Neupane, G., Mattson, E.D., Cannon, J.C., Atkinson, T.A., McLing, T.L., Wood, T.R., Worthing, W.C., Dobson, P.F., and Conrad, M.E., 2016b. Potential hydrothermal resource areas and their reservoir temperatures in the Eastern Snake River Plain, Idaho. Proceedings, 41st Workshop on Geothermal Reservoir Engineering, Stanford University, Stanford, CA. 


\title{
Potential Hydrothermal Resource Areas and Their Reservoir Temperatures in the Eastern Snake River Plain, Idaho
}

\author{
${ }^{1,2}$ Ghanashayam Neupane*, ${ }^{1}$ Earl D. Mattson, ${ }^{2,3}$ Cody J. Cannon, ${ }^{4}$ Trevor A. Atkinson, ${ }^{1,2}$ Travis L. McLing, ${ }^{2,3}$ Thomas R. \\ Wood, ${ }^{2,3}$ Wade C. Worthing, ${ }^{5}$ Patrick F. Dobson, and ${ }^{5}$ Mark E. Conrad \\ ${ }^{1}$ Idaho National Laboratory, Idaho Falls, ID 83415, USA \\ ${ }^{2}$ Center for Advanced Energy Studies, Idaho Falls, ID 83401, USA \\ ${ }^{3}$ University of Idaho-Idaho Falls, Idaho Falls, ID 83402, USA \\ ${ }^{4}$ Ormat Technologies Inc., Reno, NV 89511, USA \\ ${ }^{5}$ Lawrence Berkeley National Laboratory, Berkeley, CA 94720 USA \\ E-mail: Ghanashyam.Neupane@inl.gov
}

Keywords: Eastern Snake River Plain, ESRP, RTEst, geothermal, geothermometer

\begin{abstract}
The Eastern Snake River Plain (ESRP) in southern Idaho is a region of high heat flow. Sustained volcanic activities in the wake of the passage of the Yellowstone Hotspot have turned this region into an area with great potential for geothermal resources as evidenced by numerous hot springs scattered along the margins of the plain and several hot-water producing wells and hot springs within the plain. Despite these thermal expressions, it is hypothesized that the pervasive presence of an overlying groundwater aquifer in the region effectively masks thermal signatures of deep-seated geothermal resources. The dilution of deeper thermal water and re-equilibration at lower temperature are significant challenges for the evaluation of potential resource areas in the ESRP. Over the past several years, we collected approximately 100 water samples from springs/wells for chemical analysis as well as assembled existing water chemistry data from the literature. We applied several geothermometric and geochemical modeling tools to these chemical compositions of ESRP water samples. Geothermometric calculations based on principles of multicomponent equilibrium geothermometry with inverse geochemical modeling capability (e.g., Reservoir Temperature Estimator, RTEst) have been useful for evaluating reservoir temperatures, and have indicated numerous potential moderate to high temperature geothermal prospects in the ESRP. Specifically, areas around southern/southwestern side of the Mount Bennett Hills and within the Camas Prairie in the western-northwestern regions of the ESRP and its margins suggest temperatures in the range of $140-200^{\circ} \mathrm{C}$. In the northeastern portions of the ESRP, Lidy Hot Springs, Ashton, Newdale, and areas east of Idaho Falls have expected reservoir temperatures $\geq 140{ }^{\circ} \mathrm{C}$. In the southern ERSP, areas near Buhl and Twin Falls are found to have temperatures as high as $160{ }^{\circ} \mathrm{C}$. These areas are likely to host potentially economic geothermal resources; however, further detailed study is warranted at each site to evaluate hydrothermal suitability for economic use.
\end{abstract}

\section{INTRODUCTION}

The eastern Snake River Plain (ESRP) in southeastern Idaho is a region of high heat flow with great potential for significant geothermal resources (Figure 1). A limited number of deep wells (such as INEL-1) and several hot springs and wells along the margin of ESRP also provide direct evidence of a high-temperature regime at depth in the area. However, most of the shallow wells within the ESRP generally have low field-measured temperature, and it is likely that the Eastern Snake River Plain Aquifer (ESRPA) is obscuring geothermal signature from depth. The ESRPA is a prolific aquifer hosted in a thick sequence of thin-layered, highly transmissive basalt flows. The aquifer rapidly transports cold water from the Yellowstone Plateau and surrounding mountain basins to springs along the Snake River Canyon west of Twin Falls, Idaho. The flush of cold water through the overlying ESRPA masks the geothermal signature of the heat existing at depth (e.g., Smith, 2004). Importantly, the geothermal gradient below the ESRP aquifer system increases rapidly (Blackwell, 1989; McLing et al., 2002; Nielson et al., 2012) providing additional evidence of the presence of a deep geothermal resource in the area.

Previously, we made an initial geothermometric assessment of the ESRP using limited water chemistry dataset (Neupane et al., 2014; Cannon et al., 2014). We followed on that work by collecting several new water samples from numerous geothermal features in the ESRP and surrounding areas. In this paper, we provide geothermometric assessment of some potential geothermal resource areas in the ESRP. Specifically, we present geothermometric temperatures of geothermal areas distributed around southern/southwestern side of the Mount Bennett Hills, Camas Prairie, Lidy Hot Springs, Ashton area, Newdale area, and areas east of Idaho Falls. Similarly, we also present geothermometric results of geothermal areas around Buhl and Twin Falls area in the southern ESRP. The reservoir temperatures of these geothermal sites were estimated with traditional (e.g., Fournier, 1977) as well as a multicomponent geothermometry tool [e.g., Reservoir Temperature Estimator (RTEst) (Palmer et al., 2014; Mattson et al., 2015)] based on the chemical composition of thermal water samples.

\section{GEOLOGIC AND GEOTHERMAL SETTING OF EASTERN SNAKE RIVER PLAIN}

The Snake River Plain (SRP) is a topographic depression along the Snake River (Figure 1) in southern Idaho. The SRP is divided into two parts, the western Snake River Plain (WSRP) and the ESRP. The WSRP is a basalt- and sediment-filled tectonic feature defined by 
a normal fault-bounded graben whereas the ESRP is formed by crustal down-warping, faulting, and successive caldera formation that is linked to the middle Miocene to Recent volcanic activities associated with the relative movement of the Yellowstone Hot Spot (Figure 1) (Pierce and Morgan, 1992; Hughes et al., 1999; Rodgers et al., 2002). The $100 \mathrm{~km}$ wide ESRP extends over $600 \mathrm{~km}$ (Hughes et al., 1999). Four events in the late Tertiary are important for creation and shaping the ESRP (Hughes et al., 1999): (1) successive MiocenePliocene rhyolitic volcanic eruptive centers from southwest near the common border of Idaho, Oregon, and Nevada trending northeast to Yellowstone National Park in northwest Wyoming, (2) Miocene to Holocene crustal extension which produced the Basin and Range province, (3) Quaternary basaltic flows, and (4) Quaternary glaciation and associated eolian, fluvial, and lacustrine sedimentation and catastrophic flooding.

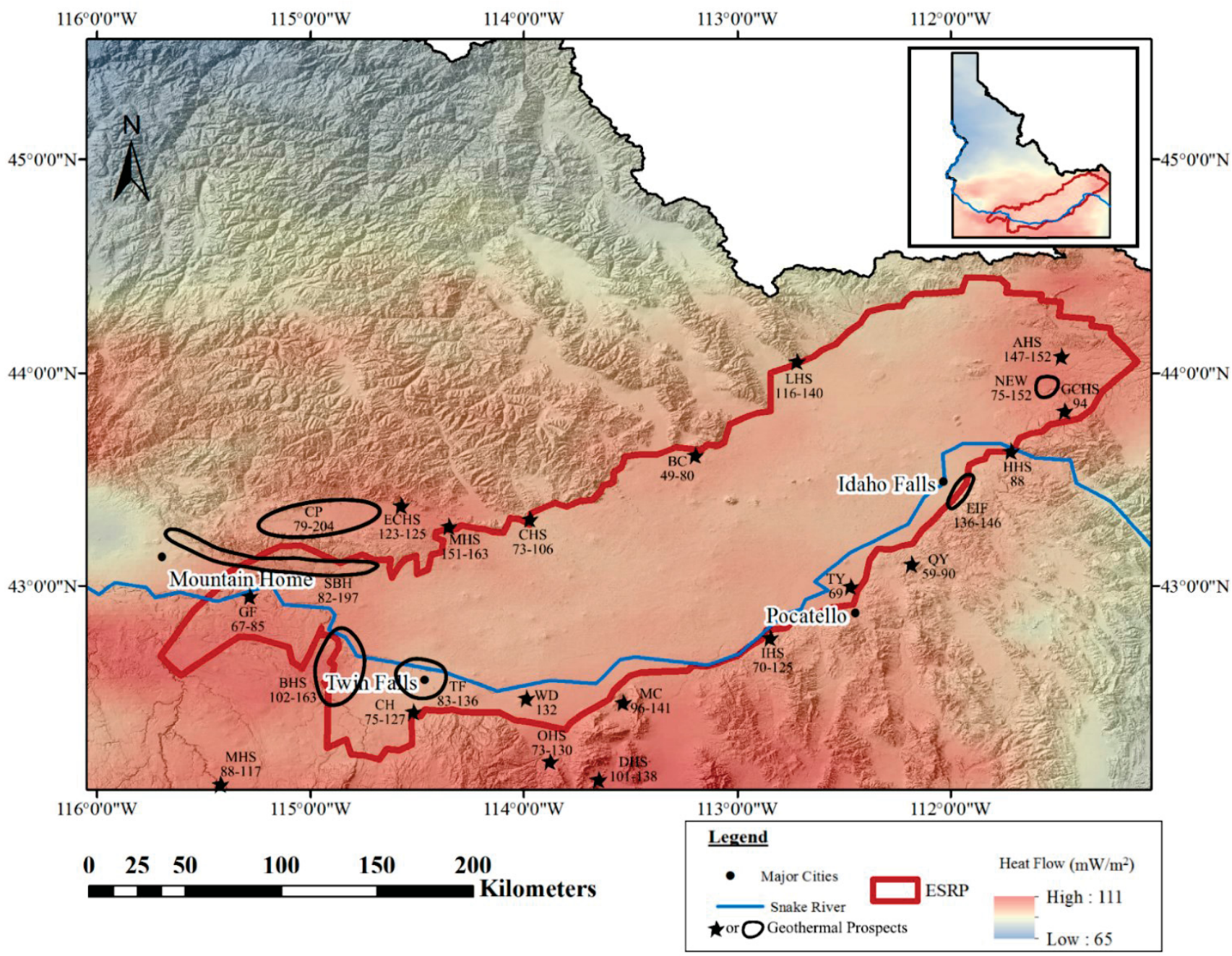

Figure 1. Map of the southern Idaho was prepared by draping heat flow map (Williams and DeAngelo, 2011) over DEM. The thick red line demarcates the margins of the ESRP from the surrounding Basin and Range province. Stars and polygons represent geothermal prospects (codenames are given in Table 1) in and around ESRP. The number or range of numbers associated with each geothermal prospect is the RTEst estimated reservoir temperature $\left({ }^{\circ} \mathrm{C}\right)$.

The ESRP consists of thick volcanic ash-flow tuffs, which are overlain by $>1 \mathrm{~km}$ of Quaternary basaltic flows (Figure 2). The felsic volcanic rocks at depth are the product of super volcanic eruptions associated with the Yellowstone Hotspot. These rocks progressively become younger to the northeast towards the Yellowstone Plateau (Pierce and Morgan, 1992; Hughes et al., 1999). The younger basalt layers are the result of several low-volume, monogenetic shield-forming eruptions of short-duration that emanated from northwest trending volcanic rifts in the wake of the Yellowstone Hot Spot (Hughes et al., 1999). The thick sequences of coalescing basalt flows with interlayered fluvial and eolian sediments in the ESRP constitute a very productive cold water aquifer system above the volcanic ash-flow tuffs (Whitehead, 1992).

Recent volcanic activity, a high heat flux $\left[\sim 110 \mathrm{~mW} / \mathrm{m}^{2}\right.$ (Blackwell, 1989; Smith, 2004)], and the occurrence of numerous peripheral hot springs suggest the presence of undiscovered geothermal resources in the ESRP. As a consequence of these geologic indicators, we hypothesize that the ESRP at depth hosts a large geothermal resource with the potential for one or more viable conventional or enhanced geothermal reservoirs. In particular, we consider the lower welded rhyolite ash-flow tuff zone (Figure 2) to have exploitable heat sources that can be tapped by EGS development. 


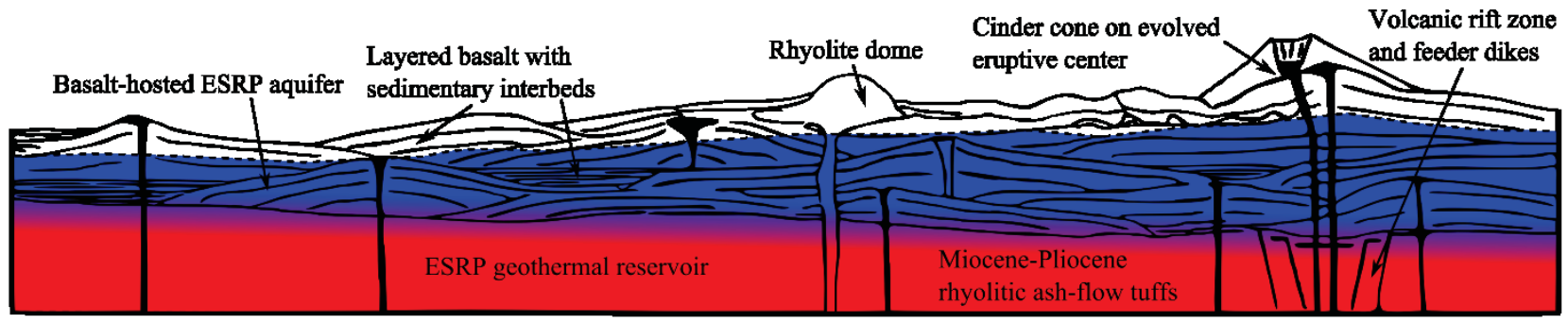

Figure 2. Schematic cross-section across the ESRP (modified from Hughes et al., 1999; Neupane et al., 2014) showing underlying rhyolitic ash-flow tuffs and overlying basalt flows with few sedimentary layers. The underlying rhyolite ash-flow tuffs are assumed to be the ESRP geothermal resource. Small amount of thermal waters are considered to be upwelling from underlying reservoir into the overlying basalt-hosted ESRP aquifer system. The presence of very productive, cold groundwater aquifer system is regarded to mask the underlying geothermal regime in the ESRP.

The ESRP system as a whole (including the deep geothermal reservoir and the overlying cold-water aquifer system) is an open and dynamic hydrogeologic system. Most water from shallow wells and springs in the ESRP are mixed waters of multiple sources, particularly a mix of meteoric water and deep-sourced reservoir water (McLing et al., 2002; Smith, 2004; Welhan, 2015). The upwelling thermal waters interact with the basalt at the base of the regionally extensive cold water aquifer (Morse and McCurry, 2002), with the altered basalt forming a permeability barrier: this helps mask the expression of the deep thermal resource (Figure 2).

\section{GEOTHERMOMETRY}

One of the tools used to prospect for geothermal resources is geothermometry, which uses the chemical compositions of water from springs and wells to estimate reservoir temperature. As an exploration tool, geothermometry offers a cost effective method to decrease exploration risk by evaluating a potential geothermal reservoir's temperature. To conduct geothermometry, measured chemical compositions of water from wells and springs that exhibit some level of elevated temperatures are needed. The application of geothermometry requires several assumptions. The most important assumptions are that the reservoir minerals and fluid attain a chemical equilibrium and as the water moves from the reservoir to sampled location, it retains its chemical composition (Fournier et al., 1974). The first assumption is generally valid (provided a long residence time); however, the second assumption is more likely to be violated because of composition altering processes, such as, re-equilibration at lower temperature, dilution (mixing), and loss of fluids (boiling) and volatiles (e.g., $\mathrm{CO}_{2}$ ) with the decrease in pressure.

Traditional geothermometers such as silica geothermometers, $\mathrm{Na} / \mathrm{K}$ geothermometer, etc., are empirical to semi-empirical approaches where a user enters the measured concentration of certain component(s) into the geothermometer equation. The reliability, sensitivity, and responsiveness of traditional geothermometers to various composition altering processes vary. For example, geothermometers based on cation concentration ratios (e.g., $\mathrm{Na} / \mathrm{K}$ geothermometer) are minimally sensitive to boiling or mixing with dilute water; while geothermometers based directly on the concentration of component(s) (e.g., quartz geothermometer) are highly sensitive to these processes (D'Amore and Arnórsson, 2000)). A drawback of many existing geothermometry approaches is that they do not adequately account for physical processes (e.g., mixing, boiling) and geochemical processes (e.g., mineral dissolution, precipitation, degassing) that may occur after the water leaves the reservoir and thereby alters its composition. If these changes are not taken into account, predictions of in-situ reservoir conditions (e.g., temperature, $\mathrm{fCO}_{2}$ ) based on the chemical composition of water samples taken from shallower depths or at the surface may be erroneous, or too imprecise to be useful.

In addition, it is difficult to quantify uncertainties associated with temperatures estimated with these geothermometers. As a result, it is not uncommon to find diverse temperature estimates for the same water using multiple traditional geothermometers. Nevertheless, because these geothermometers are easy to use and sometimes provide good results, they are considered to be an essential part of the geothermal exploration toolkit (D’Amore and Arnórsson, 2000).

A more advanced geothermometric approach is multicomponent equilibrium geothermometry (MEG). The MEG approach of geothermometry utilizes multiple chemical constituents measured in water samples for inverse geochemical modeling considering a suite of selected minerals (selected based on some knowledge of the system) so as to provide more robust temperature estimates with quantifiable uncertainties. Geothermal temperature predictions using MEG provide apparent improvement in reliability and predictability of temperature over traditional geothermometers. The basic concept of this method was developed in 1980s (e.g., Michard and Roekens, 1983; Reed and Spycher, 1984). Some previous investigators (e.g., D'Amore et al., 1987; Hull et al., 1987; Tole et al., 1993) have used this technique for predicting reservoir temperatures in various geothermal sites. Other researchers have used the basic principles of this method for reconstructing the composition of geothermal fluids and formation brines (Pang and Reed, 1998; Palandri and Reed, 2001). More recent efforts by some researchers (e.g., Bethke, 2008; Spycher et al., 2011; Smith et al., 2012; Cooper et al., 2013; Neupane et al., 2013, 2014; Cannon et al., 2014; Spycher et al., 2014; Peiffer et al., 2014; Palmer et al., 2014; Neupane et al., 2015a,b,c; Mattson et al., 2015; Neupane et al., 2016a,b) have been focused on improving temperature predictability of the MEG.

For this study, both traditional [e.g., quartz (no steam loss) (Fournier, 1977), chalcedony (Fournier, 1977), and Na-K-Ca (Truesdell and Fournier, 1973; Fournier and Potter, 1979)] and RTEst (Palmer et al., 2014; Mattson et al., 2015) geothermometric approaches were applied to estimate reservoir temperatures. For the silica geothermometers, $\mathrm{pH}$ correction on silica concentrations was not applied. While applying RTEst to each water sample, a mineral assemblage consisting of 5-7 representative minerals (Mg bearing minerals clinochlore, illite, saponite, beidellite, talc; Na bearing minerals - paragonite, saponite; K-bearing minerals - K-feldspar, clinoptilolite- 
Neupane et al.

$\mathrm{K}$, illite; Ca bearing minerals - calcite; fluorite, and chalcedony) was used for the development of the reservoir temperature estimate for each sample. For each site, the same mineral assemblage was used for all samples using the same thermodynamic database (e.g., LNNL database based thermo.dat database of Geochemist's Workbench). In general, the mineral assemblage is selected based on available information such as water chemistry (e.g., $\mathrm{pH}$ ), likely reservoir rock types and temperature range, etc. For more detailed information on selection of the mineral assemblage, see Palmer et al. (2014).

\section{WATER SAMPLES}

\subsection{New data}

As a major part of this work, we initiated a sampling campaign during the spring and summer of 2014 and 2015 (Cannon et al., 2014 ; Dobson et al., 2015; Neupane et al., 2015c). The sampling campaign was aimed at collecting samples from thermal features that either have incomplete available data or were not sampled/analyzed previously. Our goal was to develop an extensive thermal expression chemistry data set to be used for geothermometry calculations using RTEst as well as for analyzing for other trace elements, isotopes, and noble gases. Over the course of the project period, we collected and analyzed over 90 samples from thermal features in the ESRP and surrounding area. The water chemistry data will be available from the National Geothermal Data System (NGDS) web portal.

\subsection{Historical data}

Existing southeast Idaho water composition data have been obtained from the Idaho Department of Water Resources, literature searches from the Web of Science, and examining dissertations at the University of Idaho. Existing water composition data were evaluated for their quality (e.g., charge balance, etc.) and completeness (except Al) for MEG. Almost all of the historical data lacked measured concentration of Al, and for these samples, a value determined by assuming equilibrium with K-feldspar (Pang and Reed, 1998) was used in the geochemical modeling. In some instances, the Al values measured in new samples collected from nearby hot springs or hot wells were used.

Existing data and new chemical data were used for the estimation of reservoir temperatures with traditional geothermometers as well as with RTEst. In the past, we used historical data for preliminary evaluation of geothermal resources along the margins of the ESRP (e.g., Neupane et al., 2014). Some of the geothermal features with available good quality and complete geochemical data were also sampled during our sampling campaigns, and for most of these features, the existing data were found to be similar to the new chemical data.

\subsection{Hot springs and nearby hot wells}

Both compositions of water samples collected from hot springs as well as shallow hot wells were used with equal importance for the temperature estimation of several geothermal prospects in ESRP. It is generally assumed that the geothermal system manifest some kind of surface signals such as hot springs or fumaroles, however, there have been some hidden or blind geothermal systems. For example, the Raft River geothermal system was identified when shallow (120-150 m deep) wells that were drilled for domestic and stock use encountered boiling water (Williams et al., 1976). Similarly, in the ESRP, the Newdale prospect (NEW in Figure 1) was first identified by the presence of numerous hot shallow wells in the area. However, how useful hot shallow waters can be for geothermometric calculations in the southern Idaho was an issue for us when we started this work. Recently, we compared the temperature estimates of hot springs and nearby wells in southern Idaho (Neupane et al., 2015c). That study indicated that that the reservoir temperatures estimated using water compositions measured from surface thermal features and wells produce similar results. However, there are a few systems where the estimated reservoir temperatures based on water compositions measured from hot springs and hot wells are different. Neupane et al. (2015c) emphasized that when such differences exist, it is imperative to consider the consistency of the water types and distance between the sources when estimating reservoir temperatures. With the exception of the Durfee Hot Spring prospect [the same system was also noted by Neupane et al. (2015c) as one of two systems examined in southern Idaho that have divergent temperature estimates with hot spring and hot well compositions] (DHS in Figure 1), all other prospects with measured compositions from samples collected from hot springs and hot wells in the ESRP yielded similar results (see section 5).

\subsection{Geothermal prospects}

Based on the distribution of samples, 24 geothermal prospects are identified (Figures 1, 3, and Table 1). The number of samples in each prospect (Table 1) vary such that some prospects have multiple samples (e.g., Banbury Hot Springs prospect has 37 samples) from different sources where as some prospects have few number of samples (e.g., Wybenga Diary prospect has only one sample). Much more detailed descriptions of these prospects are forthcoming.

\section{RESULTS}

\subsection{Water chemistry}

Compositions of waters from hot/warm springs and wells in southeastern Idaho are presented in Figure 3. All springs/wells (with few exceptions such as Spackman well in Newdale prospect) that we sampled represent the expression of geothermal activities (field $\mathrm{T}>20$ ${ }^{\circ} \mathrm{C}$ ) in the ESRP. The highest field temperature within and along the margins of ESRP was recorded at the Magic Hot Spring Landing well $\left(75^{\circ} \mathrm{C}\right)$ in Magic Hot Spring prospect (MHS in Figure 1). The pH of ESRP thermal waters ranges from 6.3 to 9.6. These thermal waters show a large range in total dissolved solids (TDS) from about $106 \mathrm{mg} / \mathrm{L}$ (Sturm well in Ashton prospect, AHS in Figure 1) to more than 7,000 mg/L (Heise Hot Spring, HHS in Figure 1). 


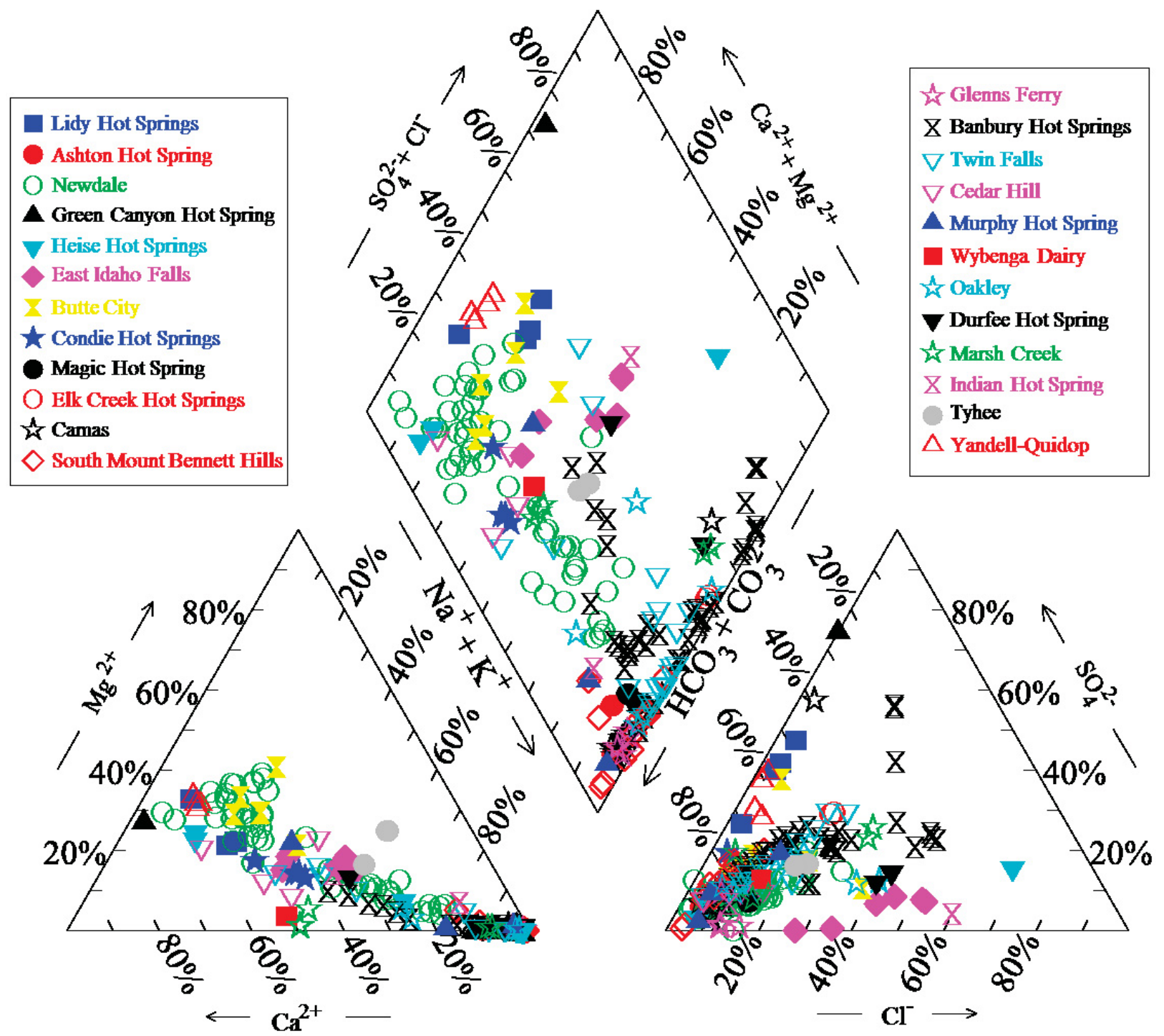

Figure 3. Chemistry of the ESRP thermal water samples shown on Piper diagram

Based on the dominant ions (Figure 3Error! Reference source not found.) in water, ESRP waters can be grouped into 10 water types. These are $\mathrm{Ca}-\mathrm{HCO}_{3}, \mathrm{Mg}-\mathrm{HCO}_{3}, \mathrm{Ca}-\mathrm{Mg}-\mathrm{HCO}_{3}, \mathrm{Na}-\mathrm{HCO}_{3}, \mathrm{Ca}-\mathrm{SO}_{4}, \mathrm{Na}-\mathrm{SO}_{4}, \mathrm{Na}-\mathrm{Cl}, \mathrm{Na}-\mathrm{K}-\mathrm{HCO}_{3}, \mathrm{Na}-\mathrm{K}-\mathrm{Cl}-\mathrm{SO}_{4}$, and Ca-Na-HCO $\mathrm{C}_{3}$ type waters. In general, ESRP waters have either $\mathrm{Ca}-\mathrm{Mg}$ or $\mathrm{Na}$ as the dominant cations and $\mathrm{HCO}_{3}$ as the dominant anion. The ESRP waters with dominant $\mathrm{HCO}_{3}$ may have been the product of carbonated water-rock interaction at low to high temperatures. Specifically, Na$\mathrm{HCO}_{3}$ waters are considered deeper ESRP water whereas $\mathrm{Ca}-\mathrm{Mg}-\mathrm{HCO}_{3}$ water are shallower ESRPA water. The few water samples (e.g., Heise Hot Spring, Green Canyon Hot Spring, etc.) with $\mathrm{Cl}$ and/or $\mathrm{SO}_{4}$ as dominant anions may have originated with water-rock interaction involving Paleozoic evaporite beds.

\subsection{Geothermometric assessments}

\section{$\underline{5.2 .1 \text { Giggenbach diagram }}$}

The sample compositions are also plotted on a Giggenbach ternary diagram (Giggenbach, 1988) to determine evidence of equilibration and/or mixing (Error! Reference source not found.) as well as to illustrate the likely water-rock interaction temperatures in the reservoirs. This plot is useful to classify waters into fully equilibrated waters, partially equilibrated, and immature waters. The diagram uses the full range of equilibrium relationships between $\mathrm{Na}, \mathrm{K}$, and $\mathrm{Mg}$ to determine the degree of equilibration between the water and the rock at depth. The plot suggests that the waters from several ESRP wells and springs are partially equilibrated that may have interacted with the reservoir rocks at temperatures ranging from $100{ }^{\circ} \mathrm{C}$ to $180{ }^{\circ} \mathrm{C}$. However, majority of the ESRP waters are immature waters, as indicated by elevated $\mathrm{Mg}$ contents. The immature waters may indicate significant mixing with cool meteoric waters, and traditional geothermometers may not be suitable tools for temperature estimation for these waters. 


\subsubsection{Temperature estimates with traditional geothermometers}

Traditional geothermometers were applied to measured water compositions for general assessment of the geothermal temperature at each sampling site. There have been several established empirical/semi-empirical geothermometers based on the relationship between concentrations (or concentration ratios) of chemical components with temperature. Even though majority of these geothermometers are based on empirically fitted curves, there have been some postulated geochemical basis (assumptions) supporting these relationships. For example, silica geothermometers are based on solubility of solid-phase silica (e.g., quartz, chalcedony, etc.) controlling the aqueous concentration of silica. Similarly, several variations of sodium-potassium geothermometers are based on water-rock interaction involving albite and K-feldspar. Similarly, the sensitivity and responsiveness of geothermometers to various composition-altering processes are not similar. For example, geothermometers based on cation concentration ratios are not sensitive to boiling or mixing with dilute water; however, geothermometers based directly on the concentration of component(s) show large temperature sensitivity to these processes. In practice, it is not uncommon to find diverse temperature estimates for the same water with multiple traditional geothermometers. Therefore, whenever the assumptions on which a geothermometer is based on are not satisfied, temperature estimates with it are likely to be erroneous.

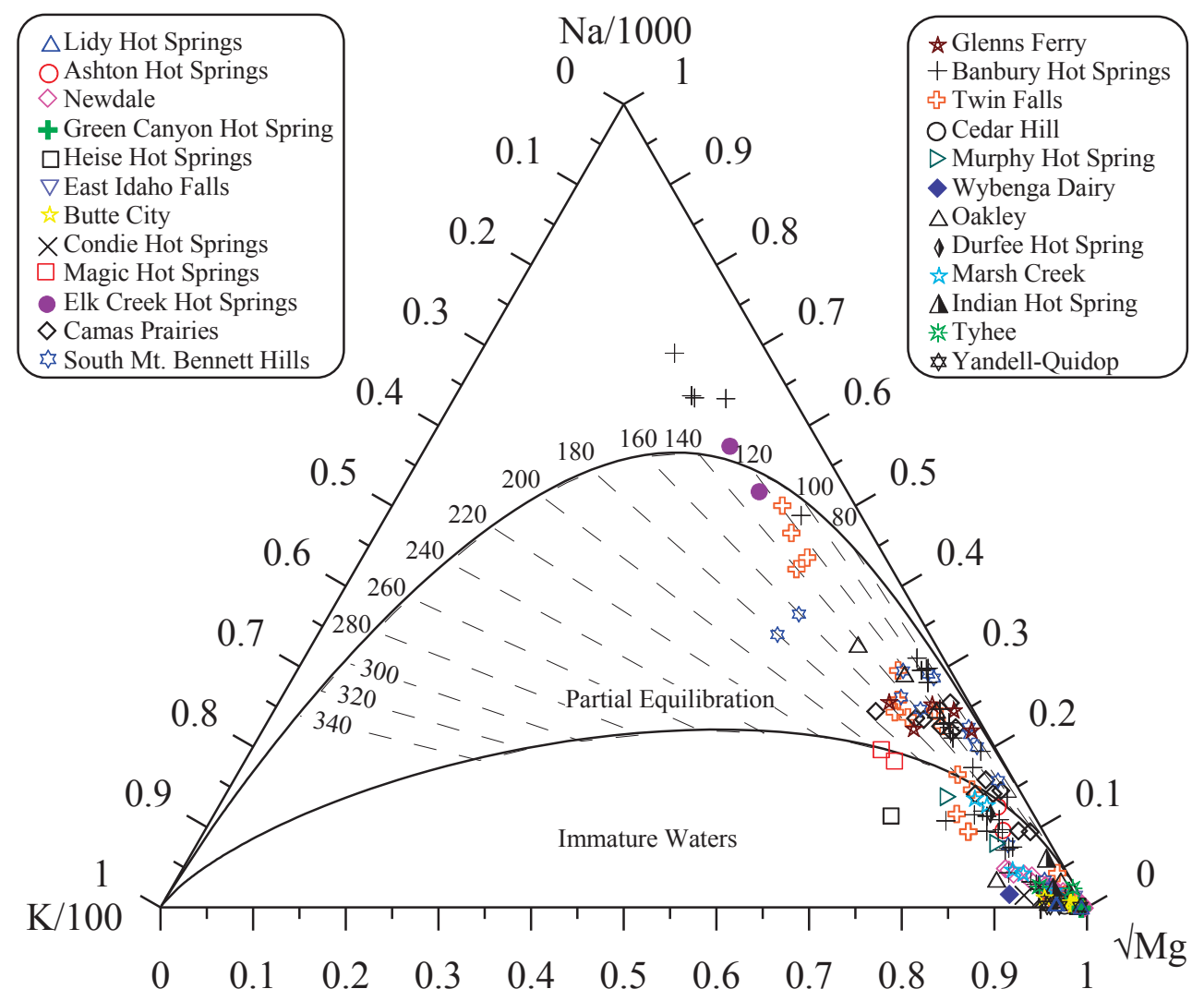

Figure 4. Giggenbach ternary diagram for the ESRP thermal water samples

For the ESRP, the traditional geothermometer-based temperatures can be difficult to use to assess the geothermal potential of prospects. For example, estimated temperature values for the Heise Hot Spring, range from $53{ }^{\circ} \mathrm{C}$ using chalcedony to $243{ }^{\circ} \mathrm{C}$ using Na/K ratios. Nevertheless, for some samples from other prospects, such as a well at the College of Southern Idaho (CSI Well2) representing the Twin Falls geothermal prospect, the range of estimated temperatures is from $85{ }^{\circ} \mathrm{C}$ to $140{ }^{\circ} \mathrm{C}$ suggesting relatively good agreement between the traditional geothermometry temperature estimates. In general, we have found that ESRP thermal estimated temperatures using the $\mathrm{Na} / \mathrm{K}$ rations are higher than estimated temperatures obtained with other geothermometers.

\subsubsection{Temperature estimates with RTEst}

All water samples collected during the sampling campaigns of 2014 and 2015 as well as useful water compositions assembled from literature for this study were used for the temperature estimation with RTEst. For each sample, 5-7 minerals (consisting mainly of silicapolymorphs, clays, zeolites, carbonates, sulfates, feldspars, etc.) were selected as a mineral assemblage.

An example of the RTEst results for a water sample collected from Miracle Hot Spring well located in Banbury Hot Springs prospect (BHS in Figure 1) is shown in 5 a shows $\log \mathrm{Q} / \mathrm{K}_{\mathrm{T}}$ curves of the reservoir mineral assemblage (calcite, chalcedony, beidellite, mordenite, and paragonite) used for the Miracle Hot Spring water composition. The $\log \mathrm{Q} / \mathrm{K}_{\mathrm{T}}$ curves of these minerals intersect the $\log \mathrm{Q} / \mathrm{K}_{\mathrm{T}}=0$ at a wide range of temperatures, making the $\log \mathrm{Q} / \mathrm{K}_{\mathrm{T}}$ curves derived from the reported water chemistry minimally useful for estimating temperature. The range of equilibration temperature for the assemblage minerals is a reflection of physical and chemical processes that may have modified the Miracle Hot Spring water composition during its ascent to the sampling point. 
To account for possible composition altering processes, RTEst was used to simultaneously estimate a reservoir temperature and optimize the amount of dilute near-surface $\mathrm{H}_{2} \mathrm{O}$ mixed with the thermal water (a physical process) and the fugacity of $\mathrm{CO}_{2}$ change (a chemical process) that may have occurred during its accent to the surface. Using these two additional optimization parameters, the results for the corrected fluid composition of Miracle Hot Spring are shown in Figure 5b. Compared to the log Q/KT curves calculated using the reported water compositions (Figure 5a), the optimized curves (Figure $5 \mathrm{~b}$ ) converge to $\log \mathrm{Q} / \mathrm{KT}=0$ within a narrow temperature range (i.e., $161 \pm 3{ }^{\circ} \mathrm{C}$ ).

The optimized temperatures and composition parameters for the other ESRP waters were estimated using RTEst in the same manner. The RTEst estimated temperatures for the ESRP geothermal samples range from about $60{ }^{\circ} \mathrm{C}$ to $204{ }^{\circ} \mathrm{C}$. The hottest reservoir temperature estimate is obtained for Wardrop Hot Spring located in north-central part of Camas Prairie (CP in Figure 1). Similarly, hot springs located on the southern side of the Mount Bennett Hills (e.g., Prince Albert Hot Spring, Latty Hot Spring) (SBH in Figure 1) also have reservoir temperature estimates as high as $200^{\circ} \mathrm{C}$.

Table 1. Estimated temperatures $\left({ }^{\circ} \mathrm{C}\right)$ for several geothermal prospects in the ESRP

\begin{tabular}{|c|c|c|c|c|c|c|}
\hline Prospects & Measured $^{\mathrm{a}}$ & RTEst $^{\mathrm{b}}$ & Quartz (nsl) $^{\mathrm{c}}$ & Chalcedony $^{\mathrm{d}}$ & $\mathrm{Na}-\mathrm{K}-\mathrm{Ca}^{\mathrm{e}}$ & Map Code ${ }^{f}$ \\
\hline Lidy Hot Springs $(4)^{g}$ & 56 & $116-140$ & $57-89$ & $25-58$ & $44-65$ & LHS \\
\hline Ashton Hot Spring (2) & 63 & $147-152$ & $113-143$ & $84-116$ & $109-117$ & AHS \\
\hline Newdale (50) & 87 & $75-152$ & $66-134$ & $26-112$ & $29-111$ & NEW \\
\hline Green Canyon Hot Spring (1) & 44 & 94 & 75 & 44 & 65 & GCHS \\
\hline Heise Hot Spring (1) & 48 & 88 & 84 & 53 & 89 & HHS \\
\hline East Idaho Falls (6) & 28 & $136-146$ & $115-143$ & $86-117$ & $45-74$ & EIF \\
\hline Butte City (6) & 41 & $49-80$ & $70-106$ & $38-77$ & $37-43$ & $\mathrm{BC}$ \\
\hline Condie Hot Spring (4) & 51 & $73-106$ & $71-82$ & $40-51$ & $71-83$ & $\mathrm{CHS}$ \\
\hline Magic Hot Spring $(2)^{\mathrm{h}}$ & 75 & $151-163$ & $139-142$ & $113-116$ & $143-149$ & MHS \\
\hline Elk Creek Hot Springs (2) & 56 & $123-125$ & $114-115$ & 86 & $107-110$ & ECHS \\
\hline Camas Prairie (13) & 73 & $79-204$ & $103-128$ & $74-100$ & $70-124$ & $\mathrm{CP}$ \\
\hline South Mount Bennett Hills (13) & 68 & $82-197$ & $110-143$ & $80-117$ & $72-160$ & SBH \\
\hline Glenns Ferry (5) & 39 & $67-85$ & $80-109$ & $48-79$ & $74-138$ & GF \\
\hline Banbury Hot Springs (37) & 72 & $102-163$ & $98-139$ & $67-127$ & $69-165$ & BHS \\
\hline Twin Falls (21) & 43 & $83-136$ & $77-119$ & $45-91$ & $70-132$ & $\mathrm{TF}$ \\
\hline Cedar Hill (4) & 38 & $75-127$ & $62-116$ & $29-87$ & $50-129$ & $\mathrm{CH}$ \\
\hline Murphy Hot Spring (3) & 55 & $88-117$ & $119-148$ & $90-122$ & $57-144$ & MHS \\
\hline Oakley Hot Spring (5) & 47 & $73-130$ & $77-125$ & $45-97$ & $82-155$ & OHS \\
\hline Durfee Hot Spring (2) & 45 & $101-138$ & $96-117$ & $66-88$ & $46-131$ & DHS \\
\hline Marsh Creek (5) & 60 & $96-141$ & $96-113$ & $66-83$ & $128-134$ & $\mathrm{MC}$ \\
\hline Wybenga Dairy (1) & 34 & 132 & 118 & 89 & 189 & WD \\
\hline Indian Hot Spring (2) & 39 & $70-125$ & $64-110$ & $32-80$ & $60-64$ & IHS \\
\hline Tyhee (3) & 41 & 69 & $63-93$ & $31-62$ & 52 & TY \\
\hline Quidop-Yandell (4) & 38 & $59-90$ & $55-63$ & $23-31$ & $43-63$ & QY \\
\hline
\end{tabular}

${ }^{\mathrm{a}}$ Maximum measured temperature for the prospects; ${ }^{\mathrm{b}}$ RTEst estimated temperature range; ${ }^{\mathrm{c}}$ quartz (no steam loss) geothermometer temperature (Fournier, 1977); ${ }^{\mathrm{d}}$ chalcedony geothermometer temperature (Fournier, 1977); ${ }^{\mathrm{e}} \mathrm{Mg}$-corrected (where applicable) Na-K-Ca geothermometer temperature (Truesdell and Fournier, 1973; Fournier and Potter, 1979); these map codes are used to represent geothermal prospects in Figure 1; ${ }^{\mathrm{g}}$ number of samples representing the prospect; ${ }^{\mathrm{h}}$ both samples represent the same well, one sample was collected directly from the well leak whereas other sample was collected from the runoff channel.

\subsection{Geothermal prospects and their reservoir temperatures}

Table 1 summarizes likely reservoir temperature range for all geothermal prospects within and along the margins of the ESRP identified in this study. The RTEst estimated temperature range for each prospect is also given in Figure 1. Some of the hottest prospects in the ESRP region are Lidy Hot Springs (LHS), Magic Hot Spring (MHS), Camas Prairie (CP), south of Mount Bennett Hills (SBH), Banbury Hot Springs (BHS), east Idaho Falls (EIF), Newdale (NEW), and Ashton Hot Spring (AHS) (Figure 1). The geothermal potential of some of these prospects are also identified by the first phase of the SRP Play Fairway analysis (Shervais et al., 2015). Below we provide brief summaries for some of the promising geothermal prospects in the ESRP region. 

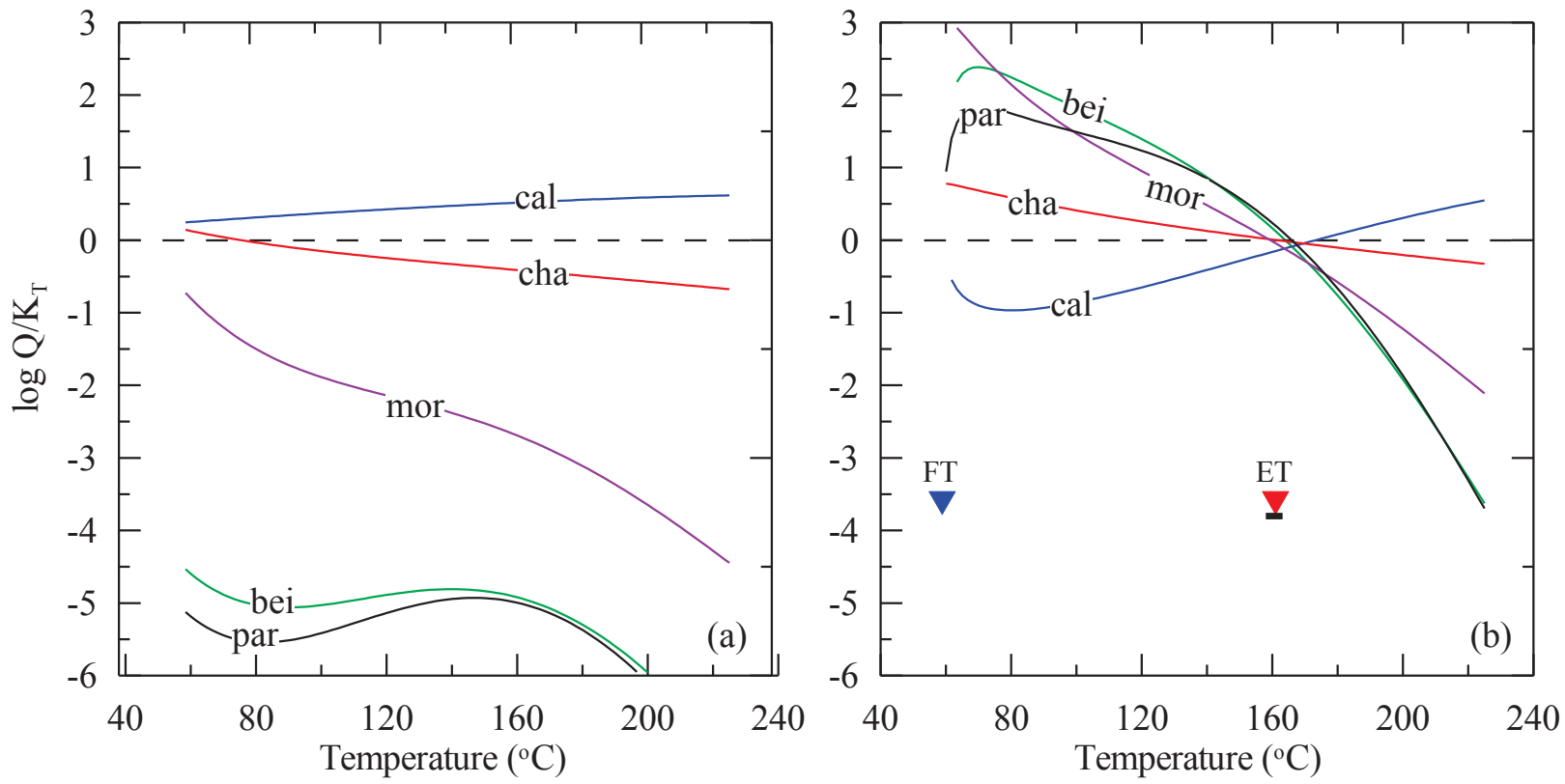

Figure 5. Graphical representation of RTEst analysis of Miracle Hot Spring well located in the Banbury Hot Springs prospect (see Figure 1). a) $\log \mathrm{Q} / \mathrm{KT}$ plot for assemblage minerals using observed fluid composition, b) $\log \mathrm{Q} / \mathrm{KT}$ plot for assemblage minerals using RTEst optimized fluid composition. In this diagram, FT is field temperature, ET is estimated temperature, and the horizontal solid bar underneath ET represents two-standard error in estimated temperature. Mineral assemblage includes: bei: beidellite-Mg, cal: calcite, cha: chalcedony, mor: mordenite-Na, and par: paragonite.

\subsubsection{Lidy Hot Springs}

The Lidy Hot Springs prospect (LHS in Figure 1) is located at the southeastern end of the Beaverhead Mountains in Clark County in Idaho. Form the early 20th century, the area was gradually developed into a commercial recreation site that provided services such as swimming, soaking, dancing, dining, and lodging to public. However, with the transfer of ownership in the early 1960s, the site ceased to offer those recreational services, and started a travertine mining activity. Two hot springs in the area are still issuing thermal water $\left(52-56{ }^{\circ} \mathrm{C}\right)$. Similarly, in the vicinity of the Lidy Hot Springs, there are other springs (e.g., Warm Spring $\left.\left(29^{\circ} \mathrm{C}\right)\right)$ issuing warm to cooler waters.

Rocks underlying the Lidy Hot Springs area consist of young volcanics and older meta-sedimentary rocks (Link, 2002). The younger rocks (Upper Miocene and Pliocene) consist of fluvial and lacustrine deposits, felsic volcanic rocks, rhyolite flows, tuffs, ignimbrites. Thick sequences of Paleozoic sedimentary rocks $(\mathrm{Pz})$ underlie the Tertiary rock types, and likely constitute the geothermal reservoir in the area.

The RTEst estimated reservoir temperature for the Lidy Hot Springs prospect is about $140{ }^{\circ} \mathrm{C}$ (Table 1). RTEst modeling result shows that the Lidy Hot Springs water may contain up to $60 \%$ cooler water and $40 \%$ deeper thermal water. Similarly, no-steam loss silicaenthalpy mixing model with the quartz solubility curve (Fournier, 1977; Fournier and Porter, 1982) yields a reservoir temperature of about $130^{\circ} \mathrm{C}$. However, silica-enthalpy mixing model with the chalcedony solubility curve (modified from Fournier, 1977; Fournier and Porter, 1982) yields a rather cooler temperature (about $60{ }^{\circ} \mathrm{C}$ ).

\subsubsection{Ashton Hot Spring}

The Ashton Hot Spring and associated geothermal area (AHS in Figure 1) is located at northern side of Ashton in Fremont County in Idaho. The existence of Ashton Hot Spring with a surface water temperature of $41^{\circ} \mathrm{C}$ was previously reported by Mitchell et al. (1980). A $1220 \mathrm{~m}$ deep geothermal exploratory well (Sturm Well-1) was drilled about $2 \mathrm{~km}$ NE from the Ashton Hot Spring in 1979 (Occidental Geothermal Inc., 1979). Driller's records indicate a bottom-hole temperature of about $63{ }^{\circ} \mathrm{C}$.

Geologic mapping of the area shows thin layers of Quaternary sediments covering underlying volcanic rocks (Link, 2002). Borehole records from the area reveal presence of thick sequences of flood basalts and felsic volcanics. Specifically, along the Sturm Well-1, the Quaternary sediments near surface are followed by layers of flood basalts (up to a depth of $82 \mathrm{~m}$ ), felsic volcanics (82-808 $\mathrm{m}$ ), and again flood basalts $(808-1220+\mathrm{m})$ with depth (Occidental Geothermal Inc., 1979).

Quartz and chalcedony geothermometers yielded reservoir temperatures of $143{ }^{\circ} \mathrm{C}$ and $116{ }^{\circ} \mathrm{C}$ for Ashton Hot Spring and $113{ }^{\circ} \mathrm{C}$ and 84 ${ }^{\circ} \mathrm{C}$ for the Sturm Well, respectively. For these two sampled features, Na-K-Ca geothermometer resulted in $117{ }^{\circ} \mathrm{C}$ and $109{ }^{\circ} \mathrm{C}$, respectively. Similarly, the RTEst produced reservoir temperatures for the Sturm Well and Ashton Hot Spring are $152 \pm 14{ }^{\circ} \mathrm{C}$ and $147 \pm 5^{\circ} \mathrm{C}$, with nearly $70 \%$ and $35 \%$ admixing of cooler water, respectively. All of these temperatures are significantly higher than the 
bottom hole temperature measured for the Sturm Well $\left(66^{\circ} \mathrm{C}\right)$. Given the measured temperature gradient $\left(48{ }^{\circ} \mathrm{C} / \mathrm{km}\right.$, Blackwell, 1989), such temperature conditions might be found at depths of about $3 \mathrm{~km}$.

\subsubsection{Newdale area}

The Newdale geothermal prospect (NEW in Figure 1) in Madison and Fremont Counties in Idaho represents a blind geothermal system, as it has no hot springs. The geothermal potential of Newdale area was identified in late 1970s by several researchers (e.g., Brott et al., 1976), based on the discovery of relatively high heat flow $\left(167 \mathrm{~mW} / \mathrm{m}^{2}\right)$. The area from Newdale town to NE across the Teton River has been considered as a potential area for geothermal energy (Brott et al., 1976, GeothermEx, 2010; Neupane et al., 2016b)). During 19791981, Union Oil of California (Unocal) drilled several geothermal test wells in the area ranging in depth from $183 \mathrm{~m}$ (Newdale No. 793) to $1204 \mathrm{~m}$ (Madison Geothermal No.1 near Rexburg, ID). The highest recorded temperature in the Unocal wells was $87.2{ }^{\circ} \mathrm{C}$ (Well \# State 2591-07-79-1).

Surficial geologic map of this area shows presence of Quaternary sediments, Quaternary flood basalts, and Quaternary felsic volcanic rocks (Bond, 1978; Link, 2002; Embree et al., 2011). Early Pleistocene flood basalts are mapped around the town of Newdale whereas felsic volcanic rocks of similar ages (Huckleberry Ridge Tuff) are mapped NE from Newdale. In geologic cross-section, Embree et al. (2011) show Huckleberry Ridge Tuff lying underneath the Early Pleistocene basalt at Newdale. Below the Huckleberry Ridge Tuff lie the Tertiary sediments intercalated with Tertiary basalt. Subsurface lithologic records of numerous wells in the area as compiled by Idaho Geological Survey indicate the presence of thick sequences of rhyolites and tuff at greater depths.

Quartz, chalcedony, and Na-K-Ca (Mg corrected) geothermometers resulted reservoir temperatures in the range of 66-134 ${ }^{\circ} \mathrm{C}$, $28-112$ ${ }^{\circ} \mathrm{C}, 29-111{ }^{\circ} \mathrm{C}$, respectively. A silica (chalcedony)-enthalpy mixing model using all Newdale area samples results in reservoir temperature of about $174{ }^{\circ} \mathrm{C}$. Similar mixing models using quartz solubility results in even higher temperature estimates $\left(224{ }^{\circ} \mathrm{C}\right)$. The RTEst temperature estimates for the Newdale area samples range $75-152{ }^{\circ} \mathrm{C}$ (Table 1). The lower end RTEst temperature estimates of this area are similar to the bottom hole temperatures $\left(83-87^{\circ} \mathrm{C}\right)$ measured at two relatively deeper $(\sim 1000 \mathrm{~m})$ Unocal wells. Moreover, it is likely that the area hosts even higher temperatures at greater depths that would correspond to the higher end RTEst temperatures. Assuming an $80^{\circ} \mathrm{C}$ thermal gradient (as indicated by two Unocal wells), the higher end RTEst temperatures would be present at about 2 km below ground surface.

\section{$\underline{\text { 5.3.4 East Idaho Falls area }}$}

The foothills (1480-1580 m above sea level) along the margins of the ESRP east of Idaho Falls (EIF in Figure 1) in Bonneville County have been known to have some wells producing warm water. The geothermal potential of the area was initially reported by Ralston et al. (1981). Specifically, they reported the existence of two wells in Rim Rock Estate that produce $\geq 20{ }^{\circ} \mathrm{C}$ water. Recently drilled shallow (depth up to $244 \mathrm{~m}$ ) wells in the Comore Loma and Blackhawk communities few kilometers south from Rim Rock Estate also produce warm $\left(21-28^{\circ} \mathrm{C}\right)$ water.

The area lies on the edge of the SRP where pronounced volcanism has taken place throughout the past 6.5 Ma. The foothills to the east of Idaho Falls consist predominantly of tuffs, ignimbrites, and ash flows related to the Miocene-Pliocene Heise volcanic field (Morgan and McIntosh, 2005). Although all shallow wells in the area bottomed out within the volcanic rocks, the volcanic rocks in the area are thought to be about $300 \mathrm{~m}$ in thickness. Mesozoic sedimentary rocks that include the limestones, sandstones, siltstones, conglomerates, and evaporite beds underneath the young volcanic rocks are assumed to be the geothermal reservoir in this area.

Quartz, chalcedony, and Na-K-Ca temperature estimates for east Idaho Falls area range from $115-143{ }^{\circ} \mathrm{C}, 86-117{ }^{\circ} \mathrm{C}$, and $45-74{ }^{\circ} \mathrm{C}$, respectively. The Mg-corrected $\mathrm{Na}-\mathrm{K}-\mathrm{Ca}$ temperature estimates for these samples are lower because of the presence of high concentrations of $\mathrm{Mg}$. The RTEst temperature estimates of east Idaho Falls water samples are very similar with a range from 136-143 ${ }^{\circ} \mathrm{C}($ Table 1).

\subsubsection{Magic Hot Spring}

The Magic Hot Spring prospect (MHS in Figure 1) is located on the northern margin of the ESRP in Camas and Blaine Counties in Idaho. Until a $79 \mathrm{~m}$ deep well (Magic Reservoir landing well) was drilled for direct use purposes in 1965 , the hot spring issued $36^{\circ} \mathrm{C}$ water (Ross, 1970). However, with the operation of the well, the hot spring dried out (Mitchell, 1976). At the beginning, the well was producing water at $66^{\circ} \mathrm{C}$, however, the water temperature subsequently increased to $74{ }^{\circ} \mathrm{C}$ by 1975 (Mitchell, 1976; Mitchell et al., 1980). The most recent (2014) temperature record for the surface discharge of the well is $75^{\circ} \mathrm{C}$.

The Magic Hot Spring area consists predominantly of Miocene-Quaternary silicic volcanic rocks and basalt flows (Struhsacker et al., 1982). The Pliocene-Miocene Poison Creek Tuff is the uppermost unit in the immediate vicinity of Magic Reservoir and is underlain by the Miocene Tuff of the Idavada Group. Other rhyolites and basalt flows are abundant in the surrounding areas but not shown in crosssection. The Cretaceous Idaho Batholith granitic rocks form the basement throughout the region.

Quartz (no steam loss), chalcedony, and Mg-corrected Na-K-Ca geothermometers resulted in 139 and $142{ }^{\circ} \mathrm{C}$, and 113 and $116{ }^{\circ} \mathrm{C}$, and 153 and $152{ }^{\circ} \mathrm{C}$ with compositions measured in water samples from the well leak and leak runoff channel, respectively. The chalcedony-enthalpy mixing model resulted in an estimated $145{ }^{\circ} \mathrm{C}$ reservoir temperature with about $50 \%$ dilution. Similarly, the quartz-enthalpy mixing model resulted in $181{ }^{\circ} \mathrm{C}$ reservoir temperature with about $60 \%$ dilution. The RTEst results indicate that the Magic Hot Spring geothermal area has a reservoir temperature about $163{ }^{\circ} \mathrm{C}$ (Table 1). 


\subsubsection{Camas Prairie area}

Camas Prairie (CP in Figure 1) is an east-west elongated (about $50 \mathrm{~km}$ by $15 \mathrm{~km}$ ) intermontane valley in Camas and Elmore Counties in Idaho. The area has several hot springs [besides the Elk Creek Hot Springs (ECHS in Figure 1) in the northeastern part of the prairie]. The Sheep and Wolf Hot Springs are located in the western part of Camas Prairie, about $4 \mathrm{~km}$ north of Hill City in Idaho. These two hot springs, separated approximately $100 \mathrm{~m}$ from each other, issue hot water at about $50{ }^{\circ} \mathrm{C}$. Two additional hot springs in the area are Wardrop Hot Springs $\left(60^{\circ} \mathrm{C}\right)$, located on the northern side of prairie near the base of the Soldier Mountains, and Barron Hot Spring ( 73 $\left.{ }^{\circ} \mathrm{C}\right)$, located on the southern side of the prairie near the base of the Mount Bennett Hills. The area also has several hot shallow wells, specifically scattered around the Wardrop and Barron Hot Spring areas.

Camas Prairie is bounded by the Mount Bennett Hills to the south and the Soldier Mountains to the north. The Mount Bennett Hills are composed predominantly of Miocene rhyolitic ash flows and lava flows of the Idavada Volcanic Group that overlies granodiorite of the Idaho Batholith. Local basalt flows and fluvial/lacustrine sediments are also present. The Soldier Mountains are composed mostly of granodiorite of the Idaho Batholith with minor amounts of younger intrusive rocks. Camas Prairie is host to an unknown thickness of Quaternary alluvial, fluvial, and lacustrine sediments with local lenses of basalt encountered in the shallow subsurface (Cluer and Cluer, 1986).

All Camas Prairie thermal water samples provide similar reservoir temperatures with the same traditional geothermometer. The quartz, chalcedony, and Na-K-Ca geothermometers results in temperature estimates in the range of 103-128, 74-99, and 70-124 ${ }^{\circ} \mathrm{C}$, respectively. The silica-enthalpy model with chalcedony solubility and quartz solubility curves resulted in temperature estimates of about $133^{\circ} \mathrm{C}$ and $173{ }^{\circ} \mathrm{C}$, respectively.

Unlike the traditional geothermometers, RTEst temperature estimates of Camas Prairie area samples show a bimodal distributionhigher temperatures for the samples from northern parts and lower temperatures for the samples from southern parts. Specifically, the hot springs from the areas along the northern part of Camas Prairie that abuts the prairie with the foothills of the Soldier Mountains (e.g., Wardrop Hot Spring, Wolf/Sheep Hot Spring) results in higher (181-204 $\left.{ }^{\circ} \mathrm{C}\right)$ RTEst reservoir temperatures. On the other hand, RTEst reservoir temperature estimates for hot springs and wells (e.g., Barron Hot Spring) in the southern parts are $79-108{ }^{\circ} \mathrm{C}$.

\subsubsection{Southern side of Mount Bennett Hills}

Several hot springs are located along the southern side of the Mount Bennett Hills in Elmore, Gooding, and Lincoln Counties in Idaho extending over $70 \mathrm{~km}$ represent this prospect (SBH in Figure 1). Some of the known hot springs in the area are the Prince Albert (Coyote) $\left(58^{\circ} \mathrm{C}\right)$, Latty $\left(65^{\circ} \mathrm{C}\right)$, and White Arrow $\left(65^{\circ} \mathrm{C}\right)$. The Bostic 1-A well $(2950 \mathrm{~m})$ drilled to the south from this area indicated the presence of hot (ca. $200^{\circ} \mathrm{C}$ ) rock at depths of about $3 \mathrm{~km}$ (Arney, 1982; Arney and Goff, 1982; Arney et al., 1984). The presence of several hot springs and hot rock at depth suggests that this part the SRP has great potential for geothermal resources.

Rocks in the area consist mainly of mafic and felsic volcanic rock with thick sequences of sediments and gravels. The Mount Bennett Hills to the north consist of predominantly of Miocene rhyolitic ash flows and lava flows of the Idavada Volcanic Group that overlies Idaho Batholith granodiorite. At the base of the Mount Bennett Hills, the basalt flows are intercalated with quaternary lacustrine sediments deposited in the Pleistocene-Pliocene Lake Idaho and the sandstones and shales of the Tertiary Glenn's Ferry Formation. At depth, an older basalt unit (Banbury basalt) and Idavada volcanics are encountered at Bostic 1-A well (Arney et al., 1984). The basement rock in the area is considered to be the Idaho Batholith granodiorite.

Reservoir temperature estimates for this area calculated with several water samples are given in Table 1. Quartz (no steam loss), chalcedony, and Na-K-Ca geothermometers resulted in 110-143, and 80-117, and 72-160 ${ }^{\circ} \mathrm{C}$, respectively. The Prince Albert and Latty Hot Springs resulted in highest temperatures for the area with these traditional geothermometers. Silica-enthalpy mixing models with chalcedony and quartz solubility curves resulted in 150 and $182{ }^{\circ} \mathrm{C}$ temperature estimates for the area. As with the traditional geothermometers, the RTEst modeling of waters from hot springs yielded higher temperature. The three hot springs in the area, Prince Albert, Latty, and White Arrow Hot Springs resulted in reservoir temperatures at $193 \pm 8,197 \pm 5$, and $177 \pm 6{ }^{\circ} \mathrm{C}$, respectively. Similarly, RTEst temperature estimate for a well (Shannon well) in the area is $137 \pm 10{ }^{\circ} \mathrm{C}$. All other wells resulted in lower reservoir temperature estimates $\left(82-122^{\circ} \mathrm{C}\right)$. The reservoir temperature estimates using the hot spring waters are similar to the bottom hole temperature $(\sim 200$ ${ }^{\circ} \mathrm{C}$, Arney et al., 1984) measured in the Bostic 1-A well. It is likely that these hot springs are sourced by deep thermal waters that ascend along the range-forming faults.

\subsubsection{Twin Falls area and Banbury Hot Springs}

The southwestern periphery of the ESRP near Twin Falls and Buhl is one of the Known Geothermal Resource Areas in southern Idaho. The area is comprised of two dense clusters of geothermal surface manifestations, Banbury Hot Springs (BHS in Figure 1) and Twin Falls (TF in Figure 1). Discharging thermal waters range in temperature from $25^{\circ} \mathrm{C}$ to $70^{\circ} \mathrm{C}$. Locally, thermal waters are being used for space heating, agriculture, and recreation.

The Twin Falls and Banbury hydrothermal areas show characteristics of both the ESRP and Basin and Range regional extension. Tertiary rhyolitic volcanic rocks underlie younger Quaternary and Tertiary basaltic units throughout the study area. Paleozoic metasedimentary rocks are thought to underlie the entire area (Lewis and Young, 1989). The thermal aquifer system in the area is located beneath basalt units within the Idavada volcanics and is under artesian conditions with temperatures of the waters increasing to the northwest. Thermal waters are thought to originate from deep circulation paths from the Cassia Mountain recharge zone to the south and through fractures in the overlying basalts of the thermal area. The waters are subsequently heated by either a regionally high 
gradient (Lewis and Young, 1989) or the young basaltic sill complexes associated with ESRP volcanism (McLing et al., 2014, Dobson et al., 2015).

Reservoir temperature estimate ranges obtained with traditional geothermometers and RTEst are given in Table 1 for both the Banbury Hot Springs and Twin Falls prospects. The highest reservoir temperatures (ca. $160{ }^{\circ} \mathrm{C}$ ) for the Banbury Hot Springs prospect are obtained for Banbury Hot Spring, Miracle Hot Spring well, and Salmon Falls Hot Spring with RTEst as well as other geothermometers. Similarly, for the Twin Falls prospect, the highest reservoir temperatures (ca. $135^{\circ} \mathrm{C}$ ) are obtained for samples from two hot shallow wells (used for direct heating - Neely, 1996) within the premises of the College of Southern Idaho.

\section{SUMMARY}

Geothermometric calculations of ESRP thermal water samples indicate numerous potential geothermal areas with elevated reservoir temperatures. Specifically, RTEst results of thermal water samples from areas around the southern/southwestern side of the Mount Bennett Hills and within the Camas Prairie in the southwestern portion of the ESRP suggest temperatures of $140-200^{\circ} \mathrm{C}$. In the northern portion of the ESRP, Lidy Hot Springs, Ashton, Newdale, and areas east of Idaho Falls have expected reservoir temperatures $\geq 140{ }^{\circ} \mathrm{C}$. Resource temperatures in the southwestern ERSP, specifically, areas near Buhl and Twin Falls are estimated to as high as $160{ }^{\circ} \mathrm{C}$. These areas are likely to host potentially economic geothermal resources; however, further detailed study is warranted for each site to evaluate their suitability for economic use.

\section{ACKNOWLEDGMENTS}

This work was supported by funding by the Assistant Secretary for Energy Efficiency and Renewable Energy, Geothermal Technologies Office of the U.S. Department of Energy under the U.S. Department of Energy Contract Nos. DE-AC07-05ID14517 with Idaho National Laboratory and DE-AC02-05CH11231 with Lawrence Berkeley National Laboratory. We thank landowners who provided access to sampling locations. We also thank Dr. Ross Spackman (Brigham Young University-Idaho) for his assistance in coordinating with landowners and filed work. Chemical analyses of the samples were conducted by Ms. Debbie Lacroix (University of Idaho) at Center for Advanced Energy Studies (CAES). We appreciate the discussion with Drs. Bill Phillips (Idaho Geological Survey), Glenn Embree (BYU-Idaho), and Dan Moore (BYU-Idaho).

\section{REFERENCES}

Arney, B.: Evidence of former higher temperatures from alteration minerals, Bostic 1-A well, Mountain Home, Idaho. GRC Transactions, 6, (1982), 3-6.

Arney, B.H., Gardner, J.N., Belluomini, S.G.: 1984, Petrographic analysis and correlation of volcanic rocks in Bostic 1-A well near Mountain Home, Idaho. LA-9966-HDR, Los Alamos National Laboratory, (1984).

Arney, B. H. and Goff, F.: Evaluation of the hot-dry-rock geothermal potential of an area near Mountain Home, Idaho. LA-9365-HDR, Los Alamos National Laboratory (1982).

Bethke, C.M.: Geochemical and Biogeochemical Reaction Modeling. Cambridge University Press, pp. 547, (2008).

Blackwell, D.D.: Regional implications of heat flow of the Snake River Plain, northwestern United States. Tectonophysics, 164, (1989), 323-343.

Blackwell, D., Steele, J.L., and Carter, L.S.: Heat flow patterns of the North American continent: A discussion of the DNAG geothermal map of North America. In Neotectonics of North America, eds. D.B. Slemmons, E. R. Engdahl, and D. D. Blackwell, Geological Society of America, DNAG, Map, 1:423437, (1991).

Bond, J. G.: Geologic map of the state of Idaho, scale 1:500,000. Idaho Bur. of Mines and Geology, (1978).

Brott, C.A., Blackwell, D.D, and Mitchell J.C.: Geothermal investigations in Idaho, Part 8: Heat flow study of the Snake River Plain, Idaho, Idaho Department of Water Resources. Water Information Bulletin, 30, (1976), 195 pp.

Cannon, C., Wood, T., Neupane, G., McLing, T., Mattson, E., Dobson, P., and Conrad, M.: Geochemistry sampling for traditional and multicomponent equilibrium geothermometry in southeast Idaho. GRC Transactions, 38, (2014), 524-431.

Cluer, J.K., Cluer, B.L.: The late Cenozoic Camas Prairie Rift south-central Idaho, Contributions to Geology, University of Wyoming, 24(1), (1986), 91-101.

Cooper, D.C., Palmer, C.D., Smith, R.W., and McLing, T.L.: Multicomponent equilibrium models for testing geothermometry approaches. Proceedings, 38th Workshop on Geothermal Reservoir Engineering Stanford University, Stanford, CA (2013).

D'Amore, F. and Arnórsson, S.: Geothermometry, in Isotopic and Chemical Techniques in Geothermal Exploration, Development and Use (S. Arnórsson, ed.): IAEA (Editorial), Vienna, pp. 152-199, (2000).

D'Amore, F., Fancelli, R., and Caboi, R.: Observations on the application of chemical geothermometers to some hydrothermal systems in Sardinia. Geothermics, 16, (1987), 271-282.

Dobson, P.F., Kennedy, B.M., Conrad, M.E., McLing, T., Mattson, E., Wood, T., Cannon, C., Spackman, R., van Soest, M., and Robertson, M.: He isotopic evidence for undiscovered geothermal systems in the Snake River Plain. Proceedings, $40^{\text {th }}$ Workshop on Geothermal Reservoir Engineering, Stanford University, Stanford, CA (2015). 
Neupane et al.

Embree, G.F., Phillips, W.M., and Welhan, J.A.: Geologic map of the Newdale quadrangle, Fremont and Madison Counties, Idaho. Idaho Geological Survey, University of Idaho, Moscow, Idaho 83844-3014, (2011).

Fournier, R.O. and Truesdell, A.H.: An empirical Na-K-Ca geothermometer for natural waters. Geochim. Cosmochim. Acta, 37, (1973), $1255-1275$.

Fournier, R.O.: Chemical geothermometers and mixing models for geothermal systems. Geothermics, 5, (1977) 41-50.

Fournier, R.O.: A revised equation for the Na/K geothermometer. GRC Transactions, 3, (1979), 221-224.

Fournier, R.O. and Potter, R.W. II: Magnesium correction to the Na-K-Ca chemical geothermometer. Geochim. Cosmochim. Acta, 43, (1979), 1543-1550.

GeothermEx, Inc.: Independent technical report: Resource evaluation of the Newdale geothermal prospect, Madison and Fremont Counties, Idaho, USA. Geothermix, Inc., Richmond, California, USA, February 10, 2010, p. 101, (2010).

Giggenbach, W.F.: Geothermal solute equilibria. Derivation of Na-K-Mg-Ca geoindicators. Geochim. Cosmochim. Acta, 52, (1988), 2749-2765.

Hughes, S.S., Smith, R.P., Hackett, W.R., and Anderson, S. R.: Mafic volcanism and environmental geology of the eastern Snake River Plain. Idaho Guidebook to the Geology of Eastern Idaho. Idaho Museum of Natural History, (1999), 143-168.

Hull, C.D., Reed, M.H., and Fisher, K.: Chemical geothermometry and numerical unmixing of the diluted geothermal waters of the San Bernardino Valley Region of Southern California. GRC Transactions, 11, (1987), 165-184.

Lewis, R.E. and Young, H.W.: The hydrothermal system in central Twin Falls County, Idaho: U.S. Geological Survey Water Resources Investigations Report 88-4152, p. 44, (1989).

Link, P.K.: Clark County, Idaho. Digital Atlas of Idaho, Idaho State University, Geosciences Department, p. 3, (2002).

Mattson, E.D., Smith, R.W., Neupane, G., Palmer, C.D., Fujita, Y., McLing, T.L., Reed, D.W., Cooper, D.C., and Thompson, V.S.: Improved geothermometry through multivariate reaction-path modeling and evaluation of geomicrobiological influences on geochemical temperature indicators: Final Report No. INL/EXT-14-33959, Idaho National Laboratory (INL), Idaho Falls, Idaho, (2015).

McLing, T.L., Smith, R.W., and Johnson, T.M.: Chemical characteristics of thermal water beneath the eastern Snake River Plain. In: Geology, Hydrogeology, and Environmental Remediation: Idaho National Engineering and Environmental Laboratory, Eastern Snake River Plain, Idaho, P.K. Link and L.L. Mink, eds. Geological Society of America Special Paper 353, (2002), $205-211$.

McLing, T., McCurry, M., Cannon, C., Neupane, G., Wood, T., Podgorney, R., Welhan, J., Mines, G., Mattson, E., Wood, R., Palmer, C. and Smith, R.: David Blackwell's Forty Years in the Idaho Desert, The Foundation for 21st Century Geothermal Research; Geothermal Resources Council Transactions,38, (2014), 143-153.

Michard, G. and Roekens, E.: Modelling of the chemical components of alkaline hot waters. Geothermics, 12, (1983), 161-169.

Mitchell, J.C.: Geothermal Investigations in Idaho - Part 7: Geochemistry and geologic setting of the thermal waters of the Camas Prairie Area, Blaine and Camas Counties, Idaho. Idaho Department of Water Resources, Water Information Bulletin 30, (1976).

Mitchell, J.C., Johnson, L.L, and Anderson, J.E.: Geothermal Investigations in Idaho - Part 9: Potential for direct heat applications of geothermal resources. Idaho Department of Water Resources, Water Information Bulletin 30, (1980).

Morgan, L.A., and McIntosh, W.C.: Timing and development of the Heise volcanic field, Snake River Plain, Idaho, western USA. Geological Society of America Bulletin, 117, (2005), 288-306.

Morse, L.H. and McCurry, M.: Genesis of alteration of Quaternary basalts within a portion of the eastern Snake River Plain aquifer. Special Papers Geological Society of America, (2002) 213-224.

Neely, K.W.: Geothermal heat keeps students warm at the College of Southern Idaho. GRC Transactions, 20, (1996), 129-136.

Neupane, G., Smith, R. W., Palmer, C. D., and McLing, T. L.: Multicomponent equilibrium geothermometry applied to the Raft River geothermal area, Idaho: preliminary results. In Geological Society of America Abstracts with Programs, 45 (7), (2013).

Neupane, G., Mattson, E.D., McLing, T.L., Palmer, C.D., Smith, R.W., and Wood, T.R.: Deep geothermal reservoir temperatures in the Eastern Snake River Plain, Idaho using multicomponent geothermometry. Proceedings, Thirty-Ninth Workshop on Geothermal Reservoir Engineering, Stanford University, Stanford, California, February 24-26, 2014 SGP-TR-202, (2014).

Neupane, G., Mattson, E.D., McLing, T.L., Palmer, C.D., Smith, R.W., Wood, T.R., and Podgorney, R.K.: Geothermal reservoir temperatures in southeastern Idaho using multicomponent geothermometry. Proceedings, World Geothermal Congress 2015, Melbourne, Australia, 19-25 April 2015, (2015a).

Neupane, G., Baum, J.S., Mattson, E.D., Mines, G.L., Palmer, C.D., and Smith, R.W.: Validation of multicomponent equilibrium geothermometry at four geothermal power plants. Proceedings, Fortieth Workshop on Geothermal Reservoir Engineering Stanford University, Stanford, California, January 26-28, 2015, (2015b). 
Neupane, G., Mattson, E.D., Mines, G.L., McLing, T.L., Dobson, P.F., Conrad, M.E., Wood, T.R., Cannon, C., Worthing, W.: Geothermometric temperature comparison of hot springs and wells in southern Idaho. GRC Transactions, 39, 495-502 (2015c).

Neupane, G., Mattson, E.D., McLing, T.L., Palmer, C.D., Smith, R.W., Wood, T.R., and Podgorney, R.K.: Geothermometric evaluation of geothermal resources in southeastern Idaho. Geoth. Energ. Sci, 4(1), (2016a), 11-22.

Neupane, G., Mattson, E.D., Cannon, J.C., Atkinson, T.A., McLing, T.L., Wood, T.R., Worthing, W.C., and Conrad, M.E.: Mixing effects on geothermometric calculations of the Newdale Geothermal area in the Eastern Snake River Plain, Idaho. Proceedings, 41st Workshop on Geothermal Reservoir Engineering, Stanford University, Stanford, California, February 22-24, 2016 SGP-TR209 (2016b).

Nielson, D.L., Delahunty, C., and Shervais, J.W.: Geothermal systems in the Snake River Plain, Idaho, characterized by the Hotspot project. GRC Transactions, 36, (2012) 727-730.

Occidental Geothermal, Inc.: Sturm 1, Computer Processed Log. Department of Water Resources, Idaho, p. 18, (1979)

Palandri, J.L. and Reed, M.H.: Reconstruction of in situ composition of sedimentary formation waters. Geochim. Cosmochim. Acta, 65, (2001), 1741-1767.

Palmer, C.D., Ohly, S.R., Smith, R.W., Neupane, G., McLing, T., Mattson, E.: Mineral selection for multicomponent equilibrium geothermometry. GRC Transactions, 38, (2014), 453-459.

Pang, Z.H. and Reed, M.: Theoretical chemical thermometry on geothermal waters: Problems and methods. Geochim. Cosmochim. Acta, 62, (1998), 1083-1091.

Peiffer, L., Wanner, C., Spycher, N., Sonnenthal, E., Kennedy, B.M., Iovenitti, J.: Optimized multicomponent vs. classical geothermometry: insights from mod-eling studies at the Dixie Valley geothermal area. Geothermics, 51, (2014), $154-169$.

Pierce, K. L., and Morgan, L. A.: The track of the Yellowstone hot spot: Volcanism, faulting, and uplift. Geological Society of America Memoirs, 179, (192), 1-54.

Ralston, D.R., Arrigo, J.L., Baglio, J.V. Jr., Coleman, L.M., Souder, K., and Mayo, A.L.: Geothermal evaluation of the thrust area zone in southeastern Idaho, Idaho Water and Energy Research Institute, University of Idaho, (1981).

Reed, M. and Spycher, N.: Calculation of $\mathrm{pH}$ and mineral equilibria in hydrothermal waters with application to geothermometry and studies of boiling and dilution. Geochim. Cosmochim. Acta, 48, (1984), 1479-1492.

Rodgers, D.W., Ore, H.T., Bobo, R.T., McQuarrie, N., and Zentner, N.: Extension and subsidence of the eastern Snake River Plain, Idaho. Tectonic and Magmatic Evolution of the Snake River Plain Volcanic Province. Idaho Geological Survey Bulletin, 30, (2002), 121-155.

Ross, S.H.: Geothermal potential of Idaho. Geothermics Special Issue 2, (1970), 975-1008.

Shervais, J.W., Glen, J.M., Liberty, L.M., Dobson, P., Gasperikova, E., Sonnenthal, E., Visser, C., Garg, S., Evans, J.P., Siler, D., DeAngelo, J., Athens, N., and Burns, E.: Snake River Plain play fairway analysis - Phase 1 Report. GRC Transactions, 39, (2015), 761-769.

Smith, R.P.: Geologic setting of the Snake River Plain aquifer and vadose zone. Vadose Zone Journal, 3, (2004), 47-58.

Smith, R.W., Palmer, C.D., and Cooper, D.: Approaches for multicomponent equilibrium geothermometry as a tool for geothermal resource exploration. Abstracts, AGU Fall Meeting, San Francisco, 3-7 December 2012, (2012).

Spycher, N.F., Sonnenthal, E., and Kennedy, B.M.: Integrating multicomponent chemical geothermometry with parameter estimation computations for geothermal exploration. GRC Transactions, 35, (2011), 663-666.

Spycher, N., Peiffer, L., Sonnenthal, E. L., Saldi, G., Reed, M. H., and Kennedy, B. M.: Integrated multicomponent solute geothermometry. Geothermics, 51, (2014), 113-123.

Struhsacker, D.W., Jewell, P.W., Ziesloft, J., and Evans, S.H. Jr.: The geology and geothermal setting of the Magic Reservoir area, Blaine and Camas Counties, Idaho. In: Cenozoic geology of Idaho, B. Bonnichsen and R.M. Breckenridge, eds., Idaho Bureau of Mines and Geology Bulletin 26, (1982), 377-393.

Tole, M.P., Ármannsson, H., Pang, Z.H., \& Arnórsson, S.: Fluid/mineral equilibrium calculations for geothermal fluids and chemical geothermometry. Geothermics, 22, (1993), 17-37.

Welhan, J.A.: Thermal and Trace-Element Anomalies in the Eastern Snake River Plain aquifer: toward a conceptual model of the EGS resource. GRC Transactions, 39, (2015), 363-375.

Whitehead, R.L.: Geohydrologic framework of the Snake River Plain regional aquifer system, Idaho and eastern Oregon. Regional aquifer system analysis-Snake River Plain, Idaho. US Geological Survey Professional Paper 1408-B, (1992).

Williams, C.F., and DeAngelo, J.: Evaluation of Approaches and Associated Uncertainties in the Estimation of Temperatures in the Upper Crust of the Western United States, GRC Transactions, 35, (2011), 1599-1605. 


\section{Neupane et al.}

Williams, P.L., Mabey, D.R., Zohdy, A.A.R., Ackermann, H., Hoover, D.B., Pierce, K.L., and Oriel, S.S.: Geology and geophysics of the southern Raft River Valley geothermal area, Idaho, USA. Proceedings, Second UN Symposium on the Development and Use of Geothermal Resources, San Francisco, Lawrence Berkeley National Laboratory, (1976), 1273-1282. 
Appendix $\mathrm{H}$.

Neupane, G., Mattson, E.D., Cannon, J.C., Atkinson, T.A., McLing, T.L., Wood, T.R., Worthing, W.C., and Conrad, M.E., 2016b. Mixing effects on geothermometric calculations of the Newdale Geothermal area in the Eastern Snake River Plain, Idaho. Proceedings, 41st Workshop on Geothermal Reservoir Engineering, Stanford University, Stanford, CA. 


\title{
Mixing Effects on Geothermometric Calculations of the Newdale Geothermal Area in the Eastern Snake River Plain, Idaho
}

\author{
${ }^{1,2}$ Ghanashayam Neupane*, ${ }^{1}$ Earl D. Mattson, ${ }^{2,3}$ Cody J. Cannon, ${ }^{4}$ Trevor A. Atkinson, ${ }^{1,2}$ Travis L. McLing, ${ }^{2,3}$ Thomas R. \\ Wood, ${ }^{2,3}$ Wade C. Worthing, and ${ }^{5}$ Mark E. Conrad \\ ${ }^{1}$ Idaho National Laboratory, Idaho Falls, ID 83415, USA \\ ${ }^{2}$ Center for Advanced Energy Studies, Idaho Falls, ID 83401, USA \\ ${ }^{3}$ University of Idaho-Idaho Falls, Idaho Falls, ID 83402, USA \\ ${ }^{4}$ Ormat Technologies Inc., Reno, NV 89511, USA \\ ${ }^{5}$ Lawrence Berkeley National Laboratory, Berkeley, CA 94720 USA \\ E-mail: Ghanashyam.Neupane@inl.gov
}

Keywords: Eastern Snake River Plain, Newdale, RTEst, geothermal, geothermometer

\begin{abstract}
The Newdale geothermal area in Madison and Fremont Counties in Idaho is a known geothermal resource area whose thermal anomaly is expressed by high thermal gradients and numerous wells producing hot water (up to $51^{\circ} \mathrm{C}$ ). Geologically, the Newdale geothermal area is located within the Eastern Snake River Plain (ESRP) that has a time-transgressive history of sustained volcanic activities associated with the passage of Yellowstone Hotspot from the southwestern part of Idaho to its current position underneath Yellowstone National Park in Wyoming. Locally, the Newdale geothermal area is located within an area that was subjected to several overlapping and nested caldera complexes. The Tertiary caldera forming volcanic activities and associated rocks have been buried underneath Quaternary flood basalts and felsic volcanic rocks. Two southeast dipping young faults (Teton Dam Fault and an unnamed fault) provide the structural control for this localized thermal anomaly zone. Geochemically, water samples from numerous wells in the area can be divided into two broad groups $-\mathrm{Na}-\mathrm{HCO}_{3}$ and $\mathrm{Ca}-(\mathrm{Mg})-\mathrm{HCO}_{3}$ type waters. Each type of water can further be subdivided into two groups depending on their degree of mixing with other water types or interaction with other rocks. For example, some bivariate plots indicate that some $\mathrm{Ca}-(\mathrm{Mg})-\mathrm{HCO}_{3}$ water samples have interacted only with basalts whereas some samples of this water type also show limited interaction with rhyolite or mixing with $\mathrm{Na}-\mathrm{HCO}_{3}$ type water. Traditional geothermometers [e.g., silica variants, Na-K-Ca (Mg-corrected)] indicate lower temperatures for this area; however, a traditional silica-enthalpy mixing model results in higher reservoir temperatures. We applied a new multicomponent equilibrium geothermometry tool (e.g., Reservoir Temperature Estimator, RTEst) that is based on inverse geochemical modeling which explicitly accounts for boiling, mixing, and $\mathrm{CO}_{2}$ degassing. RTEst modeling results indicate that the well water samples are mixed with up to $75 \%$ of the near surface groundwater. Relatively, the $\mathrm{Ca}-(\mathrm{Mg})-\mathrm{HCO} 3$ type water samples are more diluted than the $\mathrm{Na}-\mathrm{HCO}_{3}$ type water samples. However, both water types result in similar reservoir temperatures, up to $150{ }^{\circ} \mathrm{C}$. Samples in the vicinity of faults produced higher reservoir temperatures than samples away from the faults. Although both the silica-enthalpy mixing and RTEst models indicated promising geothermal reservoir temperatures, evaluation of the subsurface permeability and extent of the thermal anomaly is needed to better define the hydrothermal potential of the Newdale geothermal resource.
\end{abstract}

\section{INTRODUCTION}

The Newdale geothermal area in Madison and Fremont Counties in Idaho represents a blind geothermal system in the north-eastern part of Eastern Snake River Plain (ESRP) (Figure 1). The ESRP is a region of high heat flow with great potential for significant geothermal resources (Brott et al., 1976; Blackwell, 1989). In general, the ESRP consists of thick volcanic ash-flow tuffs, which are overlain by $>1$ km of Quaternary basaltic flows (Hughes et al., 1999; Anders et al., 2014; McLing et al., 2014). The felsic volcanic rocks at depth are the product of super volcanic eruptions associated with the Yellowstone Hotspot. These rocks progressively become younger to the northeast towards the Yellowstone Plateau (Pierce and Morgan, 1992; Hughes et al., 1999). The younger basalt layers are the result of several low-volume, fissure type or monogenetic shield-forming eruptions of short-duration that emanated from northwest trending volcanic rifts in the wake of the Yellowstone Hot Spot (Hughes et al., 1999). The thick sequences of coalescing basalt flows with interlayered fluvial and eolian sediments in the ESRP constitute a very productive aquifer system above the volcanic ash-flow tuffs (Whitehead, 1992).

The geothermal potential of Newdale area was identified in 1970s by several researchers (e.g., Brott et al., 1976), specifically, with the discovery of relatively high heat flow $\left(167 \mathrm{~mW} / \mathrm{m}^{2}\right)$. Subsequent studies on geology, geophysics, and geochemistry of the area identified a zone called Newdale thermal anomaly zone (Mabey, 1978; Prostka and Embree, 1978; Mitchel et al., 1980). The area around the town of Newdale and NE across the Teton River (Figure 1) has been considered as a potential area for geothermal energy (Brott et al., 1976, GeothermEx, 2010). During 1979-1981, Union Oil of California (Unocal) drilled several geothermal test wells in the area ranging in depth from $183 \mathrm{~m}$ to $1025 \mathrm{~m}$ (Well St 08 in Figure 1). The highest recorded temperature in Unocal wells was $87.2^{\circ} \mathrm{C}$ (Well St-07 in Figure 1). Currently, Standard Steam Trust LLC (SST) holds a set of leases for further exploration and development in an area of about $53.4 \mathrm{~km}^{2}$ around Newdale and defines this area as 'Newdale geothermal energy prospect' (GeothermEx, 2010). 
In this paper, we present geochemical and geothermometric assessments of the Newdale geothermal area. The geochemical evaluation of the area was conducted by employing graphical presentations of water compositions of hot shallow wells. Specifically, the ternary and bivariate plots of various aqueous species and their ratios were used to understand types of water and mixing trends in the area. Geothermometric evaluation of the area was conducted using traditional as well as multicomponent equilibrium geothermometry (MEG) tools. Specifically, the effect of mixing of cooler water in the thermal water on geothermometric results was evaluated with an MEG code, Reservoir Temperature Estimator (RTEst) (Palmer et al., 2014).

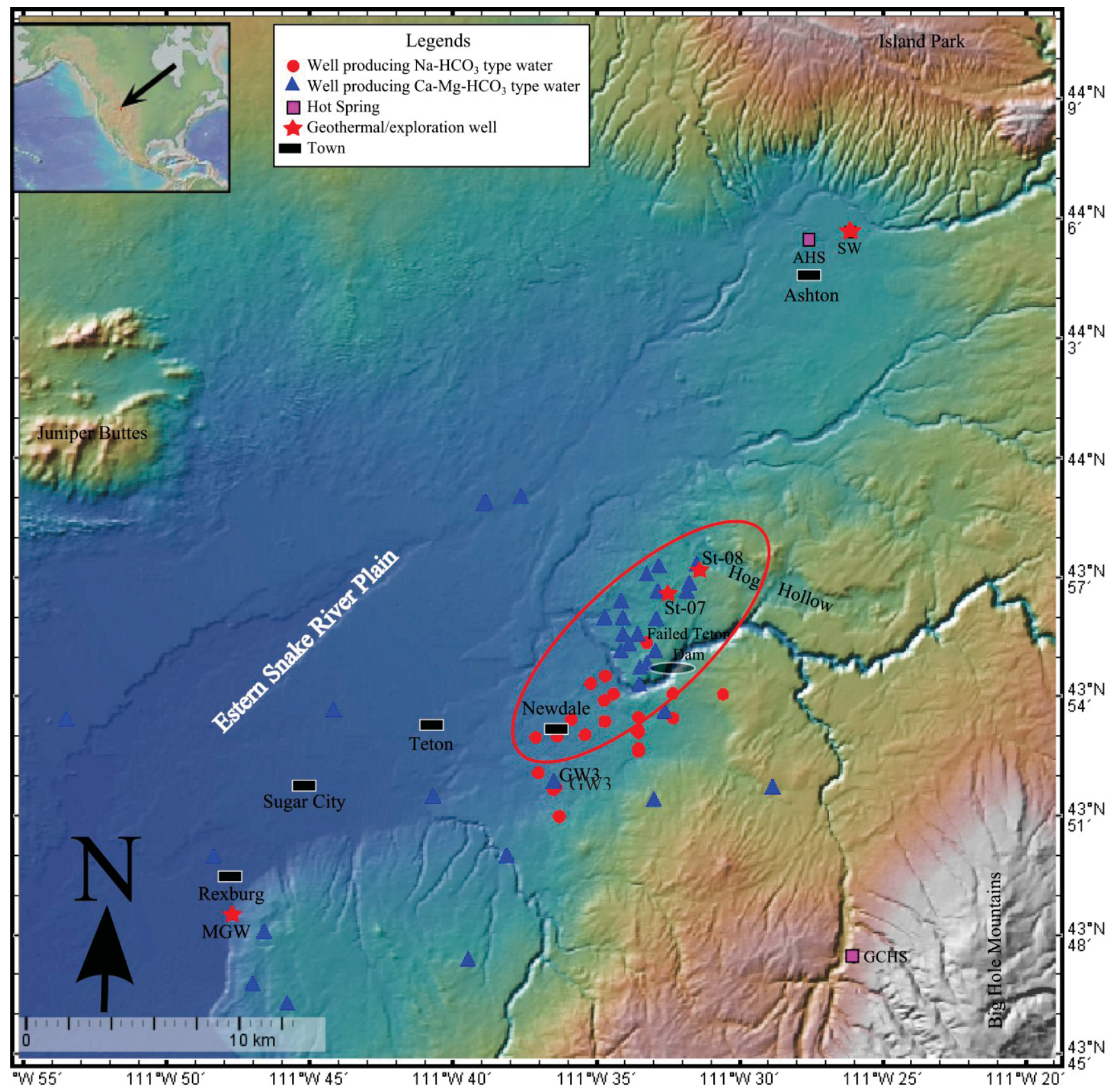

Figure 1. Location of Newdale geothermal prospect in the Eastern Snake River Plain. St-07: State 2591-07-79-1 well, St-08: State 2591-08-79-1 well, MGW: Madison Geothermal well (1204 m), SW: Sturm Well, AHS: Ashton Hot Spring, and GCHS: Green Canyon Hot Spring. GW3 is a groundwater well. Hog Hollow is a geographically depressed area in the northeastern part of prospect. 


\section{GEOLOGIC SETTING}

Surficial geologic map of this area shows presence of Quaternary sediments, Quaternary flood basalts, and Quaternary felsic volcanic rocks (Bond, 1978; Link, 2002; Embree et al., 2011). Early Pleistocene flood basalts are mapped around the town of Newdale whereas felsic volcanic rocks of similar ages are mapped NE from Newdale. In geologic cross-section, Embree et al. (2011) show Huckleberry Ridge Tuff lying underneath the Early Pleistocene basalt at Newdale. Below the Huckleberry Ridge Tuff lie the Tertiary sediments intercalated with Tertiary basalt (Figure 2). Subsurface lithologic records of numerous wells in the area as compiled by the Idaho Geological Survey indicate the presence of thick sequences of rhyolites and tuff at greater depths.

Based on geologic, geomorphologic (Prostka and Embree, 1978) and gravity anomaly features (Mabey, 1978), a series of overlapping and intersecting calderas that developed during 4.45-6.62 Ma (Morgan and McIntosh, 2005) have been inferred as Rexburg Caldera Complex (RCC) covering a large area including Rexburg, Teton, Sugar City, and Newdale areas, and possibly even extending north to the Ashton area (Malde, 1991; Blackwell et al., 1992; Anders et al., 2014). Specifically, the Newdale geothermal area is located along the three inferred caldera margins (Prostka and Embree, 1978). Recently, Anders et al. (2014) mapped the Blacktail Creek Tuff caldera (a caldera unit of RCC) rim that passes through the Newdale geothermal area along the Teton River. It is important to note that the Teton River within the thermal anomaly area acts as a boundary for surficial rock types (Embree et al., 2011) as well as geochemical boundary for the water types (Figure 1). Specifically, the surficial rocks to the north/northeastern side of the river are felsic volcanic rocks associated with the Quaternary Huckleberry Ridge Tuff (Qyh in Figure 2) whereas surficial rocks to the southern side are Quaternary flood basalts. The geologic cross-section (Figure 2) does not show any surficial basalts because it traverses exclusively through the northern part of the prospect where the Quaternary Huckleberry Ridge Tuff and Quaternary sediments are mapped as surficial rocks (Embree et al., 2011).

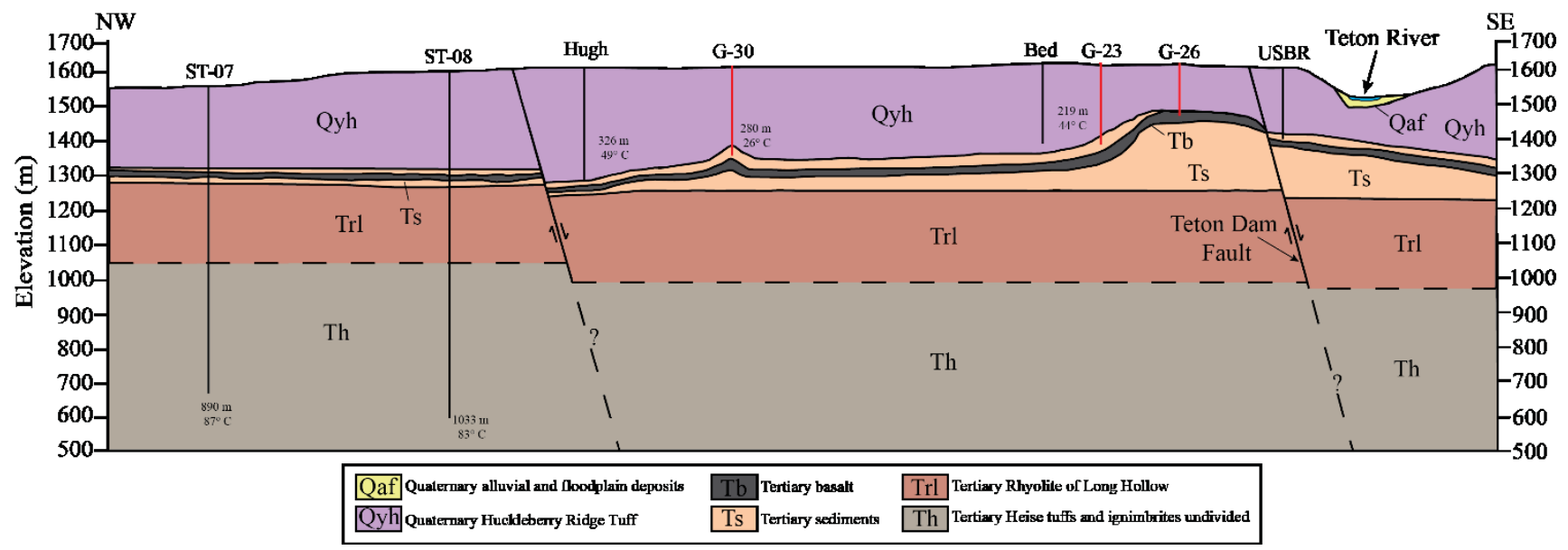

Figure 2. Geologic cross-section through Newdale geothermal area. The cross-section line passes through between two Unocal wells (St-07 and St-08 in Figure 1) and does not encounter Quarternary basalts. Stratigraphic architecture of the crosssection is constrained with available lithologic records of wells and geologic cross-section of Embree et al. (2011). The locations of two faults were adapted from geologic map (Embree et al., 2011).

It is likely that this area has highly fractured zones at depth because of the presence of intersecting caldera-ring fractures (Prostka and Embree, 1978; Anders et al., 2014). However, at present, the fractured zone has been buried underneath the thick sequences of postRCC volcanic and sedimentary sequences. Besides the likely presence of buried caldera ring fractures at depth, two southeast dipping parallel faults are mapped in the area (Embree et al., 2011). Specifically, the Teton Dam Fault has been traced along a stretch of Teton River near the failed Teton dam (Figure 1) and extended further to NE and SW (Prostka and Embree, 1978; Embree et al., 2011). The other fault is located NW of the Teton Dam Fault. Prostka and Embree (1978) also show a NW striking and SW dipping fault (Warm Creek Fault) that extends from the Big Hole Mountains to the SE and intersects the NE terminus of the Teton Dam Fault. However, this fault has not been shown on the new geologic map prepared by Embree et al. (2011). Moreover, Embree and Hogan (1999) show a series of shallow and short faults inferred from surface lineaments that transect the Hog Hollow area (Figure 1) located in the northeastern part of the Newdale geothermal area. The significance of Teton Dam Fault and other associated faults for the Newdale geothermal system has yet to be fully evaluated. In general, these faults may act as structural control for the geothermal setting by providing upward pathways for migration of hotter fluid from depth. However, the Teton Dam Fault and the other faults in the area may have a limited role in circulating hotter fluids from depth to the surface such that these faults may have been located within the postRCC zone without providing a continuous flow path from ring fracture zones to the surface. Moreover, the lack of surface expressions (e.g., hot springs) in the area may be related to a lack of sufficient hydraulic/convective head gradient because the water table in the area is located several tens of meters below ground surface. 


\section{GEOTHERMOMETRY}

One of the prospecting tools for geothermal resources is geothermometry, which uses the chemical compositions of water from springs and wells to estimate reservoir temperature. As an exploration tool, geothermometry offers a cost effective method to decrease exploration risk by evaluating a potential geothermal reservoir's temperature. To conduct geothermometry, measured chemical composition of water from wells and springs that exhibit some level of elevated temperatures are needed. The application of geothermometry requires several assumptions. The most important assumptions are that the reservoir minerals and fluid attain a chemical equilibrium and as the water moves from the reservoir to sampled location, it retains its chemical compositions (Fournier et al., 1974). The first assumption is generally valid (provided a long residence time); however, the second assumption is more likely to be violated because of composition altering processes, such as, re-equilibration at lower temperature, dilution (mixing), and loss of fluids (boiling) and volatiles (e.g., $\mathrm{CO}_{2}$ ) with the decrease in pressure.

Traditional geothermometers such as silica geothermometers, $\mathrm{Na} / \mathrm{K}$ geothermometer, etc., are empirical to semi-empirical approaches where a user enters the measured concentrations of certain component(s) into the geothermometer equation. The reliability, sensitivity, and responsiveness of traditional geothermometers to various composition altering processes vary. For example, geothermometers based on cation concentration ratios (e.g., $\mathrm{Na} / \mathrm{K}$ geothermometer) are minimally sensitive to boiling or mixing with dilute water; while geothermometers based directly on the concentration of component(s) (e.g., quartz geothermometer) are highly sensitive to these processes (D'Amore and Arnórsson, 2000). A drawback of many existing geothermometry approaches is that they do not adequately account for physical processes (e.g., mixing, boiling) and geochemical processes (e.g., mineral dissolution, precipitation, degassing) that may occur after the water leaves the reservoir and thereby alter its composition. If these changes are not taken into account, predictions of in-situ reservoir conditions (e.g., temperature, $\mathrm{fCO}_{2}$ ) based on the chemical composition of water samples taken from shallower depths or at the surface may be erroneous, or too imprecise to be useful.

In addition, it is difficult to quantify uncertainties associated with temperatures estimated with these geothermometers. As a result, it is not uncommon to find diverse temperature estimates for the same water using multiple traditional geothermometers. Nevertheless, because these geothermometers are easy to use and sometimes provide good results, they are considered to be an essential part of the geothermal exploration toolkit (D’Amore and Arnórsson, 2000).

A more advanced geothermometric approach is MEG. This approach utilizes multiple chemical constituents measured in water samples for inverse geochemical modeling considering a suite of selected minerals (selected based on some knowledge of the system) so as to provide more robust temperature estimates with quantifiable uncertainties. Geothermal temperature predictions using MEG provide apparent improvement in reliability and predictability of temperature over traditional geothermometers. The basic concept of this method was developed in 1980s (e.g., Michard and Roekens, 1983; Reed and Spycher, 1984). Some previous investigators (e.g., D'Amore et al., 1987; Hull et al., 1987; Tole et al., 1993) have used this technique for predicting reservoir temperature in various geothermal sites. Other researchers have used the basic principles of this method for reconstructing the composition of geothermal fluids and formation brines (Pang and Reed, 1998; Palandri and Reed, 2001). More recent efforts by some researchers (e.g., Bethke, 2008; Spycher et al., 2011; Smith et al., 2012; Cooper et al., 2013; Neupane et al., 2013, 2014; Cannon et al., 2014; Spycher et al., 2014; Peiffer et al., 2014; Palmer et al., 2014; Neupane et al., 2015a,b,c; Mattson et al., 2015; Neupane et al., 2016a,b) have been focused on improving temperature predictability of the MEG.

For this study, both traditional [e.g., quartz (no steam loss) (Fournier, 1977), chalcedony (Fournier, 1977), and Na-K-Ca (Truesdell and Fournier, 1973; Fournier and Potter, 1979)] and RTEst (Palmer et al., 2014; Mattson et al., 2015) geothermometric approaches were applied to estimate reservoir temperatures. For the silica geothermometers, $\mathrm{pH}$ correction on silica concentrations was not applied. While applying RTEst to each water sample, a mineral assemblage consisting of 5-7 representative minerals was used for the development of reservoir temperature estimate using the LLNL based thermodynamic database (thermo.dat database of Geochemist's Workbench). In general, the mineral assemblage was selected based on available information such as water chemistry (e.g., $\mathrm{pH}$ ), likely reservoir rock types and temperature range, etc. For more detailed information on selection of the mineral assemblage, see Palmer et al. (2014).

\section{WATER SAMPLES}

\subsection{General}

Locations of Newdale area water samples are shown in Figure 1. The water compositions used in this study represent both wells producing waters at elevated temperatures $\left(\geq 20^{\circ} \mathrm{C}\right)$ and cooler water $\left(<20^{\circ} \mathrm{C}\right)$. The temperatures of the wells with warmer water range from $21-51{ }^{\circ} \mathrm{C}$ whereas temperatures of cooler wells range from $8.5-17.5^{\circ} \mathrm{C}$.

\subsection{Water Chemistry}

All Newdale area wells produce dilute (TDS ranging from 200 to $520 \mathrm{mg} / \mathrm{kg}$ with an average value of $375 \pm 80 \mathrm{mg} / \mathrm{kg}$ ) and near-neutral ( $\mathrm{pH}$ ranging from 6.4 to 8.5) water. Major cations in Newdale water samples are $\mathrm{Na}, \mathrm{Ca}$, and $\mathrm{Mg}$ whereas major anions are $\mathrm{HCO}_{3}, \mathrm{Cl}_{1} \mathrm{~F}$, and $\mathrm{SO}_{4}$. Water samples in the area are of two types: $\mathrm{Na}-\mathrm{HCO}_{3}$ and $\mathrm{Ca}-(\mathrm{Mg})-\mathrm{HCO}_{3}$ (Figure 3). In the ESRP, the $\mathrm{Na}-\mathrm{HCO}$ and $\mathrm{Ca}-$ $(\mathrm{Mg})-\mathrm{HCO}_{3}$ type waters are often related to deeper water that have interacted with rhyolite at relatively higher temperature and shallower ESRP groundwater that have mostly interacted with basalt at cooler temperature, respectively (Mann, 1986; McLing et al., 2002; Welhan, 2015). Recently, Cannon (2015) showed that the $\mathrm{Ca}-\mathrm{Mg}-\mathrm{HCO}_{3}$ groundwater gradually changes to $\mathrm{Na}-\mathrm{HCO}$ type water when interacted with ESRP basalts at $70{ }^{\circ} \mathrm{C}$ for a long time. Therefore, the water types in the ESRP region are more likely to reflect the degree of thermal influence on water-rock interaction independent of rock types. The $\mathrm{Na}-\mathrm{HCO}_{3}$ waters have slightly higher TDS (ranging from 340 to $520 \mathrm{mg} / \mathrm{kg}$ with an average value of $440 \pm 60 \mathrm{mg} / \mathrm{kg}$ ) than Ca- $(\mathrm{Mg})-\mathrm{HCO}_{3}$ waters (ranging from 200 to $480 \mathrm{mg} / \mathrm{kg}$ with an average value of $330 \pm 60 \mathrm{mg} / \mathrm{kg}$ ). 
The cations ternary and the diamond plots in Figure 3 show that these two groups of water aligned along a trend from Na+K vertex to $\mathrm{Ca}-\mathrm{Mg}$ baseline; however, such trend is missing in the anions ternary plot. Nevertheless, the anions ternary diagram shows a type-water independent trend that extends from the $\mathrm{HCO}_{3}$ vertex towards the $\mathrm{Cl}-\mathrm{SO}_{4}$ baseline. A similar type-water independent trend can be found on a bivariate plot constructed for $\mathrm{HCO}_{3}$ and $\mathrm{Cl}$ (Figure 4a). The trend depicted in Figure 4a reflects the intensity of water-rock interaction (regardless of the rock types) that a water sample might have experienced. In general, the higher the degree of water-rock interaction, the higher the concentrations of $\mathrm{HCO}_{3}$ and $\mathrm{Cl}$ in water. Other bivariate plots (Figure 4b through Figure 4e), however, show linear alignment of $\mathrm{Na}-\mathrm{HCO}_{3}$ and $\mathrm{Ca}-(\mathrm{Mg})-\mathrm{HCO}_{3}$ type water samples. Traditionally, such linear alignment of water samples on bivariate plots is considered to be the result of mixing of the two end member water compositions at different proportions. Figure $4 \mathrm{f}$ indicates that the both $\mathrm{Na}-\mathrm{HCO}_{3}$ and $\mathrm{Ca}-(\mathrm{Mg})-\mathrm{HCO}_{3}$ type waters are meteoric in origin and the variations in major ion concentrations in them is a reflection of the varying degrees of water-rock interaction involving different rock types, temperatures, and mixing with other water types.

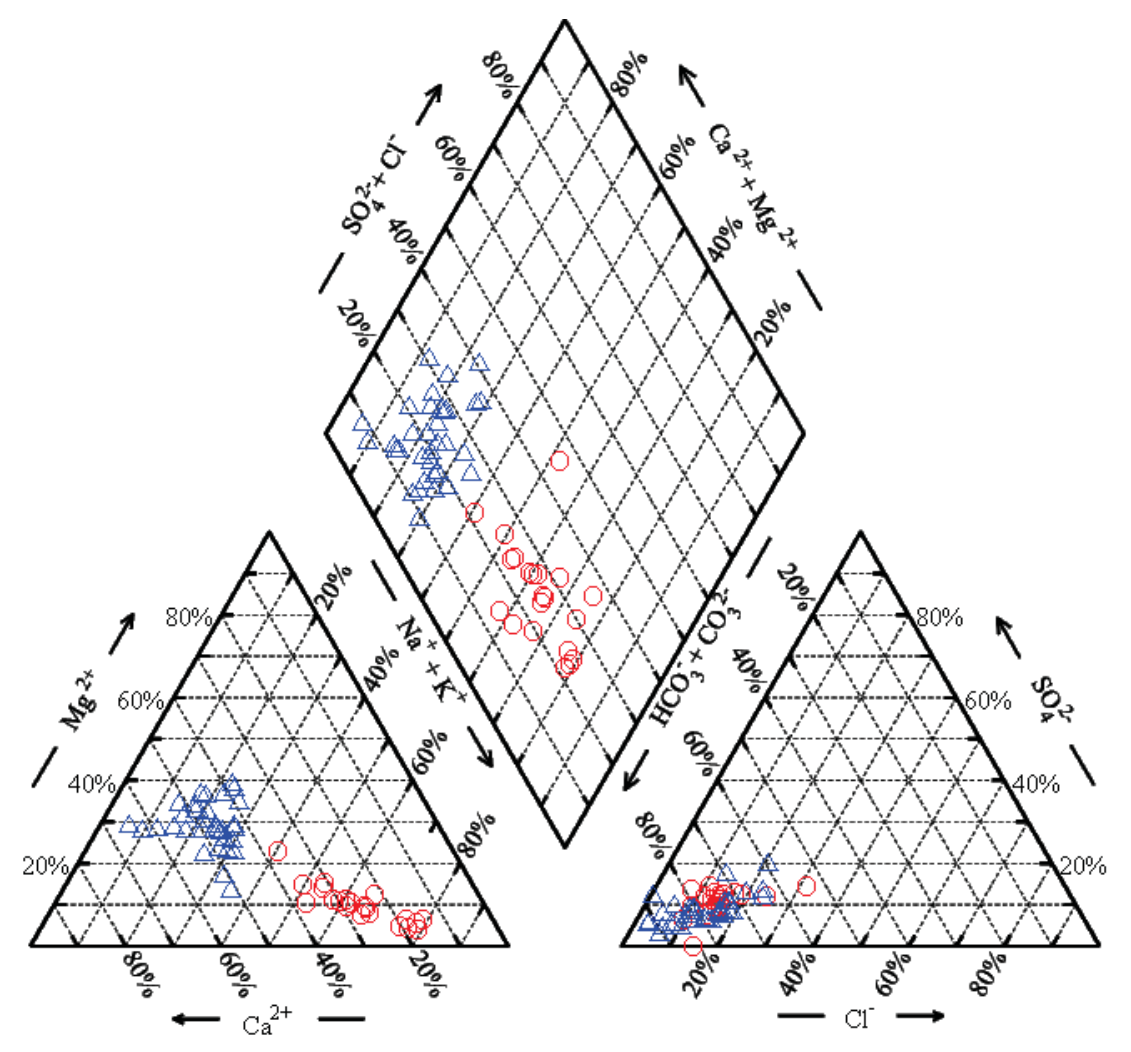

Figure 3. Piper diagram representing chemistry of water samples from Newdale geothermal area. Red circles and blue triangles represent $\mathrm{Na}-\mathrm{HCO}_{3}$ and $\mathrm{Ca}-(\mathrm{Mg})-\mathrm{HCO}_{3}$ type waters, respectively.

Although bivariate plots shown in Figure $4 \mathrm{~b}$ through Figure $4 \mathrm{f}$ depict the apparent linear alignment of $\mathrm{Na}-\mathrm{HCO}$ and $\mathrm{Ca}-(\mathrm{Mg})-\mathrm{HCO} 3$ type waters, some additional bivariate plots with other components and ratios (Figure 5a through Figure 5f) show two distinct mixing (and/or degree of water rock interactions) trends, one for the $\mathrm{Na}-\mathrm{HCO}_{3}$ and other for the $\mathrm{Ca}-(\mathrm{Mg})-\mathrm{HCO}_{3}$ type waters. These diagrams indicate that for $\mathrm{Ca}-(\mathrm{Mg})-\mathrm{HCO}_{3}$ type waters, one end-member (dilute one) can be represented by a pristine water (rain/snow melt). However, the composition of other end member (towards higher TDS) is not known, but such composition for each sample can be reconstructed with RTEst modeling. All intermediate waters have formed either by mixing of low and high TDS end-member waters at various proportions, or by varying degree of water-rock interaction.

Some bivariate plots (e.g., Figure 5b, d, and f) that includes $\mathrm{Cl}$ (concentration or as part of ratio) in their construction indicate that the cooler end member water that mixed with the $\mathrm{Na}-\mathrm{HCO}_{3}$ type waters is very dilute $\mathrm{Ca}-(\mathrm{Mg})-\mathrm{HCO}$ type water or pristine water. However, other bivariate plots that do not include $\mathrm{Cl}$ in their construction (e.g., Figure 5a, c, and e) indicate that the end member water that mixed with $\mathrm{Na}-\mathrm{HCO}_{3}$ type waters may have a composition similar to some intermediate $\mathrm{Ca}-(\mathrm{Mg})-\mathrm{HCO} 3$ type water. Since $\mathrm{RTEst}$ does not handle complex geochemical behavior (e.g., precipitation, cation exchange, and so on), we assume that some variant of intermediate $\mathrm{Ca}-(\mathrm{Mg})-\mathrm{HCO}_{3}$ type water is the end member water that is mixed with $\mathrm{Na}-\mathrm{HCO}_{3}$ type waters. As with the cases of Ca$(\mathrm{Mg})-\mathrm{HCO}_{3}$ type waters, the higher TDS end member composition of $\mathrm{Na}-\mathrm{HCO}_{3}$ type waters are not known, and for each sample, the original thermal water is reconstructed with RTEst modeling. 

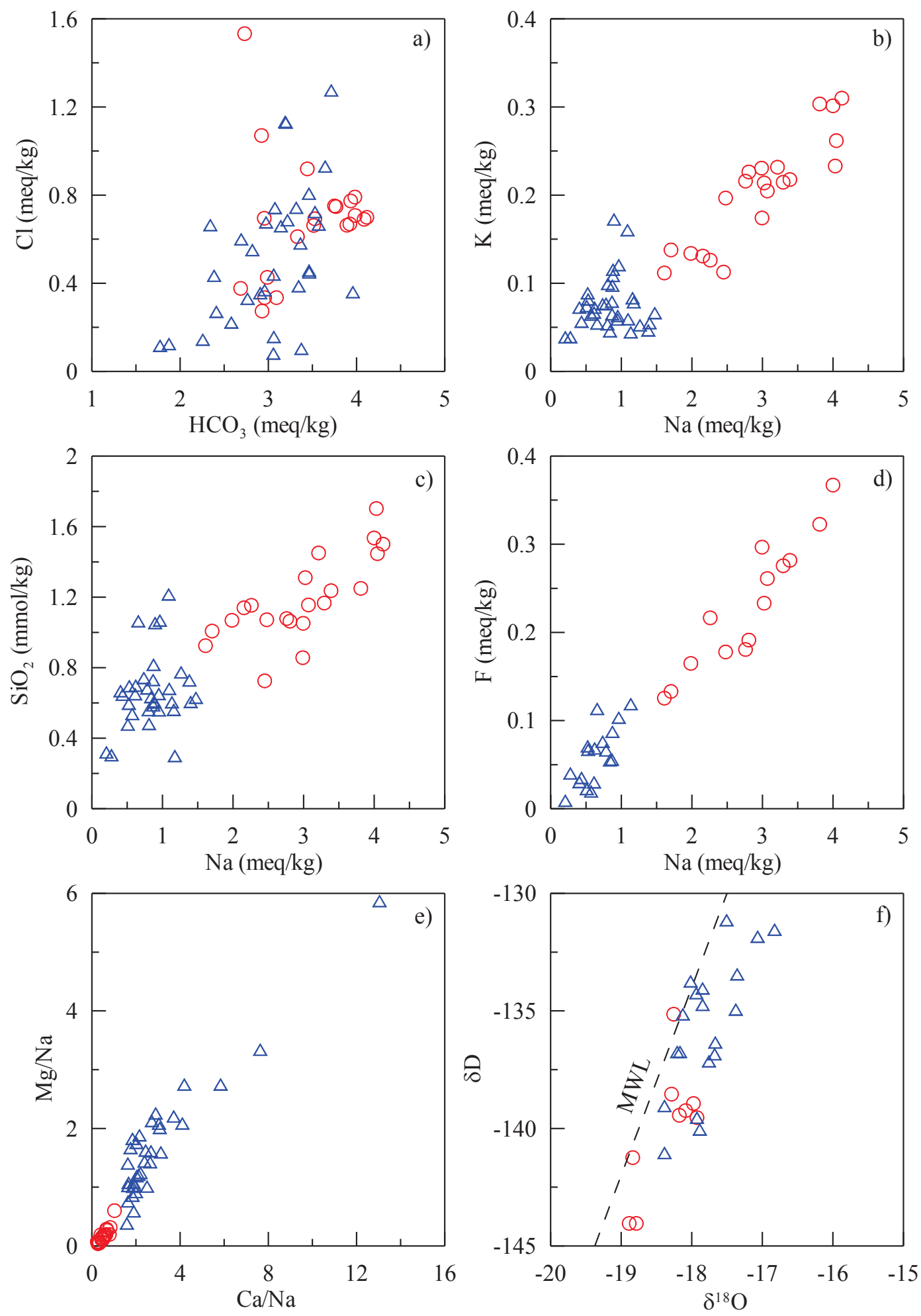

Figure 4. Bivariate diagrams constructed for some components, isotopes, and components ratios in Newdale and surrounding area water samples. Red circles and blue triangles represent $\mathrm{Na}-\mathrm{HCO}_{3}$ and $\mathrm{Ca}-(\mathrm{Mg})-\mathrm{HCO}_{3}$ type waters, respectively.

Bivariate plots shown on Figure 6 also supports this assumption that some intermediate $\mathrm{Ca}-(\mathrm{Mg})-\mathrm{HCO}_{3}$ type water is likely to be the end member water that is mixed with $\mathrm{Na}-\mathrm{HCO}_{3}$ type waters at different proportions. Figure $6 \mathrm{a}$ indicate that the $\mathrm{Na}-\mathrm{HCO}_{3}$ type water may be divided into two groups showing slightly different mixing trends. Figure $6 \mathrm{~b}$ indicates that the $\mathrm{Ca}-(\mathrm{Mg})-\mathrm{HCO} \mathrm{Haters}_{3} \mathrm{may}$ have two sub-groups with two mixing/water rock interaction trends. The first group of $\mathrm{Ca}-(\mathrm{Mg})-\mathrm{HCO}_{3}$ type water samples has low $\mathrm{F}$, and these water samples do not show further enrichment in F with progression of water-rock interaction. On the other hand, the second 
Neupane et al.

group of water samples shows a tendency of slightly increasing F with increasing concentration of Ca (and TDS as well, figure not shown); however, it may be difficult to discern whether the increasing $\mathrm{F}$ concentration merely reflects the fact that these waters may have had limited water-rhyolite interaction or they receive increasing amounts of $\mathrm{Na}-\mathrm{HCO}_{3}$ type water.
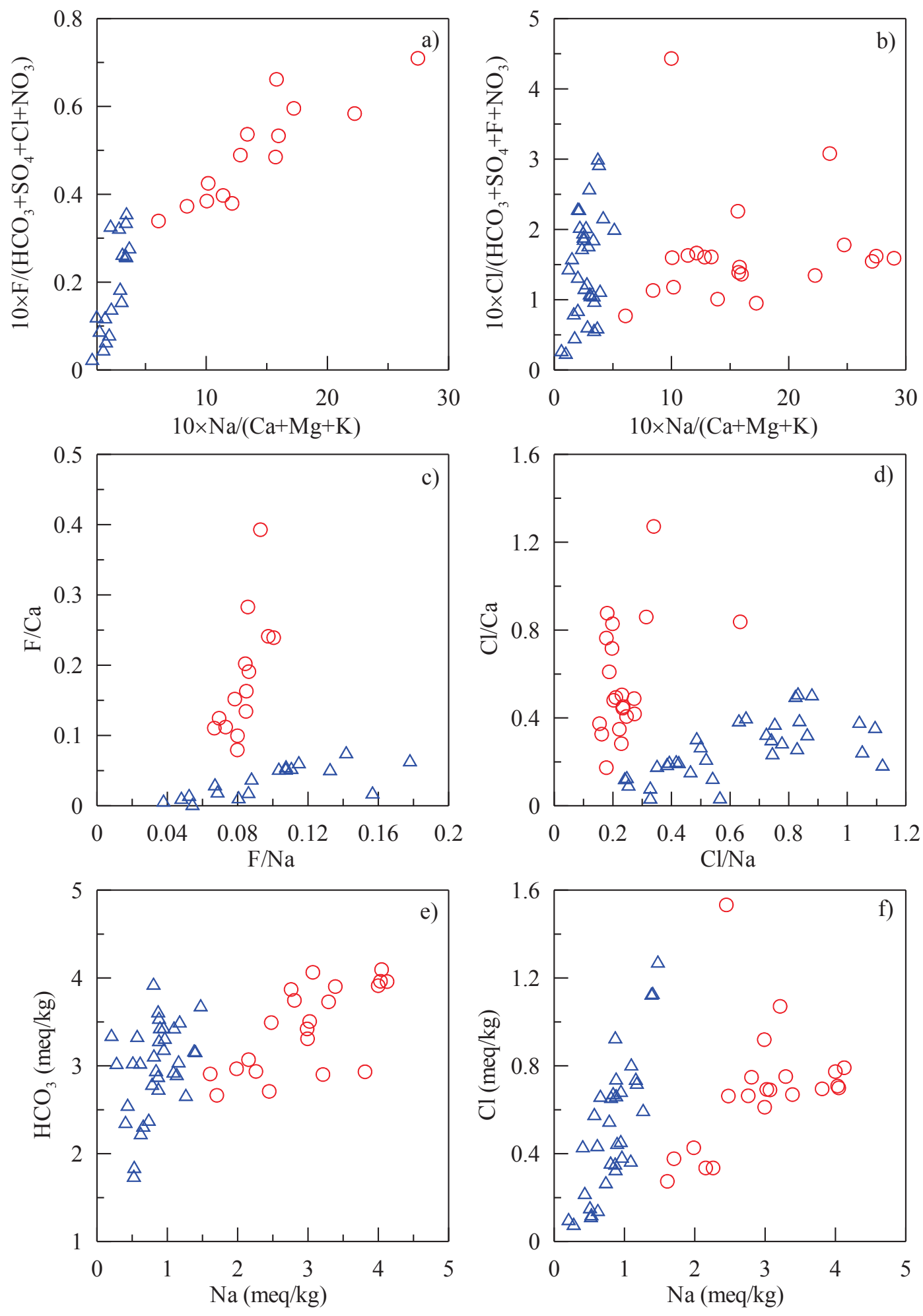

Figure 5. Bivariate diagrams constructed for some components and components ratios in Newdale and surrounding area water samples. Red circles and blue triangles represent $\mathrm{Na}-\mathrm{HCO}_{3}$ and $\mathrm{Ca}-(\mathrm{Mg})-\mathrm{HCO}_{3}$ type waters, respectively. 

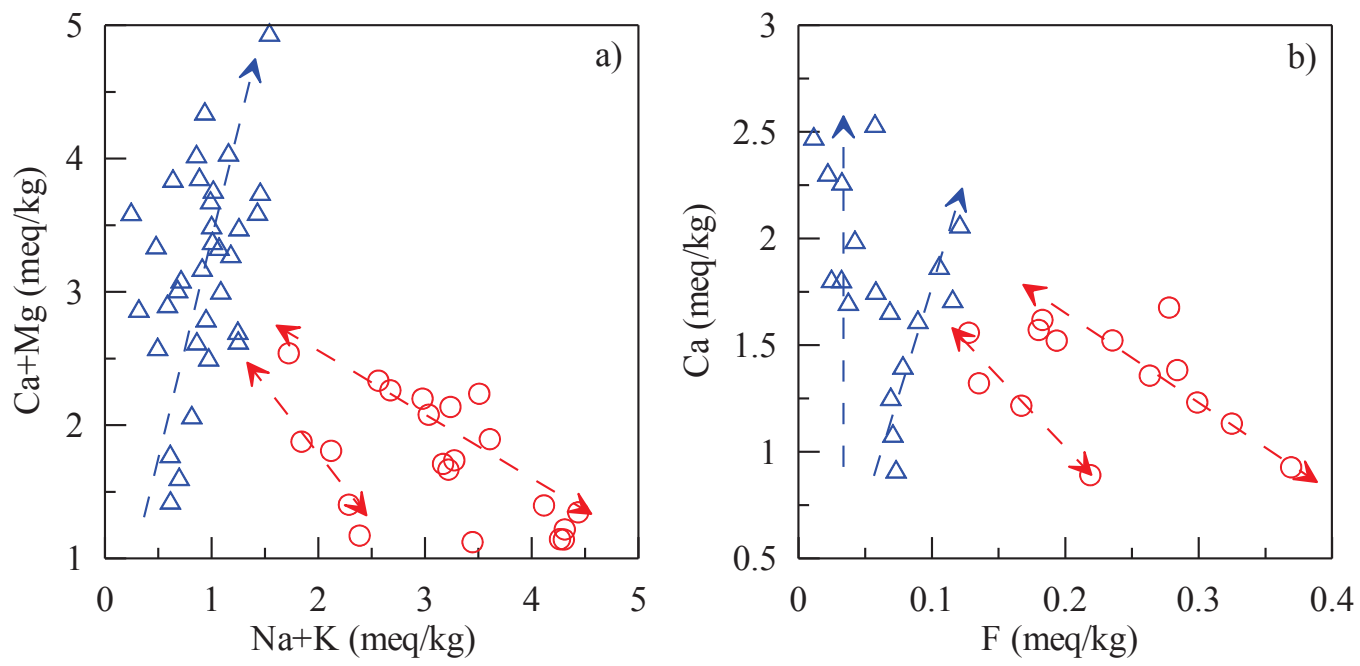

Figure 6. Bivariate diagrams constructed for some components in Newdale and surrounding area water samples. Red circles and blue triangles represent $\mathrm{Na}-\mathrm{HCO}_{3}$ and $\mathrm{Ca}-(\mathrm{Mg})-\mathrm{HCO}_{3}$ type waters, respectively.

Concentration of $\mathrm{F}$ in water samples is highly influenced by the degree of past interaction with felsic volcanic rocks. However, the majority of low F water samples are from the area north of Teton River where the subsurface lithology is dominated with felsic rocks. At first, it appears incongruent with the near surface rock types, however, the wells located north of Teton River tap water from a sediment-basalt aquifer sandwiched between pre-Huckleberry Ridge and Huckleberry Ridge felsic volcanic rocks (Figure 2). Similarly, wells distributed on the southern side of the Teton River where near surface rocks are basalts mostly tap $\mathrm{Na}_{-} \mathrm{HCO}_{3}$ type water from felsic volcanic rock units underneath the basalts.

\section{GEOTHERMOMETRIC CALCULATIONS}

\subsubsection{Traditional geothermometers}

On a Giggenbach diagram, all Newdale water samples plot in immature water field (Figure 7). For this geothermal prospect, this diagram is minimally useful except indicating that these waters may be less suitable for traditional geothermometry.

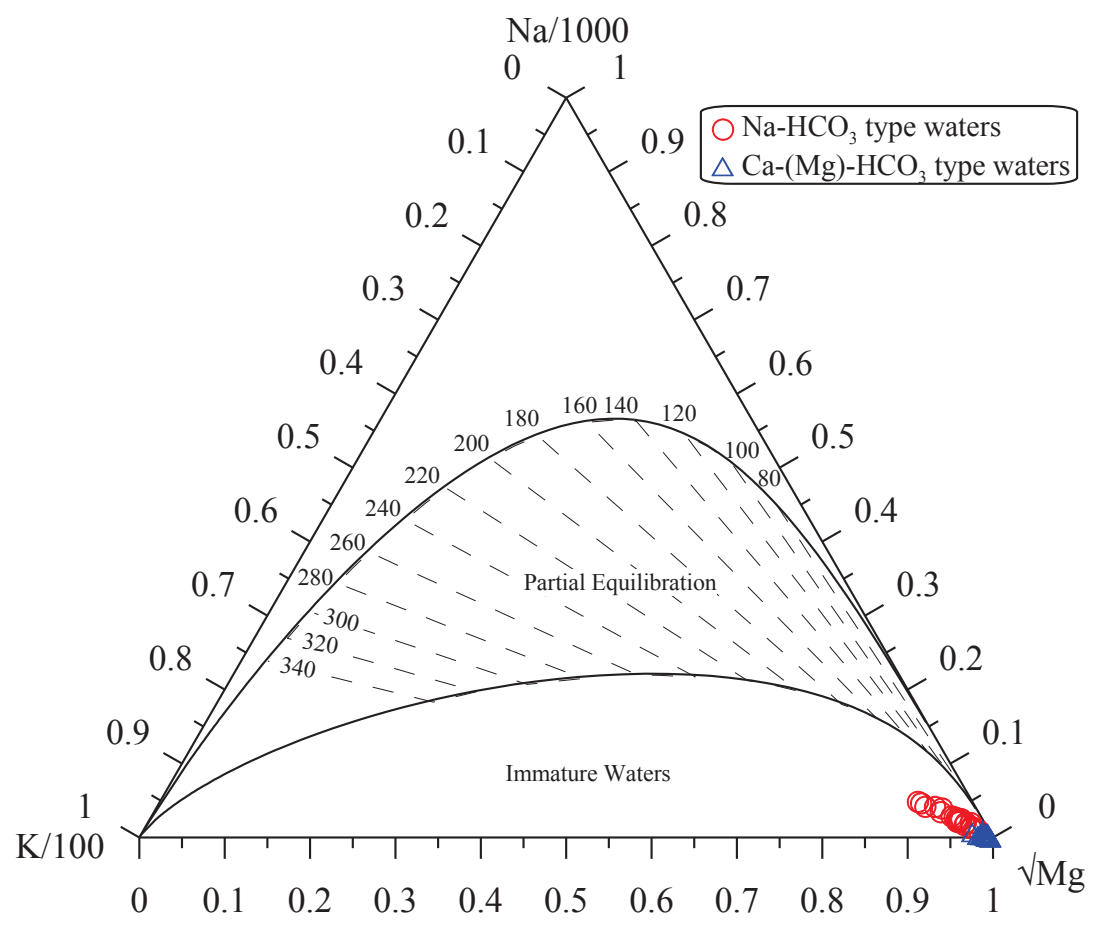

Figure 7. Newdale area water samples plotted on Giggenbach diagram. 
Reservoir temperature estimates obtained with quartz, chalcedony, and $\mathrm{Na}-\mathrm{K}-\mathrm{Ca}\left(\mathrm{Mg}\right.$-corrected) geothermometers for $\mathrm{Ca}-(\mathrm{Mg})-\mathrm{HCO}{ }_{3}$ type waters are lower when compared to the temperature estimates obtained with the respective geothermometers for the $\mathrm{Na}^{-} \mathrm{HCO}_{3}$ type waters (Table 1). The range of temperatures with quartz, chalcedony, and $\mathrm{Na}-\mathrm{K}-\mathrm{Ca}(\mathrm{Mg}$-corrected) geothermometers for $\mathrm{Ca}-(\mathrm{Mg})-$ $\mathrm{HCO}_{3}$ type waters are 66-119 ${ }^{\circ} \mathrm{C}, 28-93{ }^{\circ} \mathrm{C}, 29-81{ }^{\circ} \mathrm{C}$, respectively. Similarly, range of estimated temperature with these geothermometers for $\mathrm{Na}-\mathrm{HCO}_{3}$ type waters are $97-134{ }^{\circ} \mathrm{C}, 65-112{ }^{\circ} \mathrm{C}$, and $50-111{ }^{\circ} \mathrm{C}$, respectively. A silica (quartz)-enthalpy mixing model (Fournier, 1977; Fournier and Porter, 1982) using all samples resulted in a reservoir temperature of about $224{ }^{\circ} \mathrm{C}$. However, the silica (chalcedony)-enthalpy mixing model resulted in reservoir temperature of about $174{ }^{\circ} \mathrm{C}$ (Figure 8 ).

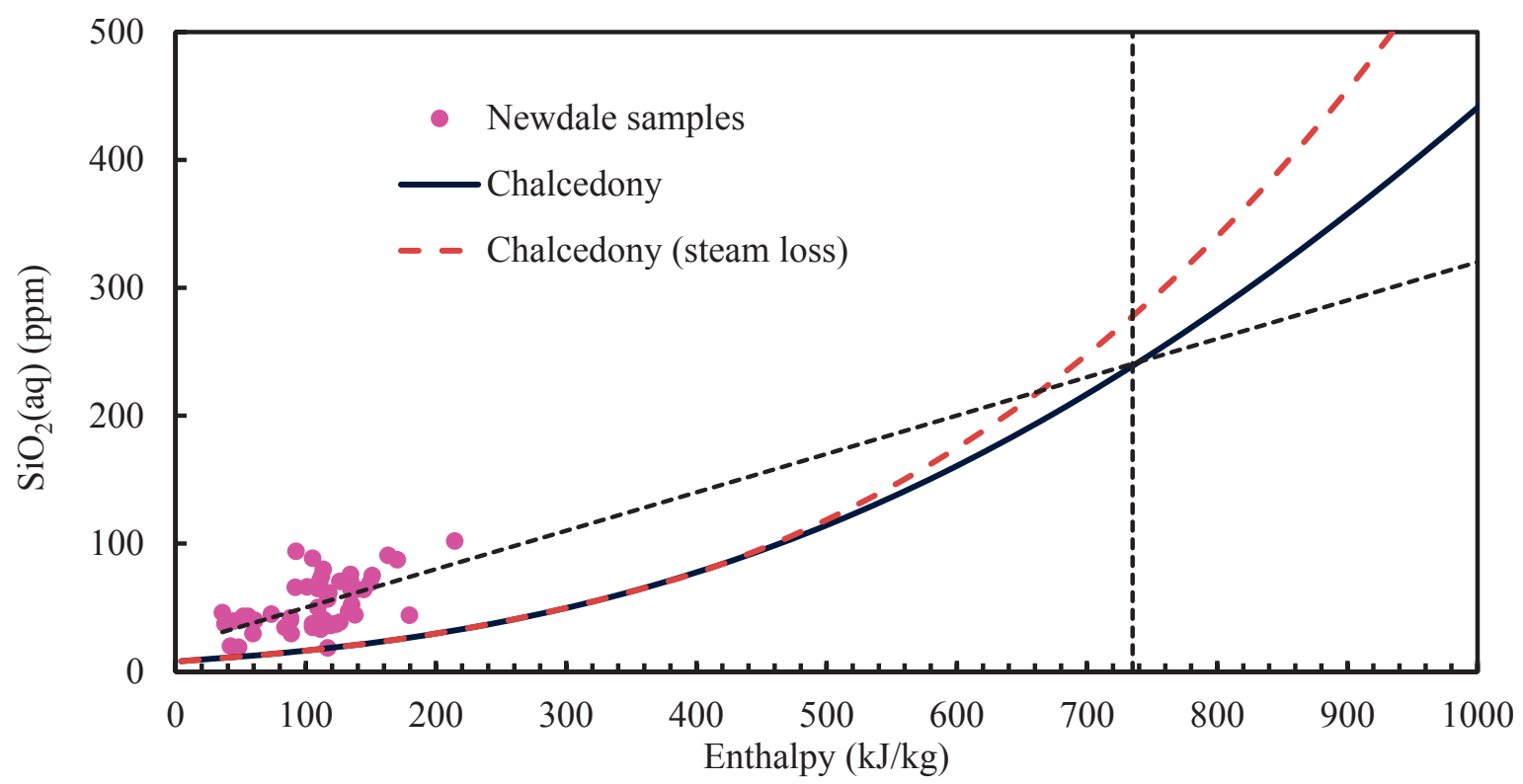

Figure 8. Silica (chalcedony)-enthalpy mixing model (modified from Fournier, 1977; Fournier and Porter, 1982) applied to all Newdale area samples.

\subsection{Multicomponent geothermometry}

Since $\mathrm{Na}-\mathrm{HCO}_{3}$ type waters show mixing trends (Figure 6) with a variant of $\mathrm{Ca}-(\mathrm{Mg})-\mathrm{HCO}_{3}$ type water; RTEst modeling of these samples were performed using the option that helps reconstruct thermal fluid using mixing, fugacity of $\mathrm{CO}_{2}$, and $\mathrm{T}$ as optimization parameters. The Groundwater well-3 (GW3 in Figure 1) water composition was selected to define the end member cooler water composition for RTEst modeling of $\mathrm{Na}-\mathrm{HCO}_{3}$ type waters. The $\mathrm{GW} 3$ water is a $\mathrm{Ca}-(\mathrm{Mg})-\mathrm{HCO}_{3}$ type water that approximately falls along the mixing trends for both types of water on some bivariate plots (Figure 4, Figure 5a,b,e,f). During RTEst modeling, some variant of this water composition is found applicable to all $\mathrm{Na}-\mathrm{HCO}_{3}$ type waters as well as to majority of $\mathrm{Ca}-(\mathrm{Mg})-\mathrm{HCO}$ type waters. Specifically, $\mathrm{SiO}_{2}(\mathrm{aq})$ concentration in $\mathrm{GW} 3$ water, which has unusually high concentration of $46 \mathrm{mg} / \mathrm{L}$ at $8.5^{\circ} \mathrm{C}$, was not included in the end member cooler water composition for RTEst modeling. The same approach was used for most of the $\mathrm{Ca}-(\mathrm{Mg})-\mathrm{HCO}{ }_{3}$ type waters, however, for some $\mathrm{Ca}-(\mathrm{Mg})-\mathrm{HCO}_{3}$ type waters (Remington Produce, Schwendiman, Pauline, Mark Ricks, and Lavere Ricks wells), RTEst modeling was performed using pure water to account for the mixing. For these samples, use of GW3 based end member water resulted in similar estimated temperatures as with the pure water but similar or poor convergence (large standard error). As noted in the previous section, the assumption of some pristine water as end member cooler water for $\mathrm{Ca}-(\mathrm{Mg})-\mathrm{HCO} 3$ type waters is geochemically satisfactory to all bivariate plots (Figure 4, Figure 5, and Figure 6).

The RTEst estimated temperature for all water compositions are given in Table 1. The ranges of RTEst temperature estimates for Na$\mathrm{HCO}_{3}$ and $\mathrm{Ca}-(\mathrm{Mg})-\mathrm{HCO}_{3}$ type waters are $75-152{ }^{\circ} \mathrm{C}$ and $85-138{ }^{\circ} \mathrm{C}$, respectively. RTEst results indicate that Newdale area samples contained 10 to $75 \%$ of cooler water fractions. Relatively, $\mathrm{Ca}-(\mathrm{Mg})-\mathrm{HCO}_{3}$ type waters have greater fractions $(30-75 \%)$ of cooler water than $\mathrm{Na}-\mathrm{HCO}_{3}$ type waters (10-50\%). The relatively cooler temperatures obtained with the traditional geothermometers for the Ca$(\mathrm{Mg})-\mathrm{HCO}_{3}$ type waters may have resulted because they are more diluted with cooler waters than the Na-HCO3 type waters.

The lower RTEst temperature estimates obtained for some samples from this area are similar to the bottom hole temperatures $\left(83-87{ }^{\circ} \mathrm{C}\right)$ measured at two relatively deeper $(\sim 1000 \mathrm{~m})$ Unocal wells (St-07 and St-08 in Figure 1). Moreover, it is likely that the area hosts hotter zone at greater depth reaching to the higher RTEst temperature estimates. Assuming an $80{ }^{\circ} \mathrm{C}$ thermal gradient (as indicated by two Unocal wells), the higher RTEst temperature estimates would be available at about $2 \mathrm{~km}$ depth. 
Neupane et al.

Table 1. Geothermometric reservoir temperatures (in ${ }^{\circ} \mathrm{C}$ ) estimated using water compositions from several sampling features in northeastern ESRP

\begin{tabular}{|c|c|c|c|c|}
\hline Wells & RTEst $\mathrm{T} \pm \sigma^{\mathrm{a}}$ & Quartz (nsl) $^{b}$ & Chalcedony $^{\mathrm{c}}$ & $\mathrm{Na}-\mathrm{K}-\mathrm{Ca}^{\mathrm{d}}$ \\
\hline 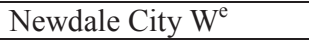 & $96 \pm 4$ & 117 & 90 & 85 \\
\hline Wanda Woods W2 & $141 \pm 7$ & 122 & 97 & 65 \\
\hline Walz Enterprises W & $131 \pm 8$ & 113 & 86 & 70 \\
\hline Wanda Woods W1 & $110 \pm 7$ & 114 & 86 & 71 \\
\hline Wallace Little W & $106 \pm 4$ & 120 & 93 & 70 \\
\hline Henry Harris W & $133 \pm 5$ & 113 & 85 & 68 \\
\hline Donanld Trupp W & $115 \pm 3$ & 120 & 94 & 108 \\
\hline Wayne Larson W & $122 \pm 3$ & 130 & 107 & 111 \\
\hline Schwendiman W & $137 \pm 4$ & 111 & 83 & 63 \\
\hline Clyde W & $139 \pm 5$ & 113 & 86 & 56 \\
\hline Cinder Block W & $119 \pm 3$ & 117 & 90 & 79 \\
\hline $\mathrm{G} 21$ & $138 \pm 3$ & 116 & 89 & 69 \\
\hline G23 & $75 \pm 6$ & 97 & 65 & 83 \\
\hline G25 & $135 \pm 3$ & 134 & 112 & 68 \\
\hline G41 & $138 \pm 3$ & 127 & 103 & 79 \\
\hline G43 & $136 \pm 5$ & 117 & 90 & 75 \\
\hline G44 & $102 \pm 4$ & 104 & 74 & 50 \\
\hline G50 & $113 \pm 3$ & 128 & 105 & 110 \\
\hline G54 & $118 \pm 2$ & 126 & 102 & 80 \\
\hline G78 & $152 \pm 5$ & 108 & 78 & 44 \\
\hline G80 & $103 \pm 2$ & 114 & 86 & 60 \\
\hline Remington Produce $W^{e}$ & $134 \pm 7$ & 113 & 86 & 39 \\
\hline Dean Swindelman $W$ & $129 \pm 12$ & 113 & 86 & 44 \\
\hline Pauline $W$ & $85 \pm 5$ & 94 & 61 & 44 \\
\hline Mark Ricks $W$ & $125 \pm 4$ & 103 & 72 & 50 \\
\hline Lavere Ricks $W$ & $116 \pm 8$ & 96 & 63 & 49 \\
\hline G22 & $104 \pm 10$ & 98 & 66 & 53 \\
\hline$G 24$ & $117 \pm 6$ & 119 & 93 & 74 \\
\hline G26 & $118 \pm 13$ & 91 & 57 & 49 \\
\hline$G 28$ & $122 \pm 2$ & 83 & 48 & 29 \\
\hline G30 & $101 \pm 10$ & 66 & 28 & 33 \\
\hline G31 & $92 \pm 7$ & 88 & 54 & 41 \\
\hline G36 & $110 \pm 8$ & 94 & 61 & 31 \\
\hline G37 & $138 \pm 3$ & 113 & 85 & 41 \\
\hline G38 & $98 \pm 3$ & 88 & 54 & 46 \\
\hline G39 & $121 \pm 1$ & 91 & 58 & 44 \\
\hline G55 & $104 \pm 5$ & 100 & 69 & 81 \\
\hline G56 & $102 \pm 8$ & 91 & 57 & 57 \\
\hline G64 & $96 \pm 4$ & 88 & 54 & 58 \\
\hline G65 & $89 \pm 7$ & 90 & 56 & 45 \\
\hline G66 & $102 \pm 7$ & 91 & 58 & 49 \\
\hline G67 & $134 \pm 12$ & 92 & 59 & 33 \\
\hline
\end{tabular}

${ }^{a}$ RTEst estimated temperature with associated standard error; ${ }^{b}$ quartz (no steam loss) geothermometer temperature (Fournier,1977); ${ }^{c}$ chalcedony geothermometer temperature (Fournier,1977); ${ }^{\mathrm{d}}$ Mg-corrected (where applicable) Na-K-Ca geothermometer temperature (Truesdell and Fournier, 1973; Fournier and Potter II, 1979), ${ }^{\mathrm{e}}$ wells with regular and italicized fonts produce $\mathrm{Na}^{-\mathrm{HCO}} 3$ and $\mathrm{Ca}-\mathrm{Mg}$ $\mathrm{HCO}_{3}$ type waters, respectively.

\section{CONCLUSIONS}

The Newdale geothermal area in Madison and Fremont Counties in Idaho is a known geothermal resource area whose thermal anomaly is expressed by high thermal gradients and numerous wells producing warm water (up to $51{ }^{\circ} \mathrm{C}$ ). Geochemical evaluations of water samples from numerous wells in the area indicate that the area has two types of waters $-\mathrm{Na}-\mathrm{HCO}_{3}$ and $\mathrm{Ca}-(\mathrm{Mg})-\mathrm{HCO}$. These two water types are considered to be the product of water-interactions involving felsic and basic volcanic rocks and mixing with dilute and cooler groundwater. Each water type can further be subdivided into two groups depending on their degree of mixing with other water types or interaction with other rocks. For example, some bivariate plots indicate that some $\mathrm{Ca}-(\mathrm{Mg})-\mathrm{HCO}_{3}$ water samples have interacted only with basalts whereas some samples of this water type also show limited interaction with rhyolite or mixing with Na$\mathrm{HCO}_{3}$ type water. Traditional geothermometers [e.g., silica variants, Na-K-Ca (Mg-corrected)] indicate lower temperatures for this area; however, a traditional silica-enthalpy mixing model results in higher reservoir temperatures. Multicomponent geothermometry (e.g., RTEst) results indicate that the well water samples are mixed with up to $75 \%$ of the near surface groundwater. Relatively, Ca-(Mg)$\mathrm{HCO}_{3}$ type water samples are more diluted than the $\mathrm{Na}-\mathrm{HCO}_{3}$ type water samples. However, both water types result in similar reservoir temperatures, up to $150{ }^{\circ} \mathrm{C}$. Geothermometric results and the available geothermal gradient data of the area indicate that the reservoir is 
likely to be located at a depth of about $2 \mathrm{~km}$. However, further evaluation of the subsurface permeability and extent of the thermal anomaly is needed to better define the hydrothermal potential of this geothermal resource.

\section{ACKNOWLEDGMENTS}

This work was supported by funding by the Assistant Secretary for Energy Efficiency and Renewable Energy, Geothermal Technologies Office of the U.S. Department of Energy under the U.S. Department of Energy Contract Nos. DE-AC07-05ID14517 with Idaho National Laboratory and DE-AC02-05CH11231 with Lawrence Berkeley National Laboratory. We thank landowners who provided access to sampling locations. We also thank Dr. Ross Spackman (Brigham Young University-Idaho) for his assistance in coordinating with landowners and filed work. Chemical analyses of the samples were conducted by Ms. Debbie Lacroix (University of Idaho) at Center for Advanced Energy Studies (CAES). We appreciate the discussion with Drs. Bill Phillips (Idaho Geological Survey), Glenn Embree (BYU-Idaho), and Dan Moore (BYU-Idaho).

\section{REFERENCES}

Anders, M. H., Rodgers, D. W., Hemming, S. R., Saltzman, J., DiVenere, V. J., Hagstrum, J. T., Embree, G. F., and Walter, R. C.: A fixed sublithospheric source for the late Neogene track of the Yellowstone hotspot: Implications of the Heise and Picabo volcanic fields, Journal of Geophysical Research: Solid Earth, 119, (2014), 2871-2906.

Bethke, C.M.: Geochemical and Biogeochemical Reaction Modeling. Cambridge University Press, pp. 547, (2008).

Blackwell, D.D.: Regional implications of heat flow of the Snake River Plain, northwestern United States. Tectonophysics, 164, (1989), 323-343.

Bond, J. G.: Geologic map of the state of Idaho, scale 1:500,000. Idaho Bur. of Mines and Geology, (1978).

Brott, C.A., Blackwell, D.D., and Mitchell, J.C.: Geothermal Investigations in Idaho, Part 8, Heat Flow in the Snake River Plain Region, Idaho. Water Information Bulletin No.30, Idaho Department of Water Resources, (1976).

Cannon, C., Wood, T., Neupane, G., McLing, T., Mattson, E., Dobson, P., and Conrad, M.: Geochemistry sampling for traditional and multicomponent equilibrium geothermometry in southeast Idaho. GRC Transactions, 38, (2014), 524-431.

Cooper, D.C., Palmer, C.D., Smith, R.W., and McLing, T.L.: Multicomponent equilibrium models for testing geothermometry approaches. Proceedings, 38th Workshop on Geothermal Reservoir Engineering Stanford University, Stanford, CA (2013).

D’Amore, F. and Arnórsson, S.: Geothermometry. In S. Arnórsson, ed., Isotopic and Chemical Techniques in Geothermal Exploration, Development and Use, IAEA (Editorial), Vienna, p. 152-199, (2000).

D'Amore, F., Fancelli, R., and Caboi, R.: Observations on the application of chemical geothermometers to some hydrothermal systems in Sardinia. Geothermics, 16, (1987), 271-282.

Embree, G.F., and Hoggan R.D.: Secondary deformation within the Huckleberry Ridge Tuff and subjacent Pliocene units near the Teton Dam: Road log to the regional geology of the eastern margin of the Snake River plain, Idaho. In S.S. Hughes and G.D. Thackray, eds., Guidebook to the Geology of Eastern Idaho, Idaho Museum of Natural History, Pocatello, Idaho, p. 181-202, (1999).

Embree, G.F., Phillips, W.M., and Welhan, J.A.: Geologic map of the Newdale quadrangle, Fremont and Madison Counties, Idaho. Idaho Geological Survey, University of Idaho, Moscow, Idaho 83844-3014, (2011).

Fournier, R.O.: Chemical geothermometers and mixing models for geothermal systems. Geothermics, 5, (1977) 41-50.

Fournier, R.O.: A revised equation for the Na/K geothermometer. GRC Transactions, 3, (1979), 221-224.

Fournier, R.O. and Truesdell, A.H.: An empirical Na-K-Ca geothermometer for natural waters. Geochim. Cosmochim. Acta, 37, (1973), $1255-1275$.

Fournier, R.O. and Potter, R.W. II: Magnesium correction to the Na-K-Ca chemical geothermometer. Geochim. Cosmochim. Acta, 43, (1979), 1543-1550.

Fournier, R. O. and Potter, R.W. II: Revised and expanded silica (quartz) geothermometer. Geotherm. Resour. Counc. Bullet., 11(10), (1982), 3-12.

GeothermEx, Inc.: Independent technical report: Resource evaluation of the Newdale geothermal prospect, Madison and Fremont Counties, Idaho, USA. Geothermix, Inc., Richmond, California, USA, February 10, 2010, p. 101, (2010).

Giggenbach, W.F.: Geothermal solute equilibria. Derivation of Na-K-Mg-Ca geoindicators. Geochim. Cosmochim. Acta, 52, (1988), 2749-2765.

Hughes, S.S., Smith, R.P., Hackett, W.R., and Anderson, S. R.: Mafic volcanism and environmental geology of the eastern Snake River Plain. Idaho Guidebook to the Geology of Eastern Idaho. Idaho Museum of Natural History, (1999), 143-168.

Hull, C.D., Reed, M.H., and Fisher, K.: Chemical geothermometry and numerical unmixing of the diluted geothermal waters of the San Bernardino Valley Region of Southern California. GRC Transactions, 11, (1987), 165-184.

Mabey, D.R.: Gravity and aeromagnetic anomalies in the Rexburg area of eastern Idaho. Open-File Report 78-382, U.S. Geological Survey, (1978). 
Neupane et al.

Mann, L.J.: Hydraulic properties of rock units and chemical quality of water for INEL-1: a 10,365-foot deep test hole drilled at the Idaho National Engineering Laboratory, Idaho (No. IDO-22070). Geological Survey, Idaho Falls, ID (USA), Water Resources Div. (1986).

Mattson, E.D., Smith, R.W., Neupane, G., Palmer, C.D., Fujita, Y., McLing, T.L., Reed, D.W., Cooper, D.C., and Thompson, V.S.: Improved geothermometry through multivariate reaction-path modeling and evaluation of geomicrobiological influences on geochemical temperature indicators: final report (No. INL/EXT-14-33959). Idaho National Laboratory (INL), (2015).

McLing, T.L., Smith, R.W., and Johnson, T.M.: Chemical characteristics of thermal water beneath the eastern Snake River Plain. In: Geology, Hydrogeology, and Environmental Remediation: Idaho National Engineering and Environmental Laboratory, Eastern Snake River Plain, Idaho, P.K. Link and L.L. Mink, eds. Geological Society of America Special Paper 353, (2002), $205-211$.

McLing, T., McCurry, M., Cannon, C., Neupane, G., Wood, T., Podgorney, R., Welhan, J., Mines, G., Mattson, E., Wood, R., Palmer, C. and Smith, R.: David Blackwell's Forty Years in the Idaho Desert, The Foundation for 21st Century Geothermal Research; Geothermal Resources Council Transactions,38, (2014), 143-153.

Michard, G. and Roekens, E.: Modelling of the chemical components of alkaline hot waters. Geothermics, 12, (1983), $161-169$.

Mitchell, J.C., Johnson, L.L, and Anderson, J.E.: Geothermal Investigations in Idaho - Part 9: Potential for direct heat applications of geothermal resources. Idaho Department of Water Resources, Water Information Bulletin 30, (1980).

Morgan, L.A. and McIntosh, W.C.: Timing and development of the Heise volcanic field, Snake River Plain, Idaho, western USA. GSA Bulletin, 117, (2005), 288-306.

Neupane, G., Smith, R. W., Palmer, C. D., and McLing, T. L.: Multicomponent equilibrium geothermometry applied to the Raft River geothermal area, Idaho: preliminary results. In GSA Abstracts with Programs, 45 (7), (2013) 0).

Neupane, G., Mattson, E.D., McLing, T.L., Palmer, C.D., Smith, R.W., and Wood, T.R.: Deep geothermal reservoir temperatures in the Eastern Snake River Plain, Idaho using multicomponent geothermometry. Proceedings, Thirty-Ninth Workshop on Geothermal Reservoir Engineering, Stanford University, Stanford, California, February 24-26, 2014 SGP-TR-202 (2014).

Neupane, G., Mattson, E.D., McLing, T.L., Palmer, C.D., Smith, R.W., Wood, T.R., and Podgorney, R.K.: Geothermal reservoir temperatures in southeastern Idaho using multicomponent geothermometry. Proceedings, World Geothermal Congress 2015, Melbourne, Australia, 19-25 April 2015 (2015a).

Neupane, G., Baum, J.S., Mattson, E.D., Mines, G.L., Palmer, C.D., and Smith, R.W.: Validation of multicomponent equilibrium geothermometry at four geothermal power plants. Proceedings, Fortieth Workshop on Geothermal Reservoir Engineering Stanford University, Stanford, California, January 26-28, 2015 (2015b).

Neupane, G., Mattson, E.D., Mines, G.L., McLing, T.L., Dobson, P.F., Conrad, M.E., Wood, T.R., Cannon, C., Worthing, W.: Geothermometric temperature comparison of hot springs and wells in southern Idaho. GRC Transactions, 39, 495-502 (2015c).

Neupane, G., Mattson, E.D., McLing, T.L., Palmer, C.D., Smith, R.W., Wood, T.R., and Podgorney, R.K.: Geothermometric evaluation of geothermal resources in southeastern Idaho. Geoth. Energ. Sci., 4(1), (2016a), 11-22.

Neupane, G., Mattson, E.D., Cannon, J.C., Atkinson, T.A., McLing, T.L., Wood, T.R., Worthing, W.C., Dobson, P.F., and Conrad, M.E.: Potential hydrothermal resource areas and their reservoir temperatures in the Eastern Snake River Plain, Idaho. Proceedings, 41st Workshop on Geothermal Reservoir Engineering, Stanford University, Stanford, California, February 22-24, 2016 SGP-TR209 (2016b).

Palandri, J.L. and Reed, M.H. (2001). Reconstruction of in situ composition of sedimentary formation waters. Geochim. Cosmochim. Acta, 65, 1741-1767.

Palmer, C.D., Ohly, S.R., Smith, R.W., Neupane, G., McLing, T., Mattson, E.: Mineral selection for multicomponent equilibrium geothermometry. GRC Transactions, 38, (2014), 453-459.

Pang, Z.H. and Reed, M.: Theoretical chemical thermometry on geothermal waters: Problems and methods. Geochim. Cosmochim. Acta, 62, (1998), 1083-1091.

Peiffer, L., Wanner, C., Spycher, N., Sonnenthal, E., Kennedy, B.M., Iovenitti, J.: Optimized multicomponent vs. classical geothermometry: insights from mod-eling studies at the Dixie Valley geothermal area. Geothermics, 51, (2014), $154-169$.

Pierce, K. L., and Morgan, L. A.: The track of the Yellowstone hot spot: Volcanism, faulting, and uplift. Geological Society of America Memoirs, 179, (192), 1-54.

Prostka, H.J. and Embree, G.F.: Geology and geothermal resources of the Rexburg area, eastern Idaho. Open-File Report 78-1009, U.S. Geological Survey, (1978).

Reed, M. and Spycher, N.: Calculation of $\mathrm{pH}$ and mineral equilibria in hydrothermal waters with application to geothermometry and studies of boiling and dilution. Geochim. Cosmochim. Acta, 48, (1984), 1479-1492.

Smith, R.W., Palmer, C.D., and Cooper, D.: Approaches for multicomponent equilibrium geothermometry as a tool for geothermal resource exploration. Abstracts, AGU Fall Meeting, San Francisco, 3-7 December 2012. 
Spycher, N.F., Sonnenthal, E., and Kennedy, B.M.: Integrating multicomponent chemical geothermometry with parameter estimation computations for geothermal exploration. GRC Transactions, 35, (2011), 663-666.

Spycher, N., Peiffer, L., Sonnenthal, E. L., Saldi, G., Reed, M. H., and Kennedy, B. M.: Integrated multicomponent solute geothermometry. Geothermics, 51, (2014), 113-123.

Tole, M.P., Ármannsson, H., Pang, Z.H., \& Arnórsson, S.: Fluid/mineral equilibrium calculations for geothermal fluids and chemical geothermometry. Geothermics, 22, (1993), 17-37.

Welhan, J.A.: Thermal and Trace-Element Anomalies in the Eastern Snake River Plain aquifer: toward a conceptual model of the EGS resource. GRC Transactions, 39, (2015), 363-375.

Whitehead, R.L.: Geohydrologic framework of the Snake River Plain regional aquifer system, Idaho and eastern Oregon. Regional aquifer system analysis-Snake River Plain, Idaho. US Geological Survey Professional Paper 1408-B, (1992). 


\section{Appendix I.}

Conrad, M.E., Dobson, P.F., Sonnenthal, E.L., Kennedy, B.M., Cannon, C., Worthing, W., Wood, T., Neupane, G., Mattson E., and McLing, T., 2016. Application of isotopic approaches for identifying hidden geothermal systems in southern Idaho. Proceedings, 41st Workshop on Geothermal Reservoir Engineering, Stanford University, Stanford, CA. 


\title{
Application of Isotopic Approaches for Identifying Hidden Geothermal Systems in Southern Idaho
}

\author{
Mark E. Conrad ${ }^{1}$, Patrick F. Dobson ${ }^{1}$, Eric L. Sonnenthal ${ }^{1}$, B. Mack Kennedy ${ }^{1}$, Cody Cannon ${ }^{2}$, Wade Worthing ${ }^{2}$, Thomas \\ Wood $^{2}$, Ghanashyam Neupane ${ }^{3}$, Earl Mattson ${ }^{3}$ and Travis McLing ${ }^{3}$ \\ ${ }^{1}$ Earth and Environmental Sciences Area, Lawrence Berkeley National Laboratory, Berkeley, CA \\ ${ }^{2}$ University of Idaho - Idaho Falls, ID \\ ${ }^{3}$ Idaho National Laboratory, Idaho Fall, ID \\ Corresponding author: msconrad@lbl.gov
}

Keywords: Isotopes, geothermometry, Snake River Plain, high-temperature water-rock interaction

\begin{abstract}
Southern Idaho is an area of high heat flow with significant potential geothermal resources. However, shallow cold groundwater effectively masks thermal signatures of deep-seated geothermal systems in the area. In order to attempt to see through the shallow groundwater, we are applying a combination of geochemical and isotopic tools relying on dissolved gas and chemical species that have low concentrations in the dilute groundwater to prospect for high-temperature systems in the deep subsurface. For the first phase of the project, our efforts were focused in and around the eastern Snake River Plain (ESRP). We have collected and analyzed the isotopic compositions of more than 40 samples from thermal springs and wells from the region. Of potential isotope geothermometers, the sulfate-water oxygen isotope geothermometer has given the most promising results, yielding calculated temperatures similar to multicomponent chemical geothermometers. Other isotopic tools that have proven useful are shifts in the isotopic compositions $(\delta \mathrm{D}$ and $\delta^{18} \mathrm{O}$ ) of groundwater away from the local meteoric water line indicating high-temperature interaction with reservoir rocks or mixing with a magmatically derived fluid. In addition, the $\delta \mathrm{D}$ and $\delta^{13} \mathrm{C}$ of dissolved methane in several of the samples indicate that the methane formed in a high temperature magmatic system. Taken together with the analyses of multi-component chemical geothermometry and a separate study of the ${ }^{3} \mathrm{He} /{ }^{4} \mathrm{He}$ from the same features, the results have identified two promising areas warranting more concentrated study in the Twin Falls area and the Camas Prairie region between the ESRP and the Idaho batholith.
\end{abstract}

\section{INTRODUCTION}

The western United States has been identified as an area with high potential for geothermal development (Blackwell et al., 2011) and the eastern Snake River Plain (ESRP) in southern Idaho is one of the most promising regions. The ESRP extends from the Twin Falls area in south-central Idaho northeast to the Yellowstone area (Figure 1). The geology of the ESRP consists of thick deposits of Miocene-Eocene rhyolitic tuff deposits produced from a series of volcanic centers formed by migration of the Yellowstone hotspot to its current location (Pierce and Morgan, 1992; Hughes et al., 1999). The rhyolitic rocks are overlain by Quaternary basalt flows generated from northwest trending volcanic rifts formed from extensional activity following passage of the Yellowstone hotspot (Hughes et al., 1999). The basalt flows and accompanying sedimentary interbeds can reach thicknesses of greater than $1 \mathrm{~km}$. These highly permeable rocks host a major aquifer carrying run-off water from the mountainous regions surrounding the ESRP (Whitehead, 1992).

The high heat flux in the ESRP $\left(\sim 110 \mathrm{~mW} / \mathrm{m}^{2}\right.$; Smith, 2004) and abundant hot springs along the margins of the plain suggest that there should be significant, exploitable geothermal reserves in the area. The deep rhyolitic rocks are the likely host rocks for the geothermal reservoir, with the high heat flow resulting from underlying young basaltic sill intrusions (e.g., Nielson and Shervais, 2014; Welhan, 2015; Shervais et al., 2015), but the high-volume, rapidly flowing shallow aquifer in the overlying basalts makes it difficult to use heat flow measurements to pinpoint areas of high potential. Most water from shallow wells and springs in the ESRP are mixed waters of multiple sources, dominated by meteoric water that may mask or significantly attenuate the thermal signal of any deep geothermal waters (McLing et al., 2002; Welhan, 2015). However, due to the dilute nature of the meteoric water, some of the chemical signatures of the high temperature systems may persist.

We are conducting this study to test the hypothesis that geochemical signatures of deep geothermal activity can be used to "see through" the shallow aquifer in the ESRP. Results of related efforts to compare the results of traditional chemical geothermometry to temperatures calculated using RTEst (Palmer et al., 2014), an advanced multi-component equilibrium geothermometer, are presented elsewhere (Neupane et al., 2016). Briefly, where traditional geothermometry does not account for physical relationships (e.g., boiling, mixing) or chemical equilibrium with complex mineral assemblages typical of real rock systems, RTEst does account for these parameters. In addition, the results of a survey of helium isotope ratios in the samples collected for this project are presented in a previous paper (Dobson et al., 2015). In this paper, the results of isotopic analyses of water $\left(\delta \mathrm{D}\right.$ and $\left.\delta^{18} \mathrm{O}\right)$, dissolved inorganic carbon $\left(\delta^{13} \mathrm{C}\right)$, sulfate $\left(\delta^{34} \mathrm{~S}\right.$ and $\left.\delta^{18} \mathrm{O}\right)$ and dissolved methane $\left(\delta \mathrm{D}\right.$ and $\left.\delta^{13} \mathrm{C}\right)$ are presented and discussed. The locations of samples collected for this project along with those of previous sampling efforts are plotted on Figure 1 below. 


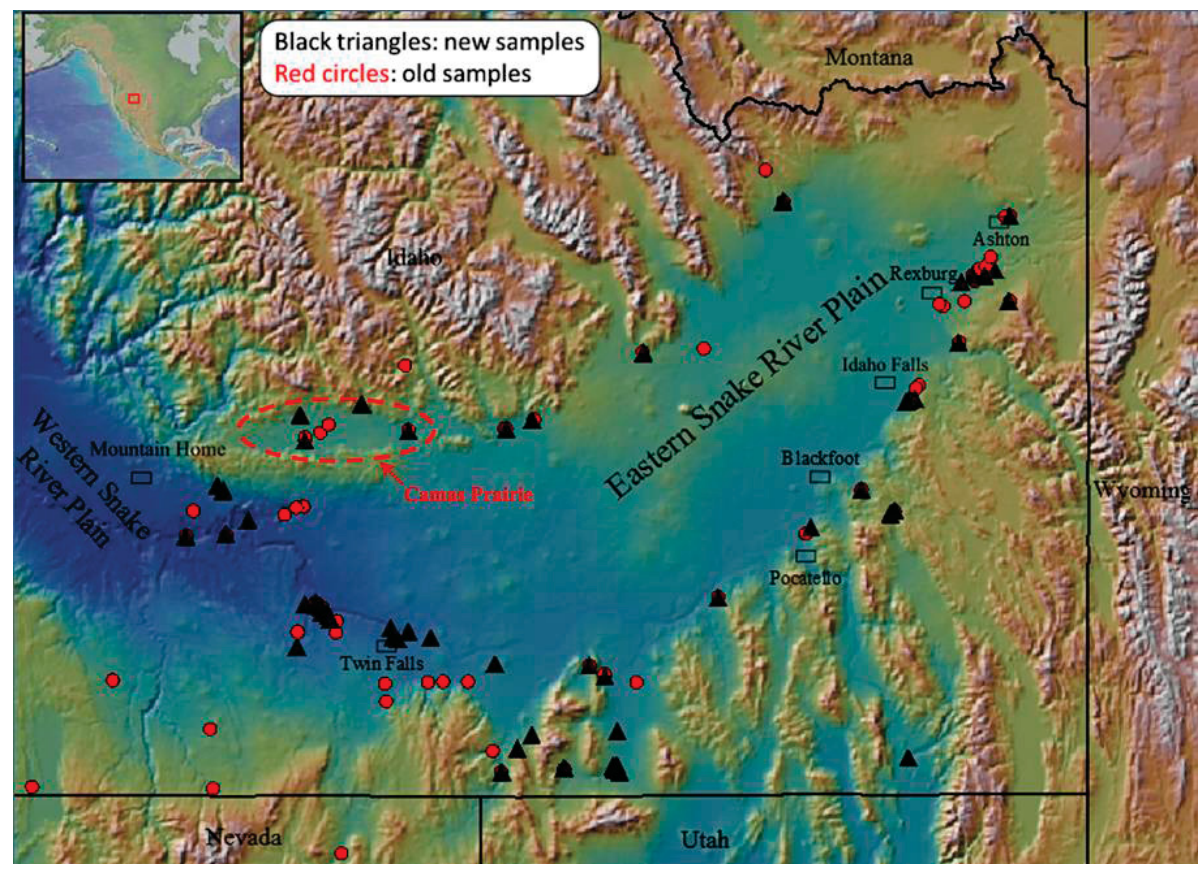

Figure 1: Map of southeastern Idaho showing the Eastern Snake River Plain and the locations of prior geothermal samples plus those collected and analyzed for this project. Note the Camas Prairie area highlighted on the map.

\section{FIELD AND LABORATORY METHODS}

\subsection{Sampling Methods}

Samples for this investigation were collected from both groundwater thermal wells and hot springs. Samples from groundwater wells were collected as near the outlet as possible following purging of at least 3 times the volume of water in the well casing. Spring samples were taken as close to the outlet as possible, determined by the hottest point within the features. At each sampling site, 3 types of samples were collected. For $\delta \mathrm{D}$ and $\delta^{18} \mathrm{O}$ of water and $\delta^{13} \mathrm{C}$ of total dissolved inorganic carbon (DIC), a sample of water was collected directly into a $60 \mathrm{ml}$ syringe rinsed once with water from the source. The sample was then passed through a $0.2 \mu \mathrm{m}$ filter and injected into a $40 \mathrm{ml}$ amber vial filled to the top and immediately capped. The sample was then stored at $4{ }^{\circ} \mathrm{C}$ until it could be analyzed. For analyses of the $\delta^{34} \mathrm{~S}$ and $\delta^{18} \mathrm{O}$ of dissolved sulfate, a $40 \mathrm{ml}$ centrifuge tube was filled with water and $\mathrm{HCl}$ added to drop the $\mathrm{pH}$ down to $\sim 2$ to preserve the sample and drive off any dissolved inorganic carbon in the sample. For dissolved gas samples, filtered water was injected into 60 or $160 \mathrm{ml}$ evacuated vials capped with thick, blue butyl rubber stoppers until the bottle was filled. The sample was stored at $4{ }^{\circ} \mathrm{C}$ until it could be analyzed.

\subsection{Isotope Analyses}

\subsubsection{Water Isotope Measurements}

The hydrogen and oxygen isotopic compositions of the water samples were analyzed separately at the Center for Stable Isotope Biogeochemistry (CSIB) at the University of California, Berkeley. $\delta \mathrm{D}$ values of water are analyzed using a hot chromium reactor unit $\left(\mathrm{H} /\right.$ Device $\left.^{\mathrm{TM}}\right)$ interfaced with a Thermo Delta Plus XL mass spectrometer. The $\delta^{\mathbf{1 8}} \mathrm{O}$ in water is analyzed by continuous flow using a Thermo Gas Bench II interfaced to a Thermo Delta Plus XL mass spectrometer. The precision of these analyses determined by repeated analysis of internal standards is $\pm 0.8 \%$ o $(1 \sigma)$ for $\delta \mathrm{D}$ and $\pm 0.12 \%$ o $(1 \sigma)$ for $\delta^{18} \mathrm{O}$. Results are presented relative to V-SMOW.

\subsubsection{Dissolved Sulfate Isotope Analyses}

Following delivery of the acidified samples in the lab, $\sim 1 \mathrm{ml}$ of $1 \mathrm{~N} \mathrm{BaCl}_{2}$ solution was added to each sample resulting in the precipitation of $\mathrm{BaSO}_{4}$. After waiting $>1$ day for the precipitates to settle, the supernatant solution is decanted off and de-ionized water added to container and the sample re-suspended. The resulting sample is then centrifuged, the supernatant removed and the sample dried for $>1$ day. The sulfur and oxygen isotopic composition of the $\mathrm{BaSO}_{4}$ is then analyzed. The sulfur isotope compositions of the samples were analyzed at the Center for Isotope Geochemistry (CIG) at Lawrence Berkeley National Laboratory by combustion in a Costech Elemental Analyzer with the $\delta^{34} \mathrm{~S}$ values of the resulting $\mathrm{SO}_{2}$ analyzed on a Thermo Delta V Plus mass spectrometer. The precision of those measurements is $\pm 0.2 \%$ o $(1 \sigma)$. The $\delta^{18} \mathrm{O}$ values of the $\mathrm{BaSO}_{4}$ precipitates were analyzed at CSIB using an Elementar PYRO Cube interfaced to a Thermo Delta V mass spectrometer. The precision of those measurements is $\pm 0.5 \%$ o $(1 \sigma)$. Sulfur isotope analyses of $\mathrm{H}_{2} \mathrm{~S}$ in the samples were also attempted, but the concentrations in the samples were too low.

\subsubsection{Dissolved Inorganic Carbon (DIC) Isotope Analyses}

The DIC in the samples were analyzed by addition of 0.1 to $1.0 \mathrm{ml}$ of sample to a He-purged vial containing $1 \mathrm{ml}^{\circ} 70 \% \mathrm{H}_{3} \mathrm{PO}_{4}$. The $\delta^{13} \mathrm{C}$ values of the resulting $\mathrm{CO}_{2}$ were then analyzed by injection into a Micromass Trace Gas pre-concentration system interfaced to a 
Micromass JA series isotope ratio mass spectrometer at CIG. The precision of those measurements is $\pm 0.3 \%$ ( $1 \sigma)$. Concentrations of DIC in the samples were also determined from these analyses by comparison with standards of known concentrations. These measurements are good to approximately $\pm 10 \%$ of the measured value $(1 \sigma)$.

\subsubsection{Dissolved Methane Isotopic Analyses}

The dissolved gas samples were prepared for analysis by creating a headspace in the sample followed by addition of He gas to the headspace. For isotopic analyses, samples of the headspace gas were flushed through a sample loop on a 6-port Valco Vici valve and then injected into the column of a Thermo Trace Gas Ultra connected to the Delta V Plus mass spectrometer. For $\delta^{13} \mathrm{C}$ analyses, the methane was separated chromatographically, and combusted to $\mathrm{CO}_{2}$, which was then analyzed in the mass spectrometer $(1 \sigma$ precision $=$ $\pm 0.2 \%$ ). $\delta \mathrm{D}$ analyses were done by pyrolysing the $\mathrm{CH}_{4}$ to $\mathrm{H}_{2}$ gas, which was then analyzed in the mass spectrometer $(1 \sigma$ precision $=$ $\pm 5 \%$ ). Concentrations of $\mathrm{CH}_{4}$ in the headspace were calculated by comparing the total peak areas of the samples to those of known standards. Those concentrations were then converted to dissolved concentrations using Henry's law. Hydrogen isotope analyses of $\mathrm{H}_{2}$ in the samples were also attempted, but the concentrations were too low.

\section{RESULTS AND DISCUSSION}

\subsection{Sulfate-Water Oxygen Isotope Geothermometer}

The difference between the oxygen isotopic compositions of sulfate and water can be used to calculate the temperature of formation of the sulfate (McKenzie and Truesdell, 1977; Fowler et al., 2013). There are, however, several secondary factors that can change the isotopic composition of one or the other of these two phases after the sulfate has formed. For sulfate, mixing with another source of sulfate along the pathway to the surface (e.g., gypsum/anhydrite in evaporite beds) can shift the oxygen isotopic composition of the dissolved sulfate. This can sometimes be inferred based on knowledge of the subsurface geology and/or the sulfur isotope composition of the sulfate. Sulfur in igneous/magmatic systems generally has much lower sulfur isotopic composition than sedimentary gypsum. Microbial reduction of sulfate can also shift the isotopic composition of the residual sulfate, but requires highly anaerobic conditions and will also shift the isotopic composition of the sulfur. The oxygen isotopic composition of the sulfate can also re-equilibrate with the water at lower temperatures, but this is a relatively slow process and is likely only an issue where the thermal waters have a long residence time in a shallower, cooler reservoir. For the water, the biggest issue is mixing with another source of water with a different oxygen isotope composition than the reservoir water. In the ESRP, the isotopic compositions of waters are similar between deep reservoirs and the shallow groundwater. The $\delta^{18} \mathrm{O}$ of the water can also be shifted by boiling and/or significant water-rock interaction after formation of the sulfate, but these effects can often be seen by comparison with the hydrogen isotopic composition of the water.

For our temperature calculations, we used the revised sulfate-water oxygen isotope geothermometer formulated by Fowler et al. (2013). To test the applicability of this geothermometer, we collected and analyzed the oxygen isotopic compositions of sulfate and water in fluids injected during a fracture stimulation experiment conducted at the Newberry Volcano in the Oregon Cascades (Cladouhos et al., 2015). About 2.5 million gallons of water were injected under pressure into a subsurface zone at the site and allowed to equilibrate with the rock for 3 weeks. At that point the water was allowed to flow back out of the well and samples were collected for chemical and isotopic analyses. The calculated temperatures using the sulfate-water oxygen isotope geothermometer are plotted on Figure 2 with an average down-hole temperature calculated using GeoT, a multi-component chemical geothermometer (Spycher et al., 2014). The isotope geothermometry values are a bit lower, possibly due to background sulfate, but in general the temperatures appear to be approaching equilibrium for the final samples.

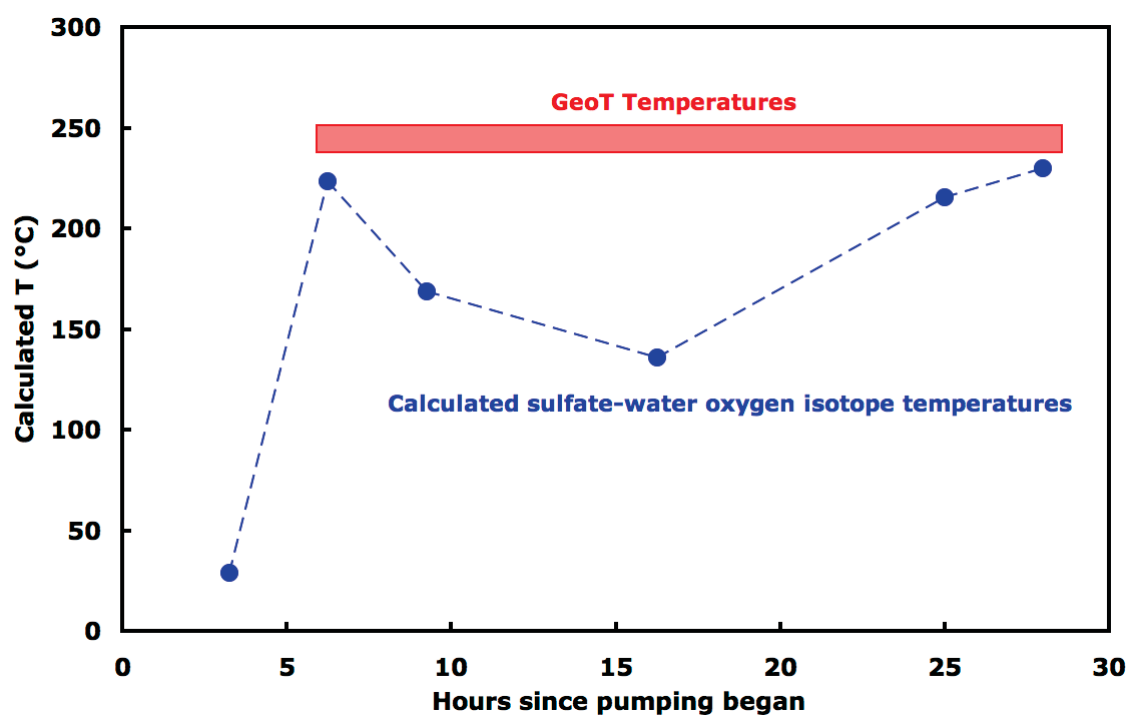

Figure 2: Temperatures calculated for flow-back samples from the Newberry Volcano EGS stimulation test. 


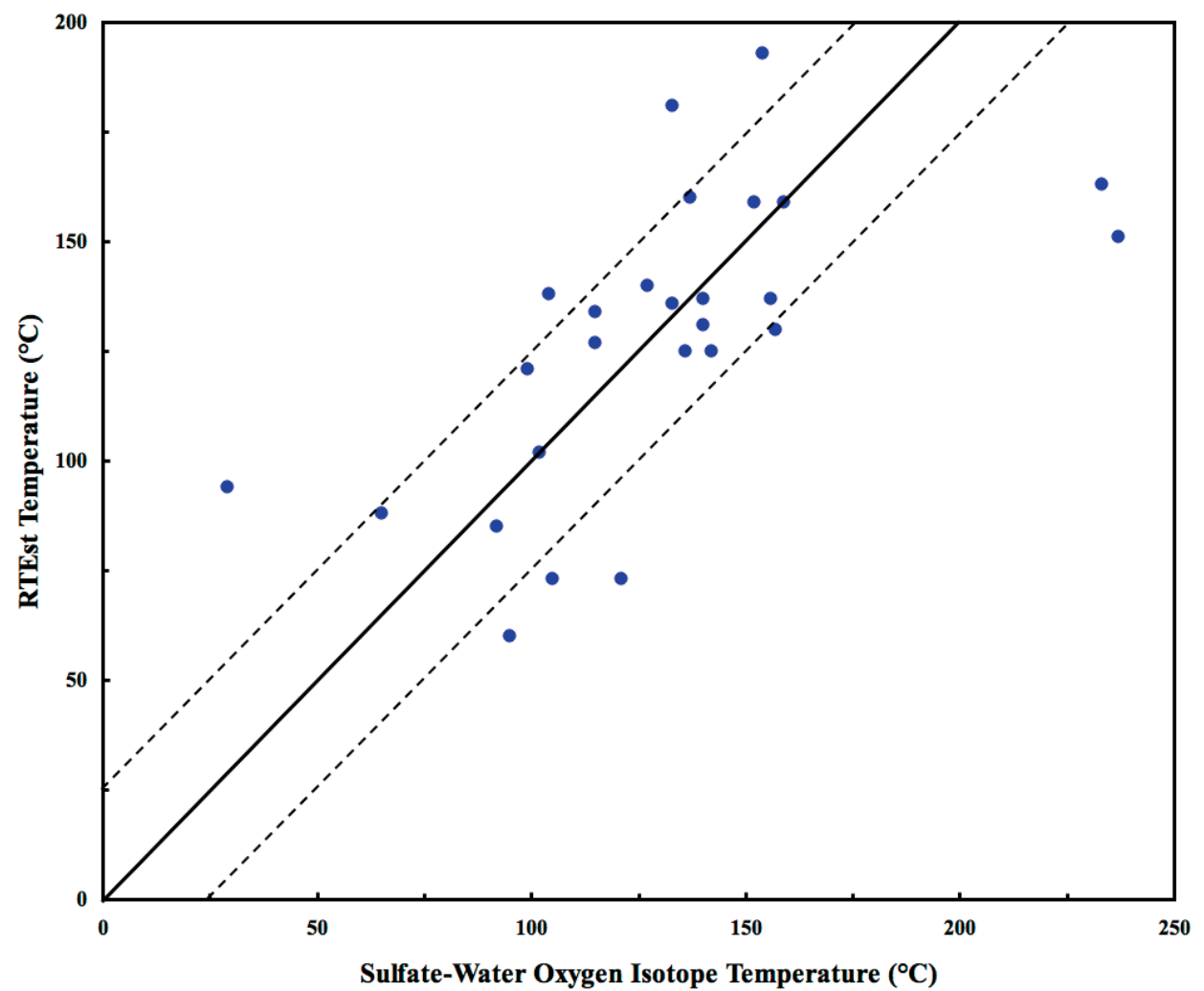

Figure 3: Comparison between temperatures calculated using the sulfate-water oxygen isotope geothermometer versus temperatures calculated using the RTEst. The solid line represents a 1:1 comparison and the dashed lines indicate the range of temperatures within $\pm 25^{\circ} \mathrm{C}$ of each other.

Temperatures calculated using the sulfate-water oxygen isotope geothermometer for samples collected for this project that contained sufficient sulfate for isotopic analyses are given in Table 1. Also included are RTEst temperatures calculated for the same samples. Given all of the uncertainties associated with both techniques, there is a remarkable correlation between the two geothermometers with most being with $\pm 25^{\circ} \mathrm{C}$ of each other (Figure 3). In some cases such as Green Canyon Hot Springs and Heise Hot Springs, the sulfate concentrations were high, likely representing interaction with sedimentary evaporite interbeds in the basalts which would result in low calculated temperatures for the sulfate-water oxygen isotope geothermometer. Otherwise, there are no clear explanations for some of the samples with much higher sulfate-water temperatures, suggesting that they might represent deep, hot geothermal systems.

Results calculated with both geothermometers indicate two areas with widespread high temperature geothermal fluids at depth. Temperatures calculated with the sulfate-water oxygen isotope geothermometer for the Twin Falls region average $137^{\circ} \mathrm{C}$ which is essentially identical to the average temperature calculated with RTEst of $138^{\circ} \mathrm{C}$. These values are higher than those reported by Mariner et al. (1997) $\left(90-106^{\circ} \mathrm{C}\right)$ for the same region using the sulfate-water oxygen isotope geothermometer. Although these temperatures are on the low side, especially for electricity generation, they come from several features spread across a large area, suggesting there may be hotspots within the region that might be suitable for power generation. The Camas Prairie is the other highly encouraging area with sulfate-water temperatures exceeding $200^{\circ} \mathrm{C}$ and RTEst temperatures approaching that level. This area was also identified as a geothermal prospect through geothermal play fairway analysis (Shervais et al., 2015).

\subsection{Water Isotopes and Water-Rock Interaction}

During high-temperature water-rock interaction, the isotopic composition of the water can be shifted to the right of the meteoric water line (Taylor, 1974). The change in the isotopic composition of the water is mostly limited to the oxygen isotopic composition of the water due to the fact that most igneous/volcanic rocks contain very little hydrogen compared to water but have significant oxygen. Mixing with water derived from cooling, degassing magmas can also produce a similar effect (Giggenbach, 1992). Boiling/evaporation will also shift the residual water off the meteoric water line, but these changes will also significantly affect the hydrogen isotopic compositions of the water. It is important to note that mixing with shallower, non-thermal waters can dilute these signals.

The water isotope compositions of the samples collected for this project are plotted on Figure 4. Most of the samples plot close to the meteoric water line (precipitation in this region tends to be slightly offset to the right of the global meteoric water line), but there are several samples that have oxygen isotope composition shifted 1-3\%o to the right of the meteoric water line. Four of these samples collected from three locations are from the Camas Prairie region and are some of those with anomalously high temperatures calculated with the sulfate-water oxygen isotope geothermometer. A water sample associated with a flow zone at $1745 \mathrm{~m}$ depth collected from the $\mathrm{MH}-2$ well (which encountered temperatures of $150^{\circ} \mathrm{C}$; Nielson and Shervais, 2014) also exhibited a similar shift in its oxygen isotope composition (Freeman, 2013) 


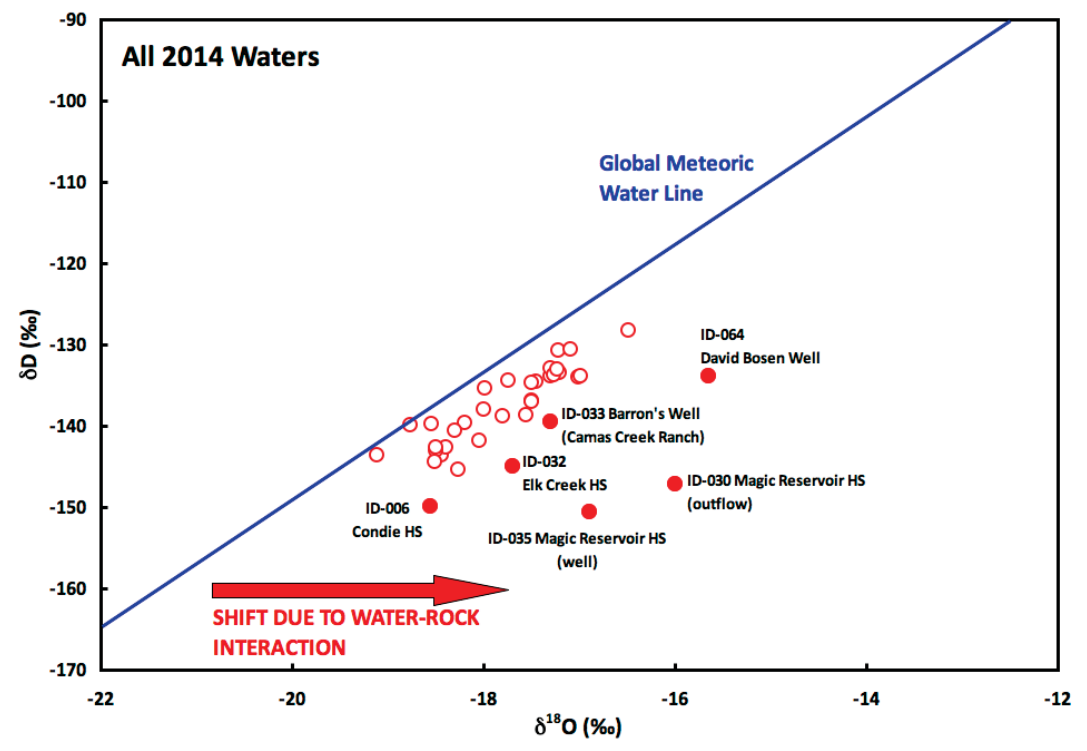

Figure 4: Hydrogen and oxygen isotopic compositions of water from ESRP samples with the global meteoric water line for comparison. Most waters fall very close to the meteoric water line, but there a several that are significantly shifted to the right of the meteoric water line, which is an indication of oxygen isotope exchange during high-temperature water-rock interaction in hydrothermal systems or mixing with magmatically-derived fluids.

\subsection{Methane Isotope Signatures of High-Temperature Sources}

The carbon and hydrogen isotopic compositions of $\mathrm{CH}_{4}$ can offer clues as to the mechanism of formation and its post-formation history. Figure 5 is modified from Whiticar et al. (1986) and outlines the primary field of methane formed under thermogenic conditions in hydrocarbon reservoirs and the two primary microbial mechanisms for low-temperature methanogenesis (acetoclastic versus $\mathrm{CO}_{2}$ reduction). Also shown on this plot is the general field of methane formed abiotically in high-temperature magmatic or hydrothermal systems outlined by Welhan et al. (1988). It is also important to note that the isotopic compositions of the methane can be significantly altered by microbial oxidation in aerobic groundwater.

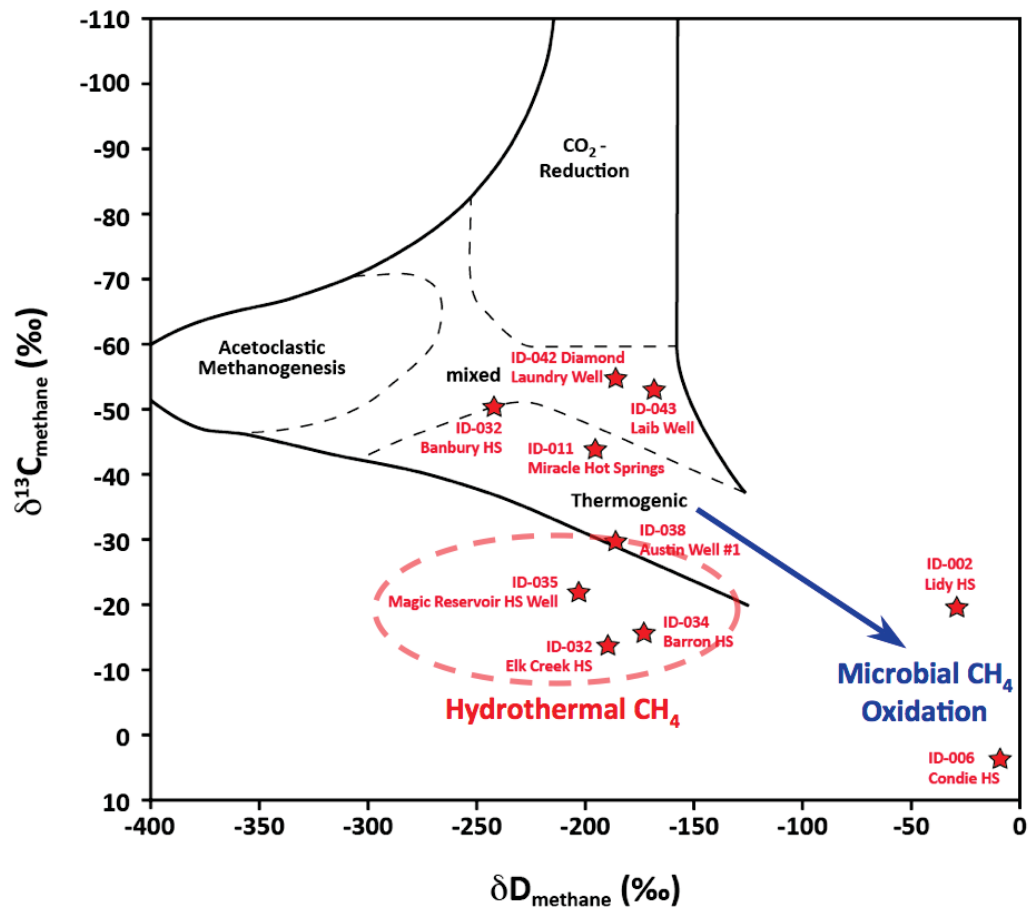

modified from Whiticar et al. (1986)

Figure 5: Carbon and hydrogen isotopic compositions of dissolved methane in samples collected from the ESRP plotted with the ranges of values expected for methane formed by different mechanisms. Most notable are the samples outlined by the red dashed line (all from the Camas Prairie) with isotopic compositions typical of methane formed in hightemperature hydrothermal systems. 
The isotopic compositions of samples for which we were able to analyze both the hydrogen and carbon isotopes of $\mathrm{CH}_{4}$ are plotted on Figure 5. Of this group, there are a couple of samples (Condie Hot Springs and Lidy Hot Springs) that have clearly undergone significant methane oxidation. This is not surprising since both sampling points were from open-air pools of water. The most interesting thing about these samples is that despite significant oxidation, there were still high enough concentrations of methane remaining for isotopic measurements. There are also a number of samples in the thermogenic/mixed origin areas of the plot. These are all from the Twin Falls area and could have been formed from thermal degradation of organic matter in the subsurface. Most interestingly, the remaining 3 samples plot in the field of high temperature hydrothermal methane. These samples are the same three from the Camas Prairie area with the water with the strongly shifted oxygen isotope composition and also have high sulfate-water oxygen isotope temperatures.

\section{CONCLUSIONS}

The results of study demonstrate the value of isotopic data for identifying areas with high potential for geothermal exploitation, especially when combined with other tools such as multi-component chemical geothermometers. Through this work, we have identified two very promising areas for further study.

1. Numerous intermediate temperature geothermal springs and wells characterize the Twin Falls region. These thermal features yield calculated temperatures in the range of $140 \pm 20^{\circ} \mathrm{C}$ across a wide area and may be indicating the existence of higher temperature hotspots in the region. In addition, helium isotope data collected from some of the same thermal springs and wells (Dobson et al., 2015) indicate the presence of mantle helium that may be related to recent basaltic intrusions that may be providing the heat driving the geothermal activity in the area.

2. Both RTEst and the sulfate-water isotope geothermometer indicate temperatures into the $200^{\circ} \mathrm{C}$ range at several thermal features in the Camas Prairie. Further, shifts in the isotopic compositions of the thermal waters indicating high-temperature water-rock interaction or mixing with magmatically-derived fluids may be occurring at depth and isotopic signatures of hydrothermal methane also point to significant geothermal resources in the area. Finally, several of these features also had elevated ${ }^{3} \mathrm{He} /{ }^{4} \mathrm{He}$ values indicating the potential presence of a mantle-derived heat source.

\section{ACKNOWLEDGMENTS}

This work was conducted with funding from the Assistant Secretary for Energy Efficiency and Renewable Energy, Geothermal Technologies Program, of the U.S. Department under the U.S. Department of Energy Contract Nos. DE-AC02-05CH11231 with Lawrence Berkeley National Laboratory and DE-AC07-05ID14517 with Idaho National Laboratory. 


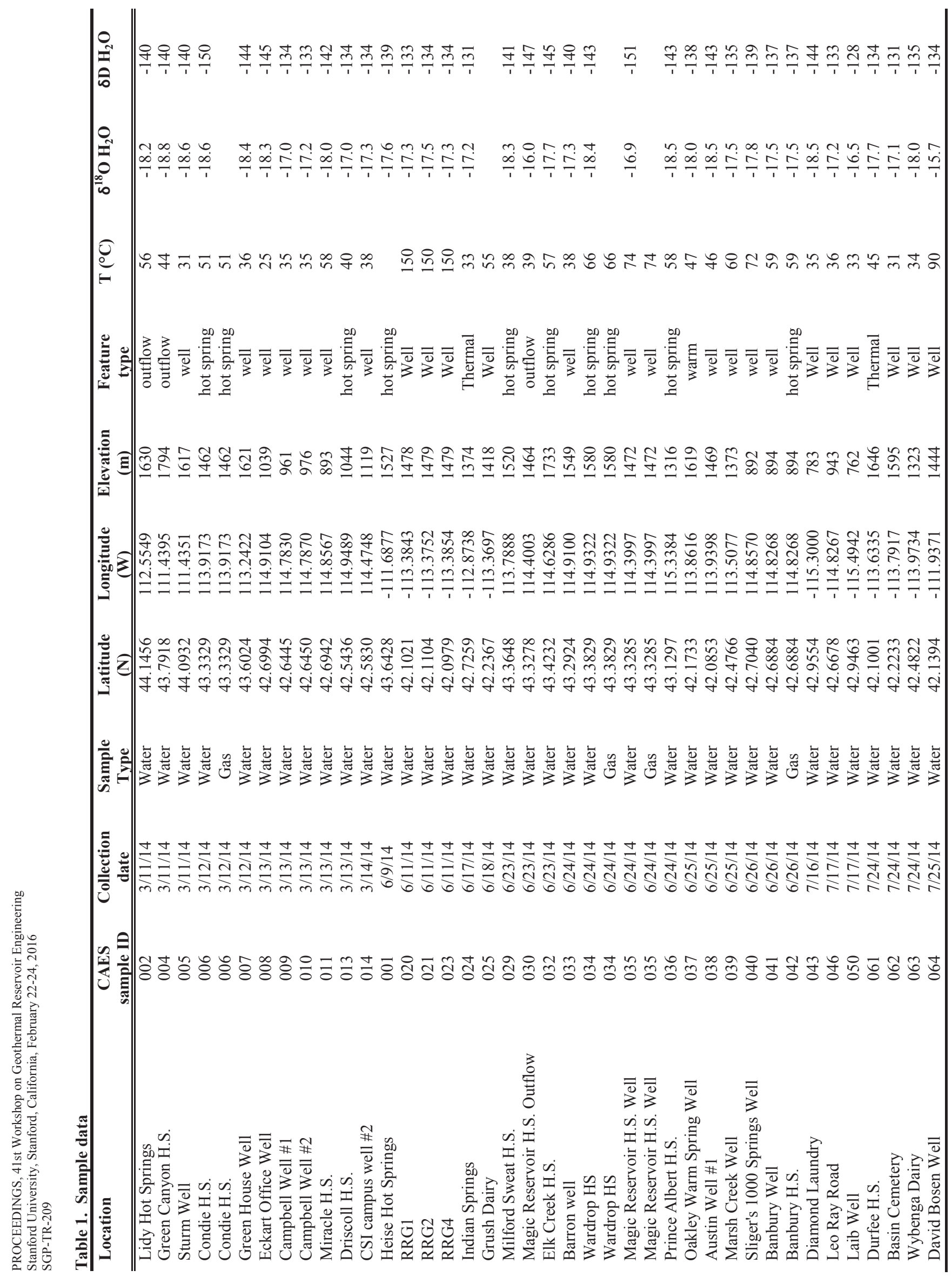




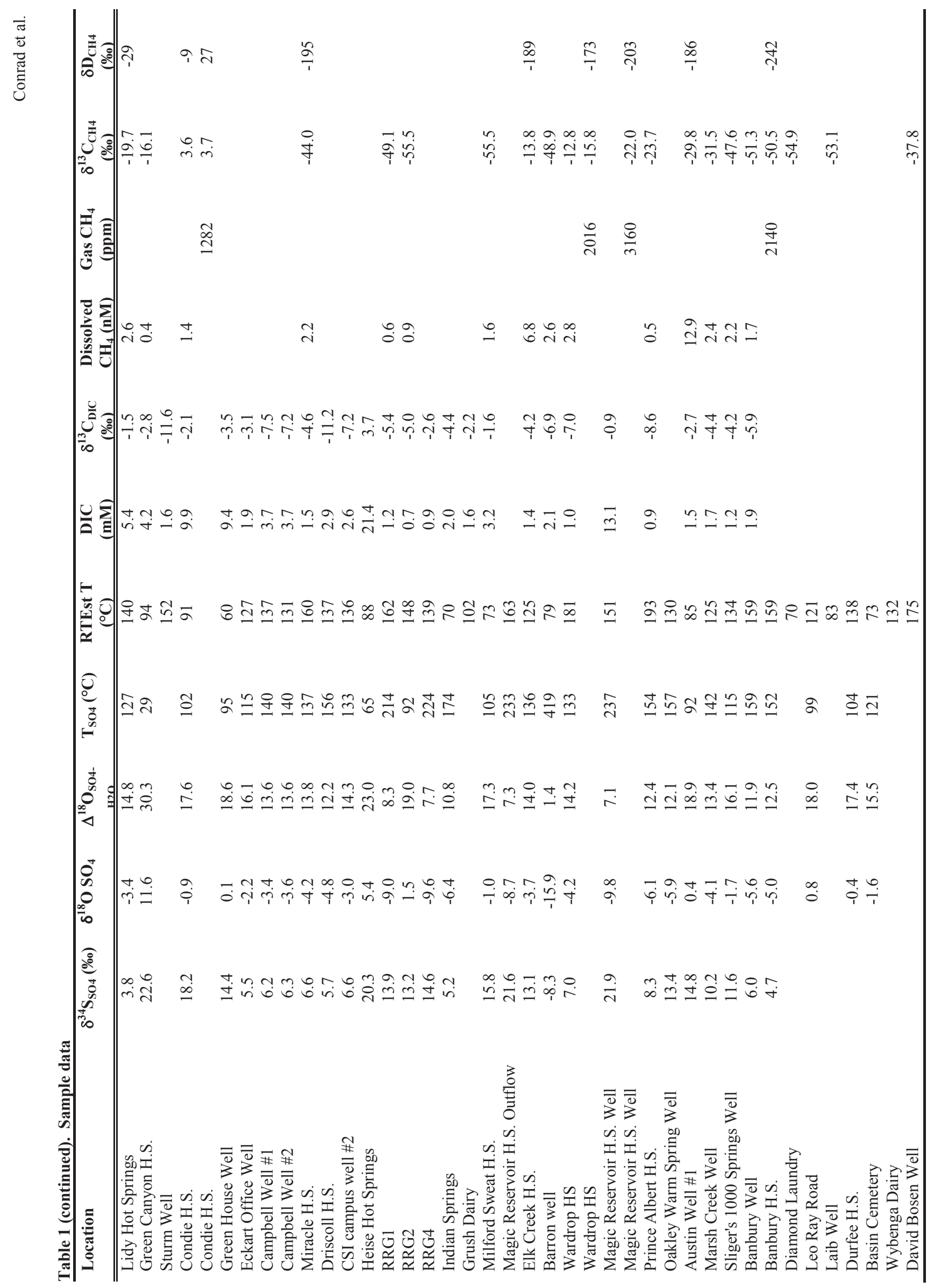




\section{REFERENCES}

Blackwell, D.D., M.C. Richards, Z.S. Frone, J.F. Batir, M.A. Williams, A.A. Ruzo, R.K Dingwall (2011), SMU Geothermal Laboratory Heat Flow Map of the Conterminous United States, 2011: Available at http:/www.smu.edu/geothermal.

Cladouhos, T.T., Petty, S., Swyer, M.W., Uddenberg, M.E., Grasso, K., and Nordin, Y.: Results from Newberry Volcano EGS Demonstration, 2010-2014. Geothermics (2015), http://dx.doi.org/10.1016/j.geothermics.2015.08.009.

Dobson, P.F., B.M. Kennedy, M.E. Conrad, T. McLing, E. Mattson, T. Wood, C. Cannon, R. Spackman, M. van Soest and M. Robertson (2015) He Isotopic Evidence for Undiscovered Geothermal Systems in the Snake River Plain, Proceedings, Fortieth Workshop on Geothermal Reservoir Engineering, Stanford University, Stanford, California, January 26-28, 2015.

Freeman, T.G. (2013) Evaluation of the geothermal potential of the Snake River Plain, Idaho, based on three exploration holes. MS thesis, Utah State University, $90 \mathrm{p}$.

Fowler, A.P.G, L.B. Hackett, C.W. Klein (2013) Reformulation and performance evaluation of the sulfate-water oxygen isotope geothermometer: CRC Transactions 37, 393-401.

Giggenbach, W.F. (1992) Isotopic shifts in waters from geothermal and volcanic systems along convergent plate boundaries and their origins. Earth and Planetary Science Letters 113, 495-510.

Hughes, S.S., Smith, R.P., Hackett, W.R., and Anderson, S. R.: Mafic volcanism and environmental geology of the eastern Snake River Plain. Idaho Guidebook to the Geology of Eastern Idaho. Idaho Museum of Natural History, (1999), 143-168.

Mariner, R.H., Young, H.W., Bullen, T.D., and Janik, C.J.: Sulfate-water isotope geothermometry and lead isotope data for the regional geothermal system in the Twin Falls area, south-central Idaho. Geothermal Resources Council Transactions 21, (1997), $197-201$.

McLing, T.L., Smith, R.W., and Johnson, T.M.: Chemical characteristics of thermal water beneath the eastern Snake River Plain. In: Geology, Hydrogeology, and Environmental Remediation: Idaho National Engineering and Environmental Laboratory, Eastern Snake River Plain, Idaho, P.K. Link and L.L. Mink, eds. Geological Society of America Special Paper 353, (2002), $205-211$.

McKenzie, W.F., and Truesdell, A.H.: Geothermal reservoir temperatures estimated from the oxygen isotope compositions of dissolved sulfate and water from hot springs and shallow drillholes. Geothermics 5, 51-61.

Neupane, G., Mattson, E.D., Cannon, J.C., Atkinson, T.A., McLing, T.L., Wood, T.R., Dobson, P.F., and Conrad, M.E.: Potential hydrothermal resource areas and their reservoir temperatures in the Eastern Snake River Plain, Idaho. Proceedings, 41st Workshop on Geothermal Reservoir Engineering, Stanford University, Stanford, California, February 22-24, 2016 SGP-TR-209 (2016).

Nielson, D.L., and Shervais, J.W. (2014) Conceptual model for Snake River Plain geothermal systems, Proceedings, $39^{\text {th }}$ Workshop on Geothermal Reservoir Engineering, Stanford University, Stanford, CA, SGP-TR-202.

Palmer, C.D., Ohly, S.R., Smith, R.W., Neupane, G., McLing, T., Mattson, E.: Mineral selection for multicomponent equilibrium geothermometry. GRC Transactions, 38, (2014), 453-459.

Pierce, K. L., and Morgan, L. A.: The track of the Yellowstone hot spot: Volcanism, faulting, and uplift. Geological Society of America Memoirs, 179, (192), 1-54.

Shervais, J.W., Glen, J.M., Liberty, L.M., Dobson, P., Gasperikova, E., Sonnenthal, E., Visser, C., Nielson, D., Garg, S., Evans, J.P., Siler, D., DeAngelo, J., Athens, N., and Burns, E. (2015) Snake River Plain Play Fairway Analysis - Phase I report. Geothermal Resources Council Transactions 39, 761-769.

Smith, R.P.: Geologic setting of the Snake River Plain aquifer and vadose zone. Vadose Zone Journal, 3, (2004), 47-58.

Spycher, N., Peiffer, L., Saldi, G., Sonnenthal, E., Reed, M.H., and Kennedy, B.M. (2014) Integrated multicomponent solute geothermometry. Geothermics 51, 113-123.

Taylor, H.P. (1974) Application of oxygen and hydrogen isotope studies to problems of hydrothermal alteration and ore deposition. Econ. Geol. 69, 843-883.

Welhan, J.A. (2015) Thermal and trace-element anomalies in the Eastern Snake River Plain aquifer: Towards a conceptual model of the EGS resource. GRC Transactions 39, 363-376.

Welhan, J.A., R.J. Poreda, W. Rison, H. Craig (1988) Helium isotopes in geothermal and volcanic gases of the western United States: I. Regional variability and magmatic origin: J. Volcanology Geotherm. Res. 34, 185-199.

Whitehead, R.L.: Geohydrologic framework of the Snake River Plain regional aquifer system, Idaho and eastern Oregon. Regional aquifer system analysis-Snake River Plain, Idaho. US Geological Survey Professional Paper 1408-B, (1992).

Whiticar, M.J., E. Faber and M. Schoell (1986) Biogenic methane formation in marine and fresh-water environments $-\mathrm{CO}_{2}$ reduction versus acetate fermentation isotope evidence. Geochim. Cosmochim. Acta 50, 693-709. 


\section{Appendix J.}

Cannon, C.J., 2015. Evidence for mixing and re-equilibration in the Twin Falls Banbury hydrothermal system and its effects on reservoir temperature estimation. MS Thesis, University of Idaho, 184 p. 


\title{
EVIDENCE FOR MIXING AND RE-EQUILIBRATION IN THE TWIN FALLS - BANBURY HYDROTHERMAL SYSTEM AND ITS EFFECTS ON RESERVOIR TEMPERATURE ESTIMATION
}

\author{
A Thesis \\ Presented in Partial Fulfillment of the Requirements for the \\ Degree of Master of Science \\ with a \\ Major in Hydrology \\ in the \\ College of Graduate Studies \\ University of Idaho \\ by \\ Cody J Cannon \\ Major Professor: Thomas R. Wood, Ph.D. \\ Committee Members: Ghanashyam Neupane, Ph.D., Robert W. Smith, Ph.D. \\ Department Administrator: Mickey E. Gunter, Ph.D.
}

November 2015 


\section{AUTHORIZATION TO SUBMIT THESIS}

The thesis of Cody J. Cannon, submitted for the degree of Master of Science with a major in Hydrology and titled, "EVIDENCE OF MIXING AND RE-EQUILIBRATION IN THE TWIN FALLS - BANBURY HYDROTHERMAL SYSTEM AND ITS EFFECTS ON RESERVOIR TEMPERATURE ESTIMATION," has been reviewed in final form.

Permission, as indicated by the signatures and dates given below, is now granted to submit final copies to the College of Graduate Studies for approval.

Major Professor:

Date:

Thomas R. Wood, Ph.D.

Committee Members:

Date:

Ghanashyam Neupane, Ph.D.

Date:

Robert W. Smith, Ph.D.

Department

Administrator:

Date:

Mickey E. Gunter, Ph.D. 


\section{ACKNOWLEDGEMENTS}

I am forever grateful to all the selfless people who made this study possible.

First, I must thank my major professor Dr. Tom Wood of whom I have the utmost respect and admiration. I am immeasurably indebted to him for all of his long hours spent working with me, his invaluable advice, continuous support and reassurance, and for always having his door open to my incessant questions and worries. I have learned countless lessons from him not only pertaining to scientific research but life in general. He is highly regarded as an expert

hydrogeologist throughout the region, a skilled research scientist, and by those lucky enough, a good friend. He is a great man and a consummate professional.

I recognize the unyielding support of Dr. Hari Neupane without whose broad geochemical and geothermal knowledge; none of this work would be possible. He is not only a brilliant mind, but also a very caring person who sacrificed much of his valuable time. The scientific research competence of Dr. Bob Smith has proven vitally important to this study. He has a special knack for seeing beneath the surface of problems and has given me direction when I needed it the most. I am extremely grateful for the guidance provided by Travis McLing, whose expertise as a geologist in the field and in the laboratory have been a source of inspiration for me throughout this process. Dr. Earl Mattson has been a continual source of guidance and support throughout this process and was instrumental in providing focus to an otherwise broad collection of data. I also acknowledge the support and guidance of Dr. Pat Dobson and Dr. Mark Conrad of the Lawrence Berkeley National Laboratory.

Lastly, I must send out a very special thank you to Debbie Lacroix, whose analytical chemistry expertise is responsible for the original data in this study, Dr. Ross Spackman whose study area field expertise and incredible relational skills resulted in the collection of samples in this study, and to Eric Hass of the Department of Energy's Geothermal Technologies Office for funding this project. 


\section{DEDICATION}

This work is dedicated to my incredible wife, Emily Cannon, for her unconditional love, unwavering support, and steadfast belief in me even through the tough times when I don't believe in myself. She is my best friend and the best friend any man could ask for. To my parents, Ellen and Gary Cannon, for believing in me from the beginning, convincing me that nothing is impossible, and teaching me that I am never alone. To my sister, Christi Cannon, for reminding me to never take myself too seriously. Lastly and chiefly, this thesis is dedicated to Jesus Christ in whose mighty company I am blessed to be counted. For making me a new man, His constant companionship, and grace through His selfless finished work, I am and will continue to be eternally grateful.

"He is a man in a way that we have forgotten men can be; truthful, blunt, emotional, nonmanipulative, sensitive, compassionate.”- Brennan Manning 


\begin{abstract}
The Twin Falls - Banbury area is one of many Known Geothermal Resource Areas located along the periphery of the Eastern Snake River Plain (ESRP). The ESRP is a topographical plain, which was formed by the bimodal volcanism of successive caldera formations associated with the migration of the Yellowstone Hot Spot over the last 16 Ma. Despite temperature gradients of 45-60 ${ }^{\circ} \mathrm{C} / \mathrm{km}$ (double the global average) and high heat flow values $\left(110 \mathrm{~mW} / \mathrm{m}^{2}\right)$, geothermal utilization within the ESRP is largely limited to direct use with no commercial geothermal development. A gradational trend between deep rhyolite derived $\mathrm{Na}-\mathrm{K}-\mathrm{HCO}_{3}$ waters of the deep system and basalt hosted $\mathrm{Ca}-\mathrm{Mg}-\mathrm{HCO}_{3}$ thermal water is observed in deep exploration wells. Mixing between the fluids of the deep system and cooler overlying groundwater as well as re-equilibration of thermal fluids during ascension are considered possibilities that may explain this trend and the low geothermometry temperature estimations of the area. The Twin Falls - Banbury area was chosen as the location for an in depth investigation into the possibility of geothermal mixing and re-equilibration as an explanation for the lower than expected geothermometry.

Evidence for mixing is provided by partial equilibration conditions in most thermal samples as well as a variety of linear mixing trends between both conservative chemical species $(\mathrm{Cl}, \mathrm{B}, \delta \mathrm{D}$, etc.) and more reactive species ( $\mathrm{Ca}, \mathrm{Mg}, \mathrm{Na}$, and $\mathrm{K}$ ). The reactive species show two distinct chemical trends between the two water types that may constitute evidence for different flow paths and/or reequilibration of thermal fluids at lower temperatures. Multicomponent equilibrium geothermometry (MEG) analysis through the inverse modeling tool RTEst (Palmer, 2013) provides more reliable reservoir temperature estimates for the area through the use of likely reservoir mineral assemblages and the compensation of a mixing component. Results from MEG also support the possibility of reequilibration. The combination of MEG, high temperature water-rock interaction experiments, and local geological and hydrological data have resulted in a revised conceptual flow model of the Twin Falls - Banbury hydrothermal system.
\end{abstract}




\section{TABLE OF CONTENTS}

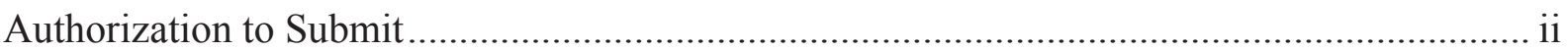

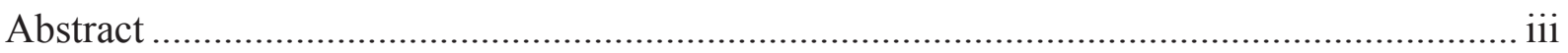

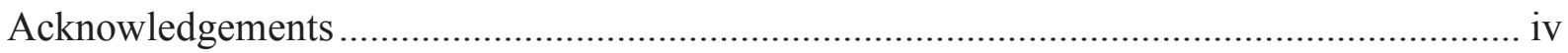

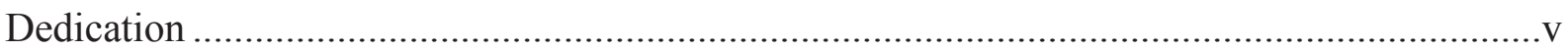

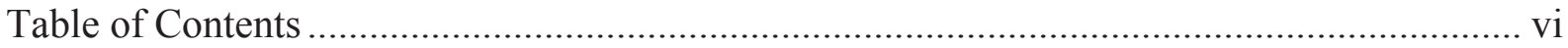

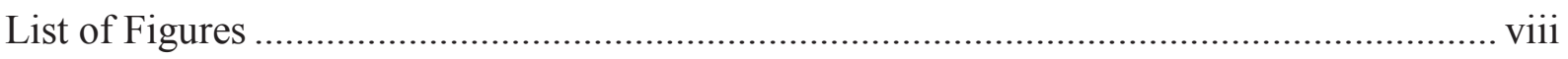

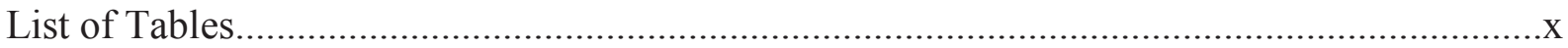

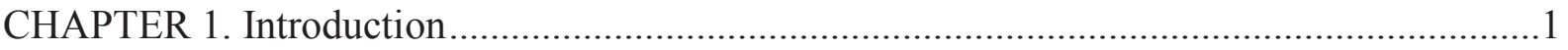

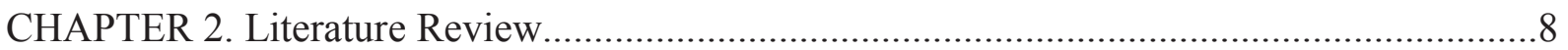

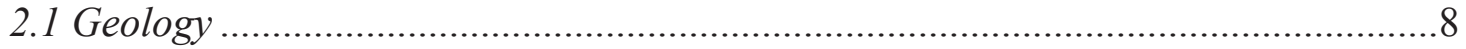

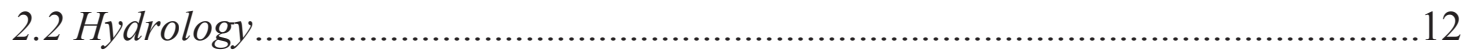

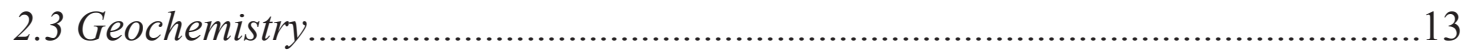

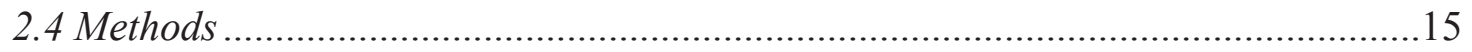

2.4.1 Solute Chemical Geothermometry .....................................................15

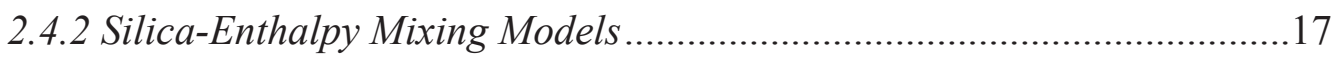

2.4.3 Multicomponent Equilibrium Geothermometry ....................................18

2.4.5 High Temperature Water-Rock Interaction Experiments .......................20

CHAPTER 3. Geochemistry of Thermal

Waters in the Twin Falls - Banbury Thermal Area .....................................22

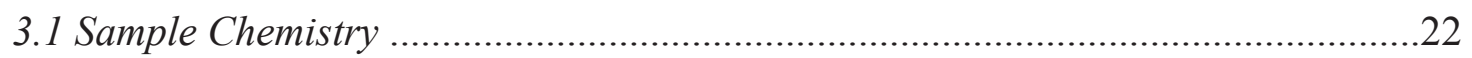

3.2 Principle Component and Hierarchical Cluster Analysis .....................................28

3.3 Evidence for Mixing Between Thermal Water and Groundwater..........................33

3.4 Binary Diagram Mixing Trend Analysis ..............................................................36

3.5 Aerial and Geologic Distribution of Water Types ..............................................43

CHAPTER 4. Geothermometry Estimation of Reservoir

Temperatures in the Twin Falls - Banbury Thermal Area .............................48

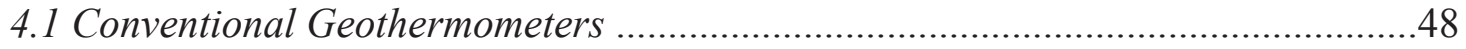

4.1.1 Silica Geothermometers .................................................................49

4.1.2 Cation Geothermometers ....................................................................53

4.2 Silica-Enthalpy Mixing Models for the Twin Falls - Banbury Thermal Area ........63

4.3 MEG Analysis of the Twin Falls - Banbury Thermal Area ..................................66

4.4 RTEst Results for the Twin Falls - Banbury thermal Area ..................................71

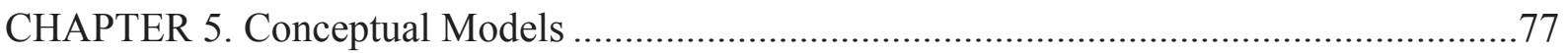

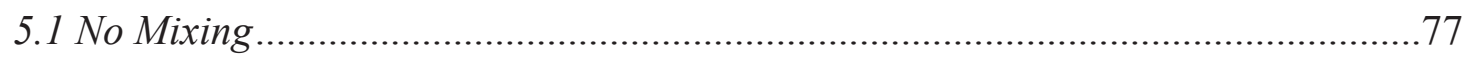




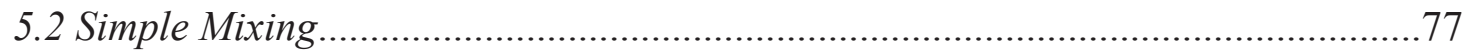

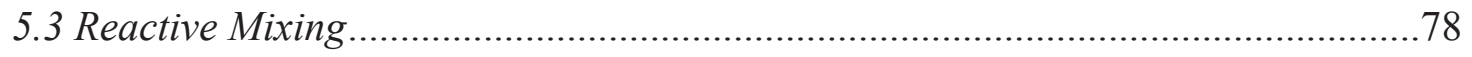

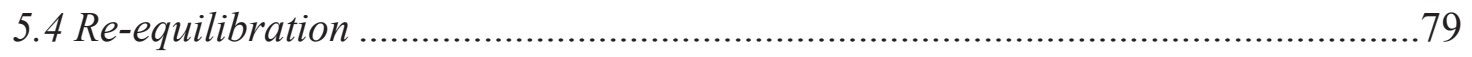

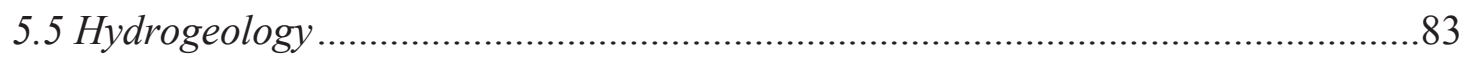

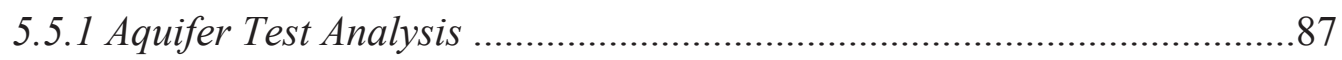

CHAPTER 6. Water-Rock Interaction and Mixing Experiments .........................................93

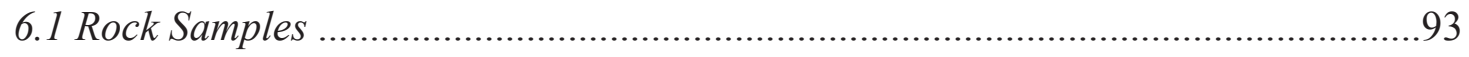

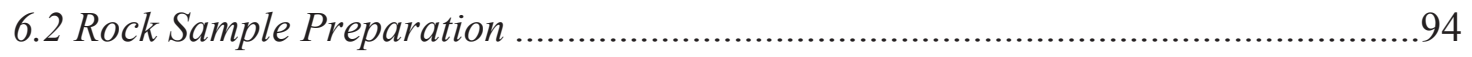

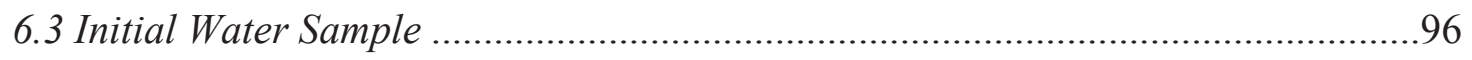

6.4 Experimental Procedure: Part 1 ........................................................................97

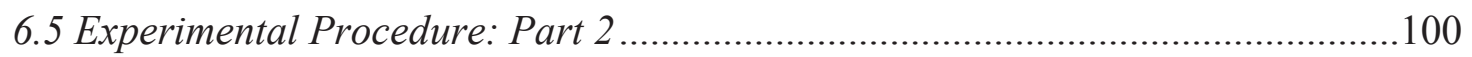

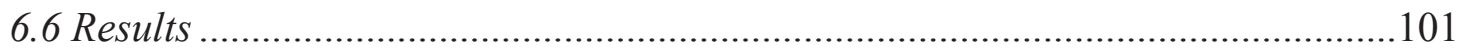

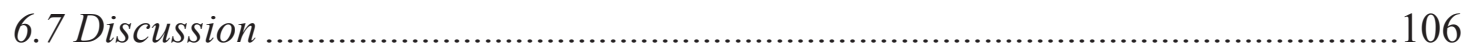

CHAPTER 7. Summary and Conclusions .................................................................... 108

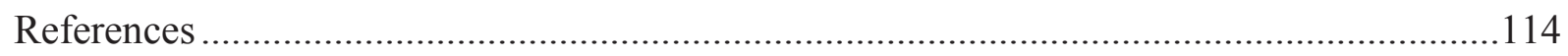

Appendix A. Sample Collection Procedure …............................................................... 125

Appendix B. Analytical Chemistry QA/QC .....................................................................136

Appendix C. Charge Balance for $\mathrm{Ca}-\mathrm{HCO}_{3}$ and $\mathrm{Na}-\mathrm{HCO}_{3}$ waters.....................................152

Appendix D. Well Logs Utilized in Geologic Cross Sections ............................................ 154 


\section{LIST OF FIGURES}

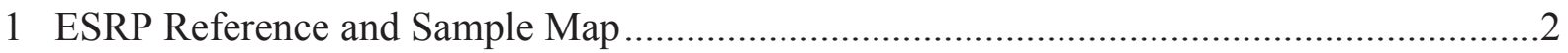

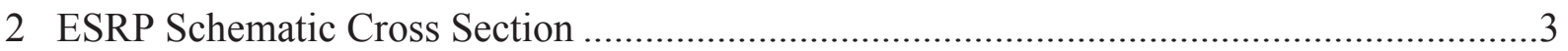

3 Twin Falls - Banbury Area Heat Flow and Sample Map ...................................................

4 Twin Falls - Banbury Hydrothermal Area Reference Map .................................................. 9

5 General Stratigraphy for the Twin Falls - Banbury Area ………….................................11

6 Principle Component Analysis Biplot Chart........................................................................

7 Hierarchical Cluster Analysis Dendrogram for the Twin Falls - Banbury Area ...................32

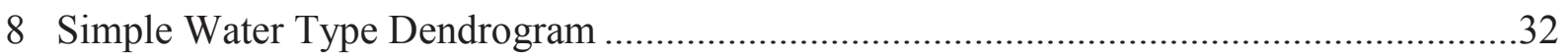

9 Piper Diagram of $\mathrm{Na}-\mathrm{HCO}_{3}$ and $\mathrm{Ca}-\mathrm{HCO}_{3}$ Waters in the Twin Falls - Banbury Area........34

10 Giggenbach Ternary Diagram of $\mathrm{Na}-\mathrm{HCO}_{3}$ and $\mathrm{Ca}-\mathrm{HCO}_{3}$ Waters ...................................36

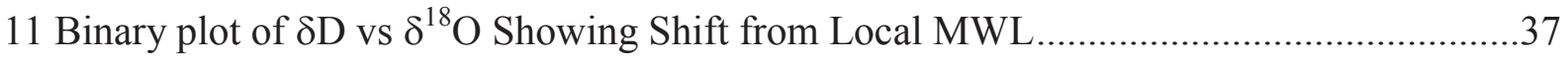

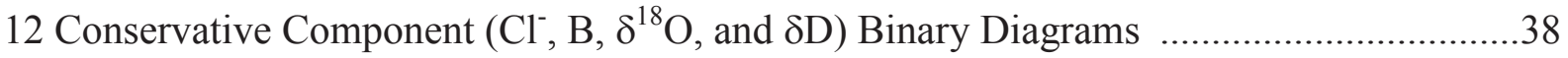

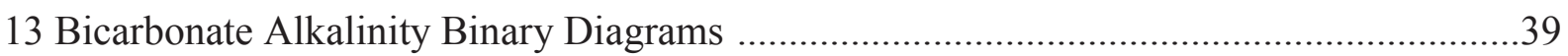

14 Simple Gradational Trend Binary Diagrams of Reactive Components ................................41

15 Binary Diagrams Showing Complex Relationships of $\mathrm{Na}^{+} \mathrm{vs} \mathrm{Ca}^{2+}, \mathrm{Mg}^{2+}$, and $\mathrm{K}^{+}$............42

16 Map Showing Trend from $\mathrm{Ca}-\mathrm{HCO}_{3}$ to $\mathrm{Na}-\mathrm{HCO}_{3}$ Waters Away from Recharge …….......45

17 Water Type Distribution Map of the Banbury Thermal Area Along a Normal Fault .........46

18 Water Type Distribution Map of the Twin Falls Thermal Area .........................................4

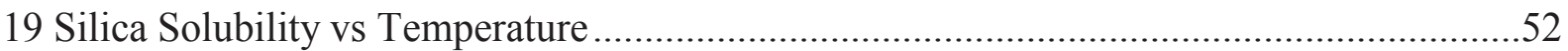

20 Silica-Enthalpy Mixing Model (Quartz) Applied to the Twin Falls-Banbury Area ............66

21 Silica-Enthalpy Mixing Model (Chalcedony) Applied to the Twin Falls-Banbury Area....67

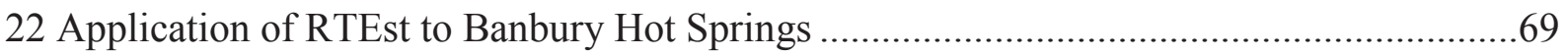

23 Reconstructed (Optimized) $\mathrm{Ca}-\mathrm{HCO}_{3}$ Thermal Water Binary Diagrams ...........................74

24 Conceptual Model for the Twin Falls - Banbury Hydrothermal Area ................................82

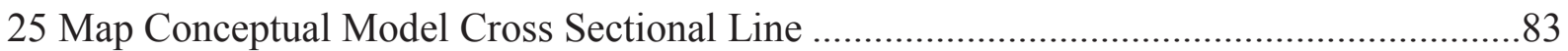

26 Geologic Cross Section of the Banbury Hot Springs Cluster Area ………………..............8

27 Map of the Cross Sectional Line Through the Banbury Hot Springs Area ……..................8

28 Geologic Cross Section of the Twin Falls Thermal Cluster Area........................................86

29 Map of the Cross Sectional Line Through the Twin Falls Thermal Area..............................87

30 Aquifer Pumping Tests for the CSI 1 and 2 Thermal Wells ............................................89

31 Plot of Temperature vs Drawdown for the CSI 1 and 2 Thermal Wells............................90

32 Cooper-Jacob Solution for the CSI 1 Pump and Recovery Tests ......................................93

33 Experimental Rock and Water Sample Location Maps ..................................................96

34 Rock Sample Preparation for Water-Rock Interaction Experiments ..................................97

35 Reactor Cell Configuration for Water-Rock Interaction Experiments ...............................99

36 Diagram of Water to Rock and Thermal Water to Groundwater Experimental Ratios ....102

37 Experimental Results Showing Calcium Concentrations from Initial Mixing .................104

38 Experimental Results Showing Magnesium Concentrations from Initial Mixing ..............104 
39 Experimental Results Showing Silica Concentrations from Initial Mixing.....................105

40 Experimental Results Showing Sodium Concentrations from Initial Mixing ...................105

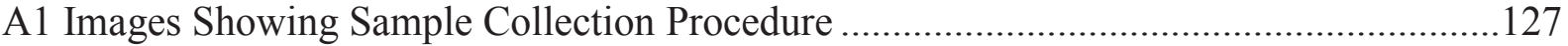

A2 YSI ${ }^{\circledR}$ Professional Plus Calibration Procedure ….................................................... 135

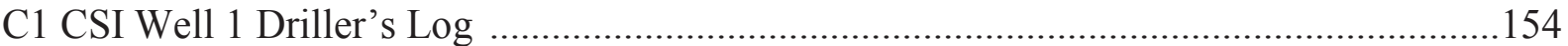

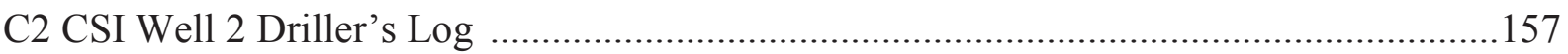

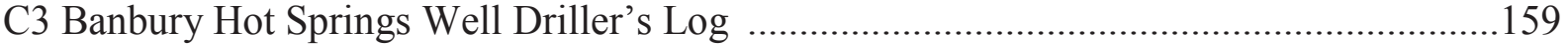

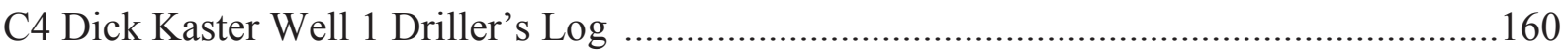

C5 Dick Kaster Well 2 Driller's Log .................................................................................. 161

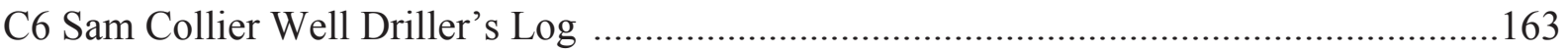

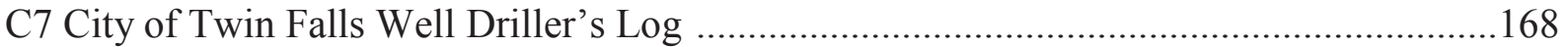

C8 Twin Falls High School Well Driller's Log ...............................................................169

C9 Mike Archibald Well Driller's Log ...........................................................................170

C10 Canyon Springs Golf Course Well Driller's Log …................................................172

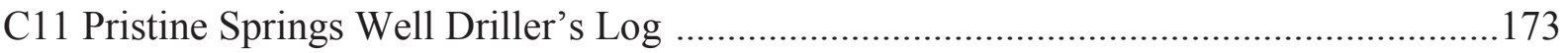




\section{LIST OF TABLES}

1 Original Chemical Concentrations for Twin Falls - Banbury Thermal Waters ....................25

2 Selected Historical Chemical Concentrations for Twin Falls - Banbury Thermal Waters ..26

3 Principle Component Analysis Eigen Values of Major Cations ...........................................29

4 Pearson's Correlation Coefficients for PCA Variables ........................................................30

5 Silica Geothermometer Temperature Estimations for $\mathrm{Na}-\mathrm{HCO}_{3}$ Waters ...............................60

6 Silica Geothermometer Temperature Estimations for $\mathrm{Ca}-\mathrm{HCO}_{3}$ Waters ............................61

7 Cation Geothermometer Temperature Estimations for $\mathrm{Na}-\mathrm{HCO}_{3}$ Waters ...........................62

8 Cation Geothermometer Temperature Estimations for $\mathrm{Ca}-\mathrm{HCO}_{3}$ Waters ..........................63

9 Alteration Mineral Assemblages and Weighting Factors Used in RTEst Modeling ............71

10 RTEst Temperature Estimates of $\mathrm{Na}-\mathrm{HCO}_{3}$ Waters Using Pure Water and $\mathrm{Ca}-\mathrm{HCO}_{3}$ Waters Using Local Groundwater ..................................................................

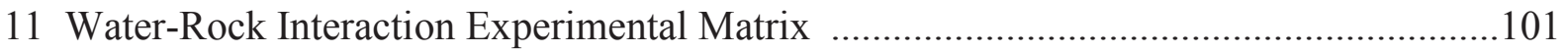

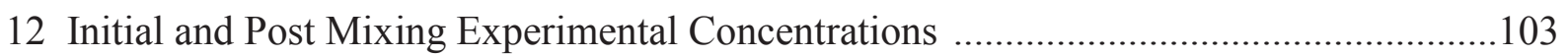

A1 Field Parameters for Data Collected in the ESRP in 2014 ............................................129

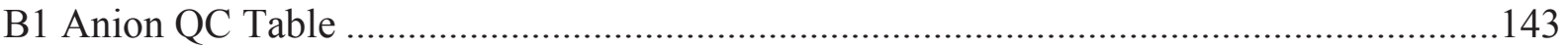

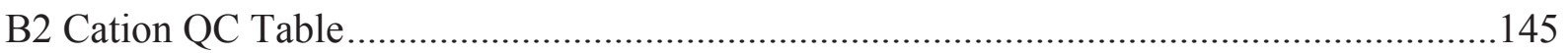

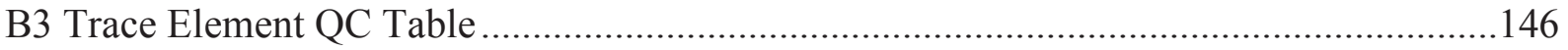

B4 Chemical Concentrations for ESRP 2014 Hydrothermal Samples ..................................150

$\mathrm{C} 1$ Charge Balances for $\mathrm{Na}-\mathrm{HCO}_{3}$ Thermal Waters..........................................................152

$\mathrm{C} 2$ Charge Balances for $\mathrm{Ca}-\mathrm{HCO}_{3}$ Thermal Waters …….................................................153 


\section{CHAPTER 1: INTRODUCTION}

The Twin Falls - Banbury hydrothermal area is one of many Known Geothermal Resource Areas (KGRA) located along the periphery of the Eastern Snake River Plain (ESRP). The ESRP is considered to be one of the most favorable areas for geothermal development within the state of Idaho (Tester et al., 2006) which the USGS estimates is home to over 4,900 MWe of undiscovered geothermal resources with a mean power production potential of $30 \mathrm{GWe}$ (Williams, 2008). Regional subsurface temperature gradients of 45-60 ${ }^{\circ} \mathrm{C} / \mathrm{km}$ (double the global average) have been calculated throughout the region and heat flow values of over $150 \mathrm{~mW} / \mathrm{m}^{2}$ have been projected for depths to $6 \mathrm{~km}$ (Brott et al., 1976; Blackwell and Richards, 2004). Despite the high observed potential, utilization of geothermal fluids has been limited to direct use applications (direct use heating, greenhouses, fisheries, etc.) for over a century with no commercial geothermal development within or along the plain proper. This is likely due to the masking of the deep geothermal signature by the Eastern Snake River Plain Aquifer (ESRPA), a prolific basalt hosted aquifer system that overlies the rhyolites, which are thought to host thermal reservoirs throughout the region.

The ESRP is a topographical lowland which was formed by the middle Miocene to recent bimodal volcanism by a succession of caldera formations associated with the migration of the North American Plate over the Yellowstone Hot Spot (Hughes et. al., 2002; Rodgers et. al., 2002; Pierce and Morgan, 2009). Caldera formation resulted in a series of younger to the east rhyolite units (Morgan et al., 1984; Leeman et al., 2008) that are overlain by extensive younger basalt flows of Tertiary to Holocene age. The basalt sequence forms the ESRPA which carries cold water from the Yellowstone Plateau down gradient to the Thousand Springs area in Twin Falls, ID. Because of the thick overlying cold water aquifer, most of the 
thermal springs and wells throughout the area are observed along the margins of the ESRP. It is thought that deep thermal water is able to make its way to the surface through a variety of structurally and geologically controlled conduits.

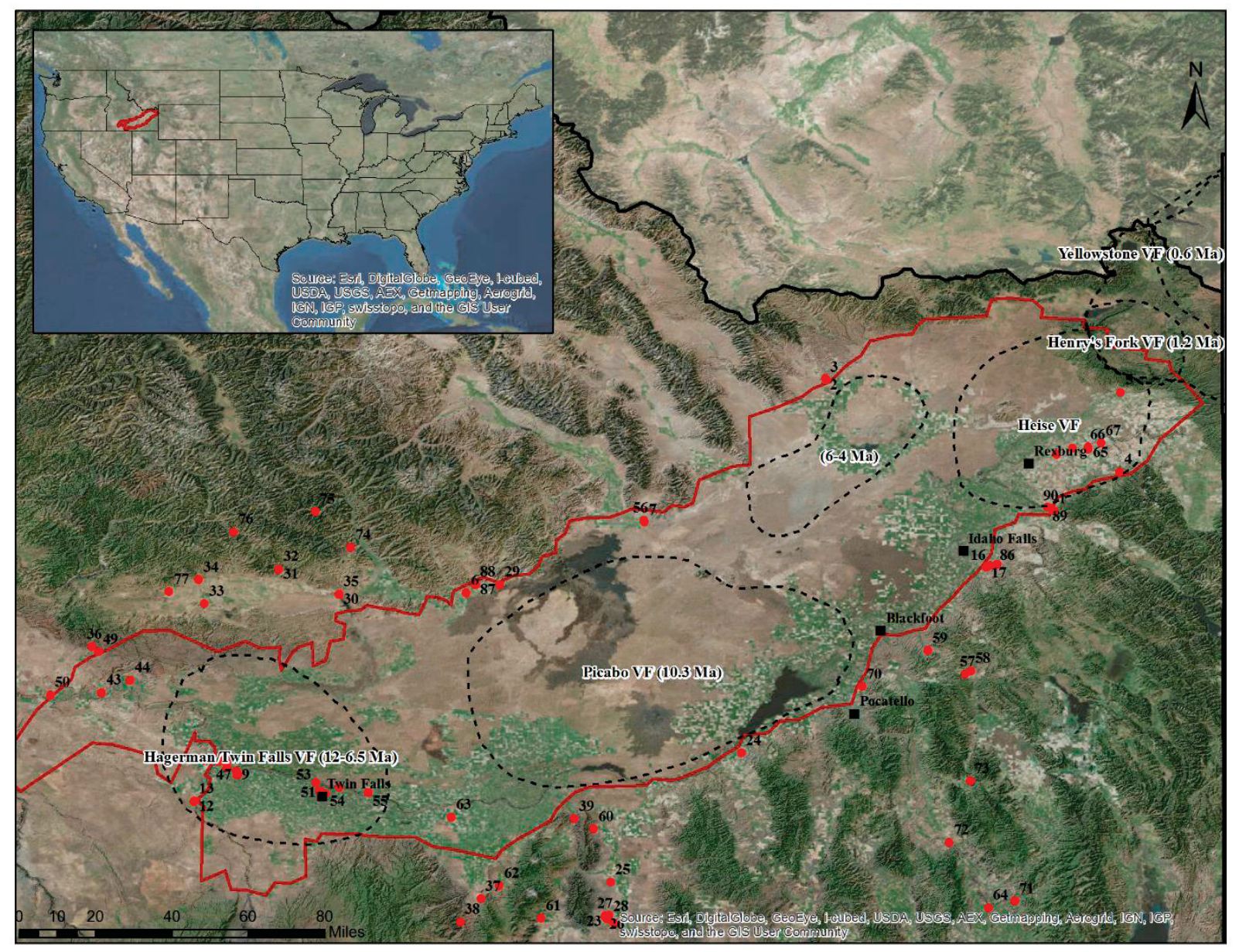

Figure 1. Map of the ESRP showing location relative to the United States (inset) and the approximate locations of caldera centers. Red points represent thermal samples collected in the 2014.

Many compositions for thermal fluids of the ESRP have been recorded (e.g., Ross, 1971; Young and Mitchell, 1973; Ralston et. al., 1981; Lewis and Young, 1982; Wood and Low, 1988; Parliman and Young, 1992; Mariner et al., 1991, 1997; McLing et al., 2002). However, most of the previous studies do not attempt to account for mixing with a cooler groundwater component though some acknowledge it. A gradational trend between Na-K$\mathrm{HCO}_{3}$ type waters associated with deep rhyolites and shallower $\mathrm{Ca}-\mathrm{Mg}-\mathrm{HCO}_{3}$ thermal waters 
has been observed in deep wells that penetrate the upper aquifer system (McLing et al., 2002; Mann, 1986). Many have explained this trend through mixing between thermal waters and groundwater where mixed waters exhibit a composition between the two end member waters (McLing et al., 2002; Neupane et al., 2014; Cannon et al., 2014).

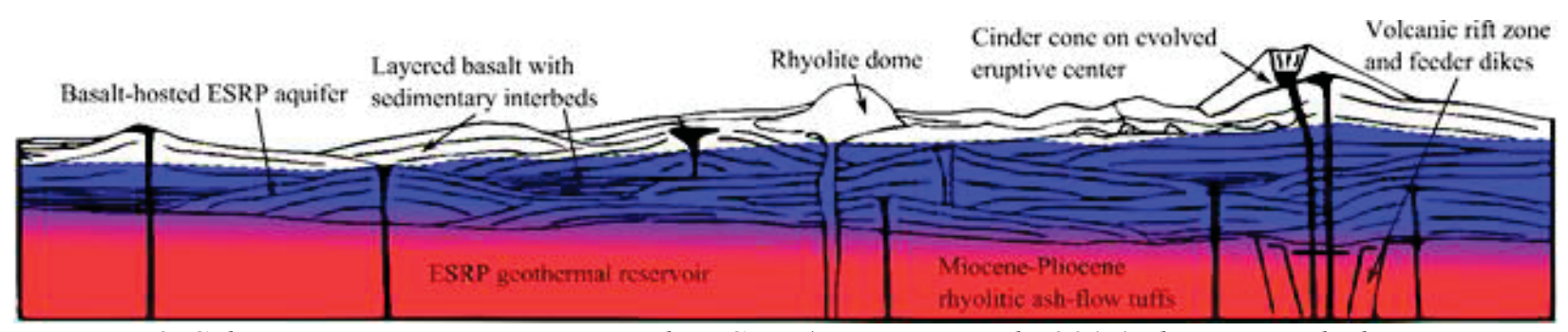

Figure 2. Schematic cross-section across the ESRP (Neupane et. al., 2014) showing underlying rhyolitic ash-flow tuffs and overlying basalt flows with few sedimentary layers. The rhyolite ash-flow tuffs underlying the basalt aquifer system are assumed to be the ESRP geothermal reservoir.

Although there are many historical thermal fluid compositions for the ESRP, many of them are incomplete in that they lack important trace elements. This study is part of a larger Department of Energy Geothermal Technologies Office funded project to provide more accurate reservoir temperature estimations throughout the ESRP by using a modern technique called multicomponent equilibrium geothermometry (MEG). MEG utilizes trace elements (particularly aluminum) to estimate temperature using the saturation states of hydrothermal alteration minerals, many of which are aluminosilicates. MEG is also capable of accounting for mixing between thermal fluids and groundwater through inverse modeling. To this end, a collaboration between the University of Idaho, the Lawrence Berkeley National Laboratory, and the Idaho National Laboratory collected samples in 2014 in order to provide more reliable temperature estimates that are corrected for the effects of mixing.

The Twin Falls - Banbury area (Figure 3) was chosen as the location for an in depth investigation into the possibility of geothermal mixing and re-equilibration as an explanation 


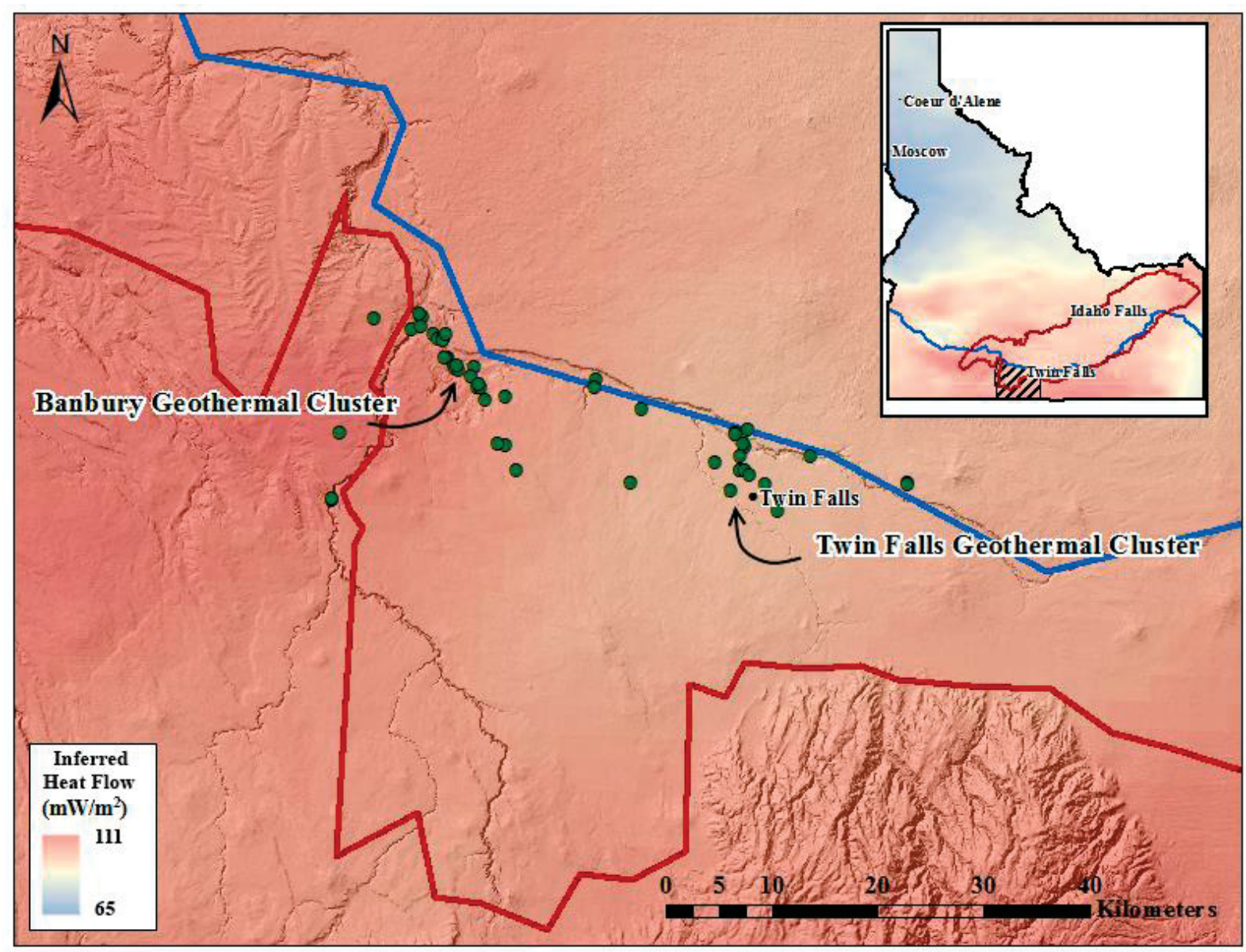

Figure 3. Study area map superimposed on the USGS heat flow map (Williams and Deangelo, 2011). Map depicts the Twin Falls - Banbury hydrothermal area relative to the ESRP margin (red line). Green points correspond to thermal waters utilized in this study.

for the lower than expected reservoir temperature estimations of the area. The area was chosen due to the high sample density obtained in the 2014 sampling campaign as well as the amount of historical data available for the area. The area is comprised of two dense clusters of geothermal surface manifestations along the trend of the Snake River near the southwestern end of the ESRP. This study attempts to combine various geochemical techniques with local hydrology and geology to provide evidence for mixing, estimate reservoir temperature while accounting for mixing, consider the possibility of re-equilibration, and refine the conceptual model for the Twin Falls - Banbury hydrothermal system. However, before investigating the 
Twin falls - Banbury area in detail, it is important to identify exactly what is meant by "mixing" and the different scenarios by which mixing can occur.

\section{Mixing Scenarios Defined}

The chemical signature of geothermal water is often impacted or altered by mixing with shallower waters, thereby masking the actual reservoir temperatures calculated using geothermometry. This study examines the effects of mixing on calculated temperatures via an in-depth investigation on a relatively well known geothermal area, the Twin Falls - Banbury thermal system in south-central Idaho. Dilution corrections will be made using established mixing models and the multicomponent equilibrium geothermometry (MEG) tool RTEst (Reservoir Temperature Estimator) (Palmer et al., 2013). The effect of chemical reequilibration with rocks outside the geothermal reservoir at sub-reservoir temperatures is also considered. Mixing and re-equilibration is a practical problem facing geothermal explorationists in many areas, e.g. ESRP and similar thermal regimes. For the purposes of this work, three mixing scenarios are defined:

1) "simple mixing" or non-reactive mixing;

2) flow pathway mixing (both reactive and non-reactive)

3) re-equilibration.

Simple mixing involves the ascension of thermal water from depth through a conduit like a fault or fracture. The thermal water component is uninterrupted during ascension, cooling only through conduction and/or advection. Upon discharging at the surface, the thermal water is quickly mixed with surface water such as precipitation, a stream, or spring. In this case the thermal water is undiluted (no mixing prior to discharge) until it is mixed with 
surface water. Most mixing models are setup to directly address this type of dilution (Fournier, 1977; Arnòrsson, 1983; 1985). Solute-enthalpy mixing models developed in the 1970s and 80s can be utilized to adjust for simple mixing and refine the calculated reservoir temperatures. MEG methods including RTEst can remove the influence of the cold water component based on the convergence of multiple mineral saturation indices.

The second scenario, flow path mixing, involves mixing of thermal water as it makes its way from depth to the surface. In the case of the ESRP, thermal water ascending through a fracture may be mixed with cooler groundwater as the conduit is intersected by permeable cold water zones prior to discharging at the surface or through a well. This scenario may constitute a combination of both simple and reactive mixing depending on sufficient residence times that allow for reactions to occur between the two waters and/or surrounding rock. Reactive mixing is made evident through the alteration of ratios of some chemical constituents while other more conservative species (i.e. $\mathrm{Cl}^{-}, \mathrm{B}$ ) will mix non-reactively as their ratios remain constant through dilution.

The third scenario involves the re-equilibration of thermal water or mixed thermal water with a new reservoir rock. The geochemical signature of re-equilibrated waters does not reflect the temperature of the deep thermal reservoir but only the temperature at which the waters last attained equilibrium. Because re-equilibration violates a key assumption in all geothermometry techniques (Huenges and Ledru, 2011), it has largely been ignored in geothermal investigations. Many researchers have warned about re-equilibration when discussing the applicability of their techniques (Fournier, 1977; Arnòrsson, 1985; Reed and Spycher, 1984; Giggenbach, 1988, Neupane, 2015) but few have attempted to quantify or account for its effects. Unlike the previous two scenarios, re-equilibration presents a 
significant problem that can't be solved by MEG nor can it be accounted for with conventional geothermometry and mixing model techniques. To better understand if reequilibration is at play in this area, water-rock interaction and mixing experiments based on the Twin Falls - Banbury geothermal system are performed in this study. 


\section{CHAPTER 2: LITERATURE REVIEW OF THE TWIN FALLS - BANBURY HYDROTHERMAL SYSTEM}

The hydrothermal system in Twin Falls, Idaho is the most utilized and perhaps the most prolific geothermal prospect throughout southern Idaho. Substantial use of the system began in the 1970 s with the utilization of thermal water for fish propagation, irrigation, heating, and resorts (Street and Detar, 1987). All of these applications are still in operation today. One of the most promising areas for further development is located near Hagerman, Idaho where the Thousand Springs Resort produces $72{ }^{\circ} \mathrm{C}$ geothermal water from a 750 foot well. Electrical production and further geothermal investigations have been considered but limited due to concerns over observed declining thermal water levels although temperature declines are not evident (Fleischmann, 2006). Reservoir temperature estimations made by earlier researchers utilizing geothermometry techniques produced results that are insufficient for power production. However, preliminary results of this study show that mixing between groundwater and thermal water may have masked the true higher temperature signature of this

area. The following section provides a review of the relevant literature pertaining to the Twin Falls - Banbury hydrothermal area.

\subsection{Geology}

Mabey (1982) stated that the Snake River Plain was one of the least understood geologic provinces in the United States. While it has been described as a graben and various rift structures, it is described by most as a regional down warping associated with the bimodal volcanism due to the successive caldera formations of the Yellowstone Hotspot beginning approximately 16 Ma (Hughes et. al., 1999; Rodgers et. al., 2002; Pierce and Morgan, 2002). 


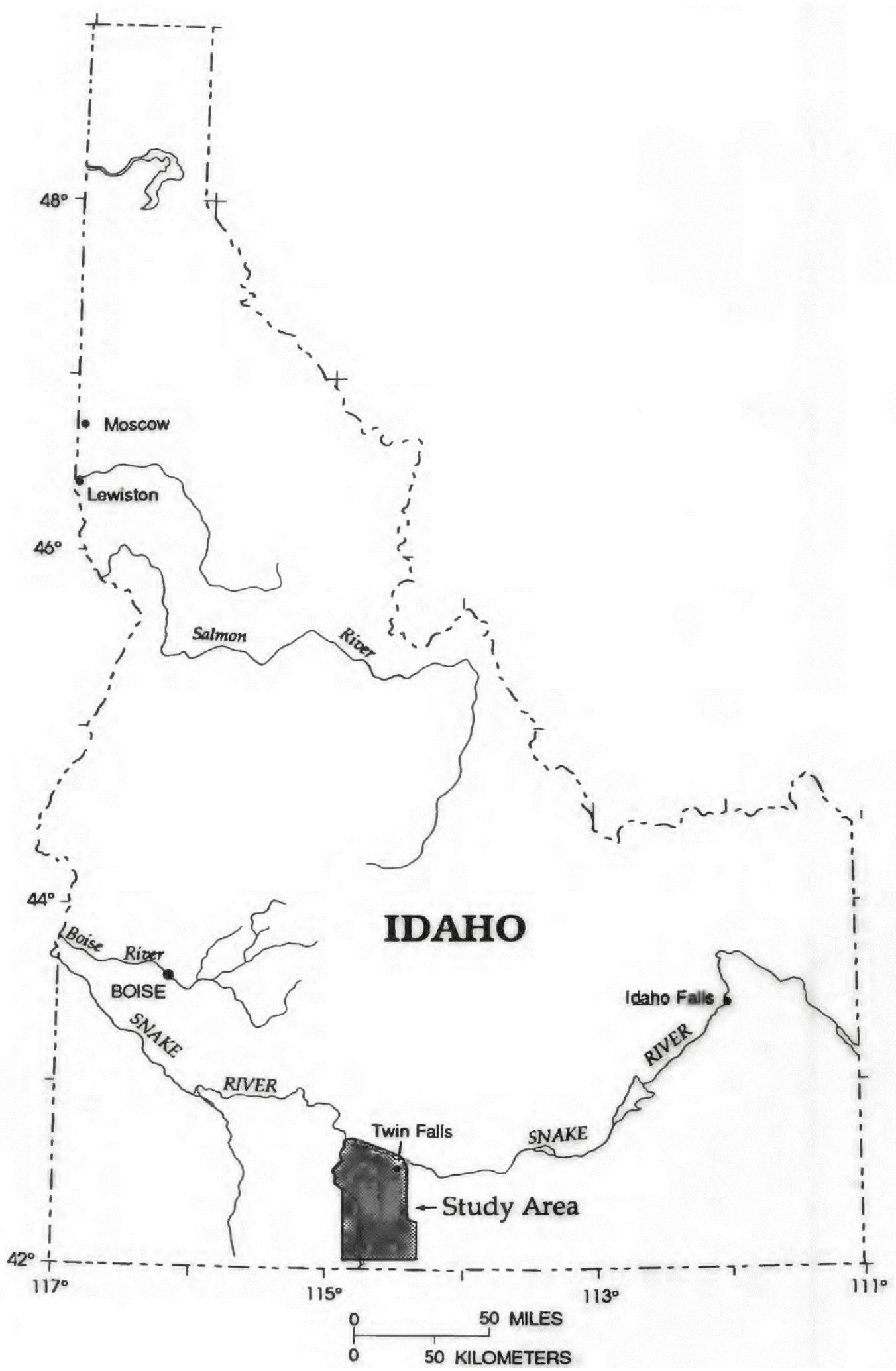

Figure 4. Map of the Twin Falls - Banbury hydrothermal study area, Lewis and Young (1982) 
The Twin Falls and Banbury hydrothermal areas show characteristics of both the ESRP and basin and range regional extension. Tertiary rhyolitic volcanic rocks underlie younger quaternary and tertiary basaltic units throughout the study area. The rhyolitic units of the Idavada volcanics dip northward from the Cassia Mountains in the southern portion of the study area disappearing beneath the basaltic units of the ESRP with no clear evidence of down faulting supporting the conceptual model of ESRP regional down warping (Street and Detar, 1987). However, normal faults associated with Basin and Range extension are present in the northwestern portion of the study area. Many of these faults do not cut across basalts and are constrained to the Idavada volcanics trending north to northwest along the Salmon Falls Creek. These structures mark the beginning of the Western Snake River Plain and continue across the Bruneau Desert to the west (Kuntz, 1977).

Miocene Banbury basalts are the most predominant basalt units in the study area and may be up to 305 meters (1,000 ft.) thick (Lewis and Young, 1989). Along with overlying and interbedded Pleistocene lacustrine sediments of the Glenn's Ferry Formation (Malde and Powers, 1972), these basalts make up a locally significant shallow groundwater system. However, the most ubiquitous unit in the study area are the Tertiary volcanics of the Idavada formation which are predominantly comprised of welded rhyolitic ash flow tuff units with secondary rhyolite lava flows, andesites, and intercalated lacustrine sediments (Rember and Bennett, 1979). The Idavada volcanics are likely representative of many undifferentiated volcanic episodes from 12 to $6 \mathrm{Ma}$ (Street and Detar, 1987). Electrical resistivity data shows that the Idavada volcanics are continuous over most of the area ranging in thickness from 700 to 3,000 ft. (2,000 ft average) (Lewis and Young, 1989). Lithologic logs from the recently drilled deep exploration well of Project Hotspot in nearby Kimberly, ID shows the Idavada 
volcanics are at least 3,800 ft. thick and reach depths up to 6,423 ft. (Shervais et al., 2013). General stratigraphy of the study area is depicted in Figure 5 below showing Tertiary rhyolites

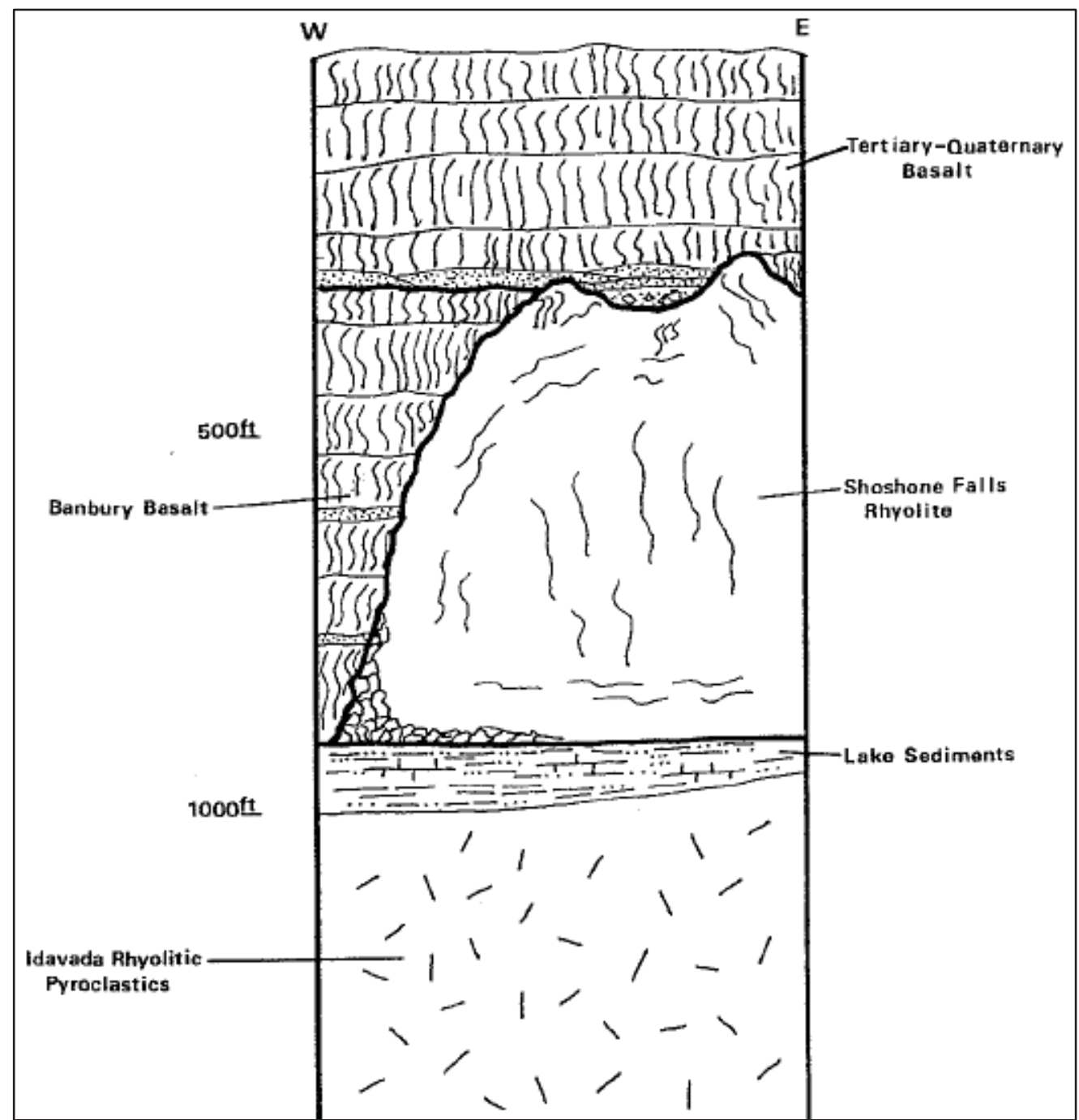

Figure 5. General stratigraphy of the Twin Falls-Banbury area (Street and DeTar, 1987).

underlying the entire study area, lacustrine sediments, Tertiary Banbury basalts, a distinct single andesitic flow layer of the Idavada called the Shoshone Falls rhyolite, and finally overlying Tertiary and Quaternary basalts. 
Although none of the well logs within the study area penetrate the extent of the Idavada volcanics, Paleozoic marine sediments are thought to underlie the entire area (Lewis and Young, 1989). Pennsylvanian age carbonates outcrop just to the southeast of the town of Buhl, ID and make up the core of the Cassia Mountains near the Idaho-Nevada border to the south. The extent of the Paleozoic carbonates beneath the Idavada volcanics is unknown but over 5,000 feet of carbonates have been reported in the mountains of northern Nevada (Schroeder, 1912).

\subsection{Hydrology}

The Twin Falls area hydrology is separated into two separate and distinct aquifer systems. There exists a shallow, cold water aquifer system in which flow paths between areas of recharge and discharge are relatively short. This system contains aquifer sub units within Banbury Basalts and thin sedimentary interbeds. Groundwater flow direction is generally northward or northwestward (in southeastern portions of the area near the city of Twin Falls) toward the Snake River. The majority of recharge to this system comes from the south and southeast in the low hills where annual precipitation reaches 45 inches. Hydraulic heads are below land surface. The aquifer is considered to be unconfined but may be confined in some areas. Water from this shallow system is typically around $20{ }^{\circ} \mathrm{C}$ while some shallow groundwater reaches elevated temperatures due to the mixing of cooler water with thermal water (Lewis and Young, 1989).

The thermal aquifer system $\left(20{ }^{\circ} \mathrm{C}\right.$ to $\left.72{ }^{\circ} \mathrm{C}\right)$ is located beneath basalt units within the Idavada volcanics and is under artesian conditions with temperatures of the waters increasing to the northwest. Lewis and Young (1982) produced a generalized potentiometric surface map showing an overall north and northwestern gradient in the aquifer. Permeability within the 
reservoir rock itself is associated with fractures developing from tectonic movement, joints and fractures resulting from cooling during emplacement, intergranular porosity of the nonwelded ash flow tuffs, and contacts between flow boundaries. Street and Detar (1987) described the results of a pumping test during the development of two deep thermal heating wells (450 and 675 meters) completed in the Idavada volcanics at the College of Southern Idaho in Twin Falls. Transmissivity $\left(554-923 \mathrm{~m}^{2} / \mathrm{d}(44,600-74,300 \mathrm{gpd} / \mathrm{ft})\right)$ and storativity (5.8E-4 to 6.2E-4) values were measured for the Idavada rhyolites. It was concluded that no hydrologic boundaries exist between the Twin Falls and Banbury area systems.

Thermal waters are thought to originate from deep circulation paths from the Cassia Mountain recharge zone to the south and through fractures in the overlying basalts of the thermal area. The waters are subsequently heated by either a regionally high gradient (Lewis and Young, 1989) or the young basaltic sill complexes associated with ESRP volcanism (McLing et al., 2014, Dobson et al., 2015).

\subsection{Geochemistry}

Lewis and Young (1982) characterized the highest temperature thermal waters of this area as sodium-bicarbonate type and stated that they are slightly alkaline. In 1989, they showed that water chemistry of the thermal waters indicates mixing with a shallow cold water component through relationships of stable isotopes, chloride, and enthalpy. They highlighted a mixing trend from cooler $\mathrm{Ca}-\mathrm{HCO}_{3}$ to $\mathrm{Na}-\mathrm{HCO}_{3}$ using a Piper trilinear diagram but made no effort to address the effects of dilution on geothermometry calculations. Traditional geothermometry calculations were performed using the $\mathrm{Na}-\mathrm{K}-\mathrm{Ca}$ geothermometer and silica geothermometers (chalcedony and quartz). Mg corrections to the $\mathrm{Na}-\mathrm{K}-\mathrm{Ca}$ geothermometer were not made as the corrections were deemed insignificant for waters with around $1 \mathrm{ppm} \mathrm{Mg}$ 
concentration despite a concentration of $0.2 \mathrm{ppm} \mathrm{Mg}$ being widely regarded as the boundary for correction (Fournier and Potter, 1979).

The 19 samples taken in the Lewis and Young (1982) study were near saturation with calcite thus giving skeptical temperature estimations for the $\mathrm{Na}-\mathrm{K}-\mathrm{Ca}$ geothermometer. A simple mixing analysis was done by plotting the $\mathrm{Na}-\mathrm{K}-\mathrm{Ca}$ temperature predictions versus the silica geothermometer predictions. Waters that plotted on or near the equal temperature line for these two geothermometers were considered to be representative of reservoir water (not mixed). These waters include several of the highest temperature waters including the $72{ }^{\circ} \mathrm{C}$ water of the 1000 Springs Resort. The authors drew the conclusion that $70-100{ }^{\circ} \mathrm{C}$ was the likely reservoir temperature from these conventional geothermometry methods. Young and Mitchell (1973) came up with a similar but slightly higher estimate of $85-135^{\circ} \mathrm{C}$.

In 1997, Mariner et al., conducted a study in Twin Falls and Jerome Counties using sulfate-water isotope geothermometry. They estimated a reservoir temperature of $90-106{ }^{\circ} \mathrm{C}$. However, recent sulfate-water isotope geothermometry results show temperature estimates of $159{ }^{\circ} \mathrm{C}$ for this area (Conrad et al., 2015). Lead isotopic values from this study showed that thermal waters in the area have a signature reflective of Paleozoic carbonates. This suggests that despite the overprinting of a rhyolitic signature (high silica and high fluoride), thermal waters may be originating even deeper in the system within Paloezoic carbonates.

${ }^{14} \mathrm{C}$ isotopes were used to date the waters of the Twin Falls geothermal system. Age estimations for Twin Falls area thermal are around 4,000 to 10,000 years old (Mariner et al., 1991). Lewis and Young (1982) attributed low deuterium values in the waters to a historically cooler climate making the waters at least 8,000 years old and possibly up to 15,000 years old. Discharge measurements for wells in the area in early 1979 indicated a thermal water 
discharge of 10,300 acre-ft annually (Lewis and Young, 1982). However, there have been significant declines to the utilization of this system for heating, low-head hydro power production, and fish propagation (Street and Detar, 1987). Fleischmann (2006) listed this area in his Geothermal Development Needs in Idaho stating that more exploration is warranted due to the masking of the high temperature resource by the overlying cold water system. The report states that more exploration is needed to determine the source of heat and a resource may be confirmed with deep drilling.

\subsection{Methods}

With advancements in geothermal science, there exists more substantial evidence for mixing in this region. Recent geothermometry studies have shown that the Twin Falls Banbury hydrothermal system may represent a higher temperature resource than what was previously estimated (Cannon et al., 2014; Conrad et al., 2015). The following sections describe the geochemical methods utilized in this study.

\subsubsection{Solute Chemical Geothermometry}

Geothermal fluids have widely varied chemistries, reflecting the geologic setting and the host rock from which they emanate. Geothermometers are experimentally and empirically based equations that take advantage of specific high temperature mineral-solute reactions that are slow to equilibrate at lower temperature. These equations give geoscientists insight into the reservoir temperature achieved by the thermal water at depth prior to ascent to the surface.

Several assumptions are made in order for geothermometers to be useful. The first assumption is that equilibrium between host rock and water is obtained at depth. This assumption has been proven valid through research on several commercial geothermal power plants. The second major assumption is that the thermal fluid composition is not altered by secondary 
processes (boiling, mixing, reactive processes, etc.) during its ascent to the surface. This assumption is made but is often invalid and corrections need to be made to the predicted temperatures.

Utilization of geothermometers began in the late 1970s with the development of the silica geothermometers, which are perhaps the most widely used geothermometers. The quartz and amorphous silica geothermometers were first developed by Fournier (1977) and are based on the experimentally determined prograde relationship between silica concentration and increasing temperature. Different polymorphs of silica dominate at different temperatures and thus not all silica geothermometers are appropriate at all temperatures. This led to the development of the chalcedony geothermometer by Arnorsson et al. (1983). However, not all thermal fluids are hosted within silicic reservoirs leading to the development of cation geothermometers.

Cation geothermometers are based on temperature-dependent cation exchange reactions. For example, the Na-K geothermometer (Fournier, 1979; Giggenbach et al. 1988) uses the ratio of sodium to potassium based on the reaction between albite $\left(\mathrm{NaAlSi}_{3} \mathrm{O}_{8}+\mathrm{K}^{+}\right)$ and the K-feldspar adularia $\left(\mathrm{KAlSi}_{3} \mathrm{O}_{8}+\mathrm{Na}^{+}\right.$). The Na-K-Ca geothermometer (Fournier and Truesdell, 1973) was developed to deal with waters having high concentrations of calcium making the Na-K geothermometer unsuitable. However, high concentrations of $\mathrm{Mg}(>0.2$ ppm) yield anomalously high results for the $\mathrm{Na}-\mathrm{K}-\mathrm{Ca}$ geothermometer. As a result the $\mathrm{Mg}$ correction for the Na-K-Ca geothermometer was developed to account for the higher $\mathrm{Mg}$ concentrations at temperatures less than $180{ }^{\circ} \mathrm{C}$ and where $\mathrm{Mg}$ is present in clays and carbonates. This correction was intended for unmixed waters although high magnesium concentrations are often an indication of mixing with a cooler groundwater component. Other 
cation geothermometers include the Na-Li geothermometer (Fouillac et al., 1981), which uses the ratio of sodium to lithium and is based on cation exchange reactions that take place with clays and zeolites and the K-Mg geothermometer (Giggenbach et al. 1988) which is useful when sodium and calcium have not equilibrated between fluid and rock.

\subsubsection{Silica-Enthalpy Mixing Models}

While the Quartz geothermometer is capable of correcting for steam loss due to boiling, none of the conventional geothermometers mentioned previously are capable of accounting for mixing. As a result, models were developed to better account for mixing. The silica-enthalpy mixing model used in this study is based on the positive relationship between silica solubility and increasing temperatures. However, in this model, respective enthalpies of sample waters calculated from field temperatures are used as plot coordinates rather than temperature because enthalpy is conserved as waters mix and boil whereas temperature is not (Fournier, 1977). This model can be applied with two separate scenarios. A trend line is drawn from the point representing the non-thermal component of the mixed water (lowest silica and enthalpy), through the mixed water from thermal springs. The intersection of this line with a silica solubility curve approximates the enthalpy of the hot-water component at reservoir conditions if there was no boiling prior to mixing. The enthalpy at the boiling temperature $\left(100^{\circ} \mathrm{C}\right)$ which is $419 \mathrm{~J} / \mathrm{g}$ is intersected with the projected trend line. From this intersection, a horizontal line is drawn to the quartz maximum steam loss line. This new enthalpy value can be used to calculate the reservoir temperature if boiling occurred prior to mixing (Fournier, 1977).

While mixing models have aided in making better predictions in areas where rapid simple mixing occurs, they are not comprehensive enough to compensate for reactive secondary 
processes that may affect waters prior to or after mixing. Finally, the prediction of a reservoir temperature based solely on two or three chemical species contains more error than is desirable. Estimations that utilize an entire reservoir mineral assemblage based on likely alteration minerals within the reservoir are considered, in theory, to provide much more accurate temperature predictions.

\subsubsection{Multicomponent Equilibrium Geothermometry}

Reed and Spycher developed the basic concept of multicomponent equilibrium geothermometry (MEG) in 1984. The major advantage of MEG over more conventional geothermometry techniques is the use of a reservoir mineral assemblage (RMA) that represents the full suite of minerals likely to be present in a geothermal reservoir. The approach uses the calculated ion activity products $(\mathrm{Q})$ of chemical species within the RMA to determine the degree of saturation $\left(\log \mathrm{Q} / \mathrm{K}_{\mathrm{T}}\right)$ where $\mathrm{K}_{\mathrm{T}}$ is the temperature dependent mineralwater equilibrium constant. The temperature at which all minerals have near zero saturation indices is taken to be the temperature at which thermal fluid last equilibrated.

While there is an obvious advantage to utilizing an entire RMA as opposed to a few basis chemical species, MEG also allows for adjustments to be made to account for secondary alteration processes that effect calculated temperatures; including the amount of water gained (dilution/mixing) or lost (boiling) and the effects of degassing. The loss of $\mathrm{CO}_{2}$ has been shown to affect the $\mathrm{pH}$ of geothermal waters and is commonly shown by the oversaturation of calcite (Palandri and Reed, 2001).

Despite the advantages of MEG over conventional geothermometry methods, there has been little application in geothermal assessment and development. Some previous investigators (e.g., D’Amore et al., 1987; Tole et al., 1993; Hull et al., 1987) have used this technique for 
predicting geothermal temperature. The first two of these authors utilized a MEG technique to predict reservoir temperatures and develop conceptual models. However, both noted the difficulty that secondary processes pose to predicting an accurate equilibrium temperature. Hull et al. (1987) made an attempt to account for the dilution of thermal water by a cooler groundwater component (similar to the ESRP conceptual model). They noted that the use of a real groundwater component from a nearby source was problematic due to the production of bulk compositions with negative molalities of $\mathrm{Mg}, \mathrm{Al}, \mathrm{Fe}$, and $\mathrm{Ca}$. The use of deionized water as a mixing agent resulted in more successful temperature predictions. Hull et al. (1987) explained this phenomena by stating that either 1) the nearby cold water component is dissimilar to the actual mixing agent or 2) the mixture of thermal water and groundwater undergoes additional reactions (precipitation, exchange, etc.) and thereby re-equilibrate at a cooler temperature or within a new host rock.

More recent efforts by some researchers (e.g., Bethke, 2008; Cooper et al., 2013; Neupane et al., 2013; Spycher et al., 2014; Neupane et al., 2014) have focused on improving temperature predictability of the MEG method. The two latest tools (computer codes) are the GeoT tool developed by Spycher et al. (2014) and the Reservoir Temperature Estimator (RTEst) tool developed by Palmer (2014). RTEst is the method used in this study. RTEst couples the React module of The Geochemist's Workbench ${ }^{\circledR}$ (GWB) (Bethke and Yeakel, 2012) and the optimization program PEST (Doherty, 2013) to optimize parameters including temperature, water, and $\mathrm{CO}_{2}$ fugacity. RTEst works to obtain an estimated reservoir temperature by repeatedly calculating mineral saturation indices while allowing temperature, solvent mass, and $\mathrm{CO}_{2}$ fugacity to fluctuate. The ultimate goal of this inverse modeling is to minimize the objective function $\Phi$ given here by: 


$$
\Phi=\sum\left(\mathrm{SI}_{\mathrm{i}} \mathrm{W}_{\mathrm{i}}\right)^{2} \quad \text { where } \mathrm{SI}=\left(\log \mathrm{Q} / \mathrm{K}_{\mathrm{T}}\right) \text { and } \mathrm{w}_{\mathrm{i}}=\text { weighting factor for a mineral. }
$$

The minimization of the objective function represents the minimization of the collective distances away from zero for all saturation indices within the RMA. In theory, the reservoir temperature is obtained when $\Phi$ is essentially zero. The weighting factor $\left(\mathrm{w}_{\mathrm{i}}\right)$ ensures that each mineral contained in a chosen mineral assemblage is considered equally and the results are not skewed by reaction stoichiometry (Neupane et al., 2014).

\subsubsection{High Temperature Water-Rock Interaction Experiments}

Geothermal alteration in aqueous solutions has been extensively studied but application in geothermal reservoir characterization and development is limited. High temperature water-rock interaction experiments can provide valuable information on alteration temperature, rock composition, and especially fluid composition (Browne, 1978; Lesher et al., 1986; Reyes, 1990; Davis et al., 2003). Research into water-rock interaction at high temperatures began in the late 1950s. Khitarov (1959) investigated the interaction of high temperature waters with particular interest in granite, feldspars, and micas. Basharina (1958) successfully extracted many water-soluble constituents from an andesitic ash and in 1963, Ellis and Mahon targeted silicic volcanic rocks in particular comparing experimentally determined fluid compositions with natural ones in New Zealand.

Data from natural geothermal systems shows that local equilibria between geothermal fluids and alteration minerals controls major component concentration (except $\mathrm{Cl}^{-}$and other mobile elements) in fluids at temperatures as low as $50{ }^{\circ} \mathrm{C}$ (Ellis, 1970; Arnórsson et al., 1983; Stefánsson and Arnórsson, 2002). Although primary rock type is important, it is 
considered to have less of an effect on geothermal alteration than permeability, temperature, and fluid composition (Henley and Ellis, 1983; Rodriguez, 2001). Browne (1978) showed that Quartz, K-feldspar, albite, chlorite, Fe-epidote, calcite, illite, and pyrite were the principal alteration minerals in many rock types including rhyolites, sandstones, basalts, and andesites. However, later studies showed that significant differences occur between alteration minerals in different rock types particularly at lower temperatures $\left(<150^{\circ} \mathrm{C}\right)$ (Bethke, 1986; Reyes, 1990; Mas et al., 2006, Weisenberger and Selbekk, 2009; Rodriguez, 2011). This study utilizes the differences in alteration minerals between silicic volcanic type rocks like the Idavada volcanics and the basalts of the ESRP in which smectite clays and zeolites are dominant (Morse and McCurry, 2002; Sant, 2012).

The aforementioned geochemical techniques are utilized in this study to better understand the role of mixing and re-equilibration within the Twin Falls - Banbury hydrothermal system and the implications such secondary processes have on geothermal temperature estimation within other areas of the ESRP. 


\section{CHAPTER 3: GEOCHEMISTRY OF THE THERMAL WATERS IN THE}

\section{TWIN FALLS - BANBURY GEOTHERMAL AREA}

The following section details the aqueous geochemistry for the Twin Falls - Banbury hydrothermal system as it relates to the problem of mixing between the deep thermal water and shallow groundwater components of the system. Water chemistry data from previous hydrothermal studies of both the Twin Falls and Banbury Hot Springs areas are compiled and combined here with the new data obtained from the 2014 ESRP sampling campaign in order to establish sufficient sample density to:

1) Classify the waters based on their respective chemistries;

2) Observe mixing and water-rock interaction trends with both conservative and reactive chemical species through the use of binary diagrams;

3) Observe the areal distribution of water types and its relation to local geology and geologic structures

4) Apply conventional geothermometry and mixing model techniques to all of the waters; and

5) Delineate appropriate mixing components for use within the multicomponent equilibrium geothermometry (MEG) tool RTEst.

\subsection{Sample Chemistry}

Sample compilation focused predominately on hydrothermal water samples within the study area but also include cooler groundwater samples from the assumed recharge zone located in the hills to south (to the east and south of the town of Robertson, ID). Interestingly, recharge area groundwater samples $\left(4.5-12{ }^{\circ} \mathrm{C}\right)$ and cooler thermal waters within the region $\left(<30{ }^{\circ} \mathrm{C}\right)$ contain high amounts of silica (average $\left.61 \mathrm{ppm}\right)$ providing particularly valuable 
evidence for mixing (Arnórsson, 1985) in that high silica concentrations are likely due to mixing with a thermal component. Thermal waters range in temperature from $25{ }^{\circ} \mathrm{C}$ to $70{ }^{\circ} \mathrm{C}$. Sample selection criteria include temperature, location, and extensiveness of chemical data (possessing data from both conservative $\left[\mathrm{Cl}^{-}, \mathrm{F}^{-}, \mathrm{Li}, \mathrm{B}, \delta \mathrm{D}\right]$ and reactive $\left[\mathrm{Ca}^{2+}, \mathrm{Mg}^{2+}, \mathrm{K}^{+}, \mathrm{Na}^{+}\right.$, $\left.\mathrm{CO}^{3-}, \mathrm{SiO}^{-}\right]$species). Samples meeting the criteria were omitted only if they share the same location as a newly collected sample or lie outside of the study area. In this case is bound to the north by the Snake River which represents a groundwater boundary from the Twin Falls Banbury area.

Chemical data for both the Banbury and Twin Falls area were compiled from four previous studies including the two isotopic studies conducted by R.H. Mariner et al. (1991 and 1997) and the USGS geothermometry studies of the Banbury (1982) and Twin Falls (1989) areas produced by R. E. Lewis and H.W. Young. These data sets are the most complete sets in terms of chemical constituents reported as compared to some of the earlier work presented in the Geothermal Investigations of Idaho series (Street and Detar, 1987; Young and Mitchell, 1974; Mitchell et al., 1980). Reported concentrations from these sources remain original and unaltered in this study with the exception of the calculation of total dissolved solids (TDS and the conversion of alkalinity listed as $\mathrm{mg} / \mathrm{L} \mathrm{CaCO}_{3}$ to alkalinity as $\mathrm{HCO}_{3}$ from samples originating from the Geothermal Resources in the Banbury Hot Springs Area (Lewis and Young, 1982). In total, 62 samples comprise the data set including 17 new samples collected under this study. Chemical concentrations are shown in Table 2. New samples contain trace elemental analyses that are absent from previous studies. New samples were collected primarily to satisfy the need for a more extensive chemical data set (particularly Al) to more effectively utilize the MEG tool RTEst. The new analyses enabled 
the use of a variety of hydrothermal alteration mineral assemblages comprised of various aluminosilicates.

Information regarding the chemical analysis of new samples as well as the QA/QC reports can be found in Appendix B. Charge balance calculations show that most waters are within $\pm 15 \%$ of a 1:1 charge balance and are presented in Appendix C. The waters range in TDS from as low as $62 \mathrm{mg} / \mathrm{L}$ in cold groundwater samples to $565 \mathrm{mg} / \mathrm{L}$ in thermal water samples. Waters from these samples seem to comprise two distinct groups based on differences in several constituents. One group of waters, which comprises a mix of all of the cold water samples and several thermal waters exhibit much higher calcium and magnesium concentrations and tend to have lower TDS concentrations than the other group.

Groundwaters in the area and throughout the ESRP are considered $\mathrm{Ca}-\mathrm{Mg}-\mathrm{HCO}_{3}$ in type and contain similarly high magnesium concentrations. This is to be expected as magnesium is largely absent in geothermal waters. Because of increased water-rock interaction at higher temperatures, magnesium is taken up by magnesium bearing clay minerals (Ellis, 1971; Fournier and Potter, 1979; Giggenbach, 1988). The second group of waters exhibits higher sodium, silica, chloride, and TDS concentrations. This is to be expected with ESRP geothermal waters due to the prograde relationship between temperature and solubility (chloride/silica) and the increase in cation-exchange reaction within deep rhyolites (sodium) (Fournier, 1977, Arnórsson, 1985; McLing et al., 2002). These differences and others are taken into account in the classification of the waters. Thermal waters were categorized in order to investigate the effects of secondary processes on thermal waters that may be shown in chemical trends between water types. Rather than arbitrarily separate the water types (i.e. graphically), multivariate cluster analysis was performed on selected chemical data. 
Table 1. Chemical concentrations of hydrothermal water samples from the Twin Falls Banbury area taken in 2014 for this study. All concentrations are given in units of $\mathrm{mg} / \mathrm{L}$. $\mathrm{HCO}_{3}$ and $\mathrm{CO}_{3}$ values are alkalinity measurements given in $\mathrm{mg} / \mathrm{L}$.

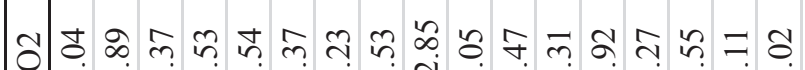
की

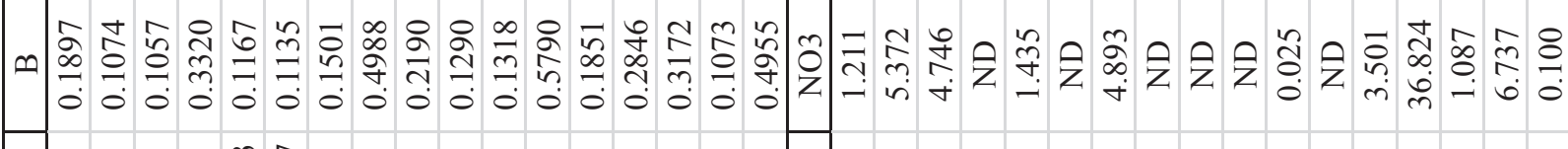

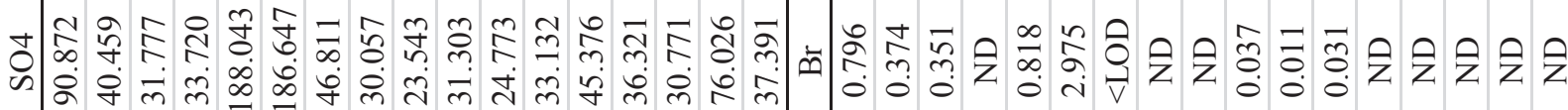

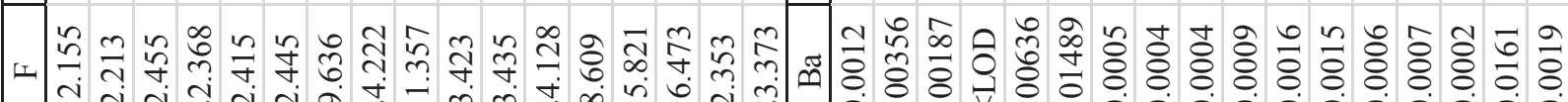

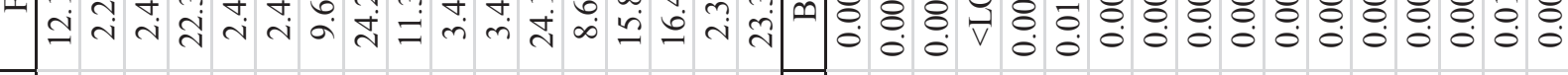

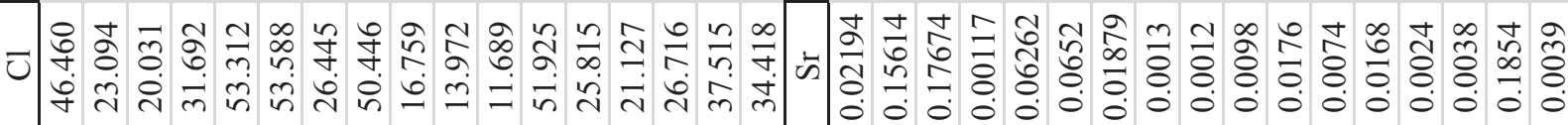
ت

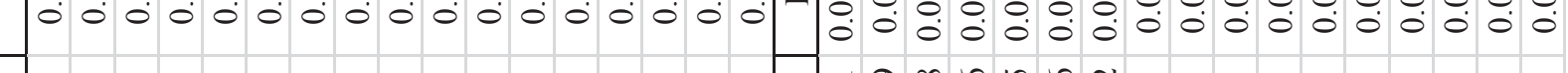

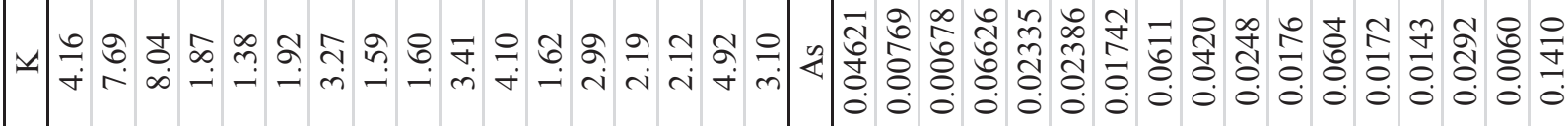

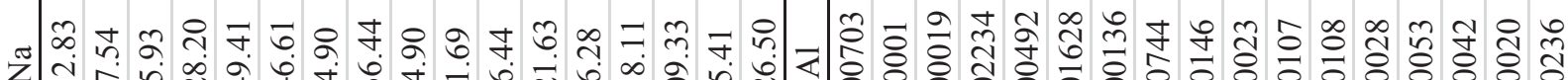
Z゙

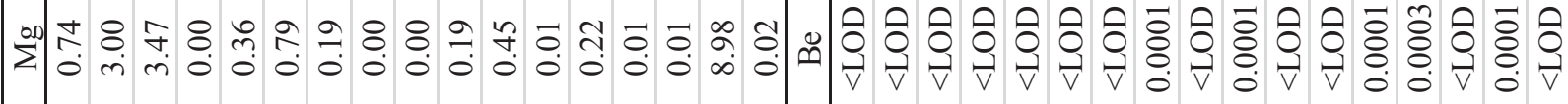

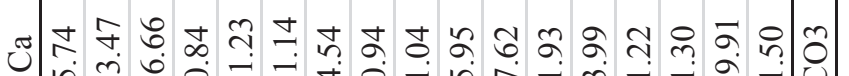

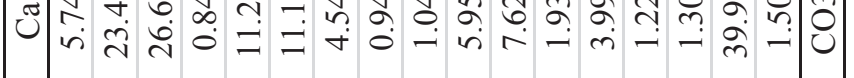

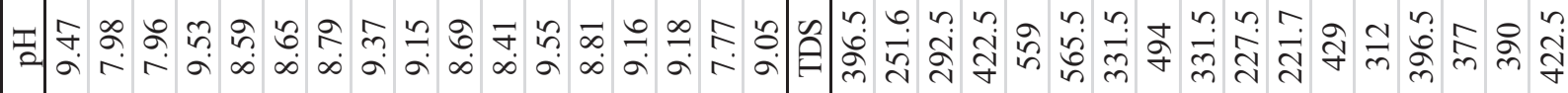

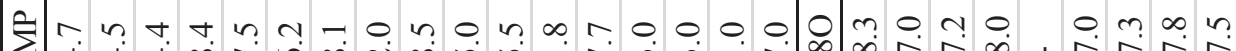

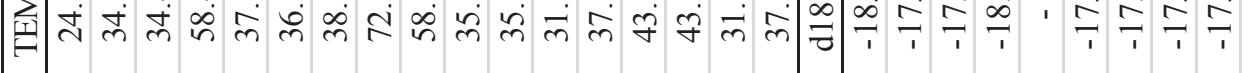

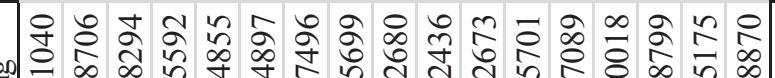

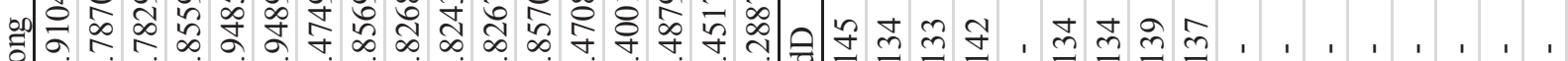

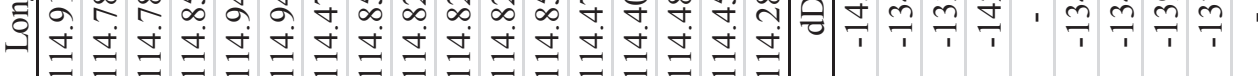

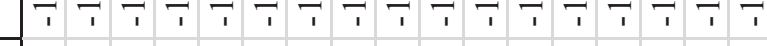

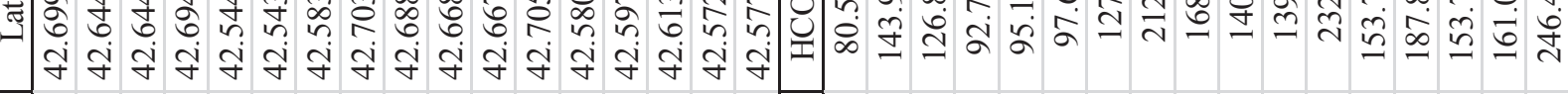

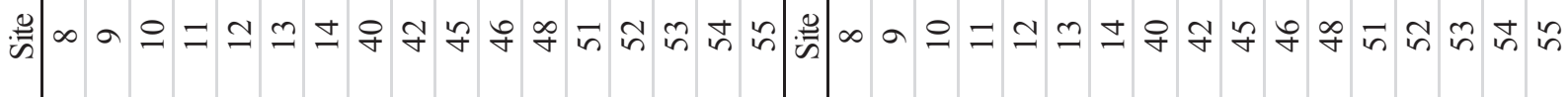


Table 2. Selected chemical concentrations of hydrothermal water samples from previous studies. All concentrations are given in units of $\mathrm{mg} / \mathrm{L}$. Decimal degree coordinates (WGS84) are approximated from original township and range values. Bold values correspond to TDS values generated by summing major cation and anion concentrations. Site names correspond to a particular study: LY82/89 = Lewis and Young, 1982; 89 and M91 = Mariner et al., 1991.

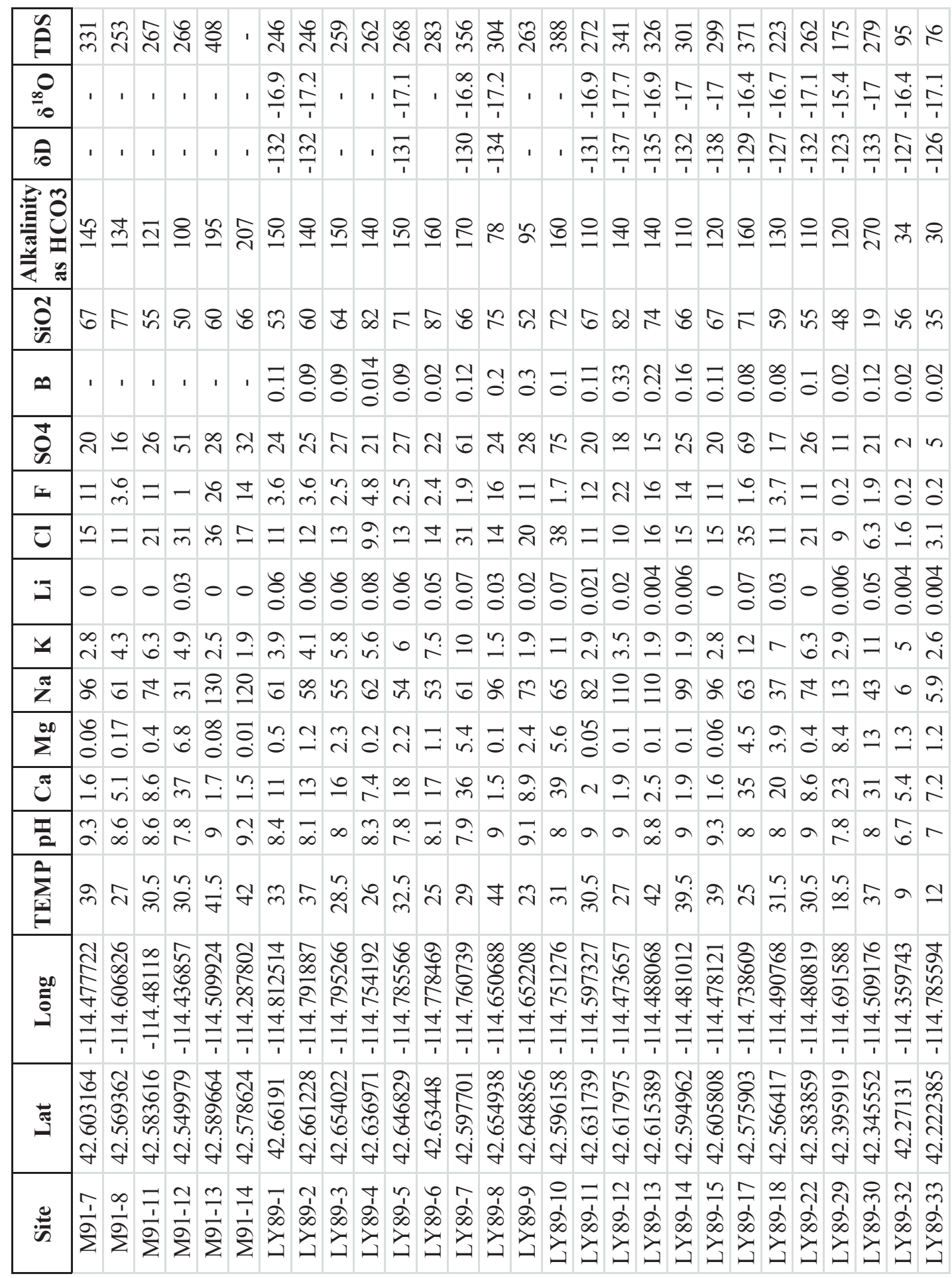




\begin{tabular}{|c|c|c|c|c|c|c|c|c|c|c|c|c|c|c|c|c|c|}
\hline$\tilde{\theta}$ & §્ત & $\stackrel{\infty}{=}$ & $\stackrel{ \pm}{ \pm}$ & & $\widetilde{\sigma}$ & $\stackrel{m}{8}$ & ติ & $\infty$ & $\stackrel{\infty}{\stackrel{\infty}{+}}$ & है & $\underset{\nabla}{\nabla}$ & $\stackrel{9}{\frac{\pi}{m}}$ & $\bar{m}$ & 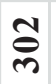 & $\frac{\theta}{m}$ & 워 & $\frac{0}{m}$ \\
\hline$\underset{0}{0}$ & $\frac{a}{0}$ & $\stackrel{\hat{\sigma}}{\frac{1}{1}}$ & $\begin{array}{l}\infty \\
\dot{0} \\
\stackrel{1}{1}\end{array}$ & $\begin{array}{l}0 \\
\dot{ \pm} \\
\end{array}$ & 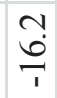 & ' & ' & & ' & ' & & ' & ' & ' & ' & 1 & 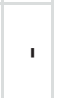 \\
\hline 10 & 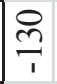 & $\frac{\bar{m}}{T}$ & 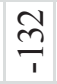 & $\stackrel{\overbrace{}}{7}$ & $\underset{\tau}{\overparen{I}}$ & ' & ' & ' & ' & ' & I & 1 & ' & 1 & ' & 1 & 1 \\
\hline 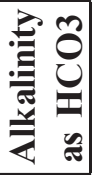 & $\overrightarrow{\mathcal{V}}$ & $\stackrel{ }{=}$ & 8 & త్ & તి & $\infty$ & $\infty$ & I & 6 & $\stackrel{\infty}{ \pm}$ & 8 & $\stackrel{+}{2}$ & తి & $\stackrel{ \pm}{I}$ & $\exists$ & $\stackrel{\Phi}{n}$ & กำ \\
\hline ֶ̊ & $\stackrel{\infty}{\infty}$ & 8 & 6 & $\tilde{n}$ & $\underset{m}{\infty}$ & + & $\tilde{\infty}$ & $\infty$ & $\infty$ & $\hat{\sigma}$ & $\infty$ & t & $\infty$ & $\stackrel{i}{n}$ & $\hat{n}$ & $\bar{n}$ & $\bar{n}$ \\
\hline 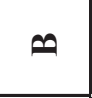 & in & $\stackrel{\circ}{\circ}$ & $\begin{array}{l}\Omega \\
0 \\
0\end{array}$ & $\stackrel{0}{\circ}$ & $\begin{array}{l}2 \\
\delta \\
0\end{array}$ & ণ্ণি & $\bar{n}$ & ग़ & $\stackrel{\overbrace{}}{0}$ & $\frac{1}{0}$ & $\stackrel{\overbrace{}}{0}$ & $\vec{\jmath}$ & $\stackrel{8}{\circ}$ & $\frac{7}{0}$ & $\exists$ & $\stackrel{7}{0}$ & $\exists$ \\
\hline $\begin{array}{l}\dot{0} \\
0\end{array}$ & & 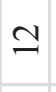 & $\begin{array}{l}\infty \\
\infty \\
\infty\end{array}$ & 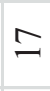 & $\stackrel{\vec{r}}{\dot{r}}$ & $m$ & ले & ল্ & নী & $\stackrel{\infty}{\sim}$ & $\hat{\imath}$ & $\stackrel{\infty}{\sim}$ & $\stackrel{n}{m}$ & ஜ্లি & $\stackrel{\sim}{\sim}$ & ㄱ. & 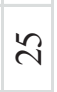 \\
\hline 工 & $\ddot{0}$ & 0 & $\stackrel{\infty}{0}$ & ?? & $\vec{\circ}$ & 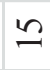 & $\bar{\lambda}$ & $\bar{\sim}$ & 구 & $\stackrel{+}{\circ}$ & $\simeq$ & 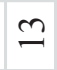 & $\stackrel{\infty}{-}$ & $\dot{r}$ & $\vec{m}$ & $\stackrel{\sim}{m}$ & $\hat{\jmath}$ \\
\hline $\bar{v}$ & 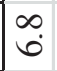 & $\stackrel{\nabla}{0}$ & 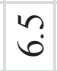 & $\stackrel{0}{-}$ & $\dddot{m}$ & $\stackrel{\infty}{+}$ & $\bar{n}$ & ల্ & in & $\Xi$ & $\approx$ & ㄱ & 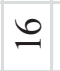 & $\stackrel{m}{-}$ & $=$ & $=$ & $=$ \\
\hline $\bar{\beth}$ & $\mid \begin{array}{l}\tilde{y} \\
\tilde{0} \\
0 \\
0\end{array}$ & 0 & ô & $\begin{array}{l}+ \\
8 \\
0\end{array}$ & $\begin{array}{l}+ \\
8 \\
0\end{array}$ & 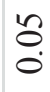 & 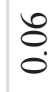 & $\stackrel{+}{O}$ & $\underset{\dot{0}}{\dot{O}}$ & $\underset{0}{\stackrel{J}{0}}$ & $\underset{0}{\Delta}$ & $\hat{0}$ & $\stackrel{n}{0}$ & $\stackrel{n}{0}$ & $\stackrel{n}{0}$ & $\stackrel{n}{o}$ & $\begin{array}{l}n \\
0 \\
0\end{array}$ \\
\hline 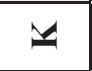 & oे & $\begin{array}{l}\infty \\
i\end{array}$ & 广 & $\begin{array}{l}0 \\
\dot{m}\end{array}$ & $\begin{array}{l}o \\
i\end{array}$ & $\stackrel{+}{\sim}$ & $\because$ & $\because$ & $\stackrel{\infty}{-}$ & Э & $\stackrel{\infty}{-}$ & $\stackrel{0}{-}$ & $\frac{9}{r}$ & $\hat{\mathrm{i}}$ & $\begin{array}{l}\infty \\
i\end{array}$ & $\begin{array}{l}\infty \\
i\end{array}$ & $\ddot{n}$ \\
\hline z & 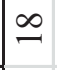 & 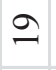 & $\stackrel{\infty}{-}$ & 2 & $\underset{\sim}{\dot{r}}$ & $\stackrel{ }{n}$ & \& & 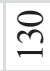 & 8 & ঃ & 8 & $\hat{a}$ & $\ddot{n}$ & 8 & ర్ & $\widehat{6}$ & ర్ \\
\hline$\sum^{\infty}$ & $N$ & $\begin{array}{l}o \\
\text { i }\end{array}$ & $\stackrel{m}{\sim}$ & $\begin{array}{l}\stackrel{+}{~} \\
\dot{0}\end{array}$ & $\tilde{0}$ & $\overrightarrow{0}$ & $\overrightarrow{0}$ & $\overrightarrow{0}$ & $\overrightarrow{0}$ & $\overrightarrow{0}$ & : & $\overrightarrow{0}$ & $\grave{m}$ & ํ. & ֻุ & ?ִ & $\tilde{n}$ \\
\hline$\tilde{U}$ & $\vec{\sim}$ & ปิ & $\stackrel{\infty}{-}$ & ঙे & $\begin{array}{l}o \\
\stackrel{i}{0}\end{array}$ & $\grave{0}$ & $\because$ & $\hat{\sigma}$ & $\hat{\sigma}$ & $?$ & $\stackrel{m}{m}$ & $\stackrel{a}{0}$ & $\stackrel{0}{2}$ & $\begin{array}{l}\vec{v} \\
\text { i }\end{array}$ & $\infty$ & $\stackrel{n}{r}$ & $\stackrel{0}{=}$ \\
\hline$\overline{2}$ & $\stackrel{\infty}{r}$ & $\stackrel{n}{r}$ & $\stackrel{0}{r}$ & $\stackrel{0}{r}$ & 0 & $\stackrel{\nabla}{\sigma}$ & $\tilde{a}$ & $\stackrel{\nabla}{\sigma}$ & $\bar{a}$ & å & $\stackrel{\nabla}{\sigma}$ & $a$ & $\stackrel{N}{a}$ & $\vec{\infty}$ & $\underset{\infty}{+}$ & $\begin{array}{l}0 \\
\infty\end{array}$ & $\stackrel{m}{\infty}$ \\
\hline$\sum_{i=1}^{\theta}$ & $\approx$ & $\stackrel{\sim}{\sim}$ & กิ & $?$ & $\stackrel{f}{\forall}$ & $\mathcal{\sigma}$ & تُ & in & $\because$ & กิ & $\stackrel{n}{f}$ & లి & $\mathscr{F}$ & ষ্ & $\approx$ & $\frac{n}{m}$ & $\begin{array}{l}n \\
\stackrel{n}{m}\end{array}$ \\
\hline ְ⿱ & 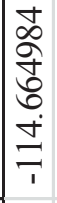 & $\begin{array}{l}\infty \\
\infty \\
0 \\
\hat{\sigma} \\
\dot{ \pm} \\
\pm \\
\overline{1}\end{array}$ & $\begin{array}{l}2 \\
\infty \\
0 \\
0 \\
\dot{ \pm} \\
= \\
1\end{array}$ & 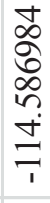 & 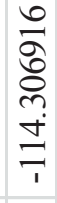 & 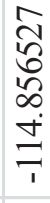 & $\begin{array}{l}\bar{m} \\
\stackrel{\tilde{y}}{\Delta} \\
\infty \\
\dot{ \pm} \\
\vec{J}\end{array}$ & $\begin{array}{l}2 \\
2 \\
\delta \\
\infty \\
\infty \\
\dot{\Xi} \\
=\end{array}$ & 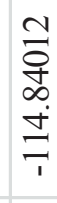 & 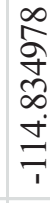 & 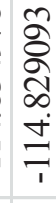 & 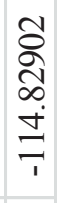 & 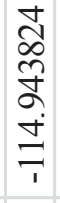 & 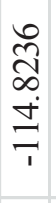 & 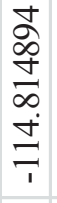 & $\begin{array}{l}\stackrel{J}{J} \\
\underset{D}{\infty} \\
\dot{\Xi} \\
\bar{J}\end{array}$ & $\begin{array}{l}\overline{\widehat{D}} \\
\hat{\sigma} \\
\infty \\
\vdots \\
\bar{\Xi} \\
\overline{1}\end{array}$ \\
\hline త్ & 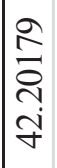 & 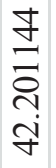 & 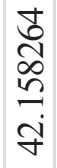 & 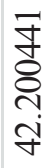 & 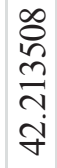 & $\begin{array}{l}\frac{n}{n} \\
\frac{i}{2} \\
\stackrel{f}{f}\end{array}$ & 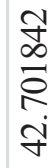 & 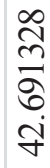 & $\begin{array}{l}\vec{\infty} \\
\infty \\
0 \\
\dot{\gamma} \\
\mathcal{\gamma}\end{array}$ & \begin{tabular}{l} 
J \\
$\tilde{n}$ \\
$\tilde{0}$ \\
0 \\
\multirow{\gamma}{*}{}
\end{tabular} & 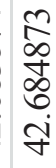 & $\begin{array}{l}\vec{n} \\
\tilde{I} \\
0 \\
\dot{0} \\
\dot{y}\end{array}$ & 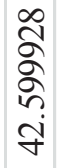 & 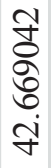 & 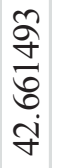 & $\begin{array}{l}7 \\
8 \\
8 \\
8 \\
\dot{8} \\
\dot{y}\end{array}$ & $\begin{array}{l}n \\
2 \\
\infty \\
\infty \\
\tilde{\sigma} \\
\dot{y} \\
\mathcal{y}\end{array}$ \\
\hline 部 & 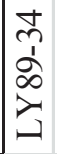 & 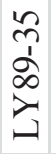 & $\begin{array}{l}0 \\
2 \\
2 \\
\infty \\
1 \\
1\end{array}$ & $\hat{n}$ & $\begin{array}{l}\infty \\
2 \\
2 \\
\infty \\
\nu \\
\end{array}$ & $\begin{array}{l}m \\
\dot{1} \\
\infty \\
\\
-1\end{array}$ & 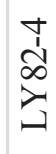 & $\begin{array}{l}n \\
\dot{1} \\
\infty \\
\\
-1\end{array}$ & $\begin{array}{l}0 \\
1 \\
\infty \\
0 \\
1\end{array}$ & 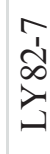 & 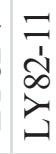 & 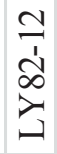 & $\begin{array}{l}n \\
1 \\
\infty \\
\infty \\
\vdots\end{array}$ & 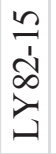 & $\begin{array}{l}\infty \\
\vdots \\
\infty \\
\infty \\
\ddots 1\end{array}$ & $\begin{array}{l}a \\
\vdots \\
\infty \\
\vdots \\
\vdots\end{array}$ & 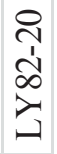 \\
\hline
\end{tabular}




\subsection{Principle Component and Hierarchical Cluster Analysis}

With each sample being characterized by several chemical and physical variables, the aqueous geochemistry study of the area becomes a multivariate problem. The multivariate statistical method chosen for this study is hierarchical cluster analysis (HCA). This method was chosen as an unbiased means to separate waters into discrete groupings based on concentrations of several chemical components as opposed to the more graphical means provided by Piper diagram analysis. HCA is a widely utilized data classification practice in Earth sciences (Davis, 1986) and has begun to be utilized more extensively in groundwater geochemical studies in recent years (Meng and Maynard, 2001; Cloutier et al., 2008; Kanade and Gaikwad, 2011). HCA produces a hierarchy of clusters, ranging from small clusters of very similar items to larger clusters of increasingly dissimilar items without assuming any underlying trend in the data as opposed to several partitioning methods which assume a specific number of clusters outright. The measure of similarity in this instance of HCA is provided by the Euclidean distance, given by the Pythagorean Theorem. Sample groups are joined with a linkage rule until all of the observations are sorted into different clusters. The linkage method utilized in this study is Ward's methods which uses an analysis of variance approach to establish the distance between clusters. Many studies have found that the use of the Euclidean distance and Ward's method produce the most distinctive groupings within which samples are more or less homogeneous (Adar et al., 1992; Guler et al., 2002; and Zumlot et al., 2012).

It is usually suggested that prior to HCA, some sort data reduction be done in order to both gain insight into the correlation of variables and source of major variance, and ultimately to simplify the data into a more meaningful and manageable set. Principle component analysis 
(PCA) is utilized for data reduction in this study. The premise of PCA is that every sample can be represented as a single point in a K-dimensional space (depending the number of variables being analyzed). All points within the data set can essentially be approximated by a single plane (whose axes are principle components and Eigen vectors) space by a least squares regression. The result is a few orthogonal components (Eigenvalue $>1$ ) that explain the majority of the variance within the data set (Meng and Maynard, 2001).

PCA produces factor or component scores which are essentially coordinates corresponding to individual data points within each principle component. These scores can then be utilized in HCA as opposed to clustering based on the raw values for all variables. Like the Piper diagram analysis, major cations and anions were chosen in this study as the variables for PCA. Other constituents such as $\mathrm{SiO}^{2-}$ and $\mathrm{F}^{-}$did not account for much of the variance within the data and were omitted. Both PCA and HCA ordinarily require a normal distribution of all variables included or a transformation is suggested. Key components $\left(\mathrm{K}^{+}\right.$ and $\mathrm{Na}^{+}$) are normally distributed within this data set while other components contain a slight right skew. A log transformation was performed prior to PCA and HCA but resulted in erroneous partitioning of water samples incongruent with Piper diagram classification. For this reason, the data presented here are not transformed. The Eigenvalues for the principle components produced are shown below in Table 3. The principle components used are highlighted in bold.

Table 3. Principle components and corresponding \% variance

\begin{tabular}{lrrrrrrr}
\hline & \multicolumn{1}{c}{ F1 } & \multicolumn{1}{c}{ F2 } & \multicolumn{1}{c}{ F3 } & \multicolumn{1}{c}{ F4 } & \multicolumn{1}{c}{ F5 } & \multicolumn{1}{c}{ F6 } & F7 \\
\hline Eigenvalue & $\mathbf{3 . 0 9 6}$ & $\mathbf{2 . 0 8 8}$ & $\mathbf{1 . 0 6 8}$ & 0.373 & 0.210 & 0.111 & 0.054 \\
Variability (\%) & 44.225 & $\mathbf{2 9 . 8 2 8}$ & 15.258 & 5.330 & 3.007 & 1.584 & 0.768 \\
Cumulative \% & $\mathbf{4 4 . 2 2 5}$ & $\mathbf{7 4 . 0 5 2}$ & $\mathbf{8 9 . 3 1 1}$ & $\mathbf{9 4 . 6 4 1}$ & $\mathbf{9 7 . 6 4 8}$ & $\mathbf{9 9 . 2 3 2}$ & 100.0 \\
\hline
\end{tabular}


Pearson's correlation coefficients are shown below in Table $4 . \mathrm{Na}^{+}$and $\mathrm{Cl}^{-}, \mathrm{K}^{+}$and $\mathrm{Ca}^{2+}, \mathrm{Mg}^{+}$and $\mathrm{K}^{+}$, and $\mathrm{SO}_{4}{ }^{2-}$ and $\mathrm{Cl}^{-}$are all significantly and positively correlated as is the case in a majority of groundwater studies. In contrast, $\mathrm{K}^{+}$and $\mathrm{Cl}^{-}$are shown to be very weakly correlated in this study where they are commonly correlated in many groundwater studies (Rani and Babu, 2008; Muthulakshmi et al., 2013). However, the groundwater samples in this study tend to have higher potassium concentrations and do not follow the $\mathrm{Na}^{+}>\mathrm{Ca}^{2+}>\mathrm{Mg}^{+}>$ $\mathrm{K}^{+}$trend exhibited in other studies. This source of potassium is significant in mixing trends and will be discussed further in section 3.5. Additionally, it is worth noting that bicarbonate alkalinity does not seem to be correlated strongly with any other chemical component and may not be useful in further evaluation of mixing trends. Figure 6 (below) is a biplot of the first two principle components representing about $74 \%$ of the variance within the data set. Negative and positive correlations can be seen here. It is important to note that $\mathrm{SO}_{4}{ }^{2-}$ and $\mathrm{HCO}_{3}$ - lie close to the principle component (F2) axis meaning they are not responsible for much of the variance within the dataset.

Table 4. Pearson's (n) correlation table of PCA variables (chemical components)

\begin{tabular}{lccrrrrr}
\hline Variables & $\mathrm{Ca}$ & $\mathrm{Mg}$ & $\mathrm{Na}$ & \multicolumn{1}{c}{$\mathrm{K}$} & \multicolumn{1}{c}{$\mathrm{Cl}$} & \multicolumn{1}{c}{$\mathrm{SO} 4$} & \multicolumn{1}{c}{$\mathrm{HCO} 3$} \\
\hline $\mathrm{Ca}$ & $\mathbf{1}$ & 0.855 & -0.568 & 0.784 & -0.021 & 0.184 & 0.012 \\
$\mathrm{Mg}$ & & $\mathbf{1}$ & -0.507 & 0.631 & -0.073 & 0.059 & 0.135 \\
$\mathrm{Na}$ & & & $\mathbf{1}$ & -0.518 & 0.715 & 0.436 & 0.421 \\
$\mathrm{~K}$ & & & & $\mathbf{1}$ & -0.160 & 0.007 & 0.100 \\
$\mathrm{Cl}$ & & & & & $\mathbf{1}$ & 0.684 & 0.323 \\
$\mathrm{SO} 4$ & & & & & & $\mathbf{1}$ & -0.019 \\
$\mathrm{HCO} 3$ & & & & & & & $\mathbf{1}$ \\
\hline
\end{tabular}




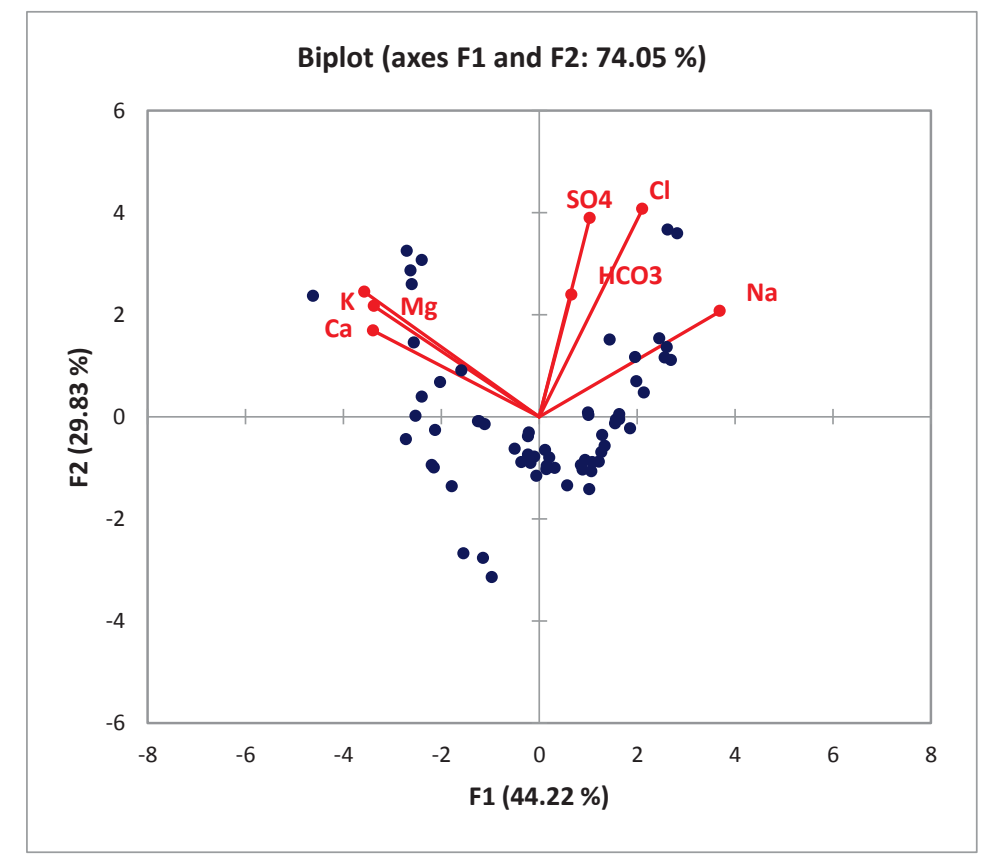

Figure 6. Biplot of principle components 1 and 2 with variables (red lines) and samples (blue dots

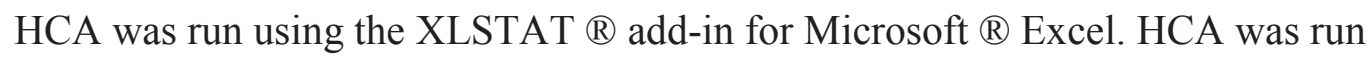
using both principle component scores and raw chemical data. The PCA proved valuable in producing only three water types as opposed to the six produced without data reduction. The dendrograms in Figures 7 and 8 represent the final cluster output. Water types are listed in Tables 5-8 with the corresponding author initials and dates preceding the sample numbers. Two of the waters classified as type 3 waters (CC-12 and CC-13) are believed to have been influenced by local irrigation water (evident by much higher sulfate and chloride values than surrounding areas). For this reason, they have been grouped into type 2 waters for mixing trend applications. The waters fall into two main end members:

1) $\mathrm{Na}-\mathrm{HCO}_{3}$ (Type 1) waters characterized by high temperatures, high $\mathrm{Na}^{+}$ concentrations, and low $\mathrm{Ca}^{2+}$ and $\mathrm{Mg}^{+}$concentrations.

2) $\mathrm{Ca}-\mathrm{HCO}_{3}$ (Type 2) waters characterized by lower temperatures, low $\mathrm{Na}^{+}$ concentrations, and high $\mathrm{Ca}^{2+}$ and $\mathrm{Mg}^{+}$concentrations. 


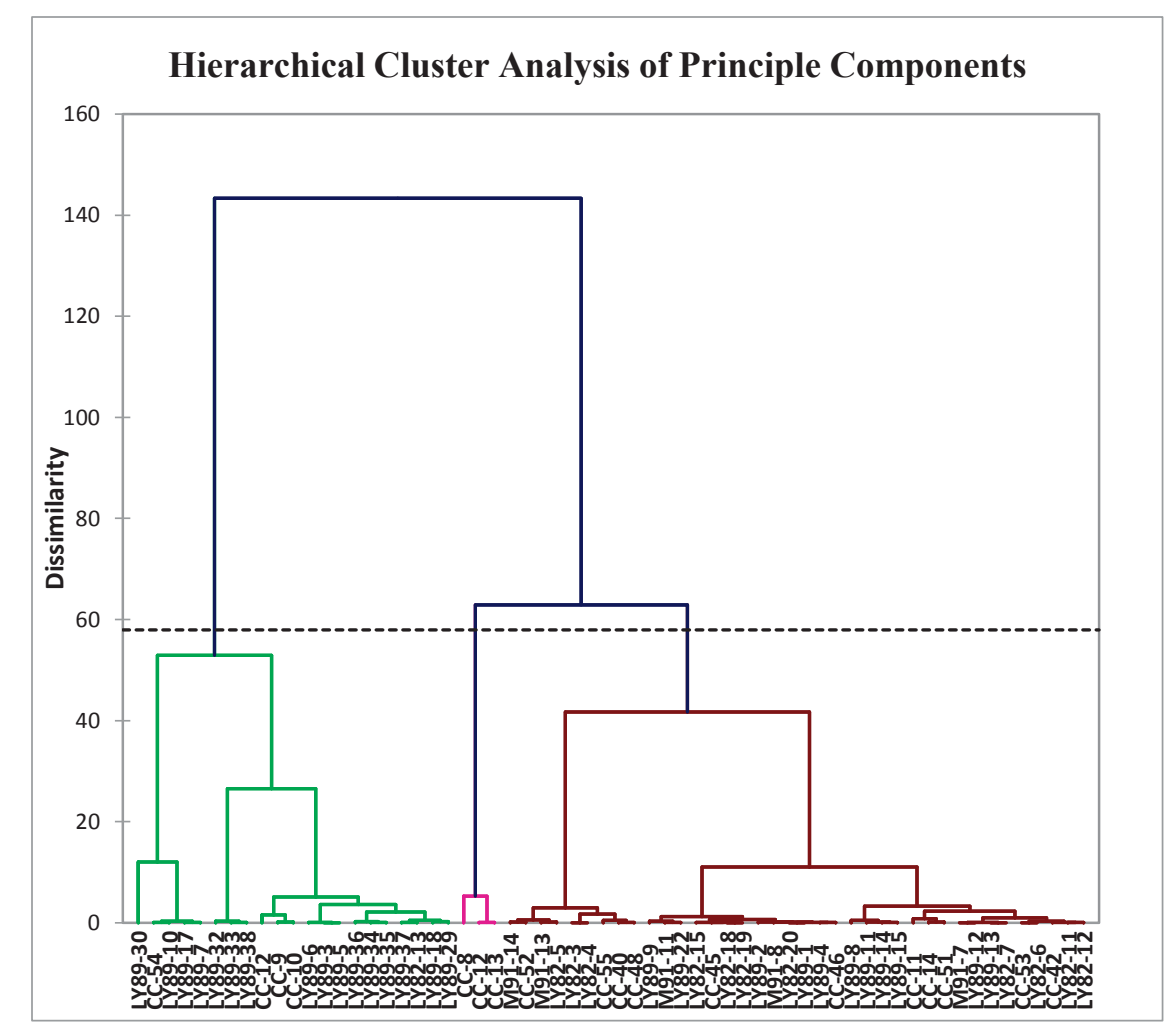

Figure 7. Dendrogram showing clusters of samples provided by HCA on principle components.

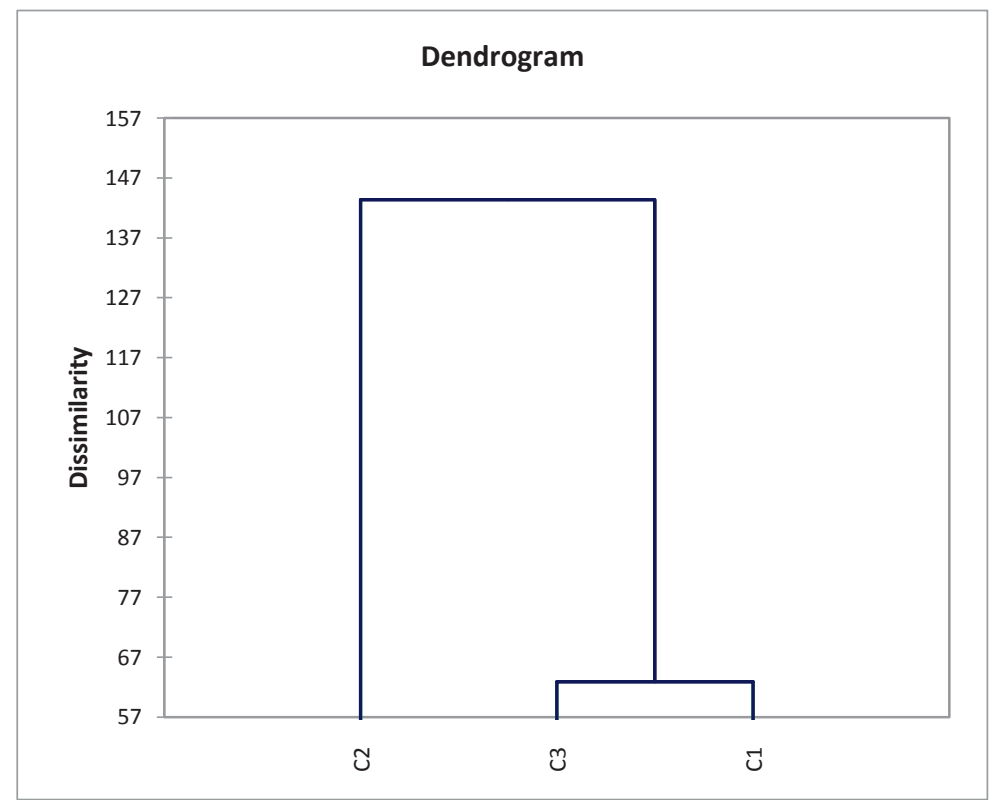

Figure 8. Simple dendrogram showing the resultant 3 water types. 


\subsection{Evidence for Mixing Between Thermal Water and Groundwater}

After the completion of water classification by cluster analysis, the samples were plotted on a Piper diagram (Piper, 1944) to gain a visual representation of sample distribution. The Piper diagram is perhaps the most common method used in classifying waters (Fetter, 2001) due to it being an easy to comprehend graphical representation based on concentrations of all major anions $\left(\mathrm{SO}_{4}{ }^{2-}, \mathrm{Cl}^{-}\right.$, and $\left.\mathrm{CO}_{3}{ }^{2-}+\mathrm{HCO}_{3}{ }^{-}\right)$and major cations $\left(\mathrm{Ca}^{2+}, \mathrm{Mg}^{2+}\right.$, and $\mathrm{Na}^{+}+$ $\mathrm{K}^{+}$). Two separate trilinear diagrams are used to plot the relative percentages of cations and anions. These two separate points are then projected onto the Piper diagram diamond using a matrix transformation to form a single point, which can then be used to classify a water.

Earlier hydrothermal studies in regions of the ESRP have noted the characteristic trend between the two aforementioned end member waters (Mann, 1986; Wood and Lowe, 1988, Mariner et al., 1991; McLing et al., 2002). $\mathrm{Na}-\mathrm{HCO}_{3}$ type waters are generally associated with deeper groundwater sources with increased ion-exchange reactions replacing calcium with sodium during hydrothermal alteration of feldspars as a result of longer residence times and higher temperatures (White, 1967; Edmunds and Shand, 2009). Giggenbach (1991) described the formation of $\mathrm{Ca}-\mathrm{Na}-\mathrm{HCO}_{3}$ and $\mathrm{Ca}-\mathrm{HCO}_{3}$ type thermal waters as a result of mixing with a ground water component like the $\mathrm{Ca}-\mathrm{Mg}-\mathrm{HCO}_{3}$ waters that dominate the upper aquifer system of the ESRP (McLing et al., 2002; Wood and Lowe, 1988). Deep wells (>1 km) that penetrate the upper basalt hosted portion of the aquifer, e.g. the INEL-1 and Project Hotspot: Kimberly and Kimama wells (Shervais et al., 2013), reveal the pure $\mathrm{Na}-\mathrm{HCO}_{3}$ thermal end member. Mann (1986) described the change in composition from deep rhyolite hosted $\mathrm{Na}-\mathrm{HCO}_{3}$ water to mixed $\mathrm{Ca}-\mathrm{Na}-\mathrm{HCO}_{3}$ basalt hosted water in the INEL-1. McLing et al. (2002) showed perhaps the best visual representation of this trend with a Piper diagram consisting of thermal 
waters throughout the ESRP. Lewis and Young (1989) also observed this trend in the Twin Falls area. However, due to sporadic and regional sample population and small sample density, these studies lacked a significant number of mixed intermediate $\mathrm{Ca}-\mathrm{Na}-\mathrm{HCO}_{3}$ type samples to fully support this mixing hypothesis (Figure 9).

EXPLANATION

- Type 1 Waters (From HCA)

- Type 2Waters (From HCA)

- Type 3 Waters (From HCA)

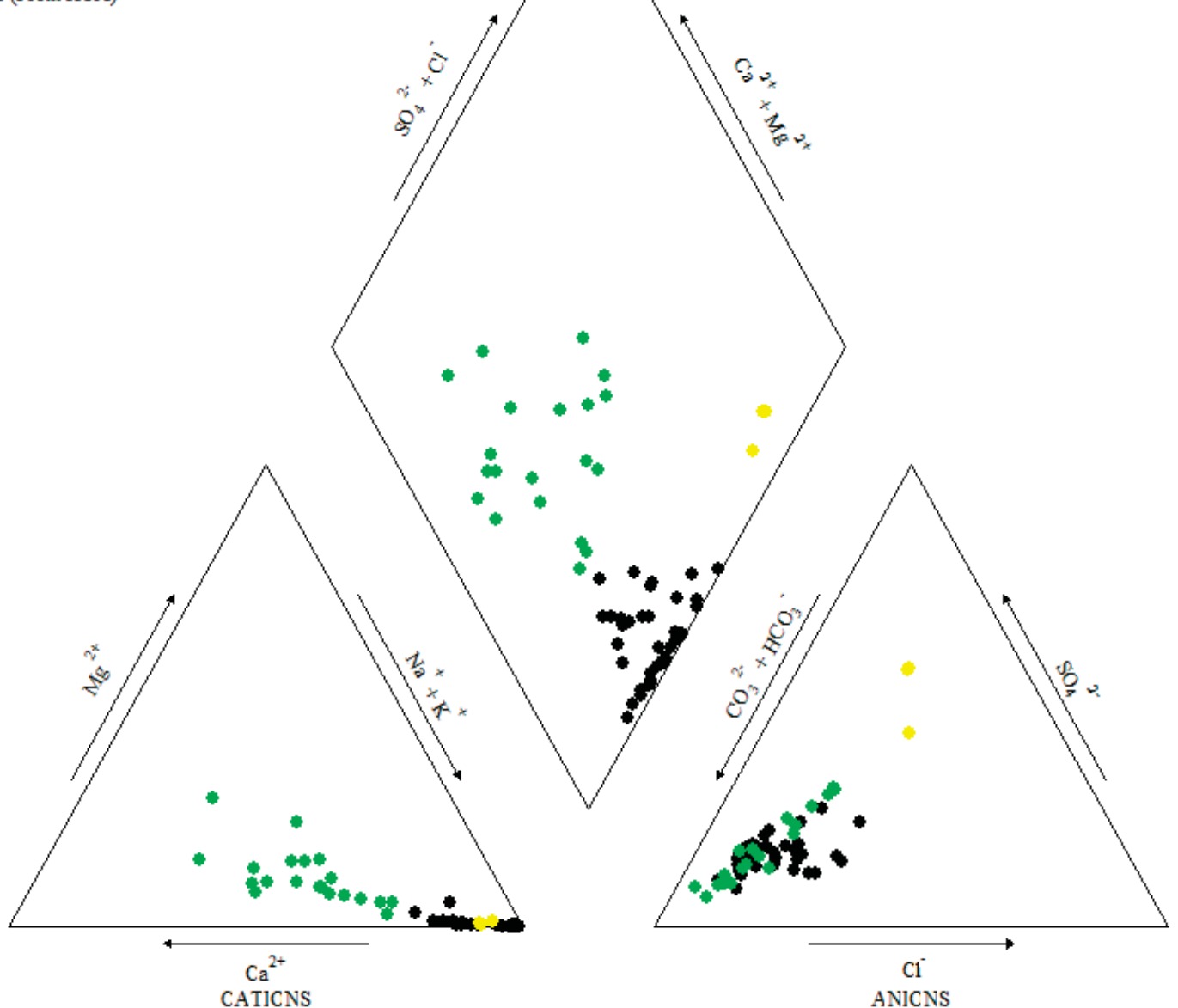

Figure 9. Piper trilinear diagram showing the relationship between $\mathrm{Na}-\mathrm{HCO}_{3}$ thermal waters (black) and $\mathrm{Ca}-\mathrm{HCO}_{3}$ thermal waters (green). Yellow samples appear to have been altered by nearby irrigation.

Piper diagram analysis for the 62 water samples utilized in this study gives a strong visual representation of the trend between water types. Figure 9 shows the distribution between Type $1\left(\mathrm{Na}-\mathrm{HCO}_{3}\right)$ waters in the upper left corner of the diagram and Type $2(\mathrm{Ca}-$ 
$\mathrm{HCO}_{3}$ ) type waters in the lower right corner. A significant trend and overlap can be seen between water types. In particular, the trend observed in the cation portion of the diagram demonstrates the gradual exchange between $\mathrm{Na}^{+}$and $\mathrm{Ca}^{2+}$. It is important to note that anion concentrations $\left(\mathrm{Cl}, \mathrm{HCO}_{3}{ }^{-}\right.$, and $\left.\mathrm{SO}_{4}{ }^{2-}\right)$ seem to be independent of water type and the degree of mixing.

Sample compositions are also plotted on a Giggenbach ternary diagram (Figure 10) to determine evidence of equilibration and/or mixing. The Giggenbach ternary diagram (1988) was developed as a means to classify waters into fully equilibrated (mature) waters, partially equilibrated, and immature waters (dissolution of rock without equilibration). The latter two categories show evidence of mixing with cool meteoric waters. The diagram uses the full range of equilibrium relationships between the $\mathrm{Na}, \mathrm{K}$, and $\mathrm{Mg}$ alteration minerals expected to form after recrystallization to determine the degree of equilibration between the water and the rock of thermal influence at depth. Few previous geothermal investigations in south central Idaho and the ESRP made use of the Giggenbach diagram as evidence for mixing. No previous studies in the Twin Falls - Banbury thermal area have utilized this diagram.

In Figure 10 below, most samples plot in the partially equilibrated and immature portions of the diagram with only a few plotting near or within the mature portion. The majority of $\mathrm{Ca}-\mathrm{HCO}_{3}$ type waters are grouped in the far right corner of the diagram reflecting the influence of high magnesium concentrations presumably from mixing with groundwater. Both the Piper and Giggenbach diagram sample distributions provide particularly valuable evidence for mixing in this area. 


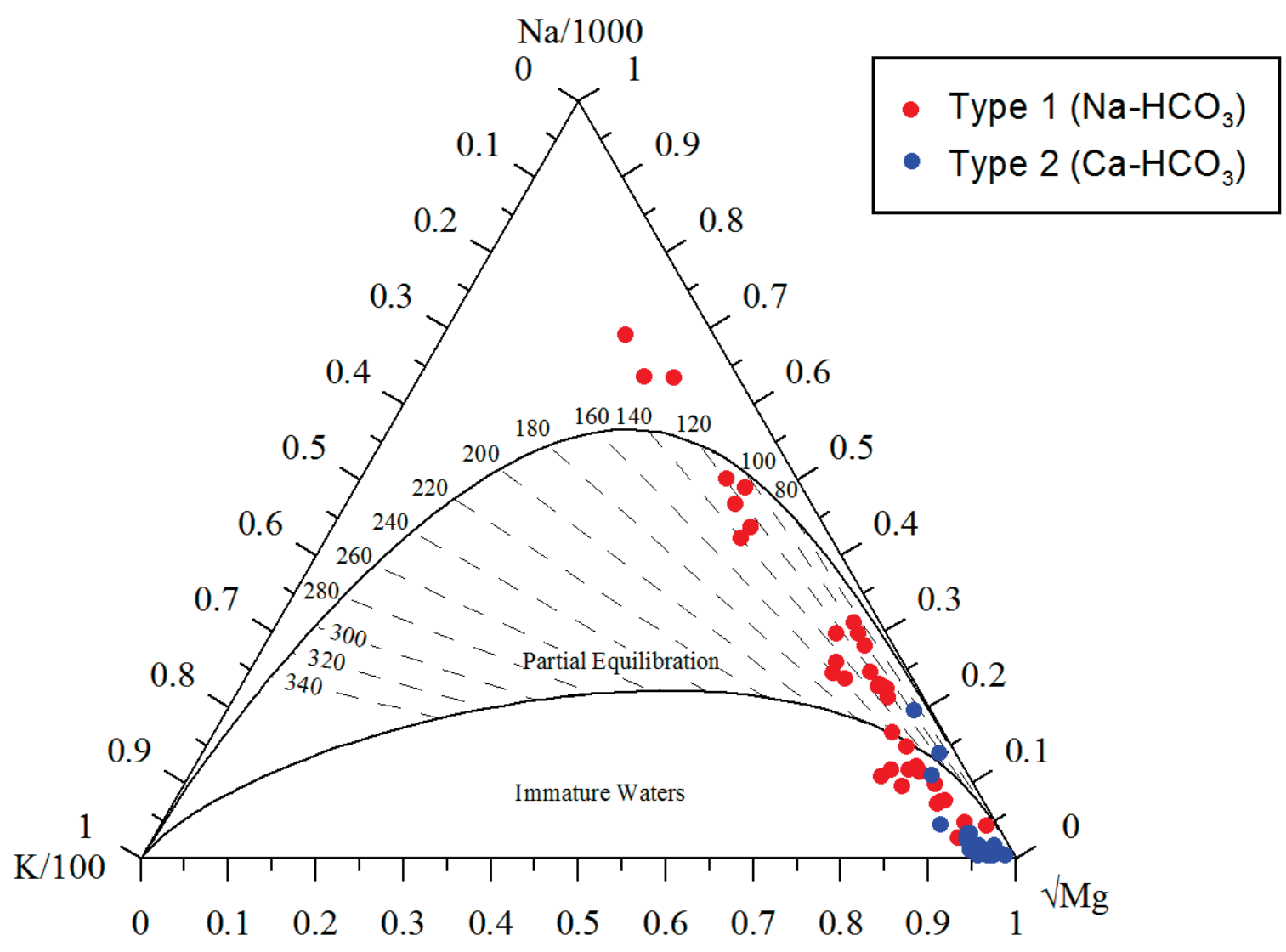

Figure 10. Giggenbach ternary diagram showing the distribution of the two water types with respect to degree of equilibration. Blue points represent $\mathrm{Ca}-\mathrm{HCO}_{3}$ thermal waters and red points represent $\mathrm{Na}-\mathrm{HCO}_{3}$ waters.

\subsection{Binary Diagram Mixing Trend Analysis}

Binary diagrams consisting of conservative species that are not be incorporated into geothermal minerals have been utilized in mixing evaluations for many years (Fournier, 1979; Arnórsson, 1985; Huenges and Ledru, 2011). The evaluation of linear relationships between components including $\mathrm{Cl}^{-}, \mathrm{B}, \mathrm{F}^{-}$and $\delta \mathrm{D}$ provide particularly good evidence for mixing as the ratio between conservative elements will remain fixed as concentrations are simply lowered through dilution. This study utilizes mixing relationships between conservative components (non-reactive mixing) and also those between reactive components in order to obtain a more complete picture of the overall controls on mixing. Preliminary results show that the MEG 
tool RTEst does not result in satisfactory convergence of mineral saturation index lines when a local groundwater sample is mixed with $\mathrm{Na}-\mathrm{HCO}_{3}$ thermal waters. While $\mathrm{Na}-\mathrm{HCO}_{3}$ thermal waters show evidence for mixing, they may not mix directly with groundwater. Instead, an "intermediate" composition between the two thermal waters may be the mixing component. Additionally, secondary reactive processes may alter thermal waters after mixing resulting in re-equilibration. Binary diagram trends between the two water types may reveal controls on mixing in greater detail and may determine an intermediate end member composition for use in MEG reservoir temperature predictions.

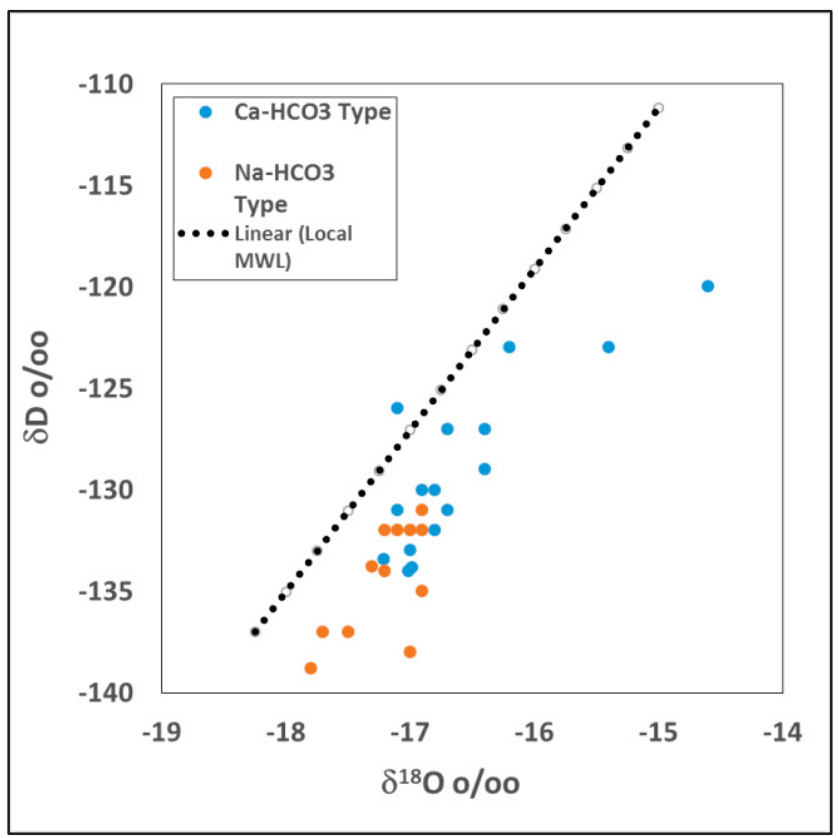

Figure 11. Plot of $\delta D$ vs $\delta^{18} O$ showing the shift of sample waters from the local meteoric water line.

Thermal water samples with available deuterium and oxygen-18 isotope data are plotted in Figure 11 above. Samples display a significant right shift from the local meteoric water line (USGS, 2004). The isotopic shift in ${ }^{18} \mathrm{O}$ is typical of geothermal waters and is most likely a result of increased water-rock interaction at depth resulting in oxygen enrichment (Taylor, 1974; Clark, 2015). Deuterium shifts, on the other hand, are likely not explained by any hydrothermal process as it is conserved through these processes. A likely explanation is 
that recharge occurred during an older and colder time (Pleistocene) in which precipitation concentrations were isotopically lighter with respect to deuterium. This explanation is consistent with carbon-14 age data of waters in the area provided by Mariner et al. (1991). Another possible explanation for shifts in $\delta \mathrm{D}$ concentration is the enrichment of deuterium through isotopic fractionation due to boiling (Bottinga, 1968; Taylor, 1974; Truesdell, et al.; 1978) .The possibility of boiling is discussed further in chapter 4.2. The relationship between these two isotopes shows a gradational trend with waters becoming more depleted with
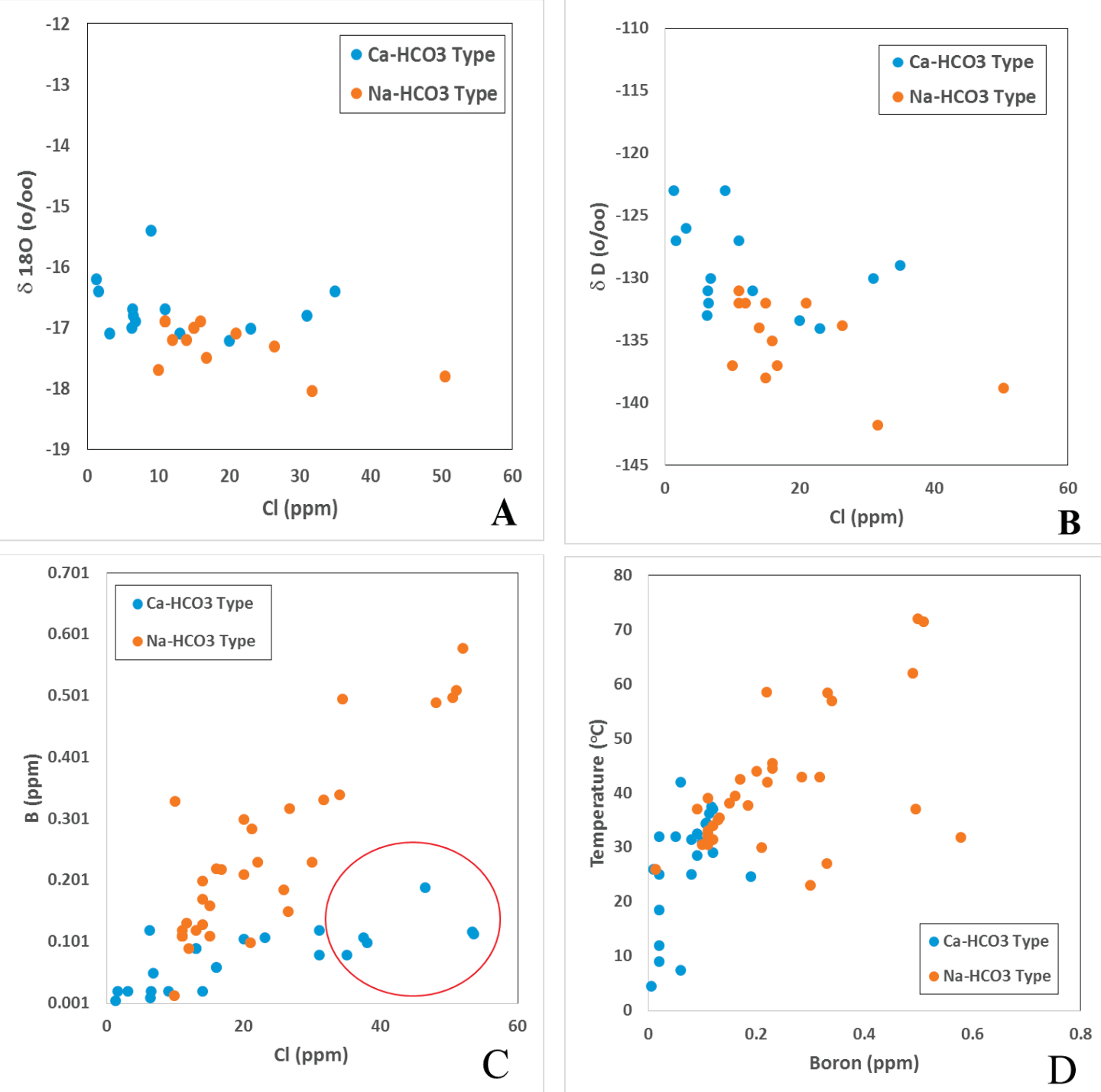

Figure 12. Plots of conservative components $\left(C l^{-}, B, \delta^{18} \mathrm{O}\right.$, and $\left.\delta D\right)$. 
respect to oxygen-18 in the deeper $\mathrm{Na}-\mathrm{HCO}_{3}$ type waters.

Gradational trends between conservative constituents such as boron and chloride are thought to constitute some of the best evidence for mixing (Huenges and Ledru, 2011). Boron and chloride concentrations are much higher in geothermal waters than in cold waters as can be seen by the linear relationship between boron and surface water temperature in the Figure 12D. The ratio of chloride to boron will not be affected by mixing, as these constituents are not considered to be incorporated into geothermal minerals. The concentrations will simply decrease with dilution from mixing between thermal and cold waters will result in a steady decline as seen in Figure $12 \mathrm{C}$ with a $\mathrm{B} / \mathrm{Cl}^{-}$slope of about $0.1 / 10$ with the exception of a few circled values from the Lewis and Young (1982) study. The intersection of the $\mathrm{Cl}^{-} / \mathrm{B}$ trend is expected to meet the chloride axis in the range of $10 \mathrm{ppm}$ (chloride precipitation and cold water range) with a 0 ppm boron concentration (Arnórsson, 1985). Linear relationships between these two components and $\delta^{18} \mathrm{O}$ and $\delta^{2} \mathrm{H}$ also constitute sufficient evidence for mixing (Huenges and Ledru, 2011).
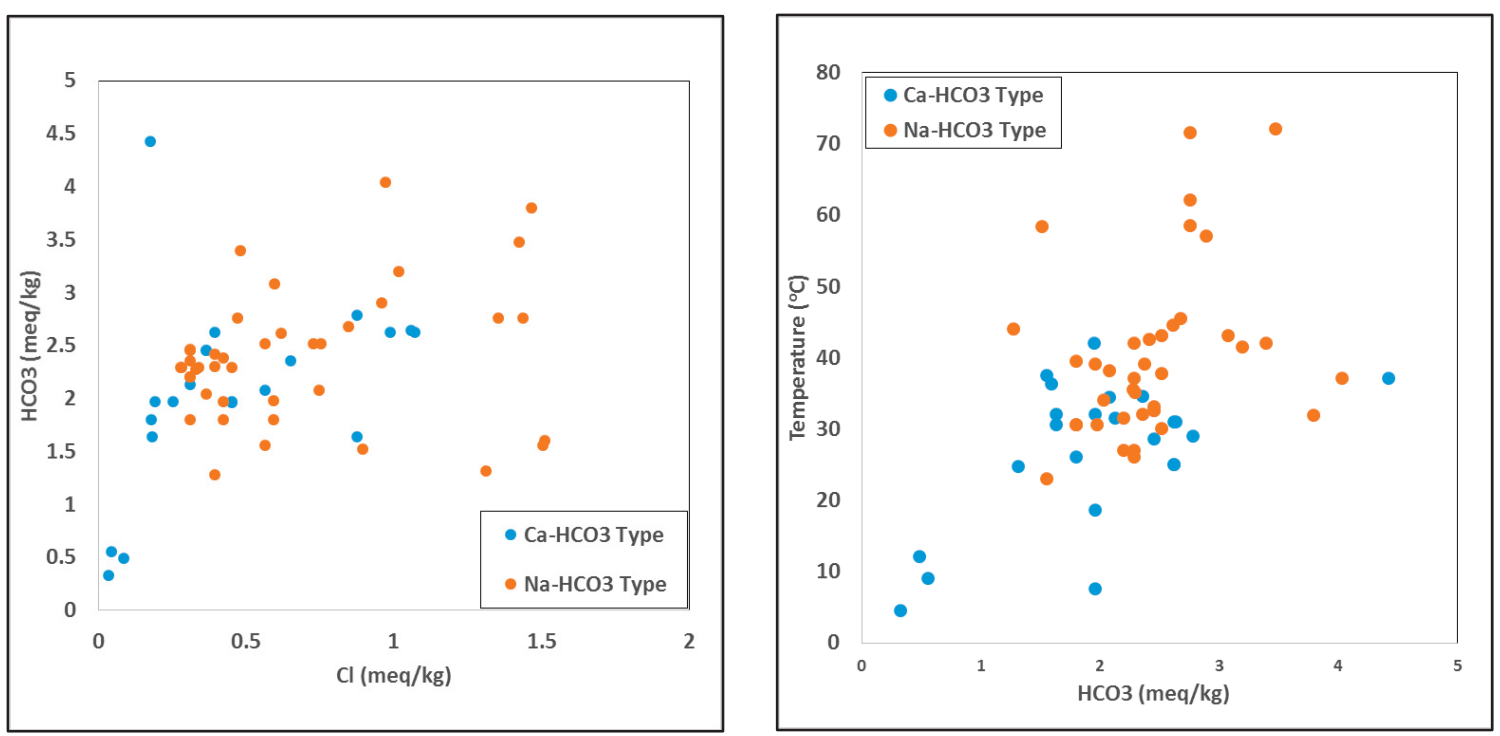

Figure 13. Plot showing the lack of relationship between $\mathrm{HCO}^{-}$and $\mathrm{Cl}$ - and Temperature. 
It is important to note that some chemical components cannot be used in distinguishing between the two waters and that no mixing trend may manifest itself. This is the case with carbonate alkalinity of this system, seen in Figure 13 above. There does not appear to be any discernible relationship between bicarbonate concentrations and temperature or chloride. This observation signifies that bicarbonate concentration acts
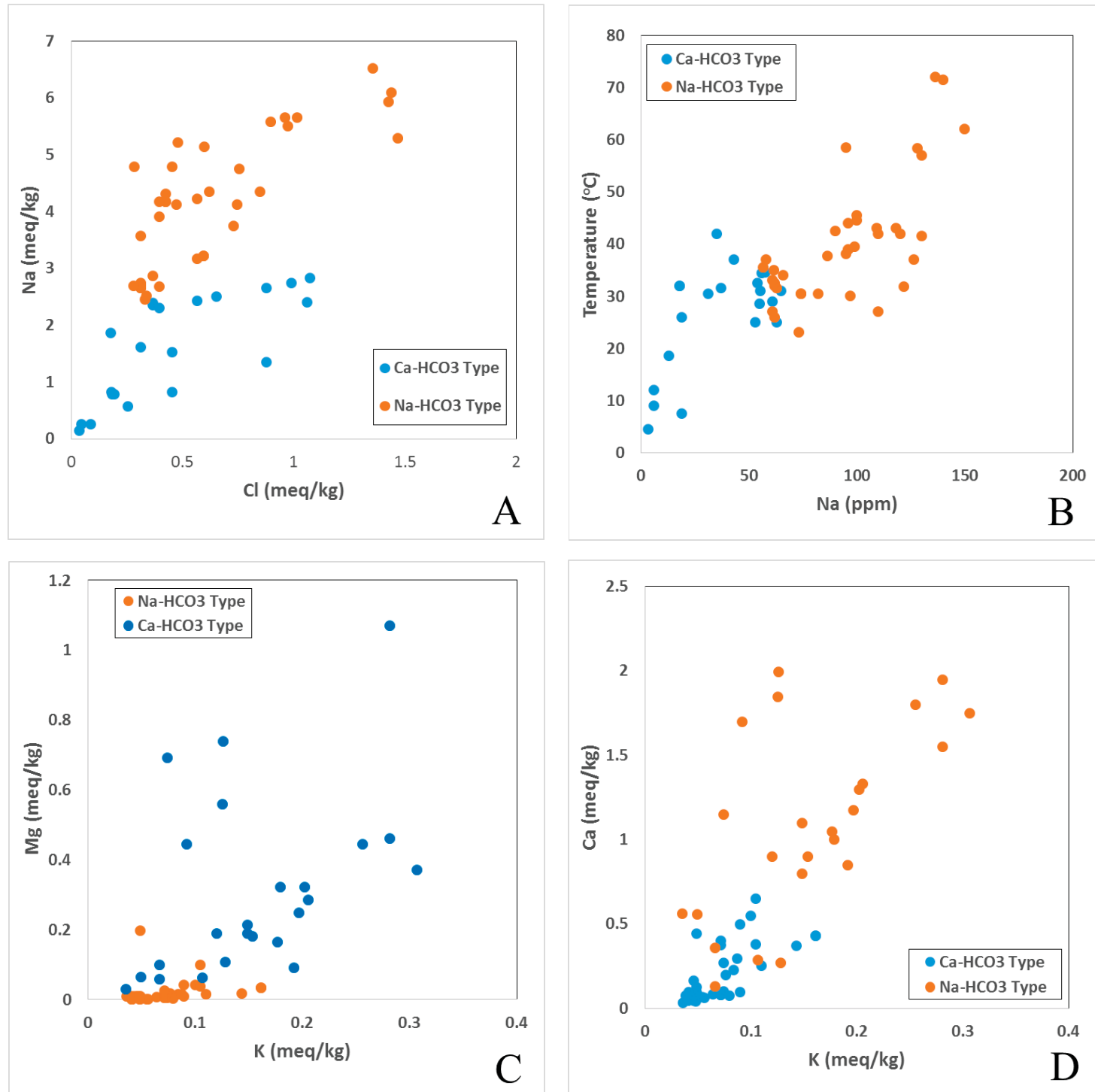

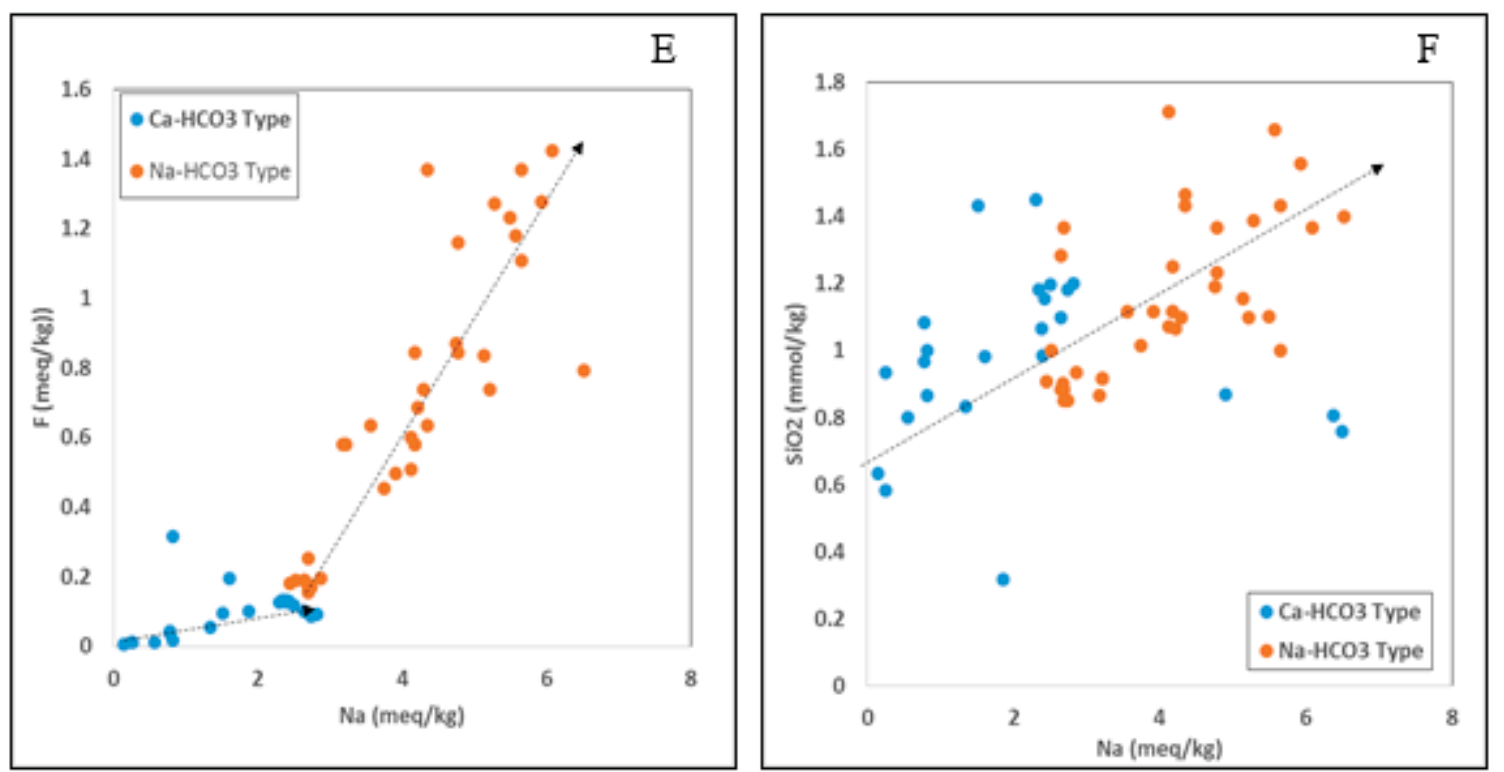

Figure 14. Binary plots between several reactive components showing simple mixing relationships.

independently of the mixing process. For this reason, either a local groundwater bicarbonate concentration or an average bicarbonate concentration should be utilized in RTEst modeling.

When examining relationships between major cations and anions for the thermal water samples, some distinct linear relationships become evident. The $\mathrm{Na}^{+} / \mathrm{Cl}^{-}$relationship as well as the $\mathrm{Na}^{+}$vs temperature relationship observed in Figures 14A and B shows the distinct transition between the sodium rich thermal end member to cooler more dilute waters. The $\mathrm{Na}^{+} / \mathrm{Cl}^{-}$trend passes through the origin signifying that little to no sodium and chloride need to be utilized in the dilution portion of MEG modeling. Figures $14 \mathrm{C}$ and D show the positive relationship between both $\mathrm{Mg}^{2+}$ and $\mathrm{K}^{+}$and $\mathrm{Ca}^{2+}$ and $\mathrm{K}^{+} . \mathrm{Na}-\mathrm{HCO}_{3}$ thermal waters are depleted with respect to $\mathrm{Mg}^{+}$and $\mathrm{K}^{+}$compared with the $\mathrm{Ca}-\mathrm{HCO}_{3}$ type waters. The $\mathrm{Na}-\mathrm{HCO}_{3}$ type waters begin with virtually no magnesium and grade into higher concentrations perhaps with increasing dilution. The same trend is seen between $\mathrm{Ca}^{2+}$ and $\mathrm{K}^{+}$where $\mathrm{Na}-\mathrm{HCO}_{3}$ type waters begin with little to no calcium and grade into more calcium rich waters. An important 
observation gained here is that if an "intermediate" reactive mixing component is to be used in RTEst modeling, it will require the addition of potassium.

Fluoride concentrations in the thermal water samples yield two separate trends. The $\mathrm{Ca}-\mathrm{HCO}_{3}$ type waters contain little to no amount of fluoride while the $\mathrm{Na}-\mathrm{HCO}_{3}$ type shows a steep trend in fluoride concentrations. Elevated fluoride concentrations are common throughout the ESRP and are often attributed to increased reaction with rhyolites (Mitchell et al., 1980). The sharp separation in fluoride trends between the two waters could signify that the $\mathrm{Ca}-\mathrm{HCO}_{3}$ type waters are mixed with a small amount of thermal water or have had little water-rock interaction with rhyolites. There is also a positive relationship between $\mathrm{SiO}_{2}{ }^{-}$and $\mathrm{Na}^{+}$as shown in Figure $14 \mathrm{~F}$ showing increased silica concentration towards $\mathrm{Na}-\mathrm{HCO}_{3}$ thermal end member waters. Unlike many other solute trends, which begin at near zero concentrations, $\mathrm{SiO}_{2}{ }^{-}$begins at around $40 \mathrm{ppm}$ corresponding to high $\mathrm{SiO}_{2}{ }^{-}$concentrations in the groundwater of the study area compared to most of the ESRPA (Lewis and Young, 1989).
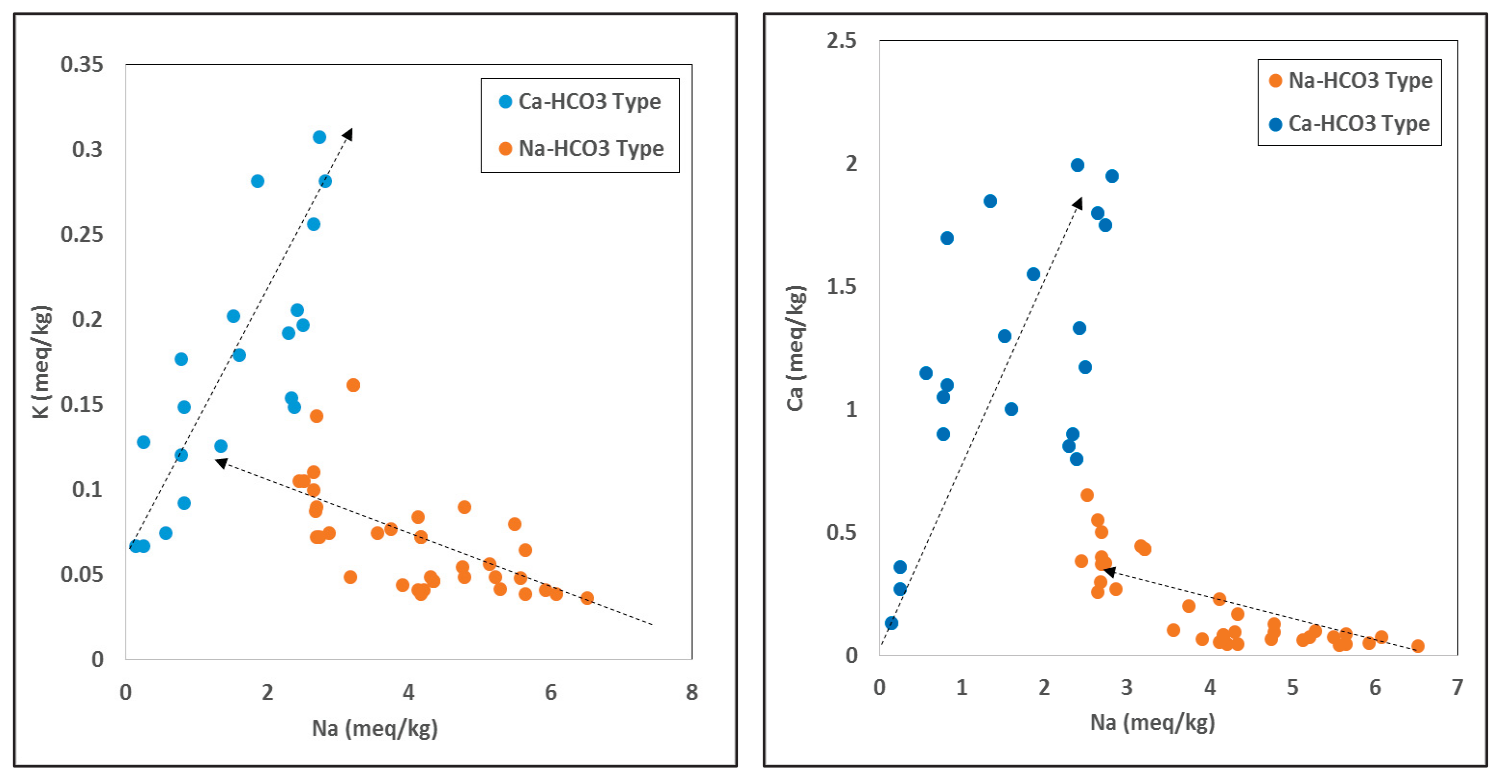

Figure 15. Binary plots showing the complex relationship between $\mathrm{Na}^{+}$and $\mathrm{K}^{+}$and $\mathrm{Na}^{+}$and $\mathrm{Ca}^{2+}$ 
While the previously discussed relationships have been relatively simple, the relationships between $\mathrm{K}^{+}, \mathrm{Ca}^{2+}$, and $\mathrm{Mg}^{2+}$ vs $\mathrm{Na}^{+}$are more complex. In both these trends (shown in Figure 15 above) there is a sharp near-vertical boundary that separates the trends of the two water types. Possible explanations for the sharp increase in $\mathrm{Ca}^{2+}$ and $\mathrm{K}^{+}$exhibited by the $\mathrm{Ca}-\mathrm{HCO}_{3}$ type waters include:

1) A significant source of $\mathrm{Ca}^{2+}, \mathrm{K}^{+}$, and $\mathrm{Mg}^{2+}$ within the basalts and sediments of the Banbury formation that overly the rhyolites of the Idavada volcanics (source of Na$\mathrm{HCO}_{3}$ waters).

2) Re-equilibration via an exchange reaction resulting in an increase in $\mathrm{Na}^{+}$and $\mathrm{K}^{+}$and a decrease in $\mathrm{Ca}^{2+}$ and $\mathrm{Mg}^{2+}$ concentrations resulting in the formation of $\mathrm{Ca}-\mathrm{HCO}_{3}$ thermal waters.

3) Two separate and distinct flow paths (different temperatures and host rocks) resulting in the two thermal water types.

The use of binary diagrams presented in this section provides support for mixing between thermal water and groundwater as well as provides information about the concentrations of constituents to be used in the mixing portion of inverse MEG modeling. Mixing and/or reequilibration mechanisms will be explored further in Chapters 4-6.

\subsection{Areal and Geologic Distribution of Water Types}

Water samples were plotted by type (according to HCA) on digital orthoimagery (USDA, 2011) and geologic maps (Gillerman et al., 2005; Othberg et al., 2005). The spatial distribution shown below in Figure 16 shows the progression from $\mathrm{Ca}-\mathrm{HCO}_{3}$ type waters from the Cassia Mountain recharge zone to $\mathrm{Na}-\mathrm{HCO}_{3}$ type waters towards the boundary of the Snake River. Figure 16 shows the direction of groundwater movement from a potentiometric 
surface created using water level data from the USGS National Water Information System. Figures 17 and 18 show detailed views of the Banbury and Twin Falls area clusters. All of the thermal samples within the Banbury cluster fall along a major normal fault, which parallels the path of the Snake River. This distribution shows the gradation from $\mathrm{Ca}-\mathrm{HCO}_{3}{ }^{-}$type waters to more thermal $\mathrm{Na}-\mathrm{HCO}_{3}{ }^{-}$type waters northward along the fault away from the recharge zone. A likely scenario for this observed gradation is the ascension of thermal waters through the normal fault and the increase in the amount of mixing southward of the fault. The Twin Falls cluster shows the same gradation away from the area of recharge towards the Snake River. Shervais et al. (2013) suggest that the thermal system in the Twin Falls area is controlled by a caldera margin. The geology and hydrology of these two areas will be discussed further in Chapter 5. 


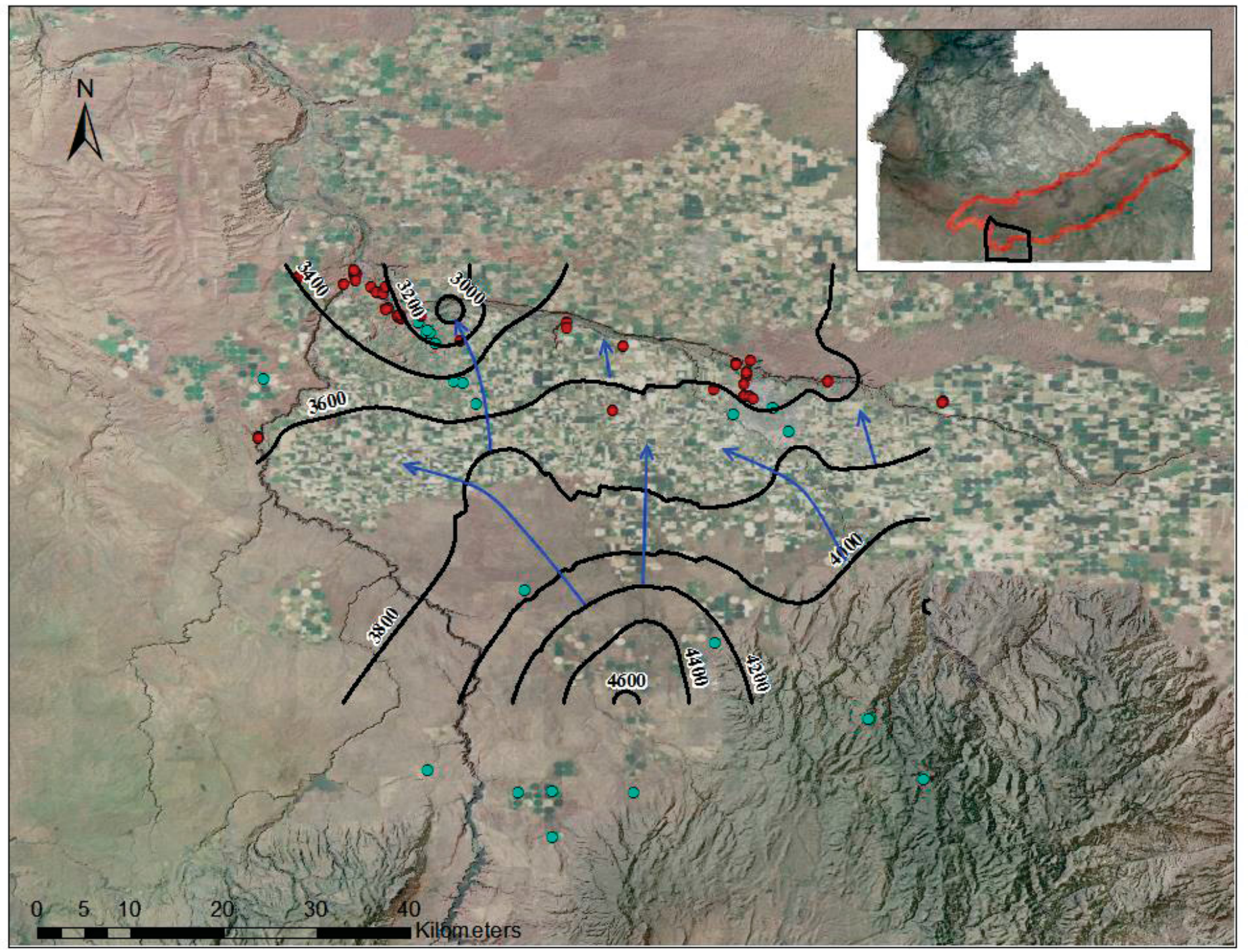

Figure 16. Map of water samples showing the gradation from $\mathrm{Ca}_{-} \mathrm{HCO}_{3}{ }^{-}$type (blue) waters to $\mathrm{Na}-\mathrm{HCO3}^{-}$type waters (red) away from the recharge zone. Groundwater flow lines (blue) produced from inverse distance weighting of water level data from the USGS National Water Information System. 


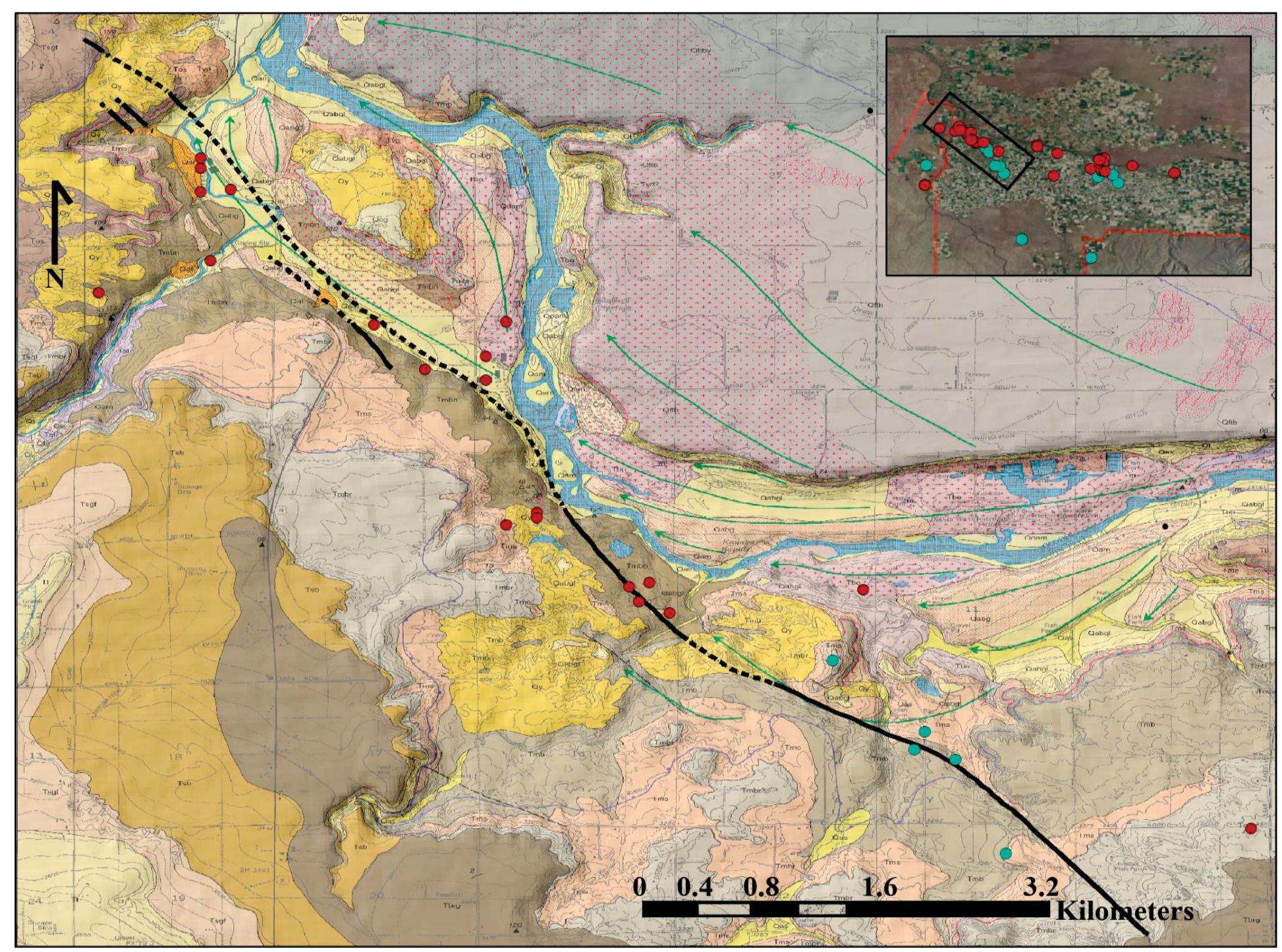

Figure 17. Banbury thermal area geologic map showing distribution of $\mathrm{Ca}-\mathrm{HCO}_{3}$ (blue) and $\mathrm{Na}-\mathrm{HCO}_{3}$ (red) waters along a normal fault. Geologic map (Gillerman et al., 2005) shows transition from Tertiary basalt flows south of the river to Quaternary basalt flows to the north. Green lines represent flood lines of the Bonneville Flood (c.15 ka). Red stipple areas correspond to dune trends. 


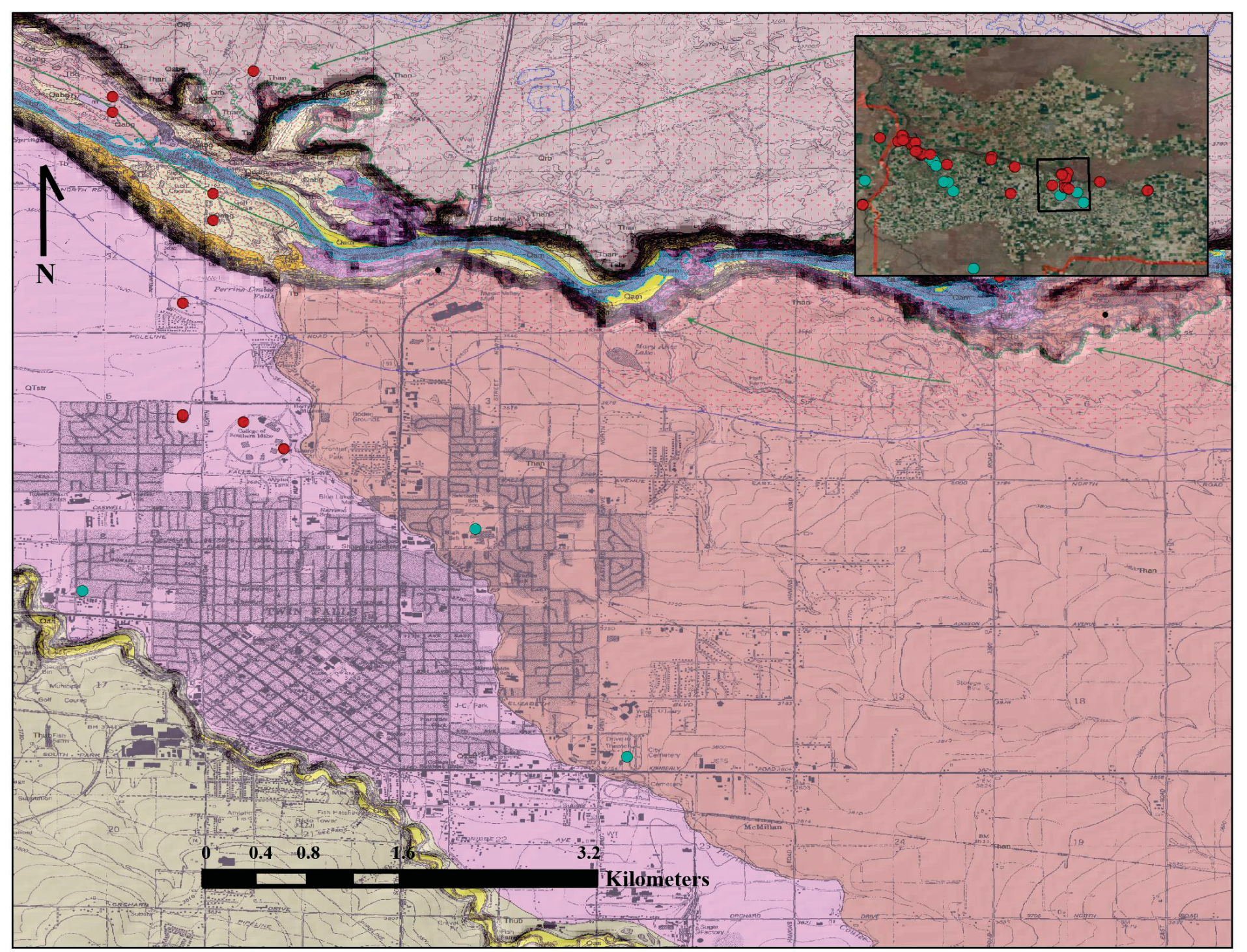

Figure 18. Twin Falls thermal area showing distribution of $\mathrm{Ca}-\mathrm{HCO}_{3^{-}}$(blue) and $\mathrm{Na}-\mathrm{HCO}_{3}^{-}$(red) waters. Geologic map (Othberg et al., 2005) shows the contacts between different Quaternary basalt flows south of the river and the outcropping of Idavada Volcanics (Shoshone Falls Rhyolite) near the river (dark purple). 


\section{CHAPTER 4: GEOTHERMOMETRY ESTIMATION OF RESERVOIR TEMPERATURES IN THE TWIN FALLS - BANBURY THERMAL AREA}

The following section details the various approaches to calculate reservoir temperatures using geothermometry techniques as well as account for the effects of the mixing described in the previous section. Conventional along with recently developed techniques are utilized in order to show differences in temperature estimation and also to account for both simple and reactive mixing. While chemical and isotope geothermometry have been applied to the Twin Falls - Banbury area, mixing models and multicomponent equilibrium geothermometry techniques have not been applied prior to this study.

\subsection{Conventional Geothermometry}

Conventional geothermometers (as referred to in this study) are empirically or experimentally determined equations that are often utilized in geothermal exploration to predict deep reservoir temperatures from surface expressions or water wells. They are based on the relationship between fluid constituents (solutes, gases, and isotopes of elements) and fluid temperature. Most are based on temperature dependent chemical equilibrium reactions involving an assemblage of hydrothermally altered minerals. Various solute geothermometers have been continuously developed and improved upon since the 1960s. Of the many chemical and isotope geothermometers developed, the most prevalent cation geothermometers and silica geothermometers will be discussed and utilized in this study. It is important to note that all of the geothermometers discussed in this section make several key assumptions as outlined by Fournier et al. (1974): 
1) Dissolved "indicator" constituent concentrations are fixed by temperature-dependent reactions between water and rock.

2) An adequate supply of all reactants is available.

3) Equilibrium with respect to indicator constituents in the reservoir is attained.

4) No re-equilibration occurs after the water leaves the reservoir

5) There is no mixing of different waters during ascension.

The assumption of equilibrium has been generally accepted as valid in the geothermal community through the study of well discharges among several geothermal fields. However, the assumption that no secondary processes have altered the fluid during its ascent from reservoir to the surface is rarely a reality. Fluids may cool adiabatically (boil) during ascent or mix with more dilute waters resulting in oversaturation and undersaturation of certain geothermal indicator constituents respectively. While some conventional geothermometers have attempted to account for the effects of boiling, none of the conventional geothermometers presented herein have accounted for dilution. For these reasons, it is important to keep the limitations and suitability of a particular geothermometer to a rock/fluid type in mind when utilizing for temperature estimation.

\section{Silica Geothermometers}

Silica geothermometers were first proposed by Fournier and Rowe (1966). They are based on the prograde relationship between silica solubility and rising fluid temperature. They are widely used in almost all geochemical investigations of geothermal systems around the world (Verma, 2000). Silica geothermometers have been developed for a variety of silica 
mineral species but they are based on the basic reaction producing dissolved silica in the form $\mathrm{H}_{4} \mathrm{SiO}_{4}$ from various silica minerals:

$$
\mathrm{SiO}_{2}(\mathrm{~s})+2 \mathrm{H}_{2} \mathrm{O} \rightarrow \mathrm{H}_{4} \mathrm{SiO}_{4}(\mathrm{aq})
$$

Dissolved silica concentrations in most natural waters are not influenced by "common ion effects" or the formation of complex ions like other geothermal indicators (Fournier, 1977). Additionally, the assumption of adequate reactant supply is generally valid for dissolved silica. In the case of the Twin Falls - Banbury thermal area, thermal waters are hosted within rhyolites of the Idavada volcanics making the silica geothermometers the most appropriate of the conventional geothermometers for temperature estimation.

Quartz solubility seems to control the dissolved silica content of most geothermal systems $>180{ }^{\circ} \mathrm{C}$. Quartz geothermometers are suggested for use in the temperature range of $120-330{ }^{\circ} \mathrm{C}$ if certain conditions are met: equilibrium with quartz, pore-fluid pressure fixed by vapor pressure of pure water, no mixing, no conductive cooling or adiabatic cooling (Fournier and Rowe, 1966). The quartz geothermometer was later modified to account for oversaturation produced by steam loss (Fournier, 1973). Two geothermometers were produced, one based on silica concentration with maximum steam loss at $100{ }^{\circ} \mathrm{C}$ and one with no steam loss at all. However, the most widely used quartz geothermometer was developed by Fournier and Potter (1982). All are shown below where concentrations of silica $\left(\mathrm{SiO}_{2}\right.$ and $\left.\mathrm{S}\right)$ are in units of $\mathrm{mg} / \mathrm{kg}$.

Quartz - Maximum Steam Loss (Fournier, 1977)

$$
t=\frac{1522}{5.75-\log \left(\mathrm{SiO}_{2}\right)}-273.15
$$


Quartz - No Steam Loss (Fournier, 1977)

$$
t=\frac{1309}{5.19-\log \left(\mathrm{SiO}_{2}\right)}-273.15
$$

Quartz Geothermometer (Fournier and Potter, 1982)

$$
t=-42.198+2.883 \times 10^{-1} S-3.668 \times 10^{-4} S^{2}+3.1665 \times 10^{-7} S^{3}+70.34 \log S
$$

Another widely utilized silica geothermometer is the chalcedony geothermometer. Chalcedony is widely regarded to be applicable for lower temperatures. However, Fournier (1991) pointed out the ambiguity between Quartz and Chalcedony as quartz controls solubility below $180{ }^{\circ} \mathrm{C}$ at some locations and chalcedony at others. Residence time, fluid temperature, rock type and fluid type all effect the controlling phase. Chalcedony, which is comprised largely of very fine quartz and mogonite crystals, probably all changes to quartz with time which makes the age of a thermal fluid of particular importance (Gíslason et al., 1997).

Chalcedony - Maximum Steam Loss (Arnòrsson et al., 1983)

$$
t=\frac{1264}{5.31-\log \left(\mathrm{SiO}_{2}\right)}-273.15
$$

Chalcedony - No Steam Loss (Arnòrsson et al., 1983)

$$
t=\frac{1112}{4.91-\log \left(\mathrm{SiO}_{2}\right)}-273.15
$$


A less commonly applied silica geothermometer is the amorphous silica geothermometer (Fournier, 1977). Due to the much higher solubility of amorphous silica compared to other silica polymorphs (Figure 19 below), the amorphous silica geothermometer yields very low temperature estimates for waters if amorphous silica is not the dominant species.

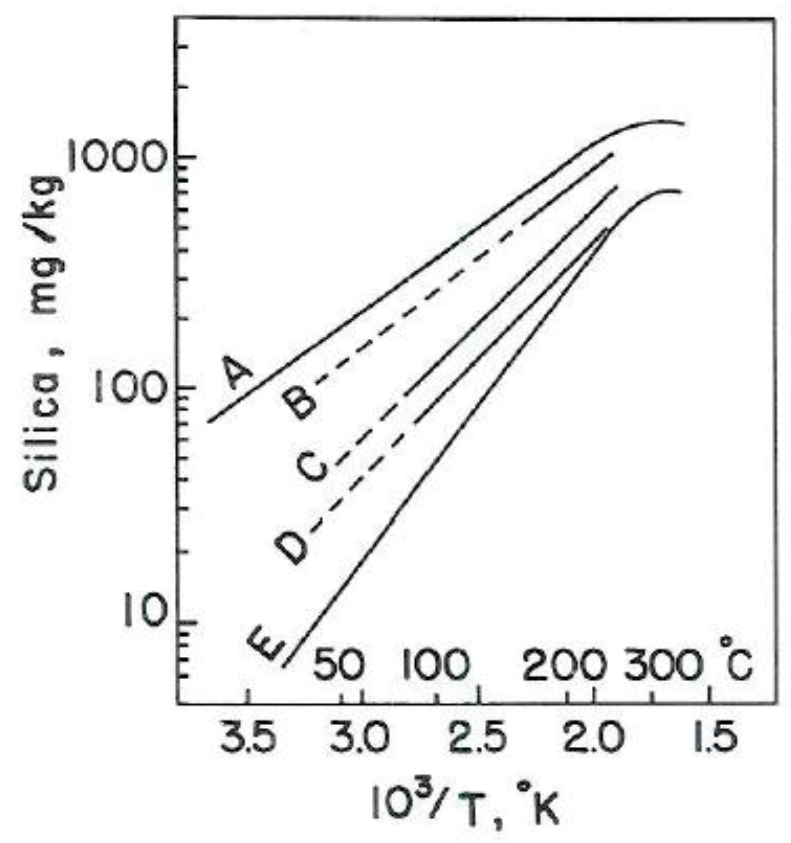

Figure 19. Solubility of silica polymorphs vs. temperature: $A=$ Amorphous silica, $B=$ Opal $C T, C=\alpha$-cristobalite, $D=$ chalcedony, and $E=$ quartz (Fournier, 1977).

Amorphous Silica (Fournier, 1977)

$$
t=\frac{731}{4.52-\log \left(\mathrm{SiO}_{2}\right)}-273.15
$$

Unfortunately, there is a wide dispersion in temperature predictions amongst silica geothermometers even when applying one geothermometer to all the wells in a geothermal 
field (Verma, 2000). This is primarily due to secondary alteration effects: steam loss, mixing, and re-equilibration (Trusedell and Fournier, 1977).

The silica geothermometers applied to the two water types of the Twin Falls Banbury thermal area give varied results with the chalcedony temperature estimates being consistently less than the quartz estimates. This is to be expected and the amorphous silica estimates yielding unrealistically low (below surface temperature and negative values). Overall, The $\mathrm{Ca}-\mathrm{HCO}_{3}$ type waters yield lower temperature estimates than the $\mathrm{Na}-\mathrm{HCO}_{3}$ type waters due to the higher silica concentrations of the $\mathrm{Na}-\mathrm{HCO}_{3}$ type waters. Quartz temperature estimates for the $\mathrm{Na}-\mathrm{HCO}_{3}$ type waters averaged $117^{\circ} \mathrm{C}$ with a $36{ }^{\circ} \mathrm{C}$ range between all measurements while the $\mathrm{Ca}-\mathrm{HCO}_{3}$ type waters yielded a $108{ }^{\circ} \mathrm{C}$ average with a much higher range of $68^{\circ} \mathrm{C}$ due to the larger range of $\mathrm{SiO}_{2}{ }^{-}$concentrations. Chalcedony temperature estimates yield an average of $91{ }^{\circ} \mathrm{C}$ with a $39{ }^{\circ} \mathrm{C}$ range for the $\mathrm{Na}-\mathrm{HCO}_{3}$ type waters while the $\mathrm{Ca}-\mathrm{HCO}_{3}$ type waters averaged $80{ }^{\circ} \mathrm{C}$ with a range of $73{ }^{\circ} \mathrm{C}$. There appears to be no significant correlation between silica-based predicted temperatures and field temperatures with many cooler water samples yielding higher estimates than some hotter samples.

\section{Cation Geothermometers}

The other often utilized type of chemical geothermometers are called cation geothermometers. These geothermometers are based on empirical and experimental cation exchange reactions with temperature-dependent equilibrium constants. A widely used cation geothermometer is the $\mathrm{Na} / \mathrm{K}$ geothermometer (Fournier, 1979; Giggenbach 1988; Truesdell, 1976; Arnòrsson et al., 1983) based on the exchange of $\mathrm{Na}^{+}$and $\mathrm{K}^{+}$between two coexisting 
alkali feldspars like the exchange between albite and various K-feldspars shown in the equation below.

$$
\mathrm{NaAlSi}_{3} \mathrm{O}_{8}+\mathrm{K}^{+} \rightarrow \mathrm{KAlSi}_{3} \mathrm{O}_{8}+\mathrm{Na}^{+}
$$

The reaction results in a decreasing $\mathrm{Na} / \mathrm{K}$ ratio with increasing fluid temperature. While ratios may be still affected by secondary processes they are considered less likely to be affected by dilution and steam loss. The $\mathrm{Na} / \mathrm{K}$ geothermometer is suitable for temperatures between 100 ${ }^{\circ} \mathrm{C}$ and $350{ }^{\circ} \mathrm{C}$ as it is slower to re-equilibrate than the quartz geothermometers. However, the $\mathrm{Na} / \mathrm{K}$ geothermometer is not useful in acidic waters which would not be in equilibrium with feldspars. More importantly for this study, the $\mathrm{Na} / \mathrm{K}$ geothermometer is not useful in waters with high calcium concentrations like many of the mixed thermal waters found in and around the ESRP.

$\mathrm{Na} / \mathrm{K}$ (Truesdell, 1976)

$$
t=\frac{856}{\log \left(\frac{N a}{K}\right)+0.857}-273.15
$$

Na/K (Fournier, 1979)

$$
t=\frac{1217}{\log \left(\frac{N a}{K}\right)+1.483}-273.15
$$


$\mathrm{Na} / \mathrm{K}$ (Arnòrsson, 1983)

$$
t=\frac{933}{\log \left(\frac{N a}{K}\right)+0.993}-273.15
$$

To account for the effects of increased calcium concentrations, Fournier and Truesdell (1973) suggested the use of a Na-K-Ca geothermometer. While the amount of total Ca in most hydrothermal systems is controlled by the solubility of calcium-bearing carbonates (usually calcite), calcium also enters into various silicate reactions and in turn is in competition with sodium and potassium. Because natural waters are generally comprised of much more sodium than potassium and aqueous potassium tends to change so as to satisfy an equilibrium expression with a given $\mathrm{Na} / \mathrm{Ca}$ ratio; a change in aqueous potassium in response to an increase in calcium will be far more evident in calculations involving the $\mathrm{Na} / \mathrm{K}$ ratio. If waters pick up additional calcium as they migrate upward, the temperature estimates made using the $\mathrm{Na} / \mathrm{K}$ geothermometer will be too low. Waters already containing increased concentrations in calcium $\left(\sqrt{ } M_{\mathrm{ca}} / M_{\mathrm{Na}}>1\right)$ capable of depositing calcium carbonate upon descent will result in temperature estimations that are too high. For this reason, the reaction configurations involving only $\mathrm{Ca}^{2+}, \mathrm{Na}^{+}, \mathrm{K}^{+}$were transposed into a generalized form:

$\log K_{\mathrm{e}}=\log (\mathrm{Na} / \mathrm{K})+\beta \log (\sqrt{\mathrm{Ca}} / \mathrm{Na})$, where $\beta$ depends upon the stoichiometry of the reaction.

Based on the distribution of natural thermal waters, Fournier and Truesdell (1973) originated a geothermometer equation which could be used to calculate temperatures based upon the relationship between $\mathrm{Ca}^{2+}, \mathrm{Na}^{+}$, and $\mathrm{K}^{+}$. The equation works for two possible $\beta$ values: $\beta=1 / 3$ for waters equilibrating above $100{ }^{\circ} \mathrm{C}$ and $\beta=4 / 3$ for waters equilibrating 
under $100{ }^{\circ} \mathrm{C}$. The user of the geothermometer must calculate $\log (\sqrt{ } \mathrm{Ca} / \mathrm{Na})+2.06$. If the value is positive, the user applies $\beta=4 / 3$ and if negative $\beta=1 / 3$. The equation utilizes the assumptions of: 1) excess silica is present (generally valid) and 2) aluminum is conserved in solid phases (not true but so little aqueous aluminum is usually present that it can be neglected).

$$
t=\frac{1647}{\log \frac{N a}{K}+\beta \log \frac{\sqrt{C a}}{N a}+2.24}-273.15
$$

Mg correction for the $\mathrm{Na}-\mathrm{K}-\mathrm{Ca}$ geothermometer

Because most geothermal fluids $>180{ }^{\circ} \mathrm{C}$ contain $<0.2 \mathrm{mg} / \mathrm{kg}$ magnesium, a correction is necessary for those fluids which contain higher amounts of magnesium (Fournier and Potter, 1979). The temperature dependence of magnesium is largely controlled by formation of chlorite in thermal waters and also biotite and actinolite at very high temperature. In cooler thermal systems, magnesium may be incorporated into clays and carbonates. The correction was devised empirically to account for waters that have high magnesium concentrations because they are saline or because the reservoir temperature is below $180{ }^{\circ} \mathrm{C}$. It was not intended to deal with waters that have been subjected to mixing and have high magnesium concentrations because of cold groundwater influence. In general, the presence of high magnesium gives anomalously high temperature results when using the Na-K-Ca geothermometer. However, the use of a magnesium correction on a mixed thermal water will result in an underestimation of true reservoir temperature. The correction is applied as such:

1) If the temperature estimate from the Na-K-Ca geothermometer is $<70{ }^{\circ} \mathrm{C}$, do not apply. 
2) Calculate correction factor R using equivalent units:

3) Do not apply the correction if $\mathrm{R}>50$ and assume the water is from cool equilibrium conditions with temperatures close to measured surface temperature regardless of geothermometry.

4) If the Na-K-Ca estimated temperature is $>70{ }^{\circ} \mathrm{C}$ and $\mathrm{R}<50$, apply the correction equation (Fournier and Potter, 1979) to obtain $\Delta \mathrm{t}$.

5) Subtract $\Delta t$ from the Na-K-Ca estimated temperature.

$$
\begin{gathered}
R=\frac{M g}{M g+C a+K}(100) \\
\triangle t_{m g}=10.66-4.7415(R)+325.867 \log (R)-\frac{1.0321 \times 10^{5}(\log R)^{2}}{T}-\frac{1.96683 \times 10^{7}(\log R)^{2}}{T^{2}}+\frac{1.6053 \times 10^{7}(\log R)^{3}}{T^{2}}
\end{gathered}
$$

\section{K-Mg Geothermometer}

The K-Mg geothermometer (Giggenbach et al., 1988) was developed for application to systems where sodium and calcium are not in equilibrium between the thermal fluid and rock. Unfortunately, the K-Mg system is distinct from other geothermal indicators in that fluid-rock equilibrium is often attained at lower temperatures. Due to this fast re-equilibration, results from the K-Mg geothermometer are often underestimations particularly in mixed waters with elevated magnesium concentrations.

$$
t=\frac{4410}{14.0+\log \left(K^{2} / M g\right)}-273.15
$$




\section{Na-Li Geothermometer}

The Na-Li geothermometer (Fouillac et al., 1981) is based on the decrease in the $\mathrm{Na} / \mathrm{Li}$ ratio with increasing fluid temperature. Lithium is regarded as one of the more conservative elements in hydrothermal systems and is slow to re-equilibrate during ascent. The controlling equilibria of this geothermometer are based on cation exchange reactions between clays and zeolites. Two geothermometers were created: one to be applied for low to moderately saline waters $\left(<11000 \mathrm{mg} / \mathrm{kg} \mathrm{Cl}^{-}\right)$and the other for marine waters. All of the waters in this study fall in the first category with the applicable geothermometer listed below.

$$
t=\frac{1195}{0.130+\log (m N a / m L i)}-273.15
$$

When applied to the water samples collected in this study, the cation geothermometers give highly varied results for the exact same well/spring. The $\mathrm{Na} / \mathrm{K}$ geothermometers tend to yield very high results for $\mathrm{Ca}-\mathrm{HCO}_{3}$ waters likely because of high calcium concentrations. In contrast, $\mathrm{Na}-\mathrm{HCO}_{3}$ waters with lower calcium concentrations likely picking up additional calcium during ascent to the surface yield much lower $\mathrm{Na} / \mathrm{K}$ temperature predictions some of which are below measured field temperatures. Because of the presence of calcium and the lack of magnesium in the $\mathrm{Na}-\mathrm{HCO}_{3}$ waters, the $\mathrm{Na}-\mathrm{K}-\mathrm{Ca}$ geothermometer is likely to yield more realistic results for these thermal features. Temperature estimates for $\mathrm{Na}-\mathrm{HCO}_{3}$ waters using this technique range from $98{ }^{\circ} \mathrm{C}$ to $166^{\circ} \mathrm{C}$ with an average of $126^{\circ} \mathrm{C}$. In contrast, the abundance of magnesium in the $\mathrm{Ca}-\mathrm{HCO} 3$ waters yields much higher temperature predictions ranging from $82{ }^{\circ} \mathrm{C}$ to $258{ }^{\circ} \mathrm{C}$. 
The high magnesium concentrations of the $\mathrm{Ca}-\mathrm{HCO}_{3}$ waters also makes the $\mathrm{Mg}$ correction for the Na-K-Ca geothermometer inapplicable likely resulting in overcorrections yielding lower than actual temperature estimates according to its originators (Fournier and Potter, 1979). The Na-Li geothermometer results are highly variable while the K-Mg geothermometer yields temperature estimates that are unrealistic (below surface temperatures or negative values). All of the temperature estimates produced by conventional geothermometry are listed below in Tables 5-8. The large disparity in temperature estimates produced by these techniques highlights the shortcomings of estimators based on few chemical species under very precise conditions that may not be present in the thermal reservoir of this study area. The results from conventional geothermometry methods support further evaluation using both models to account for mixing and multicomponent equilibrium geothermometry methods that utilize reservoir specific alteration minerals to provide more realistic temperature estimates. 
Table 5. Silica geothermometer temperature estimates for the $\mathrm{Na}-\mathrm{HCO}_{3}$ type waters of the Twin Falls - Banbury hydrothermal system. All estimates are given in degrees Celsius.

\begin{tabular}{|c|c|c|c|c|c|c|c|}
\hline \multirow{2}{*}{$\begin{array}{l}\text { Na-HCO3 } \\
\text { Type Waters }\end{array}$} & $\begin{array}{c}\text { Qtz (No } \\
\text { Steam Loss) }\end{array}$ & $\begin{array}{l}\text { Qtz (Steam } \\
\text { Loss) }\end{array}$ & $\begin{array}{l}\text { Amorphous } \\
\text { Silica }\end{array}$ & Chalcedony & Quartz & $\begin{array}{l}\text { Chalcedony } \\
\text { (Steam Loss) }\end{array}$ & $\begin{array}{c}\text { Chalcedony } \\
\text { (No Steam Loss) }\end{array}$ \\
\hline & \multicolumn{4}{|c|}{ Fournier (1977) } & $\begin{array}{l}\text { Fournier and } \\
\text { Potter (1982) }\end{array}$ & $\begin{array}{c}\text { Arnorsson et al. } \\
\text { (1983) }\end{array}$ & $\begin{array}{c}\text { Arnorsson et al. } \\
\text { (1983) }\end{array}$ \\
\hline $\mathrm{CC}-11$ & 137 & 132 & 17 & 110 & 137 & 108 & 109 \\
\hline $\mathrm{CC}-14$ & 114 & 113 & -4 & 85 & 114 & 88 & 85 \\
\hline $\mathrm{CC}-51$ & 111 & 111 & -6 & 82 & 112 & 85 & 83 \\
\hline CC-52 & 118 & 116 & 0 & 89 & 118 & 91 & 89 \\
\hline $\mathrm{CC}-53$ & 119 & 118 & 1 & 91 & 120 & 93 & 91 \\
\hline $\mathrm{CC}-55$ & 115 & 114 & -2 & 86 & 116 & 89 & 87 \\
\hline CC-40 & 133 & 130 & 14 & 106 & 134 & 105 & 105 \\
\hline CC-42 & 139 & 134 & 18 & 112 & 139 & 110 & 111 \\
\hline CC-45 & 105 & 106 & -11 & 76 & 106 & 80 & 77 \\
\hline CC-46 & 106 & 106 & -11 & 76 & 106 & 81 & 77 \\
\hline CC-48 & 127 & 124 & 8 & 100 & 127 & 100 & 99 \\
\hline LY82-3 & 128 & 125 & 8 & 100 & 128 & 100 & 99 \\
\hline LY82-4 & 126 & 124 & 7 & 99 & 127 & 99 & 98 \\
\hline LY82-5 & 129 & 126 & 10 & 101 & 129 & 101 & 101 \\
\hline LY82-6 & 129 & 126 & 10 & 101 & 129 & 101 & 101 \\
\hline LY82-7 & 116 & 115 & -2 & 87 & 116 & 90 & 87 \\
\hline LY82-11 & 130 & 127 & 11 & 103 & 130 & 102 & 102 \\
\hline LY82-12 & 114 & 113 & -4 & 85 & 114 & 88 & 85 \\
\hline LY82-15 & 107 & 107 & -9 & 78 & 108 & 82 & 79 \\
\hline LY82-18 & 105 & 105 & -12 & 75 & 105 & 79 & 76 \\
\hline LY82-19 & 103 & 103 & -13 & 73 & 103 & 78 & 74 \\
\hline LY82-20 & 103 & 103 & -13 & 73 & 103 & 78 & 74 \\
\hline LY89-1 & 105 & 105 & -12 & 75 & 105 & 79 & 76 \\
\hline LY89-2 & 111 & 110 & -7 & 81 & 111 & 85 & 82 \\
\hline LY89-4 & 126 & 124 & 7 & 99 & 127 & 99 & 98 \\
\hline LY89-8 & 122 & 120 & 3 & 93 & 122 & 95 & 93 \\
\hline LY89-9 & 104 & 104 & -12 & 74 & 104 & 79 & 75 \\
\hline LY89-11 & 116 & 115 & -2 & 87 & 116 & 90 & 87 \\
\hline LY89-12 & 126 & 124 & 7 & 99 & 127 & 99 & 98 \\
\hline LY89-13 & 121 & 119 & 3 & 93 & 121 & 94 & 93 \\
\hline LY89-14 & 115 & 114 & -2 & 86 & 115 & 89 & 87 \\
\hline LY89-15 & 116 & 115 & -2 & 87 & 116 & 90 & 87 \\
\hline LY89-22 & 106 & 106 & -10 & 77 & 107 & 81 & 78 \\
\hline M91-7 & 116 & 115 & -2 & 87 & 116 & 90 & 87 \\
\hline M91-8 & 123 & 121 & 4 & 95 & 123 & 96 & 95 \\
\hline M91-11 & 106 & 106 & -10 & 77 & 107 & 81 & 78 \\
\hline M91-13 & 111 & 110 & -7 & 81 & 111 & 85 & 82 \\
\hline M91-14 & 115 & 114 & -2 & 86 & 115 & 89 & 87 \\
\hline
\end{tabular}


Table 6. Silica geothermometer temperature estimates for the $\mathrm{Ca}-\mathrm{HCO}_{3}$ type waters of the Twin Falls - Banbury hydrothermal system. All estimates are given in degrees Celsius.

\begin{tabular}{|c|c|c|c|c|c|c|c|}
\hline \multirow{2}{*}{$\begin{array}{c}\mathrm{Ca}-\mathrm{HCO} 3 \\
\text { Type Waters }\end{array}$} & $\begin{array}{c}\text { Qtz (No } \\
\text { Steam Loss) }\end{array}$ & $\begin{array}{c}\text { Qtz (Steam } \\
\text { Loss) }\end{array}$ & $\begin{array}{c}\text { Amorphous } \\
\text { Silica }\end{array}$ & Chalcedony & \multirow{2}{*}{$\begin{array}{c}\text { Quartz } \\
\text { Fournier and } \\
\text { Potter (1982) }\end{array}$} & \multirow{2}{*}{$\begin{array}{c}\text { Chalcedony } \\
\text { (Steam Loss) } \\
\text { Arnorsson et al. } \\
\text { (1983) }\end{array}$} & \multirow{2}{*}{$\begin{array}{c}\text { Chalcedony } \\
\text { (No Steam Loss) } \\
\text { Arnorsson et al. } \\
\text { (1983) }\end{array}$} \\
\hline & \multicolumn{4}{|c|}{ Fournier (1977) } & & & \\
\hline $\mathrm{CC}-8$ & 104 & 104 & -12 & 74 & 104 & 79 & 75 \\
\hline CC-9 & 120 & 118 & 1 & 91 & 120 & 93 & 91 \\
\hline CC- 10 & 118 & 116 & 0 & 89 & 118 & 91 & 89 \\
\hline CC-12 & 98 & 99 & -18 & 67 & 98 & 73 & 69 \\
\hline CC- 13 & 100 & 101 & -15 & 70 & 101 & 75 & 72 \\
\hline CC-54 & 110 & 109 & -7 & 80 & 110 & 84 & 81 \\
\hline LY82-13 & 129 & 126 & 10 & 101 & 129 & 101 & 101 \\
\hline LY89-3 & 114 & 113 & -4 & 85 & 114 & 88 & 85 \\
\hline LY89-5 & 119 & 117 & 1 & 90 & 119 & 92 & 90 \\
\hline LY89-6 & 130 & 126 & 10 & 102 & 130 & 102 & 101 \\
\hline LY89-7 & 115 & 114 & -2 & 86 & 115 & 89 & 87 \\
\hline LY89-10 & 120 & 118 & 1 & 91 & 120 & 93 & 91 \\
\hline LY89-17 & 119 & 117 & 1 & 90 & 119 & 92 & 90 \\
\hline LY89-18 & 110 & 109 & -7 & 80 & 110 & 84 & 81 \\
\hline LY89-29 & 100 & 101 & -16 & 70 & 100 & 75 & 71 \\
\hline LY89-30 & 62 & 67 & -48 & 29 & 62 & 40 & 33 \\
\hline LY89-32 & 107 & 107 & -9 & 78 & 108 & 82 & 79 \\
\hline LY89-33 & 86 & 89 & -28 & 55 & 86 & 62 & 57 \\
\hline LY89-34 & 109 & 109 & -8 & 79 & 109 & 83 & 80 \\
\hline LY89-35 & 111 & 110 & -7 & 81 & 111 & 85 & 82 \\
\hline LY89-36 & 114 & 113 & -3 & 86 & 115 & 88 & 86 \\
\hline LY89-37 & 104 & 104 & -12 & 74 & 104 & 79 & 75 \\
\hline LY89-38 & 89 & 92 & -25 & 59 & 90 & 66 & 61 \\
\hline M91-12 & 102 & 103 & -14 & 72 & 102 & 77 & 73 \\
\hline
\end{tabular}


Table 7. Cation geothermometer temperature estimates for the $\mathrm{Na}-\mathrm{HCO}_{3}$ type waters of the Twin Falls - Banbury hydrothermal system. All estimates are given in degrees Celsius.

\begin{tabular}{|c|c|c|c|c|c|c|c|c|}
\hline \multirow{2}{*}{$\begin{array}{l}\text { Na-HCO3 } \\
\text { Type Waters }\end{array}$} & \multicolumn{4}{|c|}{$\mathrm{Na}-\mathrm{K}$} & \multirow{2}{*}{$\begin{array}{c}\mathrm{Na}-\mathrm{K}-\mathrm{Ca} \\
\text { Fournier and } \\
\text { Truesdell (1973) }\end{array}$} & \multirow{2}{*}{\begin{tabular}{l|}
$\mathrm{Na}-\mathrm{K}-\mathrm{Ca}$ (Mg Corrected) \\
Fournier and Potter (1979)
\end{tabular}} & \multirow{2}{*}{\begin{tabular}{|c|}
$\mathrm{Na}-\mathrm{Li}$ \\
Fouilliac et al. \\
$(1988)$
\end{tabular}} & \multirow{2}{*}{$\begin{array}{c}\mathrm{K}-\mathrm{Mg} \\
\text { Giggenbach et al. } \\
(1988)\end{array}$} \\
\hline & $\begin{array}{c}\text { Truesdell } \\
\text { (1976) }\end{array}$ & $\begin{array}{c}\text { Fournier } \\
(1979)\end{array}$ & $\begin{array}{c}\text { Giggenbach } \\
\text { (1988) }\end{array}$ & $\begin{array}{c}\text { Arnorsson } \\
\text { (1983) }\end{array}$ & & & & \\
\hline $\mathrm{CC}-11$ & 45 & 93 & 114 & 57 & 112 & 112 & 119 & -19 \\
\hline CC-14 & 96 & 140 & 160 & 107 & 132 & 132 & 63 & 7 \\
\hline $\mathrm{CC}-51$ & 96 & 140 & 160 & 107 & 131 & 131 & 99 & 9 \\
\hline CC-52 & 58 & 105 & 126 & 69 & 118 & 118 & 95 & -7 \\
\hline CC-53 & 60 & 108 & 128 & 72 & 118 & 118 & 69 & -6 \\
\hline CC-55 & 74 & 120 & 141 & 85 & 129 & 129 & 144 & -9 \\
\hline $\mathrm{CC}-40$ & 34 & 83 & 104 & 46 & 103 & 103 & 124 & -11 \\
\hline CC-42 & 52 & 101 & 121 & 64 & 112 & 112 & 119 & -17 \\
\hline CC-45 & 132 & 171 & 189 & 141 & 144 & 144 & 184 & 6 \\
\hline CC-46 & 156 & 191 & 208 & 164 & 154 & 140 & 190 & 10 \\
\hline CC-48 & 40 & 89 & 110 & 52 & 102 & 102 & 118 & -3 \\
\hline LY82-3 & 23 & 73 & 95 & 35 & 98 & 98 & 114 & 15 \\
\hline LY82-4 & 30 & 79 & 101 & 42 & 98 & 98 & 128 & 14 \\
\hline LY82-5 & 33 & 83 & 104 & 45 & 103 & 103 & 110 & 14 \\
\hline LY82-6 & 56 & 104 & 125 & 68 & 116 & 116 & 124 & 11 \\
\hline LY82-7 & 59 & 106 & 127 & 70 & 114 & 114 & 131 & 12 \\
\hline LY82-11 & 56 & 104 & 125 & 68 & 108 & 108 & 124 & 11 \\
\hline LY82-12 & 51 & 100 & 120 & 63 & 113 & 113 & 110 & 13 \\
\hline LY82-15 & 113 & 155 & 174 & 124 & 136 & 136 & 165 & 9 \\
\hline LY82-18 & 116 & 157 & 176 & 126 & 133 & 133 & 169 & 10 \\
\hline LY82-19 & 114 & 156 & 175 & 125 & 133 & 133 & 168 & 13 \\
\hline LY82-20 & 133 & 172 & 190 & 143 & 141 & 136 & 169 & 13 \\
\hline LY89-1 & 144 & 181 & 199 & 153 & 146 & 140 & 184 & 12 \\
\hline LY89-2 & 153 & 189 & 206 & 162 & 149 & 118 & 188 & 18 \\
\hline LY89-4 & 177 & 208 & 224 & 185 & 166 & 165 & 205 & -1 \\
\hline LY89-8 & 48 & 97 & 118 & 60 & 107 & 107 & 111 & 14 \\
\hline LY89-9 & 77 & 124 & 144 & 89 & 112 & 61 & 104 & 38 \\
\hline LY89-11 & 98 & 142 & 161 & 109 & 136 & 136 & 100 & -1 \\
\hline LY89-12 & 90 & 135 & 155 & 101 & 136 & 136 & 84 & 1 \\
\hline LY89-13 & 54 & 102 & 123 & 65 & 109 & 109 & 22 & 10 \\
\hline LY89-14 & 59 & 107 & 128 & 71 & 114 & 114 & 39 & 10 \\
\hline LY89-15 & 85 & 130 & 150 & 96 & 132 & 132 & - & 0 \\
\hline LY89-22 & 171 & 204 & 220 & 179 & 165 & 154 & - & 3 \\
\hline M91-7 & 85 & 130 & 150 & 96 & 132 & 132 & - & 0 \\
\hline M91-8 & 153 & 189 & 206 & 162 & 157 & 156 & - & 2 \\
\hline M91-11 & 171 & 204 & 220 & 179 & 165 & 154 & - & 3 \\
\hline M91-13 & 60 & 107 & 128 & 71 & 118 & 118 & - & 4 \\
\hline M91-14 & 49 & 97 & 118 & 61 & 110 & 110 & - & -7 \\
\hline
\end{tabular}


Table 8. Cation geothermometer temperature estimates for the $\mathrm{Ca}-\mathrm{HCO}_{3}$ type waters of the Twin Falls - Banbury hydrothermal system. All estimates are given in degrees Celsius.

\begin{tabular}{|c|c|c|c|c|c|c|c|c|}
\hline \multirow{2}{*}{$\begin{array}{c}\mathrm{Ca}-\mathrm{HCO} 3 \\
\text { Type Waters }\end{array}$} & \multicolumn{4}{|c|}{$\mathrm{Na}-\mathrm{K}$} & \multirow{2}{*}{$\begin{array}{c}\text { Na-K-Ca } \\
\text { Fournier and } \\
\text { Truesdell (1973) }\end{array}$} & \multirow{2}{*}{\begin{tabular}{|l|} 
Na-K-Ca (Mg Corrected) \\
Fournier and Potter (1979)
\end{tabular}} & \multirow{2}{*}{$\begin{array}{c}\text { Na-Li } \\
\text { Fouilliac et al. } \\
(1988)\end{array}$} & \multirow{2}{*}{$\begin{array}{c}\mathrm{K}-\mathrm{Mg} \\
\text { Giggenbach et al. } \\
(1988)\end{array}$} \\
\hline & \begin{tabular}{|c|} 
Truesdell \\
$(1976)$ \\
\end{tabular} & \begin{tabular}{|c|} 
Fournier \\
$(1979)$
\end{tabular} & $\begin{array}{c}\text { Giggenbach } \\
\text { (1988) }\end{array}$ & \begin{tabular}{|c|} 
Arnorsson \\
$(1983)$ \\
\end{tabular} & & & & \\
\hline CC-8 & 101 & 144 & 163 & 111 & 135 & 107 & 50 & 14 \\
\hline CC-9 & 221 & 243 & 257 & 227 & 175 & 107 & 184 & 15 \\
\hline $\mathrm{CC}-10$ & 231 & 250 & 263 & 235 & 177 & 106 & 186 & 16 \\
\hline $\mathrm{CC}-12$ & 23 & 73 & 94 & 35 & 82 & 82 & 203 & 26 \\
\hline CC- 13 & 39 & 88 & 110 & 51 & 94 & 94 & 206 & 27 \\
\hline CC-54 & 175 & 207 & 223 & 183 & 150 & 65 & 144 & 32 \\
\hline LY82-13 & 296 & 298 & 307 & 296 & 194 & 102 & 214 & 17 \\
\hline LY89-3 & 194 & 222 & 237 & 200 & 165 & 99 & 192 & 18 \\
\hline LY89-5 & 199 & 226 & 241 & 206 & 167 & 108 & 193 & 17 \\
\hline LY89-6 & 229 & 249 & 262 & 233 & 180 & 148 & 181 & 8 \\
\hline LY89-7 & 248 & 263 & 275 & 251 & 183 & 98 & 196 & 16 \\
\hline LY89-10 & 252 & 267 & 278 & 256 & 186 & 102 & 191 & 14 \\
\hline LY89-17 & 270 & 279 & 290 & 271 & 193 & 113 & 193 & 11 \\
\hline LY89-18 & 269 & 279 & 289 & 271 & 188 & 84 & 170 & 19 \\
\hline LY89-29 & 294 & 297 & 306 & 294 & 176 & 39 & 133 & 42 \\
\hline LY89-30 & 318 & 313 & 320 & 315 & 204 & 40 & 197 & 21 \\
\hline LY89-32 & 641 & 506 & 487 & 597 & 258 & 106 & 156 & 15 \\
\hline LY89-33 & 433 & 389 & 387 & 419 & 211 & 101 & 157 & 26 \\
\hline LY89-34 & 399 & 368 & 368 & 389 & 215 & 140 & 239 & 14 \\
\hline LY89-35 & 351 & 336 & 340 & 345 & 201 & 119 & - & 19 \\
\hline LY89-36 & 321 & 316 & 323 & 319 & 193 & 111 & 193 & 21 \\
\hline LY89-37 & 269 & 279 & 289 & 271 & 171 & 87 & 91 & 34 \\
\hline LY89-38 & 606 & 488 & 472 & 568 & 247 & 95 & 198 & 21 \\
\hline M91-12 & 243 & 260 & 272 & 247 & 169 & 78 & 183 & 30 \\
\hline
\end{tabular}

\subsection{Silica-Enthalpy Mixing Models for the Twin Falls - Banbury Thermal Area}

The evidence for mixing provided by the use of binary diagram trends and

Giggenbach diagram analysis (partial equilibration) suggests that conventional

geothermometry techniques cannot be taken at face value. Adjustments for dilution should be made to enable more accurate temperature prediction. Several models have been developed to deal with simple mixing (non-reactive dilution) including the silica-enthalpy model (Fournier and Truesdell, 1974) and the silica-carbonate mixing model (Arnórsson, 1985). The silicaenthalpy diagram was chosen for use in this study due to the abundance of silica within the reservoir rocks satisfying the second geothermometry assumption discussed previously. The silica-carbonate model was excluded due to the variability in carbonate measurements from 
field titrations and the effects of $\mathrm{CO}_{2}$ degassing on carbonate concentrations. The silicaenthalpy mixing model is based on the positive relationship between silica solubility and increasing temperature. To apply the model, temperatures for both the cold water and thermal components must be known. However, in this model, respective enthalpies of sample waters calculated from field temperatures are used as plot coordinates rather than temperature because enthalpy is conserved as waters mix and boil whereas temperature is not (e.g., Fournier and Truesdell, 1974).

The model yields two temperature estimates representing one situation in which waters are subjected to boiling prior to mixing and one where no boiling occurs. Enthalpy vs quartz solubility curves are used corresponding to the two separate scenarios. A straight line is drawn from the point representing the non-thermal component of the mixed water (lowest silica and enthalpy), through the mixed water thermal samples. The intersection of this line with the quartz solubility curve gives the enthalpy of the hot-water component at reservoir conditions if there was no boiling prior to mixing. The enthalpy at the boiling temperature $\left(100^{\circ} \mathrm{C}\right)$ which is $419 \mathrm{~J} / \mathrm{g}$ is intersected with the projected trend line. From this intersection, a horizontal line is drawn to the quartz maximum steam loss line. This new enthalpy value can be used to calculate the reservoir temperature if boiling occurred prior to mixing (Fournier, 1977).

In order to better constrain the temperature estimates from the mixing models, evidence for and against the possibility of boiling must be considered. As mentioned previously, shifts in $\delta \mathrm{D}$ concentrations may be explained by boiling. Truesdell et al. (1978) demonstrated the enrichment of deuterium from fractionation due to boiling in both a singlestage and continuous steam loss scenario. They observed increases of 1.44 times and $9.1 \%$ for 
chloride and $\delta \mathrm{D}$ concentrations respectively for single-stage steam loss and 1.41 times $3.1 \%$ for continuous steam loss for some of the thermal waters in Yellowstone National Park. These calculations were made utilizing a known recharge water deuterium concentration and assuming all heat loss was due to boiling from $360{ }^{\circ} \mathrm{C}$ parent water to the $93{ }^{\circ} \mathrm{C}$ boiling point.

Because local area groundwater deuterium concentrations differ from thermal water concentrations and thermal waters are likely much older (Pleistocene), a local Pleistocene deuterium concentration would be needed for such calculations. However, given a likely reservoir temperature of about $160{ }^{\circ} \mathrm{C}$ (Conrad et al., 2015) and a local boiling point of about $95{ }^{\circ} \mathrm{C}$, one can approximate how much boiling may occur in the system. Assuming that all of the heat loss in the system is due to steam loss (not likely due to evidence for groundwater mixing), we can estimate a percentage of water lost to boiling. The total enthalpy lost due to vaporization from $160{ }^{\circ} \mathrm{C}$ to $95{ }^{\circ} \mathrm{C}$ is about $277 \mathrm{~kJ} / \mathrm{kg}$ and the latent heat of enthalpy for water is about $2257 \mathrm{~kJ} / \mathrm{kg}$ (Marsh, 1987). Relating heat loss and latent heat of vaporization to evaporative mass, a maximum of about $12 \%$ of thermal water per kg could potentially be lost to boiling. Due to low chloride concentrations of thermal waters in the study area and lack of recharge deuterium values, effects from this small proportion of boiling are not likely to be evident in water chemistry. Additionally, the lack of fumaroles, sinter deposits, and supersaturation of silica suggest that influence of boiling is of minimal importance to this area.

The model developed by Fournier and Truesdell (1974) used only quartz as the controlling dissolved silica component. This approach has been modified in this study to include a chalcedony-enthalpy mixing model in addition to the quartz-enthalpy model in order to account for the possibility of chalcedony controlling silica solubility. The results are 
presented below in Figures 20-21. Because there is little evidence supporting a maximum boiling scenario in the study area, temperature estimates from these models are likely constrained to the lower (no steam loss) estimates. The estimated reservoir temperatures from the quartz-enthalpy diagram are about $143{ }^{\circ} \mathrm{C}$ (no steam loss) to $175^{\circ} \mathrm{C}$ (max steam loss).The fraction of thermal water incorporated into mixing for the no steam loss scenario is about $39 \%$. The chalcedony-enthalpy model yields a lower temperature range of $120^{\circ} \mathrm{C}$ (no steam loss) to $142{ }^{\circ} \mathrm{C}$ (max steam loss). The fraction of thermal water incorporated into mixing for the no steam loss scenario is about $49 \%$. While the temperature estimates of the mixing models may be more realistic than those of conventional geothermometers, the mixing models applied in this section account only for simple non-reactive mixing and are based on only one dissolved indicator constituent.

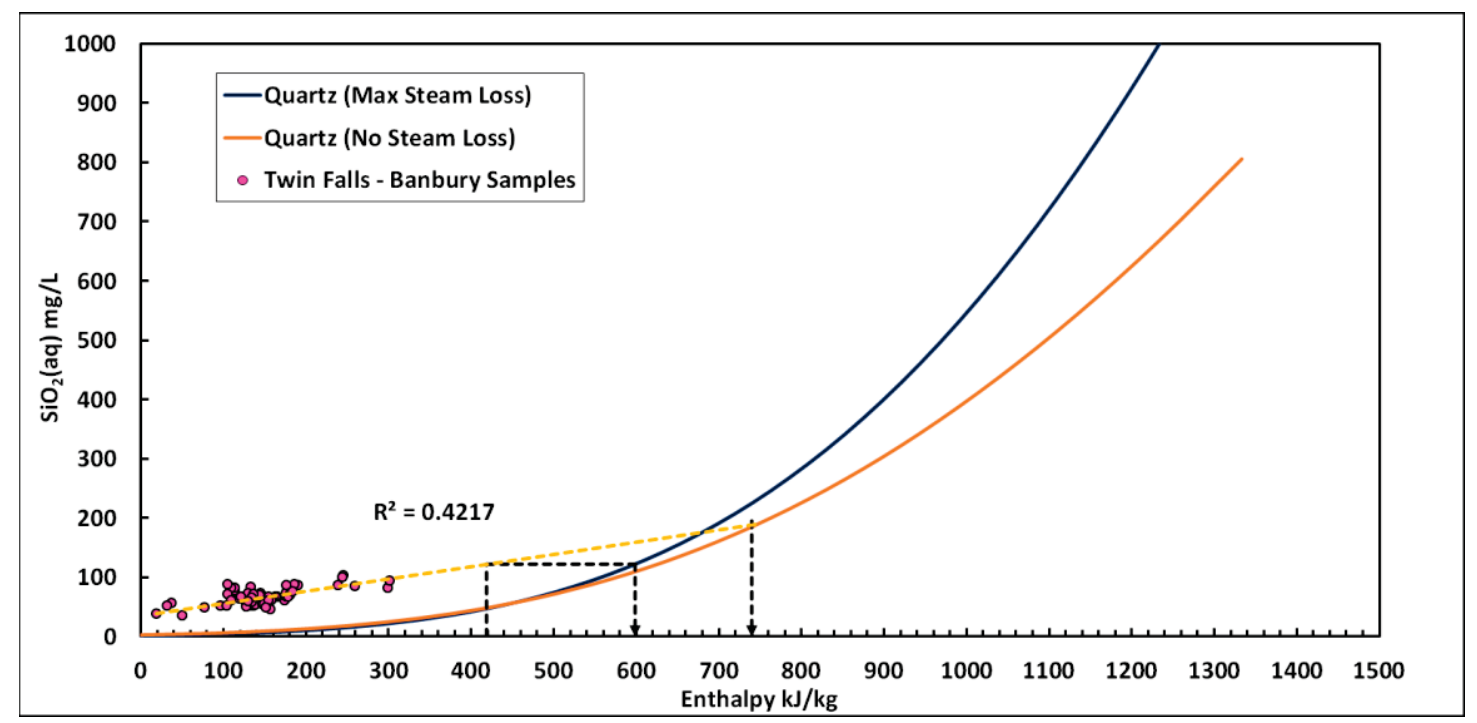

Figure 20. Silica-enthalpy model (quartz) applied to the thermal waters of the Twin Falls - Banbury system. The trend line (yellow) passes through both end member waters and is projected to the no steam loss line (orange). The intersection of the trend line with the boiling point (419 kJ/kg) is projected to the max steam loss line (blue). Temperature estimations are obtained from the resulting two enthalpy values. 


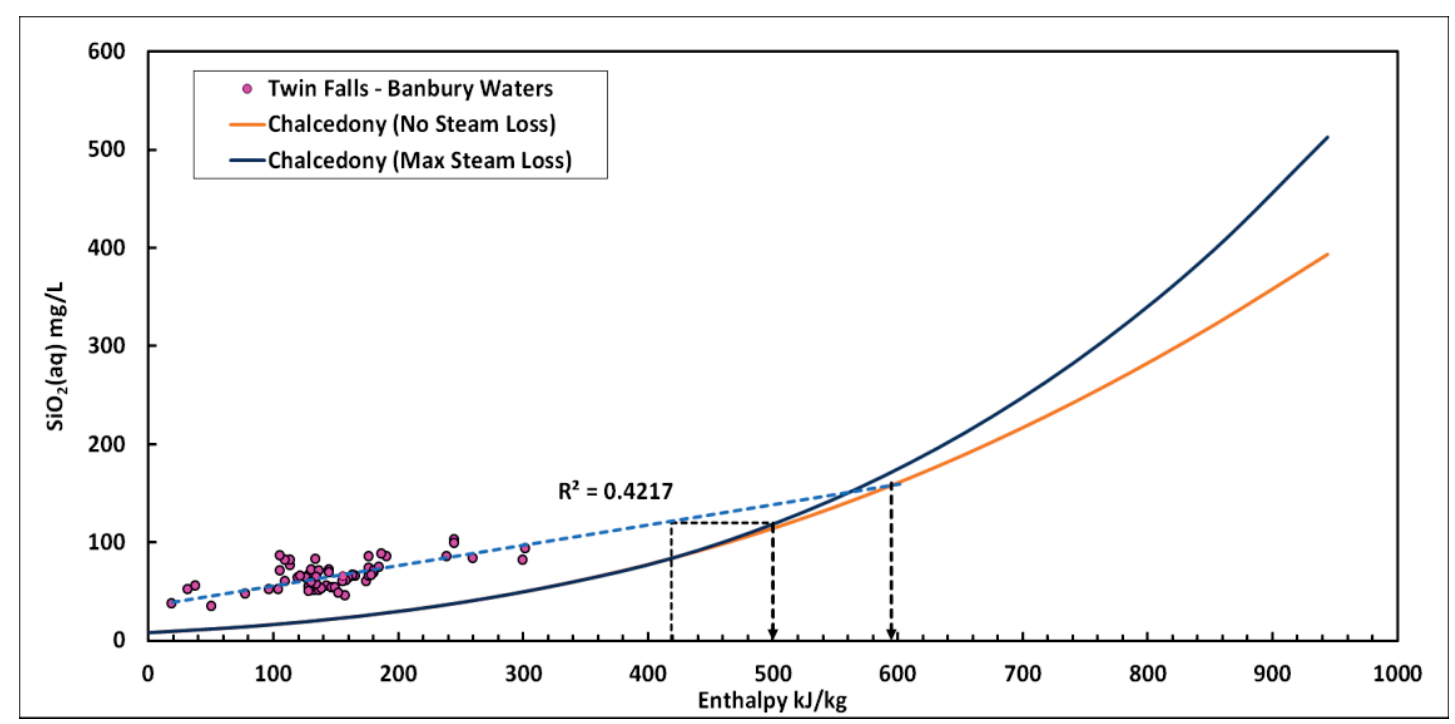

Figure 21. Silica-enthalpy model (chalcedony) applied to the thermal waters of the Twin FallsBanbury system. The trend line (yellow) passes through both end member waters and is projected to the no steam loss line (orange). The intersection of the trend line with the boiling point $(419 \mathrm{~kJ} / \mathrm{kg})$ is projected to the max steam loss line (blue). Temperature estimations are obtained from the resulting two enthalpy values.

\subsection{MEG Analysis of the Twin Falls - Banbury Area}

Recent developments in multicomponent equilibrium geothermometry (MEG) have led to appreciable improvement in the reliability and accuracy of reservoir temperature estimations compared with conventional geothermometry (Spycher et al., 2011; Smith et al., 2012; Neupane et al., 2013, 2014; Palmer et al., 2014; Cannon et al., 2014; Neupane et al., 2015). The concept behind MEG originated in the 1980s (Michard and Roekens, 1983; Reed and Spycher, 1984) and is based on the estimation of reservoir temperature through saturation indices of several minerals likely to be in equilibrium with the thermal water. The use of an entire chemical suite rather than a couple of basis species has an obvious advantage over conventional techniques. While MEG is still affected by the same secondary processes that violate the assumptions of geothermometry (boiling, dilution, etc.), new techniques allow for the correction of these processes if they can be identified. RTEst (Reservoir Temperature 
Estimator) is one such tool that can accomplish these corrections by reconstructing the last equilibrated composition of a given thermal fluid (Palmer et al., 2014; Neupane et al., 2015). Validation of the RTEst tool was demonstrated by Neupane et al. (2015) through the successful matching of estimated reservoir temperatures and actual bottom-hole temperatures of five geothermal power plants.

RTEst uses a likely reservoir mineral assemblage (RMA) in the prediction of the thermal fluid temperature within the reservoir. The reservoir temperature is taken to be the one in which all of the mineral saturation indices are in equilibrium shown by having a summed $\log \left(\mathrm{Q}_{\mathrm{i}} / \mathrm{K}_{\mathrm{i}, \mathrm{T}}\right)$ of zero where $\mathrm{Q}_{\mathrm{i}}$ and $\mathrm{K}_{\mathrm{i}, \mathrm{T}}$ are the ion activity product and temperature dependent equilibrium constant for the $\mathrm{i}^{\text {th }}$ mineral respectively. RTEst accomplishes temperature estimation by utilizing the React module of The Geochemist's Workbench ${ }^{\circledR}$ (Bethke and Yeakel, 2012) in order to model equilibrium conditions among minerals, aqueous species, and gaseous phases with respect to geochemical reactions. RTEst couples the React module with the model-independent optimization software PEST (Doherty, 2013) to optimize parameters including $\mathrm{CO}_{2}$ fugacity, amount of water gained or lost, and temperature. These parameters correspond to secondary alteration processes that affect fluid composition. Through the use of these parameters alone, RTEst is capable of compensating for the effects of boiling and simple (non-reactive mixing). However, if a cooler water end member composition is known, RTEst can "extract" this end member through inverse modeling thereby accounting for reactive mixing.

The equilibrium reservoir temperature is calculated through the minimization of the objective function, $\phi$. The objective function is essentially a weighted sum of squares of the saturation indices of the chosen RMA where RTEst acts to minimize the collective distances 
away from zeros for all saturation indices. The objective function is given by the following equation:

$$
\Phi=\sum\left(S I_{i} w_{i}\right)^{2}
$$

where $S I_{i}$ is the saturation index for the $i^{t h}$ mineral and $w_{i}$ is the weighting factor. The weighting factor $w_{i}$ is based on the number of thermodynamic components within each mineral to ensure that each mineral contributing to equilibrium with the thermal fluid is considered equally and not skewed by reaction stoichiometry (Neupane et al., 2015).

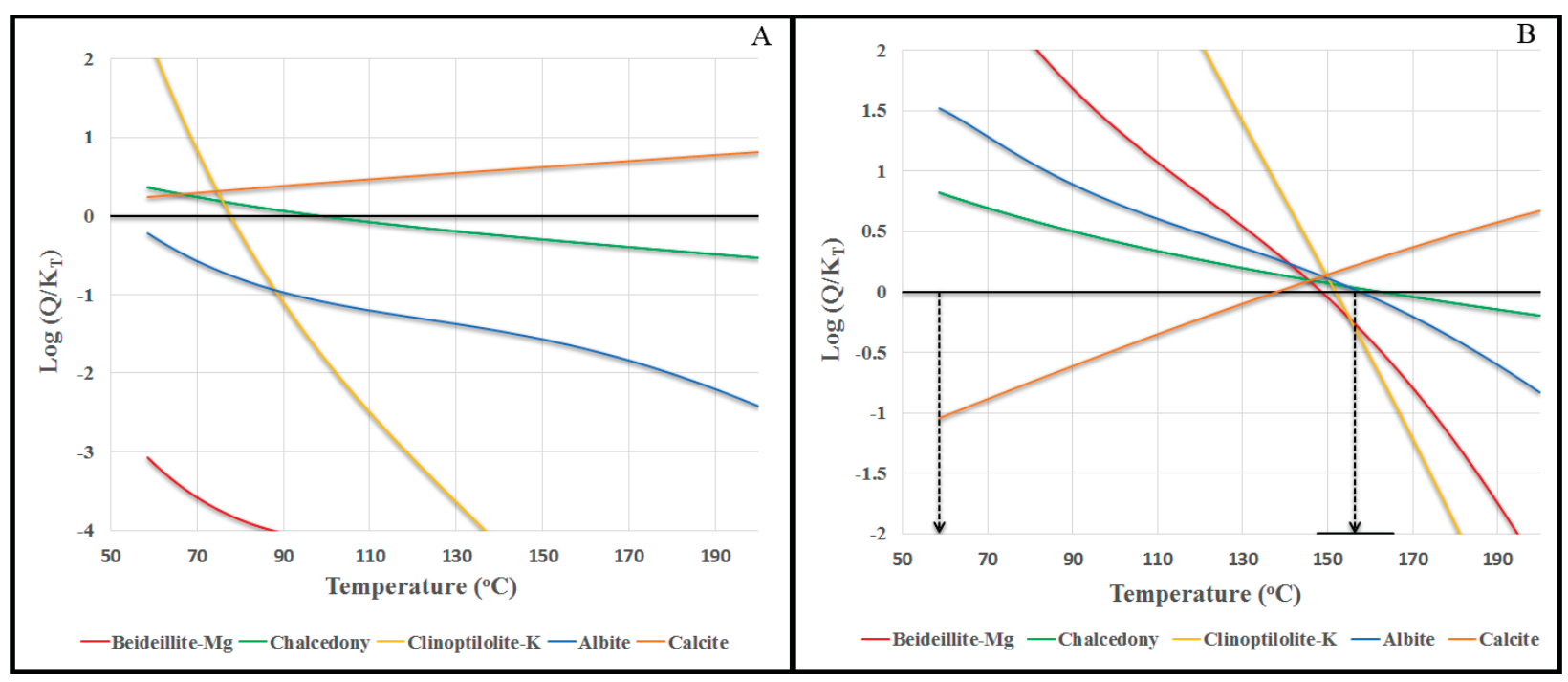

Figure 22. Temperature estimation for Banbury Hot Springs showing the $\log Q / K_{T}$ curves for minerals (Calcite, Chalcedony, Beidellite - Mg, Clinoptilolite-K, and Albite) calculated using original water chemistry. A) Without optimization of $\mathrm{H}_{2} \mathrm{O}$ mass and $\mathrm{CO}_{2}$ fugacity B) Optimized $\log Q / K_{T}$ curves showing field temperature $\left(58.4^{\circ} \mathrm{C}\right)$, estimated temperature $\left(158^{\circ} \mathrm{C}\right)$, and error bar (black bar on $x$ axis).

The reservoir mineral assemblages used here are based on alteration mineral assemblages present in hydrothermally altered basalts and rhyolites. Early work has shown that rock type has less of an effect on geothermal alteration compared with temperature, fluid composition, and permeability (Browne, 1978; Henley and Ellis, 1983). Browne (1978) 
demonstrated that basalts, rhyolites, andesites, and sandstones were all dominated by an alteration mineral assemblage including illite, calcite, pyrite, epidote, k-feldspar, albite, and quartz in the temperature range of $250-285{ }^{\circ} \mathrm{C}$. However, there are important differences between basalt and rhyolitic alteration mineral assemblages particularly at lower $\left(<200{ }^{\circ} \mathrm{C}\right)$ temperatures. At lower temperatures, secondary mineralization within geothermally altered basalts and rhyolites typically includes phyllosilicates, zeolites, oxides, hydroxides, and carbonates (Neuhoff et al., 1999; Weisenberger and Selbekk, 2009; Rodriguez, 2011). As temperatures increase, zones of mixed illite-smectite clays begin to dominate at $200-250{ }^{\circ} \mathrm{C}$, chlorite-epidote at $250-300{ }^{\circ} \mathrm{C}$, and epidote-actinolite at $>300{ }^{\circ} \mathrm{C}$. At temperatures $<200{ }^{\circ} \mathrm{C}$ kaolinite and smectite clays predominate with other minerals including zeolites, quartz and chalcedony, K-feldspar, calcite, and chlorite (Lonker et al., 1993; Larsson et al., 2002).

The main differences in geothermal alteration between basalts and the more silicic rhyolites and andesites are observed in clay mineralogy. Clays formed from the alteration of rhyolites and andesites are more $\mathrm{Na}^{+}$and $\mathrm{K}^{+}$rich compared to those formed in basalts. These clays are typically mixed illite-smectite clays as well as montmorillonites. In addition to being enriched with respect to $\mathrm{Na}^{+}$and $\mathrm{K}^{+}$, alteration clay and zeolites in rhyolites and andesites tend to be more deficient in magnesium due to the low magnesium concentrations within these rock types (Bethke, 1986; Reyes, 1990; Mas et al., 2006).

The alteration minerals particular to this study area were based largely on the work of Sant (2012) who analyzed the alteration minerals within basalt core samples from the Kimberly well of the Project Hotspot (Shervais et al., 2013). This well lies just to the east of the study area in Burley, ID and penetrates the basalts of the upper aquifer system. Of particular importance are the smectite clays observed in core samples from 1042 meters to 
1829 meters (3126 - $5487 \mathrm{ft}$.). Morse and McCurry (2002) also analyzed basalt core samples from the deep aquifer penetrating INEL-1 well located to the northeast of the study area on the Idaho National Laboratory. Both of these studies have attributed the boundary between the upper and lower aquifer systems to the development of these smectite clays. RTEst provides a means of selecting minerals based on five rock types (Tholeitic, Calc-alkaline, Silicic, Siliciclastic, and Carbonates), 3 temperature ranges (low, $50-100{ }^{\circ} \mathrm{C}$; moderate 150 to $300{ }^{\circ} \mathrm{C}$; and high, $>300{ }^{\circ} \mathrm{C}$ ), and two water types (neutral and acidic) based on a review of 48 different geothermal systems (Palmer et al., 2014). Minerals used in this study along with their corresponding weighting factors are listed below in Table 9.

Table 9. Alteration minerals used in RTEst inverse modeling with corresponding weighting factors $\left(\mathrm{W}_{\mathrm{i}}\right)$

\begin{tabular}{|l|l|}
\hline Mineral & $\mathrm{W}_{\mathrm{i}}$ \\
\hline \hline Calcite & $1 / 2$ \\
\hline Chalcedony & 1 \\
\hline Beidellite $\mathrm{Mg}$ & $1 / 6.65$ \\
\hline Kaolinite & $1 / 4$ \\
\hline Clinoptilolite-Ca & $1 / 13$ \\
\hline Clinoptilolite-K & $1 / 14$ \\
\hline Saponite-Na & $1 / 7.33$ \\
\hline Saponite-K & $1 / 7.165$ \\
\hline Illite & $1 / 6.65$ \\
\hline Heulandite & $1 / 7$ \\
\hline Fluorite & $1 / 3$ \\
\hline Talc & $1 / 7$ \\
Muscovite & $1 / 7$ \\
\hline Paragonite & $1 / 7$ \\
\hline
\end{tabular}




\subsection{RTEst Results for the Twin Falls - Banbury Thermal Area}

The following reservoir temperature estimates were made utilizing the MEG tool RTEst in order to both better predict temperatures as compared with more conventional techniques and also test the rationale behind the three mixing scenarios presented in Chapter 1 (Simple Mixing, Flow-Pathway Mixing, and Mixing with Re-equilibration). The inverse modeling performed using RTEst is capable of accounting for both simple mixing and reactive mixing through the removal of a mixing component. Pure water, local groundwater (recharge area), and an idealized intermediate water (based on binary diagram trends) were used in this study as mixing components.

No Mixing

Despite evidence for mixing, the possibility of no mixing was considered in the MEG approach. Allowing only temperature and $\mathrm{CO}_{2}$ fugacity to fluctuate as optimization parameters, adequate convergence of saturation indices was not obtained for either $\mathrm{Ca}-\mathrm{HCO}_{3}$ or $\mathrm{Na}-\mathrm{HCO}_{3}$ type thermal waters using likely alteration mineral assemblages found in basalts and rhyolites. Results were slightly better for $\mathrm{Ca}-\mathrm{HCO}_{3}$ type waters but far from meaningful with objective function $(\phi)$ values greater than or equal to 0.1 .

\section{Simple Mixing}

The possibility of simple mixing between groundwater and thermal waters was considered in RTEst modeling through the use of a $6{ }^{\circ} \mathrm{C}$ recharge area groundwater sample (Sample LY89-38) as the mixing component between the $\mathrm{Ca}-\mathrm{HCO}_{3}$ and $\mathrm{Na}-\mathrm{HCO}_{3}$ type thermal waters. Mixing between groundwater and the $\mathrm{Na}-\mathrm{HCO}_{3}$ type thermal waters is not supported through the use of RTEst as all attempts of modeling this scenario resulted in a lack 
of saturation index convergence for all likely mineral assemblages. However, mixing between groundwater and $\mathrm{Ca}-\mathrm{HCO}_{3}$ type thermal waters is supported through the use of RTEst . Objective function values $(\phi)$ of less than $1 \times 10^{-6}$ are obtained for some waters. These values are better than all previous studies utilizing RTEst in MEG analyses including those which successfully validated actual bottom-hole temperatures of geothermal power plants (Cannon et al., 2014; Neupane et al., 2014; 2015). Simple mixing is also supported through the use of pure water as the mixing component in mixing with $\mathrm{Na}-\mathrm{HCO}_{3}$ type thermal waters.

\section{Flow Pathway Reactive Mixing}

Flow Pathway or reactive mixing was investigated using an "intermediate" composition water created from the binary diagram analysis in Chapter $3 . \mathrm{Na}-\mathrm{HCO}_{3}$ type thermal waters were mixed with water that contained amounts of $\mathrm{K}^{+}, \mathrm{Ca}^{2+}$, and $\mathrm{Mg}^{2+}$ taken from the intersection of the two trends presented in Figure $15 . \mathrm{Na}-\mathrm{HCO}_{3}$ type thermal waters were modelled with waters containing between $0.12-0.15 \mathrm{meq} / \mathrm{kg} \mathrm{K}, 0.5-0.7 \mathrm{meq} / \mathrm{kg} \mathrm{Ca}{ }^{2+}$, and $0.15-0.2 \mathrm{meq} / \mathrm{kg} \mathrm{Mg}^{2+}$. This type of mixing was not supported in the attempts to mix thermal water with this "intermediate" composition as adequate conversion was not attained and temperatures at or near surface temperatures were predicted with standard deviations of temperatures reaching over $+/-150{ }^{\circ} \mathrm{C}$. Additionally, mixing between $\mathrm{Ca}-\mathrm{HCO}_{3}$ and $\mathrm{Na}$ $\mathrm{HCO}_{3}$ type thermal waters is not supported through the use of RTEst. 


\section{Re-equilibration}

The possibility of re-equilibration may be gleaned from the RTEst results. The reconstructed equilibrium water compositions produced by RTEst modeling of the $\mathrm{Ca}-\mathrm{HCO}_{3}$ type thermal waters may be significant in that if the $\mathrm{Ca}-\mathrm{HCO}_{3}$ type thermal waters were the
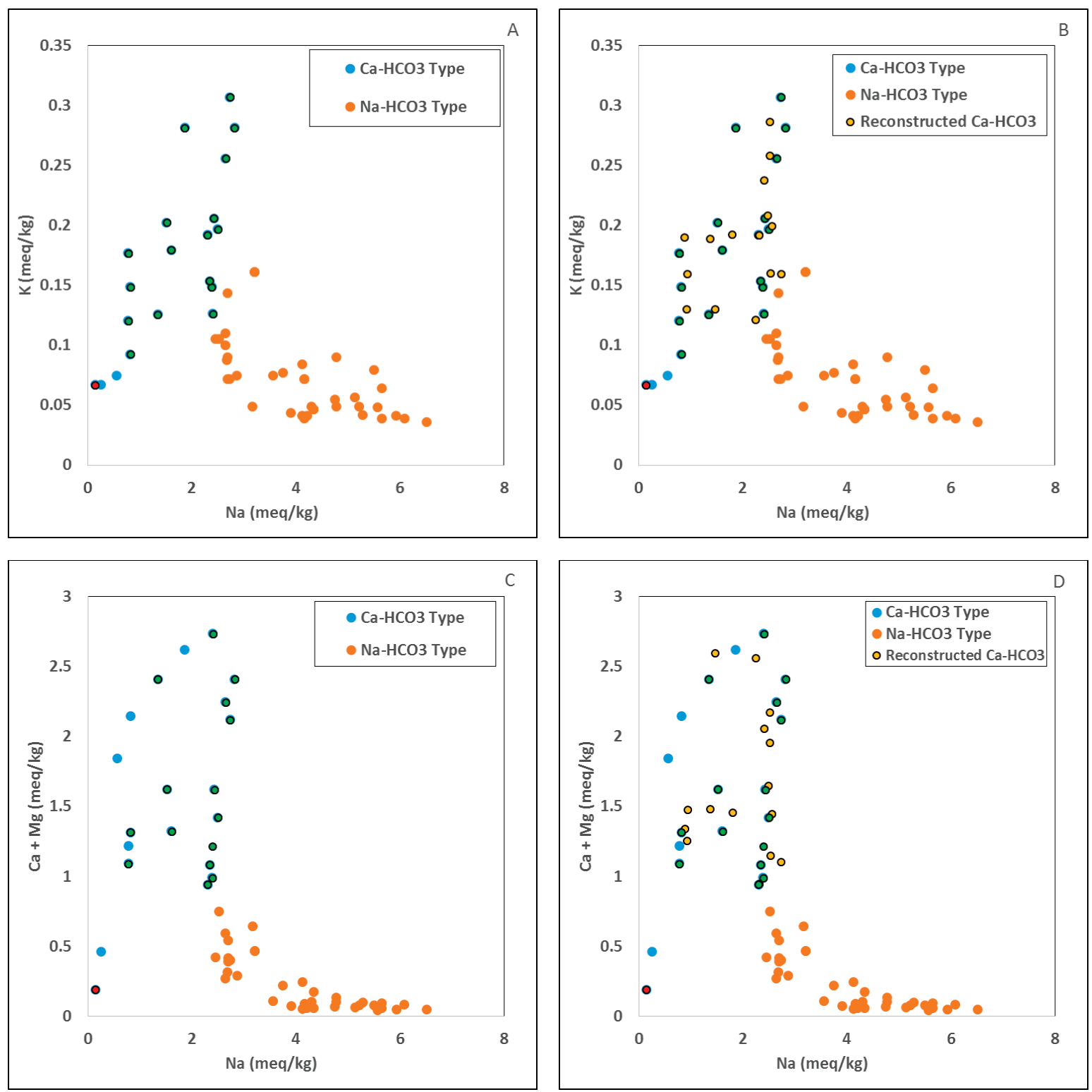

Figure 23. Initial (green) vs MEG reconstructed (yellow) compositions of $\mathrm{Ca}-\mathrm{HCO}_{3}$ thermal waters. $\mathrm{A}$ and $\mathrm{B}$ show the relationship between $\mathrm{Na}^{+}$vs $\mathrm{K}^{+}$while $\mathrm{C}$ and $\mathrm{D}$ show $\mathrm{Ca}^{2+}$ and $\mathrm{Mg}^{2+}$ vs $\mathrm{Na}^{+}$. 
result of simple mixing between groundwater and deep $\mathrm{Na}-\mathrm{HCO}_{3}$ type waters, the reconstructed (optimized) waters would be similar in composition to the $\mathrm{Na}-\mathrm{HCO}_{3}$ type waters and follow the general trends displayed in Figure 15. However, reconstructed water compositions do not resemble $\mathrm{Na}-\mathrm{HCO}_{3}$ waters suggesting that re-equilibration from the Na$\mathrm{HCO}_{3}$ waters to the $\mathrm{Ca}-\mathrm{HCO}_{3}$ is a possibility. The initial and reconstructed water compositions of the $\mathrm{Ca}-\mathrm{HCO}_{3}$ type waters are plotted with respect to $\mathrm{K}^{+}, \mathrm{Ca}^{2+}, \mathrm{Mg}^{2+}$, and $\mathrm{Na}^{+}$ concentrations in Figure 23.

The pure water mixing with $\mathrm{Na}-\mathrm{HCO}_{3}$ type thermal waters mentioned previously also opens up the possibility of re-equilibration in this system. In order for pure water to mix with the deep $\mathrm{Na}-\mathrm{HCO}_{3}$ type thermal waters of the system, a mechanism by which recharge area groundwater transitions into pure or very dilute water prior to mixing may be needed. A reaction in which $\mathrm{Ca}^{2+}$ and $\mathrm{Mg}^{2+}$ concentrations are diminished while $\mathrm{Na}^{+}$concentrations are increased would explain this phenomenon. Cation exchange reactions between alteration clays and zeolites or a precipitation reaction in which cation concentrations are diminished due to falling out of solution may be the driving forces behind this mechanism. Cation exchange reactions are more likely than reactions involving precipitation as precipitation reactions would likely result in a similar decrease of anion concentrations as both cations and anions would drop out of solution together due to the ionic bond formed during precipitation. A series of re-equilibration zones may explain the gradational change in composition from $\mathrm{Na}$ $\mathrm{HCO}_{3}$ to more $\mathrm{Ca}$-rich thermal wares. This re-equilibration mechanism is supported by the apparent relationship between: 
1) Mg-rich smectite clays (Beidellite-Mg) used in the $\mathrm{Ca}-\mathrm{HCO}_{3} \mathrm{RMA}$ and the Na-rich smectite clays (Saponite-Na) used in the $\mathrm{Na}-\mathrm{HCO}_{3} \mathrm{RMA}$. The high cation exchange capacity of smectite clays supports these findings (Carroll, 1954; Robin et al., 2015).

2) Clinoptilolite-Ca (zeolite) used in $\mathrm{Ca}-\mathrm{HCO}_{3} \mathrm{RMA}$ and Clinoptilolite-K used in the Na$\mathrm{HCO}_{3}$ RMA. Cation exchange between these two Clinoptilolite end members is explained by Pabalan and Bertetti (2001).

RTEst modeling of $\mathrm{Na}_{-} \mathrm{HCO}_{3}$ type thermal waters mixing with pure water yields temperature estimates ranging from $108{ }^{\circ} \mathrm{C}$ to $160{ }^{\circ} \mathrm{C}$. These results are in agreement with sulfate-water isotope geothermometry estimates of $150{ }^{\circ} \mathrm{C}$ for Banbury Hot Springs (Conrad et al., 2015). Modeling of $\mathrm{Ca}-\mathrm{HCO}_{3}$ type thermal waters mixing with local groundwater yields temperature estimates ranging from $84{ }^{\circ} \mathrm{C}$ to $104{ }^{\circ} \mathrm{C}$. These results may either constitute evidence for two distinct flow paths and equilibration temperatures resulting in the two water types or relationship between the two waters defined by a re-equilibration. Possible conceptual models resulting from geothermometry results will be discussed in detail in Chapter 5. Below are the RTEst temperature estimations and mineral assemblages for both $\mathrm{Ca}-\mathrm{HCO} 3$ and $\mathrm{Na}-\mathrm{HCO} 3$ type thermal waters. 
Table 10. RTEst temperature estimates (a), mass of thermal water component per $1 \mathrm{~kg}$ solution used in mixing (c), log of $\mathrm{CO}_{2}$ fugacity, RTEst objective function $(\Phi)$, selected RMAs, and (b) associated standard deviations of each measurement.

\begin{tabular}{|c|c|c|c|c|c|c|}
\hline \multicolumn{7}{|c|}{ Na-HCO3 Type Water RTEst Results - Pure Water Mixing } \\
\hline Site ID & Name & $\mathrm{T}^{\mathrm{a}} \pm \sigma^{\mathrm{b}}$ & $\mathrm{M}^{\mathrm{c}} \mathrm{H}_{2} \mathrm{O} \pm \sigma^{\mathrm{b}}$ & $\log f_{\mathrm{CO}_{2}} \pm \sigma^{b}$ & $\phi$ & RMA \\
\hline CC-11 & Miracle Hot Springs & $160 \pm 2.5$ & $0.49 \pm 0.01$ & $-0.56 \pm 0.058$ & $1.23 \mathrm{E}-4$ & Beidellite-Mg, Calcite, Chalcedony, Clinoptilolite-K, Paragonite \\
\hline CC-14 & CSI Well 2 & $136 \pm 11$ & $0.43 \pm 0.06$ & $-0.23 \pm 029$ & $2.05 \mathrm{E}-3$ & Saponite-K, Calcite, Chalcedony, Clinoptilolite-Ca, \\
\hline CC-40 & 1000 Springs (Sliger's Well) & $134 \pm 2.1$ & $0.34 \pm 0.005$ & $-0.1 \pm 0.051$ & 2.93E-4 & Calcite, Chalcedony, Illite, Paragonite, Heulandite, Fluorite \\
\hline CC-42 & Banbury Hot Springs & $158 \pm 9$ & $0.49 \pm 0.04$ & $-0.26 \pm 0.21$ & $2.25 \mathrm{E}-3$ & Beidellite-Mg, Calcite, Chalcedony, Clinoptilolite-K, Albite \\
\hline CC-45 & Leo Ray Hill & $121 \pm 6$ & $0.46 \pm 0.02$ & $-0.4 \pm 0.14$ & $2.34 \mathrm{E}-3$ & Saponite-Na, Calcite, Chalcedony, Clinoptilolite-K, Paragonite \\
\hline CC-46 & Leo Ray Road & $120 \pm 1$ & $0.48 \pm 0.045$ & $-0.31 \pm 0.02$ & $5.15 \mathrm{E}-5$ & Saponite-Na, Calcite, Chalcedony, Clinoptilolite-K, Paragonite \\
\hline CC-48 & Hensley Well & $134 \pm 17$ & $0.52 \pm 0.09$ & $-0.36 \pm 0.47$ & $8.28 \mathrm{E}-3$ & Beidellite-Mg, Calcite, Chalcedony, Clinoptilolite-K, Paragonite \\
\hline CC-51 & CSI Well 1 & $134 \pm 11$ & $0.42 \pm 0.06$ & $-0.14 \pm 0.3$ & $2.28 \mathrm{E}-3$ & Calcite, Chalcedony, Clinoptilolite-Ca, Saponite-K \\
\hline CC-52 & Larry Anderson Well & $108 \pm 3$ & $0.73 \pm 0.09$ & $-1.5 \pm 0.09$ & $5.75 \mathrm{E}-4$ & Saponite-Na, Calcite, Chalcedony, Fluorite, Talc \\
\hline CC-53 & Pristine Springs & $130 \pm 10$ & $0.54 \pm 0.08$ & $-0.92 \pm 0.3$ & $2.18 \mathrm{E}-3$ & Saponite-Na, Calcite, Chalcedony, Fluorite, Talc \\
\hline CC-55 & Anderson Campground Well & $123 \pm 3$ & $0.56 \pm 0.01$ & $-0.77 \pm 0.07$ & 7.43E-4 & Beidellite-Mg, Calcite, Chalcedony, Clinoptilolite-K, Paragonite \\
\hline
\end{tabular}

\begin{tabular}{|c|c|c|c|c|c|}
\hline \multicolumn{5}{|c|}{ Ca-HCO3 Type Water RTEst Results - Groundwater Mixing } \\
\hline Site ID & $T^{\mathrm{a}} \pm \sigma^{\mathrm{b}}$ & $\mathrm{M}^{\mathrm{c}} \mathrm{H}_{2} \mathrm{O} \pm \sigma^{\mathrm{b}}$ & $\log f_{\mathrm{Co}_{2}} \pm \sigma^{\mathrm{b}}$ & \multicolumn{1}{c|}{ RMA } & \\
\hline CC-9 (Campbell Well 1) & $95 \pm 0.46$ & $0.97 \pm 0.005$ & $-1.17 \pm 0.01$ & $1.95 \mathrm{E}-05$ & Beidellite-Mg, Calcite, Chalcedony, Kaolinite, Clinoptilolite-Ca \\
\hline CC-54 (Twin Falls High School) & $93 \pm 0.27$ & $0.97 \pm 0.003$ & $-1.25 \pm 0.007$ & $6.48 \mathrm{E}-06$ & Beidellite-Mg, Calcite, Chalcedony, Kaolinite, Clinoptilolite-Ca \\
\hline LY82-13 & $1.0 \pm 0.01$ & $-1.32 \pm 0.06$ & $4.11 \mathrm{E}-04$ & Beidellite-Mg, Calcite, Chalcedony, Muscovite, Clinoptilolite-Ca \\
\hline LY89-3 & $98 \pm 0.91$ & $1.0 \pm 0.04$ & $-1.06 \pm 0.02$ & $7.35 \mathrm{E}-05$ & Beidellite-Mg, Calcite, Chalcedony, Kaolinite, Clinoptilolite-Ca \\
\hline LY89-5 & $94 \pm 0.58$ & $0.86 \pm 0.006$ & $-1.16 \pm 0.01$ & $2.95 \mathrm{E}-05$ & Beidellite-Mg, Calcite, Chalcedony, Kaolinite, Clinoptilolite-Ca \\
\hline LY89-6 & $97 \pm 0.59$ & $0.91 \pm 0.009$ & $-1.13 \pm 0.02$ & $3.06 \mathrm{E}-05$ & Beidellite-Mg, Calcite, Chalcedony, Kaolinite, Clinoptilolite-Ca \\
\hline LY89-7 & $104 \pm 1.1$ & $0.98 \pm 0.012$ & $-1.04 \pm 0.03$ & $9.67 \mathrm{E}-05$ & Beidellite-Mg, Calcite, Chalcedony, Kaolinite, Clinoptilolite-Ca \\
\hline LY89-10 & $84 \pm 2.1$ & $1.0 \pm 0.02$ & $-1.23 \pm 0.04$ & $4.08 \mathrm{E}-04$ & Beidellite-Mg, Calcite, Chalcedony, Kaolinite, Clinoptilolite-Ca \\
\hline LY89-17 & $88 \pm 1.5$ & $1.0 \pm 0.008$ & $-1.21 \pm 0.02$ & $2.01 \mathrm{E}-04$ & Beidellite-Mg, Calcite, Chalcedony, Kaolinite, Clinoptilolite-Ca \\
\hline LY89-18 & $88 \pm 1.3$ & $1.0 \pm 0.008$ & $-1.20 \pm 0.02$ & $1.72 \mathrm{E}-04$ & Beidellite-Mg, Calcite, Chalcedony, Kaolinite, Clinoptilolite-Ca \\
\hline LY89-34 & $89 \pm 0.61$ & $0.88 \pm 0.002$ & $-1.29 \pm 0.003$ & $3.44 \mathrm{E}-05$ & Beidellite-Mg, Calcite, Chalcedony, Kaolinite, Clinoptilolite-Ca \\
\hline LY89-35 & $89 \pm 0.69$ & $0.88 \pm 0.011$ & $-1.33 \pm 0.02$ & $4.66 \mathrm{E}-05$ & Beidellite-Mg, Calcite, Chalcedony, Kaolinite, Clinoptilolite-Ca \\
\hline LY89-36 & $91 \pm 0.31$ & $0.86 \pm 0.0006$ & $-1.37 \pm 0.001$ & $9.36 \mathrm{E}-06$ & Beidellite-Mg, Calcite, Chalcedony, Kaolinite, Clinoptilolite-Ca \\
\hline M91-12 & $98 \pm 1.60$ & $0.84 \pm 0.018$ & $-1.33 \pm 0.03$ & $2.34 \mathrm{E}-04$ & Beidellite-Mg, Calcite, Chalcedony, Kaolinite, Clinoptilolite-Ca \\
\hline & $80 \pm 1.23$ & $0.91 \pm 0.02$ & $-1.54 \pm 0.04$ & $1.35 \mathrm{E}-04$ & Beidellite-Mg, Calcite, Chalcedony, Kaolinite, Clinoptilolite-Ca \\
\hline
\end{tabular}




\section{CHAPTER 5: CONEPTUAL MODELS FOR THE TWIN FALLS -}

\section{BANBURY HYDROTHERMAL SYSTEM}

The following section details the competing possible conceptual models for the Twin Falls-Banbury hydrothermal system and provides evidence for the dismissal of all but one. Four conceptual models based on the previously defined mixing scenarios are presented herein. Results from chemical analyses, mixing analyses, reservoir temperature predictions, and regional geology are utilized to support or dismiss these models.

\subsection{No Mixing Conceptual Model}

Mixing between local groundwater and thermal waters is supported by the partial equilibration and immature classifications of thermal waters made by the Giggenbach ternary diagram, the linear relationships between conservative species chloride and boron, and the linear relationship between ${ }^{18} \mathrm{O}$ and Deuterium. Mixing has been attributed as a possible explanation for the masking of geothermal signatures throughout the ESRP (McLing et al., 2002; Neupane et al., 2014; Dobson et al., 2015). However, the possibility that no mixing occurs in this system is considered unlikely due to inadequate (high) $\Phi$ value for both Ca$\mathrm{HCO}_{3}$ and $\mathrm{Na}-\mathrm{HCO}_{3}$ thermal waters using only temperature and $\mathrm{CO}_{2}$ fugacity as optimization parameters.

\subsection{Simple Mixing Conceptual Model}

The idea of simple mixing is supported by gradational trends exhibited by some chemical constituents $\left(\mathrm{Cl} / \mathrm{B},{ }^{18} \mathrm{O} / \mathrm{D},{ }^{18} \mathrm{O} / \mathrm{Cl}, \mathrm{Na} / \mathrm{Cl}, \mathrm{Na} / \mathrm{SiO}_{2}\right.$, etc. $)$ and is accounted for by silica-enthalpy mixing diagrams in Chapter 4. RTEst modeling of mixing between recharge area groundwater and $\mathrm{Ca}-\mathrm{HCO}_{3}$ type thermal water supports simple mixing between these 
two components (Table 10). However, trends exhibited in the relationships between $\mathrm{Na}^{+}, \mathrm{K}^{+}$, $\mathrm{Ca}^{2+}$, and $\mathrm{Mg}^{2+}$ among $\mathrm{Na}-\mathrm{HCO}_{3}$ and $\mathrm{Ca}-\mathrm{HCO}_{3}$ thermal waters suggest that either some reaction has taken place in addition to mixing or that the two water types are representative of two distinct flow paths. Simple mixing between local groundwater and $\mathrm{Na}-\mathrm{HCO}_{3}$ type thermal waters is not supported by MEG modeling through RTEst while the use of pure water as the mixing component is supported. Simple mixing with pure water may be explained by dilution through precipitation as thermal water is rapidly mixed at the surface as is the case in conventional mixing models (Fournier, 1977; Arnorsson, 1985). While this concept may hold up for thermal springs, it does not provide a mechanism by which pure water is mixed with $\mathrm{Na}-\mathrm{HCO}_{3}$ thermal waters in deep wells.

\subsection{Reactive Mixing}

In order for pure water or dilute $\mathrm{Na}-\mathrm{HCO}_{3}$ water (as discussed in Chapter 4) to mix with thermal $\mathrm{Na}-\mathrm{HCO}_{3}$ type waters of the deep system, there must either be 1) a flow pathway by which pure water from precipitation infiltrates directly into the deep system and mixes with thermal water or 2) a mechanism by which $\mathrm{Ca}-\mathrm{Mg}-\mathrm{HCO}_{3}$ type groundwater gradationally transitions into dilute $\mathrm{Na}-\mathrm{HCO}_{3}$ water during infiltration. For these reasons, a conceptual model with and without re-equilibration are investigated. Recharge area groundwater is thought to pick up its enriched $\mathrm{Ca}^{+}$and $\mathrm{Mg}^{2+}$ signature from the Paleozoic (Pennsylvanian and Permian) marine sediments that are exposed at the surface in the mountainous recharge area to the southeast of Buhl, ID (Lewis and Young, 1989; Mariner et al., 1997). While all nonthermal groundwater samples in between the recharge area and both the Twin Falls and Banbury hydrothermal areas are $\mathrm{Ca}-\mathrm{HCO}_{3}$ in type, the regional geology supports the possibility of a flow path for precipitation directly into the Idavada volcanics which are also 
exposed in the hills to the south of the study area. The depth and extent of the Paleozoic carbonates is largely unknown although over 1,524 meters $(5,000 \mathrm{ft}$.) sections of carbonate sediments are reported in the mountains of northern Nevada (Schroeder, 1912). Additionally, lead isotope data from thermal waters in the study area provide a carbonate signature providing evidence that carbonates persist beneath the Idavada volcanics throughout the study area (Mariner et al., 1997)

While the possibility exists for a rhyolite exclusive flow pathway, the likelihood of pure water remaining dilute from the surface to depths up to $3 \mathrm{~km}$ (Lewis and Young, 1989) is not favorable. Data from many natural geothermal systems shows that local equilibria between fluid and host rock is attained at temperatures as low as $50{ }^{\circ} \mathrm{C}$ (Arnórsson et al., 1983; Stefánsson and Arnórsson, 2002). Pure water from precipitation would likely obtain a similar signature to that of the deep $\mathrm{Na}-\mathrm{HCO}_{3}$ thermal waters having flowed through rhyolites to extensive depths. Without the possibility of re-equilibration at a lower temperature, it would follow that an increase in the fraction of thermal water component in MEG analysis would result in higher temperature estimations. This is not found to be the case as can be seen in the RTEst results presented in Chapter 4, Table 10. For instance, Miracle Hot Springs has a predicted reservoir temperature of $160{ }^{\circ} \mathrm{C}$ with an optimized thermal water component of 0.49 whereas the Larry Anderson Well has an optimized thermal composition comprised of 73\% thermal water at $130{ }^{\circ} \mathrm{C}$.

\subsection{Re-equilibration}

The gradational transition between $\mathrm{Na}-\mathrm{HCO}_{3}$ type thermal waters of the deep system to more $\mathrm{Ca}-\mathrm{HCO}_{3}$ type thermal waters nearer to the surface is found throughout the ESRP (Mann, 1986; McLing et al., 2002;). A re-equilibration mechanism may explain this 
relationship. As shown in the Figure 24 below, a mechanism by which $\mathrm{Ca}^{2+}$ and $\mathrm{Mg}^{2+}$ are diminished with increasing temperature and depth while $\mathrm{Na}+$ concentrations rise explains the rationale behind pure water or dilute $\mathrm{Na}-\mathrm{HCO}_{3}$ water mixing. Conversely, the reduction of $\mathrm{Na}+$ and rise of $\mathrm{Ca}^{2+}$ and $\mathrm{Mg}^{2+}$ during ascension may explain the transition between deep Na$\mathrm{HCO}_{3}$ thermal waters to more $\mathrm{Ca}-\mathrm{HCO}_{3}$ type thermal waters through re-equilibration. This mechanism is supported by the apparent exchange between $\mathrm{Ca}^{2+}$ and $\mathrm{K}^{+}$rich zeolites and $\mathrm{Na}^{+}$ and $\mathrm{Mg}^{2+}$ rich smectite clays. For the reasons mentioned in this chapter, a conceptual model including re-equilibration is the most likely. However, the possibility of two flow paths and equilibration temperatures resulting in the two observed thermal water types cannot be ruled out.

Figure 24 shows a cross sectional view of regional geology from the recharge area in the Cassia Mountains to Banbury Hot Springs. Suggested possible flow pathways, water types, and a re-equilibration mechanism are also represented and explained through the 4 stages listed below. This cross section was created from available well log data and local geologic maps (Gillerman et al., 2005; Othberg et al. 2005). Figure 25 shows the location of the cross section line in map view. 


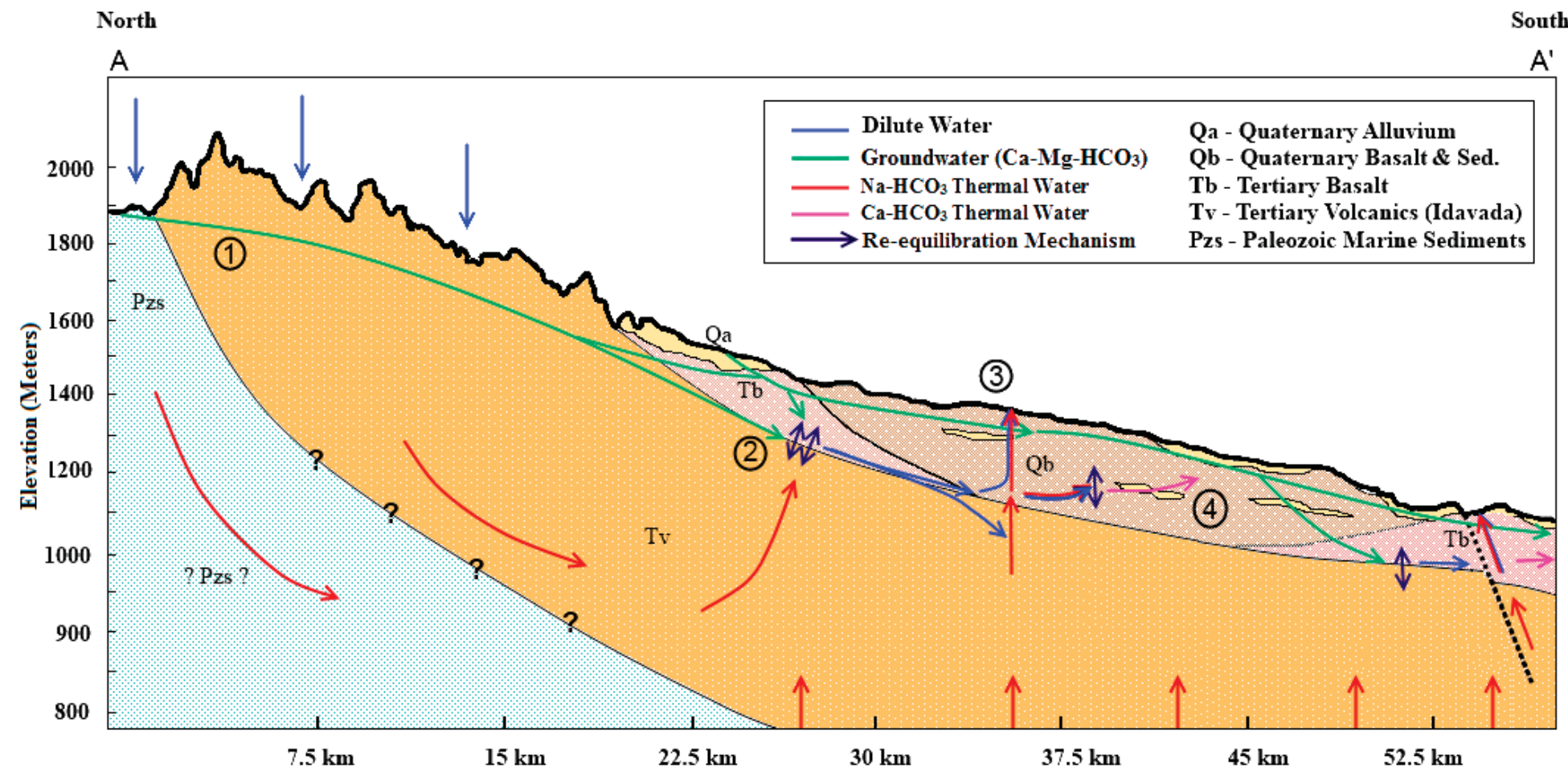

Figure 24. Conceptual model for the Twin Falls - Banbury thermal area showing possible flow pathways, water types, regional geology, and possible re-equilibration mechanism.

1) Precipitation infiltrates into the subsurface likely picking up $\mathrm{Ca}-\mathrm{Mg}-\mathrm{HCO}_{3}$ signature from Paleozoic carbonates.

2) The mixing of $\mathrm{Ca}-\mathrm{Mg}-\mathrm{HCO}_{3}$ groundwater with $\mathrm{Na}-\mathrm{HCO}_{3}$ thermal water at intermediate temperature and depth. Reequilibration (purple arrows) results in the loss of $\mathrm{Ca}^{2+}$ and $\mathrm{Mg}^{2+}$ and the gaining of $\mathrm{Na}^{+}$resulting in dilute $\mathrm{Na}-\mathrm{HCO}_{3}$ water.

3) $\mathrm{Na}-\mathrm{HCO}_{3}$ thermal water mixes with dilute water during ascension resulting in the manifestation of mixed $\mathrm{Na}-\mathrm{HCO}$ thermal water at the surface.

4) An alternate flow path through basalt results in the re-equilibration of $\mathrm{Na}-\mathrm{HCO}_{3}$ thermal water into $\mathrm{Ca}-\mathrm{HCO}_{3}$ thermal water. 


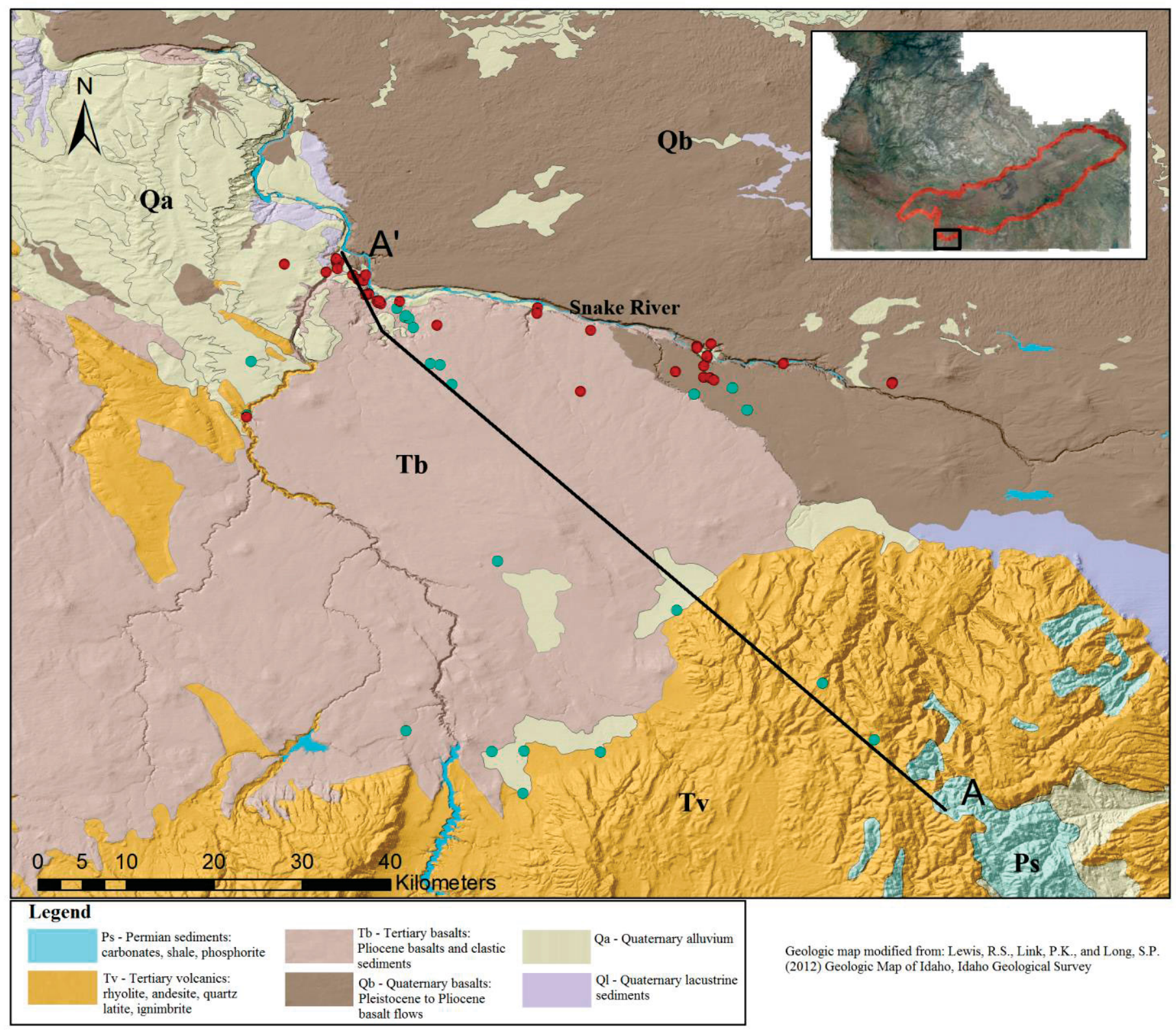

Figure 25. Cross sectional line of Figure 24 with geologic units and water type distribution (Red: $\mathrm{Na}-\mathrm{HCO}_{3}, \mathrm{Blue:} \mathrm{Ca}_{-} \mathrm{HCO}_{3}$ ) 


\subsection{Hydrogeology}

Thermal water in the Banbury hydrothermal area seems to be structurally controlled with the majority of thermal surface manifestations located along a single northwest trending normal fault associated with Basin and Range extension (Street and DeTar, 1987; Lewis and Young, 1989). According to the Idaho Geological Survey, most of the normal faults within the study area are contained within the units of the Idavada volcanics and do not offset the overlying younger basalts (Othberg et al., 2012). The normal fault near the cluster of Na$\mathrm{HCO}_{3}$ thermal waters near Banbury Hot Springs appears to be one of the exceptions. Offset to both overlying Quaternary and Tertiary basalts (Banbury basalt) is shown in a nearly $2 \mathrm{~km}$

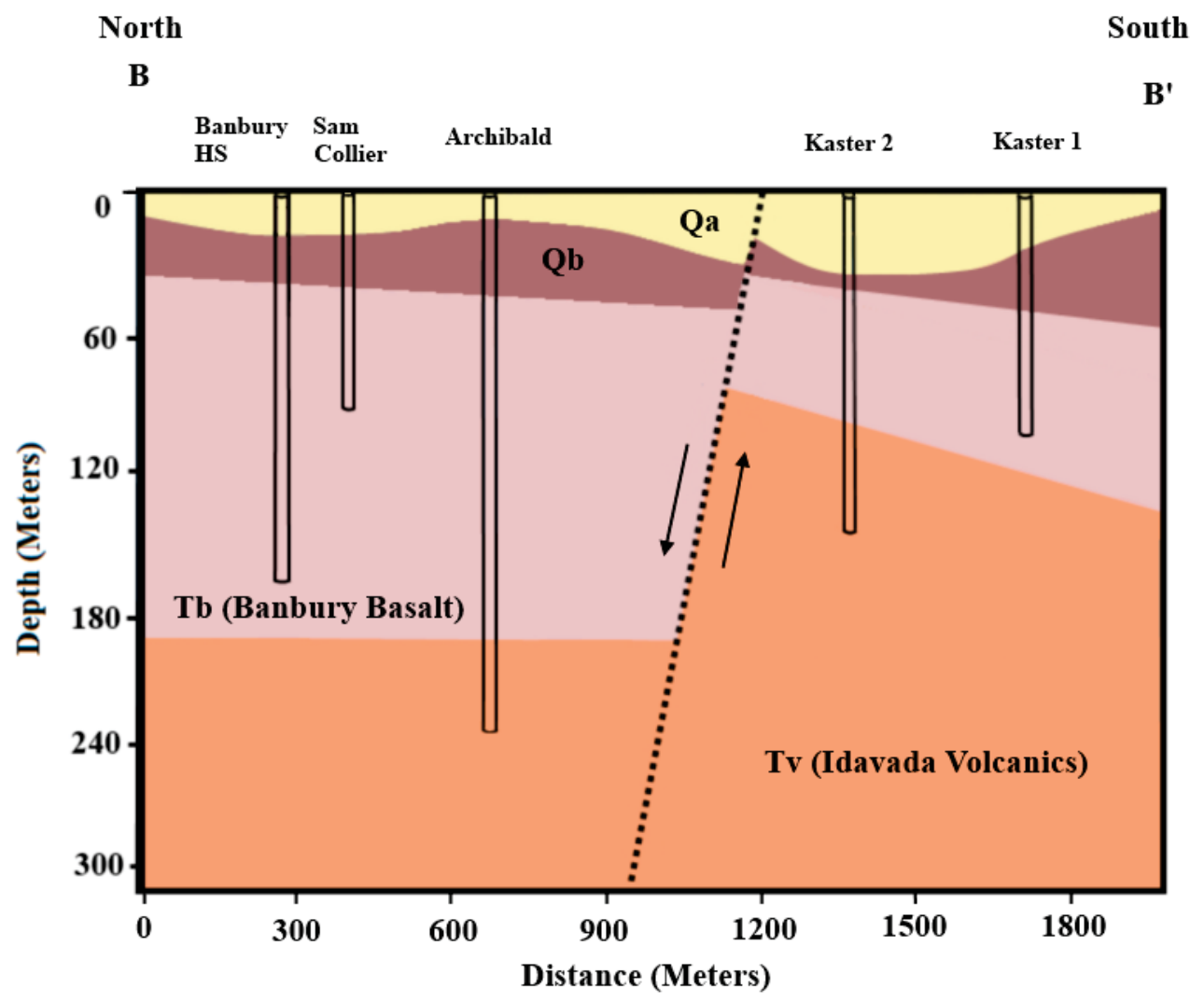

Figure 26. Geologic cross section through the Banbury Hot Springs area. 
long cross section which cuts across the fault in this area. As discussed in Chapter 3, Ca$\mathrm{HCO}_{3}$ type thermal waters are more prevalent southward towards the area of recharge and within wells completed within basalts. A possible explanation for the spatial distribution of the two thermal waters is that the $\mathrm{Ca}-\mathrm{HCO}_{3}$ type thermal waters are found in areas where faults are constrained within Idavada volcanic units thus allowing for increased residence times and re-equilibration into $\mathrm{Ca}-\mathrm{HCO}_{3}$ type waters within basalt as shown in Figure 24 . Logs of wells used in cross section construction are available in Appendix D.

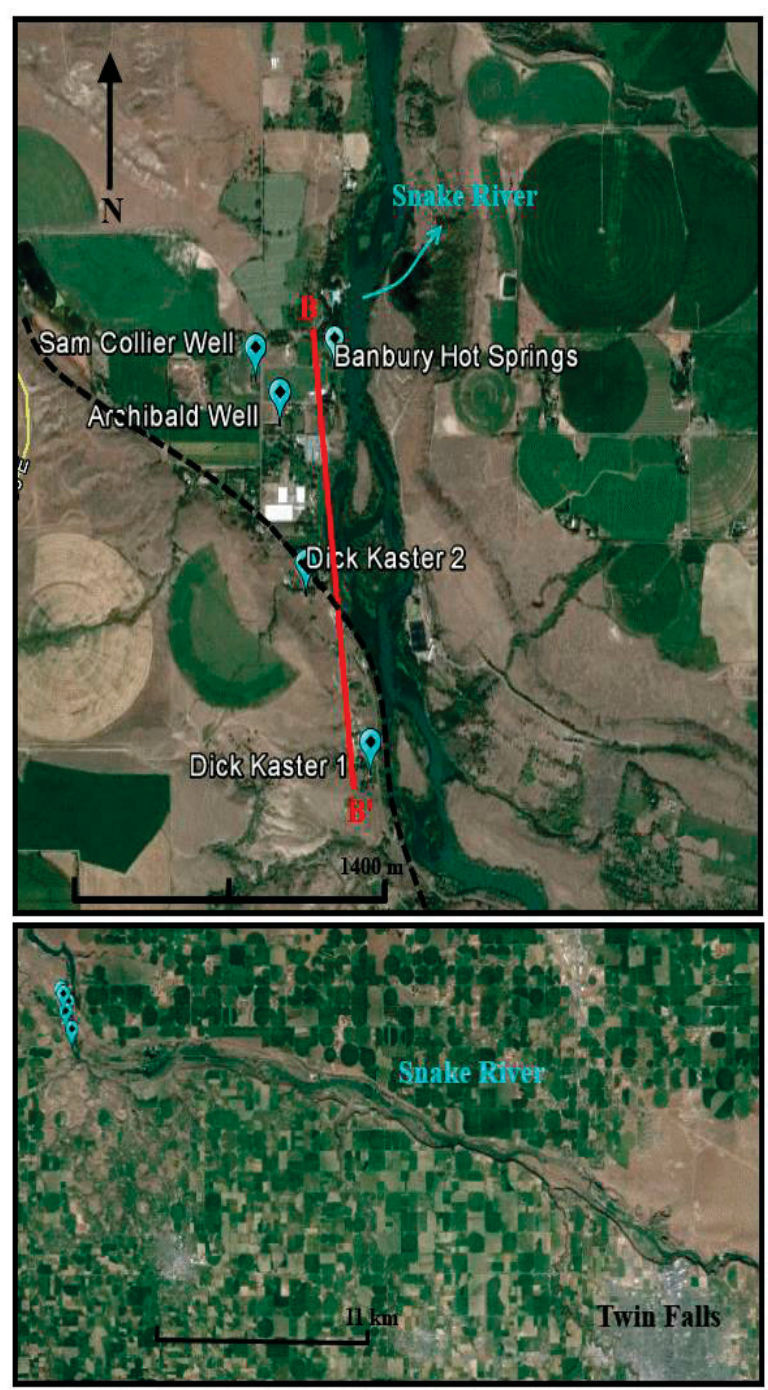

Figure 27. (Top Map of the cross section line through the Banbury area. (Bottom) Reference map. 
A similar transition from $\mathrm{Ca}-\mathrm{HCO}_{3}$ thermal waters to $\mathrm{Na}-\mathrm{HCO}_{3}$ thermal waters away from the zone of recharge is observed in the cluster of thermal expressions near the city of Twin Falls, ID. However, there is no evidence for a fault-controlled system like the one observed in the Banbury area. Figure 28 depicts the local geology of the area in cross section view with no apparent offset. Shervais et al. (2013) suggests that upflow zones in this area may be controlled by permeability associated with a buried caldera margin. The concentration of hotter $\mathrm{Na}-\mathrm{HCO}_{3}$ type waters near the Snake River where units of Idavada volcanics are exposed shows that thermal water occurrence may be controlled by thinning basalt units. Aside from the lack of faulting in the Twin Falls area, the other major difference in geology from the Banbury area are the presence of the Shoshone Falls Rhyolite (andesite unit of the Idavada volcanics) and a significant layer of lacustrine sediments above the rhyolites of the

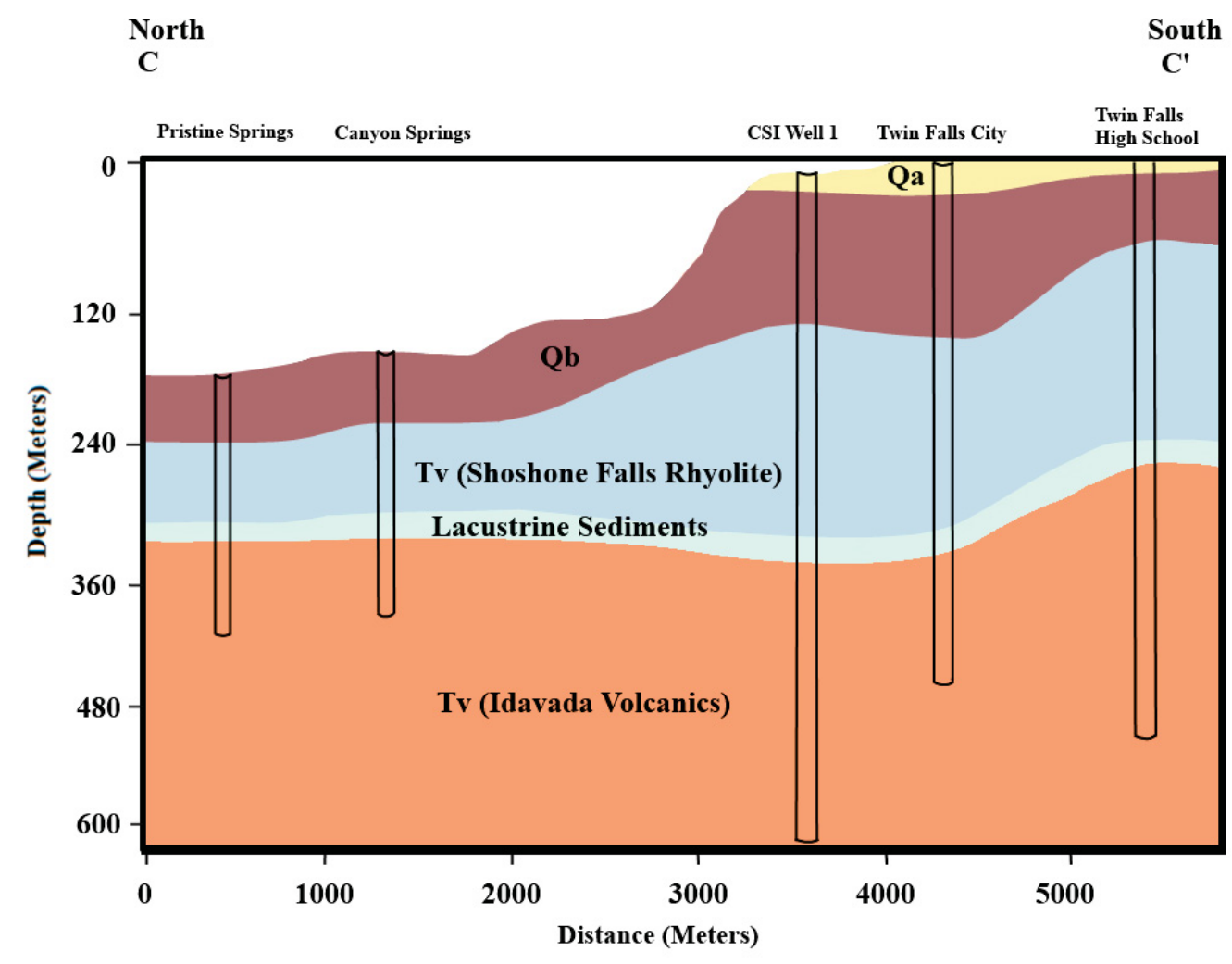

Figure 28. Geologic cross section through the Twin Falls thermal area. 
Idavada volcanics. The lacustrine sedimentary layer comprised of oolitic siltsone and claystone (Street and DeTar, 1987) may serve as the confining layer for the artesian thermal aquifer in this area.
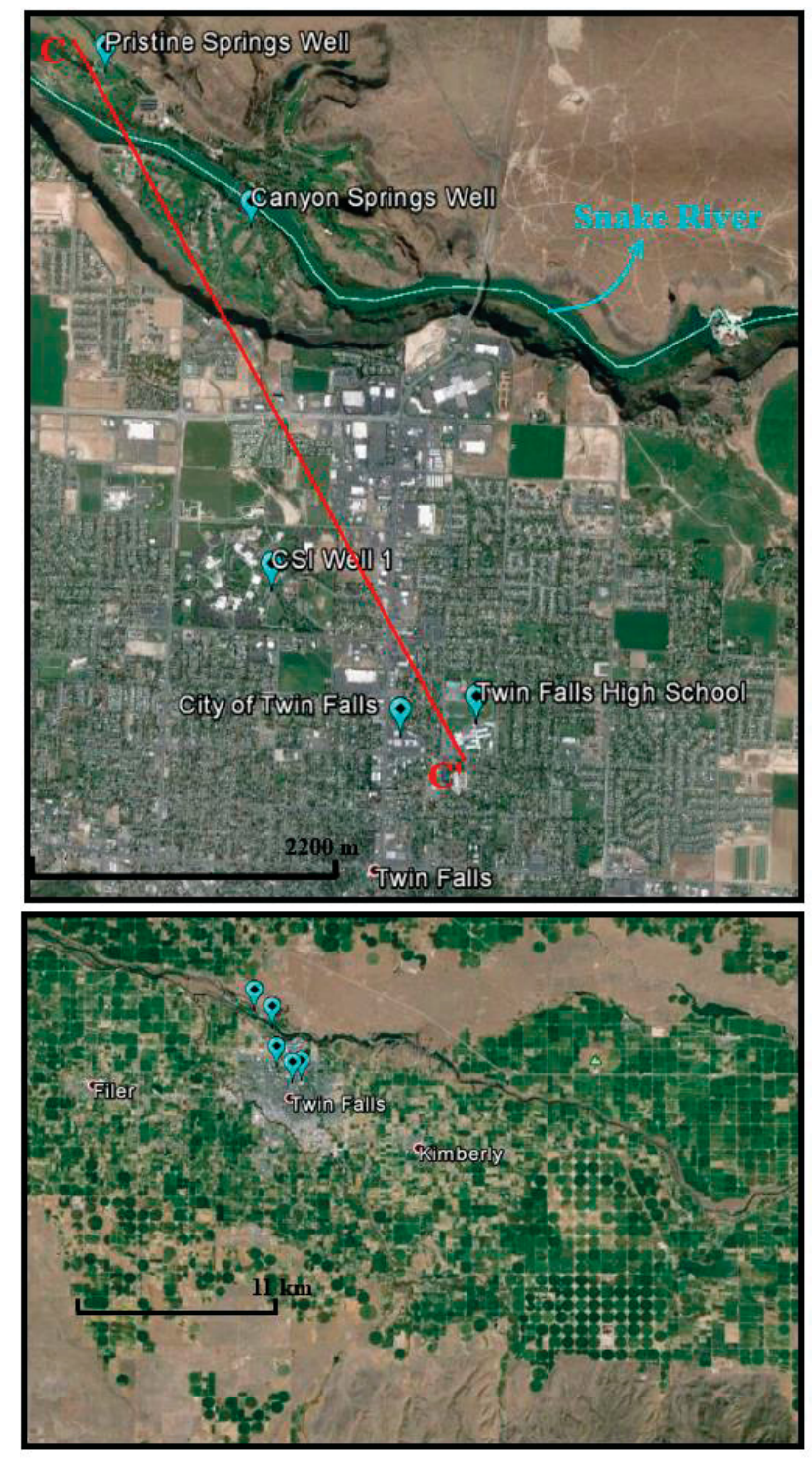

Figure 29. (Top) Map of the cross section line through the Twin Falls area. (Bottom) Reference map. 


\section{Aquifer Test and Analysis}

As discussed previously, flow pathways and residence times may be very important in allowing for re-equilibration from $\mathrm{Na}-\mathrm{HCO}_{3}$ type waters into more Ca-rich thermal waters Declines in hydraulic head in the Twin Falls - Banbury area have been observed for over thirty years (Lewis and Young, 1982; 1989; Street and DeTar, 1987) due to increased utilization of the resource with several areas showing hydraulic heads below land surface. Monitoring of thermal wells in the study area revealed that the Twin Falls and Banbury hydrothermal areas are interconnected with development and increased utilization in one area resulting in declines in the other. Flow throughout the aquifer is thought to be controlled primarily by fractures resulting from tectonic movement, cooling joints, porosity of nonwelded ash flow tuff units, and contacts between successive flows (Street and DeTar, 1987).

Aquifer parameters of the rhyolites of the Idavada volcanics were estimated first in 1982 through a pumping test of two of the deeper wells in the area (CSI 1 and 2) performed by CH2M Hill. CSI 1 and 2 (2200 and $1480 \mathrm{ft}$. deep) are geothermal wells used for spaceheating located on the campus of the College of Southern Idaho and were sampled for chemical analysis (CC-51 and CC-14) as part of this study in 2014. While water temperatures seem to have remained constant $\left(37^{\circ} \mathrm{C}\right)$ since drilling was completed in 1979 , a significant decline in hydraulic head has been observed. Street and DeTar (1987) reported hydraulic head values around 14 meters above land surface. Both of these wells are no longer flowing artesian with water levels of about 1.2 meters below land surface at present day. Due to the observed decline in water levels and the erroneous listing of CSI 1 at $1191 \mathrm{ft}$. deep (cased portion of the well) in the initial pump test report, a new pump test was conducted for both 
CSI wells from $9 / 1 / 15-9 / 5 / 15$ in an effort to establish a vertical gradient and thermal water travel times..

A 24-hr drawdown test and a 24-hr recovery test were performed for both wells. Pumping of CSI 2 began at 10:00 AM on 9/1/15 and continued until 10:00 AM on 9/2/15 after which it was allowed to recover for a full 24 hours. CSI 1 was pumped immediately after the recovery test of CSI 2 beginning around 10:00 AM on 9/3/15 continuing until around 10:00 AM on 9/4/15. Recovery of CSI 1 was also monitored and ended on 10:00 AM on 9/5/15. Solinst $®$ Levelogger $®($ Model 3001) pressure transducers were installed in both wells and hung at approximately $50 \mathrm{ft}$. beneath land surface from ports on the well heads. A Solinst ${ }^{\circledR}$ Barologger ${ }^{\circledR}$ barometric pressure transducer was kept securely at the same location as CSI 1. All transducers were set to obtain measurements every minute. Both wells were pumped at a rate of $300 \mathrm{gpm}$ although data from the pressure transducers show the pumping

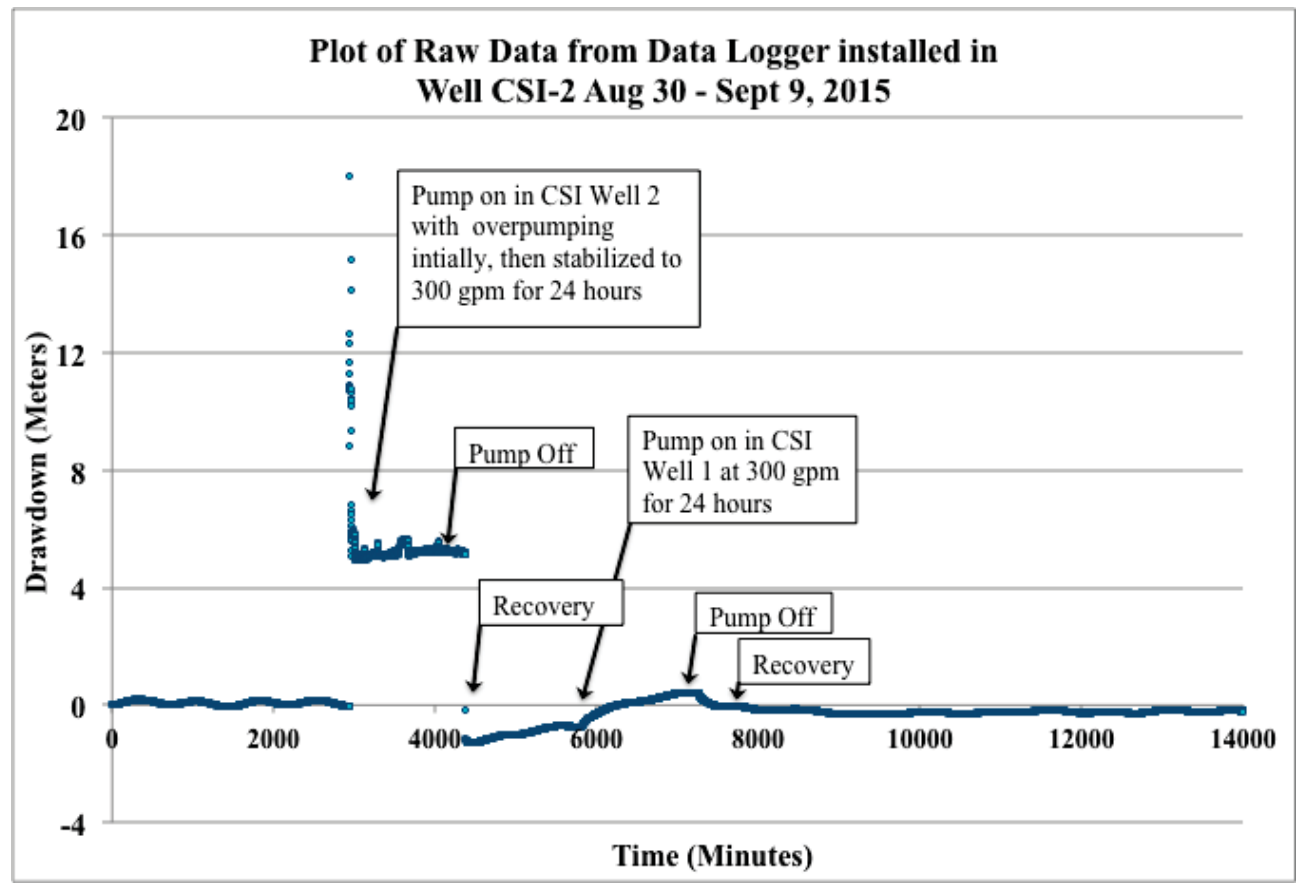

Figure 30. Plot of uncorrected drawdown from CSI Well 2 vs time since transducer installation.

rate may have taken about an hour to stabilize after initial over pumping (Figure 30). 
Due to difficulty in retrieving the pressure transducer from CSI 1, only data from CSI 2 as the pumped well and observation well is available. Figure 30 shows the pressure readings (meters of water) from CSI 2 during the entirety of both pumping and recovery tests. A cyclic antecedent trend is observed prior to the start of pumping showing a sinusoidal fluctuation of about 0.1 meters every 600 minutes. This is probably caused by a pump cycling on and off somewhere within the aquifer. At the start of the test, it can be seen that 18 meters of over pumping occurred due to the pump rate exceeding the target rate of 300 gpm until flow was regulated. Drawdown was about 5 meters during the steady pumping rate of $300 \mathrm{gpm}$. When the pump was shut off at 1440 minutes, it can be seen that the water level over recovered by 1.2 meters as noted by the double headed arrow to the left in Figure 31. Also recorded in Figure 31 is the temperature (red line) during pumping which rose nearly $15{ }^{\circ} \mathrm{C}$. There are at least two plausible explanations for the over recovery observed during the tests: 1) electronic

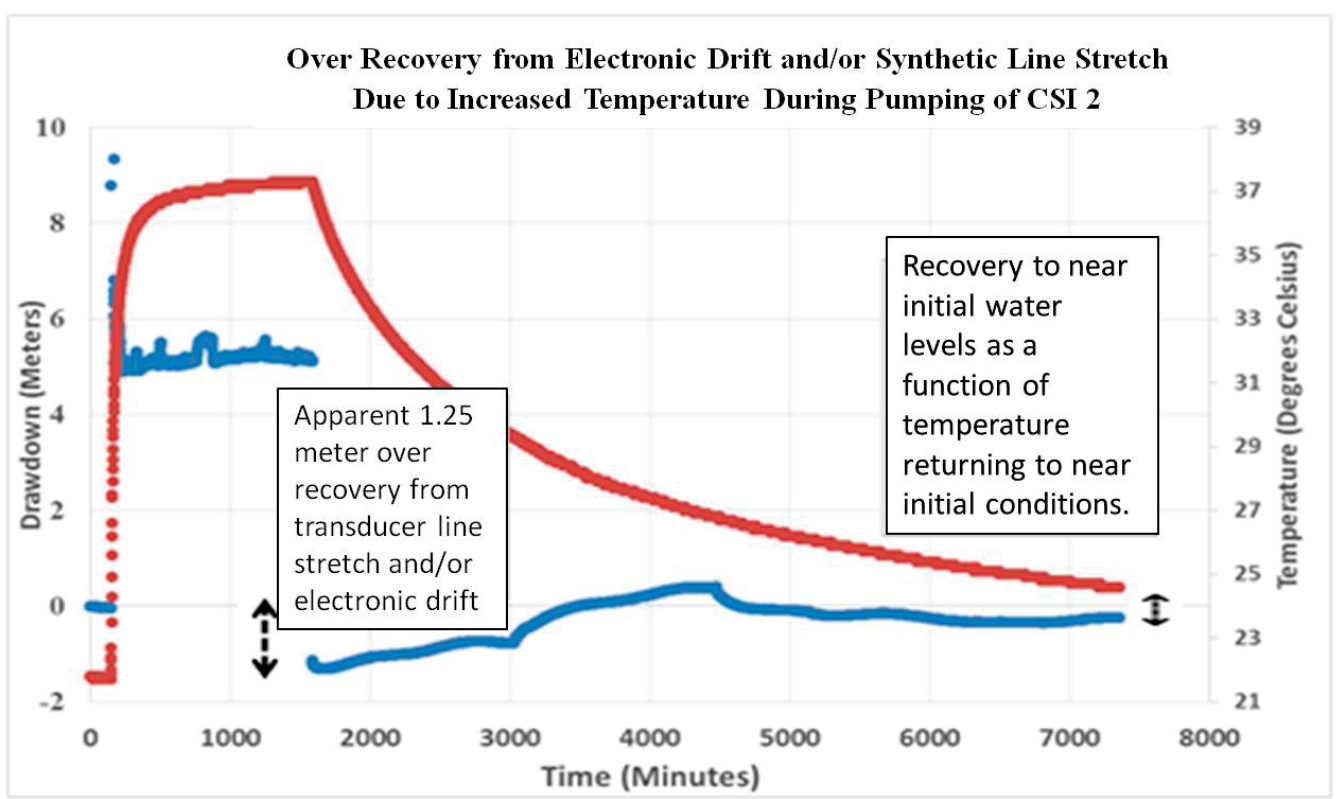

Figure 31. Plot of CSI Well 2 temperature (red) vs drawdown (blue) highlighting possibilities of electronic drift or stretch in synthetic line resulting in the observed overpumping. 
instrument drift corresponding to heating; and 2) stretch in the graduated synthetic line used to hang the transducer. As temperatures approach initial values near the end of the CSI 1 pumping test, transducer water level measurements near background levels prior to pumping.

Over pumping in the early time data and the observed over recovery in the CSI 2 pumping tests deemed the data set from CSI 2 pumping as unusable. However, timedrawdown pairs were generated for both the pumping and recovery tests for this well when CSI 1 was being pumped. Aquifer parameters were estimated using the hydrologic type curve matching software AQTESOLV®. From previous hydrologic research in the area (Street and DeTar, 1987; Lewis and Young, 1989) and the local artesian conditions, analysis was focused on confined and leaky-confined aquifer solutions. Based on cross section analysis (Figure 28) and CSI well logs (Appendix D), the lacustrine sediment layer consisting of oolitic siltstone and sandstone (Street and Detar, 1987) may serve as the confining unit for this system. The best match of the data to type curves was achieved using the Cooper-Jacob (1946) straightline method. This method is a variation of the classic Theis (1935) well function that relates the transmissivity $(\mathrm{T})$, storativity, $(\mathrm{S})$, radial distance of drawdown $(\mathrm{r})$, and pumping time $(\mathrm{t})$ to the pumping rate $(\mathrm{Q})$ in an infinite series shown below:

$$
W(u)=\left(-.5772-\ln u+u-\frac{u^{2}}{2 \times 2 !}+\frac{u^{3}}{3 \times 3 !} \ldots\right)
$$

where $\mathrm{W}(\mathrm{u})$ is the well function and $(\mathrm{u})$ is given by:

$$
u=\frac{r^{2} S}{4 T t}
$$


The final relationship between drawdown and aquifer parameters is given by:

$$
d d=\frac{Q}{4 \pi T} W(u)
$$

Cooper and Jacob (1946) approximated the relationship between drawdown and log (t) as a straight-line relationship by making the recognition that the second-order and higher terms in the infinite series become negligible with small $(\mathrm{u})$ values given by long pumping times $(\mathrm{t})$ or short radial distances $(\mathrm{r})$. Solutions to the pumping and recovery test for the CSI 1 wells are shown below in Figure 32. Calculated transmissivity values of $930 \mathrm{~m}^{2} / \mathrm{d}(75,000$ $\mathrm{gpd} / \mathrm{ft}$ ) are within the same order of magnitude and in close agreement with the values reported by Street and Detar (1987) of 554-923 $\mathrm{m}^{2} / \mathrm{d}(44,600-74,300 \mathrm{gpd} / \mathrm{ft})$. Based on the well logs of CSI 1 and 2, thermal water appears to come from a fracture zone at approximately $350-370$ meters $(1150-1215 \mathrm{ft})$ below land surface. Because both wells are open across the entire water bearing zone, calculation of a vertical gradient is not possible. Available data are insufficient to define the anisotropy of the Idavada volcanics. Thus, the data set precludes making a reasonable estimate of vertical travel times. Because of the strong artesian conditions of the deep thermal aquifer, the vertical gradient is known to be upward. However, without additional well data and depth discrete pumping tests, it is not possible to accurately quantify the vertical flow rate. Future work including detailed flow path analysis within the Idavada volcanics and the investigation into possible thermal flow paths between rhyolites and basalts is highly recommended. 

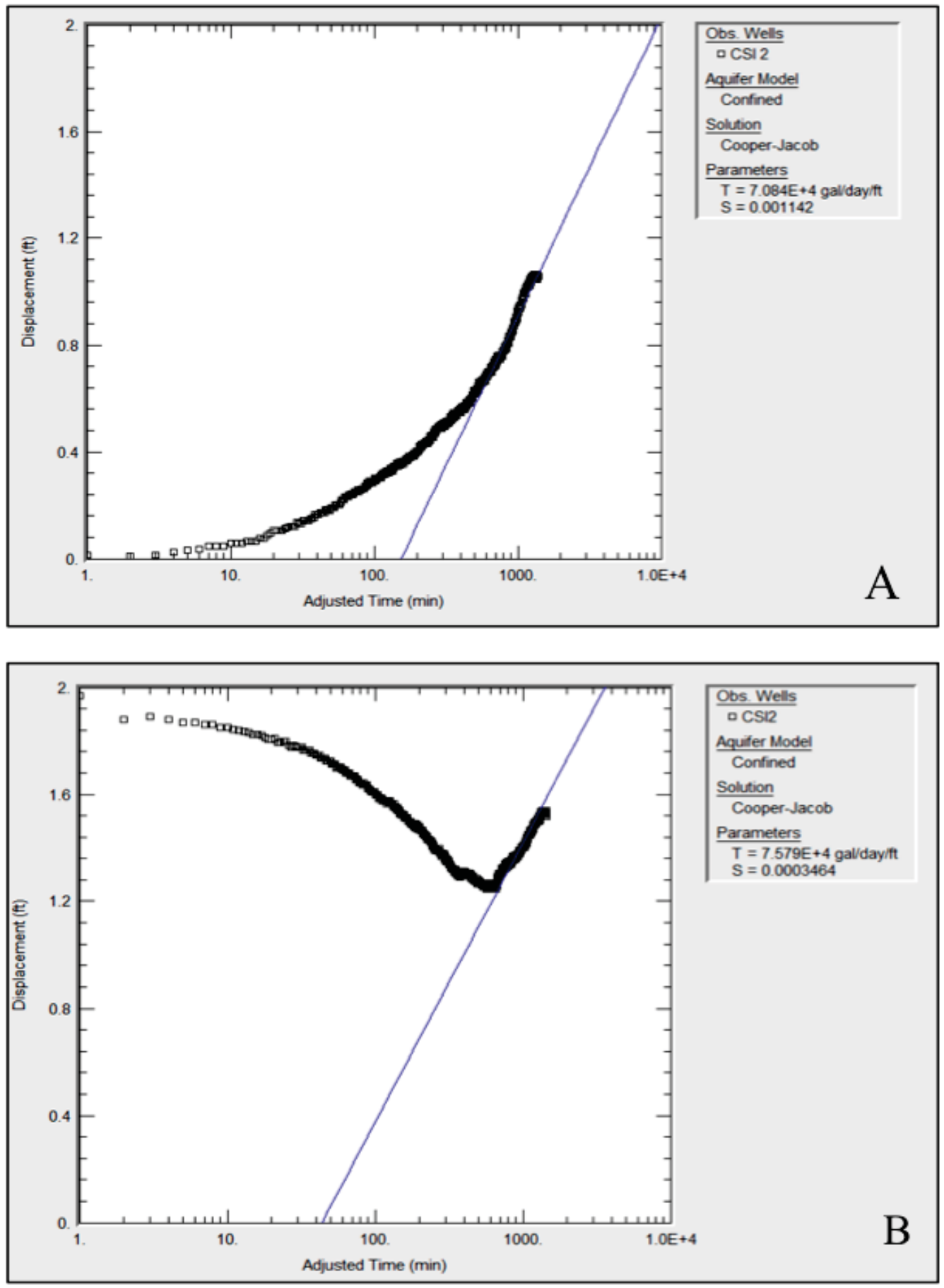

Figure 32. Cooper Jacob straight-line solution applied to barometric pressure corrected pumping (A) and recovery (B) limbs of the CSI Well 1 aquifer test. 


\section{CHAPTER 6: WATER-ROCK INTERACTION AND MIXING}

\section{EXPERIMENTS}

The concept of re-equilibration in the Twin Falls - Banbury hydrothermal system may explain the modeling results of pure water mixing with $\mathrm{Na}-\mathrm{HCO}_{3}$ type thermal waters and the apparent gradational transition between deep $\mathrm{Na}-\mathrm{HCO}_{3}$ waters and shallower $\mathrm{Ca}-\mathrm{HCO}_{3}$ thermal waters (Figure 24). Bench scale water-rock interaction and mixing experiments were constructed in order to test the validity of the potential re-equilibration mechanism which results in the exchange of $\mathrm{Ca}$ and $\mathrm{Mg}$ with $\mathrm{Na}$. This exchange results in the downward transition from local groundwater to very dilute water after mixing with $\mathrm{Na}-\mathrm{HCO}_{3}$ thermal waters and the re-equilibration of $\mathrm{Na}-\mathrm{HCO}_{3}$ thermal waters into $\mathrm{Ca}-\mathrm{HCO}_{3}$ thermal waters after mixing during ascension.

Experiments were modelled after the study area with an initial thermal water coming into equilibrium within the Idavada volcanics at $150{ }^{\circ} \mathrm{C}$ (Banbury Hot Springs temperature estimate) and subsequently being mixed with a local groundwater sample within the basalts of the ESRP and maintained at an intermediate temperature $\left(70{ }^{\circ} \mathrm{C}\right)$. Thermal water was produced within closed system stainless steel reactor cells maintained at $150{ }^{\circ} \mathrm{C}$ and saturation vapor pressure. This water was then mixed with local groundwater in three different proportions comprised of $60 \%, 40 \%$, and $20 \%$ thermal water. Chemical concentrations of mixed water samples over time are used to better understand the implications of flow pathway mixing and re-equilibration.

\subsection{Rock Samples}

Rock sample for the initial water-rock interaction were collected from the Shoshone Falls Rhyolite within the Idavada volcanics. Because core samples in sufficient quantity were 
possible to obtain, samples were obtained from an outcropping unit of Idavada volcanics near the city of Twin Falls, ID. Street and Detar (1987) gave a sample location $\left(42.598158^{\circ}\right.$, $114.463464^{\circ}$ ) and detailed description of an easily accessed portion of the Shoshone Falls Rhyolite within the Snake River Canyon. Despite the apparent misnomer, this rock is actually thought to constitute a single andesitic flow unit within the Idavada volcanics. The sample location can be seen in Figure 33A below. Basalt rock samples for the second portion of the experiment were collected from an outcrop within the ESRP at the Pleistocene Hell's Half Acre basalt flow (Figure 33C). Samples were collected here and used as a proxy for Twin Falls area basalts due to difficulty in gaining access to basaltic outcrops on private property.

\subsection{Rock Sample Preparation}

In order to increase reaction rates through increased particle surface area (Savage et al., 1992; Neupane et al., 2013), blocky samples from outcrops were reduced to a finer grain size prior to heating and interaction with sample water. Rock samples were first cut using a rock a saw into manageable sized pieces prior to being crushed into approximately $5 \mathrm{~cm}$ diameter pieces using a ball peen hammer (Figure 34). Samples were then reduced to finer

grain sizes using a Braun ${ }^{\circledR}$ Chipmunk rock crusher. The pulverized samples were then sieved (dry) and wet sieved (Figure 34) through brass (ASTM Sieve \# 60-120) sieves to separate out $0.25-0.125 \mathrm{~mm}$ particle sizes. Grain sizes in this range have been utilized for past waterrock interaction experiments to increase reaction rates (Savage et al. 1992, Rodriguez, 2011; Neupane et al., 2013). Samples were then decanted using deionized water to remove any suspended fine-grained particles and organic material. Samples were then allowed to dry for 48 hours prior to obtaining dry mass values by scale. 

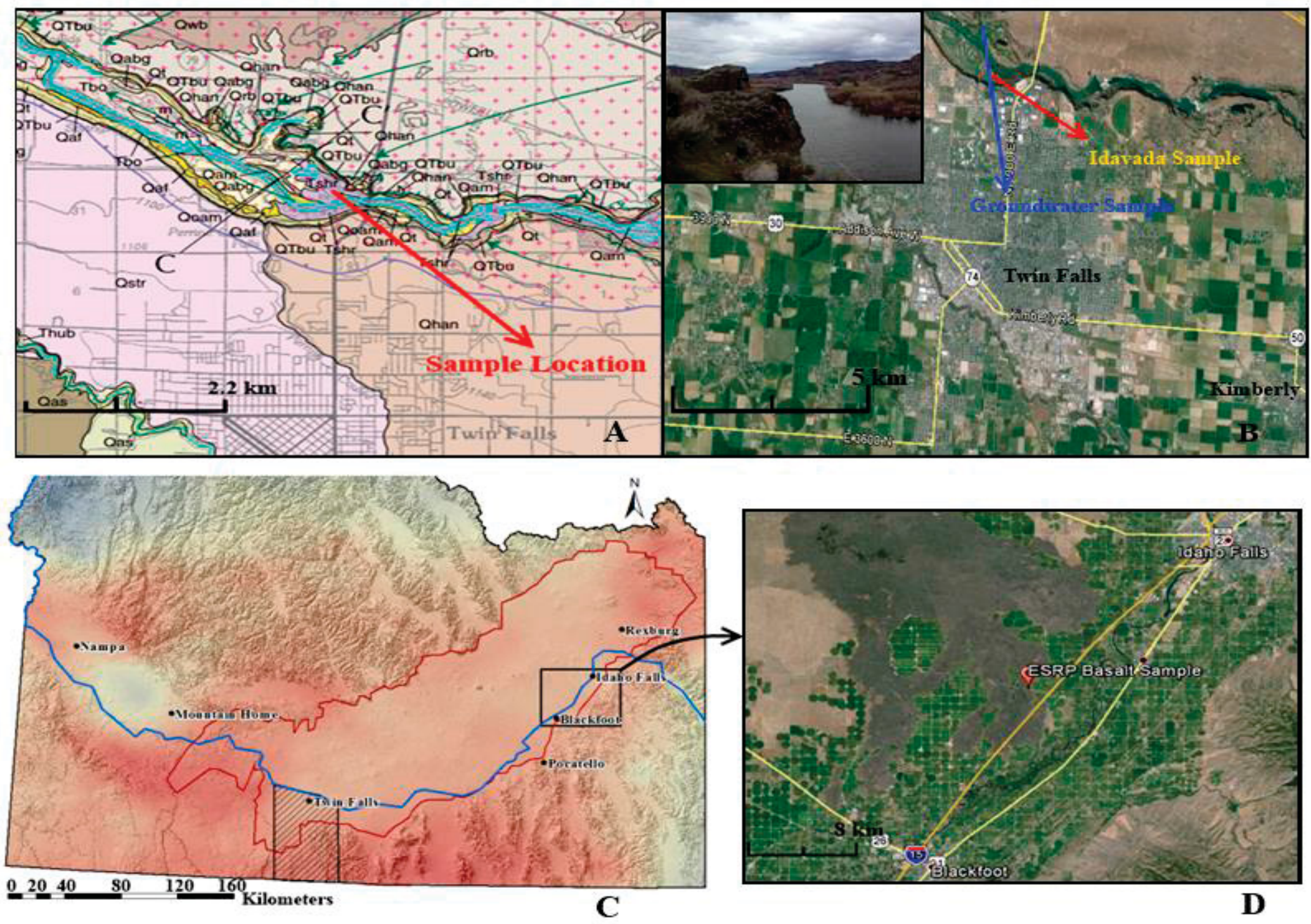

Figure 33. A) Idavada volcanics sampling location on a geologic map showing unit outcrop (dark pink). B) Idavada and groundwater sample locations map view. Inset - View of Idavada volcanics outcrop C) Reference map showing Hell's Half Acre location compared to study area. D) ESRP basalt sample location map view. 


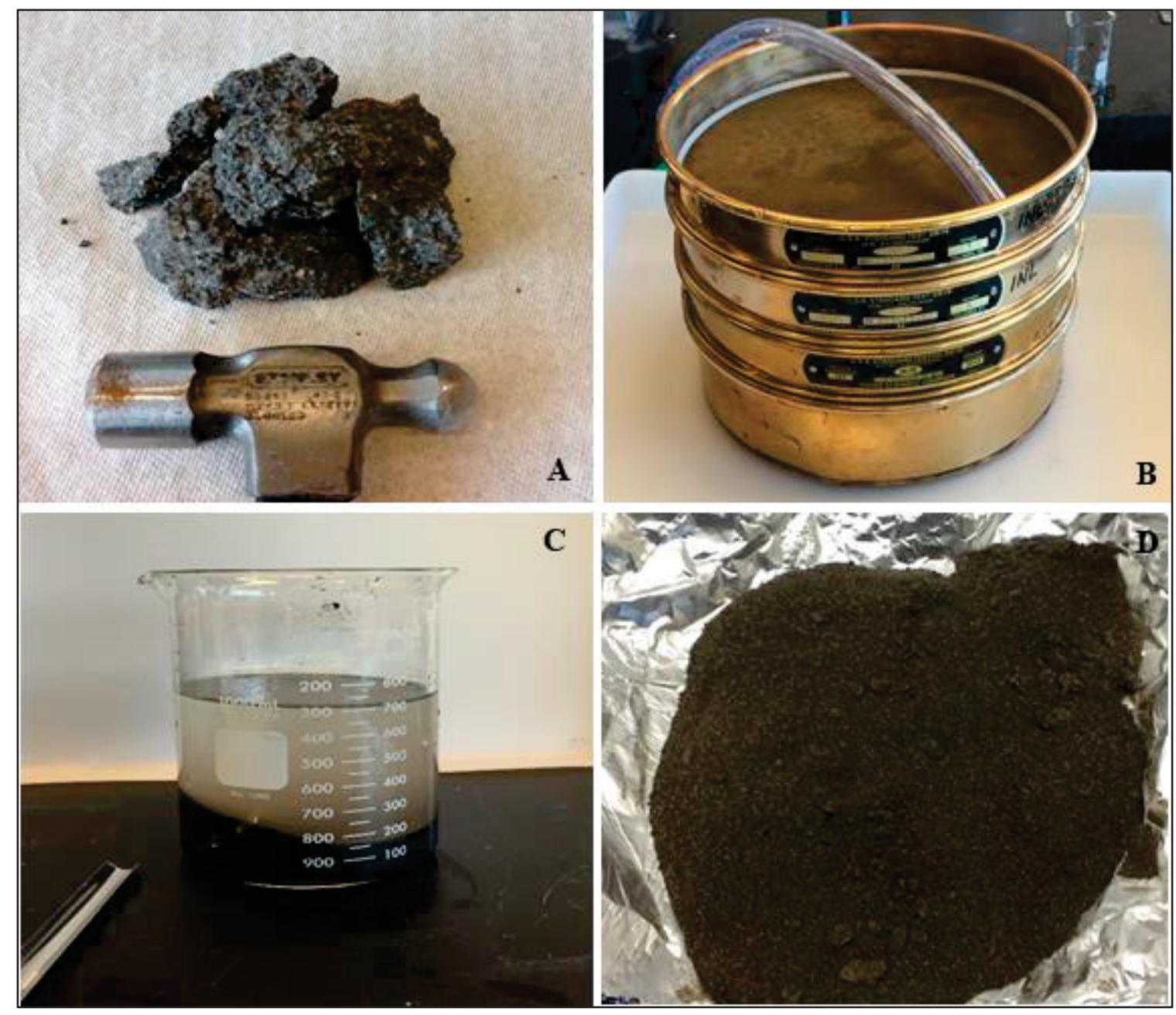

Figure 34. A) Idavada volcanics sample preparation prior to crushing. B) Wet sieving setup with deionized water line. C) Decanting process of rock sample after wet sieving. D) Final dry Idavada sample.

\subsection{Initial Water Sample}

A local groundwater sample was collected in order to use as both the source water for the formation of the $\mathrm{Na}-\mathrm{HCO}_{3}$ thermal water and as the mixing component in the second phase of the experiment. Samples were collected from a city water supply well (Blue Lakes Well) in coordination with the Twin Falls Department of Water Resources office. Sample location can be seen in Figure 33B. Samples were collected for major cation, major anion, and trace element analysis in the same manner as other geothermal samples throughout this study 
(Appendix A). Five additional 1 liter non-acidified samples were collected for use in both portions of the experiment. Initial water chemistry is presented in Table 12 and is comparable to cooler groundwater samples from earlier studies of the area (Chapter 3, Table 2).

\subsection{Experimental Procedure: Part 1}

The thermal water component for the mixing experiment was created using two stainless steel 1.0 L (Type 316) reaction vessels (Model 4523 Parr ${ }^{\circledR}$ Instrument) in which temperature, pressure, and stirring within the reactors were controlled independently. Maximum operating pressures and temperatures of these reactors are rated at $1900 \mathrm{psig}$ (131 bars) and $350^{\circ} \mathrm{C}$, respectively (Parr Instruments Company, 2011). These reaction vessels are constructed so that fluids can be sampled at operating pressure and temperature without disassembling the reactor or affecting experimental conditions. Reactor vessels were cleaned thoroughly through sanding, acid washing with a $5 \% \mathrm{HNO}_{3}$ solution, rinsing with Milli-Q Nanopure water, and finally heating at $150{ }^{\circ} \mathrm{C}$ while partially filled with Milli-Q Nanopure water for 24 hours. Additionally, reactor vessels were pressurized with ultra-pure $\mathrm{N}_{2}$ gas and left for 24 hours in order to monitor any pressure leaks due to faulty connections and/or gaskets.

After assuring the reactor vessels were clean and there were no apparent pressure leaks or temperature losses in the test runs, samples were added to two clean and empty reactor vessels (4/8/2015). 60 grams of Idavada volcanics samples were added to each vessel with $600 \mathrm{~mL}$ of groundwater sample in accordance with Parr ${ }^{\circledR}$ instrument fill volume limitations. Reactors were then gradually heated to $150{ }^{\circ} \mathrm{C}$ and a stirring frequency of $200 \mathrm{rpm}$ for 30 seconds every hour was established in order for the fluid-rock mixture to remain well mixed. Temperature and pressure were monitored remotely to assure there were no deviations from 
the set temperature and saturation vapor pressure at $150{ }^{\circ} \mathrm{C}(\backsim 4.76$ bars $)$. Reactors ran for a total of 101 days with sampling taking place at 82 days (6/28/15) and 101 days $(7 / 17 / 15)$.

Based on previous silicic water-rock interaction experiments where equilibrium conditions were observed in as few as 1-32 days (Rodriguez, 2011; Neupane et al., 2013) and personal communication with Dr. Hari Neupane, 101 days was deemed a sufficient time frame to

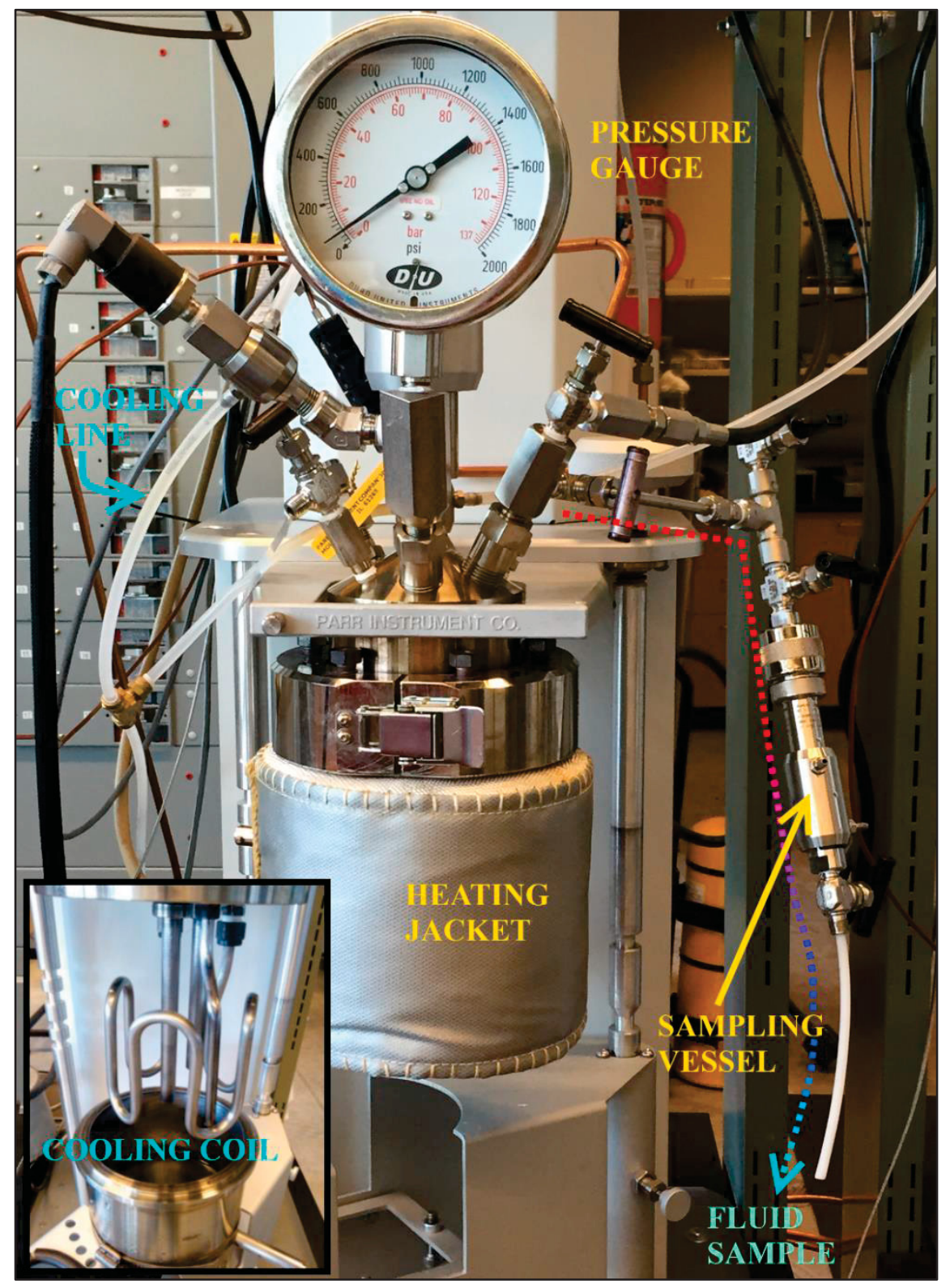

Figure 35. Water-rock interaction experiments conducted at $150^{\circ} \mathrm{C}$ using bench top Parr 1 L reactor vessels. Inset - a reactor vessel and its cooling coil. 
obtain equilibrium at $150{ }^{\circ} \mathrm{C}$. Equilibrium conditions are also supported by reaction path modeling using The Geochemist's Workbench (Bethke and Yeakel, 2013) where calculated near zero saturation index values are observed for chalcedony, calcite, and fluorite. The absence of apparent equilibrium conditions with the clays and zeolites mentioned previously in Chapters 3 and 4 may be explained by the use of the andesitic Shoshone Falls Rhyolite sample as opposed to the more abundant rhyolites within the Idavada volcanics. Additionally, the remarkably high silica concentrations observed in initial water samples may suggest that volcanic silicic glass is controlling silica equilibrium. Future work examining secondary alteration mineralization within experimental rock samples along with experimental runs with varied rock types would aid in reducing uncertainties regarding equilibrium.

Prior to sample collection, a small 5-10 $\mathrm{mL}$ volume was extracted in order to purge the sampling vessel of "dead sample" stuck from the previous sample collection. Three samples of approximately 5-8 $\mathrm{mL}$ were taken for cation, anion, and trace elemental analyses in prewashed $25 \mathrm{~mL}$ HDPE bottles. All samples were filtered through a $0.45 \mu \mathrm{m}$ filter. Cation and trace metal samples were preserved through acidification to a $\mathrm{pH}<2$ with concentrated optima grade $\mathrm{HNO}_{3}$. An additional 3-4 mL sample was taken to obtain a $\mathrm{pH}$ measurement immediately after sampling. Major anions were analyzed with ion chromatography (Dionex ICS-2100), major cations were analyzed with Inductively Coupled Plasma-Optical Emission Spectroscopy (ICP-OES iCAP 6500), and trace elements were analyzed with Inductively Coupled Plasma-Mass Spectroscopy (ICP-MS Agilent 7500ce). Water chemistry results for the initial thermal component are shown in Table 12. 


\subsection{Experimental Procedure: Part 2}

Prior to mixing thermal waters from Reactors \#5 and \#6 with groundwater and new host rock samples, the cleaning and leak test procedure described above was repeated for four new reactor vessels (\#s 1,3,4, and 8). The water rock ratio of $600 \mathrm{~mL}$ water to $60 \mathrm{~g}$ of rock sample was maintained throughout the mixing portion of the experiment. Reactors \#5 and \#6 were brought down to $70^{\circ} \mathrm{C}$ individually and transferred rapidly $(5 \mathrm{~min})$ into new reactors with cold groundwater where the mixture was heated to $70{ }^{\circ} \mathrm{C}$, maintained at saturation vapor pressure, and stirred for 30 seconds at $200 \mathrm{rpm}$ every hour. Thermal to mixed water ratios of $60 \%, 40 \%$, and $20 \%$ thermal water were utilized for reactor \#s 4,3 , and 1 respectively.

Reactor \#8 was established as the experimental control in which no ESRP basalt rock sample was added. Water to rock and thermal water to groundwater ratios are presented in Table 11.

Table 11. Water-rock Interaction Experimental Matrix

\begin{tabular}{|c|c|c|c|c|c|c|}
\hline \multicolumn{7}{|c|}{ Initial Experimental Waters } \\
\hline Reactor & $\mathrm{T}\left({ }^{\circ} \mathrm{C}\right)$ & $P_{\mathrm{H}_{2} \mathrm{O}}$ (bars) & $\begin{array}{c}\text { Idavada Sample } \\
\text { Mass (g) }\end{array}$ & $\begin{array}{c}\text { Solution Volume } \\
(\mathrm{mL})\end{array}$ & Duration (days) & \\
\hline$\# 5$ & 150 & 4.76 & 60 & 600 & 101 & \\
\hline$\# 6$ & 150 & 4.76 & 60 & 600 & 101 & \\
\hline \multicolumn{7}{|c|}{ Mixed Experimental Waters } \\
\hline Reactor & $\mathrm{T}\left({ }^{\circ} \mathrm{C}\right)$ & $P_{\mathrm{H}_{2} \mathrm{O}}$ (bars) & $\begin{array}{c}\text { Basalt Sample } \\
\text { Mass }(\mathrm{g})\end{array}$ & \begin{tabular}{l|} 
Thermal Solution \\
Volume $(\mathrm{mL})$ \\
\end{tabular} & $\begin{array}{c}\text { Groundwater Solution } \\
\text { Volume }(\mathrm{mL}) \\
\end{array}$ & Duration (days) \\
\hline$\# 1$ & 70 & 0.31 & 60 & 120 & 480 & 4 \\
\hline \# 3 & 70 & 0.31 & 60 & 240 & 360 & 40 \\
\hline$\# 4$ & 70 & 0.31 & 60 & 360 & 240 & 40 \\
\hline$\# 8$ & 70 & 0.31 & 0 & 240 & 360 & 40 \\
\hline
\end{tabular}

Because reactor \#s 3 and 8 contained thermal water derived from reactor \#5, the thermal water to groundwater ratio of $40 \%$ thermal water to $60 \%$ groundwater was utilized in control reactor \# 8 to match the ratio of reactor \# 3. $60 \mathrm{~g}$ of ESRP basalt sample was added to 
150 DEGREES CELSIUS

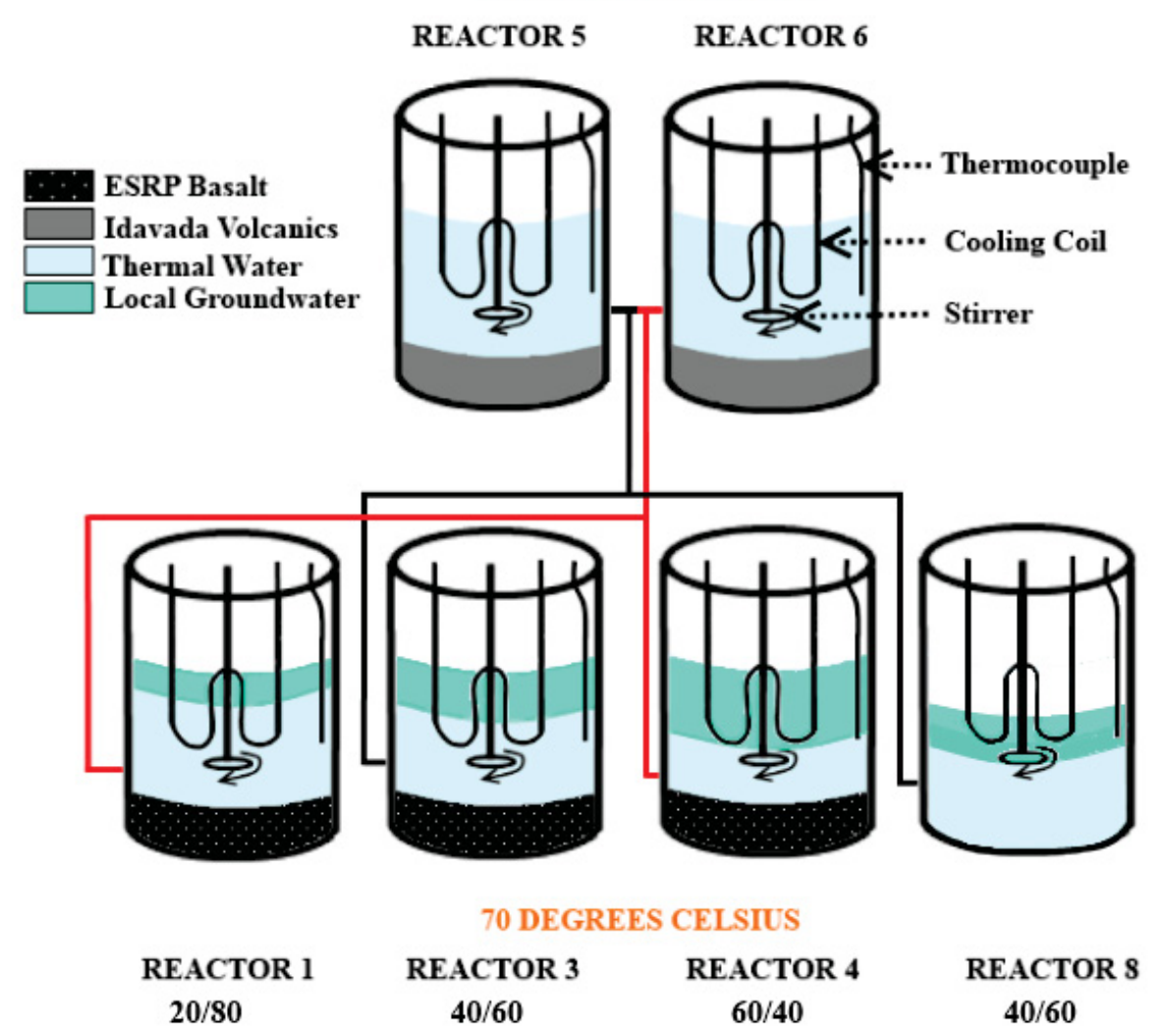

Figure 36. Experimental diagram showing the transfer of thermal water to mixed water reactors. Water to groundwater ratios are shown for Reactors \# 1, 3, 4, and 8.

each reactor vessel. All reactors were sampled at 4 hr, 8 hr, 24 hr, 48 hr, 96 hr, 10 days, 20 days, 30 days, and 40 days with the exception of reactor \# 1 which ran dry after the $96 \mathrm{hr}$ sample most likely due to the development of a pressure leak. Samples were taken for major cations, anions, and trace metals and analyzed in the same manner as the first portion of the experiment. The water chemistry results for all reactors are presented in Table 12 below.

\subsection{Results}

Experimental results with respect to solution concentration over time are shown in Table 12 for all analyzed chemical constituents. Results are presented graphically for select chemical constituents of interest in Figures 37-40. 
Table 12. Chemical analysis results from initial and mixed experimental waters.

Initial Experimental Waters

\begin{tabular}{|c|c|c|c|c|c|c|c|c|c|c|c|c|c|}
\hline Sample & $\mathrm{pH}$ & $\begin{array}{l}\text { Temp } \\
{ }^{\circ} \mathrm{C}\end{array}$ & $\begin{array}{c}F \\
\mathrm{mg} / \mathrm{L}\end{array}$ & $\begin{array}{c}\mathrm{Cl} \\
\mathrm{mg} / \mathrm{L}\end{array}$ & $\begin{array}{l}\text { SO4 } \\
\text { mg/L }\end{array}$ & $\begin{array}{l}\mathrm{NO3} \\
\mathrm{mg} / \mathrm{L}\end{array}$ & $\begin{array}{c}\mathrm{Ca} \\
\mathrm{mg} / \mathrm{L}\end{array}$ & $\begin{array}{c}\mathrm{Mg} \\
\mathrm{mg} / \mathrm{L}\end{array}$ & $\begin{array}{c}\mathrm{Na} \\
\mathrm{mg} / \mathrm{L}\end{array}$ & $\begin{array}{c}\mathrm{K} \\
\mathrm{mg} / \mathrm{L}\end{array}$ & $\begin{array}{l}\mathrm{SiO2} \\
\mathrm{mg} / \mathrm{L}\end{array}$ & $\begin{array}{c}\mathrm{Al} \\
\mathrm{mg} / \mathrm{L}\end{array}$ & $\begin{array}{c}\text { B } \\
\mathrm{mg} / \mathrm{L} \\
\end{array}$ \\
\hline "Groundwater Sample & 7.47 & 15.9 & 0.5 & 46.2 & "59.3 & 9.36 & 57.2 & 19.78 & 35.4 & 6.45 & 41.6 & $1.00 \mathrm{E}-04$ & - \\
\hline $\mathrm{CC}-1$ & 6.85 & 150 & 2.61 & 42.5 & 57.4 & 7.30 & 12.3 & 0.11 & 42.5 & 21.4 & 242 & 0.41 & - \\
\hline CC-150-6 (6-28-15) & 6.91 & 150 & 3.42 & 49.3 & 61.8 & 9.26 & 2.65 & 0.21 & 69.1 & 38.6 & 270 & 1.79 & - \\
\hline CC-150-5 (7-17-15) & 6.88 & 150 & 3.02 & 46.77 & 63.87 & 8.23 & 16.5 & 0.10 & 47.9 & 23.5 & 255 & 0.60 & 0.107 \\
\hline CC-150-6 (7-17-15) & 6.96 & 150 & 3.55 & 47.48 & 58.71 & 8.95 & $<10$ & 0.10 & 70.4 & 35.9 & 235 & 1.98 & 0.107 \\
\hline & & & & & & & & & & & & & \\
\hline \multicolumn{14}{|c|}{ Mixed Experimental Waters } \\
\hline ample & pH & Temp & $F$ & $\mathbf{C l}$ & SO4 & NO3 & $\mathbf{C a}$ & Mg & $\mathbf{N a}$ & $\mathbf{K}$ & SiO2 & $\overline{\mathrm{Al}}$ & $\bar{B}$ \\
\hline & & ${ }^{\circ} \mathrm{C}$ & $\mathrm{mg} / \mathrm{L}$ & $\mathrm{mg} / \mathrm{L}$ & $\mathrm{mg} / \mathrm{L}$ & $\mathrm{mg} / \mathrm{L}$ & $\mathrm{mg} / \mathrm{L}$ & $\mathrm{mg} / \mathrm{L}$ & $\mathrm{mg} / \mathrm{L}$ & $\mathrm{mg} / \mathrm{L}$ & $\mathrm{mg} / \mathrm{L}$ & $\mathrm{mg} / \mathrm{L}$ & ug/L \\
\hline CC-1-20/80-7-17-15 (4 Hr) & 7.59 & 70 & 2.32 & 50.0 & 71.4 & 22.5 & 23.6 & 5.66 & 61.5 & 23.3 & 127 & 1.045 & 0.114 \\
\hline CC-1-20/80-7-17-15 (8 Hr) & 7.96 & 70 & 2.08 & 48.9 & 70.4 & 9.12 & 22.4 & 5.31 & 66.7 & 24.0 & 109 & 0.119 & 0.136 \\
\hline CC-1-20/80-7-18-15 (24 Hr) & 7.62 & 70 & 1.84 & 50.0 & 86.2 & 9.25 & 18.9 & 4.25 & 79.5 & 24.4 & 77.7 & 0.161 & 0.166 \\
\hline CC-1-20/80-7-19-15 (48 Hr) & 7.35 & 70 & 1.29 & 49.7 & 107 & 8.99 & 13.9 & 2.82 & 91.7 & 23.8 & 60.5 & 0.221 & 0.162 \\
\hline CC-1-20/80-7-21-15 (96 Hr) & 7.72 & 70 & 0.544 & 48.6 & 168 & 8.58 & $<1$ & 1.21 & 138 & 23.6 & 27.9 & 0.476 & 0.150 \\
\hline CC-3-40/60-7-17-1 & 7.94 & 70 & 1.63 & 48.1 & 63.2 & 9.17 & 34.5 & 9.59 & 54.9 & 21.1 & 127 & 351 & 0.117 \\
\hline $\mathrm{CC}-3-40 / 60-7-17-15(8 \mathrm{Hr})$ & 7.91 & 70 & 1.64 & 48.5 & 63.9 & 9.24 & 38.3 & 10.85 & 51.6 & 18.3 & 110 & 0.184 & 0.100 \\
\hline CC-3-40/60-7- & 7.75 & 70 & 1.58 & 47.9 & 66.1 & 9 & 37.2 & 10.32 & 51.8 & 17.8 & 103 & 074 & 119 \\
\hline CC-3-40/60-7-19-15(48 Hr) & 7.28 & 70 & 1.53 & 48.5 & 70.1 & 9.26 & 39.6 & 10.41 & 55.6 & 18.4 & 109 & 0.072 & 0.104 \\
\hline CC-3-40/60-7-2 & 7.35 & 70 & 1.30 & 48.3 & 4 & 9 & 34.9 & 10.29 & 60.3 & 18.6 & 101 & 101 & 114 \\
\hline CC-3-40/60-7-28-15 (10Day) & 7.1 & 70 & 1.01 & 48.7 & 90.0 & 9.10 & 29.7 & 10.26 & 70.6 & 19.1 & 94.1 & 0.130 & 0.122 \\
\hline CC-3-40/60-8-5- & 6.86 & 70 & 0.851 & 48.2 & 98.8 & 9.09 & 27.2 & 9.91 & 75.6 & 19.2 & 90.3 & 0.110 & 0.122 \\
\hline $\mathrm{CC}-3-40 / 60-8-$ & 6.98 & 70 & 0.771 & 48.3 & 104 & 8.91 & 25.8 & 9.23 & 83.0 & 18.7 & 91.2 & 0.130 & 0.111 \\
\hline CC-3-40/60-8-29-15 (40 Day) & 7.15 & 70 & 0.65 & 47.95 & 107.18 & 8.98 & 21.1 & 8.58 & 87.4 & 18.9 & 78.7 & 0.117 & 0.126 \\
\hline CC-4-60/40-7-17-15 (4 Hr) & 7.92 & 10 & 1.48 & 51.0 & 09.4 & 9.22 & 42.1 & 10.74 & 47.7 & 14.6 & 130 & .078 & 0.156 \\
\hline CC-4-60/40-7-17-15 (8 Hr) & 7.82 & 70 & 1.49 & 50.8 & 70.2 & 9.18 & 40.6 & 10.37 & 46.5 & 14.3 & 119 & 0.050 & 0.157 \\
\hline CC-4-60/40-7-18-15 (24 Hr) & 7.75 & 70 & 1.41 & 50.7 & 73.0 & 9.11 & 41.3 & 10.05 & 49.8 & 15.1 & 114 & 0.050 & 0.155 \\
\hline CC-4-60/40-7-19-15(48 Hr) & 7.45 & 70 & 1.28 & 52.0 & 80.0 & 9.10 & 38.2 & 9.32 & 53.6 & 15.2 & 112 & 0.059 & 0.144 \\
\hline CC-4-60/40-7-21-15 (96 Hr) & 7.36 & 70 & 0.939 & 51.9 & 91.7 & 9.06 & 31.0 & 8.54 & 60.6 & 15.2 & 93.6 & 0.092 & 0.342 \\
\hline CC-4-60/40-7-28-15 (10 day) & 7.21 & 70 & $<0.5$ & 50.6 & 122 & 9.05 & 25.6 & 7.56 & 72.0 & 15.7 & 74.9 & 0.067 & 0.175 \\
\hline CC-4-60/40-8-5-15 (20 Day) & 7.01 & 70 & $<0.5$ & 49.1 & 125 & 8.59 & 21.3 & 5.86 & 83.7 & 15.6 & 61.2 & 0.105 & 0.256 \\
\hline CC-4-60/40-8-16-15 (30 Day) & 7.06 & 70 & $<0.5$ & 47.6 & 127 & 8.33 & 14.6 & 3.80 & 96.6 & 16.2 & 47.3 & 0.192 & 0.162 \\
\hline CC-4-60/40-8-29-15 (40 Day) & 7.21 & 70 & $<0.5$ & 46.37 & 139.66 & 8.01 & 10.7 & 3.00 & 105 & 16.1 & 50.8 & 0.198 & 0.183 \\
\hline CC-8-NoRock-7-17-15- (4 Hr) & 8.18 & 70 & 1.57 & 47.7 & 63.0 & 8.97 & 39.2 & 9.77 & 41.9 & 15.4 & 145 & 0.155 & 0.119 \\
\hline CC-8-NoRock-7-17-15 (8 Hr) & 8.14 & 70 & 1.57 & 47.7 & 63.5 & 8.93 & 41.0 & 10.72 & 43.6 & 16.0 & 146 & 0.097 & 0.086 \\
\hline CC-8-NoRock-7-18-15 (24 Hr) & 8.04 & 70 & 1.52 & 47.7 & 62.1 & 8.92 & 39.6 & 10.41 & 42.6 & 15.2 & 139 & 0.091 & 0.208 \\
\hline CC-8-NoRock-7-19-15 (48 Hr) & 7.86 & 70 & 1.48 & 47.4 & 61.3 & 8.77 & 37.2 & 10.17 & 42.6 & 15.0 & 134 & 0.075 & 0.102 \\
\hline CC-8-NoRock-7-21-15 (96 Hr) & 7.84 & 70 & 1.45 & 47.6 & 61.2 & 8.76 & 33.9 & 9.47 & 41.8 & 14.6 & 126 & 0.051 & 0.110 \\
\hline CC-8-NoRock-7-28-15 (10 Day) & 7.44 & 70 & 0.872 & 46.8 & 54.9 & 8.64 & 19.2 & 5.68 & 36.1 & 12.6 & 69.9 & 0.050 & 0.144 \\
\hline CC-8-NoRock-8-5-15 (20 Day) & 7.48 & 70 & $<0.5$ & 44.1 & 45.5 & 8.09 & $<10$ & 2.49 & 30.6 & 10.1 & 15.9 & 0.050 & 0.100 \\
\hline CC-8-NoRock-8-16-15 (30 Day) & 7.5 & 70 & $<0.5$ & 40.5 & 37.7 & 7.31 & $<10$ & 1.12 & 26.2 & 8.5 & $<10$ & 0.081 & 0.100 \\
\hline CC-8-NoRock-8-29-15 (40 Day) & 7.4 & 70 & $<0.5$ & 31.41 & 28.18 & 5.61 & $<10$ & 1.07 & 35.4 & 11.8 & $<10$ & 0.076 & 0.100 \\
\hline
\end{tabular}




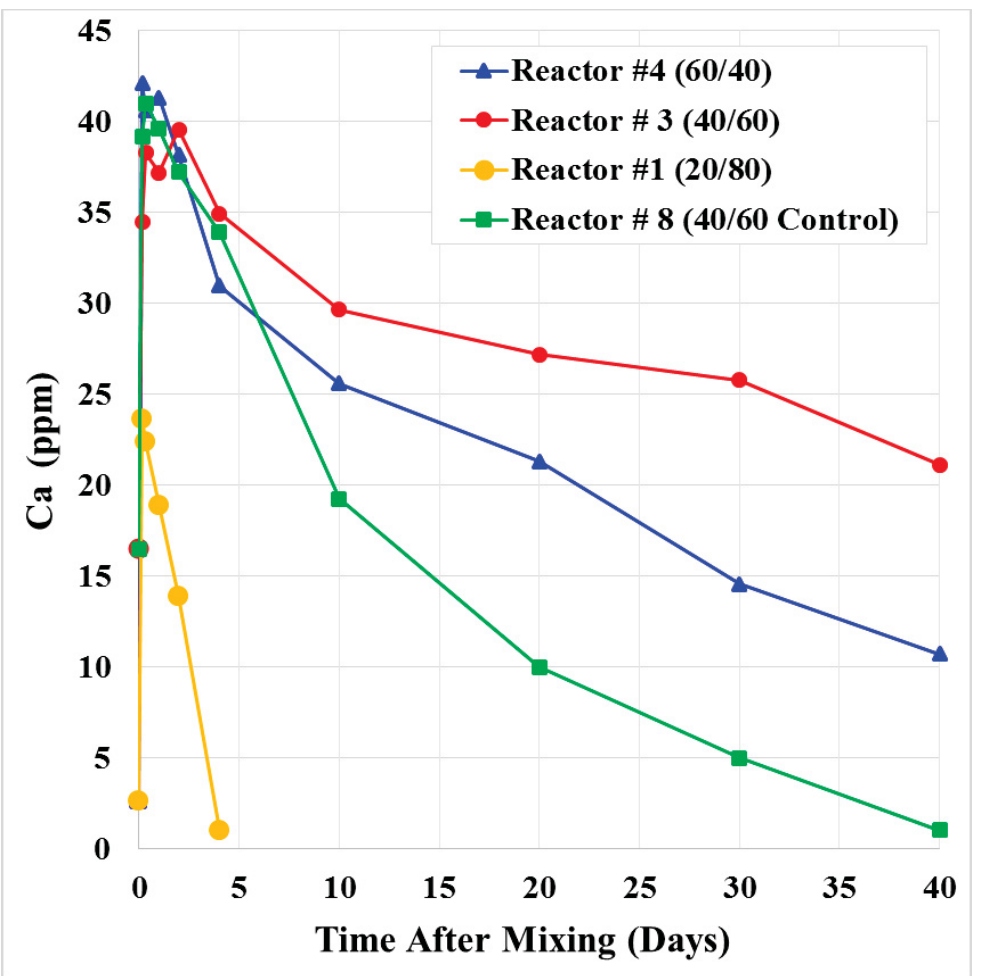

Figure 37. Calcium concentrations of experimental mixed thermal water samples over time. Ratios of thermal to groundwater are given in parentheses.

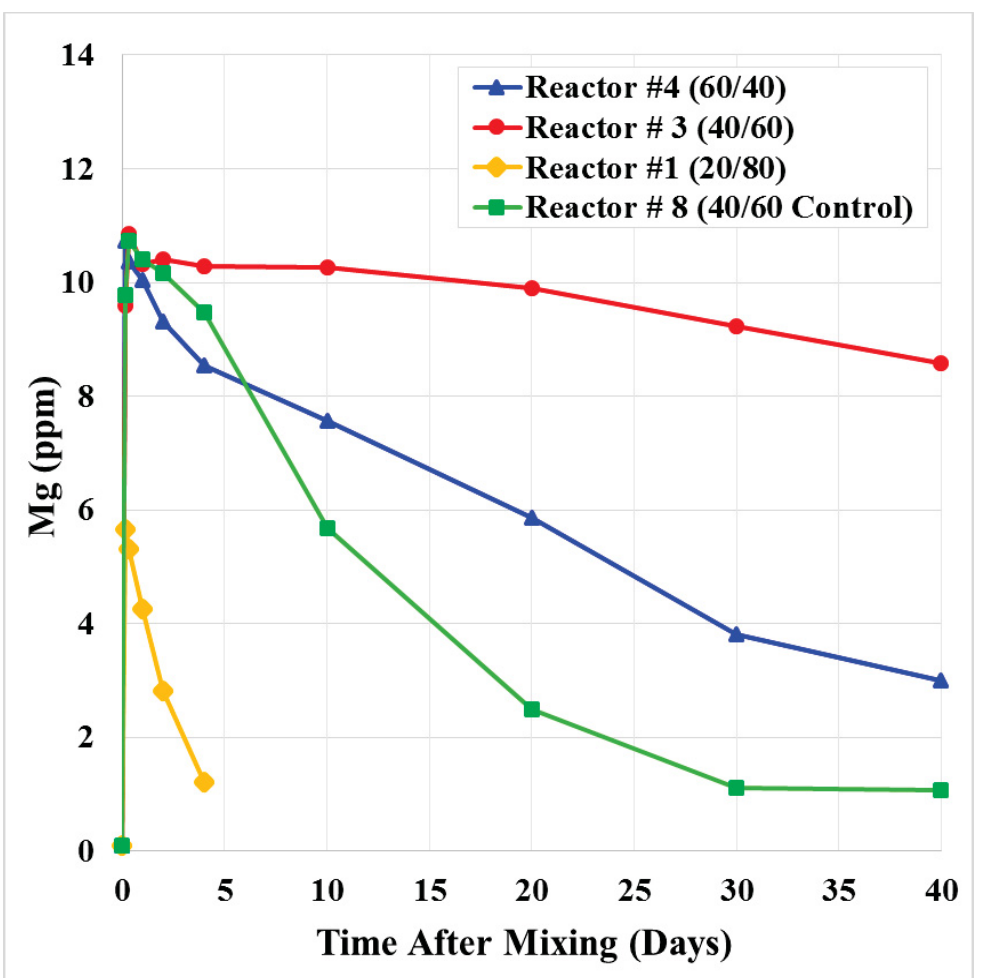

Figure 38. Magnesium concentrations of experimental mixed thermal water samples over time. Ratios of thermal to groundwater are given in parentheses. 


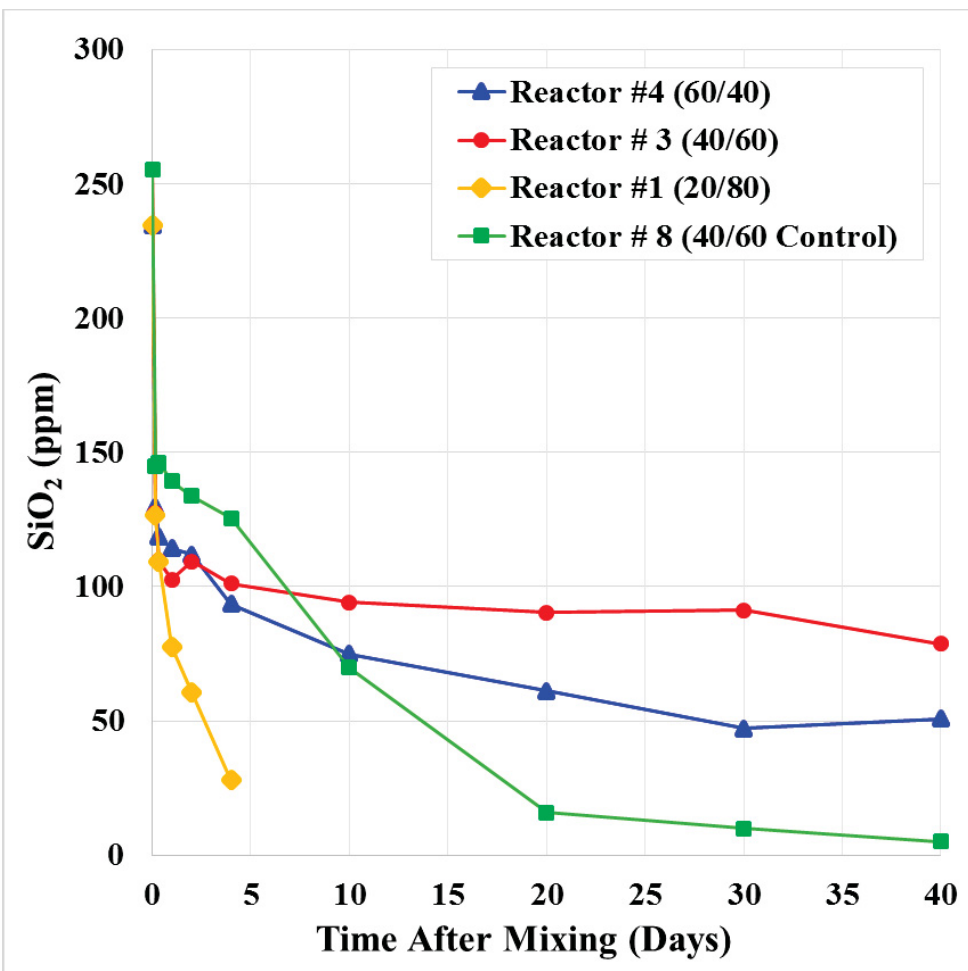

Figure 39. Silica concentrations of experimental mixed thermal water samples over time. Ratios of thermal to groundwater are given in parentheses.

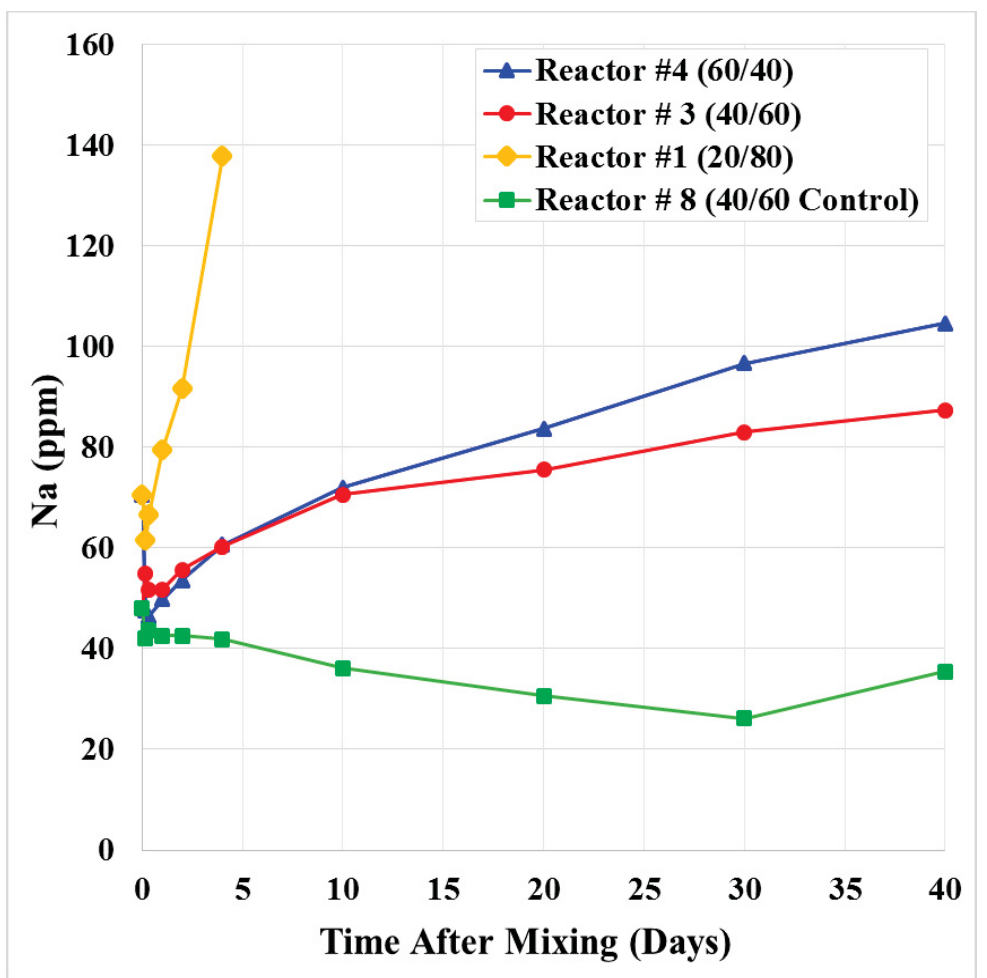

Figure 40. Sodium concentrations of experimental mixed thermal water samples over time. Ratios of thermal to groundwater are given in parentheses. 
$\mathrm{Ca}$ and $\mathrm{Mg}$ concentrations show an immediate increase after initial mixing with groundwater progressing from initial concentrations $(<10-16.5 \mathrm{ppm} \mathrm{Ca}$ and $0.1 \mathrm{ppm} \mathrm{Mg})$ to values around 35-40 ppm Ca and 9.5 - 10.5 ppm Mg (Reactors \# 3,4, and 8). Reactor \# 1, containing $20 \%$ thermal water, exhibits a less prominent initial increase in $\mathrm{Ca}$ and $\mathrm{Mg}$ concentrations rising to only about $23.6 \mathrm{ppm} \mathrm{Ca}$ and $5.66 \mathrm{ppm} \mathrm{Mg}$. After fluctuating about the initial point of increase, all reactors show significant declines in $\mathrm{Ca}$ and $\mathrm{Mg}$ concentration after the 4 day mark. The rate of decline of $\mathrm{Ca}$ and $\mathrm{Mg}$ seems to be effected by the ratio of initial thermal water to groundwater as a sharper decline for both constituents is exhibited in Reactor \# 4 containing the highest ratio (60\% thermal water) compared to Reactor \# 3 (40\% thermal water). Reactor \# 8 (control) shows a steeper decline than the previous two reactors for both $\mathrm{Ca}$ and $\mathrm{Mg}$. Due to sample loss from a likely vessel leak, Reactor \# 1 only has available data for 4 days. A very steep decline in both $\mathrm{Ca}$ and $\mathrm{Mg}$ is observed in Reactor \# 1 but the rate of decline may be influenced by the open system created by the apparent leak.

$\mathrm{SiO}_{2}$ concentrations show a dramatic decline after the initial mixing of thermal water

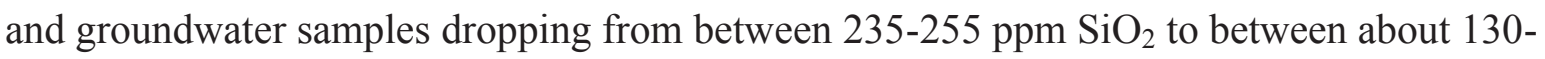
$145 \mathrm{ppm}$ at the 4 hour mark in all reactors. However, unlike $\mathrm{Ca}$ and $\mathrm{Mg}$ concentration trends which show no sign of leveling off, $\mathrm{SiO}_{2}$ seem to level off in Reactors \# 3 and 4 at around the 20 day mark. Again, Reactor \# 3 (60\% thermal water) with a greater percentage of thermal water component results in lower concentrations compared with Reactor \# 4 (40\% thermal water). Reactor \# 8 (control) does not appear to be leveling off given its sharp decline.

In contrast to the previously discussed trends, Na concentrations increase in Reactor \#s 1, 3, and 4 after initial mixing. Reactor \# 4 (60\% thermal water) exhibits a steeper rate of increase over time than Reactor \# 3 (40\% thermal water). Reactor \# 8 (control) is the only 
reactor which exhibits a fairly constant decline in Na concentrations over time. The steepest rate of increase of sodium concentrations is observed in Reactor \# 1. However, this trend may or may not be significant due to the aforementioned equipment malfunctions manifesting around the 4 day mark.

\subsection{Discussion}

The experiments conducted in this chapter replicated the mixing of a felsic volcanic derived thermal water $\left(150{ }^{\circ} \mathrm{C}\right)$ with a more dilute $\mathrm{Ca}-\mathrm{Mg}-\mathrm{HCO}_{3}$ type groundwater at an intermediate temperature $\left(70{ }^{\circ} \mathrm{C}\right)$ and the subsequent composition altering processes of the mixed water. These experiments show that the rates of change for select cations $(\mathrm{Ca}, \mathrm{Mg}$, and $\mathrm{Na}$ ) and $\mathrm{SiO}_{2}$ within mixed thermal waters may be dependent on the ratio of thermal water to groundwater within solution. A greater percentage of thermal water is correlated to a steeper rate of decline in $\mathrm{Ca}, \mathrm{Mg}$, and $\mathrm{SiO}_{2}$ concentrations and a steeper rate of increase in $\mathrm{Na}$ concentrations. An increase number of experiments with varying thermal water to groundwater ratios may show whether this correlation is significant or not. Significant differences in concentrations between thermal water, groundwater, and mixed water are observed almost immediately.

After the 4 day mark, waters begin showing significant decreasing trends with respect to $\mathrm{Ca}, \mathrm{Mg}$, and $\mathrm{SiO}_{2}$ concentrations and a significant rising trend with respect to $\mathrm{Na}$ concentrations. Reactor $\# 8$, which contained no basalt rock samples, is the only experiment to not show an increasing $\mathrm{Na}$ trend after mixing which may suggest that the transition into a more mafic rock type is necessary for the observed trends. With the exception of $\mathrm{SiO}_{2}$, these trends do not show signs of levelling off. This observation is congruent with a mechanism for re-equilibration by a precipitation or cation exchange reaction explaining the apparent mixing 
between pure or dilute $\mathrm{Na}-\mathrm{HCO}_{3}$ water with thermal $\mathrm{Na}-\mathrm{HCO}_{3}$ type waters of the Twin Falls - Banbury hydrothermal system. The inverse of the trends displayed above may explain the possible re-equilibration of rising $\mathrm{Na}-\mathrm{HCO}_{3}$ type water into more $\mathrm{Ca}-\mathrm{HCO}_{3}$ type thermal waters at cooler temperatures. 


\section{CHAPTER 7: SUMMARY AND CONCLUSIONS}

The Eastern Snake River Plain, formed by successive caldera formation associated with the migration of the Yellowstone hotspot, is considered to have some of the highest geothermal potential within the state of Idaho and the entire country (Tester et al., 2006). Geothermal potential is made evident through the many hydrothermal expressions (springs and wells) that line the periphery of the plain, anomalously high geothermal gradients (Brott et al., 1976) and heat flow values (Blackwell and Richards, 2004), and high mantle signature ${ }^{3} \mathrm{He} /{ }^{4} \mathrm{He}$ ratios (Dobson et al., 2015). Despite all of the potential within the region, geothermal development has been limited to low temperature resources and attempts at reservoir temperature estimation have resulted in lower than expected estimates. Many believe that this is due to the masking of the deep geothermal signature by the prolific overlying groundwater aquifer of the ESRPA (McLing et al., 2002; Neupane et al., 2014; Cannon et al., 2014; Dobson et al., 2015). While previous studies have acknowledged the possibility of mixing between ascending thermal waters and groundwater, few have attempted to compensate for its effects on reservoir temperature estimation through geothermometry. Because of sample density and preliminary temperature estimation results, the Twin Falls - Banbury hydrothermal system was chosen as the location for an in depth investigation into the possibility of mixing and re-equilibration in thermal waters of the ESRP.

Through principle component and hierarchical cluster analyses, two distinct thermal water types $\left(\mathrm{Na}-\mathrm{HCO}_{3}\right.$ and $\left.\mathrm{Ca}-\mathrm{HCO}_{3}\right)$ were identified in the Twin Falls - Banbury area. Na$\mathrm{HCO}_{3}$ waters are separated by from $\mathrm{Ca}-\mathrm{HCO}_{3}$ waters by higher temperatures, higher TDS, and higher $\mathrm{Na}^{+}$concentrations. $\mathrm{Ca}-\mathrm{HCO}_{3}$ waters are characterized by high $\mathrm{Ca}^{2+}$ and $\mathrm{Mg}^{2+}$ concentrations and cooler temperatures. $\mathrm{Na}-\mathrm{HCO}_{3}$ waters emanate exclusively from thermal 
springs and a select few wells that are completed within the rhyolites of the Idavada volcanics whereas the $\mathrm{Ca}-\mathrm{HCO}_{3}$ thermal waters are found in wells completed within the overlying basalts. This is consistent with the trend from $\mathrm{Na}-\mathrm{K}-\mathrm{HCO}_{3}$ thermal waters and $\mathrm{Ca}-\mathrm{Na}-\mathrm{HCO}_{3}$ thermal waters with decreasing temperature and depth observed in the deep INEL-1 well that penetrates the basalt units of the ESRPA (Mann, 1986; McLing et al., 2002).

Evidence for mixing in the study area is provided by a linear trend between these two water types on a Piper diagram (Piper, 1944), partial equilibration and immature classification of most thermal water samples on the Giggenbach ternary diagram (Giggenbach, 1988), and linear trends between several conservative chemical constituents $(\mathrm{Cl}, \mathrm{B}, \delta \mathrm{D}$, etc.). In addition to the evidence for simple mixing between the two water types, relationships between some reactive chemical constituents $(\mathrm{Na}, \mathrm{K}, \mathrm{Mg}$, and $\mathrm{Ca}$ ) display two separate and distinct trends for the two water types which suggests either:

1) The waters may be the result of two separate and unrelated flow pathways, host rocks, and/or equilibration temperatures.

Or

2) The waters have undergone some form of reactive mixing and/or re-equilibration resulting in the transition from $\mathrm{Na}-\mathrm{HCO}_{3}$ thermal waters to $\mathrm{Ca}-\mathrm{HCO}_{3}$ thermal waters and vice versa depending on the reservoir temperature, rock types, and thermal water to groundwater ratio.

Reservoir temperature estimations were made utilizing conventional geothermometry techniques, silica-enthalpy mixing models, and multicomponent equilibrium geothermometry. Silica and cation conventional geothermometers yield highly varied results and many of them are limited in their application due to high calcium and magnesium concentrations of many 
thermal water samples. Silica-enthalpy mixing models are capable for accounting for dilution effects from simple mixing and are considered to yield more reliable temperature estimations. However, these models yield a wide range of possible reservoir temperatures and are incapable of accounting for the apparent reactive mixing and/or re-equilibration. In contrast, MEG through the use of the inverse modeling tool RTEst, is capable of accounting for a mixing component while utilizing an entire assemblage of likely reservoir alteration minerals to obtain a reservoir temperature. RTEst was utilized for both $\mathrm{Ca}-\mathrm{HCO}_{3}$ and $\mathrm{Na}-\mathrm{HCO}_{3}$ thermal waters. Simple mixing between groundwater and thermal water is not supported for $\mathrm{Na}-\mathrm{HCO}_{3}$ thermal waters yet is supported for $\mathrm{Ca}-\mathrm{HCO}_{3}$ thermal waters yielding temperature estimates between around $90-100{ }^{\circ} \mathrm{C}$. The reconstructed compositions for $\mathrm{Ca}-\mathrm{HCO}_{3}$ waters produced by inverse modeling do not resemble the compositions of the $\mathrm{Na}-\mathrm{HCO}_{3}$ waters signifying that the $\mathrm{Ca}-\mathrm{HCO}_{3}$ thermal waters may be the result of re-equilibration if there exists a relationship between the two thermal water types.

An "intermediate" composition obtained from the intersection of the reactive constituent trends was utilized as the mixing component in RTEst modeling of $\mathrm{Na}-\mathrm{HCO}_{3}$ waters. This type of mixing is not supported through the use of RTEst as adequate saturation index convergence of likely reservoir minerals is not obtained. However, the use of pure water as the mixing component in RTEst modeling of $\mathrm{Na}-\mathrm{HCO}_{3}$ results in adequate saturation index convergence and reservoir temperatures as high as $160{ }^{\circ} \mathrm{C}$. The same results are achieved when dilute $\mathrm{Na}-\mathrm{HCO}_{3}$ water is used as the mixing component for $\mathrm{Na}-\mathrm{HCO}_{3} \mathrm{RTEst}$ modeling. In order to explain this phenomenon, a mechanism for re-equilibration was proposed in which groundwater $\left(\mathrm{Ca}-\mathrm{Mg}-\mathrm{HCO}_{3}\right.$ type $)$ loses $\mathrm{Ca}^{2+}$ and $\mathrm{Mg}^{2+}$ and gains $\mathrm{Na}^{+}$upon mixing with a $\mathrm{Na}-\mathrm{HCO}_{3}$ thermal water with increasing temperature and depth resulting in 
dilute water that further mixes with $\mathrm{Na}-\mathrm{HCO}_{3}$ thermal waters. Conversely, this reequilibration mechanism explains the transition from $\mathrm{Na}-\mathrm{HCO}_{3}$ thermal waters into more $\mathrm{Ca}-$ $\mathrm{HCO}_{3}$ thermal waters by the increase of $\mathrm{Ca}^{2+}$ and $\mathrm{Mg}^{2+}$ and decrease of $\mathrm{Na}^{+}$from mixing during ascension through a series of equilibration zones. The RMAs utilized in MEG inverse modeling show that $\mathrm{Ca}-\mathrm{HCO}_{3}$ waters in equilibrium with $\mathrm{Ca}^{2+}$ and $\mathrm{Mg}^{2+}$ rich smectite clays and zeolites gradually shift to $\mathrm{Na}-\mathrm{HCO}_{3}$ waters in equilibrium with $\mathrm{Na}^{+}$and $\mathrm{K}^{+}$rich smectite clays and zeolites through several zones of re-equilibration resulting in thermal water types in between the two end members.

A possible re-equilibration mechanism was tested using high temperature water-rock interaction experiments. In the experiments, a $150{ }^{\circ} \mathrm{C}$ thermal water derived from equilibration with Idavada volcanics was mixed with a local groundwater at an intermediate $70{ }^{\circ} \mathrm{C}$ within the basalts of the ESRP. Samples taken over 40 days reveal that $\mathrm{Ca}^{2+}, \mathrm{Mg}^{2+}$, and $\mathrm{SiO}^{2-}$ concentrations decrease significantly at about 4 days after initial mixing. $\mathrm{Na}+$ concentrations increase dramatically within the same observation time thus providing support for the possibility of re-equilibration of thermal waters within the Twin Falls - Banbury hydrothermal area.

A detailed look into local geology and hydrology reveals that the thermal system is likely recharged from the Cassia Mountains to the south of the study area. Groundwater likely picks up its $\mathrm{Ca}-\mathrm{Mg}-\mathrm{HCO}_{3}$ signature from the Paleozoic carbonates exposed in the area before travelling northwesterly towards the Twin Falls and Banbury thermal clusters. The Banbury hydrothermal system appears to be controlled by a single northwest trending normal fault with $\mathrm{Ca}-\mathrm{HCO}_{3}$ thermal waters grading into $\mathrm{Na}-\mathrm{HCO}_{3}$ thermal waters away from the recharge zone. A similar distribution of thermal waters is observed in the Twin Falls thermal area without the 
presence of a major fault. $\mathrm{Na}-\mathrm{HCO}_{3}$ thermal waters are located near the Snake River where overlying Quaternary and Tertiary basalt units thin allowing for Tertiary Idavada volcanics to be exposed at the surface. A pumping test was performed on two deep rhyolite-penetrating wells on the campus of the College of Southern Idaho. Estimates of aquifer transmissivity from pump/recovery test analysis agree with a previous area study (Street and DeTar, 1987) at values of $930 \mathrm{~m}^{2} / \mathrm{d}\left(7.5 \times 10^{4} \mathrm{gpd} / \mathrm{ft}\right)$. While there appears to be no decline in temperature of the Twin Falls area resource in the last 30 years, a significant decline in hydraulic head of about 15 meters (50 ft.) is observed with head values dropping from about 14 meters (45 ft.) above land surface to about 1.2 meters ( $4 \mathrm{ft}$.$) below land surface at present day.$

In its entirety, this work has resulted in the redefining of the conceptual model for the Twin Falls - Banbury thermal system. Advanced geothermometry techniques have been utilized to provide evidence for a high temperature $\left(150+{ }^{\circ} \mathrm{C}\right)$ resource in the Twin - Falls Banbury area, historic and newly collected geochemical data have been used to provide evidence for both mixing and re-equilibration of thermal waters, and the possibility of a reequilibration mechanism has been tested through a series of high temperature water-rock interaction and mixing experiments. The RTEst temperature estimates made for $\mathrm{Na}-\mathrm{HCO}_{3}$ waters are consistent with an estimate of $150{ }^{\circ} \mathrm{C}$ for Banbury Hot Springs made using sulfatewater isotope geothermometry earlier this year (Conrad et al., 2015).

In addition to providing new insights into reservoir temperature and mixing relationships, this study has raised questions that may be answered by future work. Although the possibility of the two thermal water types being unrelated and the product of two separate flow paths is considered unlikely, it cannot be ruled out from the work presented here. Additionally, the results of the mixing portion of the water-rock interaction experiments lead 
to the assumption that the transition from silicic volcanics to basalt is necessary for reequilibration to take place. Further work regarding possible flow paths between the Idavada volcanics and overlying basalts is warranted to answer both of these questions. An expansion of the experiment to include the possibility of re-equilibration without mixing, rhyolite exclusive mixing, and temperature decreases in rhyolites and basalts without mixing may also aid in the understanding of the system. Lastly, x-ray powder diffraction (XRD) and scanning electron microscopy (SEM) analysis of post experimental rock samples would aid in both the understanding of alteration mineral assemblages and the exchange or precipitation reactions responsible for re-equilibration. 


\section{REFERENCES}

Adar, E.M., E. Rosenthal, A.S. Issar, and Batelaan, O. (1992). Quantitative assessment of the flow pattern in the Southern Arava Valley (Israel) by environmental tracers and a mixing cell model. J. Hydrol., 136, p. 333-352.

Arnòrsson, S., Gunnlaugsson, E., and Svavarsson, H. (1983). The chemistry of geothermal waters in Iceland. II. Mineral equilibria and independent variables controlling water compositions. Geochim. Cosmochim. Acta, 47, p. 547-566.

Arnòrsson, S. (1985). The use of mixing models and chemical geothermometers for estimating underground temperature in geothermal systems. J. Volc. Geotherm. Res., 23, p. 299-335.

Basharina, L.A. (1958). Water extracts of the ashes and the ash-cloud gases of the Bezymyannyi volcano: Akad. Nauk SSSR, Lab. Vulkanol., Vulkanol. Stantsii Biull, v. 27, p. 38-42.

Bethke, C.M. (2008). Geochemical and Biogeochemical Reaction Modeling. Cambridge University Press, p 547.

Bethke, C.M. and Yeakel, S. (2012). The Geochemist's Workbench ${ }^{\circledR}$ Release 9.0. Reaction Modeling Guide. Aqueous Solutions, LLC, Champaign, Illinois.

Blackwell, D.D., and M.C. Richards. (2004). "Geothermal Map of North America.” American Association of Petroleum Geologists, 1 sheet, scale 1:6,500,000.

Bottinga, Y. (1968). Hydrogen isotope equilibria in the system hydrogen-water. Journal of Physical Chemistry, v. 72, p. 4338-4340.

Brott, C.A., D.D. Blackwell, and J.C. Mitchell. (1976). Geothermal Investigations in Idaho Part 8: Heat Flow in the Snake River Plain Region, Southern Idaho. Water Information Bulletin 30, Idaho Department of Water Resources.

Browne, P.R.L. (1978). Hydrothermal Alteration in Active Geothermal Fields. Annual Review of Earth and Planetary Sciences, 6: p. 229-250.

Cannon, C., Wood, T., Neupane, G., McLing, T., Mattons, E., Dobson, P., and Conrad, M. (2014). Geochemical Sampling for Traditional and Multicomponent Equilibrium Geothermometry in Southeast Idaho. Geothermal Resources Council Transcations, Vol. 38, p. 425. 
Carroll, D. (1959). Ion exchange in clays and other minerals. Geological Society of America, v. 70, p. 749-779.

Clark, I.D. (2015). Groundwater Geochemistry and Isotopes. "Tracing the Water Cycle. Taylor and Francis Group, LLC, p. 127-129.

Cloutier, V., Lefebvre, R., Therrien, R., and Savard, M.M. (2008). Multivariate statistical analysis of geochemical data as indicative of the hydrogeochemical evolution of ground water in a sedimentary rock aquifer system. J. Hydrol., 353, p. 294-313.

Cooper, H.H. and Jacob, C.E. (1946). A generalized graphical method for evaluating formation constants and summarizing well field history, Am. Geophys. Union Trans., vol. 27 , p. 526-534.

Cooper, D.C., Palmer, C.D., Smith, R.W., \& McLing, T.L. (2013). Multicomponent equilibrium models for testing geothermometry approaches. Proceedings. 38th Workshop on Geothermal Reservoir Engineering Stanford University, Stanford, CA.

Conrad, M.E., Dobson, P.F., Sonnenthal, E.L., Cannon, C., Wood, T., McLing, T., Neupane, G., and Mattson, E. (2015) Isotopic Insights into Deep Geothermal Systems in the Snake River Plain in Southeastern Idaho. $25^{\text {th }}$ Goldschmidt Conference, Prague, Czech Republic.

D'Amore, F., Fancelli, R., and Caboi, R. (1987). Observations on the application of chemical geothermometers to some hydrothermal systems in Sardinia. Geothermics, 16, p. 271 282.

Davis, J. (1986). Statistics and Data Analysis in Geology. 2nd Edn. Wiley, New York, p. 646

Davis, A.C., Bickle, M.J. and Teagle, D.A.H. (2003). Imbalance in the oceanic strontium budget. Earth and Planetary Science Letters, 211(1-2) p. 173-187.

Dobson, P.F., Kennedy, M.B., Conrad, M.E., Mcling, T., Mattson, E., Wood, T., Cannon, C., Spackman, R., van Soest, M., and Robertson, M. (2015). He Isotopic Evidence for Undiscovered Geothermal Systems in the Snake River Plain. Proceedings, 40th Workshop on Geothermal Reservoir Engineering, Stanford University, Stanford, CA, p. $2-4$

Doherty J.: PEST, Model-Independent Parameter Estimation User Manual, $5^{\text {th }}$ Edition. Watermark Numerical Computing, www.pesthompage.org, (2005) 
Edmunds, M.W., and Shand, P. (2009). Natural Groundwater Quality, "Geochemical Modeling of Processes Controlling Baseline Compositions. John Wiley \& Sons, p. $85-89$.

Ellis, A.J. (1970). Quantitative interpretation of chemical characteristics of hydrothermal systems. Geothermics, 2(Part 1),p. 516-528.

Ellis, A. J. (1971). Magnesium ion concentrations in the presence of magnesium chlorite, calcite, carbon dioxide, quartz. Amer. J. Sci. 271, p. 481-489.

Ellis A. J. and Mahon W. A. J. (1967) Natural hydrothermal systems and experimental hot water-rock interactions (Part II). Geochim. Cosmochim. Acta 31, p. 519-538.

Fetter, C.W., 2001. Applied Hydrogeology (4th ed.), Prentice-Hall, Upper Saddle River, New Jersey, p. 374.

Fleischmann, D.J. (2006). Geothermal development needs in Idaho. Geothermal Energy Association report for the U.S. Department of Energy, p. 51

Fouilliac, C., and Michard, G. (1981). Sodium/lithium ratio in water applied to geothermometry of geothermal reservoirs, Geothermics, 10, p. 55-70.

Fournier, R.O. (1977). Chemical geothermometers and mixing model for geothermal systems. Geothermics, 5, 41-50.

Fournier, R.O., and A.H. Truesdell. (1973). "An empirical Na-K-Ca geothermometer for natural waters." Geochim. Cosmochim. Acta, v. 37 p. 1255-1275.

Fournier, R.O., and R.W. Potter. (1979). "Magnesium correction to the Na-K-Ca chemical geothermometer." Geochim. Cosmochim. Acta v. 43, p. 1543-1550

Fournier R.O., and R.W. Potter II. (1982). "A revised and expanded silica (quartz) geothermometer." Geotherm. Resourc. Counc. Bull., v. 11, p.3-12

Fournier, R. O. and Rowe, J.J. (1966). Estimation of underground temperatures from the silica content of water from hot springs and wet steam wells. Am. J. Sci., 264, p. 685-691.

Fournier, R.O., and Truesdell, A.H., (1973): An empirical Na-K-Ca geothermometer for natural waters. Geochim. Cosmochim. Acta, 37, 1255-1275.

Fournier, R.O., and Truesdell, A.H. (1974). Geochemical indicators of subsurface temperature Part 2, Estimation of temperature and fraction of hot water mixed with cold water: U.S. GeoLSurvey Jour. Research, v.2, no.3, p. 263270 
Giggenbach, W.F. (1988). Geothennal solute equilibria. Deviation of Na-K-Mg-Ca geoindicators. Geochim. Cosmochim. Acta, 52, p. 2749-2765

Giggenbach, W.F. (1991). Chemical techniques in geothermal exploration; Application of Geochemistry in Geothermal Reservoir Development (D’Amore F., Ed.), UNITAR/UNDP Center on Small Energy Resources, Rome, p. 119-144.

Gillerman, V.S., Kauffman, J.D., and Othberg, K.L. (2005) Geologic Map of the Thousand Springs Quadrangle, Gooding and Twin Falls Counties, Idaho. Idaho Geological Survey

Gíslason, S.R., Heaney, P.J., Oelkers, E.H., Schott, J. (1997). Kinetic and thermodynamic properties of moganite, a novel silica polymorph. Geochimica et Cosmochimica Acta, (6), p.1193-1204.

Guler, C., Thyne, G., McCray, J. and Turner, K. (2002). Evaluation of graphical and multivariate statistical methods for classification of water chemistry data. Hydrogeol. J., 10, p. 455-474.

Henley, R.W. and Ellis, A.J. (1983). Geothermal Systems Ancient and Modern - a Geochemical Review. Earth-Science Reviews, 19(1): 1-50.

Huenges, E., and Ledru, P. (2011). Geothermal Energy Systems: Exploration, Development, and Utilization. Wiley Publishing, pp. 97-100

Hughes, S.S., R.P. Smith, W.R. Hackett, and S. R. Anderson. (1999). "Mafic volcanism and environmental geology of the eastern Snake River Plain." Idaho Guidebook to the Geology of Eastern Idaho. Idaho Museum of Natural History, p. 143-168

Hughes, S.S., Wetmore, P.H. and Casper, J.L. (2002). Evolution of Quaternary Tholeiitic Basalt Eruptive Centers on the Eastern Snake River Plain, Idaho. In B. Bonnichsen, C.M. White, and M. McCurry, eds., Tectonic and Magmatic Evolution of the Snake River Plain Volcanic Province, Idaho Geological Survey Bulletin 30, p. 23.

Hull, C.D., Reed, M.H., and Fisher, K. (1987). Chemical geothermometry and numerical unmixing of the diluted geothermal waters of the San Bernardino Valley Region of Southern California. GRC Transactions, 11, p. 165-184.

Kanade, S. and Gaikwad V.B. (2011). A multivariate statistical analysis of bore well chemistry data-Nashik and Niphad Taluka of Maharashtra, India. Univer. J. Env. Res. Technol., 1, 193-202. 
Khitarov, N.I., Lebedev, E.B., Rengarten, E.B., and Arsena, R.V. (1959). The solubility of water in basaltic and granitic melts. Geochemistry, 5, p. 479-492.

Kuntz, M.A, Covington, H.R., and Schorr, L.J. (1992) Chapter 12 - An Overview of Basaltic Volcanism of the Eastern Snake River Plain, Idaho. In Link, P.K., Kuntz, M.A., and Platt, L.B., eds., Regional Geology of Eastern Idaho and Western Wyoming, Geological Society of America Memoir 179, p. 227-267.

Larsson, D., Grönvold, K., Oskarsson, N. and Gunnlaugsson, E. (2002). Hydrothermal alteration of plagioclase and growth of secondary feldspar in the Hengill Volcanic Centre, SW Iceland. Journal of Volcanology and Geothermal Research, 114, p. 275-290.

Leeman, W.P., Annen, C. and Dufek, J. (2008). Snake River Plain - Yellowstone Silicic Volcanism: Implications for Magma Genesis and Magma Fluxes. In Annen, C. and Zellmer, G. F. (eds) Dynamics of Crustal Magma Transfer, Storage and Differentiation. Geological Society, London, Special Publications, 304, p. 235-259.

Lewis, R.E., and H.W. Young (1982). "Geothermal resources in the Banbury Hot Springs Area, Twin Falls County, Idaho.” U.S. Geological Survey Water-Supply Paper 2186, p. 27.

Lewis, R.E. and H.W. Young. (1989). The hydrothermal system in central Twin Falls County, Idaho: U.S. Geological Survey Water Resources Investigations Report 88-4152, p. 44 Lesher, C.M., Gibson, H.L. and Campbell, I.H. (1986). Composition-volume changes during hydrothermal alteration of andesite at Buttercup-Hill, Noranda-District, Quebec. Geochimica Et Cosmochimica Acta, 50(12), p. 2693-2705.

Lonker, S.W., Franzson, H. and Kristmannsdottir, H., 1993. Mineral-Fluid Interactions in the Reykjanes and Svartsengi Geothermal Systems, Iceland. American Journal of Science, 293(7): 605-670.

Mabey, D.R. (1982) Geophysics and tectonics of the Snake River Plain, Idaho, in Bonnichsen, B., and Breckenridge, R.M., eds., Cenozoic Geology of Idaho: Idaho Bureau of Mines and Geology Bulletin 26, p. 139

Malde, H. E., and Powers, H. A. (1972). Geologic map of the Glenns Ferry-Hagerman area, west-central Snake River Plain, Idaho: U.S. Geol. Survey Misc. Geol. Inv. Map 1-696 
Mann, L.J. (1986). Hydraulic properties of rock units and chemical quality of water for INEL1: A 10,365-foot-deep test hole drilled at the Idaho National Engineering Laboratory, Idaho: U.S. Geological Survey Water Resources Investigations Report 86-4020, p. 23.

Marsh, K.N. (1987) Recommended Reference Materials for the Realization of Physiochemical Properties. Blackwell, Oxford.

Mas, A., Guisseau, D., Patrier Mas, P., Beaufort, D., Genter, A., Sanjuan, B. and Girard, J.P. (2006). Clay minerals related to the hydrothermal activity of the Bouillante geothermal field (Guadeloupe). Journal of Volcanology and Geothermal Research, $158(3-4)$ p. 380

Mariner, R.H., H.W. Young, W.C. Evans, and D.J. Parliman. (1991). “Chemical, isotopic, and dissolved gas compositions of the hydrothermal system in Twin Falls and Jerome Counties, Idaho. Geothermal Resources Council Transactions, v. 15, p. 257-263.

Mariner, R.H., H.W. Young, T.D. Bullen, and C.J. Janik. (1997). Sulfate-water isotope geothermometery and lead isotope data for regional geothermal system in the Twin Falls area, south-central Idaho. Geothermal Resources Council Transactions, v. 21, p. 197-201.

McLing, T.L., R.W. Smith, and T.M. Johnson. (2002). "Chemical Characteristics of Thermal Water Beneath the Eastern Snake River Plain Aquifer.” GSA Special Paper 353, p.13. McLing, T., McCurry, M., Cannon, C., Neupane, G., Wood, T., Podgorney, R., Welhan, J., Mines, G., Mattson, E., Wood, R., Palmer, C. and Smith, R. (2014) David Blackwell's Forty Years in the Idaho Desert, The Foundation for 21st Century Geothermal Research. Geothermal Resources Council Transactions, 38, p. 143-153.

Meng, S.X., and Maynard, J.B. (2001). Use of statistical analysis to formulate conceptual models of geochemical behavior: Water chemical data from the Botucatu aquifer in Sao Paulo state. Brazil. J. Hydrol., 250, p. 78-97.

Mitchell, J.C., Johnson, L.L., and Anderson, J.E. (1980). Geothermal Investigations in Idaho Part 9: Potential for Direct Heat Application of Geothermal Resources. Idaho Department of Water Resources Water Information Bulletin No. 30

Morgan, L.A., Doherty, D.J., and Leeman, W.P. (1984). Ignimbrites of the eastern Snake River Plain, Idaho: Evidence for major caldera-forming eruptions: Journal of Geophysical Research, v. 89, p. 8665-8678. 
Morse, L.H. and McCurry, M. (2002). Genesis of alteration of Quaternary basalts within a portion of the eastern Snake River Plain aquifer. Special Papers Geological Society of America, p. 213-224.

Muthulakshmi, L., Ramu, A., Kannan, N., and Murugan, A. (2013). Application of Correlation and Regression Analysis in Assessing Ground Water Quality. International Journal of ChemTech Research Vol. 5, p. 355-356.

Neuhoff, P.S., Fridriksson, T., Arnorsson, S. and Bird, D.K. (1999). Porosity evolution and mineral paragenesis during low-grade metamorphism of basaltic lavas at Teigarhorn, eastern Iceland. American Journal of Science, 299(6): 467-501.

Neupane, G., Smith, R.W., McLing, T.L., Palmer, C.D., and Smith, W.W. (2013). Constraining Multicomponent Equilibrium Geothermometer Temperature Using Laboratory Experiments: Preliminary Results. Geological Society of America, v. 45, p. 774 .

Neupane, G., Smith, R. W., Palmer, C. D., and McLing, T. L (2013). Multicomponent equilibrium geothermometry applied to the Raft River geothermal area, Idaho: preliminary results. In Geological Society of America Abstracts with Programs, 45.

Neupane, G., E.D. Mattson, T.L. McLing, C.D. Palmer, R.W. Smith, and T.R. Wood. (2014). Deep geothermal reservoir temperatures in the Eastern Snake River Plain, Idaho using multicomponent geothermometry. Proceedings, $39^{\text {th }}$ Workshop on Geothermal Reservoir Engineering, Stanford University, Stanford, California, February 24-26, 2014 SGP-TR-202, p.12.

Neupane, G., Baum, J.S., Mattson, E.D., Mines, G.L., Palmer, C.D., and Smith, R.W., (2015). Validation of Multicomponent Equilibrium Geothermometry at Four Geothermal Power Plants. Fortieth Workshop on Geothermal Reservoir Engineering Stanford University, Stanford, California, January 26-28, SGP-TR-204, p. 1-9.

Othberg, K.L., Kauffman, J.D., and Gillerman, V.S. (2005) Geologic Map of the Twin Falls Quadrangle, Jerome, and Twin Falls Counties, Idaho. Idaho Geological Survey.

Othberg, K.L., Kauffman, J.D., and Gillerman, V.S. and Garwood, D.L. (2012) Geologic Map of the Twin Falls 30 x 60 Minute Quadrangle, Idaho. Idaho Geological Survey. Geologic Map 49 
Pabalan, R.T., and Bertetti, P.F. (2001). Cation-Exchange Properties of Natural Zeolites. Mineralogilca Society of America, v. 45, p. 453-518.

Palmer, C.D. 2013. Installation manual for Reservoir Temperature Estimator (RTEst), Idaho National Laboratory, Idaho Falls, ID.

Parliman, D.J. and Young H.W. (1992). Compilation of Selected Data for Thermal-Water Wells and Springs in Idaho, 1921 through 1991. U.S. Geological Survey Open-File Report 92-175, p. 201.

Pierce, K.L. and Morgan, L.A. (2009). Is the Track of the Yellowstone hotspot Driven by a Deep Mantle Plume? - Review of Volcanism, Faulting, and Uplift in Light of New Data, Journal of Volcanology and Geothermal Research, 188, p. 1-25.

Piper, A. M. (1944). A graphic procedure in the geochemical interpretation of water analyses. Transactions. American Geophysical Union 25, p. 914.

Ralston, D.R., J.L. Arrigo, J.V. Baglio Jr., L.M. Coleman, K. Souder, and A.L. Mayo. (1981). "Geothermal evaluation of the thrust area zone in southeastern Idaho." Idaho Water and Energy Research Institute, University of Idaho, p. 110.

Rani, A.L. and Babu S. (2008). A statistical evaluation of ground water chemistry from the west coast of Tamil Nadu, India. Indian Journal of Marine Sciences vol 37. p. 189-192.

Reed, M. and Spycher, N. (1984). Calculation of $\mathrm{pH}$ and mineral equilibria in hydrothermal waters with application to geothermometry and studies of boiling and dilution. Geochimica et Cosmochimica Acta, 48, p. 1479-1492.

Rember, W.C., and Bennett, E.H. (1979) Geologic map of the Twin Falls quadrangle, Idaho: Moscow, Idaho, Idaho Bureau of Mines and Geology, Geologic Map Series, Twin Falls Quadrangle, scale 1:250,000.

Reyes, A.G. (1990). Petrology of Philippine geothermal systems and the application of alterationmineralogy to their assessment. Journal of Volcanology and Geothermal Research, 43 p. 279-309.

Robin, V., Tertre, E., Beaufort, D., Regnault, O., Sardini, P., and Descostes, M. (2015). Ion exchange reactions of major cations $\left(\mathrm{H}^{+}, \mathrm{Na}^{+}, \mathrm{Ca}^{2+}, \mathrm{Mg}^{2+}\right.$, and $\left.\mathrm{K}^{+}\right)$on beidellite: Experimental results and new thermodynamic database. Toward a better prediction of contaminant mobility in natural environments. Applied Geochemistry v. 59, p. 74-84. 
Rodgers, D.W., H.T. Ore, R.T. Bobo, N. McQuarrie, and N. Zentner. (2002). "Extension and subsidence of the eastern Snake River Plain, Idaho.” In: C.M. White and M. McCurry, eds., Tectonic and Magmatic Evolution of the Snake River Plain Province: Idaho Geologic Survey Bulletin 30, p. 121-155.

Rodriguez, A. (2011). Water-Rock Interaction of Silicic Rocks: An Experimental and Geochemical Modeling Study. United Nations University Training Programme Reykjavik, Iceland. P. 2-21.

Ross, S.H. (1971). “Geothermal potential of Idaho.” Idaho Bureau of Mines and Geology, Pamphlet 150, p. 72.

Rounds, S.A., and Wilde, F.D. (2001). U.S. Geological Survey TWRI Book 9. Chapter 6.6: Alkalinity and Acid Neutralizing Capacity.

Sant, C.J. (2012). Geothermal Alteration of Basaltic Core from the Snake River Plain, Idaho. Utah State University. All Graduate Theses and Dissertations Paper 1451.

Savage, D., Bateman, K., and Richards, H.G. (1992). Granite-water interactions in a flowthrough experimental system with applications to the Hot Dry Rock geothermal system at Rosemanowes, Cornwall, U.K. Applied Geochemistry, v. 7 p. 226

Schroeder, F.C. (1912) A reconnaissance of the Jarbidge, Contact, and Elk Mountain mining districts, Elko County, Nevada: U.S. Geological Survey Bulletin 497, p. 36

Shervais, J.W., Schmidt, D.R., Nielson, D., Evans, J.P., Christiansen, E.H., Morgan, L., Shanks, W.C.P., Prokopenko, A.A., Lachmar, T., Liberty, L.M., Blackwell, D.D., Glen, J.M., Champion, D., Potter, K.E. and Kessler, J.A. (2013). First Results from HOTSPOT: The Snake River Plain Scientific Drilling Project, Idaho, U.S.A., Scientific Drilling, 15, p. 36-45.

Smith, R.W., Palmer, C.D., and Cooper, D.: Approaches for multicomponent equilibrium geothermometry as a tool for geothermal resource exploration. AGU Fall Meeting, San Francisco, 3-7 December 2012.

Spycher, N.F., Peiffer, L., Sonnenthal, E.L., Saldi, G., Reed, M.H., Kennedy, B.M. (2014) Integrated multicomponent solute geothermometry), Geothermics, 51, p. 113-123 
Street, L.V., and DeTar, R.E. (1987). Geothermal Resource Analysis in Twin Falls County, Idaho: Idaho Department of Water Resources: Water Information Bulletin No. 30, Part 15 , p. 46

Stefánsson, A. and Arnórsson, S. (2002). Gas pressures and redox reactions in geothermal fluids in Iceland. Chemical Geology, 190(1-4), p. 251-27

Taylor, H. P., Jr. (1974). The Application of Oxygen and Hydrogen Isotope Studies to Problems of Hydrothermal Alteration and Ore Deposition: Economic Geology, vol. 69, p. 843-883.

Tester, J.W., Anderson, B.J., Batchelor, A.S., Blackwell, D.D., DiPippo, R., Drake, E.M., Garnish, J., Livesay, B., Moore, M.C., Nichols, K., Petty, S., Toksöz, M.N., and Veatch, R. W. (2006). The future of geothermal energy - impact of enhanced geothermal systems (EGS) on the United States in the 21st century. Massachusetts Institute of Technology, p. 372.

Theis, C.V. (1935). The relation between the lowering of the piezometric surface and the rate and duration of discharge of a well using groundwater storage, Am. Geophys. Union Trans., vol. 16, p. 519-524.

Tole, M.P., Ármannsson, H., Pang, Z.H., and Arnórsson, S. (1993). Fluid mineral equilibrium calculations for geothermal fluids and chemical geothermometry. Geothermics 22, p. 17-37.

Truesdell, A.H., 1976. "Summary of section III - geochemical techniques in exploration." Proceedings of the $2^{\text {nd }}$ U.N. Symposium on the Development and Use of Geothermal Resources, San Francisco, v. 1, p. 31.

Truesdell, A.H., and Fournier, R.O., 1977: Procedure for estimating the temperature of a hot water component in a mixed water using a plot of dissolved silica vs. enthalpy. U.S. Geol. Survey J. Res., 5, p. 49- 52.

Truesdell, A.H., M. Nathenson, and R.O. Rye. 1977. The effects of subsurface boiling and dilution on the isotopic compositions of Yellowstone thermal waters. Journal of Geophysical Research 82, p. 3694-3704.

USDA (2011). Digital Orthoimagery Series of Idaho (2011, 1-meter, Natural and False Color) USDA-FSA-APFO Aerial Photography Field Office. Salt Lake City, Utah. 
USGS (2004) Development of a local meteoric water line for southeastern Idaho, western Wyoming, and southcentral Montana. Scientific Investigations Report 2004-5126 Verma, M.P. (2000). Limitations in applying silica geothermometers for geothermal reservoir estimation. $25^{\text {th }}$ Workshop on Geothermal Reservoir Engineering. Stanford University, Stanford, California, January 24026, 2000. SGP-TR-165

Weisenberger, T. and Selbekk, R.S., 2009. Multi-stage zeolite facies mineralization in the Hvalfjordur area, Iceland. International Journal of Earth Sciences, 98(5) p. 985-999. White, D.E. (1968). Thermal Waters of Volcanic Origin. Bulletin of the Geological Society of America vol. 58, p. 1649-1650.

Williams, C.F., and DeAngelo, J. (2011). Evaluation of Approaches and Associated Uncertainties in the Estimation of Temperatures in the Upper Crust of the Western United States, Geothermal Resources Council Transactions, 35, p. 1599-1605.

Williams, C.F., Reed, M.J., Mariner, R.H., DeAngelo, J. and Galanis, S.P., Jr. (2008). Assessment of Moderate- and High-Temperature Geothermal Resources of the United States, U.S. Geological Survey Fact Sheet 2008-3082, p. 4.

Wood, W.W., and W.H. Low. (1988). "Solute chemistry of the Snake River Plain Regional Aquifer System, Idaho and Eastern Oregon.” U.S. Geological Survey Professional Paper 1408-D, p. 79.

Young, H.W., and J.C. Mitchell (1973). “Geothermal Investigations in Idaho Part 1: Geochemistry and Geologic Setting of Selected Thermal Waters." USGS, IDWR Water Information Bulletin No. 30, p. 23-28.

Zumlot, T., Batayneh, A., Nazal, Y., Ghrefat, H., Mogren, S., Zaman, H., Elawadi, E., and Laboun A. (2012). Using multivariate statistical analyses to evaluate groundwater contamination in the northwestern part of Saudi Arabia. Environ Earth Sci. DOI $10.1007 / \mathrm{s} 12665-013-2392-1$ 


\section{APPENDIX A: SAMPLE COLLECTION}

Sampling Phase 1: Field Parameters, Filtration, and Collection

A mobile field sampling trailer was constructed to protect equipment and staff from harsh environmental conditions often present in southern Idaho. Sampling took place in a two phase fashion. Phase one includes the measurement of field parameters, rinsing of bottles with sample water, and bottling of samples. If sampling from a thermal spring, a piece of 0.25 -inch stainless steel pipe attached to MasterFlex ${ }^{\circledR}$ peristaltic tubing (both prewashed in $10 \%$ trace grade $\mathrm{HNO}_{3}$ ) was used as an inlet. The stainless steel tubing often includes a non-reactive Nalgene ${ }^{\circledR}$ bottle cap acting as a stabilizer to keep the inlet above sediment or algal mats and may be extended to the center of the spring using an extendable swimming pool cleaning rod. The spring water is then pumped from the source using a Geotech ${ }^{\circledR}$ Geopump Peristaltic Pump (Series II). If measuring from a thermal well, a variety of prewashed spigot fittings and couples can be used to connect to the well head outlet. Thermal water is pumped from the source into a flow through cell (YSI® 6850) where the YSI Professional Plus Multi-parameter Meter is used to record the field parameters. The YSI multimeter is calibrated daily prior to sampling. The calibration procedure and checklist can be found on page 131. If warranted, the sample water may be cooled to $<60{ }^{\circ} \mathrm{C}$ (YSI sensor limitation) using a coiled stainless steel rod submerged in ice water within a 5-gallon cooler as shown in the picture below. Relevant field parameters include $\mathrm{pH}$, oxidation-reduction potential, dissolved oxygen, temperature, conductivity, and total dissolved solids. Once field parameters are stabilized and logged, sample water travels through an EMD Millipore ${ }^{\circledR} 0.45 \mu \mathrm{m}$ Groundwater Capsule filter prior to bottling in order to rid the sample of various suspended particles. 
Three separate water samples are taken from each source in order to analyze for major cations $\mathrm{Ca}, \mathrm{K}, \mathrm{Mg}, \mathrm{Na}$, and $\mathrm{SiO} 2$ (aq)), major anions (F, Cl, SO4, and $\mathrm{NO} 3$ ), and various trace elements (Al, B, Li, Br, Sr, Se, Rb, Ba, and Bi). Bottles are prepared prior any sampling campaign. Cation and anion samples are collected in $250 \mathrm{~mL}$ HDPE bottles whereas trace element samples are collected in 1 L HDPE bottles. All bottles are filled with nanopure (18.2 $\mathrm{M} \Omega$ ) deionized water and left to sit for 24 hours. They are subsequently rinsed with this same solution before preparation. Major cation and trace element bottles are partially filled with a $10 \%$ trace grade $\mathrm{HNO}_{3}$ solution and agitated to clean the entirety of the bottle. Anion sample bottles are simply filled with nanopure deionized water once more due to the impending analyses of $\mathrm{NO}_{3}$ and $\mathrm{NO}_{2}$. Prior to being filled with sample water in the field, all bottles are emptied of their cleaning solutions (neutralized in waste container with baking soda to a $\mathrm{pH}$ of $>6$ ). Once emptied bottles are rinsed 3 times with sample water before being capped and preserved. 


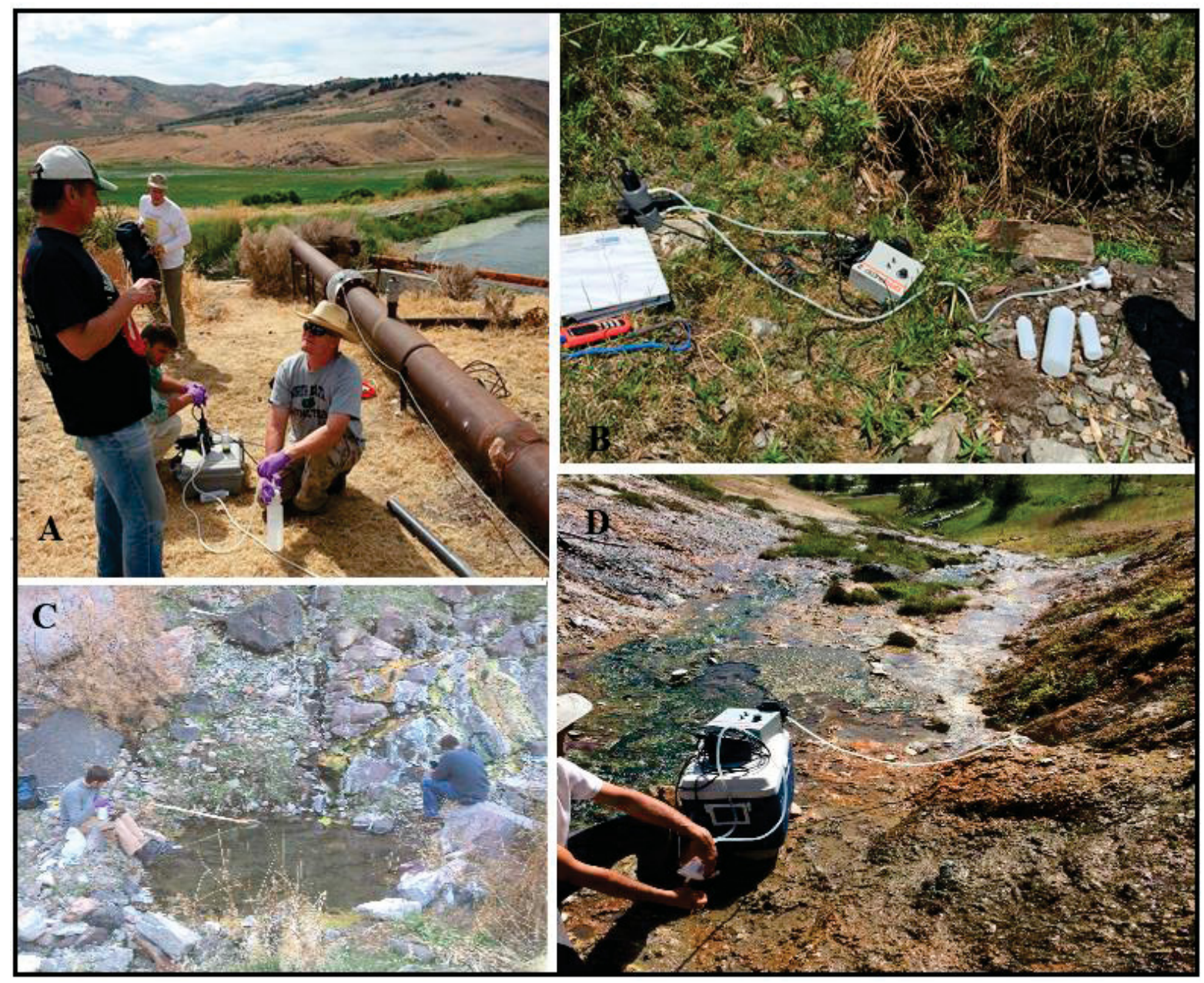

Figure A1. (A) Sample team comprised of U of I graduate student Cody Cannon (mid left), INL scientist Travis McLing (mid right), Dr. Mark Conrad (foreground) of the LBNL, and Dr. Pat Dobson (background) of the LBNL. (B) Sample equipment set up showing the peristaltic pump and tubing, $0.45 \mu \mathrm{m}$ filter, YSI ® Professional Plus Multimeter and Flow-Through Cell, and three sample bottles. (C) Sampling of Driscoll Spring near Twin Falls, ID. (D) Utilization of a coiled cooling system prior to sampling collection at Worswick Hot Springs, ID.

Sampling Phase 2: Preservation and Titration

A separate $50 \mathrm{~mL}$ filtered sample will be collected in an acid-washed graduated cylinder to be used in titration in order to determine the amount of dissolved carbonate (as $\mathrm{CO}_{3}$ and $\mathrm{HCO}_{3}$ ).

A Hach ${ }^{\circledR}$ Digital Titrator (Model 1690001) equipped with either $1.6 \mathrm{~N}$ or $0.16 \mathrm{~N}$ sulfuric acid 
is used to titrate the sample. A pH meter is rinsed with sample water and then used to monitor the samples $\mathrm{pH}$ as the acid is applied. The number of titrations it takes for the sample water to be lowered to a $\mathrm{pH}$ of 4.5 is recorded from the titrator and subsequently used to calculate the amount of carbonate in the sample. The total alkalinity calculation procedure for a digital titrator can be found in the USGS field manual chapter 6.6 (Rounds and Wilde, 2001). Simultaneously or soon after titration is complete, the major cation and trace element bottles are preserved with $70 \%$ optima grade nitric acid until a $\mathrm{pH}$ of $\leq 2$ is reached. Preservation is done to prevent precipitation of constituents or adsorption onto the bottle walls. Anion samples are not preserved and should be analyzed within approximately 28 days of sample collection as per EPA method 300.1. Cation and trace element samples have a shelf life of 6 months as per EPA Methods SW-846 and 200.8 respectively. After preservation and capping, water samples are sealed with strips of ParaFilm ${ }^{\circledR}$ and refrigerated at $4{ }^{\circ} \mathrm{C}$ until chemical analysis. Upon completion of sampling, all used tubing is cleaned by pumping $10 \%$ trace grade nitric acid from one carboy into a baking soda laden waste carboy.

All field parameters for samples utilized in this study are listed below. 
Table A1. Field parameters for select ESRP thermal samples collected in 2014.

\begin{tabular}{|c|c|c|c|c|c|c|c|c|c|c|c|c|}
\hline Timestamp & Date In Lab & Lat & Long & Site & Unit ID & \begin{tabular}{|c} 
Temperature \\
(C)
\end{tabular} & $\mathrm{pH}$ & $\begin{array}{c}\text { Conuctivity } \\
\text { (uS/cm) }\end{array}$ & $\begin{array}{c}\text { Dissolved } \\
\text { Oxygen (mg/L) }\end{array}$ & ORP (mV) & TDS $(\mathrm{g} / \mathrm{L})$ & $\begin{array}{c}\text { Alkalinity } \\
\text { (mg/Las HCO3) }\end{array}$ \\
\hline 3/10/2014 13:30 & $3 / 14 / 2014$ & 43.64283 & -111.68768 & 001 & Heise Hot Springs & 48.2 & 6.3 & 14789 & 0.43 & -269.2 & 7.0005 & 986 \\
\hline 3/11/2014 8:13 & $3 / 14 / 2014$ & 44.14558 & -112.55494 & 002 & Lidy Hot Springs 1 & 56.1 & 7.2 & 836 & 0.34 & -177.5 & 0.364 & 132 \\
\hline 3/11/2014 9:13 & $3 / 14 / 2014$ & 44.14166 & -112.55240 & 003 & Lidy Hot Springs 2 & 52.3 & 7.2 & 815 & 0.87 & -140.9 & 0.3835 & 163 \\
\hline 3/11/2014 13:12 & $3 / 14 / 2014$ & 43.79211 & -111.44009 & 004 & Green Canyon Hot Springs & 44 & 7.2 & 1152 & 2.84 & 96.9 & 0.585 & 137 \\
\hline 3/11/2014 16:40 & $3 / 14 / 2014$ & 44.09325 & -111.43534 & 005 & Sturm Well & 31.4 & 8.7 & 183 & 4.5 & 44.5 & 0.106 & 66 \\
\hline 3/12/2014 12:15 & $3 / 14 / 2014$ & 43.33278 & -113.91790 & 006 & Condie Hot Springs & 50.5 & 7 & 1075 & 0.6 & -71.8 & 0.481 & 315 \\
\hline 3/12/2014 15:09 & $3 / 14 / 2014$ & 43.60234 & -113.24214 & 007 & Greenhouse Well & 36.3 & 7.1 & 882 & 2.89 & 101.5 & 0.481 & 285 \\
\hline $3 / 13 / 20148: 53$ & $3 / 14 / 2014$ & 42.69940 & -114.91040 & 008 & Eckart Office Well & 24.7 & 9.5 & 610 & 4.71 & 39.7 & 0.3965 & 81 \\
\hline 3/13/2014 10:30 & $3 / 14 / 2014$ & 42.64497 & -114.78706 & 009 & Campbell 1 & 34.5 & 8 & 457.7 & 4.06 & 64.2 & 0.2516 & 144 \\
\hline 3/13/2014 11:13 & $3 / 14 / 2014$ & 42.64432 & -114.78294 & 010 & Campbell 2 & 34.4 & 8 & 527 & 4.57 & 64.6 & 0.2925 & 127 \\
\hline 3/13/2014 14:34 & $3 / 14 / 2014$ & 42.69457 & -114.85592 & 011 & Miracle Hot Springs & 58.4 & 9.5 & 1002 & 0.29 & -162.1 & 0.4225 & 93 \\
\hline 3/13/2014 16:19 & $3 / 14 / 2014$ & 42.54479 & -114.94855 & 012 & Driscoll Well & 37.5 & 8.6 & 1070 & 5.36 & -13.8 & 0.559 & 95 \\
\hline 3/13/2014 16:52 & $3 / 14 / 2014$ & 42.54348 & -114.94897 & 013 & Driscoll Spring & 36.2 & 8.7 & 1027 & 4.62 & 27.8 & 0.5655 & 98 \\
\hline $3 / 14 / 20148: 13$ & $3 / 14 / 2014$ & 42.58318 & -114.47496 & 014 & CSI Well 2 & 38.1 & 8.8 & 631 & 3.97 & 75.5 & 0.3315 & 127 \\
\hline 6/6/2014 9:14 & 6/6/2014 & 43.44244 & -111.90484 & 015 & Comore Loma \#6 & 20.9 & 6.7 & 828 & 6.82 & 176.6 & 0.585 & 222 \\
\hline 6/6/2014 10:56 & $6 / 6 / 2014$ & 43.43774 & -111.93018 & 016 & Comore Loma \#5 & 27.7 & 6.9 & 943 & 6.28 & 121.5 & 0.585 & 251 \\
\hline 6/6/2014 12:56 & $6 / 6 / 2014$ & 43.43142 & -111.94501 & 017 & Blackhawk \#2 & 26.8 & 6.6 & 1249 & 6.55 & 114.2 & 0.83683 & 271 \\
\hline 6/6/2014 12:56 & $6 / 6 / 2014$ & 43.43121 & -11.94469 & 018 & Blackhawk \#1 & 25.1 & 6.8 & 1176 & 7.14 & 109.7 & 0.7605 & 268 \\
\hline 6/11/2014 11:01 & $6 / 11 / 2014$ & 42.10207 & -113.38434 & 020 & Raft River Geothermal \# 1 & 150 & 7.1 & 5972 & 0.06 & -217.8 & 2.3335 & 34 \\
\hline 6/11/2014 11:52 & 6/11/2014 & 42.11042 & -113.37519 & 021 & Raft River Geothermal \# 2 & 150 & 6.9 & 4079 & 0.07 & -218.8 & 1.846 & 38 \\
\hline 6/11/2014 12:44 & $6 / 11 / 2014$ & 42.08359 & -113.35865 & 022 & Raft River Geothermal \# 7 & 150 & 6.3 & 11474 & 0.08 & -218.8 & 5.1805 & 33 \\
\hline 6/11/2014 13:39 & $6 / 11 / 2014$ & 42.09787 & -113.38541 & 023 & Raft River Geothermal \# 4 & 150 & 7.1 & 4846 & 0.09 & -219.3 & 2.1775 & 44 \\
\hline 6/17/2014 13:33 & 6/17/2014 & 42.72589 & -112.87381 & 024 & Indian Hot Springs & 32.7 & 7.2 & 1452 & 2.38 & -61.2 & 0.8255 & 223 \\
\hline 6/18/2014 9:57 & $6 / 18 / 2014$ & 42.23667 & -113.36971 & 025 & Grush Dairy & 54.7 & 9.2 & 1196 & 0.04 & -146.5 & 0.494 & 283 \\
\hline 6/18/2014 11:31 & 6/18/2014 & 42.107989 & -113.39206 & 026 & Raft River USGS Well & 79.6 & 8.1 & 5463 & 1.5 & -179.8 & 2.5805 & 95 \\
\hline 6/18/2014 12:07 & $6 / 18 / 2014$ & 42.10776 & -113.39186 & 027 & Raft River Frasier Well & 78.6 & 7.7 & 4900 & 0.2 & -175.2 & 2.444 & 60 \\
\hline 6/18/2014 13:18 & 6/18/2014 & 42.09656 & -113.37800 & 028 & Raft River Crook Well & 81 & 8.3 & 7297 & 0.46 & -85.5 & 4.6475 & 35 \\
\hline 6/23/2014 10:18 & $6 / 26 / 2014$ & 43.36414 & -113.78943 & 029 & Milford Sweat & 38.1 & 7.3 & 792 & - & 69.3 & 0.416 & 251 \\
\hline 6/23/2014 12:48 & $6 / 26 / 2014$ & 43.32777 & -114.39941 & 030 & Magic Hot Springs Landing Runoff & 39.1 & 8.6 & 2227 & - & -24.6 & 1.1375 & 710 \\
\hline 6/23/2014 15:46 & $6 / 26 / 2014$ & 43.42341 & -114.62857 & 031 & Elk Creek 1 & 50.0 & 9.1 & 758 & - & -126 & 0.338 & 93 \\
\hline 6/23/2014 16:15 & $6 / 26 / 2014$ & 43.42322 & -114.62865 & 032 & Elk Creek 2 & 55.5 & 9.1 & 812 & - & -82.6 & 0.3445 & 90 \\
\hline 6/24/2014 9:13 & $6 / 26 / 2014$ & 43.29241 & -114.91002 & 033 & Barron Well & 38.0 & 8 & 1195 & - & -104.8 & 0.624 & 181 \\
\hline $6 / 24 / 2014$ 10:24 & $6 / 26 / 2014$ & 43.38290 & -114.93224 & 034 & Wardrop Hot Springs (Gonzales' House) & 67.5 & 9 & 553 & - & -130.8 & 0.2145 & 193 \\
\hline 6/24/2014 13:10 & $6 / 26 / 2014$ & 43.32777 & -114.39941 & 035 & Magic Hot Springs Landing Well & 75.0 & 6.8 & 2951 & - & -84 & 1.183 & 703 \\
\hline
\end{tabular}




\begin{tabular}{|c|c|c|c|c|c|c|c|c|c|c|c|c|}
\hline Timestamp & Date In Lab & Lat & Long & Site & Unit ID & \begin{tabular}{|c|} 
Temperature \\
(C)
\end{tabular} & $\mathrm{pH}$ & $\begin{array}{c}\text { Conuctivity } \\
\text { (uS/cm) }\end{array}$ & $\begin{array}{c}\text { Dissolved } \\
\text { Oxygen (mg/L) }\end{array}$ & $\mathrm{ORP}(\mathrm{mV})$ & $\operatorname{TDS}(\mathrm{g} / \mathrm{L})$ & $\begin{array}{c}\text { Alkalinity } \\
\text { (mg/L as HCO3) }\end{array}$ \\
\hline 6/24/2014 16:48 & $6 / 26 / 2014$ & 43.12966 & -115.33841 & 036 & Prince Albert Hot Springs & 57.7 & 9.1 & 472.9 & - & -134.6 & 0.1963 & 105 \\
\hline 6/25/2014 10:44 & 6/26/2014 & 42.17334 & -113.86163 & 037 & Oakley Warm Spring & 46.9 & 9.3 & 667 & - & -172.7 & 0.3185 & 107 \\
\hline 6/25/2014 13:30 & $6 / 26 / 2014$ & 42.08533 & -113.93984 & 038 & Richard Austin Well 1 & 45.7 & 9 & 733 & - & -107.6 & 0.351 & 205 \\
\hline $6 / 25 / 201416: 28$ & $6 / 26 / 2014$ & 42.47663 & -113.50770 & 039 & Marsh Creek Well & 59.6 & 8.2 & 1055 & - & -147.7 & 0.429 & 124 \\
\hline 6/26/2014 10:14 & 6/26/2014 & 42.70399 & -114.85699 & 040 & 1000 Springs (Sliger's Well) & 72.0 & 9.5 & 1266 & - & -127.2 & 0.494 & 212 \\
\hline 6/26/2014 11:55 & $6 / 26 / 2014$ & 42.68841 & -114.82680 & 041 & Banbury Hot Springs Well & 58.8 & 9 & 798 & - & -112.8 & 0.3315 & 249 \\
\hline 6/26/2014 12:16 & $6 / 26 / 2014$ & 42.68841 & -114.82680 & 042 & Banbury Hot Springs & 58.5 & 9 & 820 & - & -115 & 0.3315 & 168 \\
\hline 7/15/2014 15:01 & 7/17/2014 & 42.95543 & -115.29997 & 043 & Diamond Laundry & 35.0 & 8.9 & 829 & 0.1 & -290.2 & 0.442 & 315 \\
\hline 7/15/2014 18:48 & $7 / 17 / 2014$ & 43.00294 & -115.19222 & 044 & Johnston Well & 39.0 & 9.3 & 499.4 & 0.2 & -212.1 & 0.2626 & 117 \\
\hline $7 / 16 / 201412: 02$ & $7 / 17 / 2014$ & 42.66851 & -114.82436 & 045 & Leo Ray Hill & 35.0 & 8.7 & 414.9 & 0.1 & -24.1 & 0.2275 & 140 \\
\hline $7 / 16 / 201412: 34$ & $7 / 17 / 2014$ & 42.66778 & -114.82673 & 046 & Leo Ray Road & 35.5 & 8.4 & 409.7 & 0.3 & -89.4 & 0.2217 & 139 \\
\hline $7 / 16 / 201413: 32$ & $7 / 17 / 2014$ & 42.65772 & -114.79054 & 047 & Kanaka Rapids (Zigler's House) & 30.1 & 8 & 427.3 & 3.8 & 69.3 & 0.2529 & 120 \\
\hline $7 / 16 / 201414: 29$ & $7 / 17 / 2014$ & 42.70501 & -114.85701 & 048 & Hensley Well & 31.8 & 9.6 & 741 & 0.6 & -263.5 & 0.429 & 232 \\
\hline 7/16/2014 17:38 & $7 / 17 / 2014$ & 43.11025 & -115.31258 & 049 & Latty Hot Prings & 65.0 & 9.3 & 323.1 & 1.7 & -96.2 & 0.1735 & 107 \\
\hline $7 / 16 / 201419: 50$ & 7/17/2014 & 42.94632 & -115.49423 & 050 & Laib Well & 32.5 & 7.6 & 1621 & 0.1 & -203.7 & 0.923 & 886 \\
\hline 7/17/2014 10:03 & $7 / 17 / 2014$ & 42.58050 & -114.47089 & 051 & CSI Well 1 & 37.7 & 8.8 & 586 & 3.3 & 38.7 & 0.312 & 154 \\
\hline $7 / 17 / 201411: 25$ & $7 / 17 / 2014$ & 42.59755 & -114.40018 & 052 & Larry Anderson Well & 43.0 & 9.2 & 816 & 0 & -205.1 & 0.3965 & 188 \\
\hline $7 / 17 / 201412: 42$ & $7 / 17 / 2014$ & 42.61390 & -114.48799 & 053 & Pristine Springs & 43.0 & 9.2 & 769 & 0.3 & -107.2 & 0.377 & 154 \\
\hline $7 / 17 / 201415: 16$ & $7 / 17 / 2014$ & 42.57256 & -114.45175 & 054 & Twin Falls High School & 31.0 & 7.8 & 660 & 5.6 & -13.7 & 0.39 & 161 \\
\hline $7 / 17 / 2014$ 16:49 & $7 / 17 / 2014$ & 42.57750 & -114.28870 & 055 & Anderson Campground Well & 37.0 & 9.1 & 786 & 1.2 & -191.1 & 0.4225 & 246 \\
\hline $7 / 22 / 201414: 00$ & $7 / 22 / 2014$ & 43.60827 & -113.24432 & 056 & Butte City Well & 32.5 & 7.4 & 720 & 4.2 & 611.2 & 0.432 & 386 \\
\hline $7 / 23 / 201414: 45$ & $7 / 23 / 2014$ & 43.02583 & -112.02551 & 057 & Quidop Springs 1 & 21.0 & 6.7 & 1288 & 2.3 & 324.4 & 0.9165 & 617 \\
\hline $7 / 23 / 201415: 49$ & $7 / 23 / 2014$ & 43.03717 & -112.00427 & 058 & Quidop Springs 2 & 38.1 & 6.6 & 2112 & 0.5 & -139.1 & 1.0985 & 710 \\
\hline $7 / 23 / 201418: 03$ & $7 / 23 / 2014$ & 43.11448 & -112.16660 & 059 & YaNDell Warm Springs & 22.2 & 7.3 & 635 & 3.2 & -22.2 & 0.4355 & 266 \\
\hline $7 / 24 / 201412: 07$ & 7/24/2014 & 42.43758 & -113.43432 & 060 & Skaggs Ranch & 33.3 & 7.7 & 396.6 & 0.4 & -28.8 & 0.2223 & 181 \\
\hline 7/24/2014 14:02 & $7 / 24 / 2014$ & 42.10008 & -113.63354 & 061 & Durfee Hot Springs & 44.9 & 8.8 & 690 & 4.1 & 119.3 & 0.325 & 107 \\
\hline 7/24/2014 18:01 & $7 / 24 / 2014$ & 42.22333 & -113.79167 & 062 & Basin Cemetery & 30.7 & 7.9 & 482 & 3.3 & -15.8 & 0.2827 & 122 \\
\hline $7 / 24 / 2014$ 19:17 & 7/24/2014 & 42.48216 & -113.97341 & 063 & Wybenga Dairy & 33.9 & 7.5 & 331.3 & 3.7 & 22 & 0.1839 & 115 \\
\hline $7 / 29 / 201412: 00$ & $7 / 29 / 2014$ & 42.13944 & -111.93709 & 064 & David Bosen Well & 90.0 & 6.7 & 22609 & 2.56 & 147 & 14.5 & 583 \\
\hline $7 / 30 / 201412: 00$ & $7 / 30 / 2014$ & 43.87717 & -111.55890 & 065 & SchweNDiman Well & 28.0 & 7.6 & 363 & 5.9 & 156 & 0.3 & 165 \\
\hline $7 / 30 / 201412: 00$ & $7 / 30 / 2014$ & 43.88566 & -111.55949 & 066 & Clyde Well & 32.7 & 7.5 & 398 & 4.11 & 147 & 0.3 & 183 \\
\hline 7/30/2014 12:00 & 7/30/2014 & 43.90127 & -111.50967 & 067 & Cinder Block Well & 26.3 & 7.4 & 360 & 3.66 & 146 & 0.3 & 182 \\
\hline $7 / 30 / 201412: 00$ & $7 / 30 / 2014$ & 43.88308 & -111.6186 & 068 & 3 Newdale City Well & 30.0 & 7.3 & 575 & 4.45 & 575 & 0.3 & 251 \\
\hline $7 / 30 / 201412: 00$ & $7 / 30 / 2014$ & 43.85840 & -111.67870 & 069 & Spackman Well & 14.1 & 7.2 & 336 & 7.15 & 145 & 0.2 & 190 \\
\hline $8 / 15 / 201412: 00$ & $8 / 15 / 2014$ & 42.97813 & -112.41654 & 070 & Fort Hall Thermal Well & 21.1 & 7.9 & 557 & 6.6 & 160.1 & 0.39 & 223 \\
\hline 6/17/2015 14:10 & $6 / 19 / 2015$ & 43.33723 & -115.04430 & 077 & Wolf H.S. & 50 & 9.5 & 400.5 & 2.9 & -27.3 & 0.1898 & 107 \\
\hline
\end{tabular}


YSI ${ }^{\circledR}$ Professional Plus Calibration Procedure

The following contains the order and manner in which the YSI Professional Plus instrument should be calibrated. Tips and troubleshooting not covered in this guide can be found in the YSI Professional Plus Manual and Dissolved Oxygen Handbook.

Temperature:

The YSI temperature sensor does not need to be calibrated as it is accurate to $+/-0.15^{\circ} \mathrm{C}$ and does not drift. However, you should verify that the temperature sensor is reading accurately by comparing it to a traceable thermometer before calibrating any of the other sensors.

\section{Conductivity:}

The conductivity calibration should be verified every day the instrument is used. However, the conductivity sensor is very stable and may hold its calibration for several weeks. Whether calibrating in the lab or in the field, you should use a conductivity standard and ensure that you calibrate conductivity and not specific conductance as you will most likely not be in exactly $25.0{ }^{\circ} \mathrm{C}$ water. Never use a calibration fluid that is more than a month old after opening. Rinse the cal cup and all sensors with DI water and then rinse with conductivity calibration solution. Fill the cal cup to where the top vent holes of the conductivity sensor are fully submerged. Input the standard value into the YSI calibration menu. Allow enough time for the temperature and conductivity values to stabilize and accept the calibration. Record the calibration values on the calibration sheet. 
$\mathrm{pH}:$

The $\mathrm{pH}$ calibration should be verified every day the instrument is used. However, a new $\mathrm{pH}$ sensor may be capable of holding its calibration for several days. If you're absolutely certain that the waters being sampled will all be over or below $\mathrm{pH} 7$, then a 2 point calibration is all that is necessary. Otherwise, it is best to use a 3 point calibration. Rinse the cal cup and all sensors with DI water. Proceed to rinse the cal cup and sensors with a small amount of $\mathrm{pH} 7$ buffer solution. Next, fill the cal cup with enough $\mathrm{pH} 7$ buffer so that the $\mathrm{pH}$ sensor tip and temperature sensor are submerged. Input the buffer standard into the $\mathrm{pH}$ calibration menu in the YSI. Allow enough time for $\mathrm{pH}$ values and temperature values to stabilize. Accept the calibration value. Repeat this process for $\mathrm{pH} 4$ and 10 buffers to complete the calibration. Record the stabilized $\mathrm{pH}$ values as well as the $\mathrm{pH}$ values in $\mathrm{mV}$. Ensure the $\mathrm{mV}$ values fall within the accepted range listed on the calibration sheet.

ORP:

The ORP calibration should be verified every day the instrument is used. However, a new ORP sensor may be capable of holding its calibration for several days. Rinse the cal cup and all sensors with DI water. Proceed to rinse the cal cup and sensors with a small amount of ORP Zobell calibration solution. Fill the cal cup with enough ORP calibration solution so that the ORP sensor is fully submerged. Input the standard value into the YSI handheld. Allow enough time for the temperature and ORP values to stabilize and accept the calibration. Record the pre-calibrated stabilized ORP value and ensure the post-calibrated value matches the standard. 
DO:

The dissolved oxygen sensor should be calibrated every day the instrument is used. It is not necessary to calibrate in both $\%$ and $\mathrm{mg} / \mathrm{L}$ or ppm. Calibrating in $\%$ will simultaneously calibrate $\mathrm{mg} / \mathrm{L}$ and $\mathrm{ppm}$ and vice versa. Before calibrating the DO sensor note the age of the DO membrane from previous calibrations. If it has not been changed within 8 weeks, change it. If any silver chloride has built up on the silver anode, try to simply mechanically clean it with the YSI cleaning brush. If the buildup is too heavy, use wet 400-grit sandpaper to clear away any build up. If you require chemical cleaning, soak the silver anode in a $3 \%$ (household ammonium cleaner) for 8-12 hours. Following the soak, rinse thoroughly with DI water and wipe the residue with a paper towel ensuring that no build up is trapped under the membrane. For correct sensor operation, the gold cathode must be textured properly. Use wet 400-grit sandpaper to remove build up and lightly scratch the cathode to allow more surface area for the electrolyte solution under the membrane (2-3 twists of sandpaper is usually sufficient). If any cleaning is required, make sure to record this information in the notes section of the calibration sheet.

The best way to calibrate the DO sensor is by using water saturated air. Fill the cal cup with about $1 / 8$ inches of DI water. Ensure that the DO sensor and temperature sensor are not submerged. Engage 1 or 2 threads to allow for venting into the cal cup. Wait about 10 minutes for the calibration chamber to become completely saturated. While waiting, determine the calibration \% value by dividing the true barometric pressure by 760 (cal. value will only be $100 \%$ at sea level or $760 \mathrm{mmHg}$ ) and multiplying by 100 . Allow time for readings to stabilize around calibration value and accept calibration. Record values on calibration sheet. 
Note: Chemical cleaning should be performed as infrequently as possible ( 1 or 2 times per year depending on use).

Post Calibration Values:

After completing calibration record the following values from the .glp file for the day's calibration to ensure the calibration was successful: Conductivity Cal Cell Constant (Range $5.0+/-1.0$ acceptable), DO Sensor Value (yellow membrane: $4.31 \mu \mathrm{A}-8.00 \mu \mathrm{A}), \mathrm{pH}$ Slope $(\approx$ 55 to $60 \mathrm{mV} / \mathrm{pH}, 59$ ideal). 


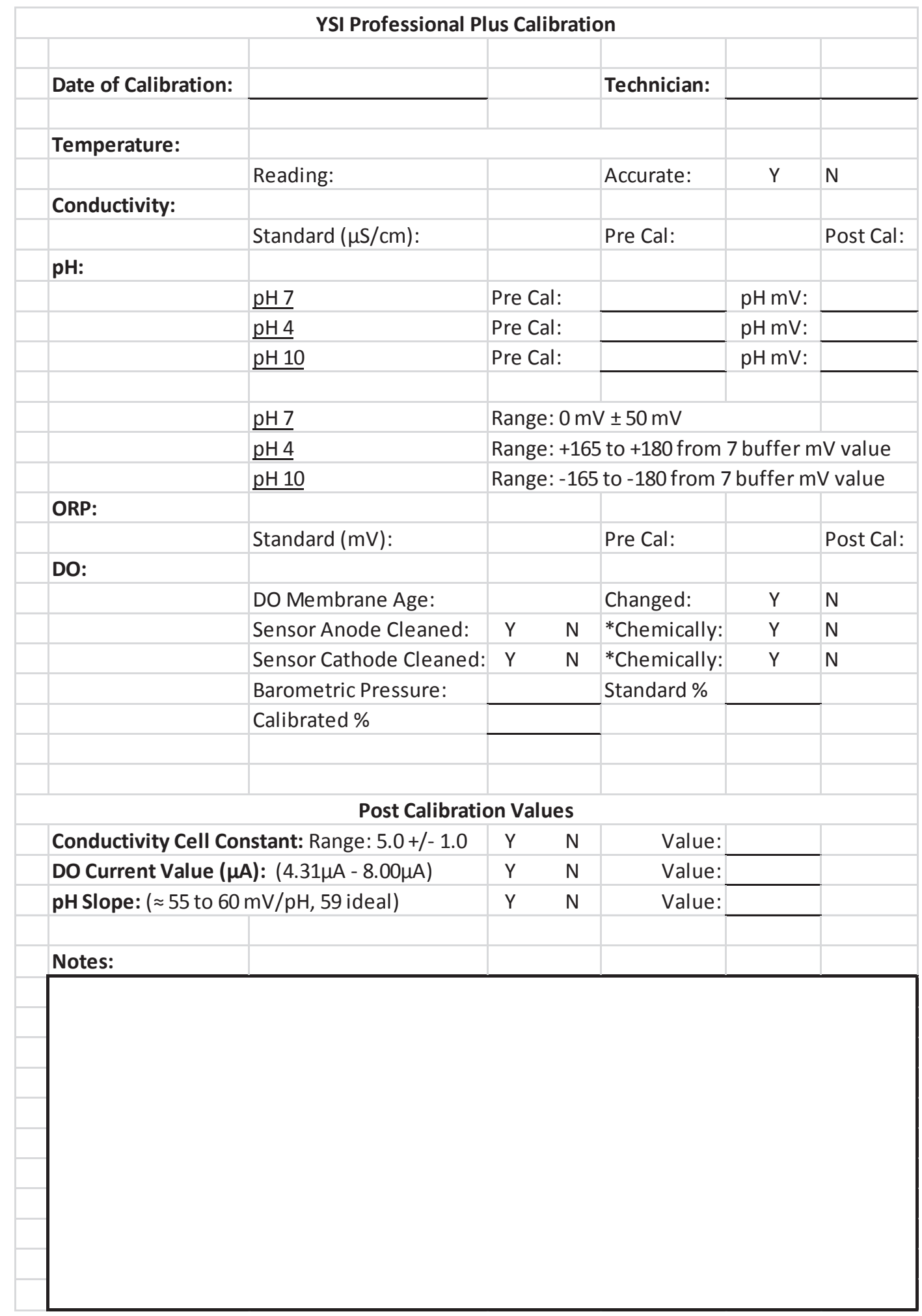

Figure A2. YSI® Professional Plus Calibration Form 


\section{APPENDIX B: CHEMICAL ANALYSIS AND QUALITY CONTROL}

Chemical analysis was performed by Cody Cannon under the supervision of analytical chemist Debbie Lacroix and the analytical chemistry laboratory lead Joanna Taylor at the Center for Advanced Energy Studies, Idaho Falls, Idaho. Samples were analyzed in accordance with their respective holding times (preserved and non-preserved) and appropriate dilutions were made to each sample when necessary. Calibration standards for each analytical instrument were prepared from various batch solutions provided by Inorganic Ventures TM in order to obtain valid concentrations in the desired range based upon previous geothermal research ( 0.1 to $500+$ ppm for major cations and anions) and trace elemental needs for multicomponent equilibrium geothermometry calculations (1 ppb to $1 \mathrm{ppm}$ ) for constituents including aluminum, magnesium, boron, etc. Analyses were conducted using the Dionex TM ICS-2100 Ion Chromatograph (IC) or major anions, the Thermo iCAP TM 6500 InductivelyCoupled Plasma Optical Emission Spectrometer (ICP-OES) for major cations, and the Agilent TM 7500ce Inductively-Coupled Plasma Mass Spectrometer (ICP-MS) for trace elements. The following sections detail the analysis and processing of samples 001-070.

\section{Ion Chromatography for Major Anions}

Samples are injected into a stream of eluent, passed through a series of ion exchange columns, and into a conductivity detector. The first column, a guard column, protects the analytical column by removing particulate and organic matter. The analytical column separates anions or cations by their relative affinities for column resins. The suppressor (between the analytical column and the conductivity detector) provides continuous suppression of background conductivity of the eluent and enhances response of the target analytes. The separated anions 
or cations are measured by conductivity. The compounds are identified based on retention times and quantified by conductivity or absorbance. Control of the instrument is provided by PC-based Chromeleon software

Ion-exchange chromatography is a means of retaining target analytes by separating out the target anions from cations in a separator column. Once separated in the column, the Dionex TM ICS-2100 IC detects the concentrations of chosen anions by means of measuring conductivity. Calibration standards 1-7 were prepared from an Inorganic Ventures ${ }^{\mathrm{TM}}$ stock solution IC-FAS-1 A containing the solutes: $\mathrm{F}^{-}, \mathrm{Cl}^{-} \mathrm{NO}^{-}, \mathrm{NO}^{-}, \mathrm{Br}^{-}, \mathrm{SO}^{2-}$, and $\mathrm{PO}^{3-}$. Solutions were prepared by means of dilutions by weight, resulting in seven standards ranging

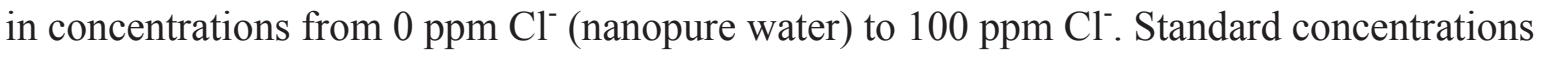
are listed below in Table 1. Analysis was carried out using a modified form of the EPA 300.1 Method (Hautman and Munch, 1997). Each run began with the analysis of 3 blank samples (nanopure water) followed by the seven standards in order to establish background levels and a calibration curve. A calibration curve coefficient of determination value of $R^{2}=0.995$ was used for all analyses in accordance with EPA 300.1. A laboratory control standard (LCS) was analyzed following the calibration standards to verify the validity of the calibration curve, followed by a nanopure dilution blank. The dilution blank was analyzed to ensure there was no analyte contamination in the water use to dilute the samples. Every ten samples, a blank sample was analyzed followed by all seven standards analyzed as samples. The blank analysis was used to verify there was no carryover during the run and the reanalysis of standards as samples was used to determine instrument drift and to aid in the LOD calculation for each analyte in the analytical run. Samples were diluted prior to analysis based on any previous water chemistry for specific samples or surrounding areas (diluted for $>100 \mathrm{ppm}^{-}$and 
$\mathrm{SO}^{2-}$ ). Samples were diluted and re-run after initial analysis if necessary so that the concentrations would fall within the calibration range. Duplicate samples were run at a frequency of one sample per run, modified from the $10 \%$ recommended by EPA 300.1 . Adherence to the recommended $90-110 \%$ recovery and $10 \%$ difference values for spikes and duplicates respectively was obtained for adequate quality control. Conductivity peak analysis was performed for each sample to ensure no interference or deviation in baseline provided by the calibration curve influenced sample concentration readings. Quality control information for standard solutions and LOD values for anions are provided in Table 1.

\section{ICP-OES analysis for Major Cations}

Samples are pumped through a nebulizer to produce a fine spray. The large droplets are removed by a spray chamber and the small droplets then pass through to the plasma. The plasma is formed by an intense magnetic field produced by radio frequency (RF) passing through a copper coil. The plasma generates photons of light by the excitation of atoms and ions. The emission of light which occurs as discrete lines, are separated according to their wavelength by diffractive optics using an Echelle optical design. The analytical signals are measured using a Charge Injection Device (CID) as the detector. The samples can be analyzed using either the radial or axial plasma views depending on the sensitivity needed. Various interferences must be considered and addressed appropriately. Control of the spectrometer is provided by PC-based iTEVA software.

Inductively-Coupled Plasma Optical Emission Spectrometry is performed by ionizing argon gas in an intense electro-magnetic field and "igniting" the plasma. Water samples are then transported via a peristaltic pump into the analytical nebulizer where the sample is made into an aerosol and forced to collide directly with the plasma flame. The sample is thereby broken 
down into charged ions after collision with electrons and charged ions of the plasma. The continuous breaking up of molecules into their respective atoms emits signature wavelengths of light that can be read and quantified by the spectrometer (Huang and Hieftje, 1989). In a similar manner to the IC analysis, standards were prepared from an Inorganic Ventures ${ }^{\mathrm{TM}}$ stock solution: QCP-CICV-1 containing the cations $\mathrm{Ca}^{2+}, \mathrm{K}^{+}, \mathrm{Mg}^{+}, \mathrm{Na}^{+}, \mathrm{Ba}^{2+}, \mathrm{Al}^{3+}$ and $\mathrm{Fe}^{3+}$. However, concentrations of aluminum and magnesium proved to be too low in many samples to obtain a reading above the LOD. For this reason, these elements were analyzed separately using the ICP-MS. Standards were prepared in the ranges of $1-25 \mathrm{ppm} \mathrm{Ca}{ }^{2+}, \mathrm{K}^{+}, \mathrm{Mg}^{+}, \mathrm{Na}^{+}$ and 1-20 ppm $\mathrm{SiO}_{2}{ }^{-}$. Additional standards were added to account for geothermal waters with high (100+ ppm) $\mathrm{SiO}_{2}{ }^{-}$and waters with higher TDS with elevated $\mathrm{Na}^{+}$(up to $1500 \mathrm{ppm}$ ) concentrations. A calibration curve was established with a $99.5 \%$ confidence, $\mathrm{R}^{2}=0.995$ in accordance with EPA Method 200.7 (Martin et al., 1994). Analysis began with the running of blanks followed by all calibration standards in order to establish background levels and a calibration curve. Blanks and standards were analyzed again after every 10 samples to determine carryover, instrument drift and LODs. Duplicate and spiked samples were added randomly and run at a frequency of one sample per run, modified from the $10 \%$ recommended by EPA 200.7 . Adherence to the recommended $70-130 \%$ recovery and $10 \%$ difference values for spikes and duplicates respectively was obtained for adequate quality control.

Multiple wavelengths of every constituent are read by the ICP-OES for each run as some wavelengths have more interferences than others. In order to pick the appropriate wavelength for each constituent, percent difference deviations from true values were calculated for each standard and the wavelength with the least percent difference $(<10 \%$ difference $)$ were chosen 
and concentrations were reported from each respective wavelength. Quality control information for standard solutions and LOD values for major cations are provided in Table 2.

\section{ICP-MS analysis for Trace Elements}

The sample is pumped with a peristaltic pump into a nebulizer where it is converted into a fine aerosol. The fine droplets are separated from the larger droplets by means of a spray chamber. From there, it is transported into the plasma torch. The plasma is formed by an intense magnetic field produced by radio frequency passing through a copper coil. The plasma generates positively charged ions. The ions are directed through the interface region, kept at a vacuum that consists of two metallic cones (sampler and skimmer) that allow the ions to pass through to the electrostatic lenses called the ion optics. These optics stop photons, particulates, and neutral species from reaching the detector. The ions travel through the octapole in the reaction cell which minimizes polyatomic spectral interferences. The ions reach the quadrupole where they are separated according to their mass-to-charge ratio $(\mathrm{m} / \mathrm{z})$ by electrostatically steering the ions of a selected mass down the middle of the rods to the detector while ejecting the other unstable ions (Greenfield, 1994). The ions are converted into an electronic signal with a detector called an electron multiplier. Control of the spectrometer is provided by PC-based MassHunter® software.

Standards were prepared from Inorganic Ventures ${ }^{\mathrm{TM}}$ stock solutions: CCS-4 (alkali, alkaline, non-transition elements) and CCS-5(fluoride soluble elements). CCS-4 was utilized for the constituents: $\mathrm{Li}, \mathrm{Be}, \mathrm{Al}, \mathrm{Mg}, \mathrm{Se}, \mathrm{As}, \mathrm{Rb}, \mathrm{Sr}, \mathrm{Ba}$, and $\mathrm{Bi}$. CCS-5 was utilized solely for boron. Boron is often regarded as an important conservative tracer in geothermal fluids. Standards utilizing CCS-4 solution were prepared for the range of 1-500 ppb of all elements. CCS-5 standards were prepared for the range $1 \mathrm{ppb}$ to $1 \mathrm{ppm}$ boron based on previous ESRP 
geothermal studies which included boron. Magnesium and aluminum were analyzed separately for all samples in order to fill in data gaps where concentrations fell below the LOD with the ICP-OES. Magnesium and aluminum standards were prepared in the range of 1 ppb to $1 \mathrm{ppm}$ for both elements.

Analysis was accomplished using a modified form of EPA method 200.8 (Creed et al., 1994). Collision cell technology was utilized to eliminate interference from polyatomic ions due to the high TDS nature of geothermal waters. A calibration curve was established with a $99.5 \%$ confidence, $\mathrm{R}^{2}=0.995$ in accordance with EPA method 200.8. Analysis began with the running of blanks followed by all calibration standards in order to establish background levels and a calibration curve. Blanks and standards were run again after every 10 samples to verify lack any contamination, to determine drift and establish the LOD for the run an internal standard of rhodium $(\mathrm{Rh})$ was analyzed with the samples to correct for any matrix interferences. Duplicate and spiked samples were added randomly and run at a frequency of one sample per run, modified from the $10 \%$ recommended by EPA 200.8. Adherence to the recommended $70-130 \%$ recovery and $10 \%$ difference values for spikes and duplicates respectively was obtained for adequate quality control. Unless a deviation greater than $10 \%$ occurred for a particular QC standard, concentration values for samples were reported from raw data. Quality control information for standard solutions and ILOD values for trace elements are provided in Table 3.

\section{Limit of Detection, Precision and Accuracy}

The Limit of detection is the lowest concentration of a given analyte that is likely to be consistently distinguished from analysis (Needleman et al., 1990). Ordinarily, it is calculated from background analyte levels provided by blank samples. In this study, ILOD was 
calculated using a "limit of blank" approximation where a Gaussian distribution of blank concentrations is assumed. An approximation assuming infinite degrees of freedom would use the student's $t$ distribution value of 1.645 for a $95 \%$ confidence interval where $\mathrm{LOD}=$ Average $_{\text {blank }}+(1.645 \mathrm{x}$ Standard Deviation blank $)$. However, in an effort to produce a more conservative approximation due to sample sizes of blanks varying from 4-5 blanks to 20 , the standard deviation of blank was multiplied by 3 instead. ILOD values for all chemical constituents in 5\% $\mathrm{HNO}_{3}$ can be seen with the blank values in Tables B1-3.

Tables B1-3 also provides information on average instrument precision and accuracy. Accuracy refers to the closeness of a measured value to a standard or known value. Accuracy can been seen in the \% Recovery column in Tables 1-3. Sample data was considered valid if the $\%$ recoveries were $\pm 10 \%$ of the known value. Therefore, data not within the $10 \%$ acceptable window was not considered valid and the data was not used. Precision refers to the closeness of two or more measurements to each other. Precision was determined by calculating the standard deviation(s) of the standards. The standard deviation provides an indication of the range of variation in the measurements. The relative standard deviation (RSD), expresses the standard deviation as a percentage, with the smaller the relative standard deviation (or standard deviation), the more precise the measurements. The average precision for this sample set can be seen in the \%RSD column in tables 1-3 below. 
Table B1. Anion QC Table

\begin{tabular}{|c|c|c|c|c|c|c|c|}
\hline \multicolumn{8}{|l|}{ Fluoride } \\
\hline $\begin{array}{c}\text { True } \\
\text { Concentration } \\
(\mathrm{mg} / \mathrm{L})\end{array}$ & $\begin{array}{c}\text { \# of } \\
\text { points }\end{array}$ & $\begin{array}{c}\text { Average } \\
\text { Concentration } \\
(\mathrm{mg} / \mathrm{L})\end{array}$ & $\begin{array}{c}\% \\
\text { Recovery }\end{array}$ & RSD (\%) & $\begin{array}{c}\text { Standard } \\
\text { Deviation } \\
(\mathrm{mg} / \mathrm{L})\end{array}$ & $\begin{array}{c}\text { 3 Times } \\
\text { Standard } \\
\text { Deviation } \\
\text { (mg/L) } \\
\text { (ILOD) }\end{array}$ & $\begin{array}{c}10 \text { Times } \\
\text { Standard } \\
\text { Deviation } \\
\text { (mg/L) } \\
\text { (ILOQ) }\end{array}$ \\
\hline Blank & 25 & 0.027 & NA & $133 \%$ & 0.036 & 0.108 & 0.361 \\
\hline 0.05 & 5 & 0.052 & $104 \%$ & $13 \%$ & 0.007 & 0.020 & 0.066 \\
\hline 0.2 & 5 & 0.199 & $100 \%$ & $7 \%$ & 0.014 & 0.043 & 0.143 \\
\hline 0.5 & 19 & 0.565 & $113 \%$ & $19 \%$ & 0.105 & 0.316 & 1.053 \\
\hline 1.0 & 17 & 1.10 & $110 \%$ & $21 \%$ & 0.236 & 0.708 & 2.359 \\
\hline 2.0 & 5 & 2.07 & $104 \%$ & $2 \%$ & 0.050 & 0.151 & 0.502 \\
\hline 3.0 & 12 & 3.19 & $106 \%$ & $7 \%$ & 0.238 & 0.713 & 2.378 \\
\hline 5.0 & 12 & 5.45 & $109 \%$ & $15 \%$ & 0.796 & 2.388 & 7.961 \\
\hline 7.0 & 12 & 7.23 & $103 \%$ & $3 \%$ & 0.229 & 0.688 & 2.293 \\
\hline 10 & 12 & 9.94 & $99 \%$ & $2 \%$ & 0.219 & 0.657 & 2.189 \\
\hline \multicolumn{8}{|l|}{ Chloride } \\
\hline Blank & 25 & 0.060 & NA & $112 \%$ & 0.067 & 0.200 & 0.666 \\
\hline 2.5 & 5 & 2.53 & $101 \%$ & $10 \%$ & 0.253 & 0.759 & 2.53 \\
\hline 5.0 & 14 & 5.22 & $104 \%$ & $4 \%$ & 0.191 & 0.573 & 1.91 \\
\hline 10 & 17 & 10.1 & $101 \%$ & $4 \%$ & 0.390 & 1.17 & 3.90 \\
\hline 25 & 17 & 25.1 & $100 \%$ & $4 \%$ & 1.03 & 3.08 & 10.3 \\
\hline 50 & 17 & 51.7 & $103 \%$ & $3 \%$ & 1.40 & 4.20 & 14.0 \\
\hline 75 & 12 & 75.9 & $101 \%$ & $2 \%$ & 1.14 & 3.42 & 11.4 \\
\hline 101 & 16 & 102 & $101 \%$ & $3 \%$ & 3.04 & 9.12 & 30.4 \\
\hline \multicolumn{8}{|l|}{ Nitrite } \\
\hline Blank & 16 & 0.088 & NA & $130 \%$ & 0.114 & 0.343 & 1.14 \\
\hline 0.2 & 5 & 0.203 & $102 \%$ & $7 \%$ & 0.015 & 0.046 & 0.154 \\
\hline 1.0 & 17 & 0.850 & $85 \%$ & $9 \%$ & 0.080 & 0.241 & 0.802 \\
\hline 2.0 & 5 & 2.18 & $109 \%$ & $1 \%$ & 0.032 & 0.096 & 0.321 \\
\hline 5.0 & 15 & 5.12 & $102 \%$ & $11 \%$ & 0.586 & 1.76 & 5.86 \\
\hline 10 & 15 & 10.2 & $102 \%$ & $11 \%$ & 1.14 & 3.43 & 11.4 \\
\hline 20 & 10 & 20.5 & $103 \%$ & $1 \%$ & 0.271 & 0.712 & 2.71 \\
\hline 35 & 10 & 36.0 & $103 \%$ & $1 \%$ & 0.461 & 1.38 & 4.61 \\
\hline 50 & 9 & 49.5 & $99 \%$ & $1 \%$ & 0.326 & 0.979 & 3.26 \\
\hline \multicolumn{8}{|l|}{ Sulfate } \\
\hline Blank & 16 & 0.045 & NA & $171 \%$ & 0.077 & 0.232 & 0.772 \\
\hline 0.4 & 5 & 0.400 & $100 \%$ & $8 \%$ & 0.031 & 0.094 & 0.314 \\
\hline 1.0 & 9 & 1.07 & $107 \%$ & $15 \%$ & 0.161 & 0.483 & 1.61 \\
\hline 1.5 & 5 & 1.55 & $103 \%$ & $5 \%$ & 0.084 & 0.252 & 0.839 \\
\hline 4.0 & 5 & 3.85 & $96 \%$ & $2 \%$ & 0.068 & 0.205 & 0.684 \\
\hline
\end{tabular}




\begin{tabular}{|c|c|c|c|c|c|c|c|}
\hline 8.0 & 5 & 7.83 & $98 \%$ & $1 \%$ & 0.092 & 0.276 & 0.919 \\
\hline 10 & 11 & 10.0 & $100 \%$ & $4 \%$ & 0.352 & 1.06 & 3.52 \\
\hline 16 & 5 & 15.6 & $98 \%$ & $1 \%$ & 0.144 & 0.432 & 1.44 \\
\hline 25 & 12 & 25.5 & $102 \%$ & $1 \%$ & 0.308 & 0.925 & 3.09 \\
\hline 50 & 12 & 49.8 & $100 \%$ & $1 \%$ & 0.648 & 1.95 & 6.49 \\
\hline 75 & 12 & 75.1 & $100 \%$ & $1 \%$ & 0.995 & 2.99 & 9.96 \\
\hline 100 & 11 & 99.1 & $99 \%$ & $1 \%$ & 1.25 & 3.75 & 12.5 \\
\hline \multicolumn{8}{|l|}{ Bromide } \\
\hline $\begin{array}{c}\text { True } \\
\text { Concentration } \\
\text { (mg/L) }\end{array}$ & $\begin{array}{c}\text { \# of } \\
\text { points }\end{array}$ & $\begin{array}{c}\text { Average } \\
\text { Concentration } \\
\text { (mg/L) }\end{array}$ & $\begin{array}{c}\% \\
\text { Recovery }\end{array}$ & RSD & $\begin{array}{c}\text { Standard } \\
\text { Deviation } \\
(\mathrm{mg} / \mathrm{L})\end{array}$ & $\begin{array}{c}\text { 3 Times } \\
\text { Standard } \\
\text { Deviation } \\
\text { (mg/L) } \\
\text { (ILOD) }\end{array}$ & $\begin{array}{c}10 \text { Times } \\
\text { Standard } \\
\text { Deviation } \\
\text { (mg/L) } \\
\text { (ILOQ) }\end{array}$ \\
\hline Blank & 16 & 0.040 & NA & $393 \%$ & 0.157 & 0.472 & 1.58 \\
\hline 0.25 & 5 & 0.236 & $94 \%$ & $2 \%$ & 0.004 & 0.011 & 0.035 \\
\hline 1.0 & 17 & 1.04 & $104 \%$ & $10 \%$ & 0.104 & 0.313 & 1.04 \\
\hline 2.5 & 5 & 2.47 & $99 \%$ & $2 \%$ & 0.060 & 0.180 & 0.601 \\
\hline 5.0 & 15 & 4.78 & $96 \%$ & $7 \%$ & 0.355 & 1.07 & 3.55 \\
\hline 10 & 15 & 9.74 & $97 \%$ & $5 \%$ & 0.472 & 1.42 & 4.72 \\
\hline 20 & 10 & 20.1 & $101 \%$ & $2 \%$ & 0.354 & 1.06 & 3.54 \\
\hline 35 & 10 & 35.7 & $102 \%$ & $2 \%$ & 0.714 & 2.14 & 7.14 \\
\hline 50 & 9 & 50.8 & $102 \%$ & $2 \%$ & 1.09 & 3.27 & 10.9 \\
\hline \multicolumn{8}{|l|}{ Nitrate } \\
\hline Blank & 16 & 0.024 & NA & $175 \%$ & 0.042 & 0.126 & 0.421 \\
\hline 0.25 & 5 & 0.261 & $104 \%$ & $2 \%$ & 0.005 & 0.016 & 0.053 \\
\hline 1.0 & 17 & 1.16 & $116 \%$ & $4 \%$ & .0510 & 1.53 & 5.10 \\
\hline 2.5 & 5 & 2.76 & $110 \%$ & $5 \%$ & 0.142 & 0.427 & 1.42 \\
\hline 5.0 & 15 & 5.02 & $100 \%$ & $13 \%$ & 0.661 & 1.98 & 6.61 \\
\hline 10 & 19 & 10.1 & $101 \%$ & $9 \%$ & 0.871 & 2.61 & 8.71 \\
\hline 20 & 10 & 20.0 & $100 \%$ & $3 \%$ & 0.520 & 1.56 & 5.20 \\
\hline 35 & 10 & 35.7 & $102 \%$ & $2 \%$ & 0.804 & 2.41 & 8.04 \\
\hline 50 & 9 & 50.8 & $102 \%$ & $1 \%$ & 0.655 & 1.97 & 6.56 \\
\hline
\end{tabular}


Table B2. Cation QC Table

\begin{tabular}{|c|c|c|c|c|c|c|c|}
\hline \multicolumn{8}{|l|}{ Calcium } \\
\hline $\begin{array}{c}\text { True } \\
\text { Concentration } \\
(\mathrm{mg} / \mathrm{L})\end{array}$ & $\begin{array}{c}\text { \# of } \\
\text { points }\end{array}$ & $\begin{array}{c}\text { Average } \\
\text { Concentration } \\
(\mathrm{mg} / \mathrm{L})\end{array}$ & $\begin{array}{c}\% \\
\text { Recovery }\end{array}$ & RSD & $\begin{array}{c}\text { Standard } \\
\text { Deviation } \\
(\mathrm{mg} / \mathrm{L})\end{array}$ & $\begin{array}{c}\text { 3 Times } \\
\text { Standard } \\
\text { Deviation } \\
\text { (mg/L) } \\
\text { (ILOD) }\end{array}$ & $\begin{array}{c}10 \text { Times } \\
\text { Standard } \\
\text { Deviation } \\
\text { (mg/L) } \\
\text { (ILOQ) }\end{array}$ \\
\hline Blank & 16 & -0.052 & NA & $-79 \%$ & 0.041 & 0.124 & 0.413 \\
\hline 1.0 & 7 & 0.994 & $99 \%$ & $8 \%$ & 0.083 & 0.248 & 0.825 \\
\hline 2.5 & 2 & 2.86 & $114 \%$ & $5 \%$ & 0.154 & 0.462 & 1.54 \\
\hline 5.0 & 6 & 5.13 & $103 \%$ & $6 \%$ & 0.319 & 0.957 & 3.19 \\
\hline 10 & 6 & 10.7 & $107 \%$ & $19 \%$ & 2.02 & 6.06 & 20.2 \\
\hline 25 & 3 & 26.0 & $104 \%$ & $11 \%$ & 2.95 & 8.85 & 29.5 \\
\hline 50 & 4 & 48.5 & $97 \%$ & $1 \%$ & 0.650 & 1.95 & 6.50 \\
\hline \multicolumn{8}{|l|}{ Potassium } \\
\hline Blank & 16 & 0.278 & NA & $72 \%$ & 0.200 & 0.599 & 2.00 \\
\hline 1.0 & 7 & 1.28 & $128 \%$ & $20 \%$ & 0.258 & 0.773 & 2.58 \\
\hline 2.5 & 2 & 2.74 & $110 \%$ & $13 \%$ & 0.368 & 1.10 & 3.68 \\
\hline 5.0 & 6 & 5.22 & $104 \%$ & $5 \%$ & 0.237 & 0.710 & 2.37 \\
\hline 10 & 7 & 10.3 & $103 \%$ & $4 \%$ & 0.442 & 1.33 & 4.42 \\
\hline 25 & 3 & 24.3 & $97 \%$ & $5 \%$ & 1.13 & 3.40 & 11.3 \\
\hline 50 & 4 & 48.4 & $97 \%$ & $2 \%$ & 0.951 & 2.85 & 9.51 \\
\hline \multicolumn{8}{|l|}{ Magnesium } \\
\hline Blank & 16 & -0.071 & NA & $-96 \%$ & 0.068 & 0.204 & 0.680 \\
\hline 1.0 & 7 & 0.980 & $98 \%$ & $19 \%$ & 0.182 & 0.546 & 1.82 \\
\hline 2.5 & 2 & 2.91 & $116 \%$ & $11 \%$ & 0.319 & 0.958 & 3.19 \\
\hline 5 & 6 & 5.28 & $106 \%$ & $8 \%$ & 0.438 & 1.31 & 4.38 \\
\hline 10 & 7 & 10.5 & $105 \%$ & $12 \%$ & 1.22 & 3.65 & 12.2 \\
\hline 25 & 3 & 26.3 & $105 \%$ & $16 \%$ & 4.12 & 12.4 & 41.2 \\
\hline 50 & 4 & 49.0 & $98 \%$ & $1 \%$ & 0.582 & 1.75 & 5.81 \\
\hline \multicolumn{8}{|l|}{ Sodium } \\
\hline Blank & 16 & 0.711 & NA & $74 \%$ & 0.529 & 1.59 & 5.30 \\
\hline 1.0 & 7 & 1.76 & $176 \%$ & $23 \%$ & 0.404 & 1.21 & 4.04 \\
\hline 2.5 & 2 & 3.22 & $129 \%$ & $4 \%$ & 0.127 & 0.380 & 1.27 \\
\hline 5 & 6 & 5.22 & $104 \%$ & $6 \%$ & 0.311 & 0.934 & 3.11 \\
\hline
\end{tabular}




\begin{tabular}{l|c|c|c|c|c|c|c|}
\hline 10 & 7 & 10.5 & $105 \%$ & $4 \%$ & 0.432 & 1.30 & 4.32 \\
\hline 25 & 3 & 24.7 & $99 \%$ & $3 \%$ & 0.713 & 2.14 & 7013 \\
\hline 50 & 4 & 47.5 & $95 \%$ & $2 \%$ & 0.803 & 2.41 & 8.03 \\
\hline Silica \\
\hline Blank & 16 & -0.029 & NA & $-186 \%$ & 0.054 & 0.161 & 0.536 \\
\hline 1.0 & 6 & 1.08 & $108 \%$ & $11 \%$ & 0.119 & 0.358 & 1.20 \\
\hline 5.0 & 7 & 5.24 & $105 \%$ & $6 \%$ & 0.317 & 0.951 & 3.17 \\
\hline 10 & 7 & 10.4 & $104 \%$ & $5 \%$ & 0.494 & 1.48 & 4.94 \\
\hline 20 & 7 & 20.9 & $105 \%$ & $4 \%$ & 0.846 & 2.54 & 8.47 \\
\hline
\end{tabular}

Table B3. Trace Element QC Table

\begin{tabular}{|c|c|c|c|c|c|c|c|}
\hline \multicolumn{8}{|l|}{ Boron } \\
\hline $\begin{array}{c}\text { True } \\
\text { Concentration } \\
\text { (ug/L) }\end{array}$ & $\begin{array}{c}\text { \# of } \\
\text { points }\end{array}$ & $\begin{array}{c}\text { Average } \\
\text { Concentration } \\
\text { (ug/L) }\end{array}$ & $\begin{array}{c}\% \\
\text { Recovery }\end{array}$ & RSD $\%$ & $\begin{array}{c}\text { Standard } \\
\text { Deviation } \\
\text { (ug/L) }\end{array}$ & $\begin{array}{c}\text { 3 Times } \\
\text { Standard } \\
\text { Deviation } \\
\text { (ug/L) } \\
\text { (ILOD) }\end{array}$ & $\begin{array}{c}10 \text { Times } \\
\text { Standard } \\
\text { Deviation } \\
\text { (yg/L) } \\
\text { (ILOQ) }\end{array}$ \\
\hline Blank & 19 & 3.98 & NA & $40 \%$ & 1.58 & 4.7 & 16 \\
\hline 1.0 & 13 & 3.03 & $303 \%$ & $76 \%$ & 2.29 & 6.9 & 23 \\
\hline 5.0 & 13 & 5.95 & $119 \%$ & $26 \%$ & 1.56 & 4.7 & 16 \\
\hline 10 & 13 & 11.1 & $111 \%$ & $13 \%$ & 1.43 & 4.3 & 14 \\
\hline 20 & 13 & 24.8 & $124 \%$ & $7 \%$ & 1.85 & 5.6 & 19 \\
\hline 50 & 13 & 49.0 & $98 \%$ & $7 \%$ & 3.35 & 10 & 33 \\
\hline 100 & 13 & 108 & $108 \%$ & $8 \%$ & 8.86 & 27 & 89 \\
\hline 500 & 13 & 541 & $108 \%$ & $9 \%$ & 46.9 & 141 & 469 \\
\hline 1000 & 13 & 1022 & $102 \%$ & $8 \%$ & 84.7 & 254 & 847 \\
\hline \multicolumn{8}{|l|}{ Lithium } \\
\hline Blank & 18 & 0.392 & NA & $145 \%$ & 0.57 & 1.71 & 5.70 \\
\hline 1.0 & 7 & 1.35 & $135 \%$ & $97 \%$ & 1.31 & 3.93 & 13.1 \\
\hline 5.0 & 5 & 5.67 & $113 \%$ & $5 \%$ & 0.257 & 0.770 & 2.57 \\
\hline 25 & 5 & 26.8 & $107 \%$ & $4 \%$ & 1.08 & 3.25 & 10.8 \\
\hline 50 & 13 & 48.1 & $96 \%$ & $11 \%$ & 5.47 & 16.4 & 54.7 \\
\hline 100 & 5 & 105 & $105 \%$ & $4 \%$ & 3.89 & 11.7 & 38.9 \\
\hline 150 & 7 & 144 & $96 \%$ & $11 \%$ & 15.2 & 45.6 & 152 \\
\hline 200 & 5 & 197 & $99 \%$ & $3 \%$ & 4.99 & 15.0 & 49.9 \\
\hline 250 & 8 & 238 & $95 \%$ & $9 \%$ & 21.3 & 64.0 & 213 \\
\hline 300 & 7 & 293 & $98 \%$ & $10 \%$ & 29.2 & 87.5 & 292 \\
\hline 350 & 7 & 338 & $97 \%$ & $9 \%$ & 30.5 & 91.4 & 305 \\
\hline 400 & 7 & 398 & $100 \%$ & $7 \%$ & 26.1 & 78.4 & 261 \\
\hline 500 & 12 & 495 & $99 \%$ & $5 \%$ & 22.7 & 68.0 & 227 \\
\hline \multicolumn{8}{|l|}{ Beryllium } \\
\hline Blank & 18 & 0.214 & NA & $114 \%$ & 0.244 & 0.732 & 2.44 \\
\hline
\end{tabular}




\begin{tabular}{|c|c|c|c|c|c|c|c|}
\hline 1.0 & 7 & 1.33 & $133 \%$ & $52 \%$ & 0.694 & 2.08 & 6.94 \\
\hline 5.0 & 5 & 5.38 & $108 \%$ & $4 \%$ & 0.195 & 0.584 & 1.95 \\
\hline 25 & 5 & 25.9 & $104 \%$ & $3 \%$ & 0.892 & 2.68 & 8.92 \\
\hline 50 & 13 & 49.3 & $99 \%$ & $10 \%$ & 4.98 & 14.9 & 49.8 \\
\hline 100 & 5 & 99.9 & $100 \%$ & $2 \%$ & 2.31 & 6.92 & 23.1 \\
\hline 150 & 7 & 151 & $101 \%$ & $2 \%$ & 3.13 & 9.39 & 31.3 \\
\hline 200 & 5 & 196 & $96 \%$ & $2 \%$ & 3.25 & 9.74 & 32.5 \\
\hline 250 & 8 & 248 & $99 \%$ & $4 \%$ & 9.26 & 27.8 & 92.6 \\
\hline 300 & 7 & 308 & $103 \%$ & $4 \%$ & 11.5 & 34.4 & 115 \\
\hline 350 & 7 & 353 & $101 \%$ & $3 \%$ & 10.2 & 30.5 & 102 \\
\hline 400 & 7 & 410 & $103 \%$ & $3 \%$ & 10.5 & 31.4 & 105 \\
\hline 500 & 12 & 505 & $101 \%$ & $3 \%$ & 15.7 & 47.0 & 157 \\
\hline \multicolumn{8}{|c|}{ Magnesium } \\
\hline Blank & 17 & 0.120 & NA & $233 \%$ & 0.28 & 0.839 & 2.80 \\
\hline 1.0 & 8 & 5.00 & $500 \%$ & $74 \%$ & 3.72 & 11.2 & 37.2 \\
\hline 5.0 & 13 & 4.53 & $91 \%$ & $44 \%$ & 2.00 & 6.00 & 20.0 \\
\hline 25 & 5 & 27.0 & $108 \%$ & $4 \%$ & 1.01 & 3.04 & 10.1 \\
\hline 50 & 13 & 54.1 & $108 \%$ & $14 \%$ & 7.78 & 23.3 & 77.8 \\
\hline 100 & 5 & 103 & $103 \%$ & $3 \%$ & 2.62 & 7.85 & 26.2 \\
\hline 150 & 7 & 165 & $110 \%$ & $3 \%$ & 4.67 & 14.0 & 46.7 \\
\hline 200 & 5 & 194 & $97 \%$ & $2 \%$ & 3.92 & 11.8 & 39.2 \\
\hline 250 & 7 & 272 & $109 \%$ & $1 \%$ & 4.06 & 12.2 & 40.6 \\
\hline 350 & 7 & 329 & $94 \%$ & $2 \%$ & 5.92 & 17.7 & 59.2 \\
\hline 400 & 7 & 384 & $96 \%$ & $1 \%$ & 3.21 & 9.64 & 32.1 \\
\hline 450 & 6 & 440 & $98 \%$ & $1 \%$ & 4.93 & 14.8 & 49.3 \\
\hline 500 & 5 & 482 & $96 \%$ & $2 \%$ & 10.6 & 31.7 & 106 \\
\hline \multicolumn{8}{|c|}{ Aluminum } \\
\hline Blank & 25 & 0.76 & NA & NA & 0.861 & 2.58 & 8.61 \\
\hline 1.0 & 15 & 2.26 & $226 \%$ & $113 \%$ & 1.23 & 3.70 & 12.3 \\
\hline 5.0 & 13 & 3.53 & $71 \%$ & $54 \%$ & 2.32 & 6.97 & 23.2 \\
\hline 25 & 5 & 27.3 & $109 \%$ & $66 \%$ & 1.20 & 3.61 & 12.0 \\
\hline 50 & 20 & 55.2 & $110 \%$ & $4 \%$ & 5.37 & 16.1 & 53.7 \\
\hline 100 & 5 & 104 & $104 \%$ & $10 \%$ & 3.37 & 10.1 & 33.7 \\
\hline 150 & 14 & 159 & $106 \%$ & $3 \%$ & 6.13 & 18.4 & 61.3 \\
\hline 200 & 5 & 195 & $98 \%$ & $4 \%$ & 5.16 & 15.5 & 51.6 \\
\hline 250 & 15 & 260 & $104 \%$ & $3 \%$ & 12.1 & 36.2 & 121 \\
\hline 300 & 7 & 311 & $104 \%$ & $5 \%$ & 7.11 & 21.3 & 71.1 \\
\hline 350 & 21 & 356 & $102 \%$ & $2 \%$ & 22.5 & 67.6 & 225 \\
\hline 400 & 7 & 417 & $104 \%$ & $6 \%$ & 8.56 & 25.7 & 85.6 \\
\hline 450 & 6 & 440 & $98 \%$ & $2 \%$ & 4.35 & 13.0 & 43.5 \\
\hline 500 & 12 & 504 & $101 \%$ & $1 \%$ & 17.2 & 51.7 & 172 \\
\hline \multicolumn{8}{|l|}{ Arsenic } \\
\hline Blank & 18 & 0.35 & NA & $125 \%$ & 0.437 & 1.31 & 4.37 \\
\hline 1.0 & 7 & 1.57 & $157 \%$ & $40 \%$ & 0.623 & 1.87 & 6.23 \\
\hline
\end{tabular}




\begin{tabular}{|c|c|c|c|c|c|c|c|}
\hline 5.0 & 5 & 5.16 & $103 \%$ & $6 \%$ & 0.311 & 0.93 & 3.11 \\
\hline 25 & 5 & 25.8 & $103 \%$ & $2 \%$ & 0.580 & 1.74 & 5.80 \\
\hline 50 & 13 & 48.6 & $97 \%$ & $8 \%$ & 3.84 & 11.5 & 38.4 \\
\hline 100 & 5 & 99.1 & $99 \%$ & $2 \%$ & 1.53 & 4.60 & 15.3 \\
\hline 150 & 7 & 145 & $97 \%$ & $3 \%$ & 3.84 & 11.5 & 38.4 \\
\hline 200 & 5 & 191 & $96 \%$ & $2 \%$ & 3.67 & 11.0 & 36.7 \\
\hline 250 & 7 & 239 & $96 \%$ & $2 \%$ & 5.75 & 17.2 & 57.5 \\
\hline 300 & 7 & 295 & $98 \%$ & $3 \%$ & 8.27 & 24.8 & 82.7 \\
\hline 350 & 7 & 340 & NA & $2 \%$ & 6.99 & 21.0 & 69.9 \\
\hline 400 & 7 & 402 & $157 \%$ & $3 \%$ & 13.4 & 40.2 & 134 \\
\hline 500 & 12 & 496 & $103 \%$ & $2 \%$ & 11.1 & 33.3 & 111 \\
\hline \multicolumn{8}{|c|}{ Selenium } \\
\hline Blank & 18 & 0.55 & NA & $119 \%$ & 0.654 & 1.96 & 6.54 \\
\hline 1.0 & 7 & 1.93 & $193 \%$ & $33 \%$ & 0.638 & 1.91 & 6.38 \\
\hline 5.0 & 5 & 5.35 & $107 \%$ & $9 \%$ & 0.507 & 1.52 & 5.07 \\
\hline 25 & 5 & 25.7 & $103 \%$ & $2 \%$ & 0.441 & 1.32 & 4.41 \\
\hline 50 & 13 & 49.5 & $99 \%$ & $8 \%$ & 4.06 & 12.2 & 40.6 \\
\hline 100 & 5 & 102 & $102 \%$ & $2 \%$ & 1.76 & 5.29 & 17.6 \\
\hline 150 & 7 & 147 & $96 \%$ & $3 \%$ & 3.77 & 11.3 & 37.7 \\
\hline 200 & 5 & 197 & $99 \%$ & $1 \%$ & 2.85 & 8.55 & 28.5 \\
\hline 250 & 8 & 240 & $96 \%$ & $4 \%$ & 8.42 & 25.3 & 84.2 \\
\hline 300 & 7 & 296 & $99 \%$ & $3 \%$ & 7.53 & 22.6 & 75.3 \\
\hline 350 & 7 & 339 & $97 \%$ & $1 \%$ & 4.35 & 13.1 & 43.5 \\
\hline 400 & 7 & 403 & $101 \%$ & $3 \%$ & 10.8 & 32.3 & 108 \\
\hline 500 & 12 & 494 & $99 \%$ & $2 \%$ & 9.50 & 28.5 & 95.0 \\
\hline \multicolumn{8}{|c|}{ Rubidium } \\
\hline Blank & 18 & 0.35 & NA & $106 \%$ & 0.371 & 1.11 & 3.71 \\
\hline 1.0 & 7 & 1.40 & $140 \%$ & $48 \%$ & 0.668 & 2.00 & 6.68 \\
\hline 5.0 & 5 & 5.61 & $112 \%$ & $2 \%$ & 0.120 & 0.36 & 1.20 \\
\hline 25 & 5 & 26.9 & $108 \%$ & $1 \%$ & 0.274 & 0.82 & 2.74 \\
\hline 50 & 12 & 50.1 & $100 \%$ & $6 \%$ & 3.21 & 9.63 & 32.1 \\
\hline 100 & 5 & 105 & $105 \%$ & $1 \%$ & 1.03 & 3.10 & 10.3 \\
\hline 150 & 7 & 151 & $101 \%$ & $2 \%$ & 2.54 & 7.62 & 25.4 \\
\hline 200 & 5 & 199 & $100 \%$ & $1 \%$ & 1.86 & 5.57 & 18.6 \\
\hline 250 & 8 & 245 & $98 \%$ & $3 \%$ & 7.16 & 21.5 & 71.6 \\
\hline 300 & 7 & 303 & $101 \%$ & $1 \%$ & 4.20 & 12.6 & 42.0 \\
\hline 350 & 7 & 345 & $99 \%$ & $1 \%$ & 3.90 & 11.7 & 39.0 \\
\hline 400 & 7 & 403 & $101 \%$ & $2 \%$ & 6.09 & 18.3 & 60.9 \\
\hline 500 & 12 & 499 & $100 \%$ & $2 \%$ & 8.90 & 26.7 & 89.0 \\
\hline \multicolumn{8}{|c|}{ Strontium } \\
\hline Blank & 18 & 0.22 & NA & $110 \%$ & 0.243 & 0.728 & 2.43 \\
\hline 1.0 & 7 & 1.38 & $138 \%$ & $46 \%$ & 0.630 & 1.89 & 6.30 \\
\hline 5 & 5 & 5.62 & $112 \%$ & $2 \%$ & 0.121 & 0.362 & 1.21 \\
\hline 25 & 5 & 26.8 & $107 \%$ & $1 \%$ & 0.267 & 0.801 & 2.67 \\
\hline
\end{tabular}




\begin{tabular}{|c|c|c|c|c|c|c|c|}
\hline 50 & 13 & 50.1 & $100 \%$ & $6 \%$ & 3.18 & 9.53 & 31.8 \\
\hline 100 & 5 & 105 & $105 \%$ & $1 \%$ & 0.989 & 2.97 & 9.89 \\
\hline 150 & 7 & 151 & $101 \%$ & $2 \%$ & 2.60 & 7.80 & 26.0 \\
\hline 200 & 5 & 197 & $99 \%$ & $1 \%$ & 1.63 & 4.90 & 16.3 \\
\hline 250 & 8 & 243 & $97 \%$ & $3 \%$ & 6.95 & 20.9 & 69.5 \\
\hline 300 & 7 & 300 & $100 \%$ & $1 \%$ & 3.70 & 11.1 & 37.0 \\
\hline 350 & 7 & 344 & $98 \%$ & $1 \%$ & 4.02 & 12.1 & 40.2 \\
\hline 400 & 7 & 402 & $101 \%$ & $1 \%$ & 4.96 & 14.9 & 49.6 \\
\hline 500 & 12 & 499 & $100 \%$ & $2 \%$ & 7.97 & 23.9 & 79.7 \\
\hline Barium & & & & & & \\
\hline Blank & 18 & 0.25 & NA & $105 \%$ & 0.263 & 0.788 & 2.63 \\
\hline 1.0 & 7 & 1.32 & $132 \%$ & $52 \%$ & 0.691 & 2.07 & 6.91 \\
\hline 5.0 & 5 & 5.40 & $108 \%$ & $3 \%$ & 0.138 & 0.414 & 1.38 \\
\hline 25 & 5 & 25.9 & $104 \%$ & $1 \%$ & 0.372 & 1.12 & 3.72 \\
\hline 50 & 13 & 48.7 & $97 \%$ & $8 \%$ & 4.03 & 12.1 & 40.3 \\
\hline 100 & 5 & 101 & $101 \%$ & $2 \%$ & 1.94 & 5.83 & 19.4 \\
\hline
\end{tabular}


Table B4. Chemical concentrations for geothermal samples collected throughout the ESRP in 2014.

\begin{tabular}{|c|c|c|c|c|c|c|c|c|c|c|c|c|c|c|c|c|c|c|c|c|c|}
\hline \multirow{2}{*}{ Site } & \multirow{2}{*}{ Lat } & \multirow{2}{*}{ Long } & \multirow{2}{*}{ Unit ID } & \multirow{2}{*}{$\begin{array}{l}\text { Alkalinity } \\
\text { as } \mathrm{HCO}\end{array}$} & \multicolumn{5}{|c|}{ ICP-OES } & \multicolumn{5}{|c|}{ ICP-MS } & \multirow[b]{2}{*}{$\mathrm{Sr}$} & \multirow[b]{2}{*}{$\mathrm{Ba}$} & \multirow[b]{2}{*}{ B } & \multicolumn{4}{|c|}{ IC } \\
\hline & & & & & $\mathrm{Ca}$ & Mg & $\mathrm{Na}$ & K & 02 & $\mathbf{L i}$ & $\mathrm{Be}$ & $\mathbf{A l}$ & As & $\mathbf{R b}$ & & & & F & Cl & SO4 & O3 \\
\hline 14 & 43.64283 & -111.68768 & Heise Hot Springs & 985.76 & 487.66 & 93.79 & 1539.72 & 206.21 & 33.63 & 2.48 & $1.17 \mathrm{E}-03$ & 0.131 & 0.032 & 0.652 & 5.466 & 0.057 & 4.550 & 4.00 & 2267.48 & 2.26 & ND \\
\hline & 44.14 & -112.55494 & Lidy Hot Springs 1 & 1.76 & 66.24 & 15.58 & 25.43 & 13.22 & 37.76 & 05 & $<$ LOD & 0.001 & 0.014 & 0.019 & 0.597 & 0.086 & 0.093 & 4.60 & 7.29 & 101.91 & ND \\
\hline 3 & 44.14166 & -112.55240 & Lidy Hot Springs 2 & 3.48 & 64.16 & 16.34 & 7.65 & 13.47 & 34.21 & .05 & $<$ LOD & 0.001 & 0.014 & 0.019 & 0.611 & 0.078 & 0.092 & 4.68 & 6.94 & 98.28 & ND \\
\hline 4 & 43.7 & -111 & Gre & 136.64 & 144.20 & 33.75 & 4.99 & 46 & 27.01 & 0.01 & $<$ LOD & $<$ LOD & 0.003 & 0.007 & 1.172 & 0.034 & 0.020 & 1.46 & 0.94 & 314.24 & 2.12 \\
\hline & & & Stu & 12 & 18 & 0.05 & 25 & 89 & .14 & 05 & OD & 0.005 & 0.012 & 0.004 & 0.005 & 0.001 & 0.039 & 2.09 & 3.28 & 77 & .63 \\
\hline & & & & 1.76 & 1.09 & 11.47 & 2.40 & 2.49 & 29.51 & 09 & LOD & 0.003 & 0.005 & 0.047 & 0.932 & 0.284 & 0.258 & 1.58 & 13.97 & 3.47 & 69 \\
\hline 4 & 43.60 & -113.24214 & Well & 5.48 & 77.81 & 27.75 & 33.83 & .36 & 31.58 & 0.04 & $<$ LOD & $<$ LOD & 0.010 & 0.021 & 0.723 & 0.096 & 0.151 & 0.74 & 22.24 & 57.52 & 6.59 \\
\hline 8 & 42.6 & -114 & Eck & .52 & 5.74 & 0.74 & 112.83 & 16 & 52.04 & .01 & $<$ LOD & 0.007 & 0.046 & 0.004 & 0.022 & 0.001 & 0.190 & 12.16 & 46.46 & 90.87 & 1.21 \\
\hline 4 & & & & & 3.47 & 00 & & 69 & צ' & 06 & & & & 0.019 & 0.156 & 0.004 & 0.107 & 2.21 & .09 & 40.46 & 5.37 \\
\hline & & & & 00 & 6.66 & 3.47 & 93 & 04 & 37 & .06 & & 00 & & & 0.177 & 0.002 & 0.106 & 2.46 & .03 & 8 & 1.75 \\
\hline 4 & 42. & -114 & Mir & .72 & .84 & 0.00 & 8.20 & 87 & 99.53 & .05 & & 222 & 0.066 & 06 & 0.001 & $<$ LOD & 0.332 & 22.37 & 69 & & ND \\
\hline 4 & 42.5 & -114 & & 16 & 1.23 & 0.36 & 149.41 & 1.38 & 45.54 & .19 & D & 05 & 0.023 & 0.005 & 0.063 & 0.006 & 0.117 & 2.42 & 3.31 & 188.04 & 1.44 \\
\hline & & & & 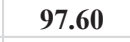 & 4 & 0.79 & 14 & 1.92 & 48 & 19 & & 16 & & & 0.065 & 0.015 & 13 & 2.45 & 99 & & ND \\
\hline & & & & & & 0.19 & & 3. & 6 & 01 & & & & & 19 & 01 & 50 & 9.64 & 4 & 1 & 4.89 \\
\hline & & & & & 50.80 & 15.25 & & 15.91 & .34 & 0.12 & & 02 & & & 0.311 & 0.163 & 0.216 & 0.38 & 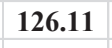 & 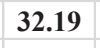 & 5.90 \\
\hline 4 & 43. & -11 & & 1.32 & 51.96 & 18.54 & 89.75 & 15.77 & 85.12 & 0.09 & D & 002 & & 0.042 & 0.243 & 0.225 & 0.215 & 0.27 & 1 & 0 & 2.76 \\
\hline 4 & 43. & & & 84 & 77.43 & 22.10 & 124.43 & 17.29 & 83.67 & .13 & D & 002 & & 0.045 & 0.405 & 0.247 & 0.341 & 0.23 & 3 & & 2.84 \\
\hline & & & & & 75.34 & 21.04 & 122.23 & 16.74 & & .13 & & & & & 0.430 & 0.229 & 0.335 & 0.26 & & & 8 \\
\hline & 42. & & $\mathbf{R a}$ & & 59.89 & 0.16 & 567.72 & 39.89 & 132.81 & 1.57 & 1.31 & & & & 1.527 & 0.028 & 0.269 & 9.08 & 9 & 3 & 0 \\
\hline & & & & 06 & 2.49 & 10 & & 37.89 & & 1.05 & & 0. & & & & 15 & 0.193 & 9.49 & & & 0 \\
\hline & & & \# 7 & 32 & 199.21 & 10 & 125 & 150.28 & $22 \mathrm{C}$ & 2.57 & 9.33 & 0.069 & 0. & 06 & 4.931 & 0.080 & 0.488 & 6.05 & 2197.12 & 59.30 & .33 \\
\hline & 42. & -113 & $\mathbf{R a}$ & 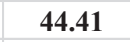 & 59.79 & 0.14 & 542.55 & 38.82 & 133.60 & 1.57 & $6.62 E-04$ & 0.066 & 0.007 & 0.396 & 1.413 & 0.023 & 0.249 & 7.15 & 790.36 & 59.32 & .06 \\
\hline & & -112. & & -0 & 80.84 & 19.52 & 126.03 & 11.48 & ביב & 0.08 & & 0.002 & & 0.028 & 2.115 & 0.288 & 0.104 & 0.50 & 27 & 19.81 & 0.36 \\
\hline & & & & & & & & & & & & & & & & & 93 & 6.70 & & & \\
\hline & 42 & & & & & 14 & & 24.85 & & 1.50 & & 0.040 & & & 1.612 & & 0.274 & 7.04 & & & .05 \\
\hline & 42.10776 & -113.39186 & Raft River Frasier Well & 59.78 & 67.22 & 0.21 & 598.27 & 22.61 & 77.42 & 1.45 & 1.08E-03 & 0.033 & 0.007 & 0.280 & 1.543 & 0.017 & 0.264 & 5.82 & 857.85 & 54.42 & 0.06 \\
\hline 028 & 42.09656 & -113.37800 & Raft River Crook Well & 5.38 & 157.70 & 0.31 & 1186.92 & 35.88 & 95.91 & 2.57 & $1.45 \mathrm{E}-03$ & 0.059 & 0.015 & 0.430 & 3.117 & 0.118 & 0.480 & 6.07 & 1679.69 & 56.51 & 0.18 \\
\hline & & & & & & 13.68 & & & & 04 & & & & 0.021 & 0.449 & 0.092 & 0.172 & 1.85 & & 49.92 & 0.01 \\
\hline 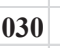 & 43.3278 & -11 & $\mathrm{Ma}$ & & 10.1 & 1.29 & 333.02 & 20.93 & 109.44 & 1.17 & & & & & 0.646 & 47 & 1.2 & 10. & 7 & & ND \\
\hline & 43.42341 & -114 & & & & 0.00 & & & & 0.21 & & 0.022 & & & 0.109 & 0.001 & 54 & $1=$ & 17 & 42.57 & ND \\
\hline & 43.42322 & -114.62865 & Elk Creek 2 & .28 & 2.27 & 0.00 & .23 & 57 & 65.30 & .21 & $<$ LOD & 0.026 & 0.005 & 0.008 & 0.112 & 0.001 & 0.252 & 15.17 & 23.14 & 42.60 & ND \\
\hline & & & & & 90 & 0.62 & & & & 0.36 & 1.8 & & & & 0.356 & 0.009 & 0.173 & 7.08 & 9.48 & 210.93 & ND \\
\hline & 43.3 & & & & & & & & & 0.05 & & & & & 0.045 & 0.000 & 0.047 & 3.35 & & & 0.00 \\
\hline 035 & 43.3278 & -114.39941 & Magic Hot Springs Well & 702.72 & 2.34 & 1.39 & 310.54 & 19.79 & 103.74 & 1.18 & 2.37E-03 & 0.009 & 0.004 & 0.126 & 0.931 & 0.223 & 1.200 & 9.95 & 74.11 & 50.34 & ND \\
\hline
\end{tabular}




\begin{tabular}{|c|c|c|c|c|c|c|c|c|c|c|c|c|c|c|c|c|c|c|c|c|c|}
\hline \multirow{2}{*}{ Site } & \multirow{2}{*}{ Lat } & \multirow{2}{*}{ Long } & \multirow{2}{*}{ Unit ID } & \multirow{2}{*}{$\begin{array}{l}\text { Alkalinity } \\
\text { as HCO3 }\end{array}$} & \multicolumn{5}{|c|}{ ICP-OES } & \multicolumn{5}{|c|}{ ICP-MS } & \multirow[b]{2}{*}{$\mathrm{Sr}$} & \multirow[b]{2}{*}{ Ba } & \multirow[b]{2}{*}{ B } & \multicolumn{4}{|c|}{ IC } \\
\hline & & & & & $\mathrm{Ca}$ & $\mathbf{M g}$ & $\mathbf{N a}$ & $\mathbf{K}$ & SiO2(aq) & $\mathbf{L i}$ & $\mathrm{Be}$ & Al & As & $\mathbf{R b}$ & & & & $\mathbf{F}$ & $\mathrm{Cl}$ & SO4 & $\mathrm{NO3}$ \\
\hline 036 & 43.12966 & -115.33841 & Prince Albert Hot Springs & 104.92 & 0.26 & 0.01 & 55.28 & 2.67 & 110.10 & 0.01 & $1.24 \mathrm{E}-04$ & 0.017 & 0.009 & 0.007 & 0.001 & 0.001 & 0.037 & 6.95 & 2.55 & 8.42 & ND \\
\hline 037 & 42.17334 & -113.86163 & Oakley Warm Spring & 107.36 & 2.23 & 0.02 & 85.72 & 2.18 & 79.21 & 0.03 & $1.26 \mathrm{E}-04$ & 0.015 & 0.001 & 0.015 & 0.053 & 0.001 & 0.052 & 7.61 & 52.57 & 21.40 & ND \\
\hline 038 & 42.08533 & -113.93984 & Richard Austin Well 1 & 4.96 & 2.14 & 0.06 & 105.97 & 1.89 & .71 & 0.07 & $1.01 \mathrm{E}-04$ & 0.025 & 0.007 & 0.006 & 0.038 & 0.014 & 0.071 & 2.42 & 16.17 & 22.80 & ND \\
\hline 039 & 42.47663 & -113.50770 & Marsh Creek Well & 4.44 & 9.08 & 0.41 & 107.78 & 4.28 & 62.55 & 0.07 & $1.69 \mathrm{E}-04$ & 0.007 & 0.001 & 0.029 & 0.094 & 0.012 & 0.063 & 13.18 & 51.77 & 50.26 & ND \\
\hline 040 & 42.70399 & -114.85699 & 1000 Springs (Sliger's Well) & 212.28 & 0.94 & 0.00 & 136.44 & 1.59 & 93.53 & 0.05 & $5.54 \mathrm{E}-05$ & 0.074 & 0.061 & 0.008 & 0.001 & 0.000 & 0.499 & 24.22 & 50.45 & 30.06 & ND \\
\hline 041 & 42.68841 & -114.82680 & Banbury Hot Springs Well & 248.88 & 0.88 & 0.00 & 96.77 & 1.65 & 103.40 & 0.03 & 8.87E-05 & 0.014 & 0.042 & 0.007 & 0.001 & 0.000 & 0.216 & 11.39 & 16.86 & 23.50 & ND \\
\hline 042 & 42.68 & -114.82680 & Banbury Hot Springs & 168.36 & 1.04 & 0.00 & 94.90 & 1.60 & 102.85 & 0.03 & $<$ LOD & 0.015 & 0.042 & 0.007 & 0.001 & 0.000 & 0.219 & 11.36 & 16.76 & 23.54 & ND \\
\hline 043 & 42.9 & -115 . & Diamond Laundry & 76 & 1.66 & 0.18 & 142.30 & 1.29 & 30.13 & 0.02 & $<$ LOD & 0.013 & 0.000 & 0.002 & 0.007 & 0.001 & 0.890 & 13.07 & 23.26 & 4.30 & 304.06 \\
\hline 044 & 43.0 & -115 & Johnston Well & 12 & 2.42 & 0.05 & 77.41 & 1.27 & & 0.02 & $<$ LOD & 0.009 & 0.002 & 0.002 & 0.002 & 0.000 & 0.329 & 16.96 & 5.95 & 10.29 & 0.44 \\
\hline 045 & & & Leo Ray Hill & & 95 & 0.19 & & & & 0.06 & 5.11E-05 & 0.002 & 0.025 & 0.008 & 0.010 & 0.001 & 0.129 & 3.42 & 13.97 & 31.30 & ND \\
\hline 046 & & & Leo $\mathrm{I}$ & 08 & 7.62 & 0.45 & 6.44 & 4.10 & & 0.06 & $<$ LOD & 0.011 & 0.018 & 0.010 & 0.018 & 0.002 & 0.132 & 3.44 & 11.69 & 4.77 & 0.02 \\
\hline 048 & & & Hensley & 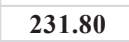 & 1.93 & 0.01 & 121.63 & 1.62 & & 0.04 & $<$ LOD & 0.011 & & 0.002 & 0.007 & 0.001 & 0.579 & 24.13 & 51.93 & 13 & ND \\
\hline 049 & 43.1 & & Latty & 1 & 0.20 & 0.01 & & 1.90 & 103.21 & 0.02 & $5.64 \mathrm{E}-05$ & 0.020 & 0.009 & 0.006 & 0.001 & 0.000 & 0.043 & 6.85 & 2.73 & 45 & 0.09 \\
\hline 050 & 42.9 & -115.4 & Laib Well & 5.72 & 9.43 & 0.55 & 291.73 & 9.84 & 57.73 & 0.34 & $4.50 \mathrm{E}-04$ & 0.176 & 0.002 & 0.018 & 0.093 & 0.094 & 2.167 & 1.74 & 66.20 & 10.37 & 164.00 \\
\hline 051 & & -114 & CSI Well 1 & & 3.99 & 0.22 & & 28 & & 0.02 & -05 & 0.003 & 0.1 & 07 & 0.017 & 0.001 & 0.185 & 8.61 & 1 & 38 & 3.50 \\
\hline 052 & & & Larry & & 1.22 & 0.01 & & 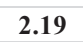 & & 0.03 & E-04 & 0.005 & 0.0 & 07 & 0.002 & 0.001 & 0.285 & 15.82 & 21.13 & 32 & 36.82 \\
\hline 053 & 42.6 & -114.48799 & Pristine $\mathrm{S}_{\mathrm{I}}$ & 2 & 1.30 & 0.01 & & 2. & 71 & 0.01 & $<$ LOD & 0.0 & 0.029 & 0.005 & 0.004 & 0.000 & 0.317 & 16.47 & 26.72 & 30.77 & 1.09 \\
\hline 054 & 42.5726 & -114 & Twin & 7 & 39.91 & 8.98 & & 4. & 55 & 0.03 & $1.04 \mathrm{E}-04$ & & 0.006 & 12 & 0.185 & 0.016 & 07 & 2.35 & 37.51 & 76.03 & 6.74 \\
\hline 055 & $42.57^{\prime}$ & -114. & pground Well & 24 & 1.50 & 0.02 & 0 & & & 0.07 & & & 0.141 & 0.009 & 0.004 & 0.002 & o & 23.37 & 34.42 & 39 & 0.10 \\
\hline 056 & & & & 385 & 51.55 & 20.88 & 32.4 & & & 0.03 & & & & 16 & 0. & 0.118 & 64 & 0.62 & 1 & 43 & 3.78 \\
\hline 057 & 43.02583 & -11 & Springs 1 & 017.052 & 165.42 & 55.84 & & 22.96 & & 0.13 & Q-04 & & & 0.034 & 1.824 & 0.026 & 0.094 & 0.81 & 23.30 & 223.91 & 1.97 \\
\hline 058 & 43.0372 & -112.0043 & Quidop Springs 2 & 710.04 & 199.48 & 68.95 & 33.80 & 34.11 & 19.61 & 0.21 & Q-02 & 0.416 & 0.027 & 0.050 & 2.598 & 0.125 & 0.129 & 0.81 & 15.16 & 344.95 & 8.84 \\
\hline 059 & 43.11448 & -112.16660 & Yandell Warm Springs & 265.96 & 72.47 & 26.33 & 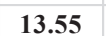 & 30 & 16 & 0.02 & DD & 0.000 & 0.003 & 04 & 0.489 & 0.045 & 0.036 & 0.60 & 16.29 & 90.37 & 1.97 \\
\hline 060 & 42.4376 & -113.4343 & Skaggs Ranch & 30.56 & 27.73 & 1.99 & 32.62 & 86 & 6 & 0.02 & $<$ LOD & 0.000 & 0.001 & 0.007 & 0.134 & 0.075 & & 1.52 & 20.37 & 4.52 & ND \\
\hline 061 & 2.1001 & -113.63354 & Durfee Hot Springs & & 8.21 & 0.35 & & 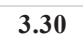 & 37 & 0.09 & $5.88 \mathrm{E}-05$ & 0.003 & 0.002 & 25 & 0.124 & 0.012 & & 6 & 59.19 & 8.16 & 0.34 \\
\hline 062 & .2233 & -113 & Basin Cemet & & .33 & 2.42 & & & & 0.01 & & 0.001 & 0.0 & & 0.168 & 0.013 & 64 & 3.58 & 47.41 & 1.01 & 1.40 \\
\hline 063 & 42.4822 & -113.97341 & Wybenga Dairy & 68 & 25.03 & 1.07 & 0.90 & 7 & 43 & 0.01 & $8.25 \mathrm{E}-05$ & 0.002 & 0.002 & 0.016 & 0.212 & 0.129 & 0.052 & 0.70 & 13.13 & 5.74 & 0.83 \\
\hline 064 & 42.1394 & -111.9371 & David Bosen Wel & .16 & 206.92 & 18.48 & 4523.31 & 794.93 & 95.12 & 6.07 & $6.75 \mathrm{E}-03$ & 0.078 & 0.076 & 4.972 & 20.351 & 3.235 & 5.555 & 5.21 & 7128.94 & 9.19 & ND \\
\hline 065 & 3.8772 & -111.55890 & Schwendiman Well & .70 & 26.86 & 6.87 & & 5.49 & 61.53 & 0.05 & OD & 0.002 & 0.007 & 0.017 & 0.080 & 0.022 & 0.087 & 2.57 & 13.67 & 5.25 & 4.50 \\
\hline 066 & 43.8857 & -111.5595 & Clyde Well & .00 & 24.67 & 7.29 & .65 & 32 & 65.03 & 0.06 & 6.09E-05 & 0.002 & 0.010 & 018 & 0.078 & 0.027 & 0.119 & 3.17 & 15.41 & 2.97 & 5.62 \\
\hline 067 & 43.9013 & -111.50967 & Cinder Block Well & 1.78 & 18.17 & 3.50 & 52.25 & 5.04 & 70.48 & 0.07 & $8.85 \mathrm{E}-05$ & 0.002 & 0.013 & 18 & 0.050 & 0.021 & 0.151 & 4.18 & 12.18 & 17.19 & 1.08 \\
\hline 068 & 43.8831 & -111.6186 & Newdale City Well & 1.32 & 7.56 & 4.70 & 0.89 & 8.12 & 70.41 & 0.12 & $5.39 \mathrm{E}-05$ & 0.002 & 0.012 & 31 & 0.086 & 0.052 & 0.215 & 5.03 & 24.86 & 29.74 & 7.18 \\
\hline 069 & 13.85840 & -111.67870 & Spackman Well & 0.32 & 37.16 & 13.68 & 11.64 & 3.00 & 29.60 & LOD & $<$ LOD & 0.001 & 0.002 & 0.004 & 0.108 & 0.033 & 0.065 & 0.46 & 5.82 & 12.91 & 7.71 \\
\hline 070 & 42.9781 & -112.4165 & Fort Hall Thermal Well & 223.26 & 55.35 & 21.27 & 29.30 & 7.14 & 49.98 & 0.03 & $<0.0001$ & $<0.01$ & 0.005 & 0.311 & 0.311 & 0.065 & 0.054 & ND & ND & ND & ND \\
\hline
\end{tabular}




\section{APPENDIX C: WATER TYPES AND CHARGE BALANCE}

Table $\mathrm{C} 1$. Major cations and anions for $\mathrm{Na}-\mathrm{HCO}_{3}$ type thermal waters utilized in this study.

Charge balances listed are given as the ratio of cations to anions calculated from meq/L units. Values with more than a $20 \%$ difference from a 1:1 balance are highlighted in red.

\begin{tabular}{|c|c|c|c|c|c|c|c|c|c|c|c|c|c|c|}
\hline Site & Lat & Long & $\mathrm{T}\left({ }^{\circ} \mathrm{C}\right)$ & pH & $\mathrm{Ca}$ & Mg & $\mathbf{N a}$ & K & Cl & $\mathbf{F}$ & SO4 & \begin{tabular}{|l} 
Alkalinity \\
as HCO3
\end{tabular} & TDS & Charge Balance \\
\hline M91-7 & 42.60316 & -114.477722 & 39 & 9.3 & 1.6 & 0.06 & 96 & 2.8 & 15 & 11 & 20 & 145 & 331 & 1.14 \\
\hline M91-8 & 42.56936 & -114.606826 & 27 & 8.6 & 5.1 & 0.17 & 61 & 4.3 & 11 & 4 & 16 & 134 & 253 & 1.00 \\
\hline M91-11 & 42.58362 & -114.48118 & 30.5 & 8.6 & 8.6 & 0.4 & 74 & 6.3 & 21 & 11 & 26 & 121 & 267 & 1.04 \\
\hline M91-13 & 42.58966 & -114.509924 & 41.5 & 9 & 1.7 & 0.08 & 130 & 2.5 & 36 & 26 & 28 & 195 & 408 & 0.94 \\
\hline M91-14 & 42.57862 & -114.287802 & 42 & 9.2 & 1.5 & 0.01 & 120 & 1.9 & 17 & 14 & 32 & 207 & 272 & 1.01 \\
\hline LY89-11 & 42.63174 & -114.597327 & 30.5 & 9 & 2 & 0.05 & 82 & 2.9 & 11 & 12 & 20 & 110 & 272 & 1.18 \\
\hline LY89-12 & 42.61798 & -114.473657 & 27 & 9 & 1.9 & 0.1 & 110 & 3.5 & 10 & 22 & 18 & 140 & 341 & 1.21 \\
\hline LY89-13 & 42.61539 & -114.488068 & 42 & 8.8 & 2.5 & 0.1 & 110 & 1.9 & 16 & 16 & 15 & 140 & 326 & 1.27 \\
\hline LY89-14 & 42.59496 & -114.481012 & 39.5 & 9 & 1.9 & 0.1 & 99 & 1.9 & 15 & 14 & 25 & 110 & 301 & 1.28 \\
\hline LY89-15 & 42.60581 & -114.478121 & 39 & 9.3 & 1.6 & 0.06 & 96 & 2.8 & 15 & 11 & 20 & 120 & 299 & 1.28 \\
\hline LY89-22 & 42.58386 & -114.480819 & 30.5 & 9 & 8.6 & 0.4 & 74 & 6.3 & 21 & 11 & 26 & 110 & 262 & 1.09 \\
\hline CC-14 & 42.58318 & -114.47496 & 38.1 & 8.79 & 4.54 & 0.19 & 95 & 3.3 & 26 & 10 & 47 & 127 & 332 & 1.03 \\
\hline CC-51 & 42.58050 & -114.47089 & 37.7 & 8.81 & 3.99 & 0.22 & 86 & 3.0 & 26 & 9 & 45 & 154 & 312 & 0.87 \\
\hline CC-52 & 42.59755 & -114.40018 & 43.0 & 9.16 & 1.22 & 0.01 & 118 & 2.2 & 21 & 16 & 36 & 188 & 397 & 1.00 \\
\hline CC-53 & 42.61390 & -114.48799 & 43.0 & 9.18 & 1.30 & 0.01 & 109 & 2.1 & 27 & 16 & 31 & 154 & 377 & 1.02 \\
\hline CC-55 & 42.57750 & -114.28870 & 37.0 & 9.05 & 1.50 & 0.02 & 126 & 3.1 & 34 & 23 & 37 & 246 & 423 & 0.81 \\
\hline LY82-3 & 42.70158 & -114.856527 & 62 & 9.4 & 0.7 & 0.1 & 150 & 1.4 & 48 & 15 & 35 & 168 & 503 & 1.17 \\
\hline LY82-4 & 42.70184 & -114.854331 & 71.5 & 9.5 & 1.5 & 0.1 & 140 & 1.5 & 51 & 27 & 33 & 168 & 505 & 0.98 \\
\hline LY82-5 & 42.69133 & -114.866789 & 57 & 9.4 & 0.9 & 0.1 & 130 & 1.5 & 34 & 21 & 34 & 177 & 485 & 1.01 \\
\hline LY82-6 & 42.6881 & -114.84012 & 45.5 & 9.1 & 0.9 & 0.1 & 100 & 1.8 & 30 & 26 & 29 & 163 & 438 & 0.81 \\
\hline LY82-7 & 42.68357 & -114.834978 & 42.5 & 9.3 & 1.3 & 0.1 & 90 & 1.7 & 14 & 9 & 28 & 148 & 359 & 1.04 \\
\hline LY82-11 & 42.68487 & -114.829093 & 44.5 & 9.4 & 3.3 & 0.1 & 100 & 1.8 & 22 & 12 & 27 & 160 & 414 & 1.03 \\
\hline LY82-12 & 42.68251 & -114.82902 & 30 & 9.3 & 0.9 & 0.1 & 97 & 1.6 & 20 & 13 & 28 & 154 & 379 & 0.99 \\
\hline LY82-15 & 42.66904 & -114.8236 & 34 & 8.7 & 5.4 & 0.2 & 66 & 2.9 & 13 & 4 & 30 & 124 & 302 & 1.00 \\
\hline LY82-18 & 42.66149 & -114.814894 & 32 & 8.4 & 8 & 0.2 & 62 & 2.8 & 11 & 3 & 26 & 144 & 310 & 0.94 \\
\hline LY82-19 & 42.66001 & -114.81414 & 31.5 & 8.6 & 7.5 & 0.3 & 63 & 2.8 & 11 & 3 & 26 & 134 & 299 & 1.00 \\
\hline LY82-20 & 42.65886 & -114.810791 & 32.5 & 8.3 & 10 & 0.5 & 62 & 3.5 & 11 & 3 & 25 & 150 & 316 & 0.97 \\
\hline LY89-1 & 42.66191 & -114.812514 & 33 & 8.4 & 11 & 0.5 & 61 & 3.9 & 11 & 4 & 24 & 150 & 246 & 0.97 \\
\hline LY89-4 & 42.63697 & -114.754192 & 26 & 8.3 & 7.4 & 0.2 & 62 & 5.6 & 10 & 5 & 21 & 140 & 262 & 0.99 \\
\hline LY89-8 & 42.65494 & -114.650688 & 44 & 9 & 1.5 & 0.1 & 96 & 1.5 & 14 & 16 & 24 & 78 & 304 & 1.43 \\
\hline CC-40 & 42.70399 & -114.85699 & 72.0 & $9.5^{\circ}$ & 0.94 & 0.00 & 136 & 1.59 & 50 & 24 & 30 & 212 & 494 & 0.89 \\
\hline CC-42 & 42.68841 & -114.82680 & 58.5 & 9 & 1.04 & 0.00 & 95 & 1.60 & 17 & 11 & 24 & 168 & 332 & 0.98 \\
\hline CC-45 & 42.66851 & -114.82436 & 35.0 & 8.69 & 5.95 & 0.19 & 62 & 3.41 & 14 & 3 & 31 & 140 & 228 & 0.87 \\
\hline CC-46 & 42.66778 & -114.82673 & 35.5 & 8.41 & 7.62 & 0.45 & 56 & 4.10 & 12 & 3 & 25 & 139 & 222 & 0.90 \\
\hline CC- -48 & 42.70501 & -114.85701 & 31.8 & 9.55 & 1.93 & 0.01 & 122 & 1.62 & 52 & 24 & 33 & 232 & 429 & 0.75 \\
\hline LY89-2 & 42.66123 & -114.791887 & 37 & 8.1 & 13 & 1.2 & 58 & 4.1 & 12 & 4 & 25 & 140 & 246 & 1.01 \\
\hline CC-11 & 42.69457 & -114.85592 & 58.4 & 9.53 & 0.84 & 0.00 & 128 & 1.87 & 32 & 22 & 34 & 93 & 423 & 1.32 \\
\hline LY89-9 & 42.64886 & -114.652208 & 23 & 9.1 & 8.9 & 2.4 & 73 & 1.9 & 20 & 11 & 28 & 95 & 263 & 1.18 \\
\hline
\end{tabular}


Table C2: Major cations and anions for $\mathrm{Ca}-\mathrm{HCO}_{3}$ type thermal waters utilized in this study. Charge balances listed are given as the ratio of cations to anions calculated from meq/L units.

\begin{tabular}{|c|c|c|c|c|c|c|c|c|c|c|c|c|c|c|}
\hline Site & Lat & Long & $\mathrm{T}\left({ }^{\circ} \mathrm{C}\right)$ & pH & $\mathrm{Ca}$ & Mg & $\mathrm{Na}$ & $\mathbf{K}$ & $\mathrm{Cl}$ & $\mathbf{F}$ & SO4 & $\begin{array}{l}\text { Alkalinity } \\
\text { as HCO3 }\end{array}$ & TDS & Charge Balance \\
\hline LY89-17 & 42.5759 & -114.738609 & 25 & 8 & 35 & 4.5 & 63 & 12 & 35 & 2 & 69 & 160 & 371 & 1.01 \\
\hline LY82-13 & 42.59993 & -114.943824 & 42 & 9.2 & 26 & 3.9 & 35 & 7.9 & 16 & 2 & 35 & 120 & 331 & 1.03 \\
\hline LY89-3 & 42.65402 & -114.795266 & 28.5 & 8 & 16 & 2.3 & 55 & 5.8 & 13 & 3 & 27 & 150 & 259 & 1.00 \\
\hline CC-9 & 42.64497 & -114.78706 & 34.5 & 7.98 & 23.47 & 3.00 & 58 & 7.69 & 23 & 2 & 40 & 144 & 252 & 1.04 \\
\hline CC-10 & 42.64432 & -114.78294 & 34.4 & 7.96 & 26.66 & 3.47 & 56 & 8.04 & 20 & 2 & 32 & 127 & 293 & 1.24 \\
\hline $\mathrm{CC}-12$ & 42.54479 & -114.94855 & 37.5 & 8.59 & 11.23 & 0.36 & 149 & 1.38 & 53 & 2 & 188 & 95 & 559 & 1.00 \\
\hline LY89-10 & 42.59616 & -114.751276 & 31 & 8 & 39 & 5.6 & 65 & 11 & 38 & 2 & 75 & 160 & 388 & 1.03 \\
\hline LY89-5 & 42.64683 & -114.785566 & 32.5 & 7.8 & 18 & 2.2 & 54 & 6 & 13 & 3 & 27 & 150 & 268 & 1.02 \\
\hline LY89-6 & 42.63448 & -114.778469 & 25 & 8.1 & 17 & 1.1 & 53 & 7.5 & 14 & 2 & 22 & 160 & 283 & 0.95 \\
\hline LY89-7 & 42.5977 & -114.760739 & 29 & 7.9 & 36 & 5.4 & 61 & 10 & 31 & 2 & 61 & 170 & 356 & 1.02 \\
\hline M91-12 & 42.54998 & -114.436857 & 30.5 & 7.8 & 37 & 6.8 & 31 & 4.9 & 31 & 1 & 51 & 100 & 266 & 1.07 \\
\hline LY89-18 & 42.56642 & -114.490768 & 31.5 & 8 & 20 & 3.9 & 37 & 7 & 11 & 4 & 17 & 130 & 223 & 1.04 \\
\hline LY89-29 & 42.39592 & -114.691588 & 18.5 & 7.8 & 23 & 8.4 & 13 & 2.9 & 9 & 0 & 11 & 120 & 175 & 1.01 \\
\hline LY89-30 & 42.34555 & -114.509176 & 37 & 8 & 31 & 13 & 43 & 11 & 6 & 2 & 21 & 270 & 279 & 0.93 \\
\hline LY89-32 & 42.27131 & -114.359743 & 9 & 6.7 & 5.4 & 1.3 & 6 & 5 & 2 & 0 & 2 & 34 & 95 & 1.17 \\
\hline LY89-33 & 42.22239 & -114.785594 & 12 & 7 & 7.2 & 1.2 & 6 & 2.6 & 3 & 0 & 5 & 30 & 76 & 1.13 \\
\hline LY89-34 & 42.20179 & -114.664984 & 32 & 7.8 & 21 & 2 & 18 & 6.9 & 7 & 1 & 10 & 120 & 200 & 0.90 \\
\hline LY89-35 & 42.20114 & -114.697878 & 26 & 7.5 & 22 & 2.6 & 19 & 5.8 & 6 & 6 & 12 & 110 & 183 & 0.90 \\
\hline LY89-36 & 42.15826 & -114.66585 & 32 & 7.6 & 18 & 2.3 & 18 & 4.7 & 7 & 1 & 9 & 100 & 174 & 0.97 \\
\hline LY89-37 & 42.20044 & -114.586984 & 7.5 & 7.6 & 34 & 5.4 & 19 & 3.6 & 16 & 0 & 17 & 120 & 208 & 1.10 \\
\hline LY89-38 & 42.21351 & -114.306916 & 4.5 & 6 & 2.6 & 0.7 & 3 & 2.6 & 1 & 0 & 3 & 20 & 62 & 0.91 \\
\hline CC-54 & 42.57256 & -114.45175 & 31.0 & 7.77 & 39.91 & 8.98 & 55 & 4.92 & 38 & 2 & 76 & 161 & 390 & 0.97 \\
\hline CC-8 & 42.69940 & -114.91040 & 24.7 & 9.47 & 5.74 & 0.74 & 113 & 4.16 & 46 & 12 & 91 & 81 & 397 & 1.04 \\
\hline CC-13 & 42.54348 & -114.94897 & 36.2 & 8.65 & 11.14 & 0.79 & 147 & 1.92 & 54 & 2 & 187 & 98 & 566 & 0.99 \\
\hline
\end{tabular}




\section{APPENDIX D: SELECT WELL DRILLER'S LOGS}

\section{Form 23\%-7 L \\ DEPARTMENT OF WATER RESOURCES \\ FEB 271980 WELL DRILLER'S REPORT \\ State law requires that this report be filed with the Director. Department of Water Resoukcps, 1 \\ fiepartment of Water Resowestin 30 days after the completion or abandonment of the well.}

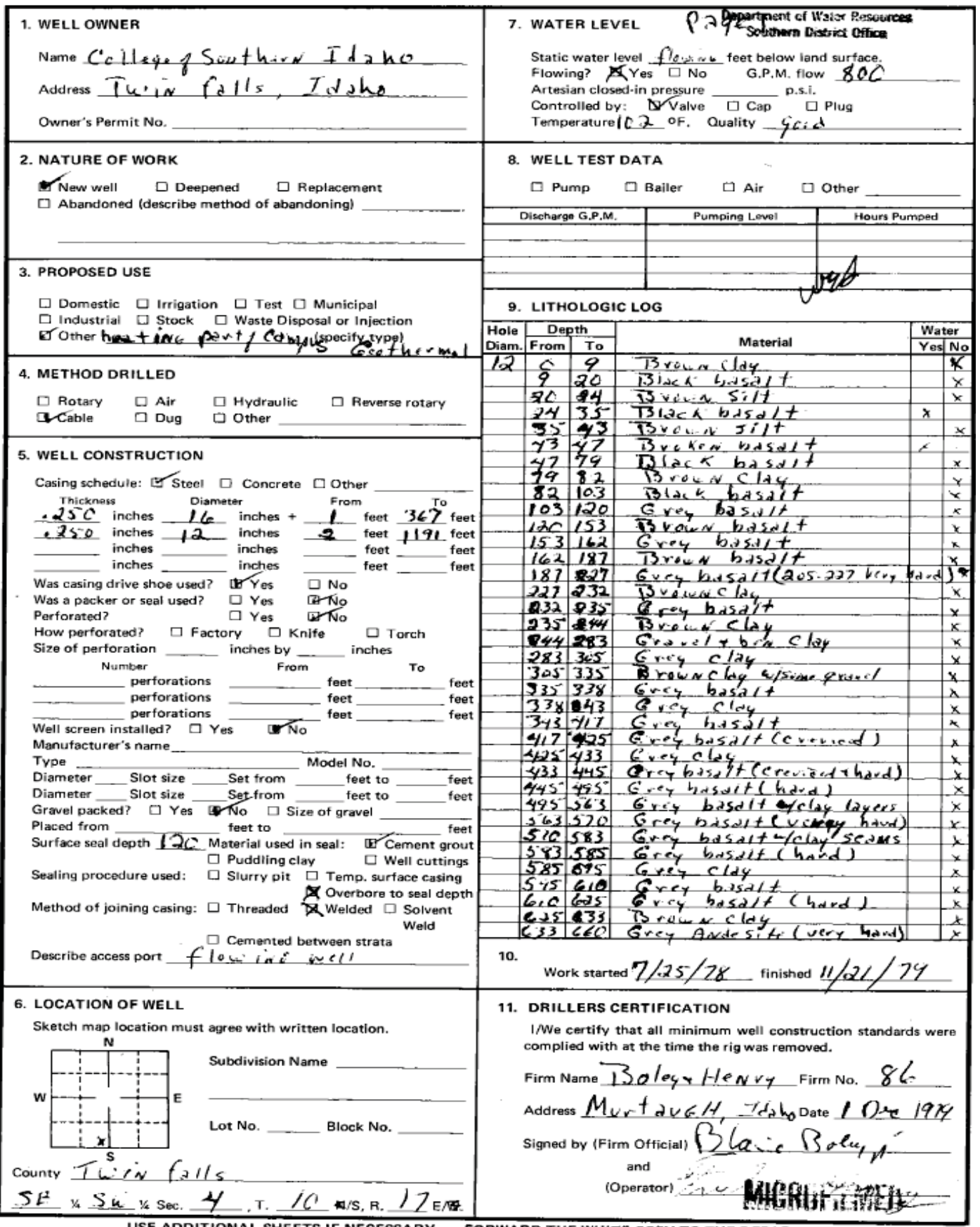



within 30 days after the completion or abandonment of the well.

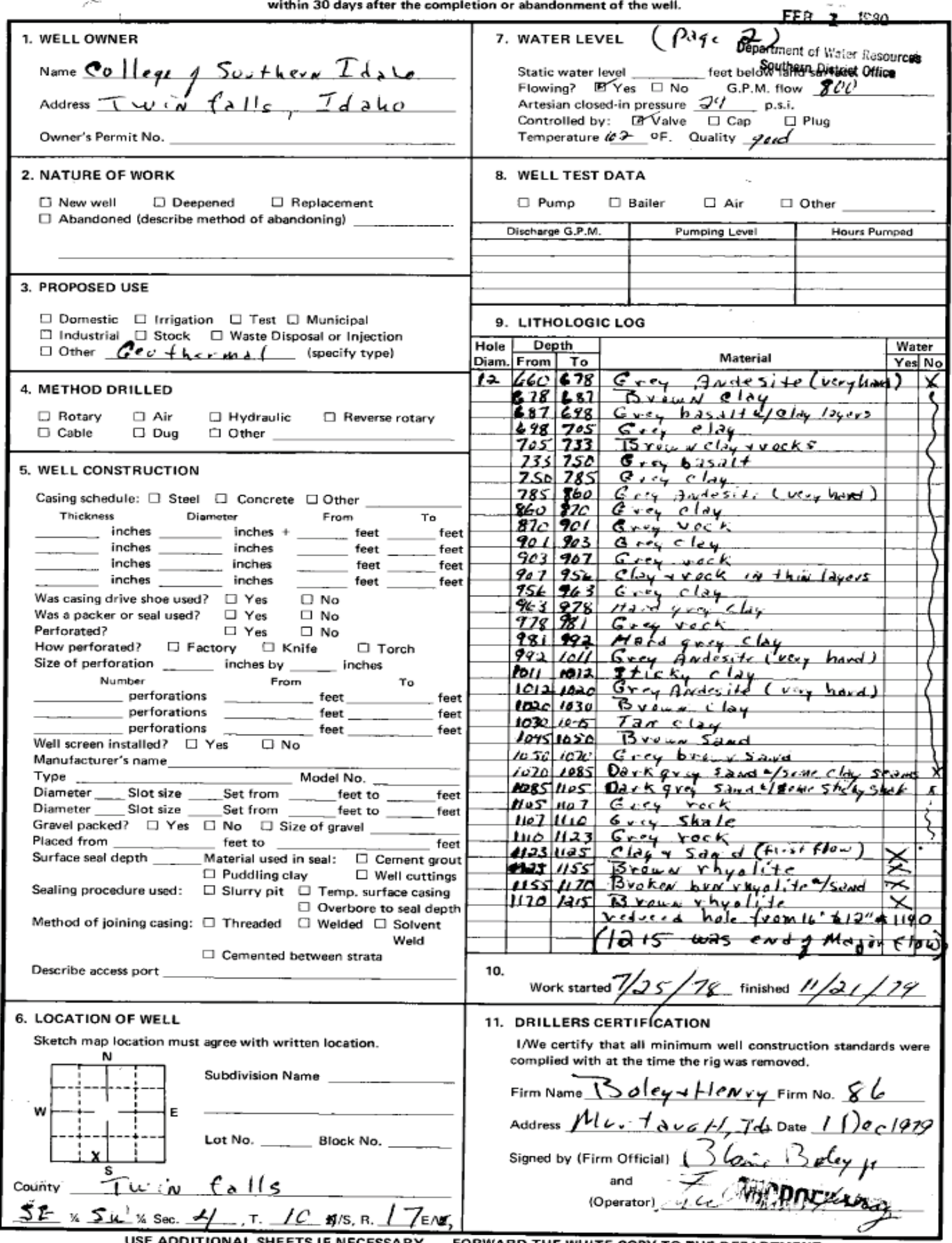




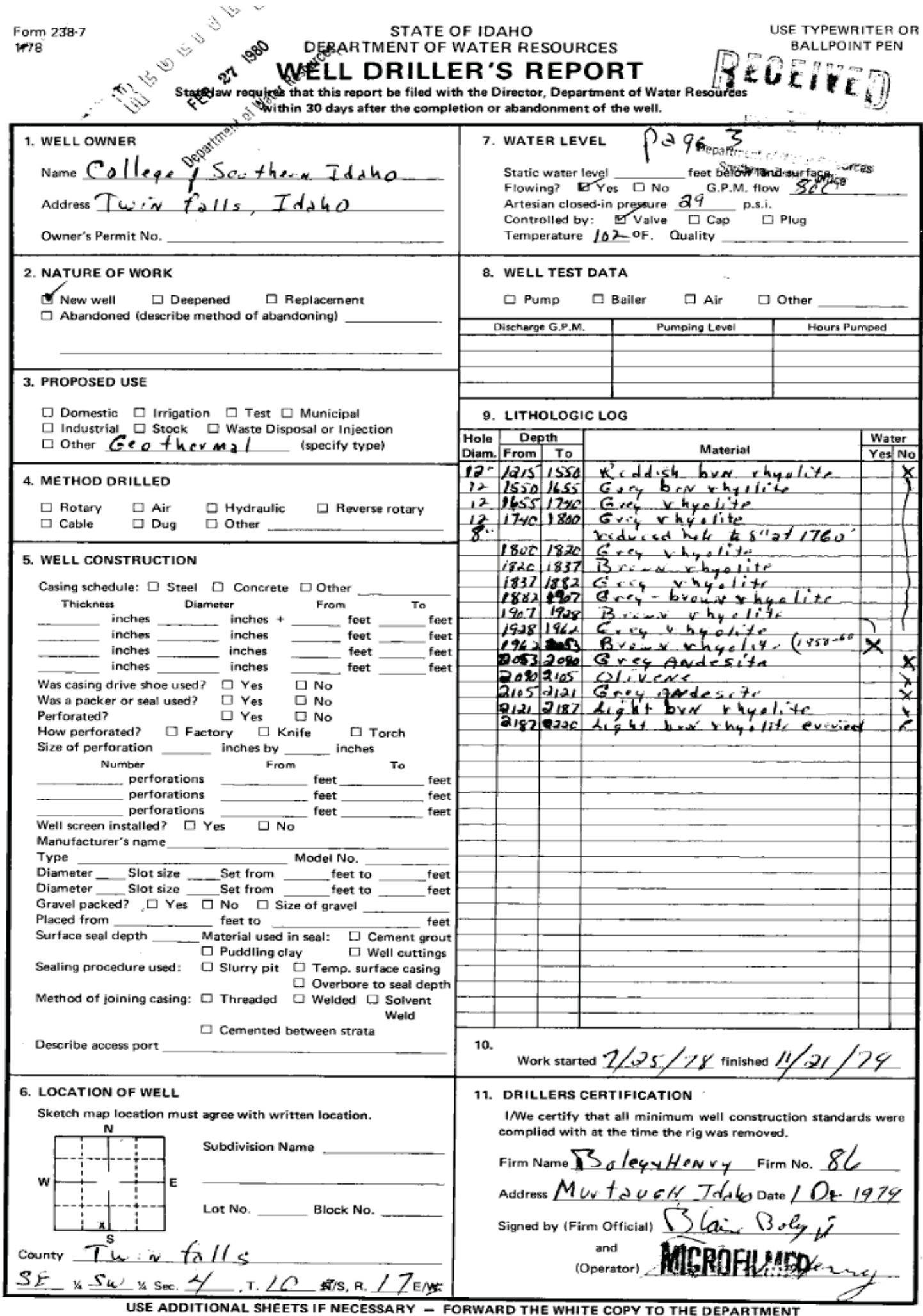

Figure C1. CSI Well 1 Driller's Log 


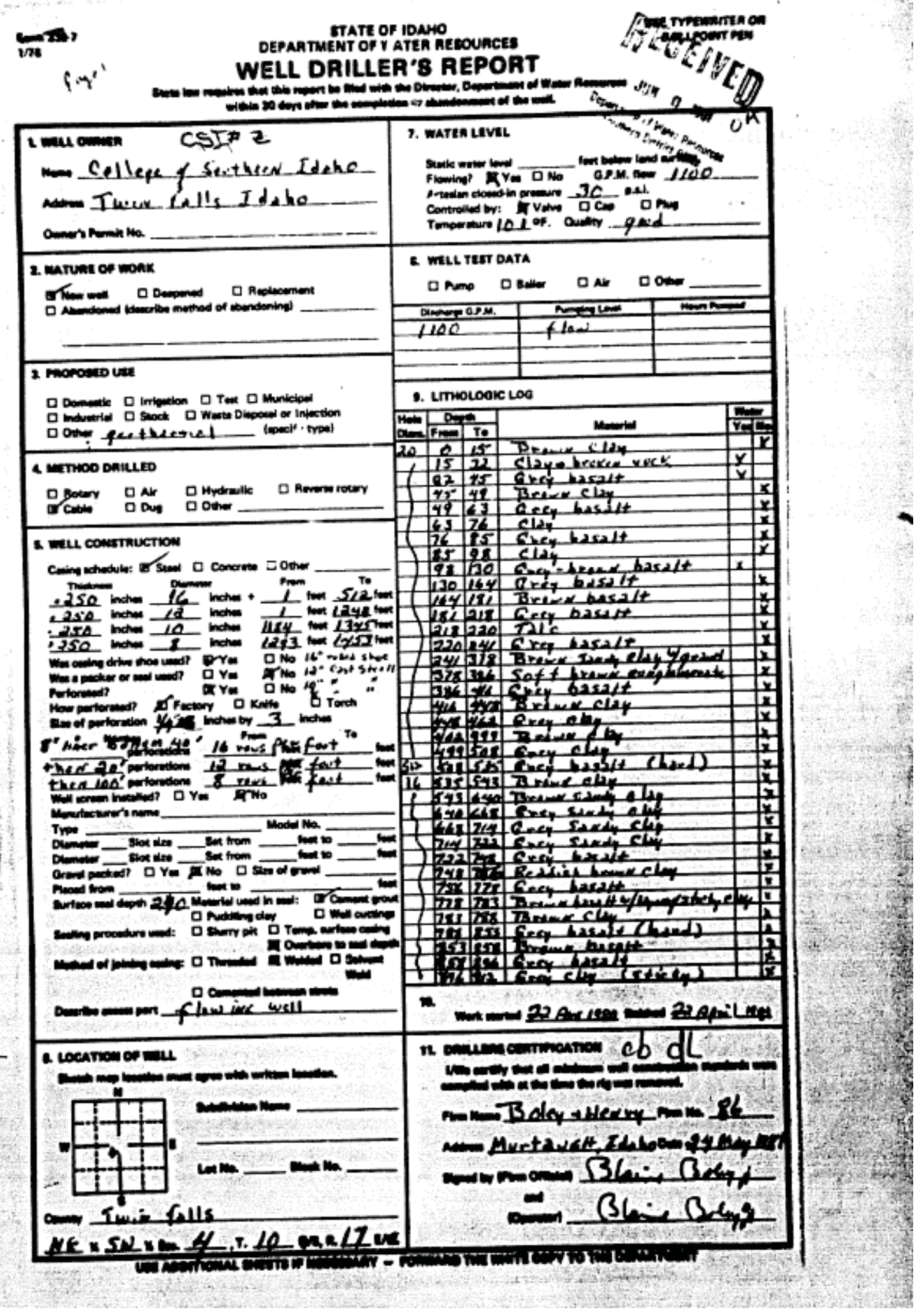




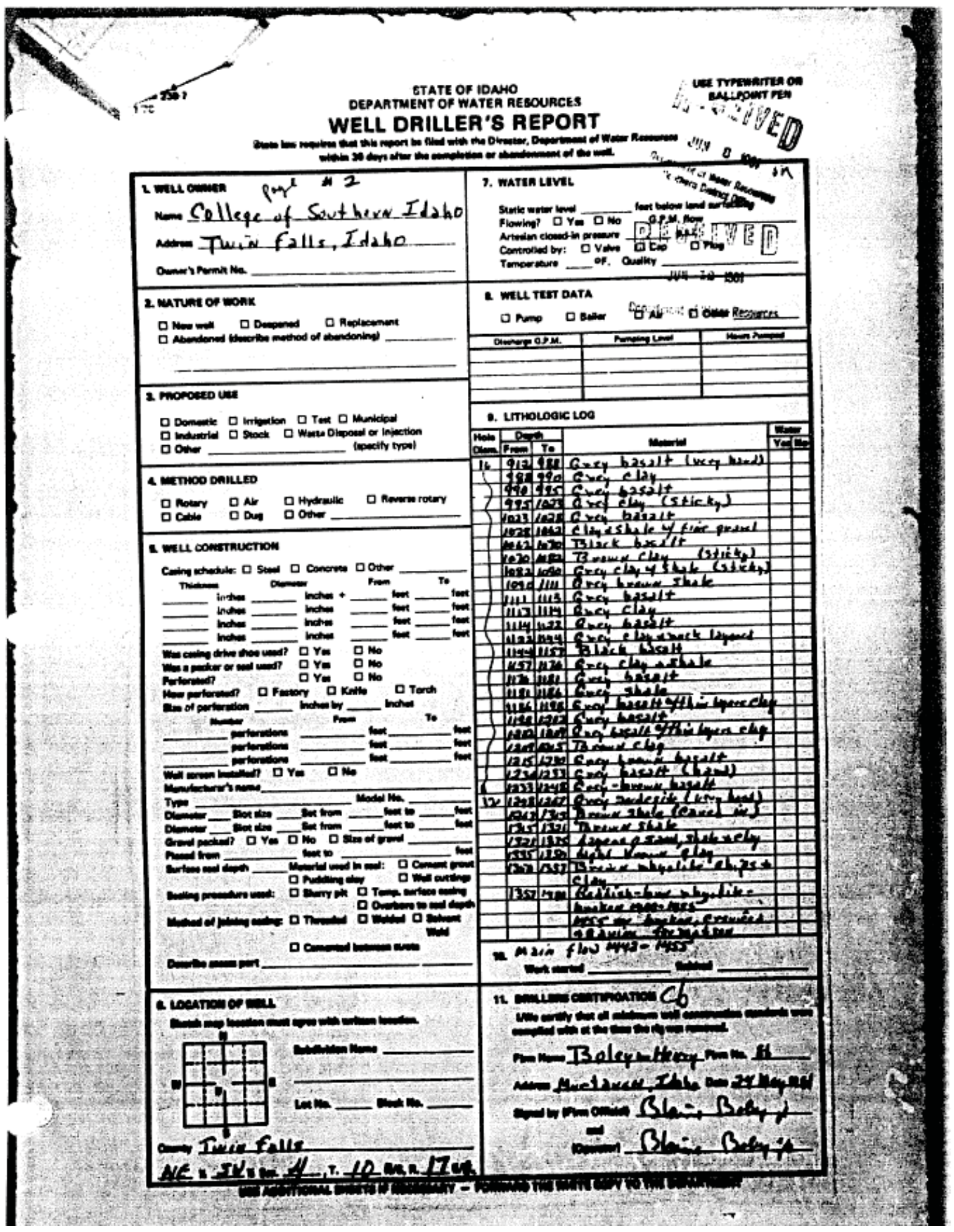

Figure C2. CSI Well 2 Driller's Log 


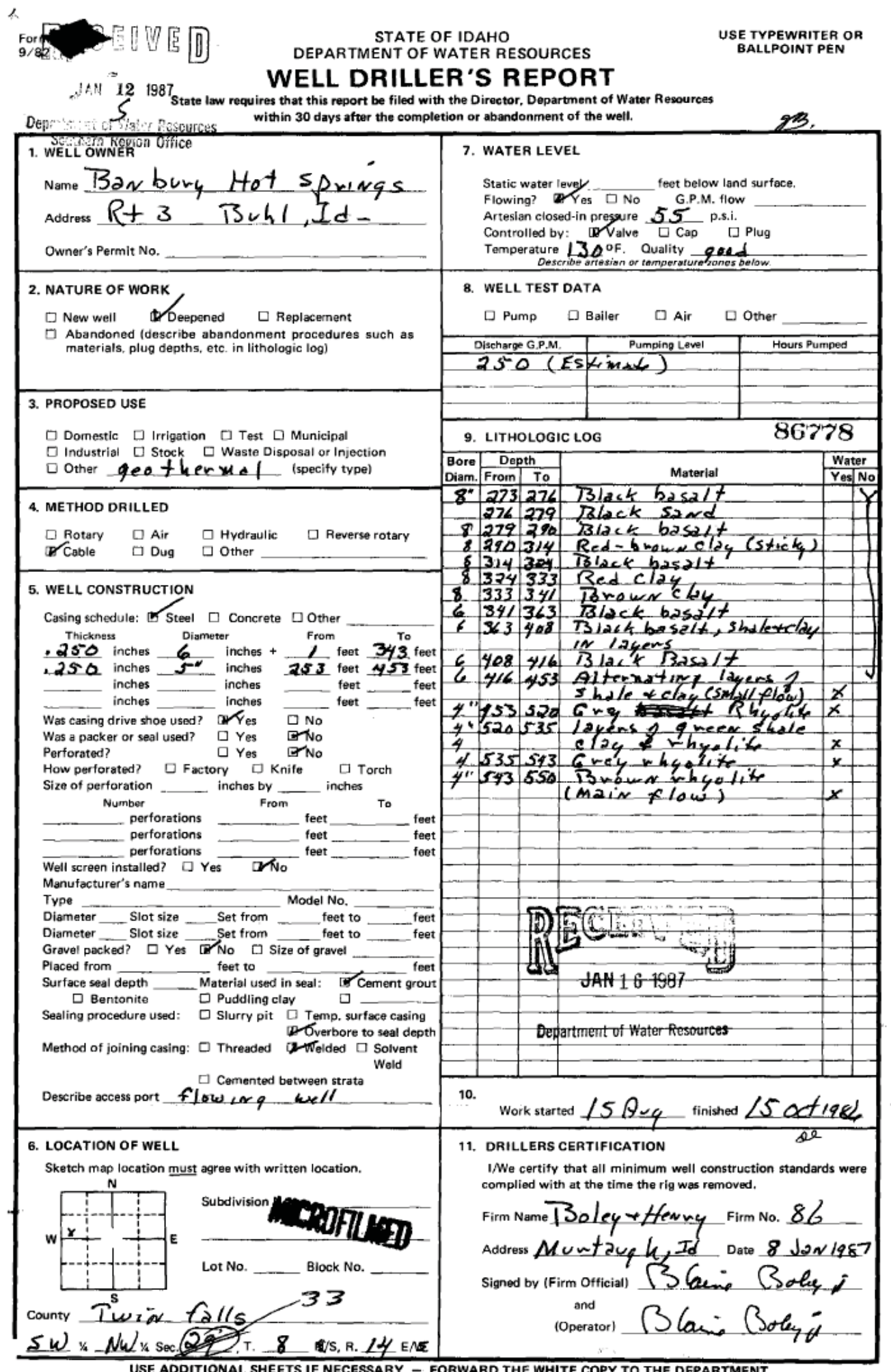

USE ADDITIONAL SHEETS IF NECESSARY - FORWARD THE WHITE COPY TO THE DEPARTMENT

Figure C3. Banbury Hot Springs Well Driller's Log 


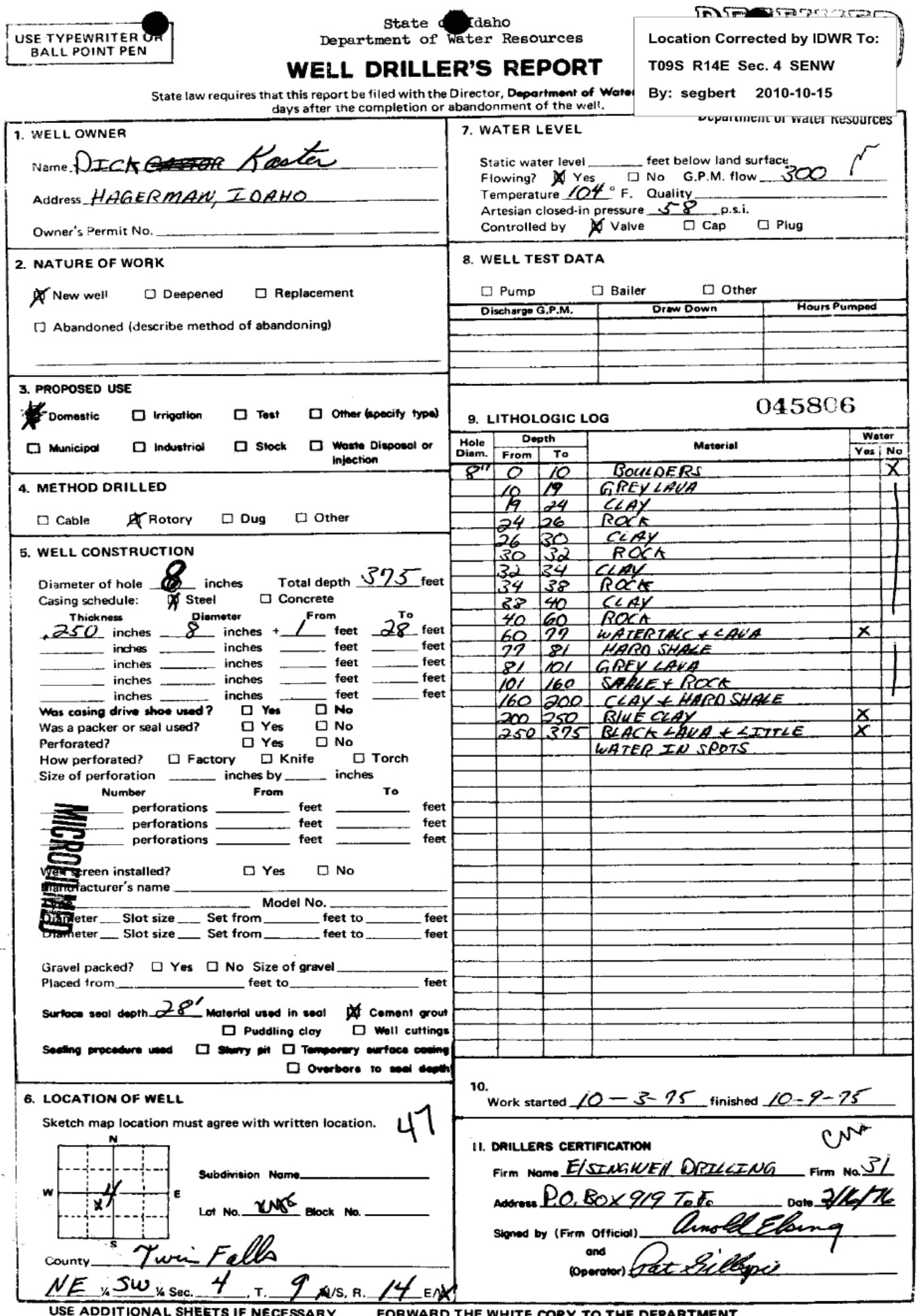

Figure C4. Dick Kaster Well 1 Driller's Log 


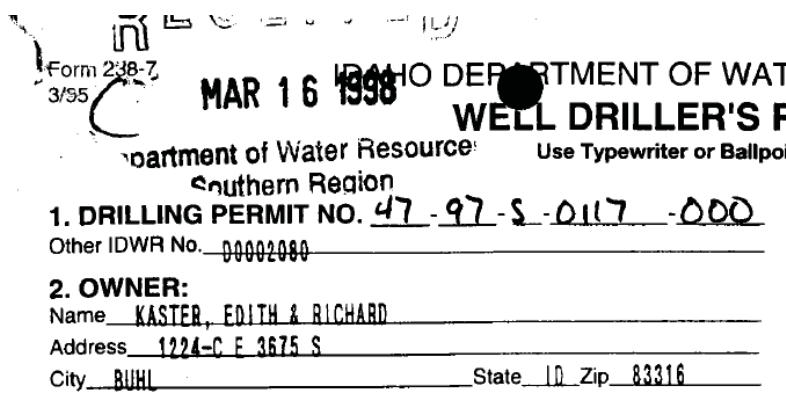

3. LOCATION OF WELL by legal description:

Sketch map location must agree with written location.

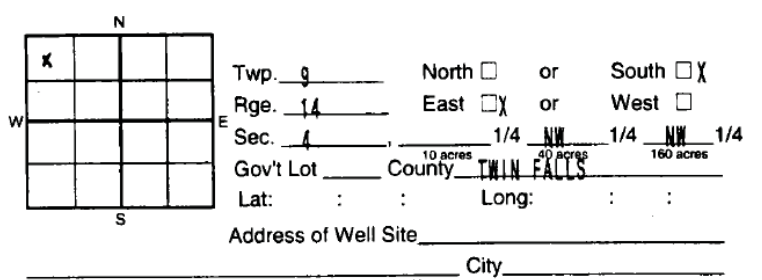

Lt. 3 Blk. 2__Sub. Name_OREGON TRALL SUBD.

4. USE:

$\begin{array}{lll}\sqsupset \text { Domestic } & \square \text { Municipal } & \square \text { Monitor } \\ \Xi \text { Irrigation }\end{array}$

5. TYPE OF WORK check all that apply (Replacement etc.)

$\square$ New Well $\square$ Modity $\square$ Abandonment $\square$ Other

6. DRILL METHOD

$\square$ Air Rotary $\square$ Cable $\square$ Muo Rotary $\square$ Other

\section{SEALING PROCEDURES}

7. SEALING PROCEDURE
\begin{tabular}{|c|c|c|c|c|}
\hline \multicolumn{2}{|c|}{ SEALFILTER PACK } & AMOUNT & \multirow{2}{*}{ METHOD } \\
\hline Material & From & To & $\begin{array}{l}\text { Sacks Or } \\
\text { Pounds }\end{array}$ & \\
\hline CEUEHI & -5 & 14 & 75 SACKS & PRESSURE GROUT \\
\hline CEMENIT & 0 & 30 & 190 SACY & PRESSURE GROUT \\
\hline & & & & \\
\hline
\end{tabular}

Was drive shoe used? $\square \mathrm{Y} \square \mathrm{N}$ Shoeßbepth(s)

Was drive shoe seal tested? $\square Y \square N$ How?

8. CASING/LINER:

\begin{tabular}{|c|c|c|c|c|c|c|c|c|}
\hline \begin{tabular}{|l|l|} 
Diameler \\
\end{tabular} & From & To & Gauge & Material & Casing & Liner & Welded & Threaded \\
\hline 10. & -.5 & 139 & 250 & STEEL & $\square x$ & $\square$ & $\square X$ & $\square$ \\
\hline 6.62 & +1 & 304 & 250 & STEEL & $\square x$ & $\square$ & $\square x$ & $\square$ \\
\hline & & & & & $\square$ & $\square$ & $\square$ & $\square$ \\
\hline
\end{tabular}

9. PERFORATIONS/SCREENS

(1) Perforations Method

$\square$ Screens Screen Type

\begin{tabular}{|c|c|c|c|c|c|c|c|}
\hline From & To & Slot Size & Number & Diameter & Material & Casing & Liner \\
\hline & & & & & & $\square$ & $\square$ \\
\hline & & & & & & $\square$ & $\square$ \\
\hline & & & & & & $\square$ & 口 \\
\hline
\end{tabular}

10. STATIC WATER LEVEL OR ARTESIAŅ PRESSURE: ft. below ground Artesian pressure $\quad$ lb.

Depth flow encountered ft. Describe access port or control devices:

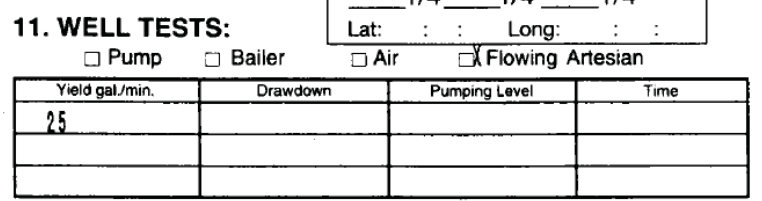

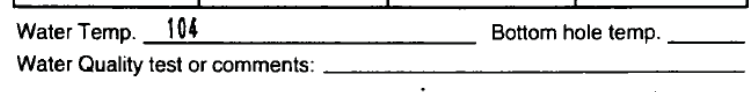

Depth first Water Encountered

12. LITHOLOGIC LOG: (Describe repairs or abandonment) Water

\begin{tabular}{|c|c|c|c|c|c|}
\hline $\begin{array}{l}\text { Bore } \\
\text { Dia. }\end{array}$ & From & To & Remarks: Ltthology, Water Quality \& Temperature & $\mathrm{Y}$ & $\mathbf{N}$ \\
\hline \multirow[t]{12}{*}{12.} & 250 & 3 & SANDY TOPSOIL & & $x$ \\
\hline & 3 & 51 & SAND & & $x$ \\
\hline & 51 & 54 & SAND \& GRAYEL & & $x$ \\
\hline & 54 & 65 & SAND & & $x$ \\
\hline & 65 & 69 & BOULDERS & & $x$ \\
\hline & 69 & 85 & SANO & & $x$ \\
\hline & 85 & 87 & SAND \& GRAVEL & & $x$ \\
\hline & 87. & 102 & SAND & & $x$ \\
\hline & 102 & 112. & SAND \& GRAYEL & & $x$ \\
\hline & 112 & 117 & BOULDERS & & $x$ \\
\hline & 117 & 120. & GRAYEL & & \\
\hline & 120 & 140 & GREY BASALT SHALE & & $x$ \\
\hline \multirow[t]{11}{*}{10} & 140 & 167 & GREY BASALT SHALE & & $x$ \\
\hline & 167 & 170 & BROHN GREY BASALT & & $\bar{x}$ \\
\hline & 170. & 177 & GREY BASALT SHALE & & $\underline{x}$ \\
\hline & $177]$ & 208 & HABD GREY BASALT. & & $x$ \\
\hline & 208. & 210. & SOFTER & & $x$ \\
\hline & 210 & 219 & GREY SHALE & & \\
\hline & 215 & 240 & GREY BLACK BASALT & & $x$ \\
\hline & 240 & 24 & SOFTER BLACK BASALT & & $x$ \\
\hline & 267) & 278 & BLACK BASALT & & $x$ \\
\hline & 278 & $28 \%$ & SOFT BLACK BASALT & & \\
\hline & 282 & 309 & HARD BROUN AND GRAY RHYOLITE & & $x$ \\
\hline \multirow[t]{10}{*}{6} & 309 & 323 & HARD BROUKK AND GRAY RHYOLITE & & $x$ \\
\hline & 323 & 324 & FRACTURED & & \\
\hline & 32 & 34 & HARO BROUN AHD GRAY RHYOLITE & & $x$ \\
\hline & 348 & 366 & HARD BROWN AND GRAY RHYOLITE & & $x$ \\
\hline & 366 & 368 & FAACTURED GREY CLAY & & $x$ \\
\hline & 369 & 420 & HARD BROUN AND GRAY RHYOLITE & & $\underline{x}$ \\
\hline & 420 & 423 & SOFT SOFT CLAY & & t \\
\hline & 423 & 438 & BROLN AND GRAY RHYOLITE & & $x$ \\
\hline & 438 & 43 & SOFT & & $x$ \\
\hline & & & TO BE CONTINUED ON NEXT PAGE & & \\
\hline \multicolumn{6}{|c|}{\begin{tabular}{lrc} 
Completed Depth & $479^{\prime}$ & \\
\cline { 2 - 3 } Date: Started & $01 / 08 / 98$ & Completed $\quad 02 / 17 / 98$
\end{tabular}} \\
\hline
\end{tabular}

\section{DRILLER'S CERTIFICATION}

IWe certify that all minimum well construction standards were complied with at the time the rig was removed.

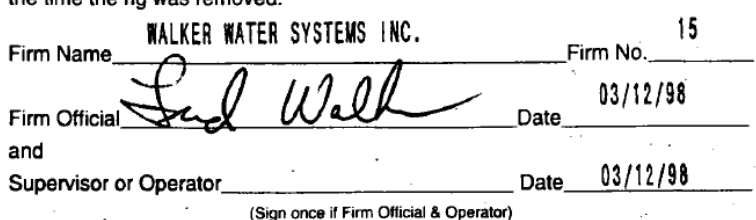


Iform 238-7.

\section{IDAHO DEP PTMENT OF WATER RESOURCE WELL DRILLER'S REPORT Use Typewriter or Ballpoint Pen}

1. DRILLING PERMIT NO. Other IDWR No. $D 0002080$

\section{OWNER:}

Name

Address

City

State___ Zip

3. LOCATION OF WELL by legal description:

Sketch map location must agree with written location.

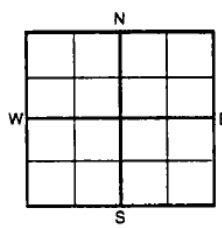

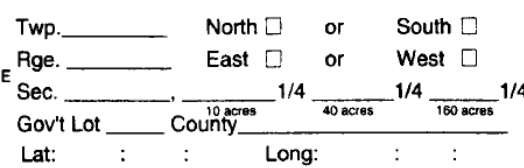

Address of Well Site

(Give at leasi name of rosd + Dislance 10 Rosd of Landomak)

City

Lt.

Blk.

Sub. Name

4. USE:

¿ Domestic $\square$ Municipal $\square$ Monitor $\square$ Irrigation

$\square$ Thermal $\square$ Injection $\square$ Other

5. TYPE OF WORK check all that apply

$\square$ New Well $\square$ Modify $\square$ Abandonment

6. DRILL METHOD

$\square$ Air Rotary $\square$ Cable $\square$ Mud Rotary $\square$ Other

\section{SEALING PROCEDURES}

\begin{tabular}{|c|c|c|c|c|}
\hline \multicolumn{2}{|c|}{ SEALFILTER PACK } & AMOUNT & \multirow{2}{*}{ METHOD } \\
\hline Material & From & To & $\begin{array}{l}\text { Sacks or } \\
\text { Pounds }\end{array}$ & \\
\hline & & & & \\
\hline & & & & \\
\hline & & & & \\
\hline
\end{tabular}

Was drive shoe used? $\square \mathrm{Y} \square \mathrm{N}$ Shoe Depth(s)

Was drive shoe seal tested? $\square Y \square N$ How?

8. CASING/LINER:

\begin{tabular}{|c|c|c|c|c|c|c|c|c|}
\hline \begin{tabular}{|l|l|l|} 
Diamer \\
\end{tabular} & From & To & Gauge & Material & Casing & Liner & Welded & Threaded \\
\hline & & & & & $\square$ & $\square$ & 口 & $\square$ \\
\hline & & & & & $\square$ & $\square$ & $\square$ & $\square$ \\
\hline & & & & & $\square$ & $\square$ & $\square$ & $\square$ \\
\hline
\end{tabular}

9. PERFORATIONS/SCREENS

- Perforations Method.

Screens Screen Type

\begin{tabular}{|c|c|c|c|c|c|c|c|}
\hline From & To & Slot Size & Number & Diameler & Material & Casing & Liner \\
\hline & & & & & & $\square$ & 口 \\
\hline & & & & & & $\square$ & $\square$ \\
\hline & & & & & & $\square$ & $\square$ \\
\hline
\end{tabular}

\section{STATIC WATER LEVEL OR ARTESIAN PRESSURE:}

$$
\text { ft. below ground }
$$

Depth flow encountered

Artesian pressure

Ib.

control devices:

ft. Describe access port or

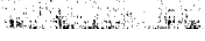

11. WELL TESTS:

$$
\square \text { Pump } \square \text { Baile }
$$

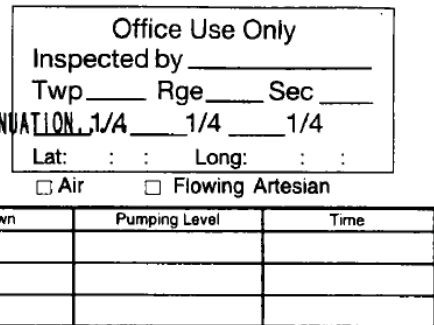

Bottom hole temp.

Water Temp.

Water Quality test or comments:

Depth first Water Encountere

12. LITHOLOGIC LOG: (Describe repairs or abandonment)

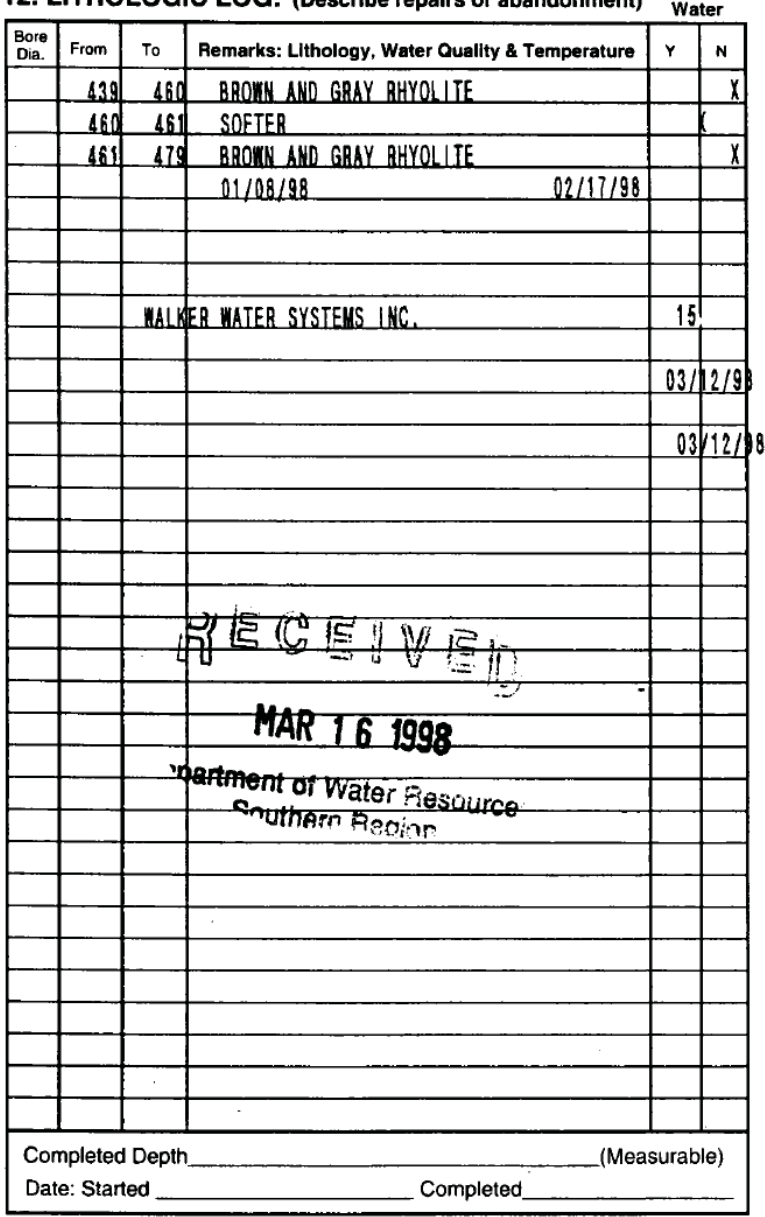

\section{DRILLER'S CERTIFICATION}

IWe certify that all minimum well construction standards were complied with at the time the rig was removed.

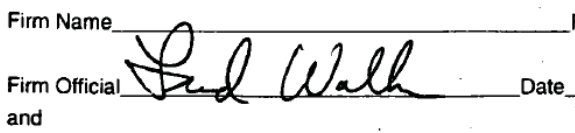

Supervisor or Operator

(Sign once if firm Official \& Operator) 


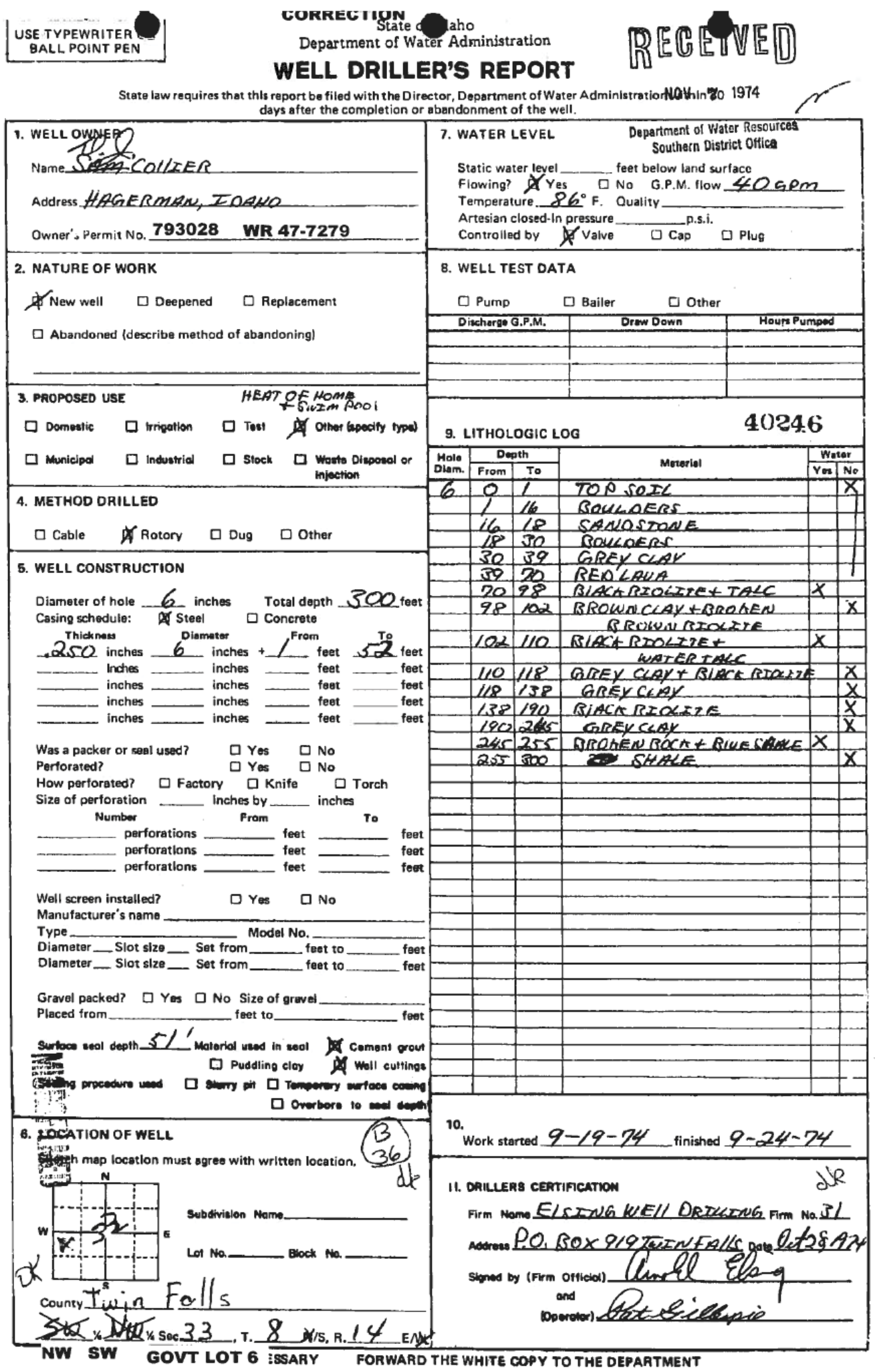

Figure C6. Sam Collier Well Driller's Log 
WELLI LOG AND REPORT OF THE

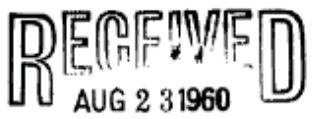
STATE RECLAMATION ENGINEER OF IDAHBepartment of ketiamation

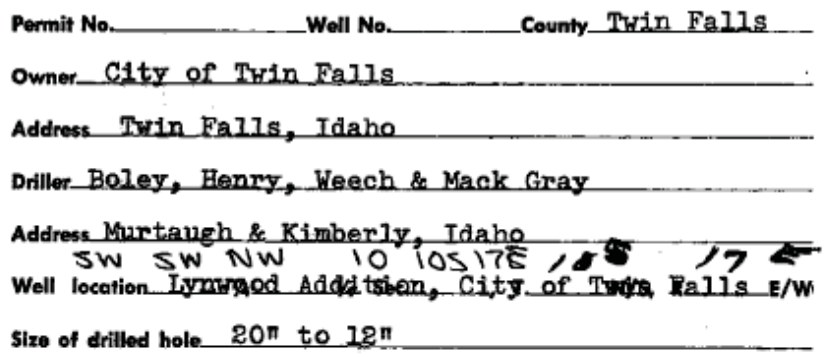

Locato well in section

\begin{tabular}{|l|l|}
\hline NW $1 / 4$ & NE $1 / 4$ \\
& \\
\hline SW $1 / 4$ & SE $1 / 4$ \\
\hline
\end{tabular}

Give depth to standing water from the ground flowing ater temp__ 87 _ofahr.

On "Pumping Tesf" delivery was. 1000 g.p.m. or__ 2 _c.f.s. Drawdown was. 450 feet.

Size of pump and motor used to make test. $10^{\mathrm{n}}$ pladg, 300 H.P. Diesel, 500 ft. setting.

Length of time of test__ 15 h _ hours_______ minutes.

If flowing well, give flow.___.f. or. 120 g.p.m. and of shut off pressure no.

If flowing well, described control works none

Water will be used for_Municipal__ Weight of casing per lineal foot

(TTPE AND SIZE OF VALVE., KTC.1

Thickness of casing _ _ $\frac{1}{2} n+$ Casing material_stee 1

and location of casing $47 \mathrm{ft}$ of $22 \pi$ OD \& $514 \mathrm{ft}$ of $16 \pi \mathrm{m}$. Cemented in. at bottom.

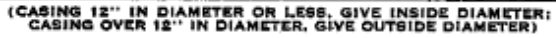

CASING RECORD

\begin{tabular}{c|c|c|c|c}
\hline $\begin{array}{c}\text { Diam. } \\
\text { Casing }\end{array}$ & $\begin{array}{c}\text { From } \\
\text { Feet }\end{array}$ & $\begin{array}{c}\text { To } \\
\text { Feot }\end{array}$ & Length & Remarks-seals, grouting, otc. \\
\hline $22 \pi$ & 0 & 471 & 471 & Cemented. \\
\hline $16 \pi$ & 0 & 514, & 514, & 121 of cement grout around the bottom. \\
\hline
\end{tabular}

Number and size :of perforations none located. foet to feet from ground

Date of commencement of well $5 / 4 / 1959$ Date of completion of well $8 / 1 / 1960$ 
WELL LOG

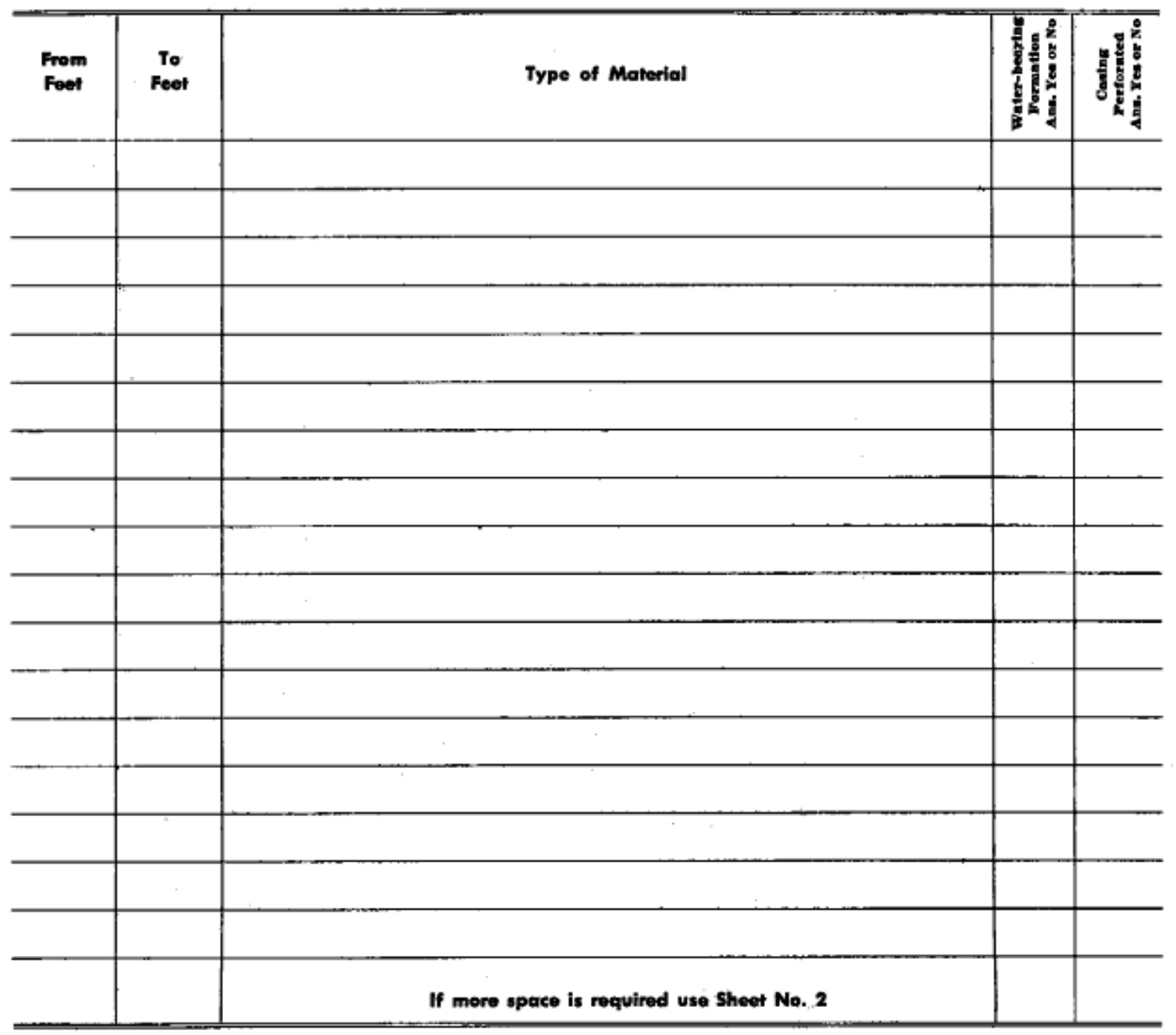

WELL DRILLER'S STATEMENT

This well was drflled under my supervision and the above information is true and correct to the best of my knewlodge and belief.

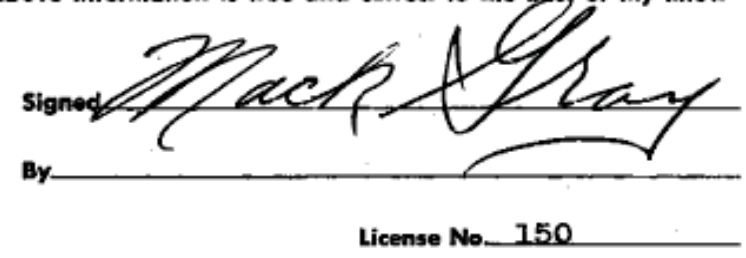

Dated. $8 / 14 / 60$

19— 


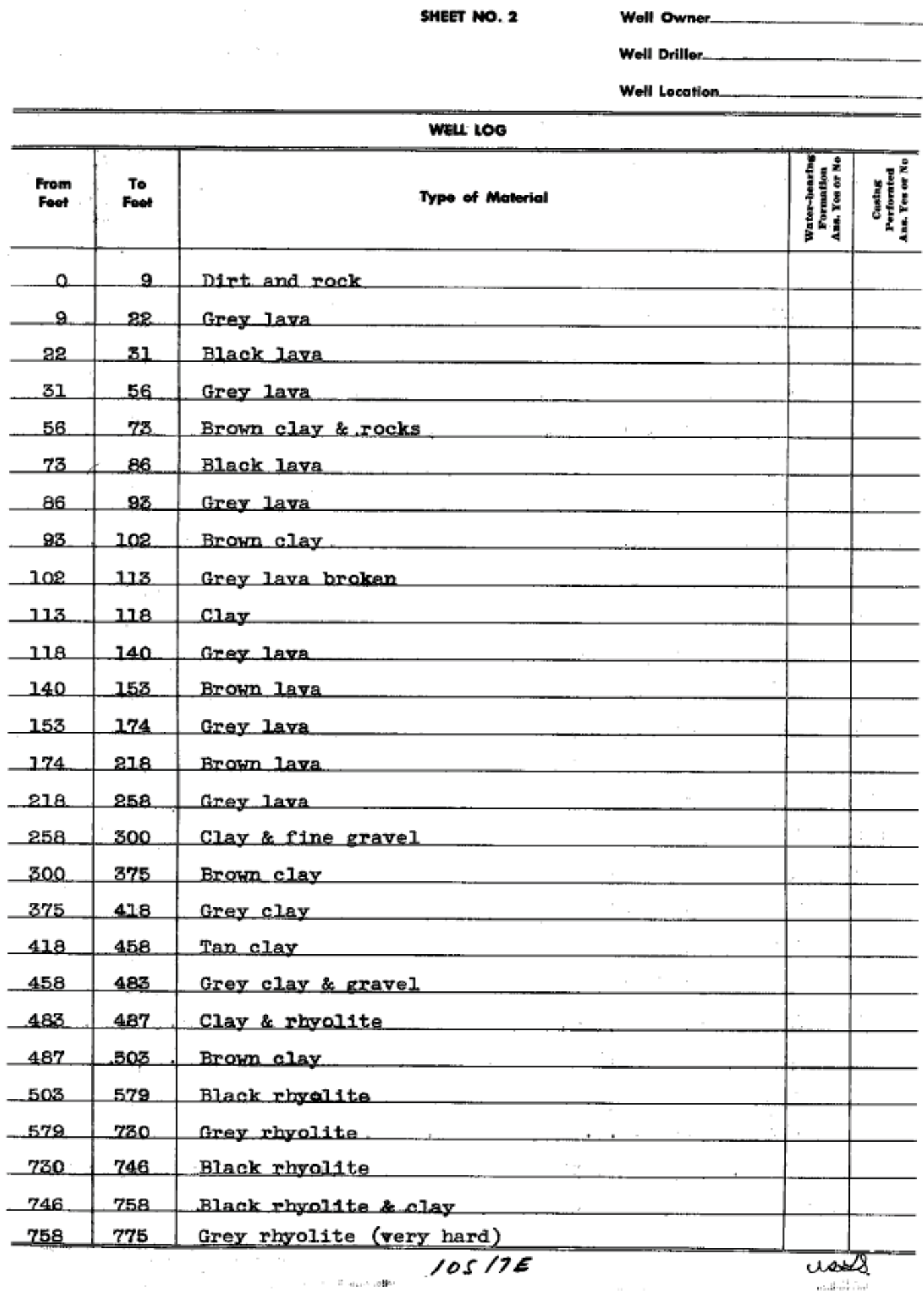




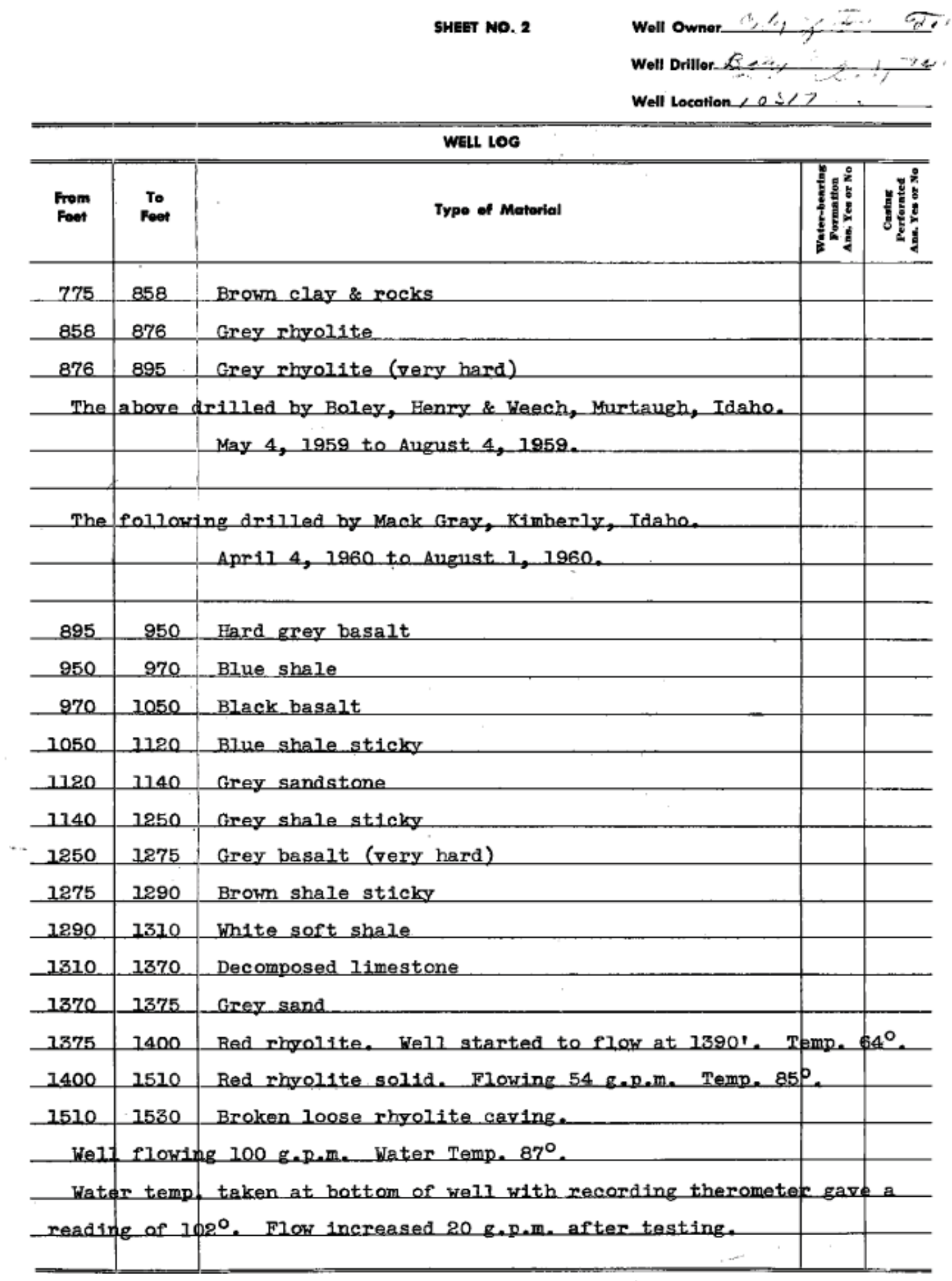

Figure C7. City of Twin Falls Well Driller's Log 


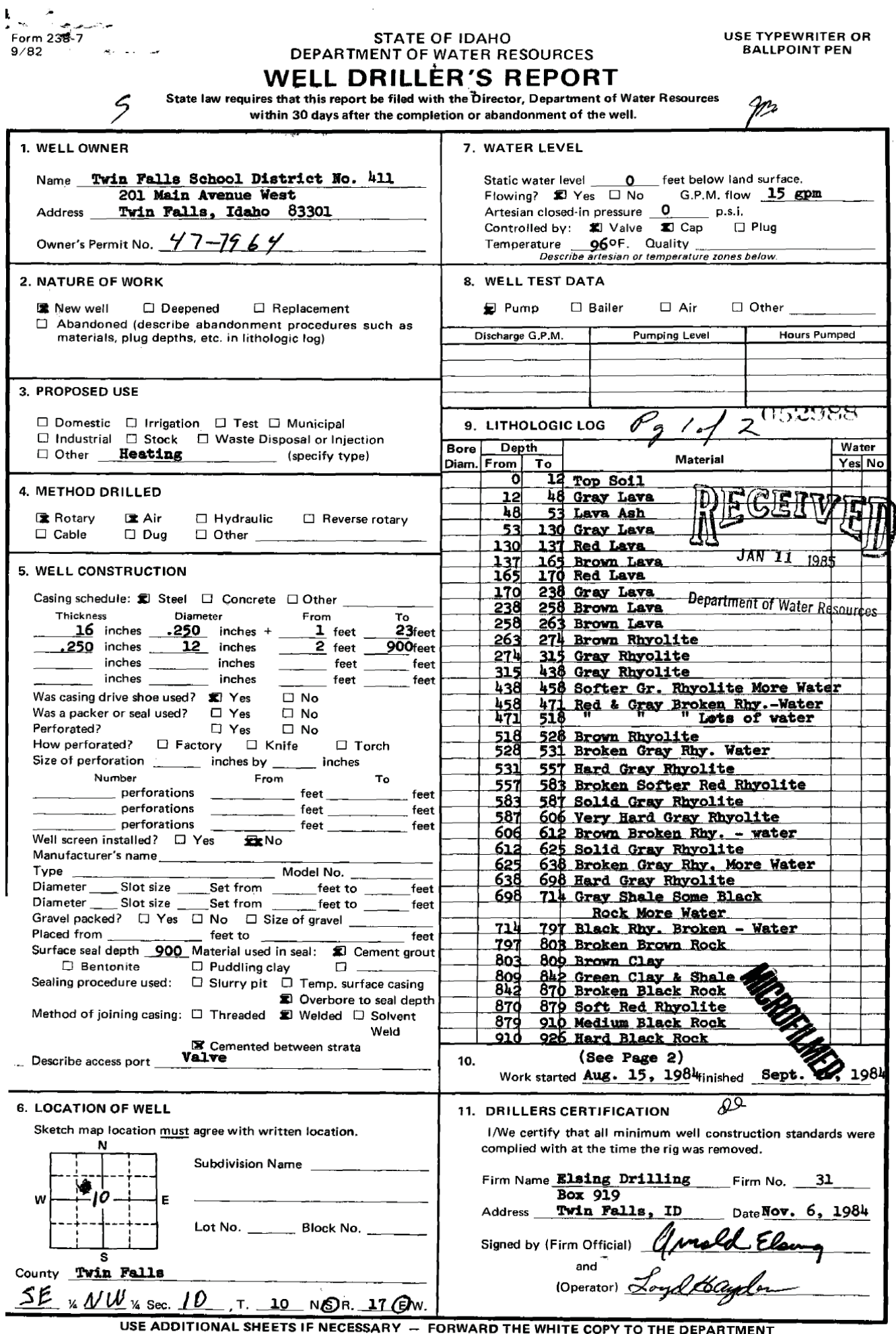




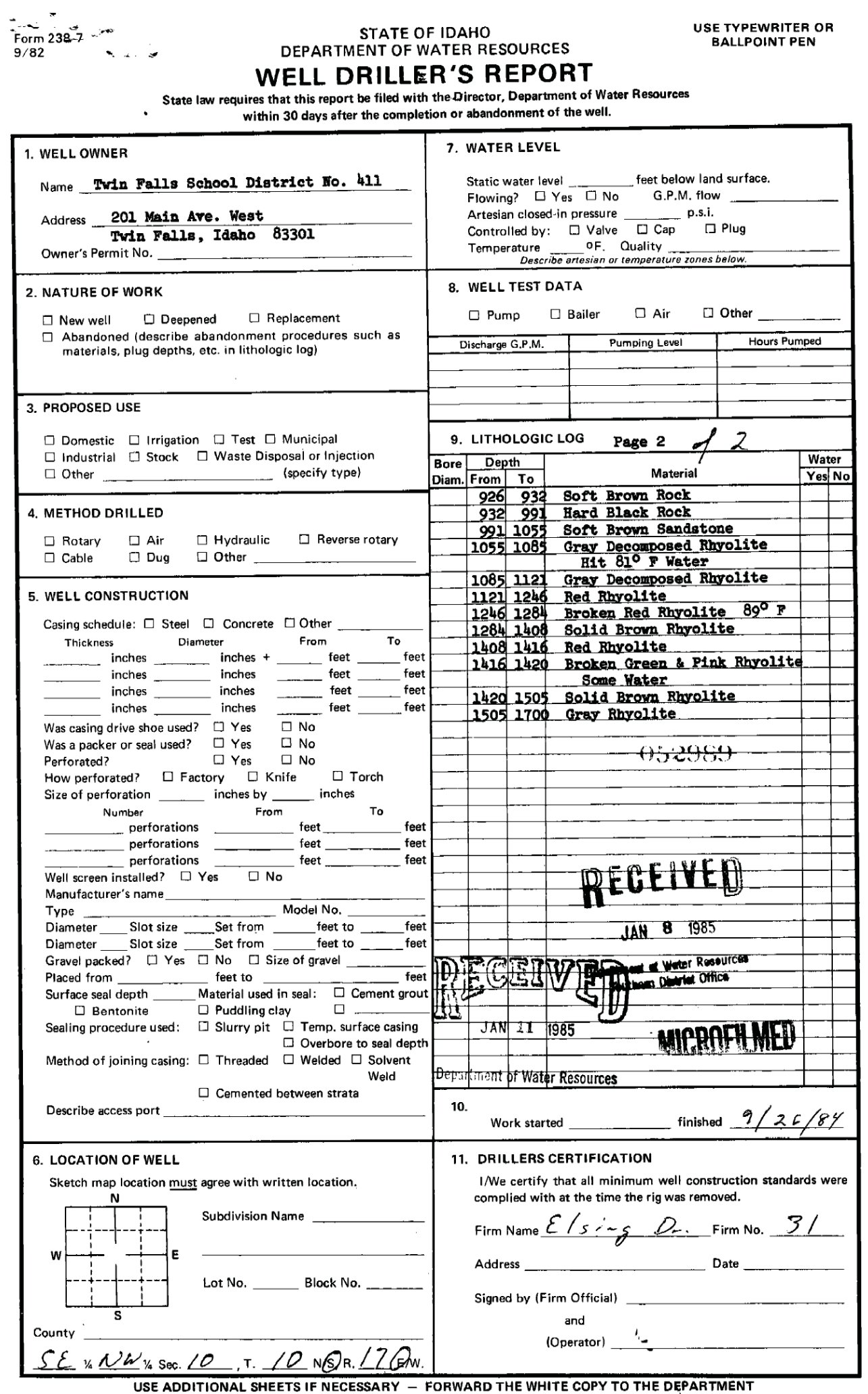

Figure C8. Twin Falls High School Well Driller's Log 


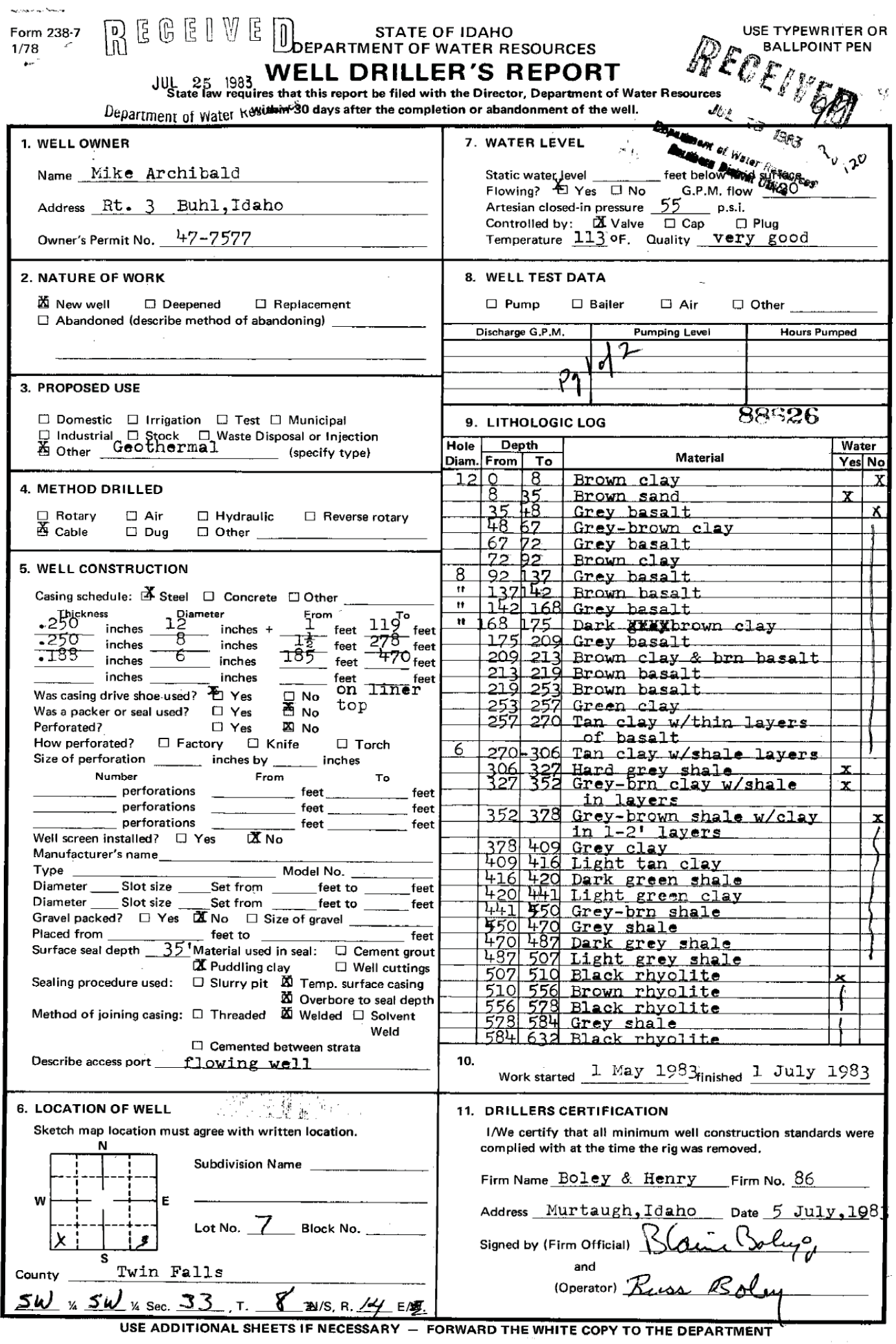




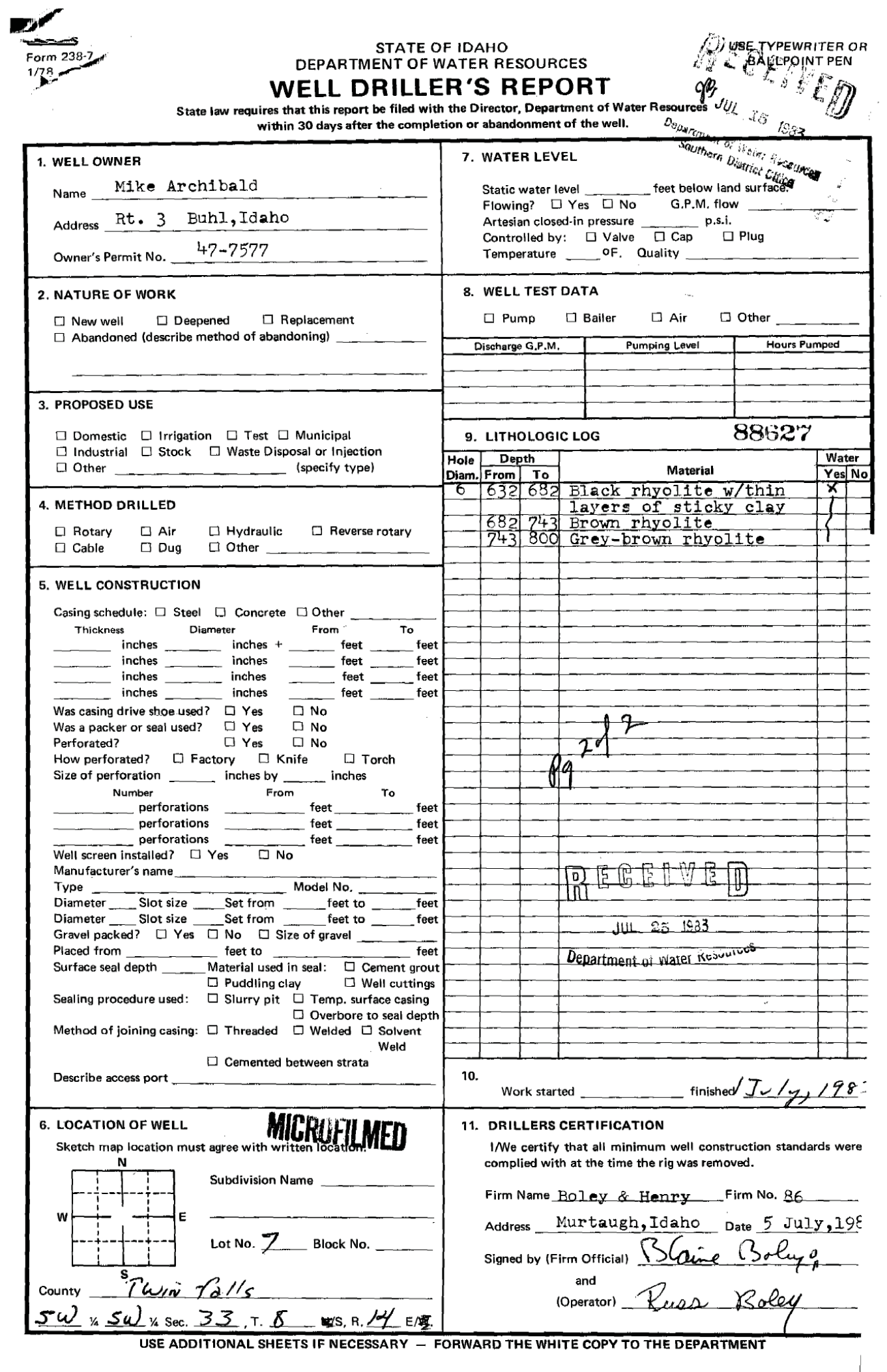

Figure C9. Mike Archibald Well Driller's Log 


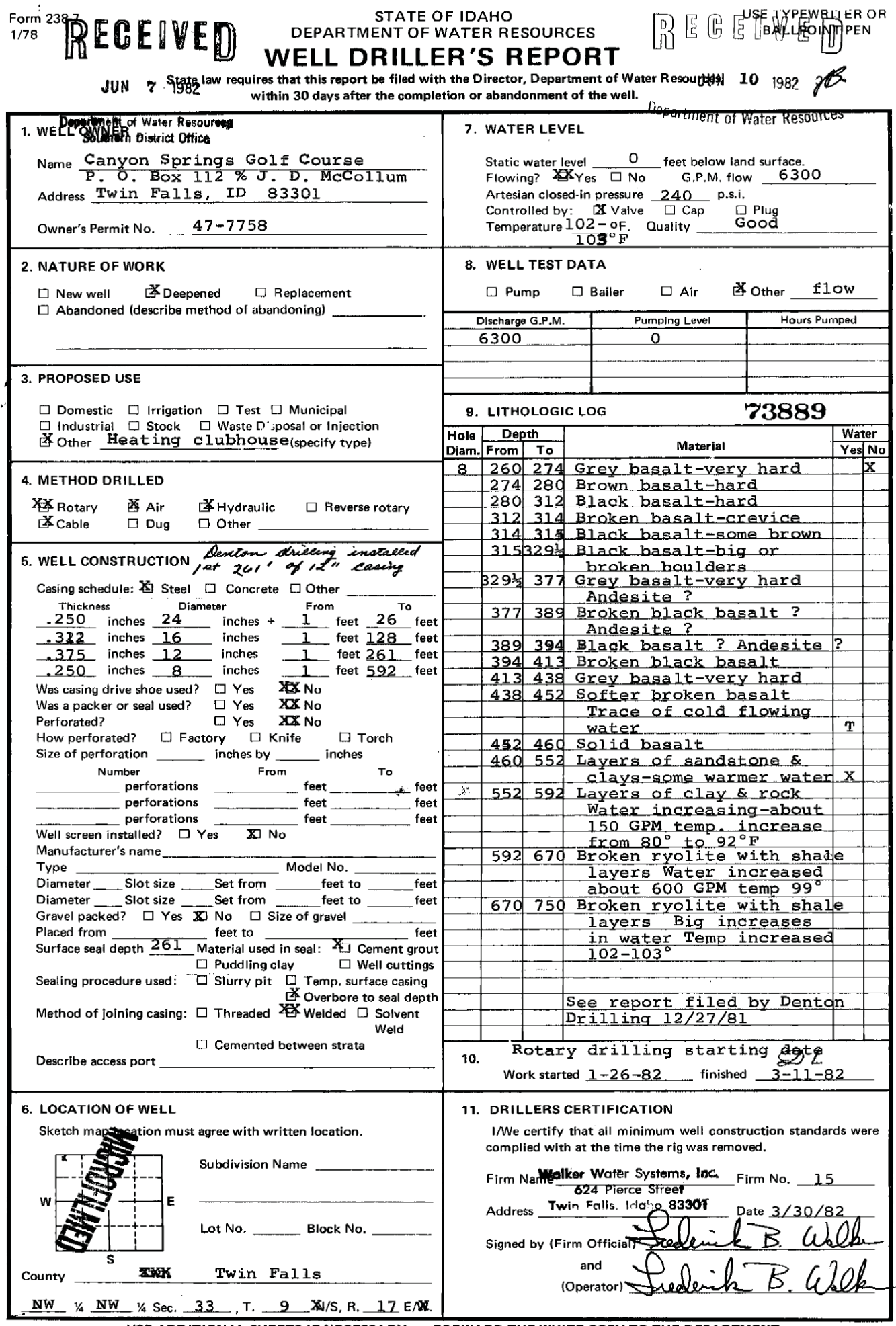

USE ADDITIONAL SHEETS IF NECESSARY - FORWARD THE WHITE COPY TO THE DEPARTMENT 


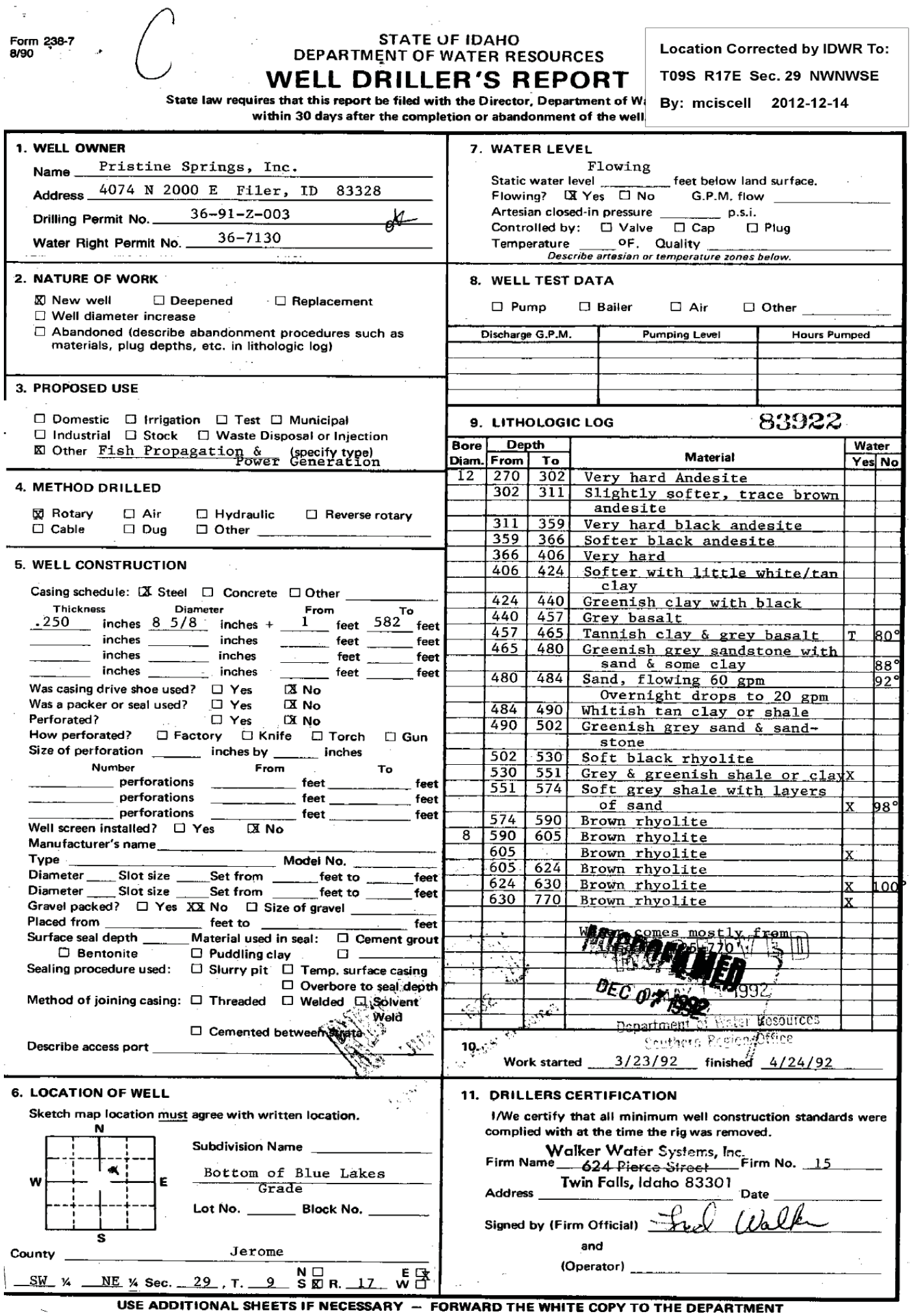

Figure C11. Pristine Springs Well Driller's Log 


\section{Appendix K.}

Dobson, P.F., Kennedy, B.M., Conrad, M.E., McLing, T., Mattson, E., Wood, T., Cannon, C., Spackman, R., van Soest, M., and Robertson, M., 2015. He isotopic evidence for undiscovered geothermal systems in the Snake River Plain. Proceedings, 40th Workshop on Geothermal Reservoir Engineering, Stanford University, Stanford, CA. 


\title{
He Isotopic Evidence for Undiscovered Geothermal Systems in the Snake River Plain
}

\author{
Patrick F. Dobson ${ }^{1}$, B. Mack Kennedy ${ }^{1}$, Mark E. Conrad ${ }^{1}$, Travis McLing ${ }^{2}$, Earl Mattson ${ }^{2}$, Thomas Wood ${ }^{3}$, Cody Cannon ${ }^{3}$, \\ Ross Spackman ${ }^{4}$, Matthijs van Soest ${ }^{5}$, and Michelle Robertson ${ }^{1}$ \\ ${ }^{1}$ Earth Sciences Division, Lawrence Berkeley National Laboratory, Berkeley, CA \\ ${ }^{2}$ Idaho National Laboratory, Idaho Falls, ID \\ ${ }^{3}$ University of Idaho-Idaho Falls, Idaho Falls, ID \\ ${ }^{4}$ Brigham Young University-Idaho, Rexburg, ID \\ ${ }^{5}$ Arizona State University, Tempe, AZ \\ Corresponding author: pfdobson@lbl.gov
}

Keywords: He isotopes, Snake River Plain, geochemistry

\begin{abstract}
The Snake River Plain is an area characterized by high heat flow and abundant Quaternary volcanism. While USGS assessments indicate that significant undiscovered geothermal resources are likely to be present in this region, no commercial geothermal development in this region has occurred. Elevated ${ }^{3} \mathrm{He} /{ }^{4} \mathrm{He}$ values reflect crustal input of mantle volatiles and may serve as a geochemical indicator of hidden geothermal systems that are masked by the presence of shallow cold water aquifers.

This study is part of an integrated geochemical investigation of thermal features in the central and eastern Snake River Plain region. Our project started by compiling existing He isotope data, regional heat flow data, and the locations of thermal wells and springs to develop compositional trends and identify new sampling opportunities where data gaps exist. Our initial field work has resulted in the highest ${ }^{3} \mathrm{He} /{ }^{4} \mathrm{He}$ measurements ever reported for the Snake River Plain, with three locations having Rc/Ra values greater than 2.0, suggesting that we can see through the effects of shallow cold water aquifers to indicate the presence of mantle-derived fluid and heat input into the shallow crust. Our new He isotopic results and previously reported data for the Snake River Plain range from 0.05 to 2.36 $\mathrm{Rc} / \mathrm{Ra}$. These results will be evaluated in conjunction with the results of conventional, isotopic, and multicomponent geothermometry studies.
\end{abstract}

\section{INTRODUCTION}

One of the key R\&D challenges for the DOE Geothermal Technologies Office Hydrothermal program is to develop techniques that can be used to identify undiscovered geothermal resources in the US, which the USGS has estimated as having a mean power production potential of $30 \mathrm{GWe}$ (Williams et al., 2008). One of the main areas with elevated heat flow in the US, the Snake River Plain (Figure 1), has no geothermal systems that have been commercially developed for energy generation. This area is characterized by abundant Quaternary volcanism associated with the migration of the Yellowstone hotspot, but in a large portion of this region there are shallow cold water aquifers that mask the presence of higher temperatures at depth.

Much of the volcanism in the Snake River Plain is associated with the migration of the Yellowstone hotspot (Pierce and Morgan, 2009), and consists of bimodal basalts and rhyolites that have been erupted over the past $17 \mathrm{Ma}$. The rhyolites were derived from a sequence of progressively younger to the east silicic volcanic centers (Morgan et al., 1984; Leeman et al., 2008). Voluminous basalt flows range in age from Tertiary to Holocene, and are found throughout both the Eastern and Western Snake River Plain. A small subset of these basalts are late Quaternary to Holocene in age, and form 8 distinct eruptive centers (Kuntz et al., 1992; Hughes et al., 2002), including the Craters of the Moon. A number of Quaternary rhyolitic domes and cryptodomes are located in the Eastern Snake River Plain - these are thought to have evolved from differentiation of basalt (McCurry et al., 2008).

While low enthalpy geothermal fluids have been harnessed for direct use in Idaho for more than a century, geothermal exploration activity in the Snake River Plain for high-enthalpy systems has been carried out sporadically over the past 50 years (Ross, 1970 ; Young and Mitchell, 1973; Parliman and Young, 1992), and has not yet resulted in the discovery and development of a commercial geothermal system in the area. One recent research study, Project Hotspot, drilled three deep $(\sim 2 \mathrm{~km})$ wells in three different regions of the Snake River Plain (Nielson et al., 2012; Shervais et al., 2013). One of these wells (Kimama) intersected a thick ( $>900 \mathrm{~m})$ cold water aquifer before encountering an elevated thermal gradient, while a second well (Kimberley) encountered a thick $(\sim 1500 \mathrm{~m})$ reservoir of $55-60^{\circ} \mathrm{C}$ water in rhyolitic lavas and tuffs. The third well (Mountain Home) discovered a high temperature $\left(\sim 150^{\circ} \mathrm{C}\right)$ geothermal system with artesian flow. None of these locations had any surface thermal features that could be used to predict the varying thermal conditions that were encountered.

With the exception of active rift zones (such as Iceland) and hot spots (Hawaii), basaltic dominated volcanic provinces are often neglected as possible hosts for productive geothermal systems (Nielson et al., 2015). This is in part due to the lack of shallow, long- 
lived magma chambers that would provide a sustained source of heat to the shallow crust. However, as evidenced by the elevated heat flow, volcanic activity in the Snake River Plain region appears to be associated with magmatic intrusions in the crust that do provide a viable source of heat based on crustal models (Peng and Humphreys, 1998; DeNosaquo et al., 2009). McCurry and Welhan (2012), Nielson and Shervais (2014), and McLing et al. (2014) all postulate that basaltic sill complexes associated with these volcanic features could serve as the heat source for geothermal systems in the Snake River Plain region. However, such subsurface features are difficult to detect using standard exploration techniques. One possible way to detect such features is to use a tracer that would be present in geothermal fluids that would identify the presence of a magmatic component. Helium isotopes may serve as such a tracer for geothermal fluids in the Snake River Plain region.

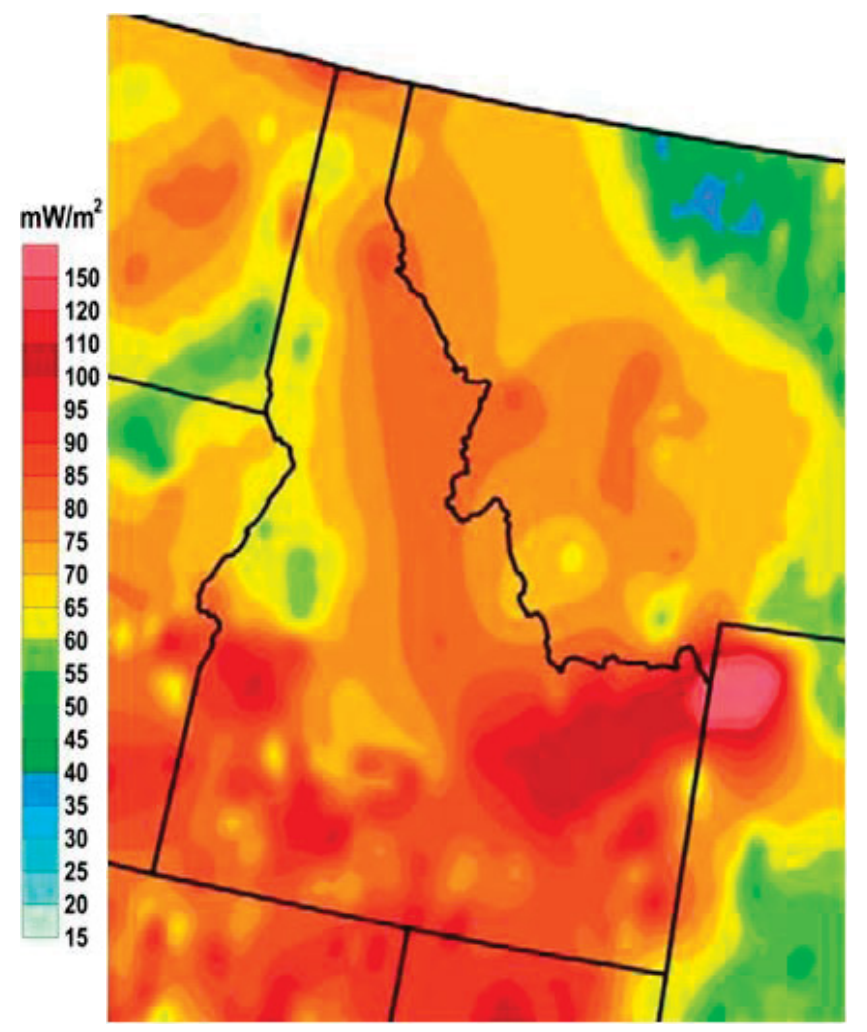

Figure 1: Heat flow map of Idaho and the surrounding region, showing elevated values in the Snake River Plain (Blackwell et al., 2011).

\section{FIELD AND LABORATORY METHODS}

Helium samples were collected during three field campaigns: September 2003, March 2014, and June 2014. Samples collected in 2014 were obtained from thermal springs and wells as part of a coordinated geochemical study of these features for multicomponent and isotopic geothermometry (McLing et al., 2014; Cannon et al., 2014). A type-K thermocouple was used to measure the temperature of the thermal features. Gas samples for noble gas analyses were collected from bubbling hot springs using an inverted plastic funnel that was connected with Tygon tubing to a copper tube. Gas was bubbled through the system to purge any atmospheric contamination, and the gas samples were then trapped in the copper tube using cold seal weld clamps, resulting in a gas sample volume of $\sim 9.8 \mathrm{~cm}^{3}$. For water samples without a gas phase, water was collected in copper tubes to trap dissolved gases for analysis. The samples were then analyzed with a noble gas mass spectrometer at the Center for Isotope Geochemistry at LBNL using the methods described in Kennedy and van Soest (2006). Helium isotopic compositions have been corrected for air contamination ( $\mathrm{Rc}$ ) using the $\mathrm{He} / \mathrm{Ar}$ and $\mathrm{Ne} / \mathrm{Ar}$ ratios by assuming all of the $\mathrm{Ne}$ and Ar were derived from air or air saturated water.

\section{RESULTS}

There are very few published He isotope values for thermal waters in the Snake River Plain region. Welhan et al. (1988) reported He isotope values ranging from 0.14 to $0.51 \mathrm{R} / \mathrm{Ra}$ for four thermal springs in the Snake River Plain region. A more comprehensive unpublished study of He isotopic variations for 19 thermal springs and wells in southern Idaho was conducted by Jenkins (1979); he reported $\mathrm{R} / \mathrm{Ra}$ values ranging from 0.1 to 1.56 , with all but two samples having values less than 1 .

The initial results of this study provide He isotope data from a wide range of thermal springs and wells in the Snake River Plain and neighboring areas. A total of $11 \mathrm{He}$ samples were collected during the 2003 field season, and an additional $21 \mathrm{He}$ samples were 
collected in 2014. Three of the areas that were sampled in 2003 were resampled in 2014 as a check on the reproducibility of the analyses. In all cases, the $\mathrm{Rc} / \mathrm{Ra}$ values for the resampled features are within $0.2 \mathrm{Rc} / \mathrm{Ra}$ of each other.

He isotope values for the features sampled thus far in this study range from a low of $0.05 \mathrm{Rc} / \mathrm{Ra}$ (for Lidy Hot Springs) up to a high value of 2.36 for the Barron's (Camas Creek Ranch) well (Figures $2 \& 3$ ). A total of eight features had Rc/Ra values greater than 1.5, with three of these having values greater than 2 . The elevated $(\mathrm{Rc} / \mathrm{Ra}>1.5)$ values cluster in three distinct regions: one near Craters of the Moon (Green House well), a second in the Twin Falls area (Miracle HS, Banbury HS and well, and Sligers well), and a third located on the northern margin of the Snake River Plain north of Twin Falls (White Arrow HS, Magic Reservoir HS well, and Barron's well).

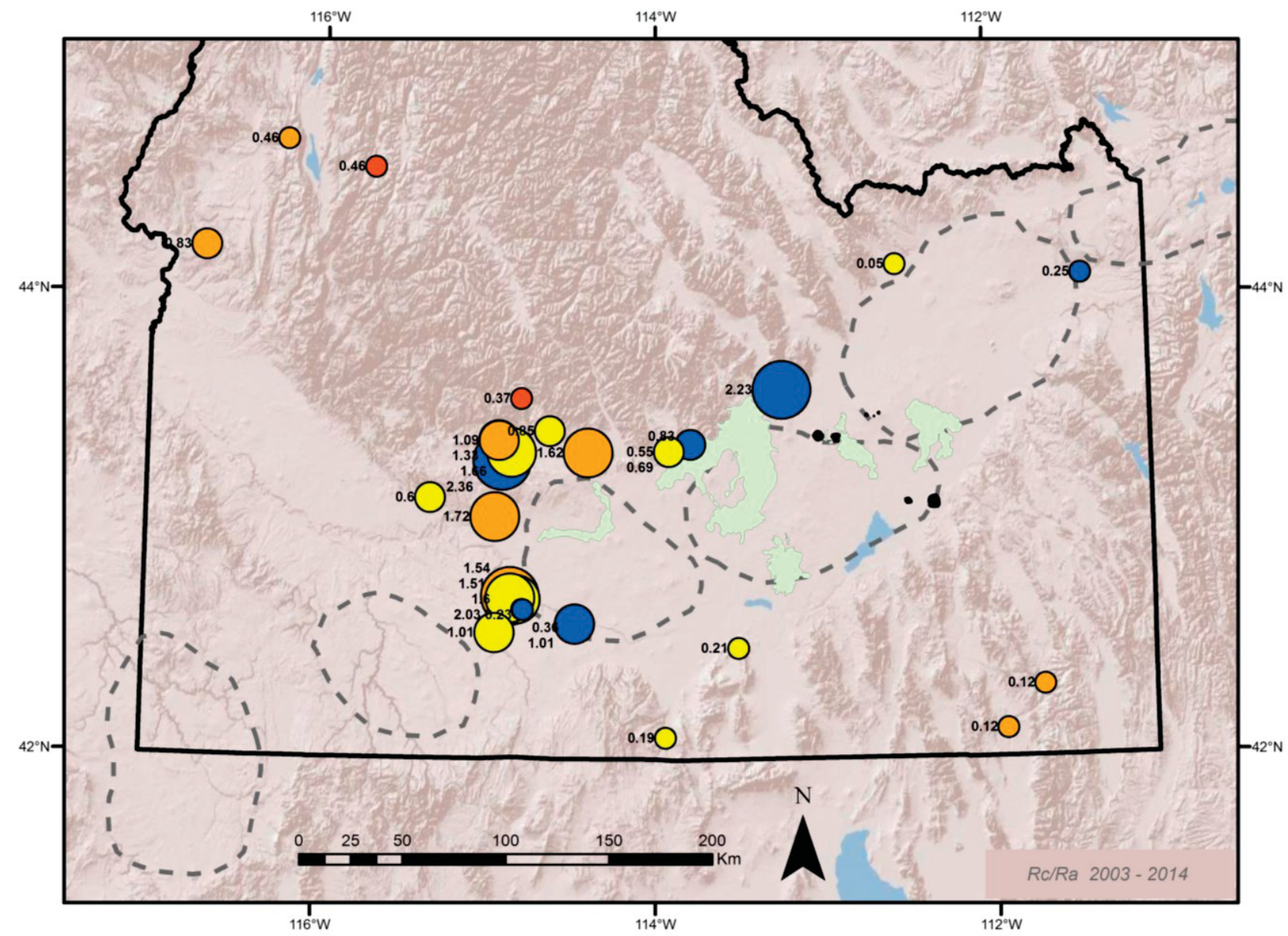

\begin{tabular}{|c|c|c|}
\hline $\begin{array}{l}\text { Quaternary silicic } \\
\text { volcanic rocks }\end{array}$ & $\begin{array}{l}\text { Temperature } \\
\text { degrees } \mathrm{C}\end{array}$ & $\begin{array}{l}\text { He Isotope } \\
\text { Rc/Ra }\end{array}$ \\
\hline Late Pleistocene-Holocene & $<<40$ & $\quad 0.00-0.50$ \\
\hline \multirow{4}{*}{$\begin{array}{l}\text { - I Tertiary silicic volcanic } \\
\text { I_ centers }\end{array}$} & $40-59$ & $0.51-1.00$ \\
\hline & $60-79$ & $1.01-1.50$ \\
\hline & $>80$ & $1.51-2.00$ \\
\hline & & .01 \\
\hline
\end{tabular}

Figure 2: He isotopic values for the Snake River Plain superimposed on a digital elevation map with locations of latest Pleistocene-Holocene basalts (Kuntz et al., 1992; Hughes et al., 2002), Quaternary rhyolites (McCurry et al., 2008), and the outlines of major Tertiary silicic volcanic centers (Leeman et al., 2008). Symbol size and number indicates Rc/Ra He value, and symbol color indicates the measured surface temperature of spring or well. 


\section{DISCUSSION}

Helium isotopes can be used to identify the source of the helium (Ballentine et al., 2002; Graham, 2002), thus facilitating its use a tracer for the origin of geothermal fluids. There are three major reservoirs of helium: the mantle, the crust, and the atmosphere. The ${ }^{3} \mathrm{He} /{ }^{4} \mathrm{He}$ of air is $1.4 \times 10^{-6}$, and is defined as Ra. Mantle (magmatic) He values are typically enriched in ${ }^{3} \mathrm{He}$, with ${ }^{3} \mathrm{He} /{ }^{4} \mathrm{He}$ ratios 7 to 9 times that of atmosphere (7-9 R/Ra). Because ${ }^{4} \mathrm{He}$ is produced by radiogenic decay of Th and $\mathrm{U}$, crustal He ratios are typically $\sim 0.02 \mathrm{R} / \mathrm{Ra}$.

Kennedy and van Soest (2007) conducted a detailed study of He isotopic compositions of thermal features across the Basin and Range. They observed that fluids from geothermal systems located on the western margin of the Great Basin that were associated a volcanic heat source had elevated ${ }^{3} \mathrm{He} /{ }^{4} \mathrm{He}$ values $(\mathrm{Rc} / \mathrm{Ra}>3)$. In contrast, amagmatic geothermal systems in the Basin and Range Province had significantly lower values ( $\mathrm{Rc} / \mathrm{Ra}$ from $\sim 0.2$ to 2 ); however, these values are considerably above crustal values ( 0.02 ). They interpreted the slightly elevated values for the nonvolcanic systems to reflect amagmatic flow of mantle fluids through the ductile lower crust. The values increased systematically from east to west, correlating with an east-west increase in crustal strain rate suggesting a concurrent east-west increase in deep crustal permeability, enhancing fluid flow to the surface. Several regions were found to have anomalously high $\mathrm{R} / \mathrm{Ra}$ values with respect to the general trend. Siler et al. (2014) looked to correlate the occurrence of major structural features in these regions to see if they might serve as localized zones of higher permeability that would further facilitate deep crustal circulation of fluids and heat.

While the Snake River Plain has a clear association with young volcanism (Figure 2), the thermal effects of this magmatic activity in the shallow crust are often masked by a thick cold water aquifer that overlies much of the Eastern Snake River Plain region (McLing et al., 2014). This cold water aquifer has a thickness reaching up to more than $900 \mathrm{~m}$ in places (Nielson et al., 2012; Shervais et al., 2013). Another challenge is that most of the thermal features encountered in the Snake River Plain are located along its margins. Fluids sampled from these features may have undergone cooling and mixing, thus making interpretation of fluid geothermometry challenging. Multicomponent geothermometry has been employed to better constrain the source temperatures of these complex fluids (Neupane et al., 2014; Cannon et al., 2014).

During the preliminary phase of this project, we examined the three regions with elevated He isotopic ratios to see if they coincide with areas that have evidence of young volcanism (Figure 2) or high heat flow (Figure 3). Only one of the areas (Green House well - Rc/Ra $=2.23$, by Arco) is near young $(<15 \mathrm{Ka})$ volcanic rocks (Craters of the Moon). This well is quite unremarkable in terms of its flowing temperature $\left(36.3^{\circ} \mathrm{C}\right)$, and multicomponent geothermometry yields a source temperature estimate of only $67 \pm 15^{\circ} \mathrm{C}(\mathrm{Cannon}$ et al., 2014). The other two high He isotope clusters (the Twin Falls area and the area near Magic Reservoir HS) are in areas with Miocene rhyolites and Plio-Pleistocene basalts (Leeman et al., 1982; Whitehead, 1992; Ellis et al., 2010) but are generally associated with higher temperature thermal features and/or wells. These clusters are located in areas with high heat flow (Figure 3 ).

One area that warrants future study is the region around Mountain Home, where drilling has revealed the existence of a hidden $150^{\circ} \mathrm{C}$ geothermal reservoir (Shervais et al., 2013). Unfortunately this well was plugged and abandoned before it could be sampled for He isotopes, but other wells in the region might contain geochemical signatures related to this system. While this area does not have Holocene volcanism, it does host Quaternary basalts (Shervais et al., 2002) and may be underlain by younger basaltic sills (Nielson and Shervais, 2014).

\section{CONCLUSIONS}

New helium isotope data for thermal waters in the Snake River Plain has revealed a number of elevated ( $\mathrm{Rc} / \mathrm{Ra}>1.5) \mathrm{He}$ isotope values that are higher than previously reported data for this region. These values suggest a significant mantle helium component. These elevated values have been observed thus far in three different areas within the Snake River Plain. There is not a clear correlation between these elevated ${ }^{3} \mathrm{He} /{ }^{4} \mathrm{He}$ values and young $(<15 \mathrm{Ka})$ volcanic features. However, this He signature may be related to basaltic intrusions that are thought to sustain the high heat flow in this region. Future work will include integration of the He data with isotope and multicomponent geothermometry and collection of additional samples in areas such as Mountain Home, where a hidden geothermal system has been discovered. Such sampling will help test whether He isotopes can help identify systems that have no surface manifestations in the Snake River Plain region.

\section{ACKNOWLEDGMENTS}

This work was conducted with funding by the Assistant Secretary for Energy Efficiency and Renewable Energy, Geothermal Technologies Program, of the U.S. Department under the U.S. Department of Energy Contract No. DE-AC02-05CH11231 with Lawrence Berkeley National Laboratory. We thank Will Smith, Hari Neupane, Wade Worthing, and Steven Levesque for their assistance in the field, and to the many property owners in Idaho who graciously allowed us access to the springs and wells on their land. We also thank Colin Williams (USGS) for sharing his heat flow maps with our team. 


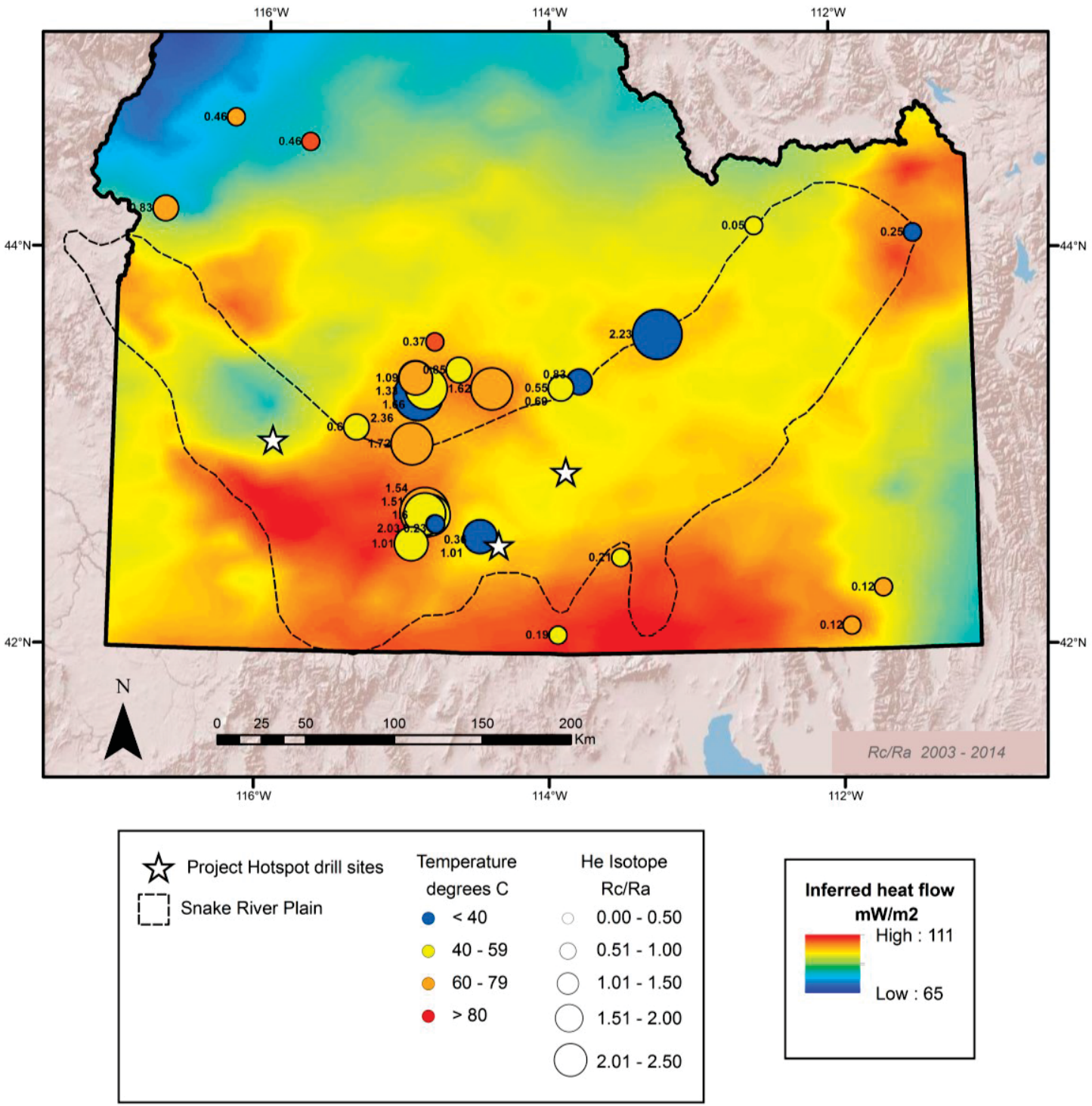

Figure 3: He isotopic values for the Snake River Plain superimposed on USGS heat flow map of the Snake River Plain (Williams and DeAngelo, 2011). Map depicts inferred heat flow below the groundwater flow system. Map was generated to identify regional-scale variations, so high heat flow in geothermal regions was capped at $120 \mathrm{~mW} / \mathrm{m}^{2}$. Outline of the Snake River Plain province from Payne et al. (2012). Symbol size and number indicates $\mathrm{Rc} / \mathrm{Ra} \mathrm{He}$ value, and symbol color indicates measured surface temperature of spring or well. The three Project Hotspot wells, depicted as stars, are (from west to east) Mountain Home, Kimberly, and Kimama (Shervais et al., 2013).

\section{REFERENCES}

Ballentine, C.J., Burgess, R., and Marty, B.: Tracing Fluid Origin, Transport and Interaction in the Crust, in Porcelli, D., Ballentine, C.J., and Wieler, R., eds., Reviews in Mineralogy \& Geochemistry-Noble Gases in Geochemistry and Cosmochemistry: Washington, D.C., Mineralogical Society of America, v. 47, (2002), 539-614.

Blackwell, D.D., Richards, M.C., Frone, Z.S., Batir, J.F., Williams, M.A., Ruzo, A.A., and Dingwall, R.K.: SMU Geothermal Laboratory Heat Flow Map of the Conterminous United States, 2011, (2011), Available at http://www.smu.edu/geothermal

Cannon, C., Wood, T., Neupane, G., McLing, T., Mattson, E., Dobson, P., and Conrad, M.: Geochemistry Sampling for Traditional and Multicomponent Equilibrium Geothermometry in Southeast Idaho, Geothermal Resources Council Transactions, 38, (2014), 425431.

DeNosaquo, K.R., Smith, R.B. and Lowry, A.R.: Density and Lithospheric Strength Models of the Yellowstone-Snake River Plain Volcanic System from Gravity and Heat Flow Data. Journal of Volcanology and Geothermal Research, 188, (2009), $108-127$. 
Dobson et al.

Ellis, B.S., Barry, T., Branney, M.J., Wolff, J.A., Bindeman, I., Wilson, R. and Bonnichsen, B.: Petrologic constraints on the development of a large-volume, high temperature, silicic magma system: The Twin Falls eruptive centre, central Snake River Plain, Lithos, 120, (2010), 475-489.

Graham, D.W.: Noble Gas Isotope Geochemistry of Mid-Ocean Ridge and Ocean Island Basalts: Characterization of Mantle Source Reservoirs, in Porcelli, D., Ballentine, C.J., and Wieler, R., eds., Reviews in Mineralogy \& Geochemistry- Noble Gases in Geochemistry and Cosmochemistry: Washington, D.C., Mineralogical Society of America, v. 47, (2002), $481-538$.

Hughes, S.S., Wetmore, P.H. and Casper, J.L.: Evolution of Quaternary Tholeiitic Basalt Eruptive Centers on the Eastern Snake River Plain, Idaho. In B. Bonnichsen, C.M. White, and M. McCurry, eds., Tectonic and Magmatic Evolution of the Snake River Plain Volcanic Province, Idaho Geological Survey Bulletin 30, (2002), 23 p.

Jenkins, W.J.: Mapping of Volcanic and Conducted Heat Flow Sources for Thermal Springs in the Western United States Using Helium Isotopes and other Rare Gases. U.S. Geological Survey unpublished report, (1979). Data reported in Kennedy and van Soest (2007) supplemental materials (www.sciencemag.org/cgi/content/full/318/5855/1433/DC1)

Kennedy, B.M., and van Soest, M.C.: Flow of Mantle Fluids through the Ductile Lower Crust: Helium Isotope Trends, Science, 318, (2007), 1433-1436.

Kuntz, M.A, Covington, H.R., and Schorr, L.J.: Chapter 12 - An Overview of Basaltic Volcanism of the Eastern Snake River Plain, Idaho. In Link, P.K., Kuntz, M.A., and Platt, L.B., eds., Regional Geology of Eastern Idaho and Western Wyoming, Geological Society of America Memoir 179, (1992), 227-267.

Leeman, W.P.: Geology of the Magic Reservoir Area, Snake River Plain, Idaho. In B. Bonnichsen and R.M. Breckenridge, eds., Cenozoic Geology of Idaho, Idaho Bureau of Mines and Geology Bulletin 26, (1982), 369-376.

Leeman, W.P., Annen, C. and Dufek, J.: Snake River Plain - Yellowstone Silicic Volcanism: Implications for Magma Genesis and Magma Fluxes. In Annen, C. and Zellmer, G. F. (eds) Dynamics of Crustal Magma Transfer, Storage and Differentiation. Geological Society, London, Special Publications, 304, (2008), 235-259.

McCurry, M., Hayden, K.P., Morse, L.H. and Mertzman, S.: Genesis of Post-Hotspot, A-Type Rhyolite of the Eastern Snake River Plain Volcanic Field by Extreme Fractional Crystallization of Olivine Tholeiite. Bulletin of Volcanology 70, (2008), $361-383$.

McCurry, M. and Welhan, J.: Do Magmatic-Related Geothermal Energy Resources Exist in Southeast Idaho? Geothermal Resources Council Transactions, 36, (2012), 699-707.

McLing, T., McCurry, M., Cannon, C., Neupane, G., Wood, T., Podgorney, R., Welhan, J., Mines, G., Mattson, E., Wood, R., Palmer, C. and Smith, R.: David Blackwell's Forty Years in the Idaho Desert, The Foundation for $21^{\text {st }}$ Century Geothermal Research. Geothermal Resources Council Transactions, 38, (2014), 143-153.

Neupane, G., Mattson, E.D., McLing, T.L., Palmer, C.D., Smith, R.W. and Wood, T.R.: Deep Geothermal Reservoir Temperatures in the Eastern Snake River Plain, Idaho using Multicomponent Geothermometry, Proceedings, 39 ${ }^{\text {th }}$ Workshop on Geothermal Reservoir Engineering, Stanford University, Stanford, CA, (2014), 12 p.

Nielson, D.L., Delahunty, C. and Shervais, J.W.: Geothermal systems in the Snake River Plain, Idaho, Characterized by the Hotspot Project, Geothermal Resources Council Transactions, 36, (2012), 727-730.

Nielson, D.L., and Shervais, J.W.: Conceptual Model for Snake River Plain Geothermal Systems, Proceedings, $39^{\text {th }}$ Workshop on Geothermal Reservoir Engineering, Stanford University, Stanford, CA, (2014), 7 p.

Nielson, D.L., Shervais, J., Evans, J., Liberty, L., Garg, S.K., Glen, J. Visser, C., Dobson, P., Gasperikova, E., and Sonnenthal, E.: Geothermal Play Fairway Analysis of the Snake River Plain, Idaho, Proceedings, 40 ${ }^{\text {th }}$ Workshop on Geothermal Reservoir Engineering, Stanford University, Stanford, CA, (2015), 9 p.

Parliman, D.J. and Young H.W.: Compilation of Selected Data for Thermal-Water Wells and Springs in Idaho, 1921 through 1991. U.S. Geological Survey Open-File Report 92-175, (1992), 201 p.

Payne, S.J., McCaffrey, R., King R.W, and Kattenhorn, S.A.: A New Interpretation of Deformation Rates in the Snake River Plain and Adjacent Basin and Range Regions Based on GPS Measurements. Geophysical Journal International, 189, (2012), $101-122$.

Peng, X. and Humphreys, E.D.: Crustal Velocity Structure across the Eastern Snake River Plain and the Yellowstone Swell. Journal of Geophysical Research, B, Solid Earth and Planets, 103(4), (1998), 7171-7186.

Pierce, K.L. and Morgan, L.A.: Is the Track of the Yellowstone hotspot Driven by a Deep Mantle Plume? - Review of Volcanism, Faulting, and Uplift in Light of New Data, Journal of Volcanology and Geothermal Research, 188, (2009), 1-25.

Ross, S.H.: Geothermal Potential of Idaho. Geothermics, Special Issue 2, v. 2, part 2, (1970), 975-1008.

Shervais, J.W., Schmidt, D.R., Nielson, D., Evans, J.P., Christiansen, E.H., Morgan, L., Shanks, W.C.P., Prokopenko, A.A., Lachmar, T., Liberty, L.M., Blackwell, D.D., Glen, J.M., Champion, D., Potter, K.E. and Kessler, J.A.: First Results from HOTSPOT: The Snake River Plain Scientific Drilling Project, Idaho, U.S.A., Scientific Drilling, 15, (2013), 36-45.

Shervais, J.W., Shroff, G., Vetter, S.K., Matthews, S., Hanan B.B., and McGee, J.J.: Origin and Evolution of the Western Snake River Plain: Implications from Stratigraphy, Faulting, and the Geochemistry of Basalts near Mountain Home, Idaho. In B. Bonnichsen, 
C.M. White, and M. McCurry, eds., Tectonic and Magmatic Evolution of the Snake River Plain Volcanic Province: Idaho Geological Survey Bulletin 30, (2002), 343-361.

Siler, D.L., Kennedy, B.M. and Wannamaker, P.E.: Regional Crustal Discontinuities as Guides for Geothermal Exploration, Geothermal Resources Council Transactions, 38, (2014), 39-47.

Welhan, J.A., Poreda, R.J., Rison, W., and Craig, H.: Helium Isotopes in Geothermal and Volcanic Gases of the Western United States, I. Regional Variability and Magmatic Origin, Journal of Volcanology and Geothermal Research, 34, (1988), $185-199$.

Whitehead, R.L.: Geohydrologic Framework of the Snake River Plain Regional Aquifer System, Idaho and Eastern Oregon, U.S. Geological Survey Professional Paper 1408-B, (1992), 32 p.

Williams, C.F., and DeAngelo, J.: Evaluation of Approaches and Associated Uncertainties in the Estimation of Temperatures in the Upper Crust of the Western United States, Geothermal Resources Council Transactions, 35, (2011), 1599-1605.

Williams, C.F., Reed, M.J., Mariner, R.H., DeAngelo, J. and Galanis, S.P., Jr.: Assessment of Moderate- and High-Temperature Geothermal Resources of the United States, U.S. Geological Survey Fact Sheet 2008-3082, (2008), 4 p.

Young, H.W. and Mitchell, J.C.: Geothermal Investigations in Idaho Part 1: Geochemistry and Geologic Setting of Selected Thermal Waters. Idaho Department of Water Administration, Water Information Bulletin 30, (1973), 43 p. 